\title{
8. SITES 116 AND 117
}

\author{
The Shipboard Scientific Party ${ }^{1}$ \\ With Additional Reports From \\ F. Aumento and B. D. Clarke, Dalhousie University, Halifax, Nova Scotia \\ J. R. Cann, University of East Anglia, Norwich, United Kingdom \\ P. J. C. Ryall, Dalhousie University, Halifax, Nova Scotia \\ P. A. Sabine, Institute of Geological Sciences, London \\ R. H. Benson, Smithsonian Institution, Washington, D. C. \\ A. H. Cheetham and E. Håkansson, Smithsonian Institution, Washington, D. C.
}

\section{SITE 116}

Location: East side of Hatton-Rockall Basin.

Position: $57^{\circ} 29.76^{\prime} \mathrm{N}, 15^{\circ} 55.46^{\prime} \mathrm{W}$; Satellite Navigation.

Depth of water: 1151 meters (corrected).

Total penetration: 854 meters.

\section{SITE 117}

Location: Boundary between Hatton-Rockall Basin and Rockall Bank (37 km ESE of 116).

Position: $57^{\circ} 20.17^{\prime} \mathrm{N}, 15^{\circ} 23.97^{\prime} \mathrm{W}$.

Depth of water: 1038 meters (corrected).

Total penetration: 313 meters.

\section{SITE BACKGROUND AND OBJECTIVES}

Although Sites 116 and 117 are nearly 40 kilometers apart, the second site was chosen as a direct consequence of the results obtained at the first, and is in essence a stratigraphic continuation of the first hole. For this reason both sites will be described and discussed in the same chapter.

Rockall Plateau (Figure 1) is a shoal area of about 1000 meters depth, some 450 by 600 kilometers in extent, lying between the Reykjanes Ridge and Northwestern Europe, and separated from them by basins or troughs of over 2500 meters depth. To the southwest, the plateau is flanked by steep scarps, but to the northeast, it is connected by

\footnotetext{
${ }^{1}$ A. S. Laughton, National Institute of Oceanography, United Kingdom; W. A. Berggren, Woods Hole Oceanographic Institution, Woods Hole, Massachusetts; Richard Benson, Augustana College, Rock Island, Illinois; T. A. Davies, Scripps Institution of Oceanography, La Jolla, California; Ulrich Franz, Technische Hochschule, Munchen, W. Germany; Lillian Musich, Scripps Institution of Oceanography, La Jolla, California; Katharina Perch-Nielsen, University Institute for Historical Geology and Paleontology, Copenhagen, Denmark; Alan Ruffman, Bedford Institute, Dartmouth, Nova Scotia (Present address: Seascope Consultants, Box 15-6-52, Purcell's Cove, Nova Scotia); J. E. van Hinte, Imperial Oil Enterprises, Ltd., Calgary, Alberta; Robert B. Whitmarsh, National Institute of Oceanography, United Kingdom.
}

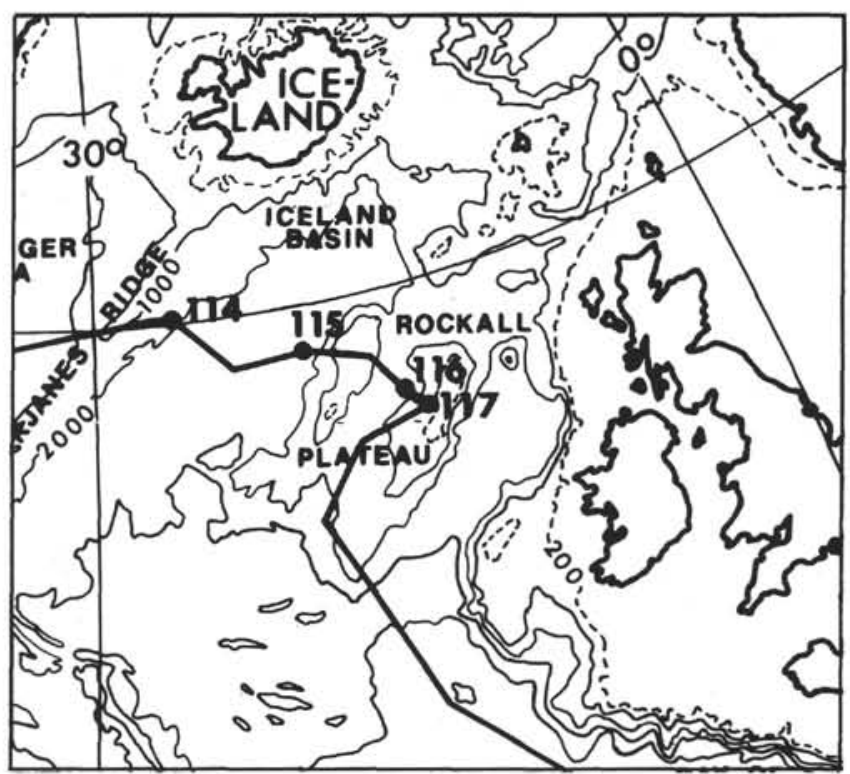

relatively shoal water to the Faroe Islands and the nearby banks and shoals.

The main topographic trends of the plateau are NE-SW. A central depression, the Hatton-Rockall Basin, is flanked to the northwest by Hatton Bank with a minimum depth of 485 meters, and to the southeast by Rockall Bank much of which is less than 200 meters in depth, but which at its northeast end appears above the sea as the small rock island of Rockall. Rockall Island is made of an aegirine granite of Lower Eocene age (Sabine, 1965) and is part of a planated Tertiary volcanic center (Roberts, 1969).

Geological and geophysical data on Rockall Plateau has been reviewed by Roberts (1971) and by Scrutton and Roberts (1971). Isotope studies of the aegirine granite of Rockall Island by Moorbath and Welke (1969) suggest that it has been intruded through a continental crust. Magnetic data show that the linear magnetic anomaly pattern, characteristic of a spreading ocean floor to the west and south, is not present on the plateau (Avery, Vogt and Higgs, 1969). The change in magnetic character at the plateau margins suggests structural differences from the surrounding areas. Free air gravity profiles across the plateau (Roberts, 1971) show that it is on the whole in isostatic equilibrium (except for Rockall Bank where there is a +70 mgal broad anomaly), implying that the crust beneath the plateau is nearer to a typical continental thickness rather 


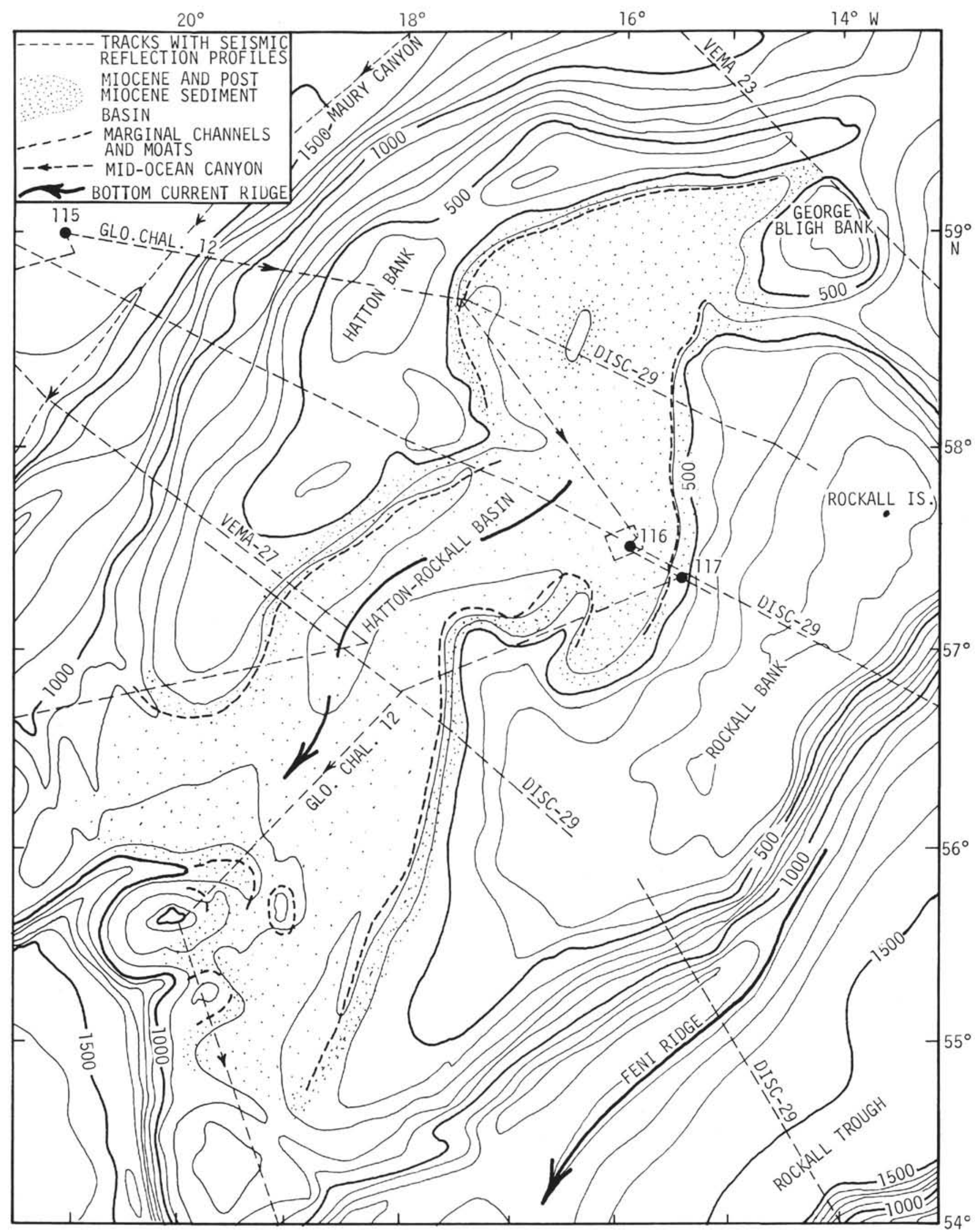

Figure 1. Bathymetric chart of Rockall Plateau showing location of tracks with seismic reflection profiles, and the limits of the Miocene sediments in Hatton-Rockall Basin. Contours in corrected fathoms at 100 fathom interval. Area outlined around Site 116 is shown in more detail in Figure 4. 
than an oceanic one. Subsequent seismic refraction experiments have confirmed that the crust below Rockall Bank (Scrutton, 1970) and below Hatton-Rockall Basin (Scrutton, personal communication) is continental both in crustal velocities and in the depth to Moho. A continental nature of Hatton and Rockall Banks was suggested by Bullard, Everett and Smith (1965) on a purely geometrical basis in order to fill a gap in the reconstruction of the continental margins of the North Atlantic prior to continental drift.

An analysis of the magnetic anomaly pattern between Rockall Plateau and Greenland (Avery, Vogt and Higgs, 1969; Vogt, Ostenso and Johnson, 1970), that is, across the Reykjanes Ridge and Iceland Basin, shows that the western margin of the plateau lies adjacent to Anomaly 24 (60 million years isochron), and that the plateau became separated from Greenland at about this time. The age of the Rockall Island granite is also $60 \pm 10$ million years (Miller and Mohr, 1965), suggesting that it was intruded at the time of the initial break from Greenland.

It has also been suggested (Vine, 1966) that Rockall Trough has resulted from an older, and now extinct, movement of Rockall Plateau away from northwestern Europe. However the evidence for this is circumstantial. The magnetic field in the trough is very smooth and unlike the magnetic field found in most parts of the ocean basins, the sediments are very thick and the interpretation of seismic refraction data is ambiguous (Scrutton and Roberts, 1971). It is clear, however, that there are two major structural discontinuities separating the trough from the plateau and from the continental margin of northwestern Europe.

Three seismic reflection profiles across Rockall Plateau revealed the existence of a large sedimentary basin (Figure 3) between Hatton and Rockall Banks (Roberts, Bishop, Laughton, Ziolkowski, Scrutton and Matthews, 1970). Another profile by Glomar Challenger-12 further defined the basin (Figure 2). The sediments of Hatton-Rockall Basin attain a thickness in places of at least 2 second two-way travel time (1700 meters at a mean velocity of 1.7 $\mathrm{km} / \mathrm{sec}$ ), with an average thickness of about 1400 meters. Two major reflecting horizons (4 and 5) were recognized on the three profiles. A series of essentially horizontally layered sediments overlie and pinch out against Horizon 4, below which there is a relatively transparent sedimentary layer. This horizon consists of a number of hyperbolic echoes suggesting structural disturbance or diapiric intrusion. Reflector 5 is considerably more irregular than reflector 4 and comprises a large number of overlapping hyperbolic echoes. It is not possible to determine from the seismic reflection results whether reflector 5 is the crystalline basement, or merely the fractured top of an even older sedimentary basin. Refraction data favors the latter explanation. This question will be discussed further when the results of the drilling at Sites 116 and 117 are interpreted.

In contrast to the Hatton-Rockall Basin, there is little penetration on Hatton and Rockall Banks. These appear to have a crystalline basement near to the sea bed. The sedimentary layer between reflectors 4 and 5 drapes the flanks of the Banks but wedges out near the top.
If Rockall Plateau is indeed a continental fragment as is suggested by the above evidence, its geological history should be preserved in the sedimentary strata of the Hatton-Rockall Basin. It was for this reason, principally, that a site was chosen to drill through these sediments on Leg 12. The elevated location of the Basin compared with Iceland Basin west of the Plateau and with Rockall Trough was believed, at the time of drilling, to afford some protection from the influence of contour current mechanisms and, hence, it was hoped that an undisturbed record of Tertiary pelagic sediments might be preserved here. In any event, the biostratigraphy should reflect Tertiary vertical movements of Rockall Plateau and their relation to changes in sea floor spreading regimes and perhaps also give information on the climatological and circulation changes resulting from the opening of the North Atlantic during the Tertiary.

Ideally, a hole in the center of Hatton-Rockall Basin penetrating to reflector 5 would have been chosen. However this was beyond the reach of the drilling capability. Therefore, the first site was chosen somewhat east of the center where some of the lower layers above reflector 4 had already pinched out so that we could be assured at least of penetrating into the transparent zone beneath the reflector 4 . Some concern was felt at the possibility of encountering hydrocarbons in the sediments, since they were believed to be of continental origin, so structural traps were avoided in the selection of the site.

The decision to drill a second hole (117) was not taken until we had penetrated through reflector 4 at Hole 116, and it was realized that we were unlikely to be able to penetrate far into the transparent layer. The Discovery-29 profile (Roberts et al., 1970) showed that the sediments above reflector 4 wedged out some 40 kilometers east of Site 116 and that a basement reflector was accessible for drilling below the transparent layer. A new major objective therefore was to sample and identify the basement reflector.

In summary the objectives were:

(a) To obtain details of the biostratigraphy and lithology of the sediments of Hatton-Rockall Basin to determine the environmental and tectonic history of Rockall Plateau.

(b) To delineate Cenozoic high latitute paleobiogeography.

(c) To determine the nature of reflector 4 and the associated depositional unconformity.

(d) To compare the transparent sediments below reflector 4 with the stratified sediments above.

(e) To obtain samples either of reflector 5, or of the basement further east to test the continental nature of the Plateau.

\section{SURVEY DATA (116)}

\section{Pre-Leg 12 Survey Data}

Prior to Leg 12, the site had been chosen on the basis of a seismic reflection profile obtained by Discovery -29 . This seismic system was tuned by careful adjustment of airgun depth, hydrophone array depth and bubble pulse interval, to a frequency of $30 \mathrm{~Hz}$. While the system gave good 


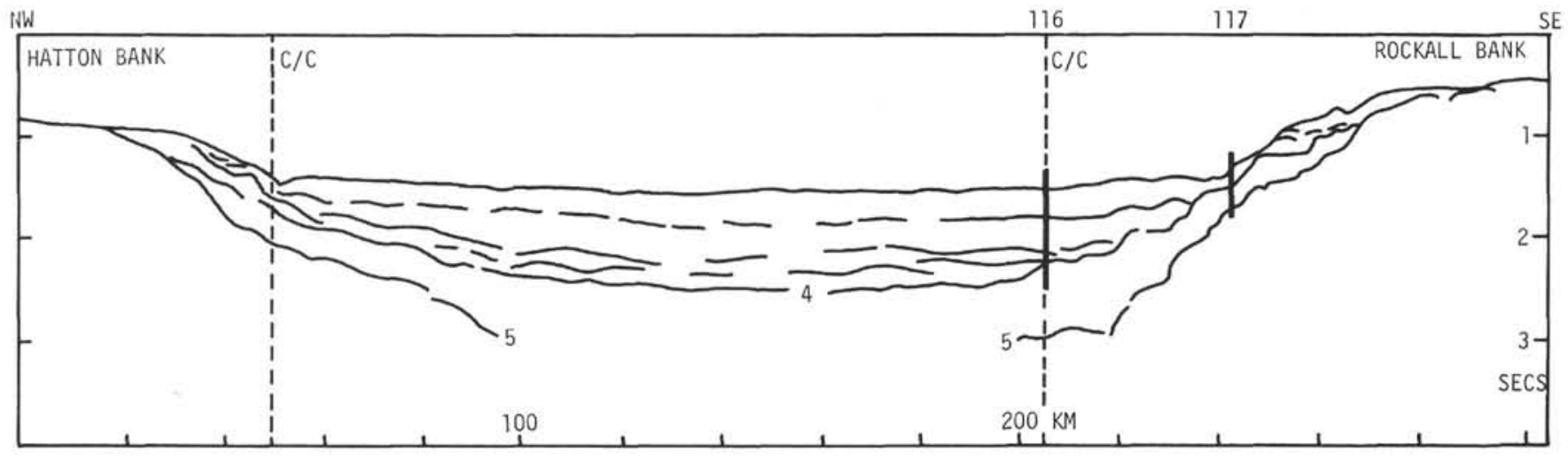

Figure 2. Line drawing of seismic reflection profile across Hatton-Rockall Basin by Glomar Challenger-12.

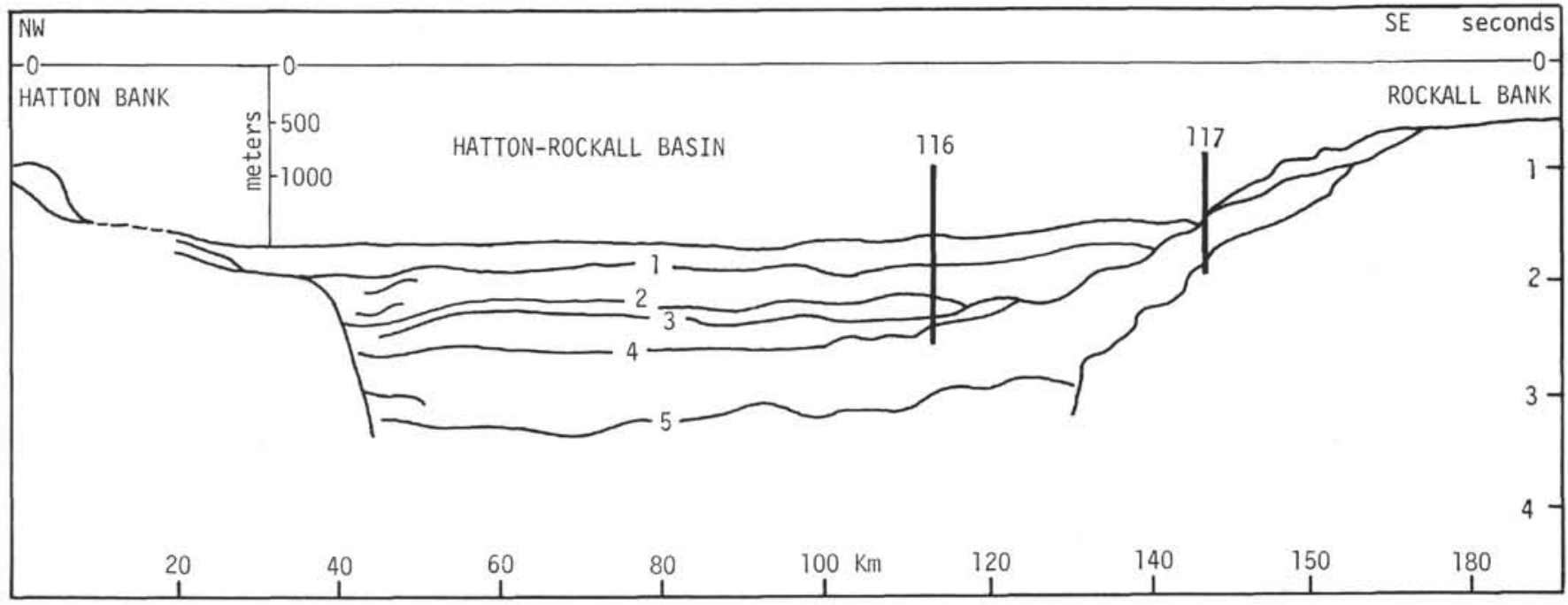

Figure 3. Line drawing of central seismic reflection profile across Hatton-Rockall Basin by Discovery-29 (after Roberts et al., 1970).

penetration and showed reflector 5 clearly, the ringing pulse shape obscured some of the finer structure nearer to the surface.

A site survey was made, therefore, by Discovery-33 in April 1970 to provide a detailed picture of the subbottom structure. Details of this survey are given in Appendix II. In summary, a box survey of 7 legs in a six mile square was made relative to an anchored buoy (Figure 4). Navigation was by radar, and the buoy position determined by satellite. Air gun profiles ( 30 to $300 \mathrm{~Hz}$ ) enabled the reflectors to be mapped, and an isopachyte map (Figure 5) of the sediments above reflector 4 was plotted, as well as an accurate bathymetric map. Within the box all layers above reflector 4 were approximately horizontal. Reflector 4 itself varied in depth below surface from 0.60 to 0.95 second. A site was chosen for drilling where Horizon 4 was well developed and at 0.85 second $(720$ meters at 1.7 $\mathrm{km} / \mathrm{sec}$ ). It turned out that this position could not be occupied accurately because of a breakdown of the satellite navigator.

\section{Survey by Glomar Challenger}

The track from Site 115 to 116 was chosen to give a profile (Figure 2) across Hatton Bank north of the long
Discovery-29 profile from northwestern Ireland to the Reykjanes Ridge, and to link with the more northerly Discovery-29 profile which did not completely cross Hatton-Rockall Basin.

In places on the west slope of Hatton Bank, up to 0.4 second of acoustically transparent sediment lie on what may be faulted basement blocks. An alternative explanation of these sediments is that they may have been deposited by contour currents traveling northward. On the east slope, the sediments of Hatton-Rockall Basin have a similar relationship to basement as they do on Rockall Bank. An acoustically transparent layer covers basement conformably, thinning toward the crest (Figure 6). It is overlain unconformably by a series of nearly horizontally bedded sediments, the unconformity being reflector 4 of Roberts et al. (1970) (Figure 3). Near Hatton Bank this sequence, which contains many reflectors, is distorted, possibly by slumping, and a channel is found characteristic of the margin of the Hatton-Rockall Basin sediments.

The draping of the transparent layer onto Hatton Bank in this section is in contrast to the section further south taken by Discovery-29, where reflector 4 abuts the basement of Hatton Bank (Figure 3), and therefore establishes the continuity of the layer over both Hatton and 


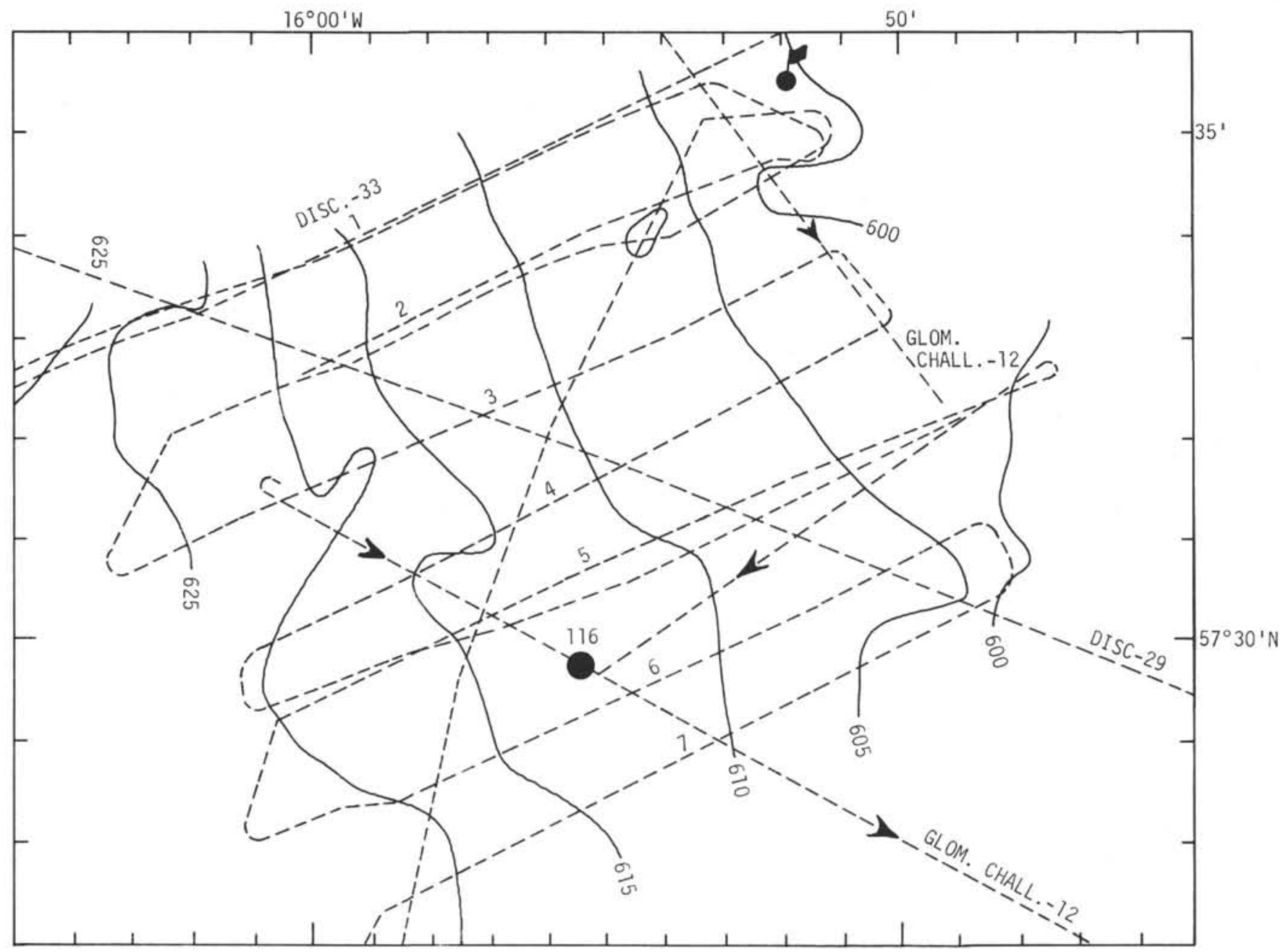

Figure 4. Track chart and bathymetry of site survey around Site 116 by Discovery-33, with Discovery-29 and Glomar Challenger-12 tracks. Depths in uncorrected fathoms (at $800 \mathrm{fm} / \mathrm{sec}$ ): Contour interval 5 fathoms.

Rockall Banks. Furthermore, the Glomar Challenger section suggests the continuity of basement from Hatton Bank to reflector 5 (Roberts et al., 1970). Such continuity could not be established by Discovery on the Rockall side of the basin. Unfortunately basement could not be followed continuously under the basin on the Glomar Challenger record, but the Discovery-29 north profile does show indications of it as deep as 2 seconds.

From the junction with the Discovery-29 north profile, the track crossed the basin to Site 116 on the Discovery-29 central profile. The basin was continuous on this track, and not divided as suggested by Roberts et al., 1970, Figure 1 . The sediment surface was characterized by numerous small indentations which appear to reflect structures in the deeper sediment horizons. They may be related to the wavy topography characteristic of contour current produced ridges. A 90 degree turn near Site 116 altered the spacing of these, suggesting that they are part of a linear pattern.

The approach to Site 116 was controlled only by poor Loran A fixes. A comparison of soundings and subbottom structure with Discovery-33 site survey showed us to be northeast of the site, so the course was altered to the southwest and the speed reduced to 4 knots (Figure 4). This new track crossed a slightly shallower region of reflector 4 shown by the isopachyte map of the site survey
(Figure 5). The gear was recovered and the beacon dropped within a mile of the site chosen on the basis of the site survey.

The position of Site 116 was only established accurately after several days of observations of sun and stars and after the cruise, by calculation from satellite passes. Working a dead reckoning track back from the site and using the site survey data as control, the Loran A fixes were found to be consistently 2 miles too far west (due to sky wave interference).

On site, reflecting horizons were chosen from three available records working with different systems and at different frequencies: Discovery (30 to $300 \mathrm{~Hz}$, Figure 7), Glomar Challenger ( 80 to $160 \mathrm{~Hz}$, Figure 8 and 160 to 320 $\mathrm{Hz}$, Figure 10). It was difficult to correlate reflectors on all three records. The best defined were obtained on the 160 to $320 \mathrm{~Hz}$ record and were labeled 1,2,3 and 4 to conform to the Discovery labels (Roberts et al., 1970). Of the upper reflectors, 1 and 3 are the strongest. Reflector 4 was somewhat diffuse and more variable in depth near the site than the higher ones, and lay about 0.80 to 0.90 second depth.

While drilling, no correlations were made between lithological changes and reflectors 1 to 3 . This was partly a result of the widely spaced cores. Reflector 1 which shows 


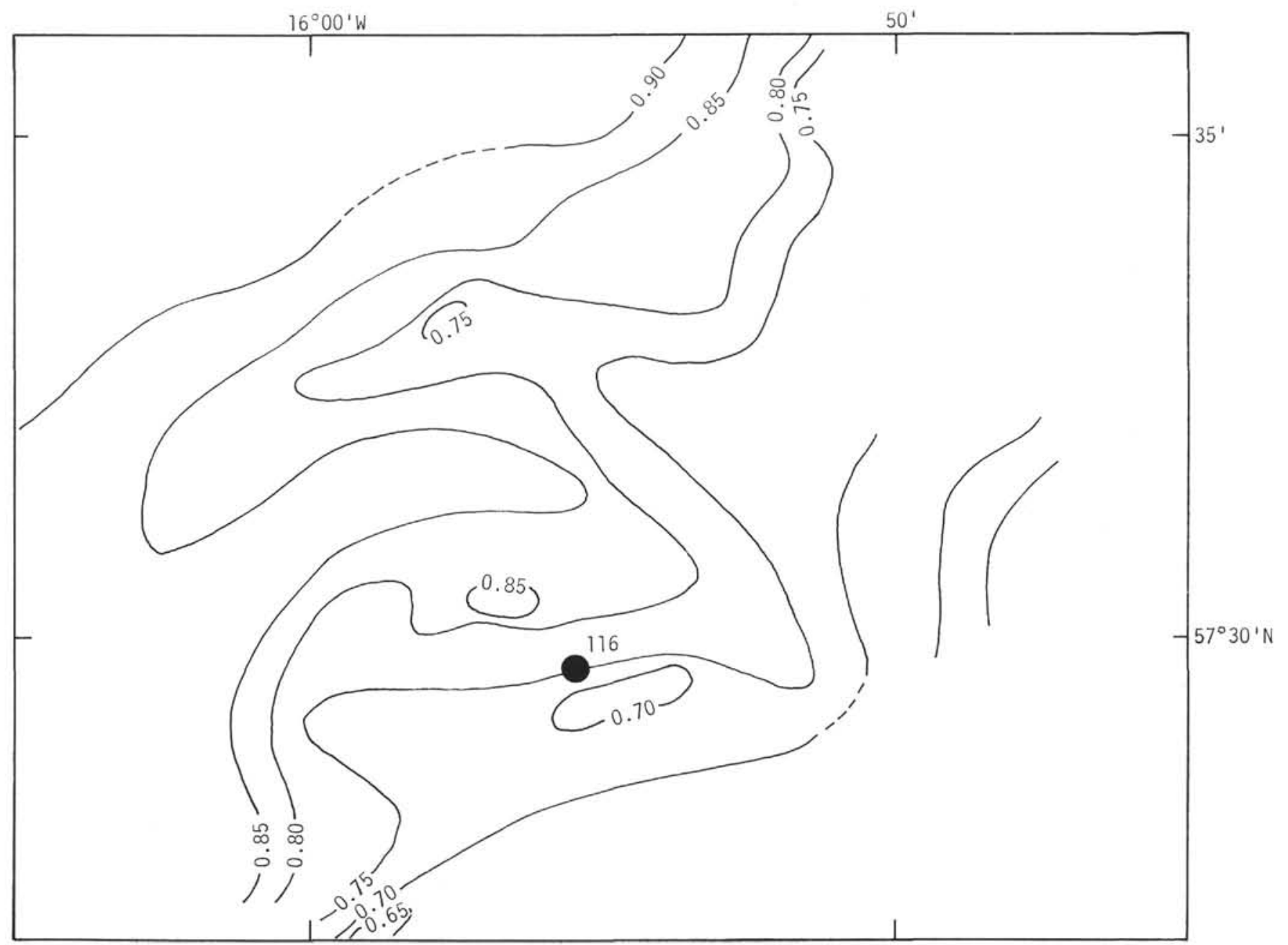

Figure 5. Isopachyte map (in seconds of two-way travel time) to Reflector 4.

strongly on the 160 to $320 \mathrm{~Hz}$ record and which would be expected at about 270 meters $(0.31$ second at $1.75 \mathrm{~km} / \mathrm{sec})$ failed to show as a drilling break. However reflectors 2 and 3 (520 and 615 meters) do relate in general to an increase in drilling hardness below 480 meters.

Reflector 4, expected at 700 meters, assuming a velocity of $1.75 \mathrm{~km} / \mathrm{sec}$, corresponded to a general increase in drilling hardness associated with hard chalks and cherts. It is discussed in greater detail in the discussion section at the end of this chapter. No seismic reflector could be correlated with the massive hard chalk sampled below 823 meters.

On leaving the site, gear was streamed while steaming WNW away from the site for 3 miles and a crossing was made over the beacon at 4 knots going ESE (Figure 4). The records were not good owing to $60 \mathrm{~Hz}$ interference, and contributed little new data on this site. The track followed the Discovery-29 track towards Rockall Bank to select a site for Hole 117, to continue the section below reflector 4 to the basement. The geophysical data pertinent to this area will be discussed under Site 117, although the story is essentiallv continuous with Site 116.

\section{DRILLING OPERATIONS (116)}

The beacon was dropped at 0830 hours on July 17 th in 1151 meters of water. After 25 minutes the signal became intermittent and then failed. Another beacon was dropped as soon as possible. The bottom assembly on the drill string consisted of a Smith 3-cone tungsten carbide insert bit, 10 drill collars and 3 bumper-subs, totaling 40,000 pounds.

The first core was cut at 50 meters depth, but on trying to recover the core barrel, the overshot became locked onto the barrel which was jammed. Repeated jerks of the sand line sheared a release pin. To recover the core barrel, the whole string had to be brought to the surface. It was found that a loose pin on the core barrel locking mechanism had prevented it from reaching the bottom so no core was retained.

The second entry into the bottom was not given an "A" number since no samples were obtained from the first, although some mud was obtained from the bit containing Lower Pleistocene material. The first core for the new hole was therefore taken at 70 meters. Thereafter until 650 meters, cores were cut every 50 meters. Full core barrels were obtained from these, but the degree of disturbance was very high and the sediment was very fluid. Often sections of the core contained little other than a slurry of white coccolith ooze. This may have been due to the increasing heave of the ship due to the weather, to the disturbing action of a 3-cone bit in sampling soft sediments, or to the need to use occasional bursts of circulation to clear the bit. 


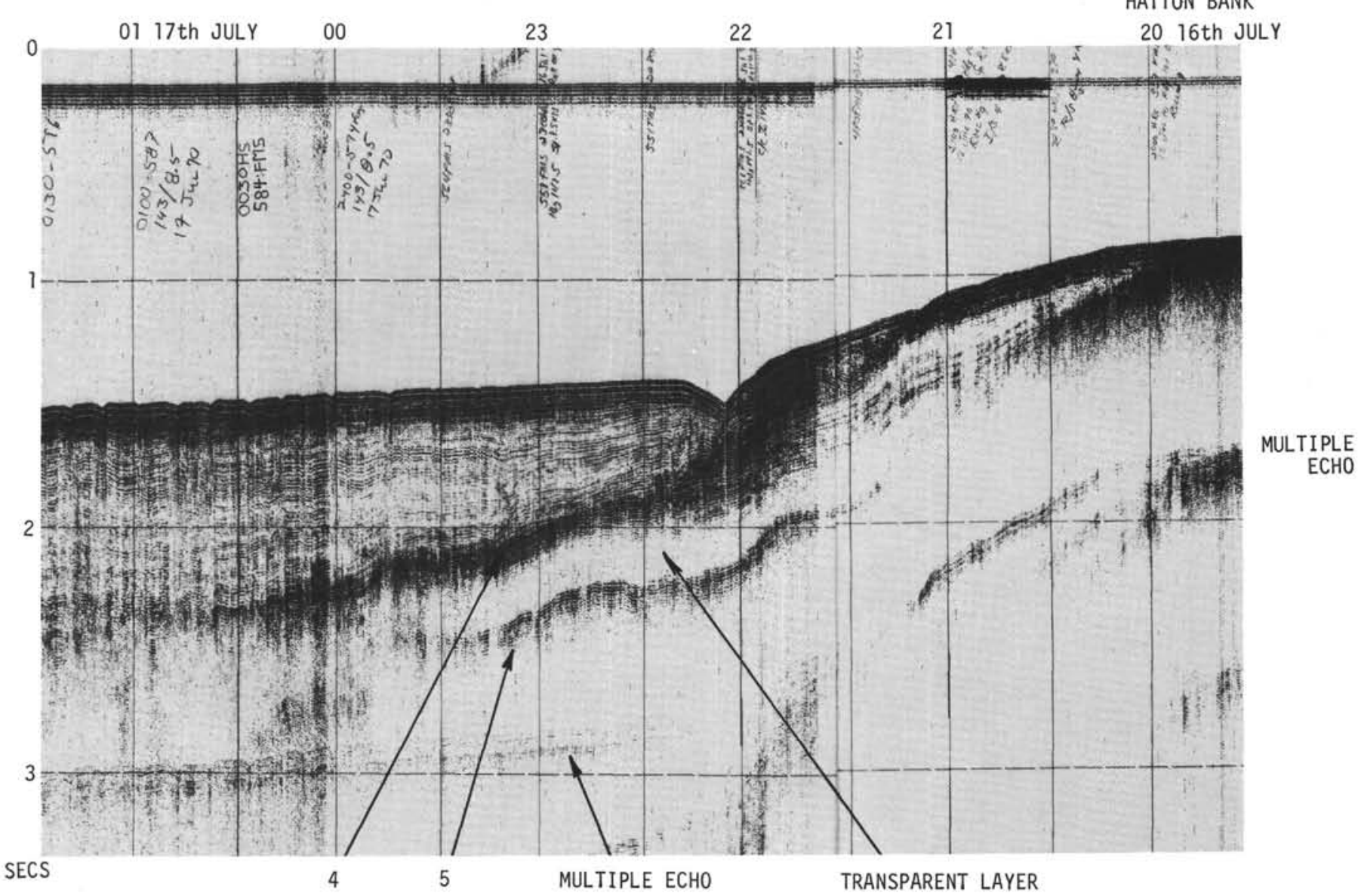

Figure 6. Seismic reflection profile by Glomar Challenger-12 across east side of Hatton Bank (80-160 Hz).

From Core 13 (649 meters) downward, continuous cores were cut in order to locate and identify reflector 4 , the predicted depth of which is dependent on the velocity chosen for the sediments above. The first core was cut using a different technique to avoid obtaining cores filled with water during breaks of circulation. Core 13 was cut with higher bit weight of 5 to $20 \mathrm{klb}$, to avoid the bit lifting off the bottom of the hole, but had to be stopped after $4 \mathrm{~m}$ because the bit became plugged. Core 14 used continuous circulation at 7 s.p.m. However both cores gave only short pieces of hard chalk in the core catcher and no soft sediment. Cores 15 to 22 were cut with no circulation except short breaks. In Core 19, drilling became harder and the core was withdrawn after 3 meters were cut before continuous circulation was necessary. In Cores 20 to 22 (701 to 728 meters), thin hard bands of chert were recovered interbedded with softer sediments.

The failure to find the unconformity expected at reflector 4 at a depth of about 700 meters led to an opening up of the core spacing. An interval of 22 meters was drilled before Core 23 was obtained which was below the Upper Oligocene/Lower Oligocene unconformity although the lithology appeared similar to that above. The bottom 3 meters were hard to cut, and more chert was found in the core. Alternating layers of hard and softer sediment were encountered down to 823 meters. Mud was spotted down the hole in order to try to remove the chert chippings which were accumulating in the hole bottom and sucked back while cutting a core, or while retrieving the core barrel.

While drilling down from Core 25 ( 806 to 810 meters), continuously hard material was encountered at 823 meters, which drilled more smoothly than the chert beds which snatched at the drill string. This was cored in 26 and $27(825$ to 840 meters) and gave a clean cut column of crystalline cherty chalk. Circulation of 15 s.p.m. was used to cut these, so any soft sediment was washed away. However 9 meters of rock were recovered from 15 meters cored. The last 2 meters of Core 27 were soft, so Core 28 was cut without circulation. However, a hard layer was again encountered and the core barrel was withdrawn after 1 meter had been cut. Hard chalk, ooze and some gray clay were recovered of Upper Eocene age.

It was intended at this stage to drill onward into the transparent layer below reflector 4. From 841 to 854 meters, drilling alternated between hard and soft layers and proceeded only at about 8 meters an hour. In view of the time available and the considerable depth to reflector 5, we decided that it was more profitable to withdraw from the hole at this site and to drill another hole at a site further east where the transparent layer is thinner and where basement is accessible. At 2300 hours on July 20th, we withdrew pipe up to the mud line. 


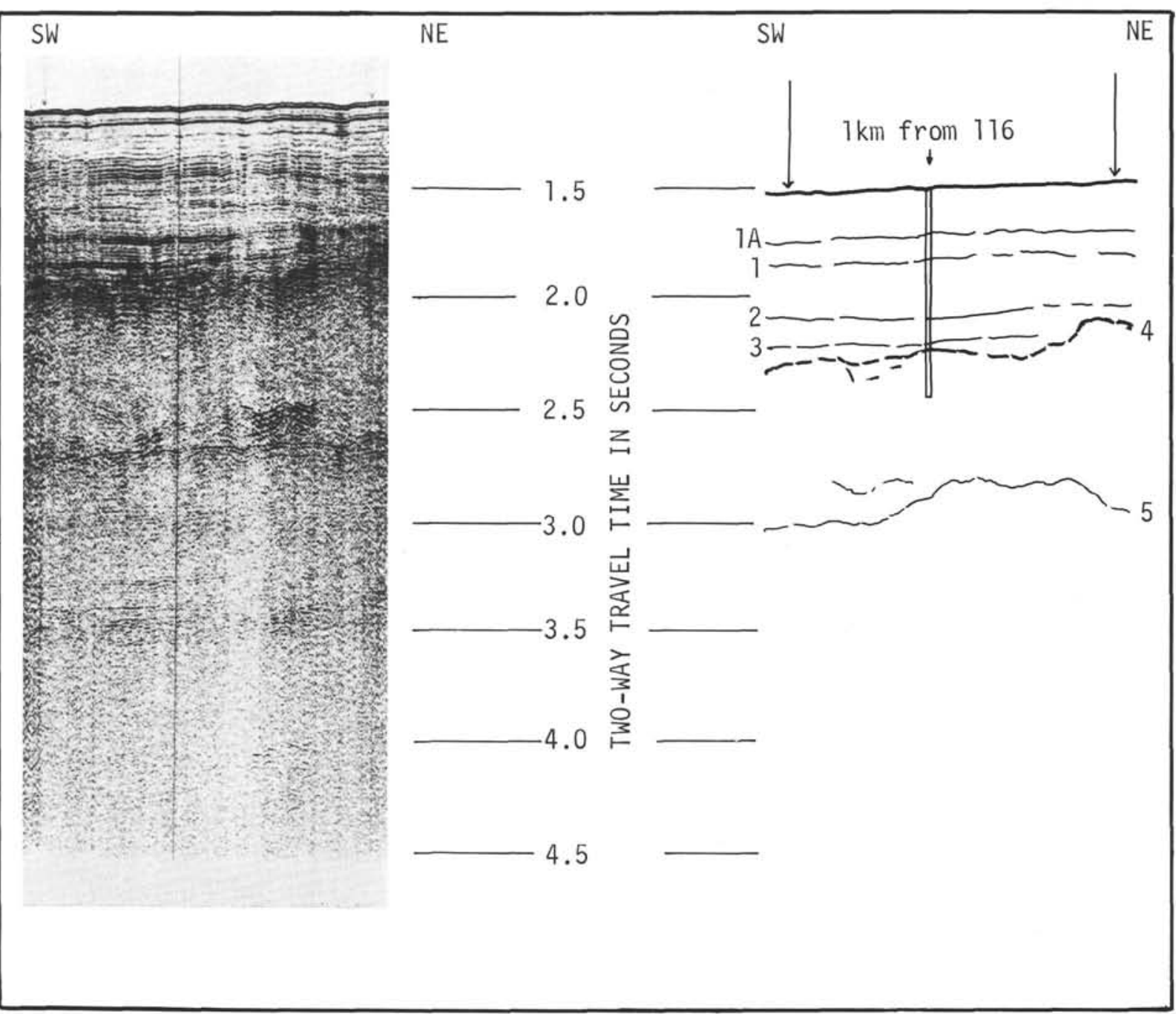

Figure 7. Seismic reflection profile of Leg 6 of site survey at 116 by Discovery-33 (30-300 Hz).

The upper layers of sediment at this site were expected to contain a good record of Pliocene-Pleistocene glaciation. A series of continuous cores was taken, therefore, from surface to 99 meters in Hole 116A by re-entering the bottom without moving ship. A considerable overlap was necessary below Core 1 of Hole 116, since there appeared to be an inconsistency of age between 116-1 and 116A-9 at equivalent depths. However the cores were all highly disturbed and the inconsistency may be more apparent than real.

All the gear was aboard and secured by 1845 hours July 21 st. Thirty-nine cores had been cut, a total of 325 meters of which 284 meters were recovered. The weather during the 4.5 days on site had again been kind with winds less than 20 knots from the west and north, and sea and swell less than 8 feet.

\section{SURVEY DATA (117)}

The track from Site 116 southeast onto Rockall Bank (Figure 9) was located along the track of the Discovery-29 profile in order to find a suitable site on the flanks of
Rockall Bank where the transparent layer below reflector 4 was near to the sea floor, where basement was within drilling reach and where there was enough sediment cover to stabilize the drill before hitting a hard layer.

The profile (Figure 10) was run to a point where it was thought there might be a pond of sediments. However, this site looked unpromising when we got there, and a site was chosen further down the slope where the upper sediments of the Hatton-Rockall Basin met the slope. The ship slowed from 8 to 4 knots while crossing the chosen site going down the slope, the profiling gear was recovered and the position reoccupied.

The profiles confirmed the draping of the transparent layer onto the rising basement of Rockall Bank and further indicated that reflector 4 consisted of a complex series of reflectors. Some of these appeared to outcrop on the slope and give rise to the cliffs and benches found there, suggesting tectonic disturbances.

When drilling was finished, the ship ran 3 miles at 069 degrees while streaming gear, then reversed course to cross 
TABLE 1

Cores Cut at Site 116

\begin{tabular}{|c|c|c|c|}
\hline Hole & Core & $\begin{array}{l}\text { Cored interval } \\
\text { (m, subbottom) }\end{array}$ & $\begin{array}{c}\text { Core recovered } \\
(\mathrm{m})\end{array}$ \\
\hline 116 & 1 & $70-79$ & 9.00 \\
\hline 116 & 2 & $109-118$ & 9.10 \\
\hline 116 & 3 & $159-168$ & 9.20 \\
\hline 116 & 4 & $209-218$ & 8.80 \\
\hline 116 & 5 & $259-268$ & 9.10 \\
\hline 116 & 6 & $309-318$ & 5.90 \\
\hline 116 & 7 & $359-368$ & 9.28 \\
\hline 116 & 8 & $409-418$ & 3.15 \\
\hline 116 & 9 & 459.468 & 4.50 \\
\hline 116 & 10 & $509-518$ & 9.20 \\
\hline 116 & 11 & $559-568$ & 9.25 \\
\hline 116 & 12 & $599-608$ & 9.28 \\
\hline 116 & 13 & $649-653$ & 0.15 \\
\hline 116 & 14 & $653-662$ & 0.10 \\
\hline 116 & 15 & $662-671$ & 9.28 \\
\hline 116 & 16 & $671-680$ & 9.28 \\
\hline 116 & 17 & $680-689$ & 9.28 \\
\hline 116 & 18 & $689-698$ & 9.28 \\
\hline 116 & 19 & $698-701$ & 6.90 \\
\hline 116 & 20 & $701-710$ & 7.50 \\
\hline 116 & 21 & $710-719$ & 9.28 \\
\hline 116 & 22 & $719-728$ & 9.28 \\
\hline 116 & 23 & $750-759$ & 9.27 \\
\hline 116 & 24 & $759-768$ & 0.80 \\
\hline 116 & 25 & $806-810$ & 7.65 \\
\hline 116 & 26 & $825-831$ & 5.09 \\
\hline 116 & 27 & $831-840$ & 3.85 \\
\hline 116 & 28 & $840-841$ & 2.60 \\
\hline $116 \mathrm{~A}$ & 1 & 0-9 & 2.24 \\
\hline $116 \mathrm{~A}$ & 2 & $9-18$ & 6.40 \\
\hline $116 \mathrm{~A}$ & 3 & $18-27$ & 8.60 \\
\hline $116 \mathrm{~A}$ & 4 & $27-36$ & 8.07 \\
\hline $116 \mathrm{~A}$ & 5 & $36-45$ & 5.46 \\
\hline $116 \mathrm{~A}$ & 6 & $45-54$ & 8.97 \\
\hline $116 \mathrm{~A}$ & 7 & $54-63$ & 7.73 \\
\hline $116 \mathrm{~A}$ & 8 & $63-72$ & 7.70 \\
\hline $116 \mathrm{~A}$ & 9 & $72-81$ & 9.00 \\
\hline $116 \mathrm{~A}$ & 10 & $81-90$ & 8.15 \\
\hline $116 \mathrm{~A}$ & 11 & $90-99$ & 9.28 \\
\hline
\end{tabular}

the beacon at 6 knots. This profile (Figure 11) crossed the slope at an angle of 50 degrees to the approach track. Basement could be easily followed for 7 kilometers from the site but thereafter suddenly dropped away. Faint echoes from reflector 5 were seen shortly afterwards but no

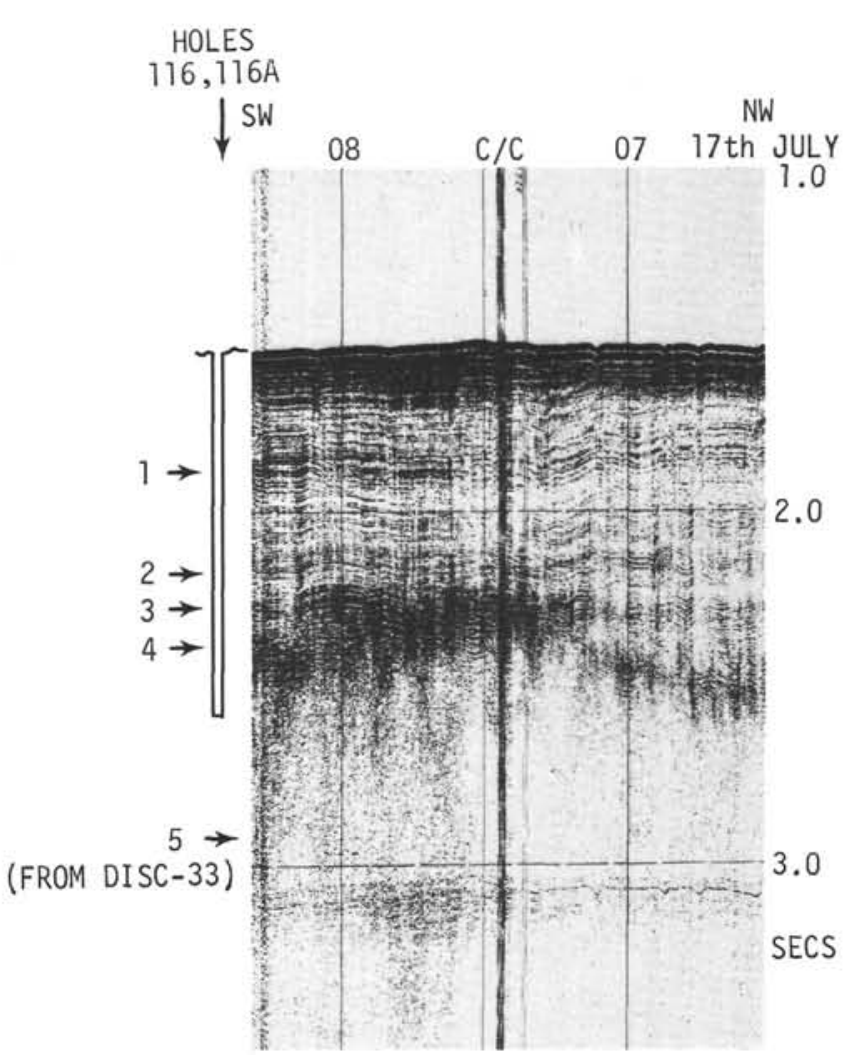

Figure 8. Seismic profile during approach to Site 116 by Glomar Challenger-12 (80-160 Hz).

continuity of basement with reflector 5 could be established.

The passage towards the next site was chosen to explore the southern extension of the Hatton-Rockall Basin. Apart from crossing a spur of Rockall Bank, the thick Miocene sediments of the basin were followed for a distance of 300 kilometers SSW right to the steep southern scarp of the Rockall Plateau (Figure 1). The Hatton-Rockall Basin therefore covers an area of approximately 400 by 100 kilometers (40,000 square $\mathrm{km})$.

At Site 117, reflections were seen in the range of 0.04 to 0.16 second and these were all ascribed to reflector 4 . It was expected, therefore, that in this zone indurated oozes, chalk and chert layers would be found similar to those drilled in Site 116 between 700 and 840 meters. These were in fact found in the depth range of 15 to 150 meters and correspond in age with sediments below the unconformity at Site 116. A mean velocity of $1.75 \mathrm{~km} / \mathrm{sec}$ for this sequence would give rise to reflections between 0.02 and 0.17 second, in good agreement with the seismic observations.

The basement reflection, from the seismic section after completion of drilling, occurs at 0.32 secs. A closer study, however, shows this to consist of three reflectors between 0.32 and 0.355 second which can be correlated with the hard clay, sandstone and basalt sampled at 280, 303 and 311 meters. These are discussed in relation to acoustic impedance changes in the section on physical properties. 


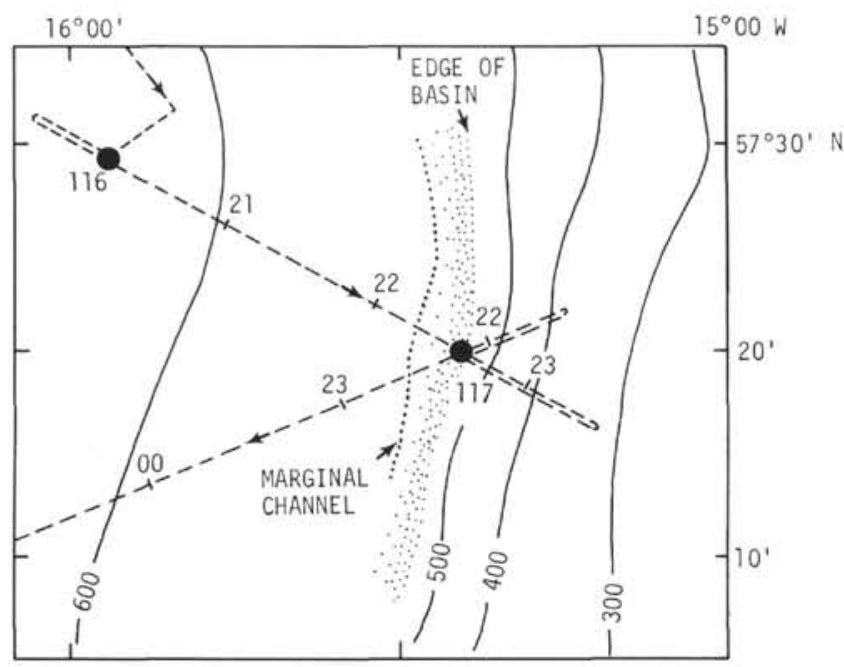

Figure 9. Tracks around Sites 116 and 117. (Depths in corrected fathoms).

\section{DRILLING OPERATIONS (117)}

The beacon was lowered at 0124 hours on July 22 nd in 1038 meters of water. The bottom hole assembly consisted of a Smith 4-cone tungsten carbide insert bit below 10 drill collars and 3 bumper-subs, a total weight of 40,000 pounds.

The sea floor was soft and only felt by the pump pressure change. However after washing in down to 16 meters, a moderately hard layer was encountered, the first of several in the top 100 meters. A small amount of weight on the bit was necessary and considerable circulation. Some gentle rotation was needed to cut through these layers, which turned out in Core 1 at 50 meters to be thin chert.

Core 1 was cut without circulation in order to preserve soft sediment and progressed very slowly. After 2 meters, the bit became plugged up and the core barrel was withdrawn. Considerable quantities of chert cuttings were recovered.

Between Core 1 and 2 at 100 meters, two pumps were used for circulation and drilling alternated between slow on hard layers and fast in between. Before cutting Core 2, mud was spotted through the circulation to remove chert chippings. Core 2 started hard, and a 10 s.p.m. pump was used. However it became softer and the pump was stopped for the last meter.

Twenty-two meters of soft drilling followed, before some more hard layers were met. Core 3 at 147 meters was cut initially with minimum circulation. However after 3 meters, the bit plugged up and considerable pumping, and raising and lowering of the drill string was necessary to restore circulation. Again chert cuttings were recovered in the core.

Throughout the period of drilling of Hole 117, the weather conditions got progressively more difficult. A fresh wind from the west required considerable engine power to maintain position head to wind; at the same time a long swell of 5 meters amplitude came from a storm in the north. This resulted in heavy rolling (up to $17^{\circ}$ either side) which made work difficult and dangerous on the drill floor. Moreover the heave of the drill platform (measured by the echo sounder to be between 3 and 6 meters) made it impossible to keep the bit on the bottom or to take good cores. The drilling superintendent decided that it was necessary to withdraw from the hole until the weather moderated. Core 3 was still in the core barrel at the bottom while withdrawing to the mud line. A sample of gray clay found in the core catcher was attributed, therefore, to a layer sampled near the top of the hole. On the basis of Hole $117 \mathrm{~A}$, it was later thought to have been sampled at the bottom of the hole.

At 0200 hours on July 23rd, the entire drill string was on board and inspected. It was found that two bumper-subs were seized up and the bit badly worn by the pounding of the heaving ship. A new bottom assembly started down into Hole $117 \mathrm{~A}$ at 0530 hours, and bottom reached at 0930 hours. The wind had by now dropped to light and the swell had gradually decreased during the night. It was possible to maintain the ship head to swell and keep her steady.

We drilled, using a center bit and 60 s.p.m. on two pumps, down to 150 meters to take the first core. The same hard layers of chert were encountered resulting in considerable torque variations.

Before coring, 60 barrels of drilling mud were shot to clear the chips. In Core 1, however, a considerable quantity of chips was recovered as well as the chalk and gray clay found in 117-3. The clay was found to be Lower Eocene indicating an unconformity below the Oligocene coccolith ooze, chalk and chert.

The next core was taken, therefore, at 174 meters and showed us to be still in the gray clay/silt sequence. Drilling now became very easy and fast, but great care had to be exercised to avoid the chert cuttings flushing back into the hole and core barrel while coring. Mud was spotted and the hole flushed before coring. To recover the soft sediment, minimum circulation was used during coring and some short bursts used for flushing. Core 4 was pulled prematurely because the bit became plugged. One hundred barrels of mud were used before Core 5 , but the bit became plugged once again after 3 meters were cut. To prevent back flow due to cuttings when opening the pipe to extract the core barrel, more mud was spotted during barrel recovery. This resulted in considerable bentonite contamination in the core.

The hole was continuously cored from Core 4 (270 meters) downward. Cores 6,7 and 8 required continuous low circulation and gave improved recovery. The sediment became progressively harder and coarser. The chert chippings problem improved.

Core 9 at 303 meters hit hard material thought to be basement and was withdrawn after 1 meter, yielding a highly fossiliferous gray sandstone. However this was not believed to be basement, and Core 10 penetrated to a softer layer again. Again gray sandstone was recovered.

At 311 meters, Core 11 was cut into an extremely hard layer. With 30,000 pounds on the bit no noticeable progress was made in over two hours. However on withdrawal, it was found that 1.85 meters of basalt had been cut. The hole was therefore finished at 1345 hours on July 24 th and the drill string was on board by 2030 hours.

In fourteen cores, 86 meters had been cut and 42 meters recovered (49 per cent).

The weather improved steadily throughout the second hole, the fresh westerly winds dying to nothing and the northerly swell fading away. 


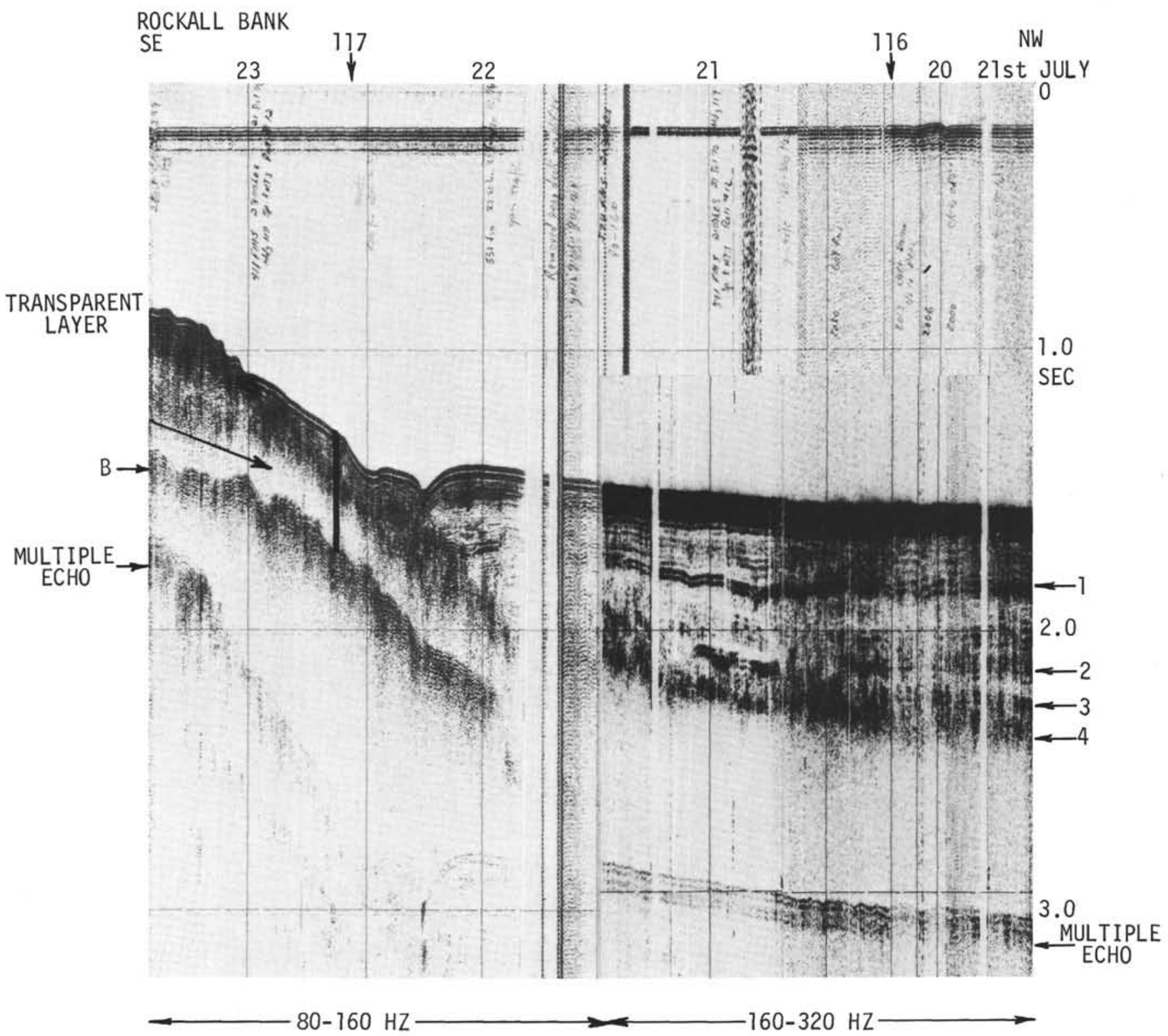

Figure 10. Seismic reflection profile across Sites 116 and 117 onto west side of Rockall Bank (at 160-320 Hz to 2145, then at $80-160 \mathrm{~Hz}$ ).

\section{LITHOLOGY}

Sites 116 and 117 are situated only 37 kilometer apart. Because of this and the possibility of stratigraphic continuity between the two sites, according to reflection records, the lithologies recovered from Holes 116, 116A, 117 and $117 \mathrm{~A}$ are described together.

The following general sequence was found:

\begin{tabular}{|c|c|c|}
\hline \multicolumn{2}{|l|}{$\begin{array}{l}\text { Site } 116 \\
\text { Depth }(\mathrm{m})\end{array}$} & $\begin{array}{c}\text { Site } 117 \\
\text { Depth }(\mathrm{m})\end{array}$ \\
\hline$-0-$ & $\begin{array}{l}\text { 4. Foraminiferal nannofossil ooze, } \\
\text { foraminiferal sand and silty clay. }\end{array}$ & \\
\hline$->854$ & 3. Limestone, chalk and ooze. & $145-$ \\
\hline & 2. Clay and basal clastic sediments. & \\
\hline
\end{tabular}

Only units 3 and 4 were sampled at Site 116 and units 1 to 3 at Site 117. The various lithologies are discussed below starting with the basalt.

Summary grain size diagrams for each site are presented in Figures 12 and 13. At Site 116 sand contents in excess of 10 per cent were only found in glacial sediments (4. in the above sequence). The single high sand content at Site 117 was in a sample of glauconitic ooze; the remaining grain size samples were Lower Eocene clay.

\section{Basalt and Sedimentary Infill of Cracks (117A, Core 11)}

This is a weathered and fractured olivine basalt in which the cracks are partly filled with micritic or zeolitic calcisparite containing Lithothamnium fragments, thick mollusc shell fragments (mostly lamellibranchs, some gastropods, all with borings), bryozoans, foraminifera (for example, Operculina), and a few basalt pebbles. Fossils 
TABLE 2

Cores Cut at Site 117

\begin{tabular}{lrcc}
\hline Hole & Core & $\begin{array}{c}\text { Cored Interval } \\
(\mathrm{m} \text {, subbottom })\end{array}$ & $\begin{array}{c}\text { Core Recovered } \\
(\mathrm{m})\end{array}$ \\
\hline 117 & 1 & $50-52$ & 1.00 \\
117 & 2 & $100-109$ & 6.00 \\
117 & 3 & $147-156$ & 1.50 \\
$117 \mathrm{~A}$ & 1 & $146-155$ & 1.50 \\
$117 \mathrm{~A}$ & 2 & $174-183$ & $\mathrm{cc}$ only \\
$117 \mathrm{~A}$ & 3 & $222-227$ & 7.25 \\
$117 \mathrm{~A}$ & 4 & $270-272$ & 8.58 \\
$117 \mathrm{~A}$ & 5 & $272-276$ & 1.40 \\
$117 \mathrm{~A}$ & 6 & $276-285$ & 4.50 \\
$117 \mathrm{~A}$ & 7 & $285-294$ & 5.60 \\
$117 \mathrm{~A}$ & 8 & $294-303$ & 2.88 \\
$117 \mathrm{~A}$ & 9 & $303-304$ & 0.40 \\
$117 \mathrm{~A}$ & 10 & $304-311$ & 0.36 \\
$117 \mathrm{~A}$ & 11 & $311-313$ & 1.85 \\
\hline
\end{tabular}

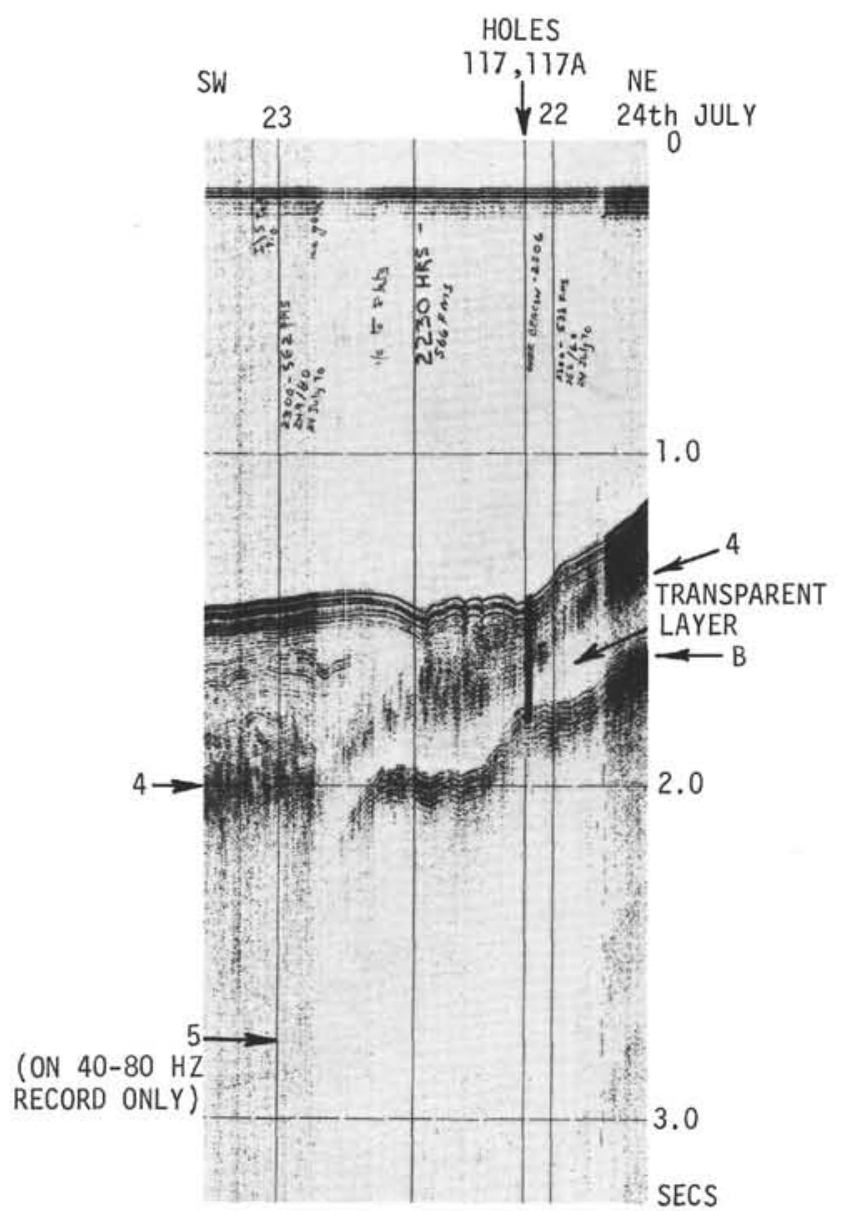

Figure 11. Seismic reflection profile after leaving Site 117 $(80-160 \mathrm{~Hz})$.
GRAIN SIZE FOR SITE 116

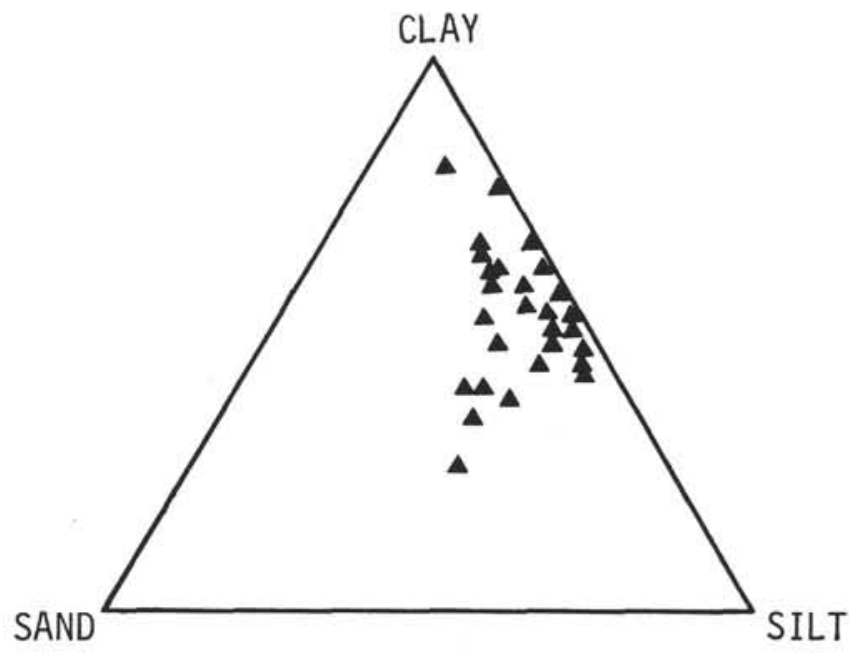

Figure 12. Grain size triangular diagram for Site 116.

\section{GRAIN SIZE FOR SITE 117}

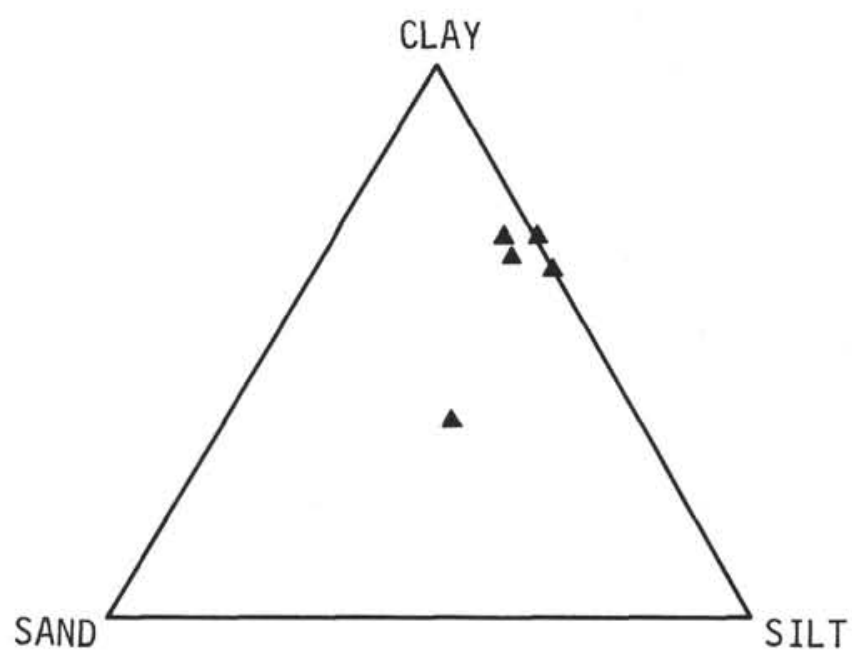

Figure 13. Grain size triangular diagram for Site 117.

found in the basalt fissures are indicative of shallow water conditions and are similar to fauna found in the overlying sediment.

Petrological descriptions of the basalts by Aumento, Clarke and Cann, a section on opaque mineralogy by Ryall and a separate report by Sabine, follow below. A comparison of the strontium and lead isotope ratios of the basalt with those of Rockall Island (Moorbath and Welke, 1969) was not considered to be possible owing to the weathered nature of the samples, and therefore isotope measurements were not attempted. 


\section{Preliminary Petrography of the Basalt}

F. Aumento and B. C. Clarke, Dalhousie University, Halifax, Nova Scotia, and

J. R. Cann, University of East Anglia, Norwich, U. K.

117A-11-1, 1-6 cm:

This is a specimen of calcareous sediment attached to weathered basalt. The sediment is rich in foraminiferal tests, bryozoans and rounded basalt fragments, some of which are highly altered. All of the components appear to be reworked, and in some cases, for example where bryozoans and basalt form part of the same clast, it can be demonstrated that their history prior to deposition must have been complex. The specimen is cut by a vein of iron-manganese oxide.

$117 \mathrm{~A}-11-2,13-20 \mathrm{~cm}, 26-32 \mathrm{~cm}, 44-47 \mathrm{~cm}, 47-52 \mathrm{~cm}$ and $107-114 \mathrm{~cm}$ :

All of the samples are of porphyritic, medium-grained basalt. Abundant phenocrysts of olivine, replaced by iddingsite and carbonate, and rare ones of plagioclase, are present. The groundmass consists of plagioclase laths $\left(\mathrm{An}_{65}\right), 1 \times 0.2$ millimeters in size, showing a rough flow texture, granular olivine altered to iddingsite and carbonate, and granular clinopyroxene and iron ore. Interstitial areas are filled with dark green chlorite. Plagioclase shows some replacement by saussurite. Thick veins cut the rock, and are filled with carbonate, chlorite (often radiating), analcite and radiating bunches of natrolite.

117A-11-2, 66-68 cm:

A calcareous sediment in contact with a highly weathered, medium-grained basalt. The sediment contains highly recrystallized debris of planktonic foraminifera.

The basalt of these specimens is a slowly cooled olivine basalt. The presence of olivine in the smallest crystal sizes suggests alkaline affinities. In several ways that are hard to define, this basalt is unlike ocean floor basalts. The abundance of olivine phenocrysts coupled with a paucity of plagioclase phenocrysts is unusual, as is the coarse grain size. The ground mass texture, with its rectangular blocky plagioclase crystals, is atypical, and so too are the areas filled with bright green chlorite. Analcite and natrolite are rare as vein fillings in ocean floor basalts. All in all, there is a suggestion here that this basalt is not of the ocean floor basalt type, and may have been formed by some other volcanic process than those operating at mid-ocean ridge crests. Geochemical information will be necessary before this suspicion can be substantiated, and this will require the availability of larger samples.

Trace element analyses have yielded the following results (in $\mathrm{ppm}$ ):

$\begin{array}{cccccc}\mathrm{Ti} & \mathrm{Rb} & \mathrm{Sr} & \mathrm{Y} & \mathrm{Zr} & \mathrm{Nb} \\ 11400 & 10.5 & 520 & 18 & 150 & 12\end{array}$

These results lie outside the range of composition of ocean floor basalts, and the sample appears to be an alkali basalt accumulated in olivine, such as is found on ocean islands and on continents.

\section{Opaque Mineralogy of Basalt}

Patrick J. C. Ryall, Dalhousie University, Halifax, Canada

Examination of polished sections has been carried out using a Reichert Zeto Pan Microscope. Total magnification was X1350. In the descriptions given below titanomagnetite deuteric (high temperature) oxidation is quoted on a 1 to 6 scale, where:

Class 1: homogenous titanomagnetite

Class 2 and 3: magnetite with increasing amounts of ilmenite lamellae

Class 4: oxidation of ilmenite lamellae to ferri-rutile and titanohematite

Class 5: appearance of black spinel spicules in remaining magnetite

Class 6: complete replacement of titanomagnetite by titanohematite, pseudobrookite and/or ferri-rutile

117A-11-1, 1-6 cm:

Relatively few magnetite grains. Those seen being uniformly gray brown (probably maghemitized) Class 1 with one probable Class 4. Fine hematite is widely disseminated throughout the specimen giving a red-orange background silicate color.

117A-11-2, 26-32 cm:

Large skeletal pale grey brown Class 1 magnetites. 117A-11-2, 107-114 cm:

Several very large (100 micron) grains of gray white (probably maghemitized) Class 1 magnetite.

The large grain size of the titanomagnetite (up to 100 microns) is more typical of subaerial than of submarine basalts, consistent with the observation of very shallow water sediments lying immediately above.

\section{Preliminary Report on the Basalt}

P. A. Sabine, Institute of Geological Sciences, London, U.K.

\section{Introduction}

The specimens examined (Plate 1) are of core recovered immediately beneath the Paleocene conglomerate in Hole $117 \mathrm{~A}$ of Leg $12,57^{\circ} 20.17^{\prime} \mathrm{N}, 15^{\circ} 23.97^{\prime} \mathrm{W}$. The specimen is from $117 \mathrm{~A}-11-2,311$ to 313 meters below sea bed, that is, 1350 meters below sea level.

The upper specimen (117A-11-2, 0 to 10 centimeters) consists of olivine-basalt with one large vesicle about $35 \mathrm{X}$ $15 \times 10$ millimeters, with a sparry mineral lining, 1 millimeter thick, and there are mineral veins, approximately horizontal in the core and many small amygdales filled with microcrystalline material. A second specimen (117A-11-2, 140 to 150 centimeters) is about 1.3 meters lower down. Material for analysis was removed and thin sections were cut from each portion of core before the remainder was removed for examination to determine whether analysis of strontium and lead isotopic ratios (at Oxford University) was possible.

\section{Petrography}

Both specimens are altered olivine-basalts. The higher is the more altered. Density, porosity and color values 
were obtained by R. W. Sanderson for two specimens, as follows:

\begin{tabular}{lcccc}
\hline Specimen & $\begin{array}{c}\text { Saturated } \\
\text { Density } \\
\rho \text { s gm/cc }\end{array}$ & $\begin{array}{c}\text { Dry } \\
\text { Density } \\
\rho \mathrm{d} \text { gm/cc }\end{array}$ & $\begin{array}{c}\text { Grain } \\
\text { Density } \\
\rho \mathrm{g} \text { gm/cc }\end{array}$ & $\begin{array}{c}\text { Effective } \\
\text { Porosity } \\
\%\end{array}$ \\
\hline $\begin{array}{l}117 \mathrm{~A}-11-2, \\
0-10 \mathrm{~cm}\end{array}$ & 2.62 & 2.55 & 2.73 & 6 \\
$\begin{array}{l}117 \mathrm{~A}-11-2, \\
140-150 \mathrm{~cm}\end{array}$ & 2.55 & 2.45 & 2.70 & 9 \\
\hline
\end{tabular}

The specimens, when dry, have color values close to $5 \mathrm{GY}$ 6/1 and to a lesser extent 5G 6/1 (Munsell, 1969). The densities and effective porosities of the rocks were obtained by a method similar to that of Parasnis (1952). Owing to the presence of natrolite in the veins cutting the rocks, the specimens were dried at a temperature of $43^{\circ} \mathrm{C}$ or slightly less instead of the usual $110^{\circ} \mathrm{C}$. Because of this low temperature drying some water may have been retained within the rock. Therefore of the above values $\rho \mathrm{d}$ may be slightly high and $\rho$ g slightly low.

The rock is seen in thin section (F7159 ${ }^{2}$, Plate 2, Figure 1) to be composed of laths of feldspar commonly 0.25 millimeter or less in length, pseudomorphs after olivine, plentiful fine-grained pyroxene, plentiful titanomagnetite, mainly in equidimensional crystals, and partly in skeletal form, possibly orthopyroxene, and abundant chloritic, or serpentinous mineral, the margins of individual areas of which are bright green. The rock displays some foliation. The pseudomorphs after olivine microphenocrysts are commonly 0.7 millimeter or less in length but form glomeroporphyritic aggregates. They are composed of carbonate and colorless chloritic matter, with deep brown or red limonitic rims, perhaps in part iddingsite.

The feldspar laths are considerably altered to very fine-grained material, much of it pale-green. Its grain size is too fine to allow readily a determination of the birefringence, but it appears to be very low and the mineral is probably chlorite. The plagioclase that remains is labradorite zoned to oligoclase andesine. In crush, the most basic feldspar found was about $\mathrm{An}_{67}$, but the most acid only $\mathrm{An}_{45}$.

The interstitial chloritic matter is partly colorless and very fine-grained but is commonly margined by bright bluish-green, moderately birefringent, vermicular crusts (Plate 2, Figure 2) of 'viridite' which is probably a smectite. Rims of orange-brown iron ore or iddingsite are also present. Bowlingite occurs in some pseudomorphs.

The opaque ore is strongly magnetic (to a small hand magnet). Examination by R. I. Lawson using a 'Geoscan' electron-probe X-ray microanalyzer suggests that it is titanomagnetite, containing about 17 per cent titanium and 2 per cent manganese. The skeletal crystals have about the same composition as the equidimensional ones. In the bright-green bordered viriditic areas, manganese was not a significant constituent of a central brown portion (which was rich in iron) and there was only a little manganese in the green rims.

\footnotetext{
${ }^{2}$ Thin section in the Petrographical collection of the Institute of Geological Sciences, London.
}

The rock is traversed by veins of coarse calcite about 9.5 to 2 millimeters thick among which there are spheroidal growths of orange-brown ore mineral, about 9.15 millimeters across, aggregates of very fine-grained carbonate possibly of higher refringence, and a little low birefringent mineral, presumed analcime. There is a very small amount of more strongly birefringent fibroradiate mineral, probably uniaxial positive, probably chalcedony, situated in the center of a vein and moulded on the carbonate.

In the vesicle, a dense velvety mat of short prisms which display many rosette growths (Plate 3 ) is composed of natrolite. Scattered clear colorless lustrous equidimensional crystals, some interpenetrant, and growing on the natrolite, are of calcite. Natrolite and calcite were noted by Matthews (1962) in cavities in lava from the Western Seamounts; and chalcedony was recorded as an alteration product. The absence of records of carbonate replacement in spilites from oceanic environments was noted by Cann (1969) as one of the features distinguishing them from continental spilites. Natrolite was also recorded by Melson et al. (1968) from rare vesicles in lavas from the Mid-Atlantic ridge.

The lower specimen also displays approximately horizontal 1 to 2 millimeter white veins near which the rock is more altered. A thin section (F7160'; Plate 2, Figure 3) shows abundant pseudomorphs, some after olivine, in an aggregate of plagioclase laths commonly 0.4 millimeter or less in length, prisms and granules of brown pyroxene, plentiful equidimensional (and some skeletal) opaque ore, mainly magnetite, but some leucoxene, and plentiful interstitial chloritic material in compact areas, some with deeper green margins. This magnetite is presumably also a titaniferous variety.

The plagioclase laths contain little chlorite but are mainly fairly fresh bytownite $\left(\mathrm{An}_{72}\right)$ zoned to andesine $\left(A n_{47}\right)$. Plagioclase that occurs in better shaped laths has the higher refringence with the sharper twinning; that with lower refringence is more equidimensional and untwinned, as is common in basaltic rocks.

The calcite, analcime and natrolite were confirmed by X-ray methods (films X5873-6L; 5885) by B. R. Young, who also found in the rock powders smectite which yielded lines at $14-15 \AA$ and lines at $18.0 \AA$ after glycerol treatment. After heat treatment at $500^{\circ} \mathrm{C}$ for 3 hours (film $\times 5932$ ) the material yielded a line at $9.5 \AA$. It was not possible to measure the 14 to $15 \AA$ peak accurately owing to the presence of chlorite. In thin section, R. W. Elliot detected that some of the carbonate in the veins is biaxial negative, with moderate $2 \mathrm{~V}$, but aragonite was not confirmed.

Examination by R. Dearnley using a Quantimet analyzer (F7160) yielded:

$\begin{array}{lr}\text { Plagioclase } & 36.50 \% \\ \text { Magnetite } & 1.05 \% \\ \text { Remainder } & 62.45 \%\end{array}$

The mean grain size length of the plagioclase laths is 0.28 millimeters. The alteration prevented further discrimination of the minerals and it was not possible to obtain any measurements on the more altered thin section, F7159.

The small amygdales (Plate 1) are nearly spherical, the largest being about 5 millimeters in diameter. On a very small cut face of about 1000 sq.mm there were 8 amygdales of approximate diameters, $5,3,2$ and 1 millimeters, 
occupying about 4 per cent of the rock. The infilling is of very fine-grained spherulitic growths, partly chlorite but partly more strongly birefringent material. Plagioclase laths in the rock around the amygdale are tangential to it.

\section{Chemical Analyses, and Norms}

In Table 3, the chemical analyses of the two chips are shown. Both are very basic, although the alteration prevents too thorough discussion. If calcium carbonate ( 12 per cent) is removed from the analysis, Column II, and the analysis recalculated, $\mathrm{SiO}_{2}$ and $\mathrm{Al}_{2} \mathrm{O}_{3}$ percentages become very close to those of Column I, although there are some significant differences in the other elements. Column I thus probably better represents fairly closely the original composition of the rock, if due allowance is made for removal of $\mathrm{CO}_{2}$ and corresponding $\mathrm{CaO}$.

The relatively low chlorine figure shows that there is no gross contamination with sea-water. The $\mathrm{FeO}: \mathrm{Fe}_{2} \mathrm{O}_{3}$ ratio confirms that the alteration is not solely a weathering phenomenon.

The 'norms' are shown in Table 4, although the alteration inhibits their use. In Column IIa, a 'norm' has been calculated to allow for removal of carbon dioxide. The marked disparity between Columns I and II, and IIa, with the appearance of 10.64 per cent nepheline suggests that the calcite has been introduced in that form and has not been produced at the expense of the calcium-bearing minerals. The normative ferromagnesian minerals occur modally in pyroxene and olivine, and much less modal magnetite and ilmenite are present

Within Yoder and Tilley's five-fold division of the basalts (1962), the rock-having normative hypersthene and olivine-may be classed as olivine-tholeiite. Although it is not a true spilite, it has affinities with this group, and comparable rocks associated with spilite have been recorded by Cann (1969) from the Carlsberg Ridge.

\section{Origin of the Basalt}

It is of some interest that both rocks fall in the field in which both normative nepheline and quartz are lacking, a characteristic that Chayes (for example, 1970) has pointed out is typical of the basalts of deep ocean ridges.

There are no borehole specimens from Rockall Bank itself. Two of the dredged basaltic pebbles from Rockall Bank in the collections of the British Museum (Natural History) have been sliced and are not similar to the DSDP specimens. It is possible that these specimens are not typical of the bank and have been derived from erratics, ballast, etc. One of the British Museum specimens $(1955,279(2 n))$, which the writer saw by courtesy of J. D. H. Wiseman, could be matched very closely among Northern Ireland Tertiary basalts, and these are presumably younger than the altered basalts now described.

The amygdaloidal and vesicular nature of the specimens might suggest that they were extruded subaerially, or only under shallow water conditions. The writer is indebted to G. P. L. Walker for suggesting (personal communication) that the water depth might not be more than 1 kilometer. Some vesicular basalts have been described from under considerable depths, of water, for example from Swallow Bank, eastern North Atlantic, where the depth of water is
TABLE 3

Chemical Analyses of Basalts ${ }^{c}$

\begin{tabular}{|c|c|c|}
\hline & $I^{a}$ & $\mathrm{II}^{\mathbf{b}}$ \\
\hline $\mathrm{SiO}_{2}$ & 43.33 & 38.14 \\
\hline $\mathrm{Al}_{2} \mathrm{O}_{3}$ & 14.73 & 12.81 \\
\hline $\mathrm{Fe}_{2} \mathrm{O}_{3}$ & 4.13 & 7.43 \\
\hline $\mathrm{FeO}$ & 6.54 & 4.29 \\
\hline $\mathrm{MgO}$ & 8.54 & 6.63 \\
\hline $\mathrm{CaO}$ & 9.24 & 11.75 \\
\hline $\mathrm{Ha}_{2} \mathrm{O}$ & 2.37 & 2.40 \\
\hline $\mathrm{K}_{2} \mathrm{O}$ & 0.81 & 1.75 \\
\hline $\mathrm{H}_{3} \mathrm{O}>105^{\circ} \mathrm{C}$ & 3.50 & 4.36 \\
\hline $\mathrm{H}_{2} \mathrm{O}<105^{\circ} \mathrm{C}$ & 2.85 & 2.60 \\
\hline $\mathrm{TiO}_{2}$ & 1.88 & 1.62 \\
\hline $\mathrm{P}_{2} \mathrm{O}_{5}$ & 0.30 & 0.25 \\
\hline $\mathrm{MnO}$ & 0.31 & 0.25 \\
\hline $\mathrm{CO}_{2}$ & 0.96 & 5.26 \\
\hline \multirow[t]{3}{*}{$\begin{array}{l}\text { Allow for minor } \\
\text { constituents }\end{array}$} & 0.29 & 0.29 \\
\hline & 99.78 & 99.83 \\
\hline & ppm & ppm \\
\hline $\mathrm{Ba}(\mathrm{s})$ & 190 & 240 \\
\hline $\mathrm{Co}(\mathrm{s})$ & 51 & 76 \\
\hline $\mathrm{Cr}(\mathrm{s})$ & 390 & 330 \\
\hline $\mathrm{Cu}(\mathrm{s})$ & 66 & 22 \\
\hline $\mathrm{Ca}(\mathrm{s})$ & 15 & 10 \\
\hline $\mathrm{Li}$ & 29 & 36 \\
\hline $\mathrm{Ni}(\mathrm{s})$ & 190 & 180 \\
\hline $\operatorname{Sr}(\mathrm{s})$ & 530 & 440 \\
\hline $\mathrm{V}(\mathrm{s})$ & 120 & 87 \\
\hline $\mathrm{Zr}(\mathrm{s})$ & 140 & 140 \\
\hline B & 19 & 33 \\
\hline $\mathrm{F}$ & 380 & 450 \\
\hline S & 100 & 110 \\
\hline $\mathrm{Cl}$ & 450 & 500 \\
\hline $\begin{array}{l}\text { (s) = spectrochemical } \\
\text { determination }\end{array}$ & & \\
\hline
\end{tabular}

Notes:

a Column I Olivine-basalt, chloritized, 311 to 313 meters below sea floor in Hole 117A of Leg 12 of Deep Sea Drilling Project. Eight centimeters from bottom of Section 2 of Core 11. F7160. Lab no. 2197.

b Column II Olivine-basalt, chloritized and carbonated. As I. Top of Section 2 of Core 11. F7159. Lab. no. 2196.

c Analysts: J. M. Murphy and G. A. Sergeant. Spectographic work by D. R. Powis. 
TABLE 4

C.I.P.W. Norms of Olivine-Basalt

\begin{tabular}{lccc}
\hline & I & II & IIa \\
\hline Z & 0.02 & 0.02 & 0.02 \\
or & 4.78 & 10.29 & 11.67 \\
ab & 20.11 & 20.45 & 3.93 \\
an & 27.05 & 19.09 & 21.95 \\
no & - & - & 10.64 \\
di & 8.62 & 3.26 & 33.24 \\
hy & 12.21 & 9.57 & - \\
ol & 7.81 & 3.80 & 2.38 \\
mt & 6.10 & 9.99 & 11.36 \\
hm & - & 0.51 & 0.64 \\
il & 3.56 & 3.05 & 3.50 \\
ap & 0.71 & 0.65 & 0.67 \\
cc & 2.18 & 11.98 & - \\
\hline
\end{tabular}

Notes:

Localities as Table 3.

Column I Olivine-basalt, chloritized. Symbol: III. 5. "4. 4". Auvergnose.

Column II Olivine-basalt, chloritized and carbonated. Symbol (II) III. 5.3."4. Camptonose.

Column IIa Analysis II recalculated to remove $\mathrm{CO}_{2}$ and $\mathrm{H}_{2} \mathrm{O}$, and total $100 \%$.

4960 meters. In describing these rocks, Matthews (1962) called attention to the occasionally expressed view that submarine lavas would not have been vesicular if extruded at depths greater than about 2.5 kilometers (under a hydrostatic pressure greater than the critical pressure of water). A factor which influences these observations is however the considerable increase in knowledge in recent years about movement of ocean floor rocks subsequent to their emplacement.

Macdonald (1963) has suggested that the depth at which vesicles start to form in Hawaiian magma is uncertain, varying "with the gas content and the degree of vesiculation (and resulting density) of the overlying magma column", but that from deep exposures of dikes, it is generally or always less than 2000 feet below the contemporaneous surface. Distinction must be drawn between the sparry-lined vesicles, which are probably part of the veining system, formed at a late stage in the history of the rock, and the nearly spherical amygdales. Their occurrence together complicates determination of the likely depth of emplacement of the lava in terms of Moore's study (1965) of Hawaiian basalt, taken into account in Jones's comparison of Icelandic and Welsh pillow lavas (1969); but more measurements of larger rock surfaces on the cores are required.

The alteration is not a weathering effect but probably deuteric or due to the lowest grade regional metamorphism. The single large gas cavity is only partly filled by mineral matter (as now preserved), which might suggest a relatively young age; but if the writer were seeking a match among British rocks, he would think that on purely petrographical grounds the Paleozoic or older rocks might provide examples. Some of the chloritic alteration products might represent devitrified glass, but is difficult to ascertain to what extent.

A very speculative suggestion is therefore that this is a shallow water extrusion.

\section{Extent of This Note}

Chemical analyses and petrographic examinations included in this report are preliminary, time and circumstances precluding further studies.

Clay and Basal Clastic Sediments (117, Core 3; 117A, Cores 2 to 10)

The upper Paleocene and lowermost Eocene sediments of Site 117 can be considered a terrigenous, transgressive, suite of sediments. There occurs in stratigraphic sequence, sandy conglomerate, sandstone, silty clay, mudstone and clay.

The sandy conglomerate is composed predominantly of poorly reworked volcanic material resulting from erosion of a basalt similar to the basement. Although the conglomerate is poorly sorted, the constituent grains are altered and rounded. The overlying sandstone is better sorted than the material below, contains mollusc shells, annelid tubes (Ditrupa, Plate 4) and is highly burrowed (Plate 5), the burrows having been infilled by carbonate-rich material.

This is overlain by sandy silt and silty clay which grades into a mudstone, in turn overlain by clay containing 14 to 18 per cent carbonate. These sediments are all dark in color. Bryozoan fragments are found from 270 meters (Core 117A-4) downward, reworked basalt fragments and mollusc shell fragments (in particular, one specimen of an articulated Ostrea sp.) below 289 meters (Core 117A-7), and there are also occurrences of larger foraminifera. The clay, like the sandstone, is also highly burrowed but shows signs of graded bedding. A 3-centimeter diameter phosphorite nodule in Section 117A-3-1 (223 meters) has inclusions of fish debris and ophiurids. Phosphorite has been found associated predominantly with marine sediments with a water depth ranging from 30 to 300 meters (Bromley, 1967).

Limestone, Chalk and Ooze (116, Cores 1 to 18: 116A, Cores 9 to $11 ; 117$, Cores 1 and 2;117A Core 1)

Although this section contains sediments of different degrees of lithification all these rocks are described together because they are basically organic rocks of high carbonate content and because the limestones, chalks and oozes do not occur as discrete thick beds but are interbedded.

The oldest sediments in this group are light gray to white Upper Eocene limestones and ooze from the bottom of Hole 116 (Cores 26 to 28). Some of the limestones are burrowed. Chloritic slickensides, small faults in the form of offset burrows, as well as laminations dipping at 30 degrees, indicate post-depositional movement (Plate 6). The limestone is very fine grained, comminuted and contains 
numerous foraminifera tests, predominantly heterohelids. The tests are recrystallized and are filled with sparry calcite.

The Oligocene and younger cores of Site 116 pass upward from predominantly hard chalk to foraminiferalnannofossil ooze. The chalk and ooze ( 80 to 98 percent carbonate) consist mainly of calcareous nannoplankton with occurrences of foraminifera ranging from common to abundant. Zoophycoid burrows (Plate 7) were identified below 760 meters and indicate a bathyal facies (F. Seilacher, personal communication). Many small faults of varying dip slip (syndepositional) were also identified below 760 meters. Cherty layers in the chalk or chert fragments are also found between 810 and 662 meters but microscopic examination of the Radiolaria samples revealed the occurrence of chert as high as 560 meters (Core 116-11). Other siliceous material seen under the microscope included diatoms, Radiolaria and sponge spicules. A detailed study by $\mathrm{R}$. N. Benson of diagenetic mobilization of biogenous silica is presented below. Secondary pyrite is a small but consistent factor in almost all the oozes when viewed under the microscope. Specks and patches of pyrite in the cores, first seen at 759 meters, persist to 710 meters. Other signs of pyrite are found at 360 meters (Core 116-7), and hydrogen-sulfide gas around 215 meters (Core 116-4). Authigenic carbonate resulting from recrystallization of calcite was also present in all cores. Except for occasional clay minerals, and one occurrence of a recognizable felspar twin, terrigenous material is not observed in this sediment.

Besides the autochthonous chert fragments, a variety of clearly allochthonous pebbles was found at several depths between 662 and 699 meters. These pebbles, which include two dreikanter at 695 meters, presumably were transported by floating vegetation. The dreikanter are presumably reworked. In Scotland wind-faceted, or specifically dreikanter, pebbles have been found in sediments of Torridonian (Phemister, 1960), Upper Old Red Sandstone (MacGregor and MacGregor, 1948) and Permian (Read, 1948; Pringle, 1948) age. These rocks outcrop today along the northwest coast of Scotland, around the Firth of Clyde and Wigtownshire, Isle of Arran and West Kintyre, respectively. All these places lie about 300 miles from Site 116. A large shale pebble (?ice-rafted) was also found at 74 meters (Core 116A-9). No pebbles were recovered from the intervening 588 meters of sediment (represented by 112 meters of core).

The upper two cores of Hole 117 contained Oligocene cherty limestone and glauconitic ooze (79 per cent carbonate). In the ooze, glauconitic aggregates and foraminifera replaced by glauconite are common. Cores $117-3$ and $117 \mathrm{~A}-1$, which overlap, contain fragments of chert or cherty limestone with some ooze, sandstone and clay.

It is interesting to compare the lithologies obtained at Sites 116 and 117 where they overlap in age. The Eocene sediments are strikingly different in that Lower Eocene clays were recovered at Site 117 while Upper Eocene hard chalky limestones and ooze were found at Site 116. Although chert was found at the base of Core 117A-1 and was the dominant constituent of Core 117-3-both of which cores had coccoliths as old as Early Eocene-there is some doubt as to whether the chert is of this age. The presence of younger coccoliths in samples of Late
Oligocene, Early Eocene and Late Paleocene age at this site suggests that material was falling down the hole. It is noticeable also that no siliceous material is involved in the lithification of the Site 116 Eocene limestone.

However comparison of the Oligocene cores shows that at this time similar lithologies were being deposited at Sites 116 and 117. Microscopic examination of the insoluble residue at 810 meters (Core 25) shows the advent of chert which persists for the next 100 meters and which is expressed as siliceous bands in ooze on a macroscopic scale. The size of the cherty limestone fragments recovered in Core 117-2 and their inclusion within a sequence of ooze strongly suggests that these siliceous rocks are in situ. A comparison of Cores 116-25 and 117-2, which lie about 15 and 40 meters, respectively, above the base of the Oligocene sediments, further emphasizes the similarity of the lithologies (Plate 8).

From about 650 meters up to 70 meters in Hole 116, the sediments were remarkably uniform, highly calcareous nannofossil (ranging from Early Miocene to Late Pliocene in age) ooze deposited at a mean rate of over $3 \mathrm{~cm} / 1000$ yrs. The sedimentation mechanism for this unit is discussed later.

Foraminiferal Nannofossil Ooze, Foraminiferal Sand and Silty Clay (116A, Cores 1 to 8 )

The Upper Pliocene and Pleistocene muds and clays of Hole $116 \mathrm{~A}$ are not unlike the oozes they overlie, in that they, too, contain large quantities of calcareous microfossils and authigenic carbonate. They differ however in containing variable quantities of detrital minerals (Figure 15) with a consequent decrease in carbonate content ( 33 to 92 per cent, average of eleven samples is 68 per cent). There also seems to be an inverse relation between the contents of sand and carbonate (Figure 14). Carbonate content always exceeds that of sand which lies between 8 and 33 per cent. Since the sand content is relatively insensitive to changes in carbonate content the latter must contain few sand size particles and/or the variations in carbonate are due to changing proportions of silt and clay.

Typical for this part of the sediment pile is an alternation of gray, unclean, clayey ooze and clean, chalky, nannofossil ooze. The quantity of glass is notably greater here than deeper in the section and palagonite, glauconite, and zeolites appear widespread throughout the material. Small quantities of clay minerals and a few presumably ice-rafted gneiss pebbles are also present.

\section{Diagnenetic Mobilization of Biogenous Silica}

One of the characteristics of the calcareous sediments cored at Site 116 in the Hatton-Rockall Basin is the fairly high percentage of biogenous silica in the $\mathrm{HC} 1$-insoluble residues. In many of the cores much of the silica shows varying degrees of diagenetic mobilization all the way to a dense chert. An attempt was made to distinguish the different siliceous components in order to understand better the chert forming process.

In a semiquantitative manner the volume of $\mathrm{HC} 1$ insoluble residue of particulate matter greater than 63 microns in diameter was determined for each core catcher sample of 116 (Figure 16). The nannoplankton ooze of 


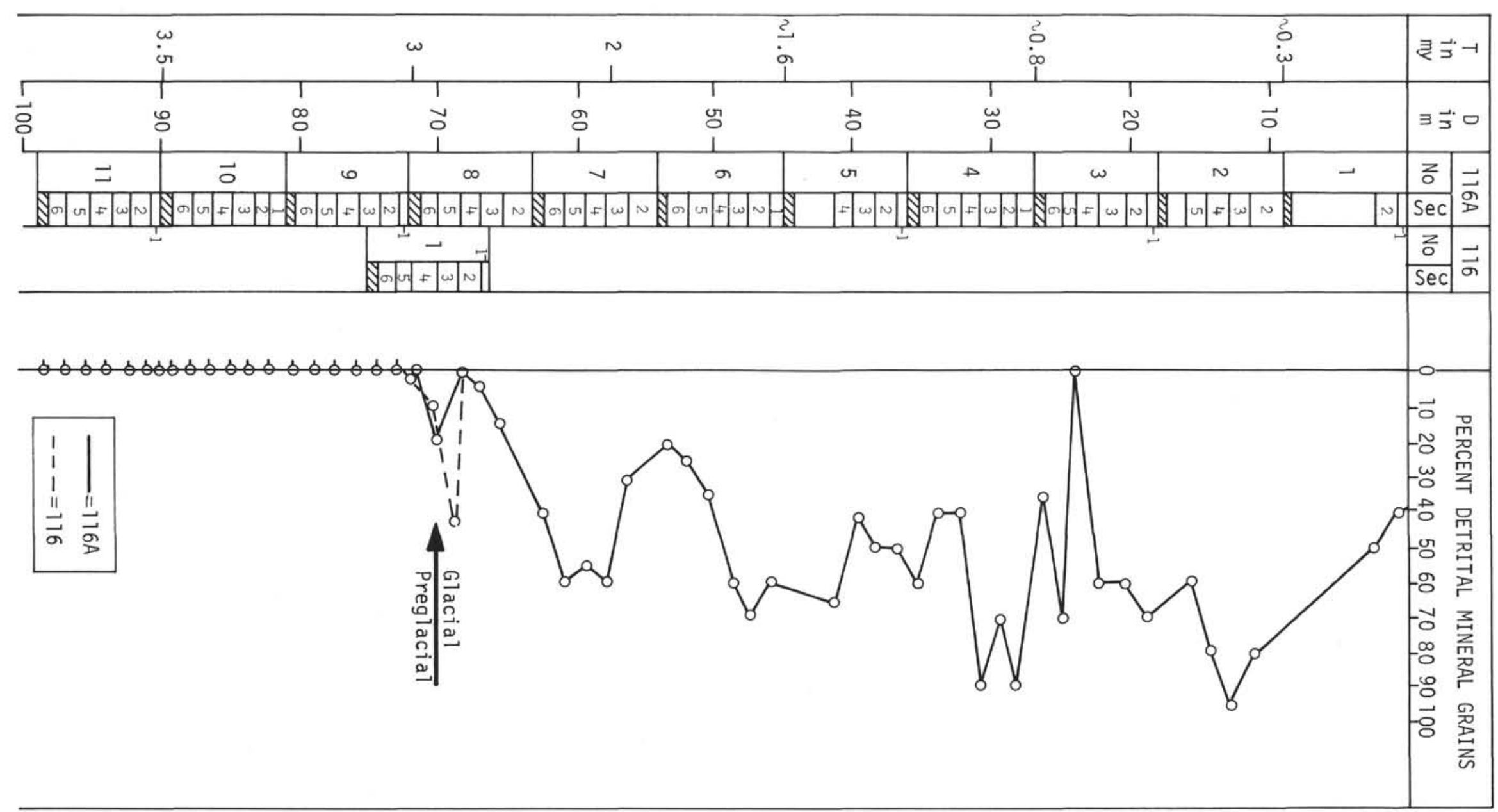




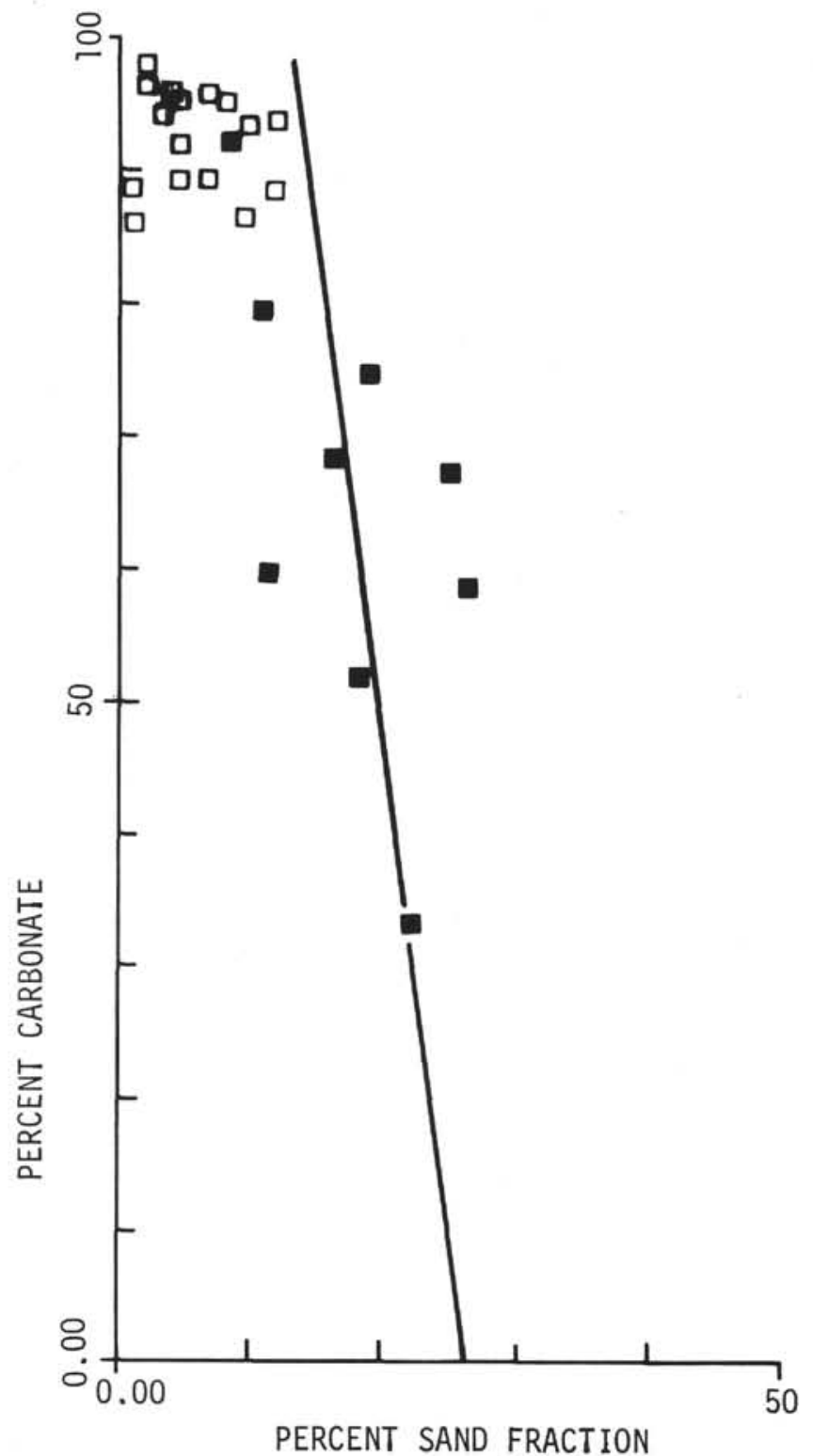

Figure 15. Carbonate content plotted against the sand content of samples obtained within 10 centimeters of the carbonate sample. The glacial samples follow the trend line indicated; the sand content of pre-glacial samples appears to independent of carbonate content.

Hole 116 consists of about 85 to 95 per cent calcium carbonate; therefore, residue volumes tend to be small. Since the amount of original sediment treated was quite large (enough to half fill a large evaporating dish), in nearly all samples (except Core 13) the volumes of residues from each core are comparable. Except for Cores 26 and 28, 90 to 100 per cent of each residue consists of silica, either predominantly biogenic or diagenetic.

Nine siliceous components were recognized in the residues (Figure 16). The source of nearly all the silica in the sediment, whether diagenetically mobilized or not, appears to be biogenic. Sponge spicules account for most of this, but in addition there are radiolarians, siliceous cysts (parts of sponges ?; see radiolarian report of Site 113), larger diatoms (smaller diatoms less than 63 microns in diameter probably make a significant contribution to the siliceous sediment), and flake-like fragments of the large diatom Ethmodiscus rex. The last are characterized by a grid pattern of closely and equally spaced minute pores ( 4 to 6 pores per 10 microns), and some show clear margins, either fringed or smooth (Plate 9, Figures 1-2). In Cores 3 through 8 , the flake-like fragments lack pores, but in all other respects they resemble the perforated ones deeper in the hole. In Figure 16 clear "flakes" are included under fragments of Ethmodiscus rex even though their origin is in doubt. They could be of volcanic origin, but their flatness and thinness suggest some other source, possibly biologic.

The four major components included under diagenetic silica are: (1) amorphous cloudy masses of silica (brownish color, matted appearance); (2) clumps of biogenous silica (identifiable biogenous, siliceous structures plus clay (?) cemented by silica into a dense but translucent mass); (3) internal casts of foraminiferal chambers (generally composed of cloudy amorphous silica but sometimes of clear chalcedonic silica); and (4) chert fragments (dense, opaque except for chalcedonic foraminiferal walls).

The chert appears to be comprised mainly of silicified foraminiferal casts cemented by cloudy amorphous silica (Plate 9, Figure 3). If indeed the diagnetic events leading to chert formation at Site 116 are sequential, their order appears to be as follows: 1) partial solution of biogenous silica to form clumps, 2) further mobilization to form cloudy masses of amorphous silica, this probably concomitant with infilling of foraminiferal chambers, 3) cementation by amorphous silica of the infilled foraminiferans still with their calcite walls intact (otherwise chamber walls would be present around the internal casts in the HCL-insoluble residues), and 4) replacement of the calcitic walls by clear chalcedonic silica.

With the possible exception of Core 11, the formation of diagenetic silica does not seem to be dependent on outside sources of silica. There may have been introduction of additional silica in Core 11 as shown by the three-fold increase in residue volume, however a similar increase without any evidence of silica mobilization occurs in Cores 16 and 17 , in this case due mainly to a large influx of fragments of Ethmodiscus rex. In Cores 20 through 28 in which diagenetic silica is about 80 to 95 per cent of the residue, the residue volumes are relatively low, being of about the same order of magnitude as in Cores 1 through 9 with nearly 100 per cent biogenous silica.

Finally, worthy of mention is the nearly complete mobilization of silica in Core 11 with very little if any mobilization above and below this level in Cores 10 and 12, respectively (Plate 10). Very few radiolarians and sponge spicules are recognizable in the residues from Core 11 ; therefore, the lack of siliceous fossils in chert beds does not necessarily imply that the source of the silica was nonbiogenic. In order for chert formation to occur it may be necessary for the siliceous fossils to be concentrated in layers or pods rather than distributed uniformly throughout the sediment. This would allow for greater ease in clumping of the siliceous elements as a first stage in diagenesis. 


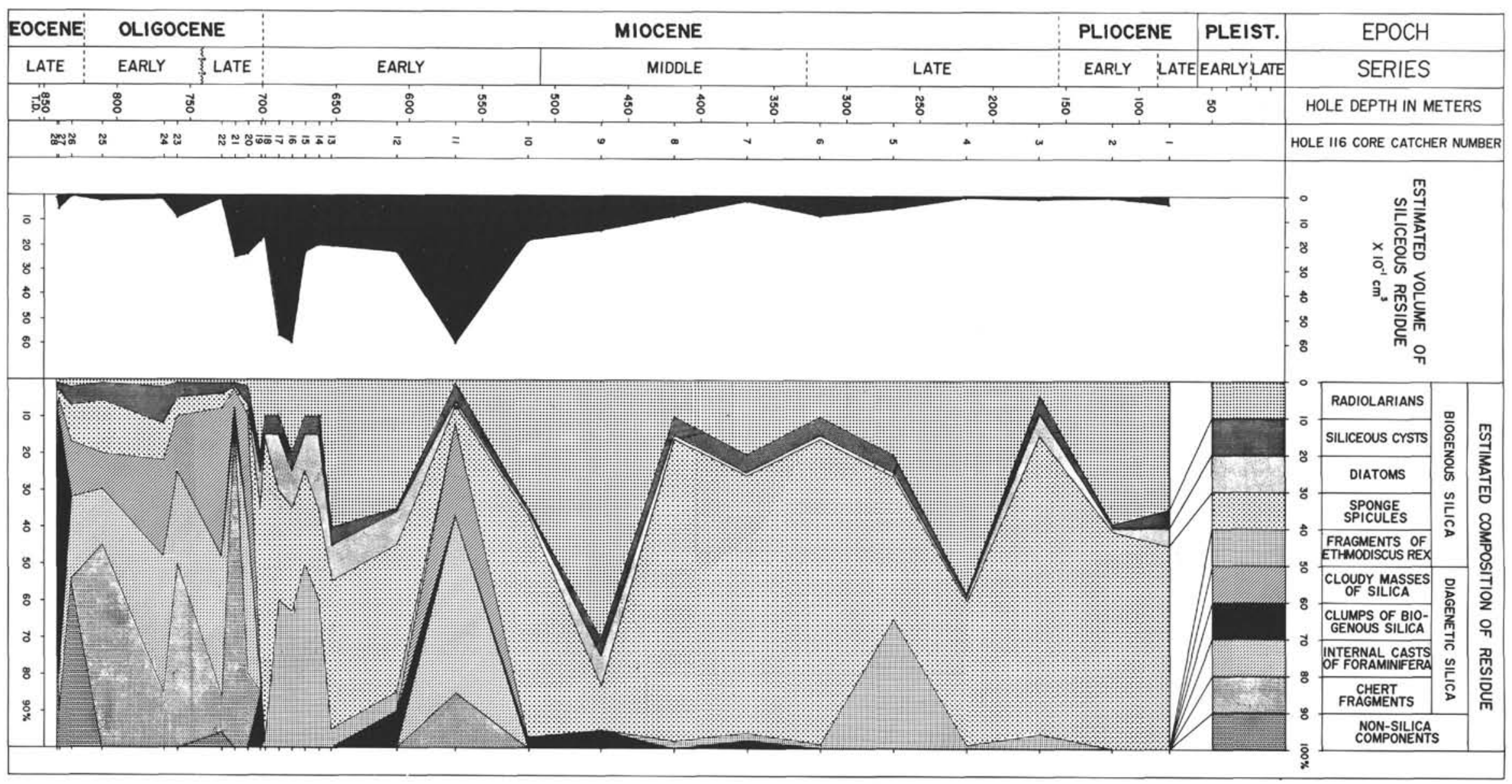

Figure 16. Particulate silica greater than 63 microns in Hole 116. 


\section{PHYSICAL PROPERTIES (116)}

At Site 116 the cores are often watery and commonly have suffered considerable deformation during coring. It is not possible to list all the affected sections here (the reader should examine the disturbance logs on the core summaries and the core photos for detailed information) but the cores most affected are 116-5, 116-10, 116-11, 116-12, 116-23 and 116-25. Many sections were not split as a result of their watery appearance, and consequently the aberrant low GRAPE densities measured over such sections are probably, but not certainly, attributable to watery patches in these cores. The watery nature of many sections has been allowed for in drawing trend lines on the density, impedance, porosity and natural gamma plots.

Density increases fairly rapidly with depth in the first 70 to 80 meters $(1.45$ to $1.7 \mathrm{gm} / \mathrm{cc}$ ) which is a sequence of ooze with foraminiferal sand and silty clay. Below this depth density only increases by a further $0.1 \mathrm{gm} / \mathrm{cc}$ in the next 650 meters. This increase is associated with the gradual change from soft foraminiferal-nannofossil ooze to ooze with chalk. The increasing firmness is also indicated by the penetrometer and by the velocity which increases from 1.5 to $1.7 \mathrm{~km} / \mathrm{sec}$ between the sea bed and 730 meters.

Below about 700 meters both density and velocity increase more rapidly as chalk becomes predominant over ooze. The rapid velocity increase in this region, in spite of the increase in density, indicates that the lithification associated with the formation of chalk causes the bulk modulus and rigidity of the sediment to increase even more rapidly than density. The deepest core contained a hard chalky limestone with density $2.05 \mathrm{gm} / \mathrm{cc}$ and velocity 2.7 $\mathrm{km} / \mathrm{sec}$.

In detail the GRAPE density plots have few interesting features. Many plots show up lumps of hard chalk in a fluid ooze. Alternations of lower density foraminiferal ooze and higher density clay are apparent in Core 116A-2, and a single pebble is detected in Section 116A-9-2. Two series of small density peaks at 5 and 7 meters in 116-4 are of unknown origin but may be associated with bubbles of hydrogen sulfide which were detected when cutting Sections 4,5 and 6 of this core.

Gamma radiation in the topmost 70 meters is on average considerably greater than at all deeper horizons sampled in the hole. The number of counts also shows appreciable fluctuations over short distances. Low counts of 550 and 350 in Cores $116 \mathrm{~A}-2$ and $116 \mathrm{~A}-3$, respectively, are associated with layers of foraminiferal ooze, and, high counts appear to be associated with detrital mineral grains in the glacial Pliocene-Pleistocene sediments. A fairly abrupt increase in radiation which occurs just above 71 meters (116A-8-5) is in the same section as the first influx of detrital grains and lies very close to the rather approximate paleontologically determined onset of glaciation. Only one carbonate sample obtained above this depth exceeds 85 per cent, while the majority of samples from below 71 meters exceed 90 per cent. It is clear, therefore, that the fluctuating gamma count may reflect the proportion of detrital mineral grains and the carbonate content of the sediment, and this in turn seems to be related to the glaciation. The subject is treated further in Chapter 13.
Below 71 meters, the natural gamma radiation is uniformly low, averaging about 200 counts, and with one exception the larger variations are associated with alternations of firm and watery core. The exception is the whole of Core 11 which has above average activity overall reaching up to 1500 counts. Unfortunately, only two sections of this core were split on board ship; these sections were composed of pale olive gray or yellowish-gray moderately mottled foraminiferal-nannofossil ooze. The carbonate content of these sections is not known, but a relatively low value of 60 per cent would probably be sufficient to give a gamma count of 1500 . It may also be significant that this core (unlike Cores 10 and 12) exhibits complete remobilization of biogenous silica.

\section{Depth of Reflectors}

Roberts et al. (1970) detected five reflectors below the Hatton-Rockall Basin. It was one of the objectives of Site 116 to determine the nature of the lowest two reflectors. Presumably due to the rather widespread cores from the middle section of Site 116 it is not possible to recognize any of the upper reflectors by studying the physical property measurements. Reflector 4 , however, does seem to be associated with the relatively rapid increase in lithification which occurs in the chalk below about 700 meters. The diffuse character of the reflector on the 160 to $320 \mathrm{~Hz}$ records is possibly due to it being caused by an increase in impedance which is gradual rather than sudden when "viewed" at a 5 to 10 meter wavelength. An explanation for the "transparent" layer below reflector 4 may be that since the chalk has reached a lithified state at this depth only gradual increases in impedance (due to increasing lithification) will occur below this depth, and these are insufficient to give rise to reflected energy. A corollary is that a deeper reflector will only occur if there is a sudden change in lithology below reflector 4 . The reflector data are summarized in Figure 17.

\section{PHYSICAL PROPERTIES (117)}

The lithologies cored at this site were such as to produce cores of chippings $(117-3,117 \mathrm{~A}-1)$ or cores fragmented by many transverse breaks (117A-6-5 onwards). Consequently, because of the loosely packed state or gaps between segments of these cores, the GRAPE data often seem to indicate low densities. Also, all sections of Core 117-2 and Sections 117A-4-1, 117A-4-3, 117A-6-1 and 117A-6-2 contained watery sediment. In drawing trend lines on the density, impedance, porosity and natural gamma plots, allowance has been made for aberrant data caused by the above effects.

The sediments cored in the top 150 meters of Site 117 are of the same age (Oligocene) and of similar lithology as those obtained just below 700 meters at Site 116. Even so, it is surprising that the density and velocity of the sediments recovered from 50 to 150 meters at Site 117 (1.7 $\mathrm{gm} / \mathrm{cc}, 1.60 \mathrm{~km} / \mathrm{sec}$ ) have similar values to those of the sediments recovered from at least 550 meters deeper at Site 116 (for example, $1.7-1.8 \mathrm{gm} / \mathrm{cc}, 1.59 \mathrm{~km} / \mathrm{sec}$ in Core 116-17). This suggests that the oozes concerned became sufficiently lithified shortly after deposition to be unaffected by the subsequent addition of up to 700 meters 


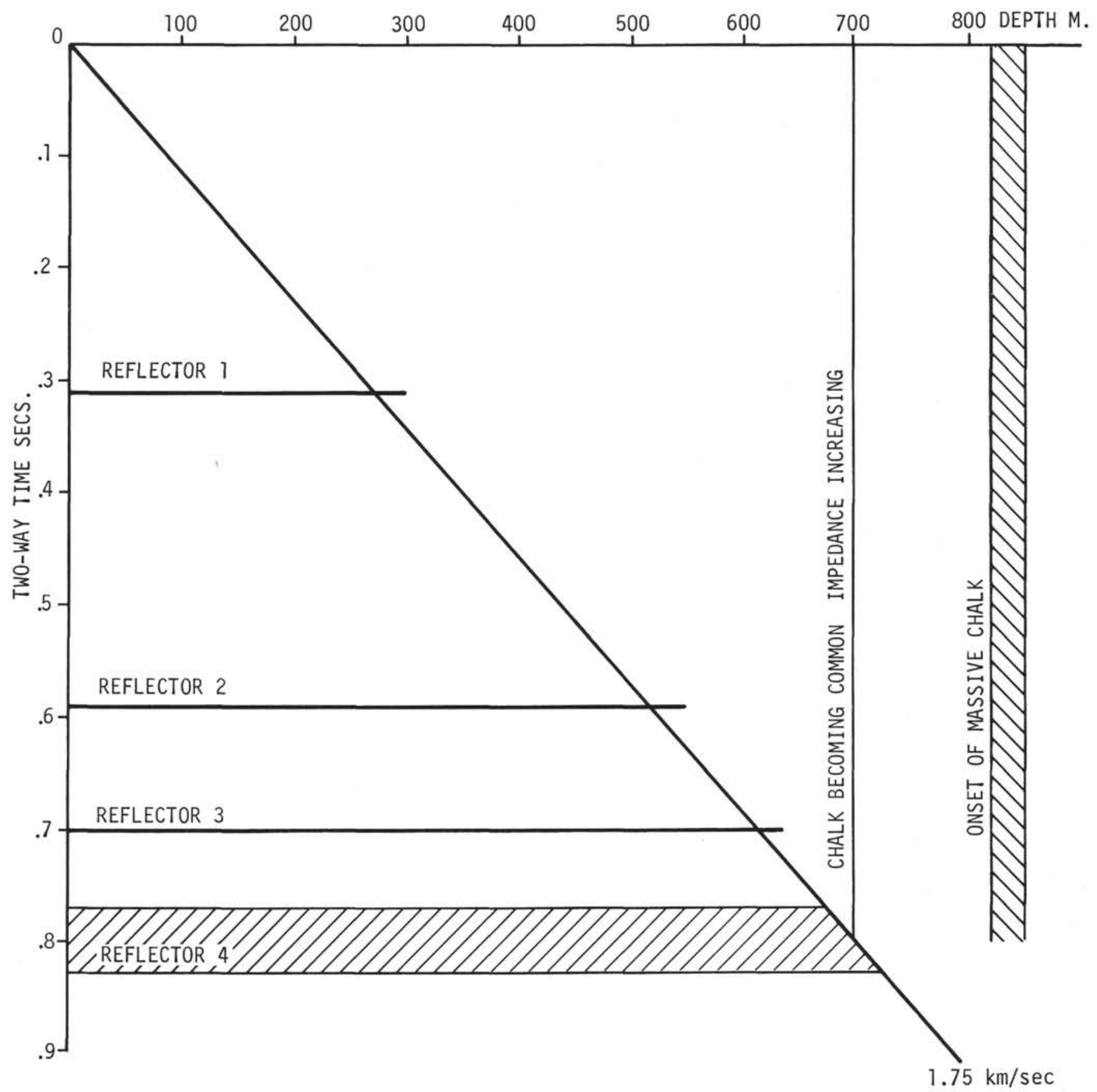

Figure 17. Two-way travel times below the sea-bed of observed reflections plotted against the downhole depths of horizons believed to have given rise to these reflections. The mean velocity to the deepest reflection associated with a definite depth is given close to the line representing this velocity. (Site 116).

of overburden (effectively about $40 \mathrm{~kg} / \mathrm{cm}^{2}$ overburden pressure). It is possible, according to the micropaleontology, for the Oligocene sedimentation rate at Site 117 to have been a fraction of that at Site 116. The slower rate of sedimentation could have led to an initially more lithified higher density ooze and vice versa. The probably shallower depth of deposition at Site 117 may also be pertinent to the formation of the lithified oozes. It should be noted, however, that the gamma activity of the Oligocene rocks differs between the two sites, averaging about 200 counts at
Site 116 and 400 at Site 117. From the sparse data available, this seems to be entirely due to a lower carbonate content at Site 117.

Section 117A-1-1 clearly indicates the dependence of gamma activity on lithology, since relatively low counts were obtained from the foraminiferal sand and ooze, intermediate counts from the cherty limestone and high counts from the clay.

The cores below 150 meters show more variable physical properties. Core $117 \mathrm{~A}-3$ generally has a 
density of $1.55 \mathrm{gm} / \mathrm{cc}$, but at its base this becomes as high as $1.65 \mathrm{gm} / \mathrm{cc}$ corresponding to a change from firm clay to dense, burrowed clay. At the same time the gamma activity also increases from 600 to just under 1200 counts as the sediment color changes from greenish-black to gray to black. The gray clay contains only 14 per cent carbonate, and therefore the 100 per cent increase in gamma activity in the black clay is not explicable solely on the basis of decreased carbonate and probably indicates enrichment in uranium and thorium.

Continuous coring was maintained between 270 meters and the bottom of the hole. The clay persists down to 285 meters and has densities between 1.45 and $1.75 \mathrm{gm} / \mathrm{cc}$. The gamma activity is variable, but two highs of 1200 and 1300 counts occur in 117A-6-5 and 117A-6-6 in association with dark bands in these sections. In the former section, 700 counts were obtained over sediment containing 21 per cent carbonate and therefore the high of 1200 is not explicable on the basis of absence of carbonate and suggests enrichment in uranium and thorium.

Core 117 A-7 contains a mudstone of density 1.7 to 1.95 $\mathrm{gm} / \mathrm{cc}(1.77-1.80 \mathrm{~km} / \mathrm{sec})$ in its upper 5.5 meters and a dense conglomerate (1.95 gm/cc, $1.93 \mathrm{~km} / \mathrm{sec})$ near its base. The mudstone has a gamma activity of 700 to 800 counts except for a peak of 920 counts in the top 60 centimeters of 117A-7-4 associated with a blue-green color. Core 117A-8 contains silty clay and sandy silt with densities up to $1.7 \mathrm{gm} / \mathrm{cc}$ and gamma activity around 1000 counts.

Core 11 was composed entirely of basalt and gave a gamma count of 250 . The (weight/volume) density and porosity and the velocity are $2.56 \mathrm{gm} / \mathrm{cc}, 6$ per cent and 4.8 $\mathrm{km} / \mathrm{sec}$, respectively.

Paleomagnetic measurements were made on four oriented specimens of basalt from Core 11 by J. Ade-Hall. All the specimens had a strong horizontal component relative to the vertical component of magnetization so that no definite determinations of the polarity of the paleofield were possible. The results are summarized in Table 5 .

TABLE 5

\begin{tabular}{cll}
\hline \multicolumn{1}{c}{ Specimen } & \multicolumn{1}{c}{ Polarity } & \multicolumn{1}{c}{ Remarks } \\
\hline $117 \mathrm{~A}-11-1,1$ to $6 \mathrm{cms}$. & Indeterminate & $\begin{array}{l}\text { Two oriented fragments } \\
\text { have weak vertical com- } \\
\text { ponents in opposite } \\
\text { senses }\end{array}$ \\
$\begin{array}{l}117 \mathrm{~A}-11-2,26 \text { to } \\
32 \mathrm{cms} .\end{array}$ & $\mathrm{R} ?$ & \\
$\begin{array}{l}117 \mathrm{~A}-11-2,44 \text { to } \\
47 \mathrm{cms} .\end{array}$ & $\mathrm{N} ?$ & \\
$117 \mathrm{~A}-11-2,107$ to & None? & $\begin{array}{l}\text { No measurable vertical } \\
\text { component }\end{array}$ \\
\hline
\end{tabular}

\section{Depth of Reflectors}

Two strong reflectors, referred to as reflector 4 and "basement," were detected below Site 117. The upper reflector is spread out between 0.04 and 0.16 second and does not clearly relate to a measured increase in impedance in the cores above 150 meters. However chert chippings were recovered from cores above this depth and reflector 4 is undoubtedly due to stringers of extra hard limestone spread over some tens of meters as is suggested by the drilling data.

The "basement" reflection, from the seismic section after completion of drilling, occurs at 0.32 second. A close inspection of the record suggests, however, that the energy in this reflection derives from two reflectors, the lower one being at 0.35 second. Measurement of the acoustic impedance of recovered core material shows that there is an impedance change at 280 meters, corresponding to the very hard clay in $117 \mathrm{~A}-6-5$ and another larger one at 303 meters is related to the hard sandstones sampled in 117A-9-1. Again at 311 meters the impedance increases on entering basaltic basement. A velocity of $1.75 \mathrm{~km} / \mathrm{sec}$ would give reflection times to these impedance changes of $0.32,0.345$ and 0.355 seconds, respectively. It is therefore likely that the start of the "basement" reflection is in fact due to the thin layer of overlying clays and sandstones and not to the basaltic basement. These data are summarized in Figure 18.

\section{PALEONTOLOGY AND BIOSTRATIGRAPHY (116)}

\section{General}

Sedimentation appears to have been continuous from Late Oligocene time to the present at this location. The extremely low estimated rates of sedimentation during the Oligocene indicate the presence of one or more unconformities in the Oligocene section. Chert horizons were encountered at about 700 meters; these become more common and persistent with increasing depth.

The material obtained from these two holes will be useful in delineating the Neogene development of planktonic and benthonic microfossils in temperate latitudes. It would appear that the present day deep-water benthonic

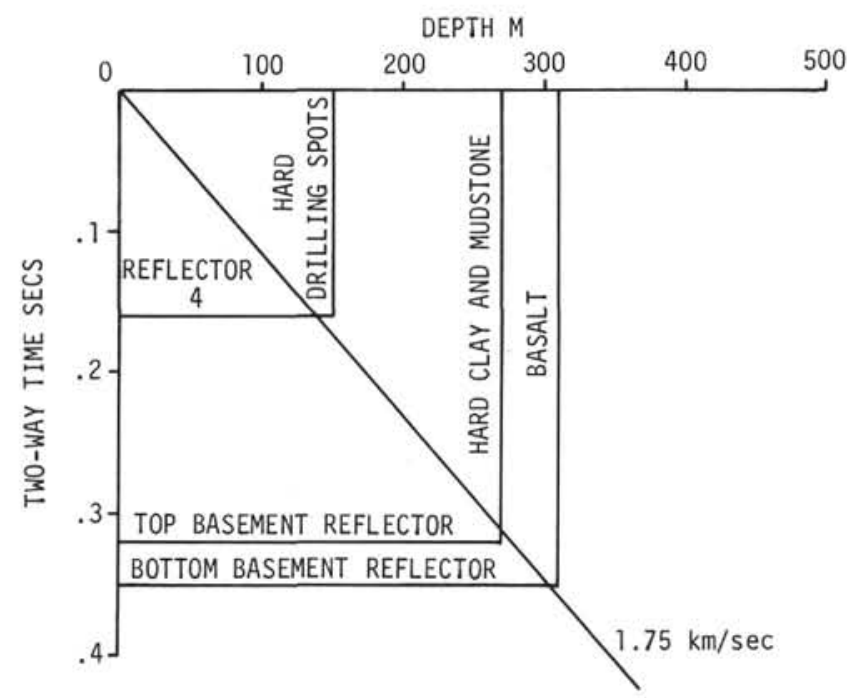

Figure 18. Two-way travel times below the sea-bed of observed reflections plotted against the downhole depths of horizons believed to have given rise to these reflections. The mean velocity to the deepest reflection associated with a definite depth is given close to the line representing this velocity. (Site 117). 
foraminiferal fauna became established in this region about 15 million years ago (near the Orbulina Datum, which was identified in Hole 116, Core 10, 509 to 518 meters). Late Neogene planktonic foraminiferal faunas are essentially similar to those encountered at the previous sites on Leg 12. Upper Oligocene and Lower Miocene sediments, approximately the interval between Core 10 (509 to 518 meters) and 22 (719 to 728 meters) are characterized by various species of the genus Globoquadrina. Species of the Globorotalia miozea group characterize Middle and Upper Miocene and Lower Pliocene sediments. As at other sites on Leg 12, Globigerian atlantica is the dominant element in Pliocene cores and is replaced in Late Pliocene-Pleistocene time by Globigerina pachyderma The Pleistocene is characterized by populations of Globigerina bulloides, $G$. pachyderma and Globorotalia inflata. It may be possible to delineate broad patterns of climatic fluctuations in the Pliocene-Pleistocene in Hole 116A, but this study is not yet completed.

Other microplankton groups are abundant at this location. Calcareous nannoplankton are common, but Miocene discoasters are calcified and difficult to identify. Site 116 contains the most complete record of Cenozoic radiolarians. Late Eocene-Oligocene forms exhibit evidence of corrosion and silicification. Diatoms are scattered throughout the stratigraphic succession. Siliceous sponge spicules occur at many levels, particularly in the MiddleLate Miocene.

In the following sections a summary is given of the major faunal components in terms of their stratigraphic development beginning with the Pleistocene.

\section{Discussion}

\section{Foraminifera}

\section{Pleistocene}

The Pliocene-Pleistocene boundary is drawn at about 60 meters (within Core 7, Hole 116A). The lower part of the Pleistocene sequence is characterized by Globigerina bulloides and Globorotalia inflata. The upper part of the Pleistocene is characterized by an abundance of Globigerina pachyderma and Globigerina bulloides. Commonly occurring accessory species include Globorotalia scitula, $G$. crassula, G. crassaformis, G. truncatulinoides, Orbulina universa and Globigerinita glutinata. The benthonic foraminiferal fauna is quite rich and diversified and includes among other forms Sigmoilopsis schlumbergeri, Pyrgo lucernula, Pyrgo murrhyna, Gyroidina neosoldanii, Uvigerina hollicki, Cibicidoides pseudoungeriana, Melonis pompilioides, Melonis barleeanum Bulimina marginata, Eponides tener and Karreriella bradyi. These forms and numerous others, characteristic of Recent sediments in the Atlantic Ocean, occur relatively commonly in sediments at this site as old as Middle Miocene.

\section{Pliocene}

The Miocene-Pliocene boundary is placed approximately at 155 meters (that is slightly above Core 3, in Hole 116A). The Pliocene, then, in this area is approximately 100 meters thick. The dominant planktonic foraminiferal element in the Pliocene is Globigerina atlantica. Relatively high frequencies of Globorotalia puncticulata and G. crassaformis serve as useful criteria in the biostratigraphic subdivision of the Pliocene at this site. Indeed, it would appear that the presence of Globorotalia puncticulata and the absence of other distinctive Pliocene forms may serve as a criteria for distinguishing Pliocene from Miocene.

\section{Miocene}

The Oligocene-Miocene boundary is tentatively drawn (on relatively weak biostratigraphic data) at about 700 meters between Cores 18 and 19 in Hole 116. The Miocene is thus about 550 meters thick at Site 116 (all data below refer to Hole 116). Cores 3 through 6 are of Late Miocene age; Cores 7 through 10 (part) are of Middle Miocene age; Core 10 (part) through 18 are of Early Miocene age.

Upper Miocene sediments are characterized by large robust specimens of Globigerina bulloides and forms apparently belonging to the Globorotalia acostaenishumerosa complex. Globigerina atlantica occurs sporadically throughout this interval and is predominantly dextrally coiled. The faunas, in general, show a marked resemblance to those recorded from the type Tortonian of Italy.

The Middle Miocene is characterized by relatively large globigerinids assigned to Globigerina praebulloides, Globoquadrina dehiscens, Globorotalia siakensis and sphaeroidinellids. Globorotalia miozea is a characteristic form in Cores 6,7 and 8 , and Globorotalia praemenardii is a relatively common form in Core 9. Globigerina nepenthes occurs in Core 7. The evolutionary development from Praeorbulina to Orbulina occurs from Core 10 to Core 9 and allows relatively precise stratigraphic dating of this part of the section. A gradual but pronounced change in the benthonic foraminiferal fauna is noticed within the lower part of the Miocene at this site. Several forms characteristic of the older sediments at this site have their upper ranges within the Lower Miocene, whereas most of the forms common in the Pliocene and Pleistocene have their lowest occurrences within this same interval.

The Lower Miocene (Cores 10 through 18) is characterized by a relatively monotonous assemblage of globoquadrinids (Globoquadrina dehiscens, G. baroemoenensis and $G$. praedehiscens). Spaeroidinellopsis seminulina is particularly common in Core 11. Globigerinita dissimilis, the dominant form in Oligocene samples below, has its highest occurrence in Core 13. Globorotalia birnageae occurs in Core 12. The dominant benthonic foraminiferal element throughout the Lower Miocene and Oligocene is a siphoninid here assigned to Siphonina tenuicarinata. Other characteristic Lower Miocene benthonic foraminifera include Planulina renzi, Oridorsalis ecuadorensis, Anaomalina alazanensis, Gyroidina complanata and Cibicidoides trincherasensis.

\section{Oligocene}

The Eocene-Oligocene boundary occurs between the base of Core 25 and the base of Core 26 in Hole 116. It is arbitrarily drawn here at the top of Core 26 at about 825 
meters. The Oligocene, thus, is about 125 meters thick. Extremely low rates of sedimentation calculated for the Oligocene (see section on sedimentation rates) suggest the presence of one or more unconformities within the Oligocene at this site. Cores 19 through 25 are assigned an Oligocene age. The Oligocene is characterized by a planktonic foraminiferal fauna of low diversity, including Globigerinita dissimilis and $G$. unicava. Chiloguembelinids occur as high as Core 23 and Globigerina ampliapertura as high as Core 24 , which suggest that Cores 20 through 22 are of Late Oligocene age and Cores 23 through 25 are of Early Oligocene age. Characteristic benthonic foraminiferal elements in the Oligocene include Siphonina tenuicarinata, Heterolepa mexicana, C. trincherasensis, Planulina renzi, Anomalina pompilioides, A. alazanensis, Oridorsalis ecuadorensis and Uvigerina havanensis. Small individuals of compressed unkeeled globorotaliids are found in Cores 24 and 25 and are assigned here to the species Globorotalia postcretacea, Globorotalia denseconnexa, and $G$. inaequiconica. The latter two species were described from the Oligocene-Lower Miocene sediments of the Polyanitskaya group of the Carpathian Mountains.

\section{Eocene}

The Eocene is represented by Cores 26 through 28 . The planktonic foraminiferal fauna consists of an assemblage of globigerinids dominated by Globigerian galavisi. Also present are $G$. linaperta and Globigerapsis index. Chiloguembelinids occur commonly but Pseudohastigerina micra has not been found. This may support the suggestion, made elsewhere by this writer, that Pseudohastigerina became extinct at high latitudes within Late Eocene time, whereas it ranges well into the Oligocene in lower latitudes. Characteristic benthonic foraminiferal elements include Osangularia mexicana, and Oridorsalis ecuadorensis.

A planktonic foraminiferal biostratigraphic subdivision of Site 116 is presented in Figures 19, 20 and 21, and some of the characteristic benthonic foraminiferal elements at Sites 116 and 117 are shown in Figure 22.

\section{Calcareous Nannoplankton}

At Site 116, a complete sequence of Neogene and some Paleogene was cored and yielded a good insight into high latitude coccolith assemblages.

\section{Pleistocene and Pliocene}

Hole $116 \mathrm{~A}$ was cored continuously to give information about the development of the fauna and flora in high latitude Pleistocene, the Pliocene/Pleistocene boundary and the age of the beginning of the glaciation in this region.

All Pleistocene zones could be recognized in Cores 1 to 7 (116A). It was hoped that this sequence would furnish an ideal profile to check temperature oscillations during the Pliocene and Pleistocene. However, the soupy calcareous oozes and slightly clay-richer oozes were mixed by drilling disturbance. It is therefore questionable how much a fine analysis of the material will yield.

In Figure 23 the results of the preliminary study of the smear slides prepared on board the ship are presented. Coccolithus pelagicus was found to vary considerably in quantity, from abundant to extremely rare or absent.

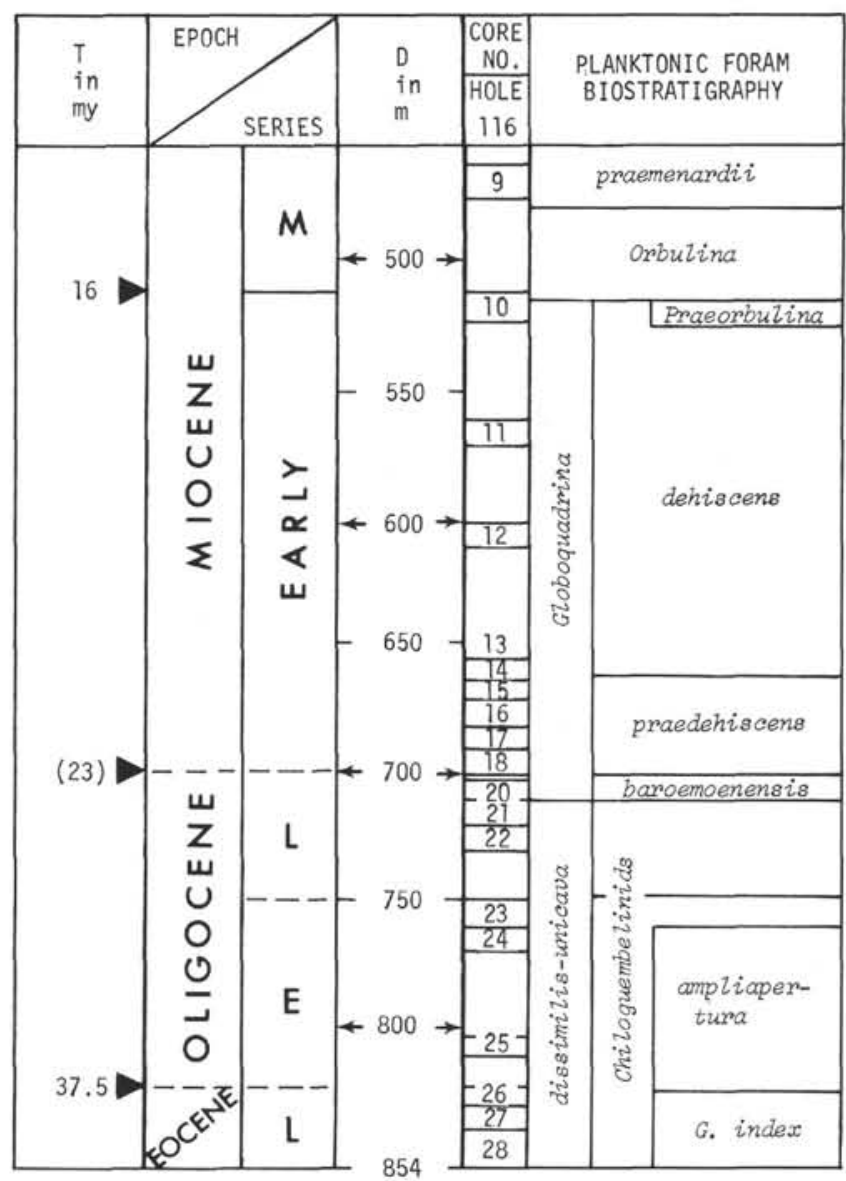

Figure 19. Late Eocene - Early Miocene planktonic foraminiferal biostratigraphy of Site 116.

Several species of Scyphosphaera are present, especially in the lower part of the sequence. A relation between the presence of detrital minerals and reworked, mostly Late Cretaceous, coccoliths can be observed. Both were not observed lower than 116A-7-1, in the lower most Pleistocene. They might reflect glacial influence. Where do the Late Cretaceous coccoliths come from? The source could be subaqueous or Ireland.

Generally, the Pleistocene and Pliocene assemblages are not much richer than those from the more northern sites. Discoasters are again extremely rare and their scarcity makes it difficult to define the Pliocene/Pleistocene boundary that has been set here above the highest 


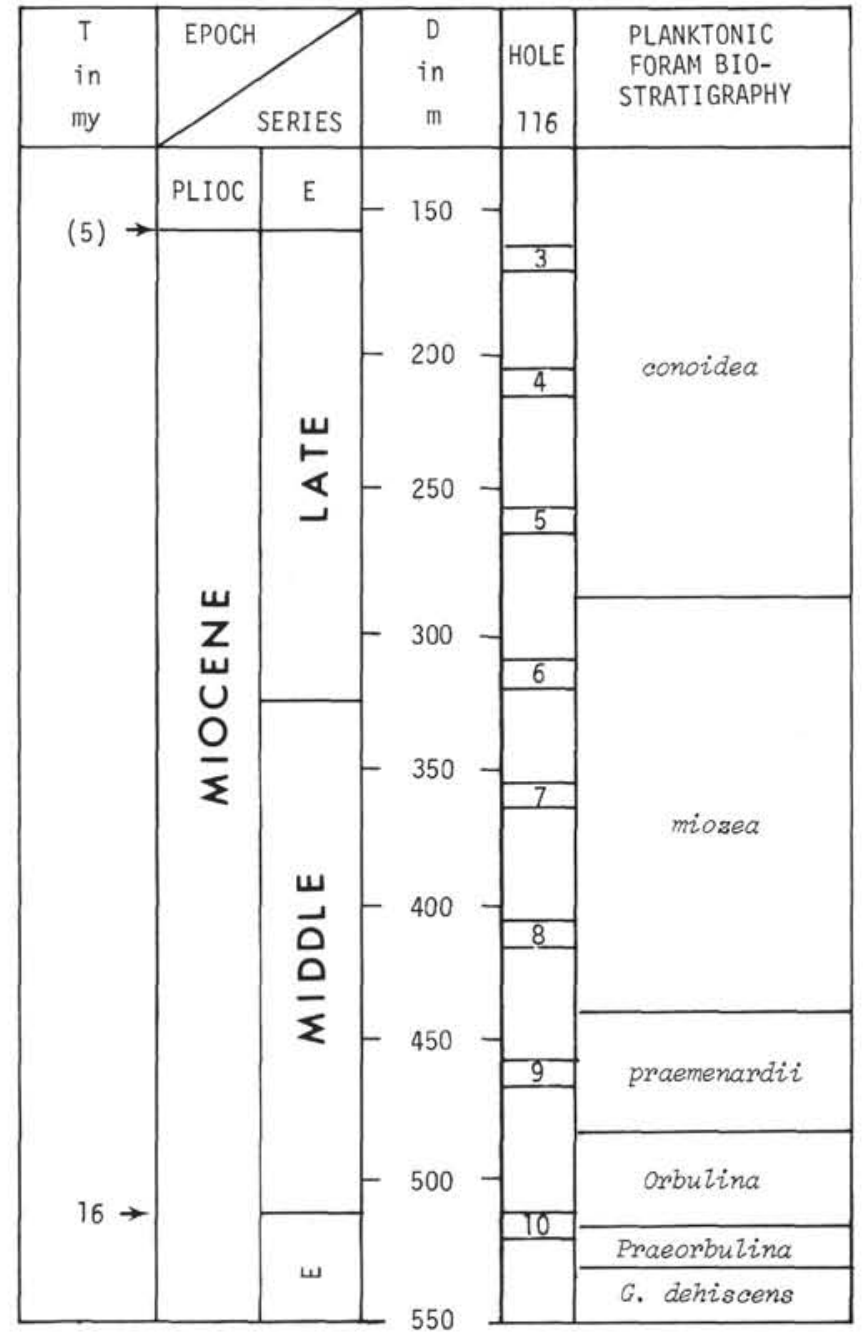

Figure 20. Middle-Late Miocene planktonic foraminiferal biostratigraphy of Site 116.

occurrence of a discoaster. Cyclococcolithus macintyrei occurs as high up as in the $C$. jaramillensis zone. Coccolithus pelagicus is present in several variations including a small central opening, an opening spanned by a crossbar or a cross and a form with a wide central opening spanned by a crossbar or a cross. Electron microscope examination of the coccolith with a crossbar has shown that it differs from Cruciplacolithus neohelis in the construction of the distal shield and the wall. A further variety shows an elevated wall covering most of the central area. It occurs together with "normal" Coccolithus pelagicus on the same coccosphaeres. Syracosphaera histrica, Syracosphaera sp. and different Pontosphaera are present and more or less frequent in most samples. Helicopontosphaera kamptneri and $H$. sellii are also present throughout the sequence. Ellipsodiscoaster lidzi (?) was found in Cores 116A-10 and 11. In Sections 116A-9-2 to 4, four-rayed Discoaster brouweri were found. Rhabdolithus sp. is more frequent in the Pliocene than in the Pleistocene. Sphenolithus neoabies (?) was only found in the core catcher of 116A-7; S. abies-otherwise found below the onset of glaciation-seems to be absent here, a fact

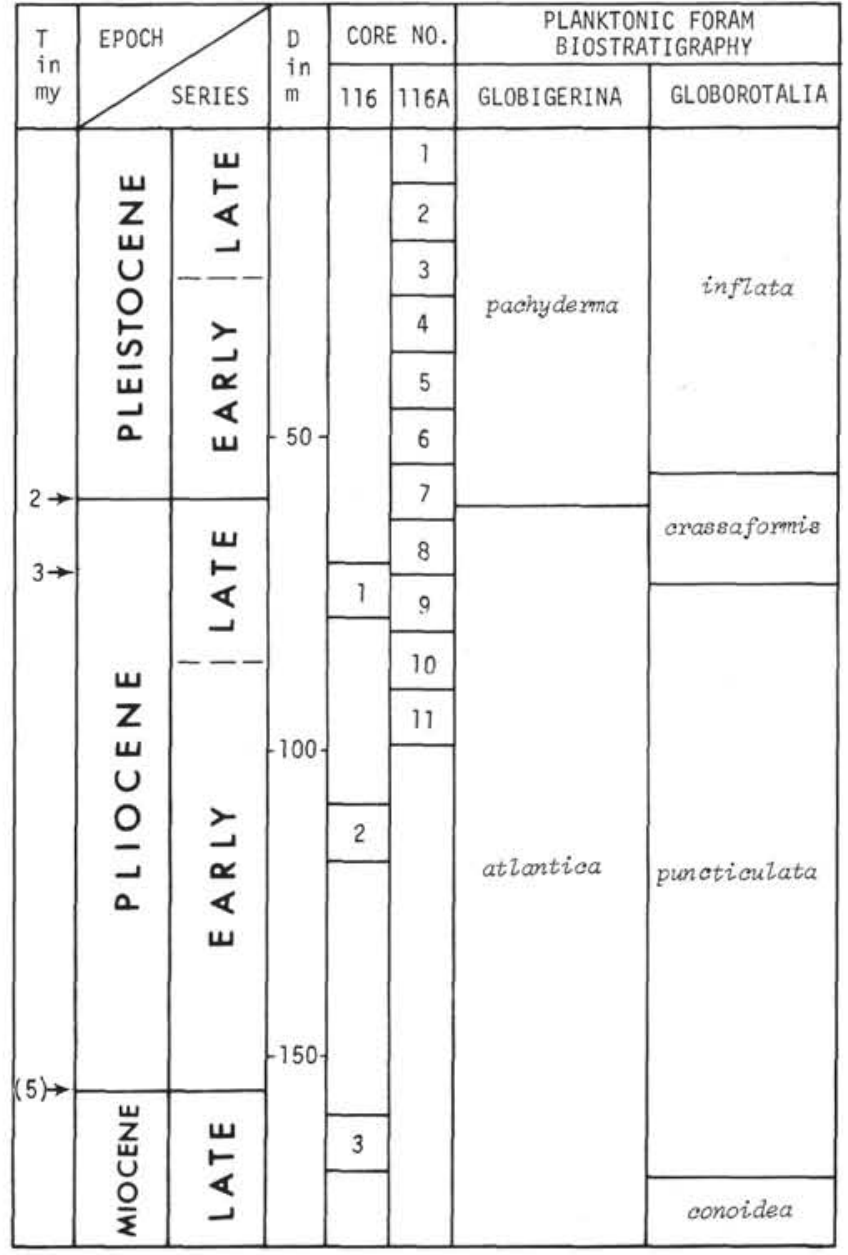

Figure 21. Pliocene-Pleistocene planktonic foraminiferal biostratigraphy of Site 116.

surprising, considering the otherwise somewhat richer assemblage. Besides the coccoliths mentioned, the coccoliths defining the zones are present and an almost constant background of innumerable very small coccoliths and/or broken coccoliths. It is those coccoliths, sometimes together with Coccolithus pelagicus, that are the main ingredients of the fine fraction of the ooze. Ceratoliths were only found as two specimens in Section 116A-10-2 in the Late Pliocene.

The lowermost core assigned to the Pliocene, Core 116-2, contains only long-ranging species, so that an exact age cannot be given for it.

\section{Miocene}

The discoasters present in the samples assigned to the Miocene-116-3 to 18 ?-are calcified and their determination difficult. Cores 4 and 5 are assigned to the Discoaster quinqueramus Zone on basis of the presence of a discoaster similar to $D$. quinqueramus and the absence of $D$. hamatus. Chiasmolithus sp. occurs in Core 5-a high occurrence for this genus. For Cores 6 to 9, only their Miocene age could be established. The presence of Helicopontosphaera parallela and Coronocyclus nitescens in Core 9 suggests the presence of the Discoaster exilis Zone or older. Only in Core 10 , a better age assignment is again possible. Together 


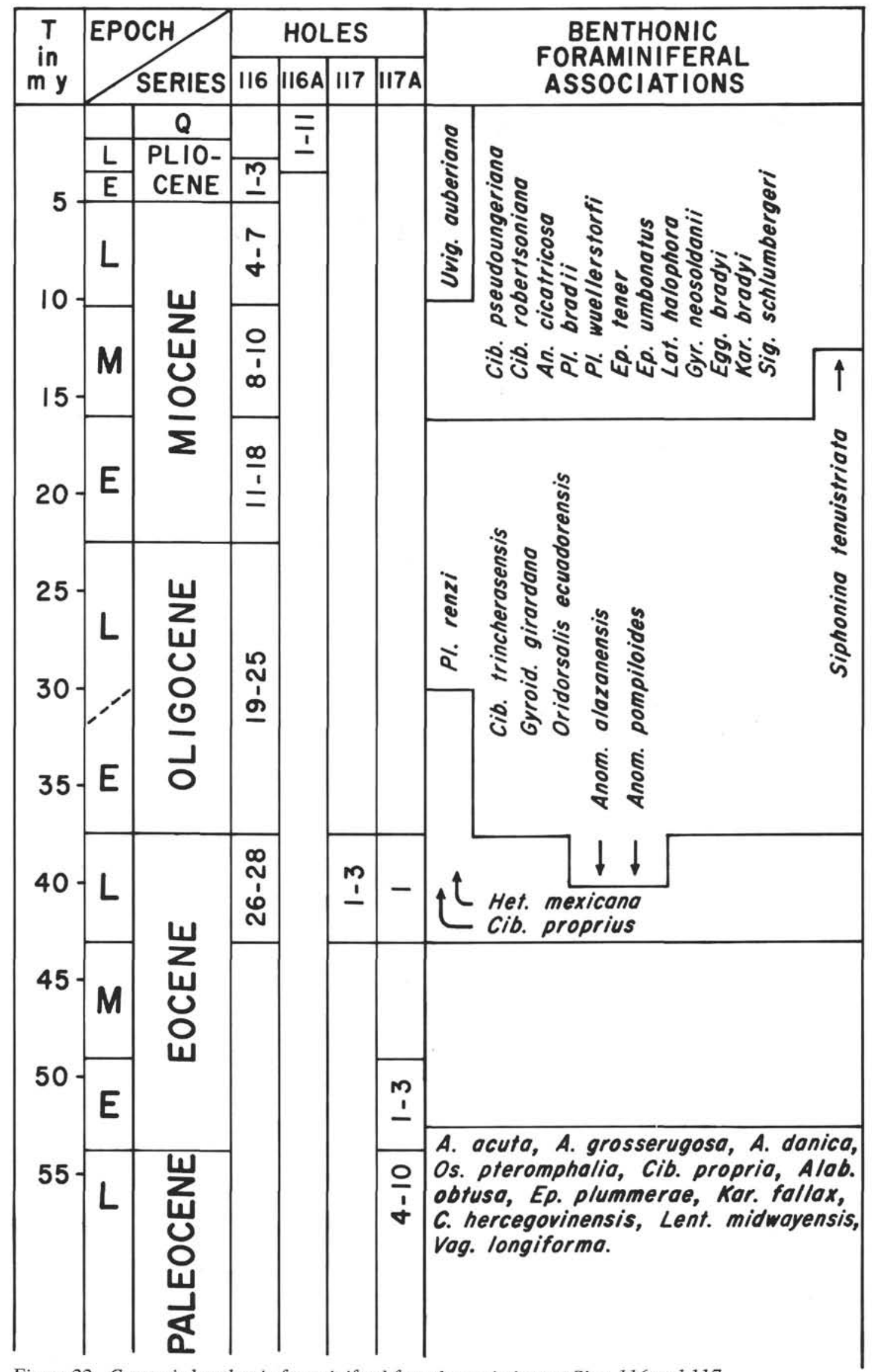

Figure 22. Cenozoic benthonic foraminiferal faunal associations at Sites 116 and 117. 


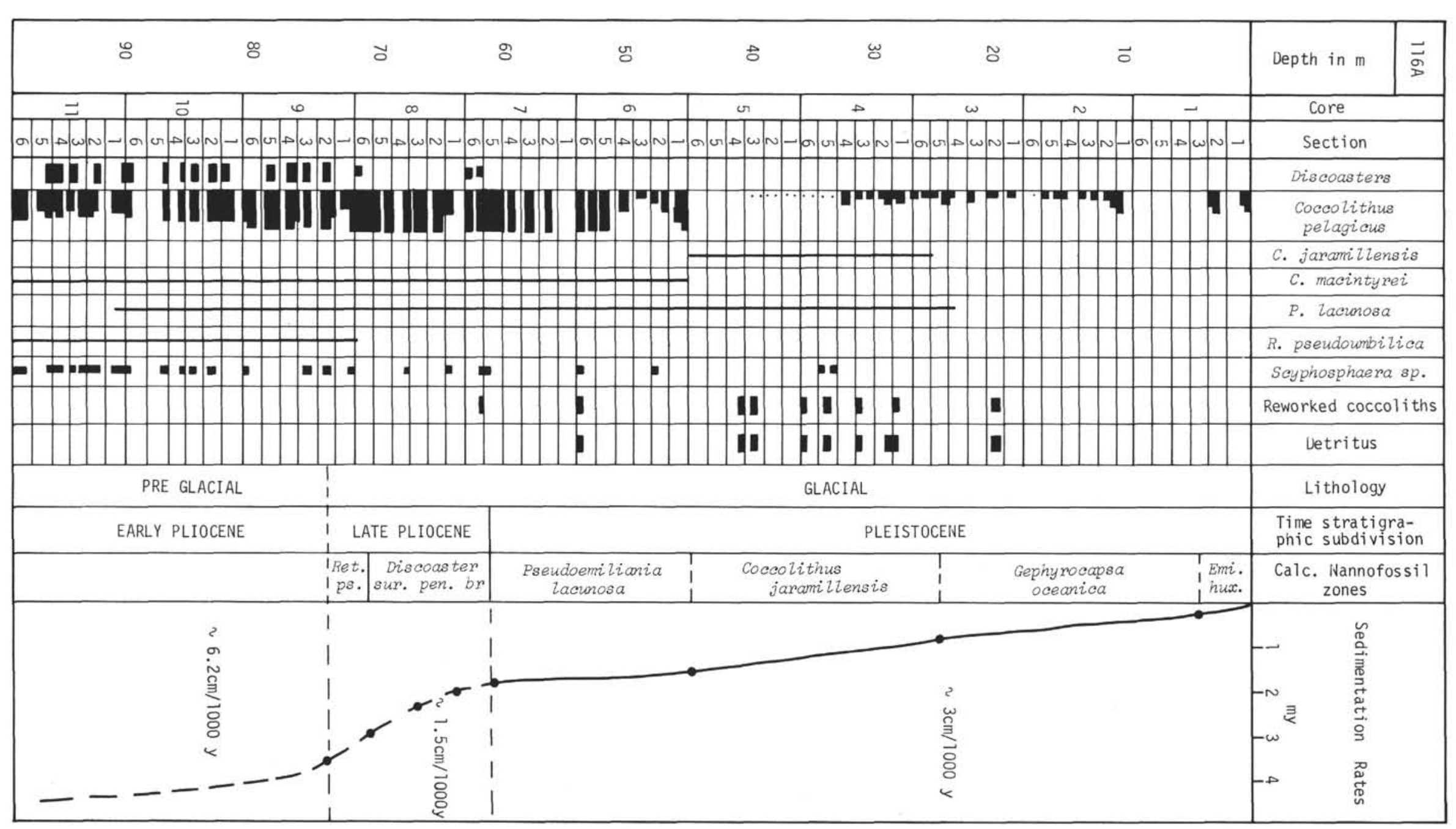

Figure 23. Stratigraphic distribution of calcareous nannoplankton in the upper Pliocene and Pleistocene and estimated average rates of sedimentation at Site 116. 
with Core 11, it represents the Sphenolithus heteromorphus Zone, with this species and Coronocyclus nitescens and Cyclococcolithus leptoporus only present in Core 10. In the tropics, the range of $C$. leptoporus and Helicopontosphaera parallela overlaps in the $H$. ampliaperta Zone (Bramlette and Wilcoxon, 1967). They overlap here, too, in Core 10, indicating that the $H$. ampliaperta Zone might be represented by Core 10 and 11. An undescribed species of Discolithina occurs occasionally in the Early Miocene and Late Oligocene. Cores 12 through 14 are tentatively assigned to the Sphenolithus belemnos Zone due to the presence of $S$. belemnos or similar sphenoliths and the missing or extreme scarcity of Triquetrorhabdulus carinatus. Normally, sphenoliths are not abundant in these cores. Best represented is generally an undescribed form and $S$. moriformis, a long-ranging species without much value for age determination. Many samples have a background of coccolith debris. Triquetrorhabdulus carinatus is present in various amounts in Cores 15 to 22 , which allows assignment of these cores to the Late Oligocene/early Miocene interval, the exact boundary being difficult to set, as Sphenolithus ciperoensis which is characteristic of this interval - seems to be absent. From Core 12 downwards, a form similar to Zygrhablithus bijugatus occurs in ascending frequency and reaches about 30 per cent of the larger coccoliths in Core 18, and below. The content in this form, however, varies from sample to sample and might well have had an influence on the characteristics of the sediment.

\section{Oligocene}

As mentioned above, the boundary between the Miocene and the Oligocene cannot be exactly defined by coccoliths at this site. Generally the Oligocene assemblages contain the same long-ranging coccoliths as the Early Miocene. Core 19 to 22 are thus assigned to the Late Oligocene. In Core 20, Triquetrorhabdulus is still present. Because Sphenolithus distentus and $S$. predistentus that mark the next lower zone are not present here (but in other high latitude Oligocene), the cores are assigned to the $S$. ciperoensis Zone $(S$. ciperoensis is also absent, but was found in other high latitude samples). Also the Oligocene shows a considerable amount of Zygrhablithus cf. Z. bijugatus, and occasionally Chiasmolithus sp. is also present.

The Early Oligocene is represented by Cores 23 to 25 that all contain Isthmolithus recurvus (rare) but no disc-shaped discoasters, indicative of the Ericsonia obruta Zone. Thus, the Mid-Oligocene seems to be missing, although this is only seen by negative evidence (lack of Mid-Oligocene species in Cores 20,21 and 22). The Early Oligocene flora is somewhat richer than the Late Oligocene and Miocene flora at this site and resembles the Early Oligocene from northern Europe. However, with the difference that here Zygrhablithus cf. $Z$. bijugatus plays a sometimes prominent part in the assemblage. Braarudosphaera bigelowi also occurs. B. bigelowi is known, in recent seas, to live in basins and gulfs rather than in the open sea (indication of restriction of the sea before nondeposition after the Early Oligocene?). The presence below and above the nondeposition period of $Z$. cf. $Z$. bijugatus in high quantities could indicate that the conditions did not change drastically in the Oligocene or that similar conditions were maintained nearby while there was nondeposition at this site-or, that sedimentation, after all, was only reduced but continuous.

\section{Eocene}

Cores 26 to 28 are believed to belong to the Late Eocene. Due to lithification, the coccoliths in these cores show a bad preservation. Isthomlithus recurvus was found in all three cores, as well as Discoaster saipanensis or D. barbadiensis. Also, the Late Eocene assemblage is comparable to the assemblages of the same age found in Northern Europe. Again, Z. cf. Z. bijugatus is present in variable amounts.

\section{Miscellaneous}

\section{Preservation}

Except for the fairly well-preserved Pliocene and Pleistocene flora, most coccoliths and discoasters are badly preserved, broken or calcified. The assemblages are generally poor, but it is difficult to say whether this is due to a primarily poor assemblage living here or to selective solution.

\section{Reworking}

Well-preserved coccoliths of Late Campanian or Early Maestrichtian age were found in several samples in the Pleistocene. Late Eocene to Early Oligocene forms occur occasionally in the Miocene (Chiasmolithus grandis, $C$. expansus). From seismic records it can be assumed, that during Miocene and later, Eocene-Oligocene sediments outcropped at the border of the basin and were eroded and transported by currents to be mixed and redeposited with the actual nannoplankton of the time. The same may be the case for the Late Cretaceous forms that occur in the Pleistocene.

\section{Radiolaria}

Of all the sites drilled during Leg 12, Site 116 has the most complete record of Cenozoic radiolarians. With the exception of Core 11 where most of the biogenous silica has been mobilized to form chert and other siliceous masses, all Hole 116 cores down to about 700 meters (Pleistocene through Oligocene-Miocene; 116-1 to 19) contain rare to common and occasionally abundant, well-preserved radiolarians. Most of the assemblages include enough representatives of low latitude Cenozoic faunas that several of the standard radiolarian zones (Moore, in press; Riedel and Sanfilippo, 1970, and in press) can be recognized (Chapter 17, Table 1). In the Oligocene-Eocene section (116, Cores 20 to 28 ), radiolarians are very rare to absent, and all are corroded or silicified. Residues of samples from all of these cores contain ample evidence of diagenetic mobilization of silica in the presence of chert fragments, silicified internal casts of foraminifers, and cloudy siliceous masses or clumps. The absence or near absence of radiolarians in this interval is more than likely the result of silica mobilization (see discussion in Lithology section). 


\section{Hole $116 \mathrm{~A}$}

Radiolarians are present in most of the sample residues from Hole $116 \mathrm{~A}$, but they are seldom common or abundant (Figure 24). Abundances increase slightly and assemblages are more diverse below the glacial-preglacial boundary (just above 116A-8-6), which is placed at a position below which detrital mineral grains are absent in the $\mathrm{HCl}$-insoluble, clay-free residues. Presumably, the presence of detrital grains, although representing a very low percentage of the total sediment, is indicative of times of glaciation and is either the result of ice-rafting or the movement of sand into deep water during the low stands of sea level. The Pliocene-Pleistocene boundary shown in Figure 24 is based on the nannofossil evidence. The complete absence of detrital mineral grains and the common occurrence of a fairly diverse radiolarian assemblage in 116A-3-4 suggest an interglacial interval. Based on the nannofossil evidence, the extrapolated age of this sample is about 0.72 million years which would place it in about the middle of the Yarmouth Interglacial of the North American Pleistocene (= MindelRiss Interglacial in Europe). Of all the interglacials recognized the Yarmouth was of the longest duration, beginning a little over one million and ending about 400,000 years before present (Ericson et al., 1964). The presence of a fairly diverse radiolarian assemblage and the absence of detrital mineral grains in 116A-3-4 either represent a sampling accident or may reflect an interglacial climatic maximum.

As at Site 114, the radiolarian assemblages in Hole 116A are dominated by the same species of spheroidal and discoidal spumellarians. Species which persist throughout all eleven cores include: Actinomma antarcticum (Haeckel), A. spp., Thecosphaera spp., Hexacontium spp., Ommatodiscus spp., Spongodiscus spp., Euchitonia spp., Lithelius minor Joergensen, $L$. spp., and orosphaerid fragments and spines. Species which occur very rarely and irregularly include: Actinomma medianum Nigrini, Heliodiscus asteriscus Haeckel, Spongocore puella Haeckel, Lamprocyclas maritalis maritalis Haeckel, L. maritalis polypora Nigrini, Androcyclas gamphonycha Joergensen, Theocalyptra davisiana (Ehrenberg), Pterocanium trilobum (Haeckel), and Cornutella profunda Ehrenberg. Species present in all eleven cores but more persistent and abundant below the Pliocene-Pleistocene boundary include: Stylodictya validispina Joergensen, Spongopyle osculosa Dreyer, Spongotrochus sp. cf. S. glacialis Popofsky, Amphisphaera cronos (Haeckel), Phorticium pylonium (Haeckel?) Cleve, Druppatractus acquilonius Hays, D. irregularis Popofsky, Lithomelissa thoracites Haeckel, Helotholus histricosa Joergensen, Eucyrtidium calvertense Martin, and Artostrobium auritum (Ehrenberg). No species worth noting are confined to the Pleistocene. Lamprocyclas heterporos Hays is present in the Pliocene but just above and below the glacial-preglacial boundary. Species which are present only below this boundary (116A-8-6 and below) include: Spongaster sp. cf. S. tetras Ehrenberg (see radiolarian report for Site 114), Theocorythium trachelium (Ehrenberg), Anthocyrtidium cineraria Haeckel, Coracalyptra cervus (Ehrenberg), Lithomitra lineata (Ehrenberg), and Carpocanistrum spp.
Hole 116

\section{PLIOCENE TO OLIGOCENE-MIOCENE}

The distribution of biostratigraphically significant radiolarian species and the standard radiolarian zones recognized in Cores 116-1 to 22 (Pliocene - Oligocene-Miocene) are given in Chapter 17, Table 1. All radiolarians are well preserved except in Cores 116-11 and 20 to 22 where they are corroded or absent because of their dissolution. Of the stratigraphically significant fossils the following are characteristic in that they are present in most samples from Cores 5 through 19: Calocyclas margatensis Campbell and Clark, Stichocorys delmontensis (Campbell and Clark), Cyrtocapsella cornuta Haeckel, and C. tetrapera Haeckel.

Core 1 corresponds in depth below sea bed with portions of Cores 8 and 9 of Hole 116A. As discussed under 116A above, the glacial-preglacial boundary occurs above Section 116A-8-6. This boundary, determined in the same way, occurs in Hole 116 just below 116A-1-3 (Figure 25). Other evidence of correspondence between the two holes is the presence of Spongaster sp. cf. S. tetras Ehrenberg in Section 116A-8-6 of 116A and in all samples from 116-1. As noted in the radiolarian report of Site 114 , the stratigraphically restricted occurrence of this species in this part of the North Atlantic may represent a migration event which occurred during the preglacial to glacial transition in the late Pliocene.

All of Core 1 plus Sections 1 and 2 of Core 2 lack stratigraphically significant fossils; therefore, no radiolarian zone is recognized for this interval. The presence of Stichocorys peregrina (Riedel) and the absence of any other significant fossils in the lower portion of Core 2 support the assignment of this interval to the Spongaster pentas Zone of Pliocene age.

Except for two very rare occurrences of Stichocorys delmontensis (Campbell and Clark), all of Core 3 and Section 1 of Core 4 lack significant fossils; therefore, no zonal determination could be made for this interval.

The interval form 116-4-2 through 116-5-CC probably represents either or both the Stichocorys peregrina and Ommatartus penultimus Zones of late Miocene age. The highest occurrence in Hole 116 of Cyrtocapsella tetrapera is in Section 116-4-2. Riedel and Sanfilippo (1970, Figure 3) indicate a questionable range of this species as high as the $S$. peregrina Zone, and for this reason 116-4-2, 97 to 98 centimeters, through $116-4-6,89$ to 90 centimeters, may represent as young a zone as this one. More convincing evidence of zonal assignment is the concurrence of Stichocorys peregrina and $S$. delmontensis from 116-4-CC through 116-5-CC. Riedel and Sanfilippo (in press, Figure 2) indicate the lower and upper evolutionary (but not morphological) limits of the former and latter, respectively, at the boundary between the $O$. penultimus and overlying $S$. peregrina Zones. The presence of Ommatartus antepenultimus Riedel and Sanfilippo in the same interval in Hole 116 argues for a more probable assignment to the $O$. penultimus Zone (Moore, in press, range chart).

All of Core 6 is unzoned because of the lack of significant fossils, other than the relatively long-ranging Stichocorys delmontensis and Cyrtocapsella tetrapera. 


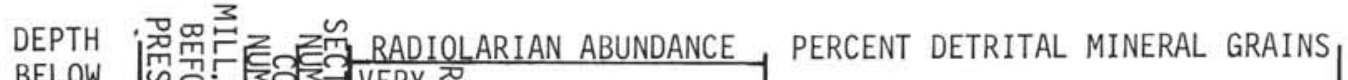

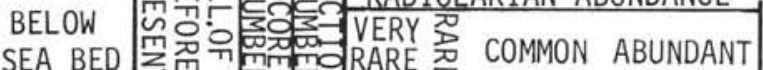

$(\mathrm{m})$

Figure 24. Results of visual examination of HCL-insoluble, clay-free residues from Hole $116 \mathrm{~A}$. 
The persistent and occasionally common to abundant occurrences of Cyrtocapsella japonica (Nakaseko) and the absence of Lithopera renzae Sanfilippo and Riedel and $L$. neotera Sanfilippo and Riedel in Cores 7 and 8 place this interval questionably in the Cannartus (?) petterssoni Zone of middle Miocene age (compare Riedel and Sanfilippo, 1970, Figure 3, with Riedel and Sanfilippo, in press, Figure 2). Also indicative of a middle Miocene age is the concurrence of digitately branched with curved, flat Oroscena spines (Friend and Riedel, 1967).

The persistent occurrence of Lithopera renzae along with the irregular occurrences of $L$. neotera place Cores 9 and 10 within the Dorcadospyris alata Zone of early middle Miocene age (Riedel and Sanfilippo, in press, Figure 2). Because of the mobilization of biogenous silica in Core 11, no significant radiolarian species are present; therefore, zonal assignment is impossible for this core.

Several species which occur in the Calocycletta virginis Zone (Riedel and Sanfilippo, in press, Figure 2) are present in Cores 12 through 19 which are assigned to this zone of early Miocene (to Oligocene (?) in lowest part) age. These include Lychnocanium bipes Riedel, Cyclampterium (?) pegetrum Sanfilippo and Riedel, Dorcadospyris simplex (Riedel), D. ateuchus (Ehrenberg), Cyclampterium(?) sp. cf. C. (?) milowi Riedel and Sanfilippo (see radiolarian report of Site 112), Cannartus prismaticus (Haeckel), Theocorys spongoconum Kling, Theocyrtis annosa (Riedel), and Carpocanopsis cingulatum Riedel and Sanfilippo.

The absence or near absence of Cyrtocapsella tetrapera and $C$. cornuta and the very rare presence of Lychnocanium bipes and Dorcadospyris ateuchus place Core 20 within the $L$. bipes Zone of Oligocene age. The corroded radiolarians of Cores 21 and 22 are nondiagnostic; therefore, no age could be assigned to these cores.

\section{EOCENE-LOWER OLIGOCENE}

In the Lower Oligocene interval (116 - 23 to 25$)$ the only Oligocene radiolarian present is Cyclampterium (?) milowi Riedel and Sanfilippo from 116 - 25 - CC. Late Eocene species identified from Cores 26 to 28 (Hole 116) include very rare specimens of Tristylospyris triceros (Ehrenberg), Calocyclas semipolita semipolita Clark and Campbell, Spongasteriscus cruciferus Clark and Campbell, Spongurus bilobatus Clark and Campbell, (?) Sethochytris babylonis (Clark and Campbell) group, Heliodiscus heliastericus Clark and Campbell, and Lophoconus titanothericeraos Clark and Campbell.

\section{PALEONTOLOGY AND BIOSTRATIGRAPHY (117)}

\section{General}

The sedimentary sequence cored at Site 117 represents Oligocene, Lower Eocene and Upper Paleocene. The Oligocene is a coccolith chalk with abundant bryozoan fragments. This chalk lies (? disconformably; 117-3-CC; 117A-1-1) on Lower Eocene shales in which foraminifera and radiolarians have been replaced by zeolites. The Upper Paleocene at Site 117 is represented by shales and silts, the latter composed of volcanic mineral grains and contains a neritic benthonic foraminiferal fauna (Figure 22), elements of which are found in the Paleocene of Europe and North
America. Worm tubes, bryozoans and molluscan shells occur in varying abundance in these silts.

Separate reports dealing with the ostracods and bryozoans at Site 117 are presented at the end of this section.

\section{Discussion}

\section{Foraminifera}

Oligocene sediments at this location are characterized by a relatively low diversity planktonic foraminiferal fauna. Among the forms present are Globigerina galavisi, $G$. angiporoides, $G$. prasaepis, Globigerinita unicava, $G$. dissimilis, G. pera, G. africana, and Globorotalia opima s.s. and $G$. opima nana. Benthonic foraminiferal elements include Heterolepa mexicana, Cibicidoides perlucida, Anomalinoides pompilioides, Vulvulina jarvisi. The Lower Eocene sediments are characterized by a small planktonic foraminifera consisting of Globigerina patagonica and small indistinct acarininids. Characteristic benthonic foraminifera include Anomalinoides grosserugosa, Osangularia pteromphalia (the dominant form), Anomalina acuta, Lenticulina decorata, Cibicidoides sulzensis, Cibicidoides propria and C. hercegovinensis. The Upper Paleocene fauna is essentially similar to that recorded above but includes also Anomalinoides danica, Allomorphina halli, Lenticulina midwayensis, Alabamina obtusa, Karreria fallax, and Vaginulina longiforma. These faunas exhibit strong similarity to Paleocene/ Lower Eocene faunas from the Gulf and Atlantic coastal plain of North America and from northwestern Europe.

Bryozoans and ostracods are abundant in the Upper Paleocene-Lower Eocene and Oligocene sediments at Site 117. These have been studied independently and the results are included as separate reports at the conclusion of this section. Other microfossils (oysters, gastropods and worm tubes) are common in Core 9 and attest to the relatively shallow water depths of the sediments immediately above the basaltic basement at this site. Specimens of a "larger foraminifera", Operculina heberti, occur in Core 117A-9; this is the northernmost reported occurrence of the genus and is a further indication of the relatively warm and shallow waters present in this area during Late Paleocene time.

\section{Calcareous Nannoplankton}

\section{Miocene-Oligocene}

The preservation of the coccoliths in most samples at this site is poor. In the Miocene-Oligocene part of the sequence, discoasters are scarce and calcified. Cores 1 to 3 (Hole 117) can be assigned to Early Miocene to Late Oligocene. They have all long-ranging species as Cyclococcolithus neogammation, C. bisectus, Sphenolithus moriformis in common, while I could not find enough age-diagnostic forms to decide on an age. As at Site 116, Zygrhablithus cf. Z. bijugatus is present and can attain a rockbuilding percentage. In some samples (117-2), Chiasmolithus sp. is abundant.

The core catcher of 117-3, the lowermost core of this hole, contains coccoliths of Early Eocene age, including Discoaster kuepperi and D. lodoensis. It is, however, mixed with coccoliths of Oligocene and ?Miocene age (Discoaster 


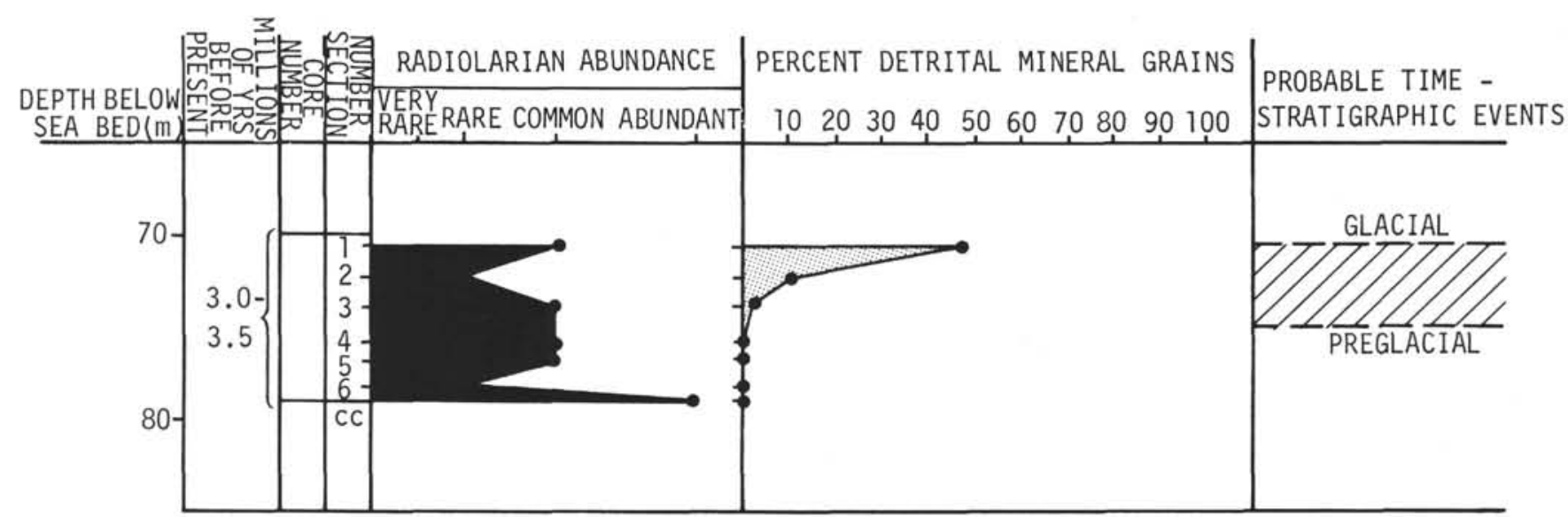

Figure 25. Results visual examination of $\mathrm{HCl}$ insoluble-free residues from Core 1, Hole 116.

exilis). In the top of this core a Late Oligocene assemblage including Sphenolithus predistentus was found. The same interval, with a nondeposition from Early Eocene to Late Oligocene, was cored in $117 \mathrm{~A}-1$.

\section{Early Eocene - Late Paleocene}

Cores 117A-2 to 10 contain a lower Eocene to upper Paleocene sequence including the zones of Marthasterites tribrachiatus, $M$. contortus and Discoaster multiradiatus. The assemblage from the $M$. tribrachiatus Zone can be compared with the Lower Eocene from Denmark. But here, as in the Oligocene, Zygrhablithus cf. Z. bijugatus is present. It does not reach the high percentages it reaches later. Also present and more frequent than in Denmark, are different species of the genus Micrantholithus and Braarudosphaera, indicating a restricted sea in the Late Paleocene - Early Eocene.

The oldest coccoliths found still indicate the presence of the Discoaster multiradiatus Zone. Thus, about 10 meters above the basalt core in Core 11, the sediment can be dated to be about 56 million years old.

\section{Miscellaneous}

In several samples of Late Oligocene, Early Eocene and Late Paleocene age, younger coccoliths were found (from the Miocene?). The mixing is probably due to the fact that chert fragments with adhering chalk kept falling down the hole from higher Oligocene-Miocene strata. No reworked Cretaceous coccoliths were found at this site.

\section{Radiolaria}

The only identifiable radiolarians in situ at Site 117 occur in Core 1 of Hole 117 and include Cyrtocapsella tetrapera Haeckel and Anthocyrtium ehrenbergi ehrenbergi (Stöhr) of Miocene age. One orosphaerid (Oropelex (?) sp., Oligocene-Lower Miocene) was recovered from the core water of 117-3.

In Hole $117 \mathrm{~A}$ the only significant radiolarian occurrence is Core 2 of Eocene age. Here the unidentifiable, very abundant radiolarians, as well as sponge spicules, are completely replaced by zeolite. A similar but rare assem. blage occurs in Core 4. Most of the remaining cores show some evidence of mobilization of biogenous silica. Dinoflagellate cysts are present in Cores 1, 3,4 and 5. Cores 6,7 and 8 are characterized by high percentages of organic matter in the $\mathrm{HCl}$-insoluble residues.

The absence of radiolarians in the late Paleocene - early Eocene sediments of the $117 \mathrm{~A}$ probably reflects the shallow water paleoenvironment at this time, and the abundant but zeolitized radiolarians of Core 2 may indicate the first signficiant deepening due to subsidence of Rockall Plateau.

Preliminary Report on the Ostracods of Holes 117 and $117 \mathrm{~A}$

\section{R. H. Benson, Smithsonian Institution, Washington, D.C.}

\section{Abstract}

Six samples obtained from upper Paleocene and Oligocene strata penetrated by adjacent DSDP Holes 117 and $117 \mathrm{~A}$ on the Rockall Bank $\left(57^{\circ} 20.17^{\prime} \mathrm{N} ; 15^{\circ} 23.97^{\prime} \mathrm{W} ; 1038\right.$ meters) have yielded over 300 ostracod specimens representing fourteen genera. Of these taxa nine are now living in the deep-sea, and the remainder are frequently found in "deep-water" fossil deposits. From consideration of the living distribution of the extant genera, the development of blindness with increasing depth, the absence of a typical shelf assemblage, and from an estimate and comparison of relative values of diversity, it is postulated that the Paleocene bottom was shallower than at present (from 100 to 600 meters depth), and that the Oligocene assemblage was formed under bathymetric conditions similar to those at present (1000 meters or more).

\section{Introduction}

Samples of Paleocene and Oligocene age from Holes 117 and $117 \mathrm{~A}$ obtained from Rockall Bank have yielded specimens representing fourteen ostracod genera. Although the systematics and distribution of fossil deep-sea Ostracoda is far from well-known, the genera of these samples are familiar to me and their probable ecological limitations could be estimated. Some of these genera still have extant species in the modern oceans, and others are known from fossil "deep-water" assemblages. Characteristic morphological traits distinguish them from their contemporaries 
inhabiting the sublittoral zone. These data can be used to infer the bathymetric ranges of the fossil ostracods of Rockall Bank during the Paleocene and Oligocene.

The Paleogene fossil record of the deep-sea (psychrospheric) ostracods is sparse. Specimens have been described from only a few core and dredge samples from the ocean floor. The assemblages from several surface outcrops in southern Europe and the Caribbean are known. Therefore the 300 well-preserved ostracod specimens from the samples of Holes 117 and 117A are particularly interesting. The Oligocene assemblage is remarkably similar to modern ones living at depths near 1000 meters. The Paleocene assemblage has a number of extinct genera that have been previously found in so-called "deep-water" deposits.

The status of knowledge of ostracods of the Atlantic Ocean floor has been given elsewhere (Benson, 1966, 1969). Information is accumulating rapidly (two generic names are given as nomina nuda here). Whereas a few years ago there were less than a hundred stations collected for ostracods from the world ocean floor, in making the present study I have referred to a data array with over 300 samples from the deep-sea (with 60 or more from the Atlantic shelf of North America). The base for the present comparison is considerable, and although the lower ends of the stratigraphic ranges of most taxa are incompletely known, some confidence can be placed in the statements of their broader environmental tolerances.

The purposes of the analyses were threefold: (1) to examine the modern depth distribution of taxa found in the cores; (2) estimation of the difference in relative species diversity between Recent shallow and deep assemblages, for comparison with that of the core samples; and (3) to determine the presence and absence of eye tubercules, representing the onset of blindness associated with increasing depth. From these analyses it was hoped that some estimate of the in situ depth of the samples could be made.

\section{Material Studied}

\section{Hole 117: Cores 2, 3 \\ Hole 117A: Cores 4, 7, 8 \\ 330 ostracod specimens}

Data on the samples studied are listed in Table 6, which also includes the ages of the cores, the genera identified, and the counts of specimens belonging to each. The specimens were silicified in part, some were deformed by compaction, but most were very well preserved. More complete discussions of other aspects of the core samples are given elsewhere in this volume.

\section{General Faunal Aspect}

Of the fourteen genera identified from the Paleocene (nine) and Oligocene (eleven), nine contain still extant species. Although some of these genera are found in shallow deposits (Echinocythereis with eye tubercules, Cytherella, Bairdia, Bythocypris, and "Hermanites"), none is especially typical of shallow shelf environments. Forms restricted to shallow shelf deposits of the Paleocene of either Europe or North America are notably absent. However, some "deepwater" forms described from the Eocene portion of the Possagno section of northeastern Italy (Ascoli, 1969) of the London Clay (Bowen, 1953; also see Hazel, 1965) or from the Paleogene sections of Trinidad (Bold, 1957, 1960) are present. Specimens of Trachyleberidea, similar in the degree of fineness of their surface morphology to the ones of the present study, have been reported from a middle Eocene sample from a submarine canyon (Gosnold 2621C; Gibson, Hazel and Mello, 1968) in the Atlantic shelf of North America. This form is also known from the London Clay (Bowen, 1953). Specimens of Agrenocythere hazelae, which may be conspecific with those of the present study, have been described as "Bradleya" hazelae and "Cythereis" hazelae from northern Italy and Trinidad.

As shown in Table 6, there is a change in assemblage composition from the Paleocene samples (117A-7 and 8) to the Oligocene samples (117-2 and 3). The number of extant genera increases, and three extinct genera (Phacorhabdotus, "Hermanites", and Trachyleberidea) disappear. The one form called "Hermanites" is related to several species known from North America ("H." midwayensis (Alexander), "H." gibsoni Hazel, and "H." dohmi (Howe and Chambers) according to Hazel (personal communication). It became extinct in the Atlantic by the Oligocene, but may have survived in the eastern Pacific ("Cythereis" kewi LeRoy; a "cold-water", upper-slope or outer-shelf inhabitant).

The number of blind members of the Oligocene assemblage increases to the exclusion of those with eye tubercules that are found in the Paleocene. Because as deep-sea (psychrospheric) ostracod taxa are both blind and have considerable longevity, this change in faunal aspect is interpreted as an increase in depth during Oligocene time.

The form called Agrenocythere (which is being described in manuscripts being prepared for publication) is of particular interest (Plate 11, Figure 5) as it occurs in many fossil localities of comparable age to the samples of Hole $117 \mathrm{~A}$. When it is found in abundance in modern oceans, the depths are usually more than 1000 meters and less than 2000 meters. At these depths it is blind, as are the specimens in the Oligocene samples of Hole 117.

It may be significant that forms such as Abyssocythere (Benson, 1971) and the antecedents to "Cythere" acanthoderma, two groups of species which are typically associated with very modern ostracod assemblages, are absent. This fact suggests some consistency in the depth ranges of deep-sea ostracods throughout the Tertiary.

The functional architecture of the ostracod carapace responds to the many factors involved with an increase in depth. Among these is the decrease in light and the corresponding loss of sight. Many of the species of the Paleocene samples had clear, functional eye tubercules, whereas those of the Oligocene samples were blind. More will be said about this subject in a later section. Also noteworthy is the usual increase in fragility (thinner walls and more intricate surface sculpture) of ostracod carapace with depth (corresponding to decreasing mechanical energy levels). Both Paleocene and Oligocene ostracod assemblages can be considered as having fragile carapaces, at least they are certainly not typical of inner shelf, high energy level environments.

In summary, the general aspect of the Oligocene ostracod assemblage suggests a deep-sea habitat (probably between 1000 and 1500 meters), and that of the Paleocene 
TABLE 6

Specimen Counts

Sample Level

\begin{tabular}{|c|c|c|c|c|c|c|}
\hline & \multicolumn{2}{|c|}{ Oligocene } & \multicolumn{4}{|c|}{ Paleocene } \\
\hline Hole & \multicolumn{2}{|c|}{117} & \multicolumn{4}{|c|}{$117 \mathrm{~A}$} \\
\hline Core & 2 & 3 & 4 & 4 & 7 & 8 \\
\hline Section & 6 & 1 & 1 & 6 & 1 & 1 \\
\hline Interval $(\mathrm{cm})$ & Bottom & $30-35$ & $42-67$ & $101-105$ & $95-100$ & $130-134$ \\
\hline Penetration (m) & 110 & 150 & 250 & $250+$ & 280 & 300 \\
\hline Depth below sea level (m) & 1148 & 1188 & 1288 & $1288+$ & 1318 & 1338 \\
\hline \multicolumn{7}{|l|}{ OSTRACODS } \\
\hline Henryhowella & 35 & & & & & \\
\hline Pterygocythere? & 8 & & & & & \\
\hline *Poseidonamicus & 8 & & & & & \\
\hline Macrocypris & 1 & & & & & \\
\hline Echinocythereis & 1 & 2 & & & & \\
\hline *Agrenocythere & 18 & & & & 13 & 6 \\
\hline Krithe & 15 & 2 & & & 2 & 1 \\
\hline Cytherella & 9 & 1 & 1 & 12 & 7 & 8 \\
\hline Bairdia & 16 & 3 & & 2 & 13 & 16 \\
\hline Bythocypris & 13 & 6 & & 2 & 16 & 4 \\
\hline Hazelina & $1(?)$ & 1 & & & 1 & 9 \\
\hline Trachyleberidea & & & 1 & 5 & 14 & 20 \\
\hline "Hermanites" & & & & 1 & 14 & 20 \\
\hline Phacorhabdotus & & & & & 1 & 1 \\
\hline Totals & 125 & 15 & 2 & 22 & 81 & 85 \\
\hline
\end{tabular}

*Proposed names of new genera now in manuscript.

assemblage (containing sighted individuals) to be shallower (deeper than 200 meters but shallower than 600 meters). The absence of typical shelf taxa, well known from the nearby continent, represents negative evidence against the likelihood that the sediments of Site 117 were very close to sea level during the Paleogene.

\section{Modern Depth Distribution}

From the presence of extant genera, such as Agrenocythere, Echinocythereis, Henryhowella and Poseidonamicus, in the Oligocene samples, and the absence of several common deeper dwelling forms, one can reconstruct the likelihood of past depth ranges; that is, assuming these have not changed substantially over the last 40 million years. I have selected these four genera because of their ease of identification and because distributions are reasonably well known. All four genera occur in Core 2 (see Table 6). These include Henryhowella, which is common to depths ranging from outer shelf to over 5000 meters, but blind forms occur only in the deeper part of the range; Agrenocythere (nomen nudum, concept includes forms related to "Cythereis" hazelae Bold, 1946, and "Cythere" radula Brady, 1880), most common to depths between 1000 and 1500 meters; Poseidonamicus (nomen nudum, concept includes forms related to "Cythere" viminea Brady, 1880), most common to depths over 2500 meters and never found in waters shallower than 1000 meters; and Echinocythereis (the species group associated with $E$. echinata Sars), which has a wide depth range but becomes blind below 600 meters. The summation of these frequency distributions is given in Figure 26 and is based on 222 recordings. Minimum depth records for the Recent distribution of each of the four genera are $300,400,1190$ and 600 meters, respectively. It is interesting to note that the present Oligocene discovery represents the shallowest of some 85 such records for Poseidonamicus. 


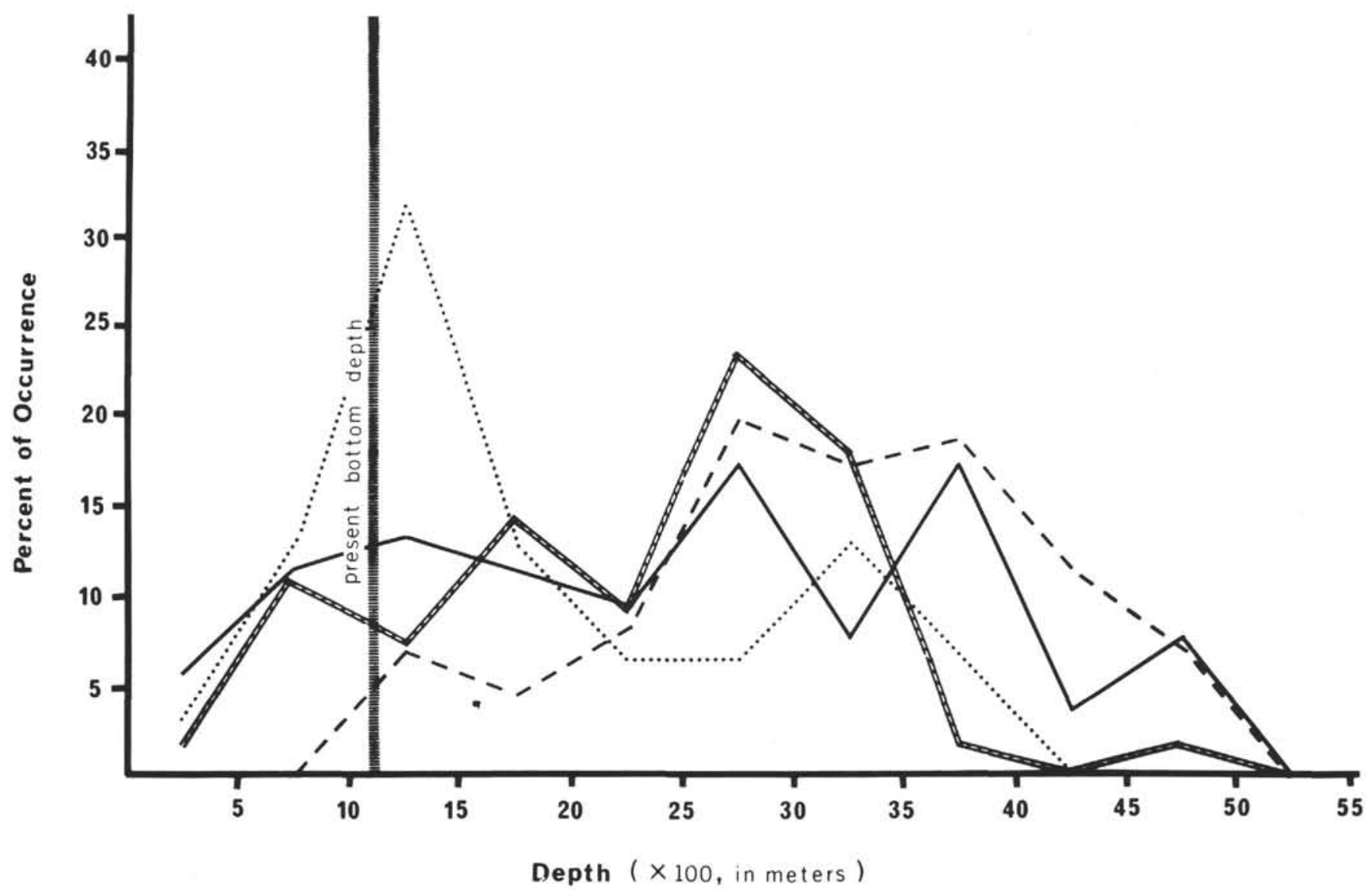

Figure 26. The relative depth distribution, expressed in percentage of the likelihood of occurrence of each of four genera, Agrenocythere (dotted line), Poseidonamicus (dashed line), Echinocy thereis (solid line) and Henryhowella (laddered line), at a given depth interval (500 meters) extending from sea level to 5500 meters depth. The present bottom depth of Site 117 (1038 meters) is also indicated.

The frequency distributions given in Figure 26 represent the relative likelihood of finding any one of the above genera living within a particular depth interval of 500 meters over a range of depth from sea level to 5500 meters. The chance of finding any of the forms in waters shallower than 500 meters is nil to less than six per cent. Most of the genera are found typically in waters greater in depth than the present bottom at Site 117. However, Agrenocythere is most typical of waters of from 1000 to 1500 meters in depth. One might judge from this distribution, combined with the limits of range of the others, that their combined occurrence indicates bottom depths at least as great as 1000 meters.

\section{Relative Species Diversity}

Several methods for determining relative species diversity are available. The one used in the present study is the number of species (S) minus the number of species with only one specimen (S-s) found in each sample plotted as the ordinate, and the number of specimens of a given sample plotted as the abcissa. The result is a bivariant plot (Figure 27) of the likelihood of finding a particular number of species (those with more than one specimen) in a sample with a specified number of individual specimens, from either the psychrosphere (depth greater than 1000 meters) or the thermosphere (depths less than 500 meters). The plot shows a good separation between the tendency for Recent shallow ostracod assemblages to contain more species than deep ocean assemblages (more than twice as many in an abundant sample). With samples of fewer than 150 specimens the two curves of the plot begin to converge, however some tendency for the shallow samples to contain more species is still indicated.

These data are taken from the deep sea from all over the world and from the shelf of eastern North America. I believe that they are representative of the size range of samples and number of included species usually encountered. The plot of four of the more abundant core samples (solid triangles) on this distribution suggests that they tend toward the species diversity of deeper water assemblages. With the material at hand, however, this analysis is not conclusive. Larger samples are required.

\section{Blindness}

Although some shallow-water ostracods are blind, most have eyes. In many, this is observable through the presence of an optically clear eye tubercule. However, no psychrospheric ostracod assemblage has yet been found containing a species with eyes. With increasing depth, the eye tubercules atrophy and disappear. Because few genera transcend the boundary of the outer shelf and upper slope, examples of gradual atrophy are difficult to find. Eyes and 


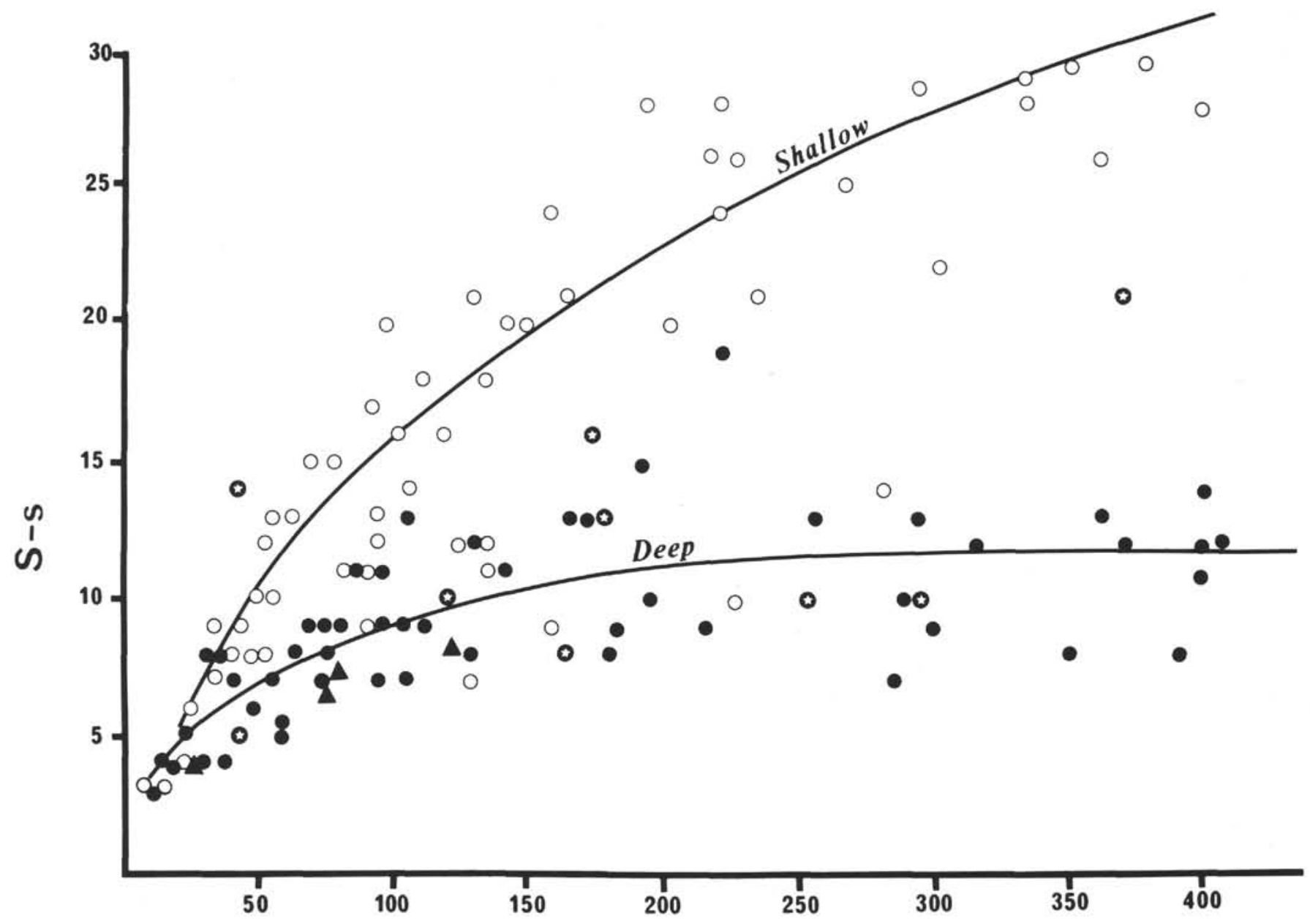

Number of Specimens

Figure 27. The relative species diversity (see text for explanation) of ostracod assemblages from approximately 60 shelf samples (open circles) and 50 deep-sea (solid, > 1000 meters; and starred dots, 500 to 1000 meters). Four of the more abundant assemblages of the core samples of Hole $117 \mathrm{~A}$ are plotted (solid triangles) for comparison.

eye tubercules can be seen to disappear with depth in Echinocythereis sp. aff. E. echinata on the northern slope of the Gulf of Mexico. Blindness in this form occurs between 600 and 800 meters.

It seems reasonable to assume that a fossil assemblage of all blind species would indicate considerable depth, and one with all or many species with eye tubercules would indicate a shelf environment. From comparison of many possible species in living faunas (a somewhat hurried search through my collection), assemblages having species with eye tubercules would seem to live in waters shallower than 600 meters. Conversely, assemblages having all blind members lived at depths greater than 800 meters. The difference between the two levels represents a zone of change where the ocular structures disappear.

As shown in Plates 11 and 12 and in Figure 28, the preponderance of ornate ostracods (those in which eye tubercules would most likely be seen) of Paleocene age (Cores 7 and 8) found in 117A were sighted, and all of those of Oligocene age (Cores 2 and 3) were blind. This change in state of visual ability can actually be seen to occur in three of the genera (Agrenocythere, Trachyleberidea and Hazelina). These data suggest an increase in depth from Paleocene to Oligocene.

\section{Conclusions}

The relative species diversity, the Recent distribution of the genera present, and the increase in blindness of ostracods found in the Paleocene and Oligocene samples of Holes 117 and $117 \mathrm{~A}$, all indicate that Site 117 was probably shallower during the Paleocene than it is today, but that it was nearly as deep during the Oligocene as now. The absence of sublittoral ostracods typical of the shelf deposits of both Europe and North America during this time interval suggests that the depths were always greater than 100 meters. Ostracods with eye tubercules in the Paleocene assemblage indicate that depths at this time were less than 600 meters. The genera (all blind) found in the Oligocene samples are all known from the psychrosphere of the Recent Atlantic. They live in depths nearly as great as 

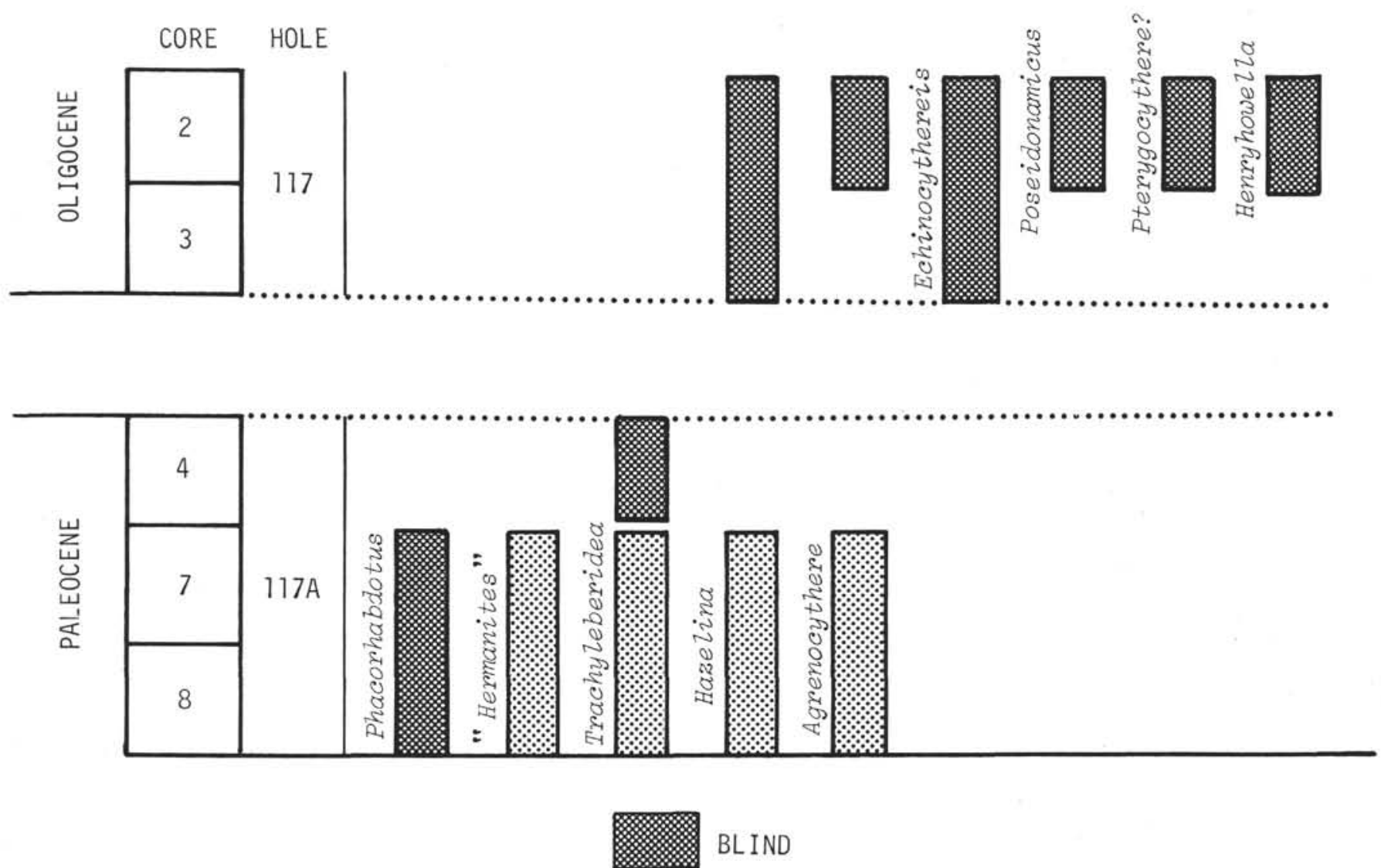

WITH EYES

\section{OSTRACODE GENERA}

Figure 28. The distribution of the more ornate ostracod genera within the sections represented by the cores of Holes 117 and $117 \mathrm{~A}$, showing their local stratigraphic ranges and also the presence or absence of eyes (eye tubercules) to indicate a change in depth of water sometime after the Paleocene and before the Oligocene.

or greater than the present site of Hole 117A. This evidence indicates that downward tectonic displacement did occur as suggested by Laughton et al. (1970), but it was not in the order of magnitude suggested, and probably at an earlier time. The greatest sinking was probably during Eocene rather than during the Miocene.

\section{ACKNOWLEDGMENTS}

I would like to thank W. A. Berggren for the opportunity to study the samples of Holes 117 and 117A, which yielded these most interesting ostracod assemblages, and both M. A. Buzas and A. H. Cheetham for their comments during the study, and J. E. Hazel for his date on the distribution of Atlantic sublittoral species and his critical review of the manuscript. This study was sponsored by the Smithsonian Institution and National Science Foundation Grant GA-17325. The stereophotographic illustrations of the specimens were made on the Kent-Cambridge Stereoscan.

\section{Preliminary Report on Bryozoa (Site 117)}

A. H. Cheetham, Department of Paleobiology, Smithsonian Institution, Washington, D. C., and Eckart Håkansson, Visiting Research Associate, Smithsonian Institution, Washington, D. C. ${ }^{3}$

\section{Abstract}

Seven samples from upper Paleocene and Oligocene sediments cored in two holes at Site 117 on the Rockall Plateau (lat $57^{\circ} 20.17^{\prime} \mathrm{N}$; long $15^{\circ} 23.97^{\prime} \mathrm{W} ; 1038$ meters) yielded more than 10,000 bryozoans referable to the orders Cheilostomata and Cyclostomata. Preliminary study of the cheilostome specimens indicates that at least 94 species belonging to 68 genera are represented. Close biogeographic connections with both Europe and North America are suggested for the Paleocene assemblages, and closer

\footnotetext{
${ }^{3}$ Permanent address: Universitetets Institut for Historisk Geologi og Palaeontologi, Copenhagen, Denmark.
} 
connections with Europe than North America for the Oligocene ones. Few of the genera in the Paleocene assemblages and several in the Oligocene ones survive in modern oceans, and their Recent bathymetric distributions, together with the distribution of colony growth forms and species diversities, indicate probable restriction of these assemblages to sublittoral and upper bathyal depths. Changes in the assemblages are consistent with a progressive isolation of the Rockall Plateau and subsidence of the sea floor at Site 117 from slightly less than 60 meters to slightly more than 200 meters below sea level from late Paleocene to Oligocene time.

\section{Introduction}

Clays, sandy silts, and cherty limestones of late Paleocene and Oligocene age cored in Holes 117 and 117A on the Rockall Plateau yielded abundant, generally wellpreserved bryozoans. More than 3500 specimens referable to the order Cheilostomata and nearly 7000 referable to the order Cyclostomata were recovered from seven samples of about $50 \mathrm{cc}$ each.

The Paleogene record of Bryozoa, especially of cheilostomes, has been extensively documented from continental areas bordering the North Atlantic. Major taxonomic discordances, expressed at generic and familial as well as specific levels, are obvious in stratigraphic and biogeographic distributions as presently understood. Stratigraphically, one of the most profound changes is between Paleocene and Eocene assemblages in both Europe and North America (Larwood et al., 1967); those from the Paleocene have a Cretaceous aspect markedly contrasting with the distinctly more modern aspect of those from the Eocene and Oligocene. For the most part, however, the most diversified of these assemblages occur well above or below the Paleocene-Eocene boundary, and the discovery of diversified faunas intermediate in position between the two would be important to interpretation of the evolutionary significance of this discordance. A similar discordance is also apparent in the biogeography of Paleogene cheilostomes, especially those in the Eocene and Oligocene, which show a pronounced separation of Old World and New World taxa. Many genera widespread in the Old World Paleogene, such as Schizostomella and Orbitulipora, have not hitherto been known to occur with New World Paleogene genera, such as Leiosella. Again, faunas intermediate in position between the continental margins of the Atlantic are potentially significant to understanding the evolution of cheilostomes. The Paleocene and Oligocene assemblages from Holes 117 and 117A partly fill these gaps and thus reveal some new relationships in cheilostome history.

This preliminary study of the cheilostomes in seven samples from Holes 117 and 117A indicates that more than 94 species belonging to 68 genera are represented. The abundance and species diversity of these assemblages are in general comparable to those of well-known Paleogene faunules from similar sediments in Europe and North America that have been inferred to have accumulated in sublittoral environments (Braga, 1963; Canu and Bassler, 1933, p. 24; Cheetham, 1963; 1966; Labracherie and Prud' homme, 1966; 1967).
Most of the cheilostomes from Holes 117 and 117A belong to undescribed species, and a few represent new genera. Even this preliminary taxonomic study, however, suggests biogeographic affinities with both western Europe and eastern North America and also indicates changes in the closeness of these relationships during the late Paleocenelate Oligocene interval represented. Some of the genera and one of the species represented survive in modern oceans, and their Recent bathymetric distributions indicate restriction of these assemblages to depths several hundred meters shallower than the present sea floor at Site 117. Changes in the paleoenvironments of these assemblages can be inferred from differences in taxonomic composition, species diversity, and relative abundances of colony growth forms.

\section{Oligocene Bryozoa from Hole 117}

Nearly 4000 bryozoan specimens representing 48 species of cheilostomes and an undetermined number of species of cyclostomes were obtained from 117-2 and 3 (Table 7 and Plates 13 through 20). More than half the specimens are cheilostomes. A few specimens are silicified and all are fragmentary, but preservation for the most part is excellent. An exception is the badly abraded and partially leached single specimen of Lunulites sp. (Table 7; Plate 13, Figure 3), which may have been reworked, possibly from Eocene sediments no longer present at Site 117 . Cores 2 and 3 have been assigned, on foraminiferal and nannofossil evidence discussed elsewhere in this volume, to the upper Oligocene, ?Sphenolithus ciperoensis and ?S. distensus Zones.

The abundance and species diversity of the faunule in the older of the two upper Oligocene samples are comparable to those of many well-known late Paleogene assemblages, such as those in the Castle Hayne Formation of North Carolina, Ocala Group of Florida, Marianna Limestone of Alabama, Upper Bracklesham Beds of Sussex, St. Estéphe Limestone of the Aquitaine, and Priabona Marl of northern Italy. The younger sample has only about half of the abundance and diversity of the older one, but shares all but two of 18 species with it. There are no apparent differences in the known stratigraphic ranges of species which occur in one sample but not the other.

The late Oligocene assemblages from Hole 117 combine Old World and North American elements. Sixteen species have Old World affinities, especially with western Europe; five have North American affinities; and three are known from both Europe and North America. Most of the species, however, are not directly comparable with previously described cheilostomes. Compared to late Paleogene assemblages in Europe and North America, these faunules conspicuously lack genera having modern representatives restricted to tropical and subtropical zones. On the other hand, some of the species have numerical dominance in both samples belong to genera, such as Adeonellopsis and Floridina, that are at present most common in tropical to warm-temperate regions. Possible representatives of coolwater genera, such as Microporina and Escharella, are much less common in these assemblages.

The Recent bathymetric distributions of seven genera and one species characteristic of the late Oligocene assemblages suggest with high probability that this association of taxa represents sublittoral depths (Figure 29). Abundance 
NUMBER OF REPORTED OCCURRENCES

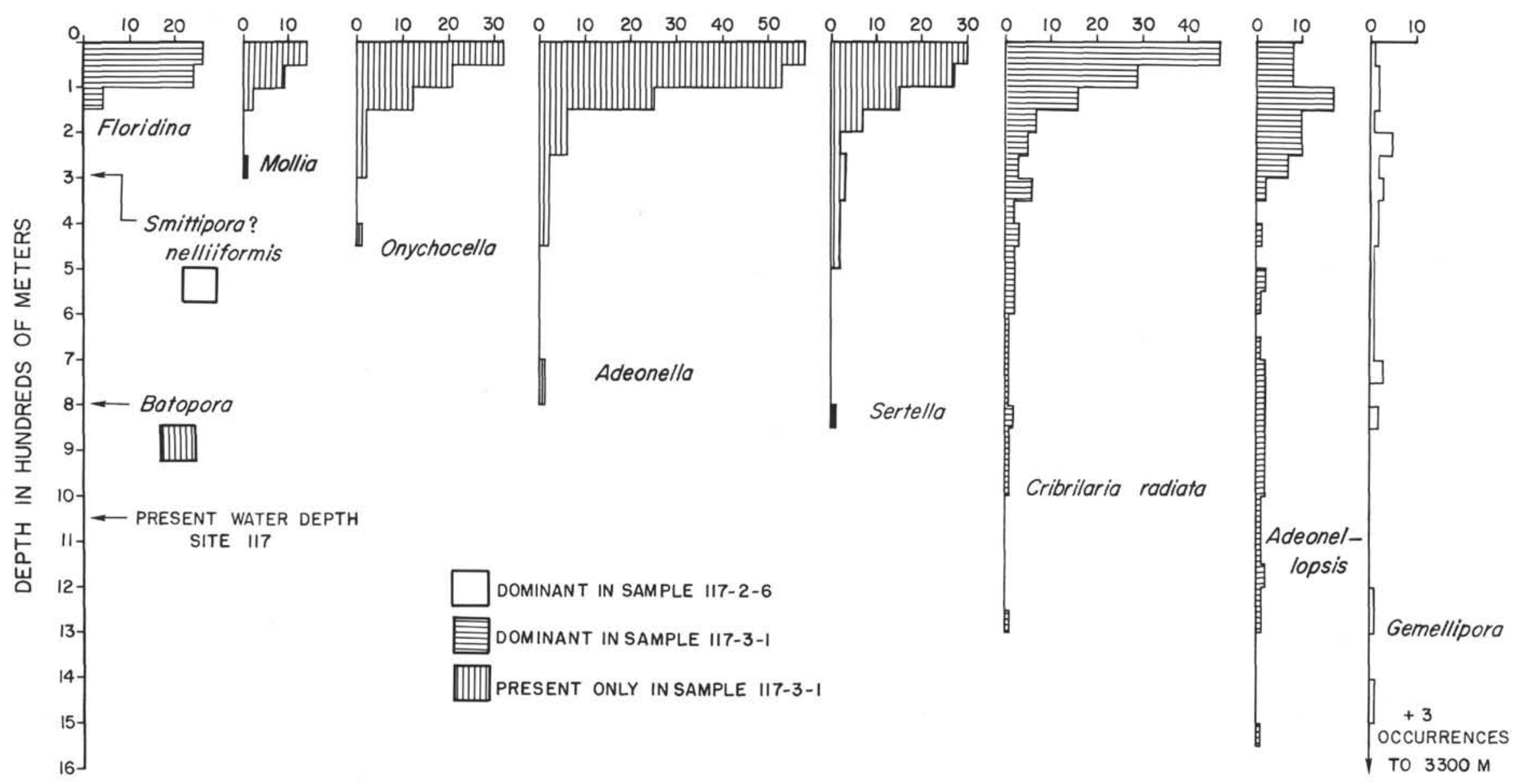

RECENT DEPTH DISTRIBUTION OF TAXA

REPRESENTED IN UPPER OLIGOCENE SAMPLES, SITE 117

Figure 29. Recent depth distribution of taxa represented in Oligucene samples, Site 117. 
of Floridina in both upper Oligocene samples might be evidence that water depths were less than 150 meters for both, except that many more species of this genus lived in Paleogene time than do now and hence its total depth range may have been significantly greater than that of Recent species alone. The peak occurrences of Adeonellopsis (100 to 150 meters) and Gemellipora (200 tp 250 meters) make an outer sublittoral depth of 150 to 200 meters more likely to have included this association of taxa. Moreover, the single known occurrence of Smittipora? nelliiformis, with which the species abundant in the younger sample compares closely in both zooecial and zoarial morphology, is at 289 meters in an area that has been extensively sampled through a great range of depths (Harmer, 1926). It seems unlikely that the late Oligocene assemblages lived at depths as great as suggested by the single known Recent occurrence of Batopora (804 meters; Cook, 1966); Paleogene species of Batopora occur with genera, such as Poricellaria, that are restricted in modern seas to depths less than 100 meters.

The species diversity of the older of the two late Oligocene assemblages from Hole 117 also suggests outer sublittoral depths. At Recent stations below 200 meters, the total number of bryozoan species is generally less than 40 per station (Schopf, 1969), whereas the cheilostomes alone total 46 species in Sample 117-3-1. The younger of the late Oligocene assemblages probably represents a depth exceeding 200 meters, as indicated by its considerably lower diversity, by the greater abundance in it of Gemellipora and Smittipora? aff. S.? nelliiformis, and by the absence from it of Mollia, Onychocella, and Adeonella. Its diversity is not, however, low enough to suggest depths in excess of 600 meters.

Both upper Oligocene samples contain high proportions of delicately erect, rigid colonies (adeoniform and vinculariiform, Table 8), commensurate with growth in littleagitated water. The most conspicuous differences between the two samples are the much lower percentage of membraniporiform specimens and the much higher proportion of cellariiform specimens in the younger sample. The rarity, relative to the older sample, of membraniporiform colonies reflects a decrease in grain size of the sediment available for encrustation, as would be expected with increasing depth. Increase in percentage of cellariiform (jointed) colonies commonly occurs with decreasing depth, but it is also associated with increasing proportions of loose, fine-grained sediment (Lagaaij and Gautier, 1965).

The abundance in both late Oligocene assemblages of taxa having overlapping bathymetric ranges makes it improbable that either assemblage represents a depositional mixture of shallow- and deep-water cheilostome species, such as appear to occur in upper Eocene strata in Tonga (Cheetham, in press).

\section{Late Paleocene Bryozoa from Hole 117A}

Nearly 7000 specimens representing 47 species of cheilostomes and an undetermined number of species of cyclostomes were obtained from Hole 117A, Cores 4, 7 and 8 (Table 7 and Plates 21 through 28). One species only, Cribrilaria radiata, appears also to be present in the upper Oligocene samples from Hole 117 (a single fragment in
Sample $117 \mathrm{~A}-4-1$ at 127 to 132 centimeters of Craspedozoum? sp., characteristic of the late Oligocene assemblages, is probable a contaminant). In contrast to their dominance in the late Oligocene bryozoan assemblages, cheilostomes comprise less than one-quarter of the bryozoan specimens in the late Paleocene faunas. The abundance, species diversity, and general aspect of the assemblages are similar to those of the upper Paleocene Vincentown Formation of New Jersey, but only a few of the species are closely related to Vincentown forms. The most consistently occurring species in the assemblages from Hole 117A, Coscinopleura sp., "Beisselina" sp., and Smittipora? sp. 3, are probably more closely related to European than to North American species of these genera.

In abundance, diversity, taxonomic composition, preservation, and colony forms the five assemblages fall in three groups that can conveniently be discussed separately (Table 7): (1) an upper group comprising the two younger samples from Core $4 ;(2)$ a middle sample, the oldest one from Core 4 ; and (3) a lower group comprising the samples from Cores 7 and 8. The age of all these assemblages has been determined, from foraminiferal and nannofossil evidence discussed elsewhere in this volume, as late Paleocene, Globigerina triloculinoides-Discoaster multiradiatus Zone.

The cheilostomes in the upper group of samples include at least 25 species. Abundance is markedly lower than in the lower group, but preservation is the best of any of the late Paleocene assemblages, and morphologic detail is comparable to that in the late Oligocene cheilostomes. Although the species compositions of the two samples assigned to this assemblage differ, both include the same abundant species. Of the 10 species having recognizable affinities, six have a Cretaceous-Paleocene aspect, and four an Eocene or younger aspect. Biogeographic affinities are about evenly divided between Europe and North America, with a high proportion (seven of 25) of species probably having affinities with both sides of the Atlantic. The high proportion of extinct genera in this assemblage makes its paleoenvironment difficult to interpret. Four taxa, Floridina, Mollia, Cribrilaria radiata and Poricellaria, have Recent representatives, all of which are common at sublittoral depths (see Figure 29 for depth distributions of the first three). The presence of Poricellaria is especially significant, for its modern representatives are tropical, reef-associated forms not found at depths exceeding 60 meters (Harmer, 1926). In colony forms, this assemblage is similar to the older of the two late Oligocene assemblages, except for lacking reteporiform colonies.

The middle sample of the upper Paleocene sequence yielded not only the smallest number of specimens but also the fewest species (five). None of the species is distinctive of the assemblage; four occur in the upper group, four in the lower group, and three in both. No species having an Eocene or younger aspect is present. Preservation is the poorest of all the samples, many of the specimens being conspicuously abraded. This and the dominance of stout colonies (exchariform; see Table 8) suggests that many of the specimens could have been reworked.

The lower late Paleocene assemblage includes the largest number of species, 32; of these, eleven also occur in the higher samples. Abundance is higher than in the other 
TABLE 7

Specimen Counts of Bryozoa from Leg 12, Site 117

Oligocene Sample Level

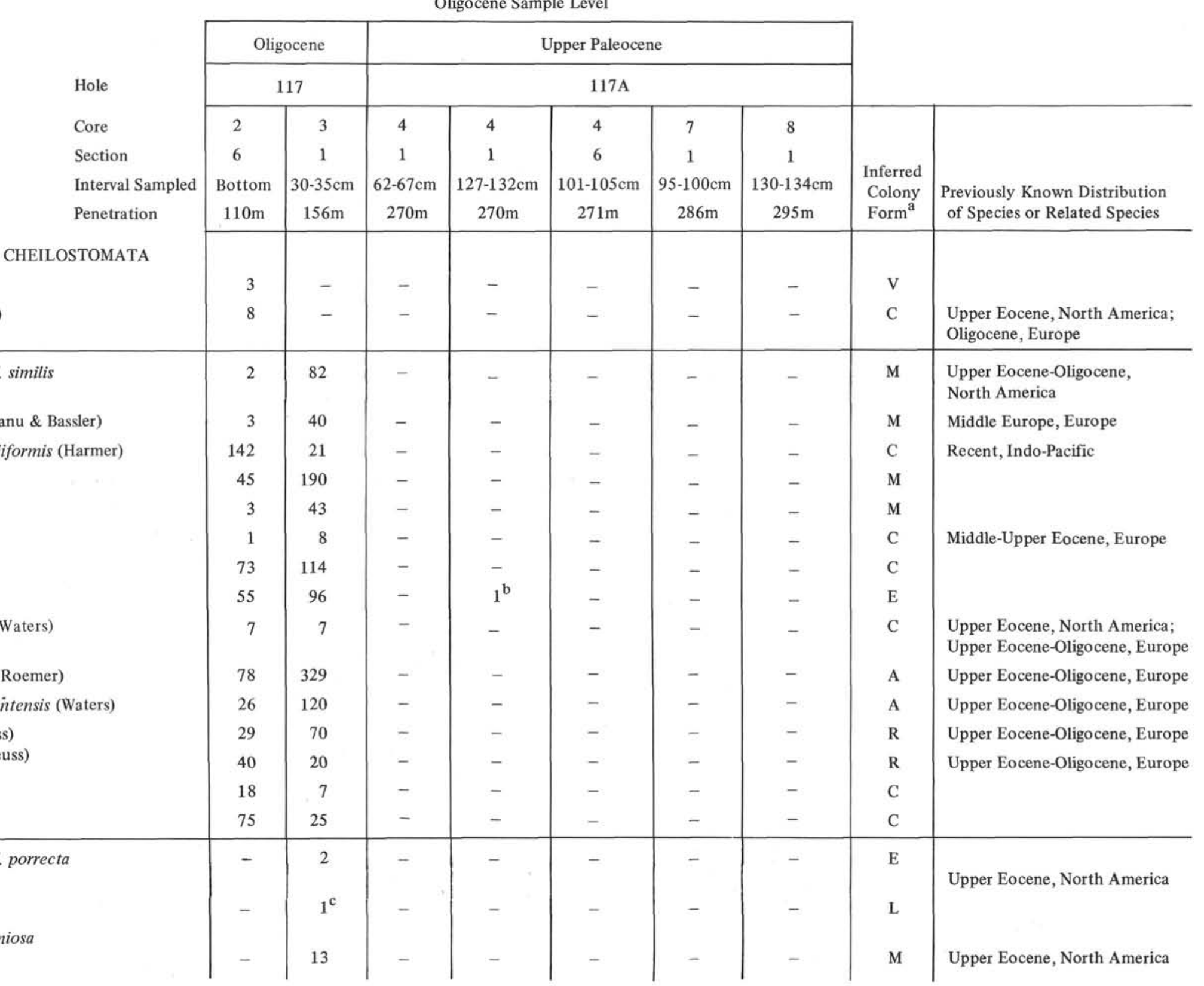

Smittoidea sp. 2

Dittosaria prima (Reuss)

Membraniporidra aff. $M$. similis

Canu \& Bassler

Antropora? oculifera (Canu \& Bassler)

Smittipora? aff. S.? nelliiformis (Harmer)

Floridina sp. 1

F. sp. 3

Setosella fragilis Canu

Cellaria sp.

Craspedozoum? sp.

Scrupocellaria elliptica (Waters)

Waters, not Reuss

Adeonellopsis subteres (Roemer)

Schizostomella aff. S. lontensis (Waters)

Sertella marginata (Reuss)

Sparsiporina elegans (Reuss)

Gemellipora sp.

pasytheid, new genus

Membraniporidra aff. M. porrecto

Canu \& Bassler

Lunulites sp. 1

Onychocella aff. O. laciniosa

Canu \& Bassler 
Smittipora? sp. 2

Floridina sp. 3

Mollia sp. 1

\section{Rosseliana? sp.}

Microporina? aff. M.? polysticha (Reuss)

Stoganoporella sp.

Gephyrotes? aff. G.? convexa

Canu \& Bassler

Corbulipora? sp.

\section{Hippopleurifera sp.}

Escharoides sp. 1

E. sp. 2

Perina sp.

Tubucella cf. T. papillosa (Reuss)

Adeonella ornatissima (Stoliczka)

Schizostomella aff. S. curryi Cheetham

\section{Cleidochasma sp.}

\section{Dakaria? sp.}

Schizomavella aff. S. trigonostoma

\section{Cheetham}

Escharella aff. E. selseyensis Cheetham

\section{E. sp. 2}

Smittoidea variabilis (Canu)

Bactridium? sp.

Leiosella aff. L, rostrifera

Canu \& Bassler

Hemiphylactella? sp.

Orbitulipora sp.

Batopora sp.

ascophoran, genus A indeterminant

\begin{tabular}{|c|c|c|c|c|c|c|c|c|c|}
\hline Smittipora? sp. 2 & - & 48 & - & - & - & - & - & $\mathrm{V}$ & - \\
\hline Floridina sp. 3 & - & 2 & - & - & - & - & - & M & - \\
\hline Mollia sp. 1 & - & 4 & - & - & - & - & - & M & - \\
\hline Rosseliana? sp. & - & 7 & - & - & - & - & -. & M & - \\
\hline Microporina? aff. $M$ ? polysticha (Reuss) & - & 29 & - & - & - & - & - & $\mathrm{C}$ & Upper Eocene-Miocene, Europe \\
\hline Stoganoporella sp. & - & 2 & - & - & - & - & - & V & \\
\hline $\begin{array}{l}\text { Gephyrotes? aff. G.? convexa } \\
\text { Canu \& Bassler }\end{array}$ & - & 3 & - & - & - & - & - & M & Upper Eocene, North America \\
\hline Corbulipora? sp. & - & 10 & - & - & - & - & - & M & - \\
\hline Hippopleurifera sp. & - & 1 & - & - & - & - & - & M & - \\
\hline Escharoides sp. 1 & - & 2 & - & - & - & - & - & M & - \\
\hline E. sp. 2 & - & 1 & - & - & - & - & - & M & - \\
\hline Perina sp. & - & 23 & - & - & - & - & - & $\mathrm{V}$ & - \\
\hline Tubucella cf. T. papillosa (Reuss) & - & 13 & - & - & - & - & - & A & Upper Eocene-Miocene, Europe \\
\hline Adeonella ornatissima (Stoliczka) & - & 121 & - & -- & - & - & - & A & Oligocene, Europe \\
\hline Schizostomella aff. $S$. curryi Cheetham & - & 51 & - & - & - & - & - & E & Upper Eocene, Europe \\
\hline Cleidochasma sp. & - & 2 & - & - & - & - & - & M & - \\
\hline Dakaria? sp. & - & 3 & - & - & - & - & - & V & - \\
\hline $\begin{array}{l}\text { Schizomavella aff. S. trigonostoma } \\
\text { Cheetham }\end{array}$ & - & 6 & - & - & - & - & - & $\mathrm{V}$ & Upper Eocene, Europe \\
\hline Escharella aff. E. selseyensis Cheetham & - & 2 & - & - & - & - & - & $\mathrm{V}$ & Middle-Upper Eocene, Europe \\
\hline E. sp. 2 & - & 3 & - & - & - & - & - & M & - \\
\hline Smittoidea variabilis (Canu) & - & 30 & - & - & - & -. & - & $\mathrm{E}$ & Middle-Upper Eocene, Europe \\
\hline Bactridium? sp. & - & 1 & - & - & - & - & - & $\mathrm{E}$ & - \\
\hline $\begin{array}{l}\text { Leiosella aff. } L, \text { rostrifera } \\
\text { Canu \& Bassler }\end{array}$ & - & 11 & - & - & - & - & - & V & Oligocene, North America \\
\hline Hemiphylactella? sp. & - & 5 & - & - & - & - & - & $\mathrm{V}$ & - \\
\hline Orbitulipora sp. & - & 1 & - & - & - & - & - & 0 & Upper Eocene-Oligocene, Europe \\
\hline Batopora sp. & - & 2 & - & - & - & - & - & $\mathrm{O}$ & $\begin{array}{l}\text { Upper Eocene-Oligocene, Europe } \\
\text { Recent, Indo-Pacific }\end{array}$ \\
\hline ascophoran, genus A indeterminant & - & 4 & - & - & - & - & - & $\mathrm{E}$ & - \\
\hline Cribrilaria radiata (Moll) & 1 & 10 & 2 & - & - & 10 & - & M & $\begin{array}{l}\text { Upper Eocene-Recent, North America- } \\
\text { Europe }\end{array}$ \\
\hline Periporosella? sp. 1 & - & - & 1 & 1 & 5 & - & - & M & Paleocene, North America \\
\hline Stamenocella sp. & - & - & 1 & 4 & - & - & - & $\mathrm{C}$ & - \\
\hline
\end{tabular}

$\mathrm{a}$
$\mathrm{b}$

Reworked? not counted in total. 
TABLE 7 - Continued

Smittipora? sp. 4

S.? sp. 5

Floridina sp. 6

F. sp. 7

onychocellid, genus B indeterminate microporid, genus indeterminate

Semiescharinella? sp. 2

Pericellaria sp.

Pachythecella? sp.

Schizostomella? sp. 1

S.? sp. 2

vittaticellid, new genus

ascophoran, genus B indeterminate

Membraniporidra? sp.

Smittipora? sp. 3

S.? sp. 7

Floridina sp. 4

Mollia sp.2

Semiescharinella? sp. 1

Coscinopleura sp.

Pliophloea sp.

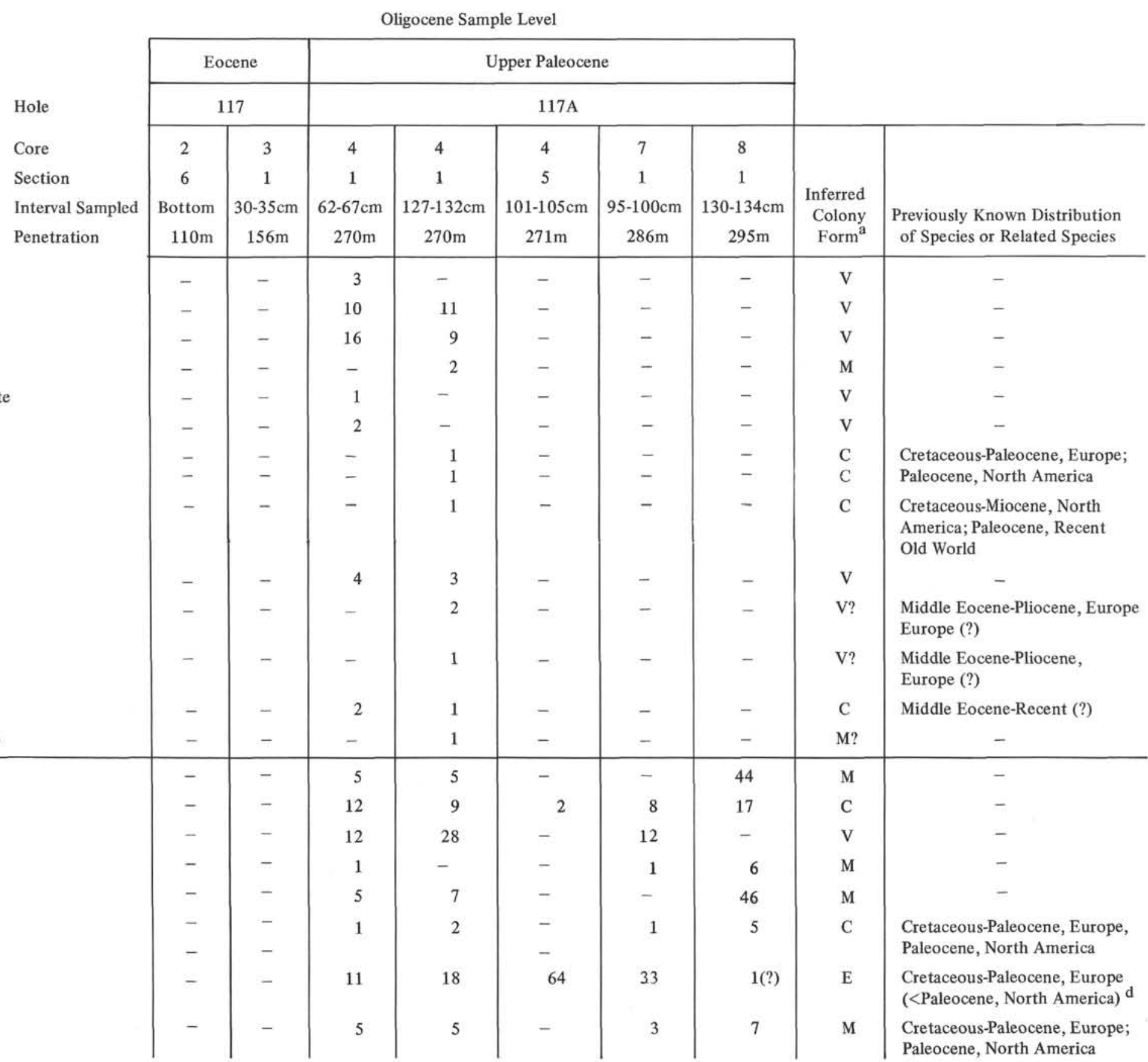


“Beisselina"sp.

\section{Ellisina? sp}

calloporid, genus indeterminate

Periporosella? sp. 2

Pithodella sp.

Stamenocella cf. S. "oculata Ulrich \& Bassler"

Lunulites sp. 2

L. sp. 3

L. sp. 4

L. sp. 5

Smittipora? sp. 6

Floridina sp. 5

cnychocellid, genus A indeterminate

Pliophloea? sp.

Kelostoma aff. $K$. elongatum Marsson

$K$.? aff. $K$.? simplex Canu \& Bassler

Tricephalopora? sp.

Castanopora? sp.

Balantiostoma cf. B. septentrionalis

(Canu \& Bassler)

Pachythecella sp.

Smittoidea? sp.

smittinid?, genus indeterminate

Fissuricella sp.

indeterminate membranimorphs

Indeterminate Floridina-like forms

indeterminate coilostegans

indeterminate acanthostegans

indeterminate ascophorans

indeterminate cheilostomes

CYCLOSTOMATA

TOTAL BRYOZOA

\begin{tabular}{|c|c|c|c|c|c|c|c|c|}
\hline- & - & 28 & 53 & 19 & 183 & 20 & A & $\begin{array}{l}\text { Cretaceous-Paleocene, Europe } \\
\text { ( }<\text { Paleocene, North America) }\end{array}$ \\
\hline - & - & - & - & 2 & 22 & 2 & M & - \\
\hline- & - & - & - & - & 19 & 101 & M & - \\
\hline- & - & - & - & - & 23 & 8 & $\mathrm{M}$ & Paleocene, North America \\
\hline - & - & - & - & - & 1 & - & $\mathrm{E}$ & Cretaceous-Paleocene, Europe \\
\hline- & - & - & - & - & 5 & 13 & $\mathrm{C}$ & Paleocene, North America \\
\hline - & - & - & - & - & - & 1 & L & Cretaceous-Paleocene, Europe \\
\hline - & - & - & - & - & - & 2 & L & Cretaceous-Paleocene, Europe \\
\hline- & - & - & - & - & 1 & - & $\mathrm{L}$ & Cretaceous-Paleocene, Europe \\
\hline - & - & - & - & - & 27 & - & $\mathrm{L}$ & Eocene, North America \\
\hline - & - & - & - & - & 4 & - & V & - \\
\hline- & - & - & - & - & 70 & 8 & M & - \\
\hline- & - & - & - & - & 27 & - & M & - \\
\hline- & - & - & - & - & - & 2 & M & - \\
\hline - & - & - & - & - & - & 3 & M & Cretaceous, Europe \\
\hline- & - & - & - & - & - & 2 & M & Paleocene, North America \\
\hline- & - & - & - & - & - & 2 & M & \\
\hline- & - & - & - & - & 1 & - & - & $\begin{array}{l}\text { Cretaceous-Paleocene, Europe, } \\
\text { North America }\end{array}$ \\
\hline- & - & - & - & - & - & 7 & M & $\begin{array}{l}\text { Cretaceous-Paleocene, Europe, } \\
\text { North America }\end{array}$ \\
\hline- & - & - & - & - & 5 & 25 & $\mathrm{~V}$ & Cretaceous-Paleocene, Europe \\
\hline- & - & - & - & - & - & 2 & $\mathrm{~V} ?$ & Eocene-Recent (?) \\
\hline - & - & - & - & - & - & 2 & $\mathrm{E}$ ? & Eocene-Recent (?) \\
\hline- & - & - & - & - & - & 3 & M & Cretaceous-Paleocene, Europe \\
\hline - & - & - & 1 & - & - & 111 & M & - \\
\hline - & - & 8 & - & - & - & 3 & M & - \\
\hline- & - & - & - & 1 & - & 1 & - & - \\
\hline - & - & 4 & 1 & - & 2 & 1 & M & - \\
\hline- & - & - & - & 2 & 1 & 1 & - & - \\
\hline- & - & 32 & 10 & 2 & 11 & 7 & - & - \\
\hline 556 & 1084 & 1212 & 1208 & 732 & 7.75 & 1379 & - & - \\
\hline 1165 & 2669 & 1378 & 1385 & 829 & 1245 & 1832 & - & - \\
\hline
\end{tabular}


TABLE 8

Percentages of Cheilostome Specimens of Inferred Colony Forms, Leg 12, Site 117

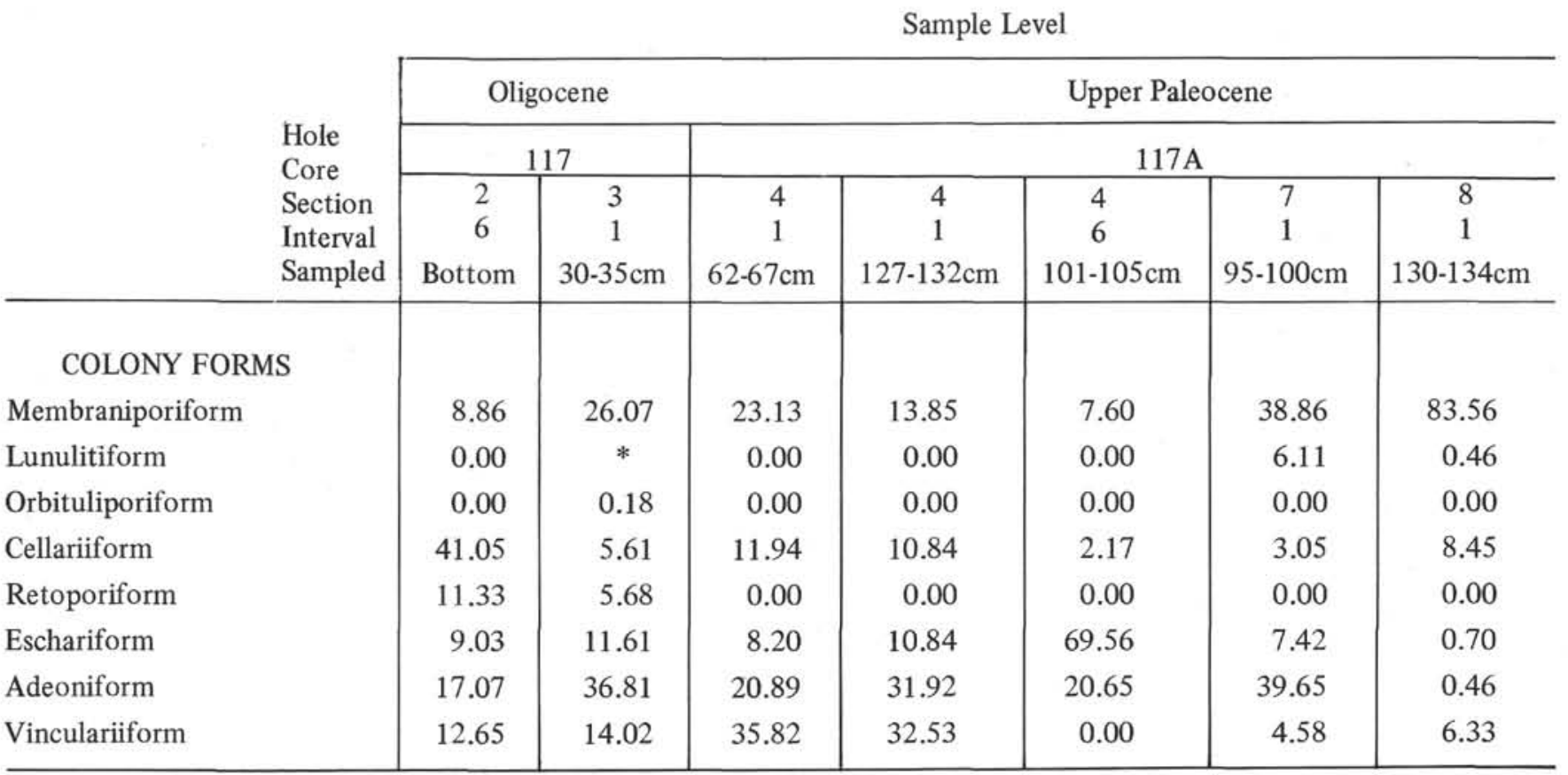

*1 specimen (reworked?)

upper Paleocene samples and nearly as high as in one of the upper Oligocene ones. Preservation is variable, both samples containing some well-preserved specimens, some that are crushed, and some that are coated with sparry calcite. The species compositions of these two samples differ more than do those of the two samples making up the upper group. Sixteen species have recognizable Cretaceous-Paleocene affinities. Cribrilaria radiata, one species of Lunulites, and possibly Smittoidea? sp. and the indeterminate smittinid are the only ones having an Eocene and younger aspect. The biogeographic affinities are slightly more toward Europe than North America, but with ten of the 32 species having close relationships with both sides of the Atlantic. Depth-diagnostic taxa are virtually absent; the presence of Mollia and Cribrilaria radiata is consistent with a depth no greater than the maximum of 60 meters inferred for the upper group of samples, but there is no positive taxonomic evidence that the lower assemblage did not live at greater depths. The high percentage of membraniporiform and lunulitiform specimens and the low percentage of vinculariiform ones suggest, however, that this was probably the shallowest cheilostome assemblage at Site 117.

The taxonomic differences between the upper and lower assemblages appear to be related more to age than to environment, the upper one including a significantly larger number of species having an Eocene and younger aspect than the lower one does. The presence of Poricellaria in the upper group indicates that the depth at which the late Paleocene assemblages lived was not deeper than 60 meters, but nothing in the fauna indicates that the depth was much less than that.

\section{Conclusions}

The changing taxonomic compositions and proportions of colony forms of late Paleocene and late Oligocene assemblages of cheilostome Bryozoa from Holes 117 and $117 \mathrm{~A}$ are generally consistent with a history of subsidence for the Rockall Plateau.

Progressive isolation of this area from the eastern and western margins of the North Atlantic is reflected in the decreasing proportions of species with recognizable European and North American affinities during the portion of Paleogene time represented by bryozoan-bearing sediments at Site 117. The decline in relationships with North America is more pronounced; species with North American or amphi-Atlantic affinities comprise 41 per cent of the late Paleocene assemblages and 17 per cent of the late Oligocene ones. The decrease in faunal similarities with Europe is less severe; European-related and amphi-Atlantic forms comprise 44 per cent of the late Paleocene assemblages and 40 per cent of the late Oligocene ones. This difference in rates of faunal isolation is in keeping with the present geographic position of the Rockall Plateau. The high rate of change of amphi-Atlantic species alone, from 31 per cent in the late Paleocene assemblages to 6 per cent in the late Oligocene ones, suggests that isolation of this area may have been directly involved in reducing transatlantic faunal interchange.

Progressive subsidence of the Rockall Plateau from inner sublittoral to upper bathyal depths is indicated by the depth distributions of Recent representatives of taxa included in the late Paleocene and late Oligocene assemblages and by changes in their proportions of colony forms. 
The youngest Paleocene assemblage probably accumulated in not more (but not much less) than 60 meters of water, to judge by the few extant shallow-water taxa and the prevalence of rigidly erect colonies in it. The absence of depth-diagnostic extant taxa from the oldest late Paleocene assemblage makes its interpretation more unsure, but its more abundant encrusting colonies, significant number of lunulitiform ones, and rare delicately erect ones all perhaps suggest a slightly shallower depth. Both late Oligocene assemblage contain a number of extant taxa that suggest depths of about 200 meters; the high diversity and greater abundance of shelf-characteristic taxa in the older assemblage indicate a depth of 150 to 200 meters, whereas the low diversity and greater abundance of upper-bathyal characteristic taxa in the younger assemblage indicate a depth greater than 200 meters but probably considerably less than 600 meters. Thus, water depth at Site 117 appears to have increased from slightly less than 60 meters to slightly more than 200 meters during the late Paleocene-late Oligocene time interval represented by the seven samples studied.

\section{ACKNOWLEDGMENTS}

We are indebted to W. A. Berggren for the samples to R. H. Benson for discussion during preparation of the report, to Robert Lagaaij and W. A. Berggren for critical reviews of the manuscript, and to JoAnn Sanner for technical assistance.

\section{Preliminary Results of a Quantitative Micropaleontological Analysis $(116,117)^{4}$}

\section{Introductions}

A quantitative micropaleontological analysis is being made of 96 samples from Sites 116 and 117 (52 of Hole 116, 22 of Hole 116A, 4 of Hole 117, and 16 of Hole 117A). The washed residue (coarser than 105 microns) of each sample was split over a sample-split until a representative cut was obtained which was small enough to have its complete microfaunal contents counted without running into numbers too high. Some samples yielded few fossils, so that the entire sample could be counted and no split was needed. Most samples had to be split several times before a workable size was obtained.

\section{Procedure}

Until now, three parameters have been determined on this material (see Figures 30, 31 and Table 9):

1. The percentage of planktonic foraminifers in the total foraminiferal fauna (plankton/benthos relation). $\mathrm{N}_{1}$ in Table 9 gives the total number of specimens used in determining the percentage; this is the complete "end split".

2. The percentage of ostracods in the number of ostracods plus benthonic foraminifers (ostracod/foraminifer relation). $\mathrm{N}_{2}$ in Table 9 gives the number of specimens used to compute this percentage. Because planktonic foraminifers dominate most samples the last split had only few

\footnotetext{
${ }^{4}$ The shipboard scientific party were assisted by E. M. Gannon of Imperial Oil Enterprises, Ltd., Calgary, Canada.
}

benthonics, and ostracods and additional material had to be included in the count. In most cases it was sufficient to use the second half of the last split. For these reasons $\mathrm{N}_{2}$ does not compare with $\mathrm{N}_{1}$.

3. The percentage of siliceous plankton in the total planktonic fauna and flora larger than 105 microns. $\mathrm{N}_{3}$ of Table 9 is the number of specimens on which this percentage is based.

The results of the calculations are graphically presented in Figures 30 and 31 . Work is in progress to determine also the diversity and dominance of the benthonic foraminiferal fauna. An interpretation of the present results (and also of the additional future results), still can only be speculative. It is not possible yet to distinguish which of the physical (hydrostatic pressure, temperature, turbidity), chemical (salinity, $p \mathrm{H}$, nutrients) or biological (nutrients, predators) properties of seawater influence a particular value of the calculated parameters, and to which amount. For instance, a high percentage of planktonic foraminifers can be indicative for normal deep water or for nutrient-rich (phytoplankton blooming) shallower water (Bandy et al., div. publ.). In other words, the changes we see in coming up section in Figures 30 and 31 do not necessarily reflect changes in water depth but could also be the results of changes in ocean current pattern, climate etc. Even assuming that we can draw conclusions on the depth of deposition, studies of the Recent are too scarce to allow for a detailed interpretation.

The conclusions below are mainly based on data published by Grimsdale and van Morkhoven (1955) for the Gulf Coast and the North Atlantic, who relate the above percentages to the depth of water overlying the seabed at the time of deposition. Their findings were basically confirmed in several subsequent investigations, but the depth limits may vary for different areas. For instance, higher plankton percentages were found in material from the Snellius Expedition (West Pacific and Indian Ocean): samples from water deeper than 1000 meters have more than 95 per cent of planktonics, 99 to 90 per cent planktonics are present in samples from 1000 to 500 meters, 95 to 70 per cent in samples from 500 to 350 meters, 70 to 40 per cent in samples from 500 to 100 meters, and 40 per cent in water shallower than 100 meters (73 samples, van Hinte, 1959). The values found by Bandy et al. (div. publ.) on the other hand are lower than those given by Grimsdale and van Morkhoven.

\section{Depth of Deposition}

It is beyond doubt that the lowest sedimentary rock at 117 was deposited at near-shoreline depth. The percentage of planktonic foraminifers in Core 11 is zero, and the fauna-flora which is present is known to have lived in the shallowest Tertiary waters. From Figure 31 it is apparent that the plateau went down during the Late PaleoceneEarly Eocene. The 50 per cent-plankton line is crossed between Cores 3 and 4 of Hole 117A, suggesting that the section below originated in waters shallower than about 200 meters, the section above in water deeper than 200 meters. It is most unfortunate that no sample from Hole 117A, Core 2 was available. The Lower Eocene of Hole $117 \mathrm{~A}$, Core 1, immediately underneath the unconformity, 


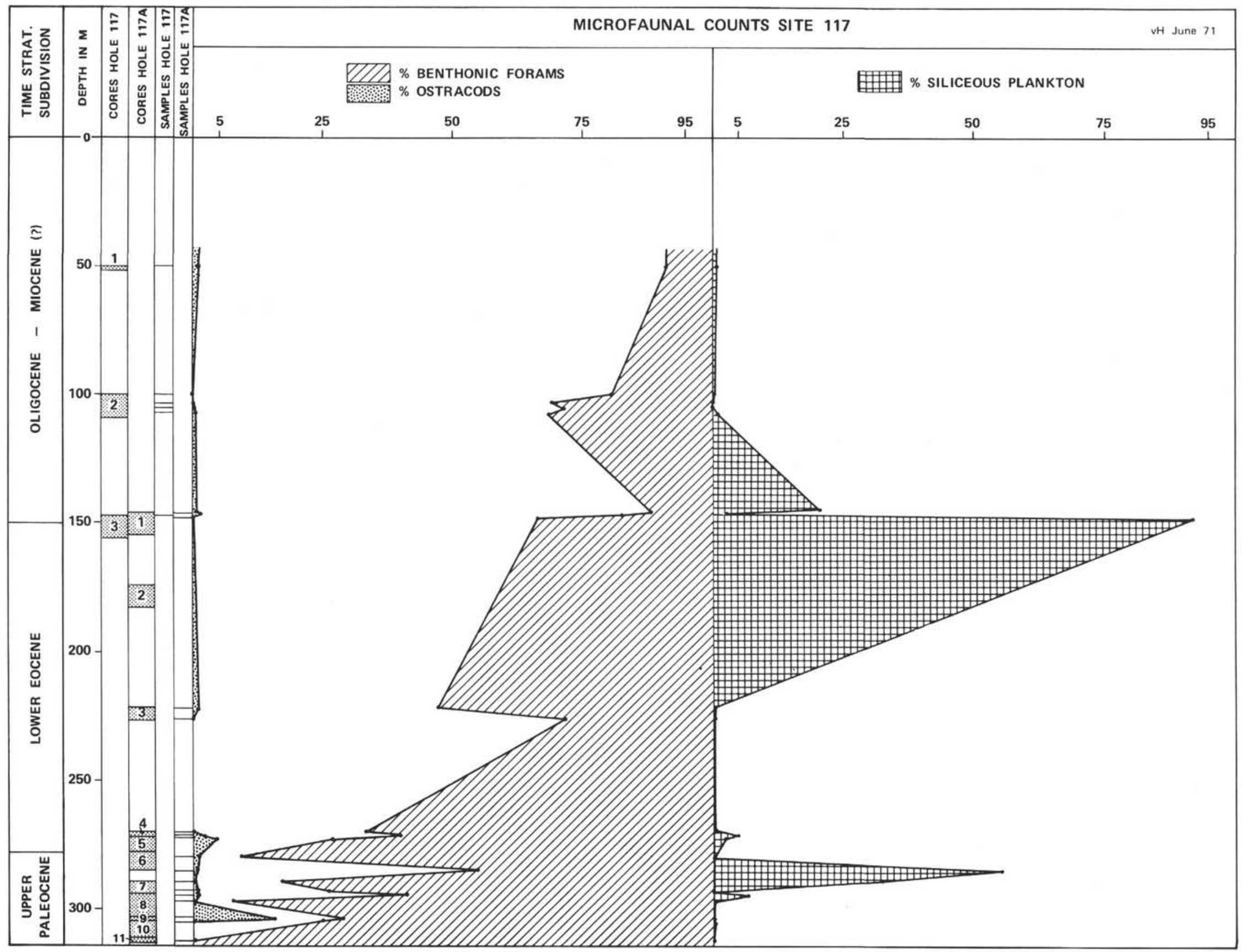

Figure 30. Microfaunal counts at Site 117. 


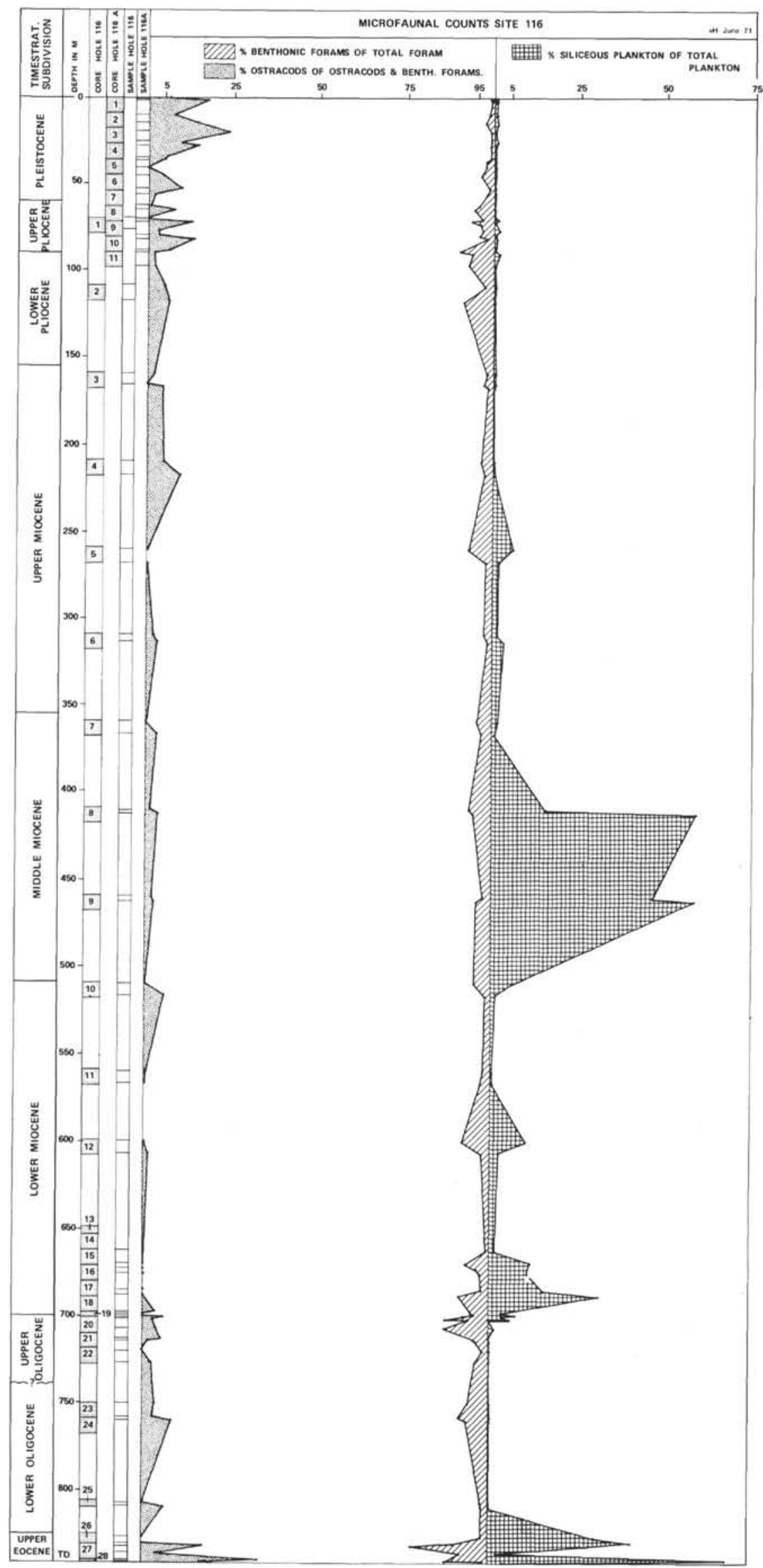

Figure 31. Microfaunal counts at Site 116. 
TABLE 9

\begin{tabular}{|c|c|c|c|c|c|c|}
\hline Hole & Core & Section & $\begin{array}{c}\text { Interval } \\
(\mathrm{cm})\end{array}$ & $\mathrm{N}_{1}$ & $\mathrm{~N}_{2}$ & $\mathrm{~N}_{3}$ \\
\hline 116 & 1 & 1 & $10-13$ & 1135 & 66 & 1106 \\
\hline 116 & 1 & 6 & $5.5-8.0$ & 2198 & 143 & 2156 \\
\hline 116 & 2 & 1 & 2.5 & 3514 & 203 & 3430 \\
\hline 116 & 2 & 6 & Base & 3844 & 359 & 3509 \\
\hline 116 & 3 & 1 & $38-41$ & 2951 & 129 & 2902 \\
\hline 116 & 3 & 5 & Base & 1482 & 42 & 1450 \\
\hline 116 & 3 & 6 & $10-13$ & 4096 & 184 & 4042 \\
\hline 116 & 4 & 1 & $21-24$ & 2136 & 163 & 2060 \\
\hline 116 & 4 & 6 & $16-19$ & 2572 & 117 & 2512 \\
\hline 116 & 5 & 0 & Base & 1755 & 125 & 1732 \\
\hline 116 & 5 & 6 & Base & 2895 & 211 & 2902 \\
\hline 116 & 6 & 1 & $30.5-33.0$ & 1526 & 107 & 1506 \\
\hline 116 & 6 & 4 & 9.12 & 1845 & 102 & 1884 \\
\hline 116 & 7 & 1 & $22-25$ & 2580 & 110 & 2505 \\
\hline 116 & 7 & 6 & $4-7$ & 1667 & 223 & 1823 \\
\hline 116 & 8 & 2 & $19-22$ & 1444 & 95 & 1599 \\
\hline 116 & 8 & 3 & $10-13$ & 804 & 137 & 1840 \\
\hline 116 & 9 & 1 & $11-14$ & 646 & 25 & 1177 \\
\hline 116 & 9 & 3 & $15-18$ & 960 & 83 & 2184 \\
\hline 116 & 10 & 0 & Base & 4611 & 238 & 4857 \\
\hline 116 & 10 & 6 & $30-33$ & 1817 & 110 & 1813 \\
\hline 116 & 11 & 0 & Base & 1875 & 227 & 1838 \\
\hline 116 & 11 & 6 & $4-7$ & 1213 & 138 & 1182 \\
\hline 116 & 12 & 1 & $11-14$ & 1564 & 124 & 1602 \\
\hline 116 & 12 & 6 & $24-27$ & 1740 & 135 & 1744 \\
\hline 116 & 15 & 1 & $8-11$ & 3147 & 81 & 3165 \\
\hline 116 & 15 & 6 & $5-8$ & 1258 & 208 & 1191 \\
\hline 116 & 16 & 2 & $17-20$ & 1014 & 146 & 1103 \\
\hline 116 & 16 & 4 & $29-33$ & 3371 & 91 & 3700 \\
\hline 116 & 17 & 4 & $21-25$ & 1246 & 120 & 1445 \\
\hline 116 & 17 & 6 & $37-40$ & 830 & 123 & 1112 \\
\hline 116 & 18 & 4 & $6-9$ & 705 & 144 & 702 \\
\hline 116 & 19 & 1 & $82-85$ & 813 & 100 & 842 \\
\hline 116 & 19 & 2 & $6-7$ & 2347 & 177 & 2246 \\
\hline 116 & 19 & 4 & $12-15$ & 56 & 16 & 52 \\
\hline 116 & 20 & 1 & $12-15$ & 149 & 34 & 141 \\
\hline 116 & 20 & 5 & $17-23$ & 194 & 50 & 172 \\
\hline 116 & 21 & 3 & $24-27$ & 4065 & 184 & 3890 \\
\hline 116 & 21 & 4 & $9-12$ & 1725 & 287 & 1663 \\
\hline 116 & 22 & 1 & Base & 2641 & 74 & 2601 \\
\hline 116 & 22 & 6 & $21-24$ & 1843 & 121 & 1770 \\
\hline
\end{tabular}

TABLE 9 - Continued

\begin{tabular}{|c|c|c|c|c|c|c|}
\hline Hole & Core & Section & $\begin{array}{c}\text { Interval } \\
(\mathrm{cm})\end{array}$ & $\mathrm{N}_{1}$ & $\mathrm{~N}_{2}$ & $\mathrm{~N}_{3}$ \\
\hline 116 & 23 & 0 & Base & 5826 & 357 & 5482 \\
\hline 116 & 23 & 6 & $129-132$ & 1588 & 138 & 1459 \\
\hline 116 & 24 & 1 & $37-39$ & 665 & 86 & 625 \\
\hline 116 & 25 & 3 & Base & 422 & 11 & 413 \\
\hline 116 & 25 & 5 & $5-7$ & 667 & 30 & 654 \\
\hline 116 & 26 & 2 & $0-2$ & 300 & 63 & 379 \\
\hline 116 & 26 & 4 & $22-24$ & 99 & 18 & 151 \\
\hline 116 & 27 & 1 & Top & 63 & 23 & 70 \\
\hline 116 & 27 & 3 & $50-53$ & 172 & 26 & 161 \\
\hline 116 & 28 & 1 & $90-93$ & 9 & 3 & 25 \\
\hline 116 & 28 & 2 & $9-12$ & 142 & 6 & 146 \\
\hline $116 \mathrm{~A}$ & 1 & 1 & $60-63$ & 4401 & 169 & 4356 \\
\hline $116 \mathrm{~A}$ & 1 & 2 & $4-7$ & 2042 & 113 & 2026 \\
\hline $116 \mathrm{~A}$ & 2 & 1 & $106-109$ & 2454 & 186 & 2418 \\
\hline $116 \mathrm{~A}$ & 2 & 5 & 6-9 & 1631 & 134 & 1591 \\
\hline $116 \mathrm{~A}$ & 3 & 1 & $27-31$ & 1308 & 156 & 1298 \\
\hline $116 \mathrm{~A}$ & 3 & 6 & 407 & 1620 & 172 & 1616 \\
\hline $116 \mathrm{~A}$ & 4 & 1 & $100-103$ & 4179 & 151 & 4125 \\
\hline $116 \mathrm{~A}$ & 4 & 6 & $7-9$ & 1559 & 117 & 1543 \\
\hline $116 \mathrm{~A}$ & 5 & 1 & $54-57$ & 2481 & 102 & 2429 \\
\hline $116 \mathrm{~A}$ & 5 & 4 & $4-7$ & 3294 & 160 & 3216 \\
\hline $116 \mathrm{~A}$ & 6 & 1 & $17-22$ & 2857 & 188 & 2755 \\
\hline $116 \mathrm{~A}$ & 6 & 6 & $10-13$ & 3788 & 128 & 3752 \\
\hline $116 \mathrm{~A}$ & 7 & 2 & $2-5$ & 3458 & 155 & 3388 \\
\hline $116 \mathrm{~A}$ & 7 & 6 & $132-135$ & 1030 & 153 & 985 \\
\hline $116 \mathrm{~A}$ & 8 & 2 & $7-10$ & 1359 & 280 & 1287 \\
\hline $116 \mathrm{~A}$ & 8 & 6 & $13-16$ & 1575 & 106 & 1485 \\
\hline $116 \mathrm{~A}$ & 9 & 1 & $8-11$ & 2154 & 343 & 2061 \\
\hline $116 \mathrm{~A}$ & 9 & 6 & $2-5$ & 1856 & 95 & 1771 \\
\hline $116 \mathrm{~A}$ & 10 & 1 & $92-95$ & 1421 & 115 & 1403 \\
\hline $116 \mathrm{~A}$ & 10 & 6 & $8-11$ & 950 & 99 & 857 \\
\hline $116 \mathrm{~A}$ & 11 & 0 & Base & 2209 & 312 & 2102 \\
\hline $116 \mathrm{~A}$ & 11 & 6 & $2-5$ & 1759 & 146 & 1623 \\
\hline 117 & 1 & 1 & $40-43$ & 2380 & 391 & 2107 \\
\hline 117 & 2 & 1 & Top & 2528 & 500 & 2085 \\
\hline 117 & 2 & 3 & $42-45$ & 2378 & 746 & 1633 \\
\hline 117 & 2 & 4 & $2-5$ & 1991 & 562 & 1431 \\
\hline 117 & 2 & 6 & $3-6$ & 504 & 173 & 333 \\
\hline 117 & 3 & 1 & $0-3$ & 485 & 154 & 402 \\
\hline
\end{tabular}


TABLE 9 - Continued

\begin{tabular}{rcccrrr}
\hline Hole & Core & Section & $\begin{array}{c}\text { Interval } \\
(\mathrm{cm})\end{array}$ & \multicolumn{1}{c}{$\mathrm{N}_{1}$} & $\mathrm{~N}_{2}$ & $\mathrm{~N}_{3}$ \\
\hline $117 \mathrm{~A}$ & 1 & 1 & $6-9$ & 1904 & 226 & 2107 \\
$117 \mathrm{~A}$ & 1 & 1 & $70-73$ & 59 & 277 & 496 \\
$117 \mathrm{~A}$ & 3 & 1 & $83-85$ & 211 & 113 & 99 \\
$117 \mathrm{~A}$ & 3 & 6 & $149-150$ & 14 & 4 & 10 \\
$117 \mathrm{~A}$ & 4 & 0 & Base & 298 & 200 & 98 \\
$117 \mathrm{~A}$ & 4 & 6 & $110-113$ & 165 & 102 & 72 \\
$117 \mathrm{~A}$ & 5 & 1 & $6-8$ & 218 & 167 & 59 \\
$117 \mathrm{~A}$ & 6 & 1 & $132-135$ & 110 & 101 & 10 \\
$117 \mathrm{~A}$ & 6 & 6 & $110-112$ & 593 & 271 & 735 \\
$117 \mathrm{~A}$ & 7 & 1 & $3-4$ & 207 & 172 & 52 \\
$117 \mathrm{~A}$ & 7 & 4 & $127-130$ & 500 & 372 & 130 \\
$117 \mathrm{~A}$ & 8 & 1 & $24-26$ & 213 & 127 & 93 \\
$117 \mathrm{~A}$ & 8 & 2 & $141-144$ & 190 & 176 & 14 \\
$117 \mathrm{~A}$ & 9 & 1 & $22-28$ & 7 & 6 & 2 \\
$117 \mathrm{~A}$ & 10 & 1 & $5-6$ & 4 & 3 & 1 \\
& $(11$, thin sections $)$ & & & & \\
\hline
\end{tabular}

has 66.2 per cent planktonic foraminifers suggesting a water depth of 500 to 800 meters. The Oligocene above the unconformity yielded 88.2 and 82.5 per cent of planktonics, indicating a depth of deposition of more than 900 meters. Cores 1 and 2 of Hole 117 are hard to interpret because the cores are mixed; Core 2 probably has 70 to 80 per cent, Core 1 more than 90 per cent plankton.

The Upper Eocene basal part of Hole 116 with its 75 to 90 per cent of planktonics possibly originated at a water depth between 700 and 1000 meters. From 830 meters (Core 26, Upper Eocene) to 700 meters downhole the foraminiferal fauna consists of more than 85 per cent of planktonics. This strongly suggests that the water depth was 1000 meters or deeper; from 700 meters up all samples have more than 90 per cent planktonics, indicating that for that part of the section depositional depth was more than 1200 meters. Finally, above 665 meters, practically all samples yielded more than 95 per cent of planktonics, which suggests that the water was 1500 meters deep or deeper.

Toward the later part of the Early Pliocene the percentage of planktonics gradually seems to decrease. This could be the natural effect of shallowing, because of sediment accumulation, and approaching the present depth of 1151 meters. One would expect this trend to continue until the Recent, but it doesn't. A renewed increase of planktonic foraminifers is apparent during the Late Pliocene and Pleistocene. This time, however, the increase is accompanied by a marked increase of ostracods and probably is not the result of increased water depth but of nutrient enrichment by upwelling water. The present-day circulation pattern over Rockall Bank (Seaton, 1967; Steele et al., 1971) thus might have established itself during the Pliocene.

\section{ESTIMATED RATES OF SEDIMENTATION (SITE 116)}

It would appear that average rates of sedimentation have remained relatively constant-about $3 \mathrm{~cm} / 1000 \mathrm{yrs}$ in this area over the past 25 million years, approximately. The estimated rates over specific intervals of time are enumerated below.

The Pliocene-Pleistocene boundary ( 2 million years) is placed on paleontologic data at about 60 meters (within Core 7, Hole 116A). This yields an average rate of sedimentation of about $3 \mathrm{~cm} / 1000$ yrs during the Pleistocene (Figure 32). Between this level and the late MioceneMiddle Miocene boundary there is one problem. Depth relationships suggests direct correlation of 116-1 with the lower part of Core 8 and most of Core 9, Hole 116A, whereas, calcareous nannoplankton biostratigraphy suggests that part of Core 8 is within the D. brouweri Zone, 116-1, which overlaps $116 \mathrm{~A}-8$ and 9 , contains the $R$. pseudoumbilica and $D$. surculus Zones. If one draws the boundary between these two zones ( 3 million years) within 116-1, at about 75 meters, then one obtains an estimated sedimentation of about $1.5 \mathrm{~cm} / 1000 \mathrm{yrs}$ for the interval 75 to 60 meters (=late Pliocene).

Calcareous nannofossil data suggest that $116-5$ is within the Discoaster quinqueramus Zone and this level (268 meters) is assigned an age of 6 million years. This yields an estimated average sedimentation rate of $6.2 \mathrm{~cm} / 1000 \mathrm{yrs}$ for the interval between 268 and 75 meters (Figure 33).

The Early/Middle Miocene boundary (=Orbulina Datum $=16$ million years) occurs at about 510 meters in Core 10, Hole 116. This yields an estimated average sedimentation rate of $2.4 \mathrm{~cm} / 1000 \mathrm{yrs}$ for the Middle Miocene.

The Oligocene-Miocene boundary ( 23 million years) is tentatively drawn (on relatively weak biostratigraphic data) at about 700 meters, between Cores 18 and 19 in Hole 116. This yields an estimated rate of sedimentation of 3 $\mathrm{cm} / 1000 \mathrm{yrs}$ for the Early Miocene. These figures are shown in parentheses in Figure 34 to indicate the uncertainty involved in these estimates.

The Eocene-Oligocene boundary (37.5 million years) occurs between the base of Core 25 and the base of Core 26 in Hole 116. It is arbitrarily drawn here at the top of Core 26, at about 825 meters. Cores 23 ( 750 to 759 meters) and 24 (806 to 810 meters) are placed in the Ericsonia obruta Zone. On the assumption that Core 23 is in the upper part of the zone, an estimate of 35.5 is made for that level. An estimated sedimentation rate of about $3.7 \mathrm{~cm} / 1000 \mathrm{yrs}$ is made for the interval between 740 to 825 meters. If we extrapolate the rate of $3 \mathrm{~cm} / 1000 \mathrm{yrs}$ estimated for the Early Miocene above, down below 700 meters, a level at 740 meters (intermediate between Cores 23 and 24 at 730 to 750 meters) would be about 25 million years. This suggests the presence of an unconformity at about 740 meters representing about a 10 million year hiatus (Figures 34 and 35 ).

Sedimentation rates may be corrected for natural consolidation using the steady density gradient of 0.00023 $\mathrm{gm} / \mathrm{cc} / \mathrm{m}$ in the upper 700 meters of the hole. The uncorrected and corrected rates appear in Table 10. 


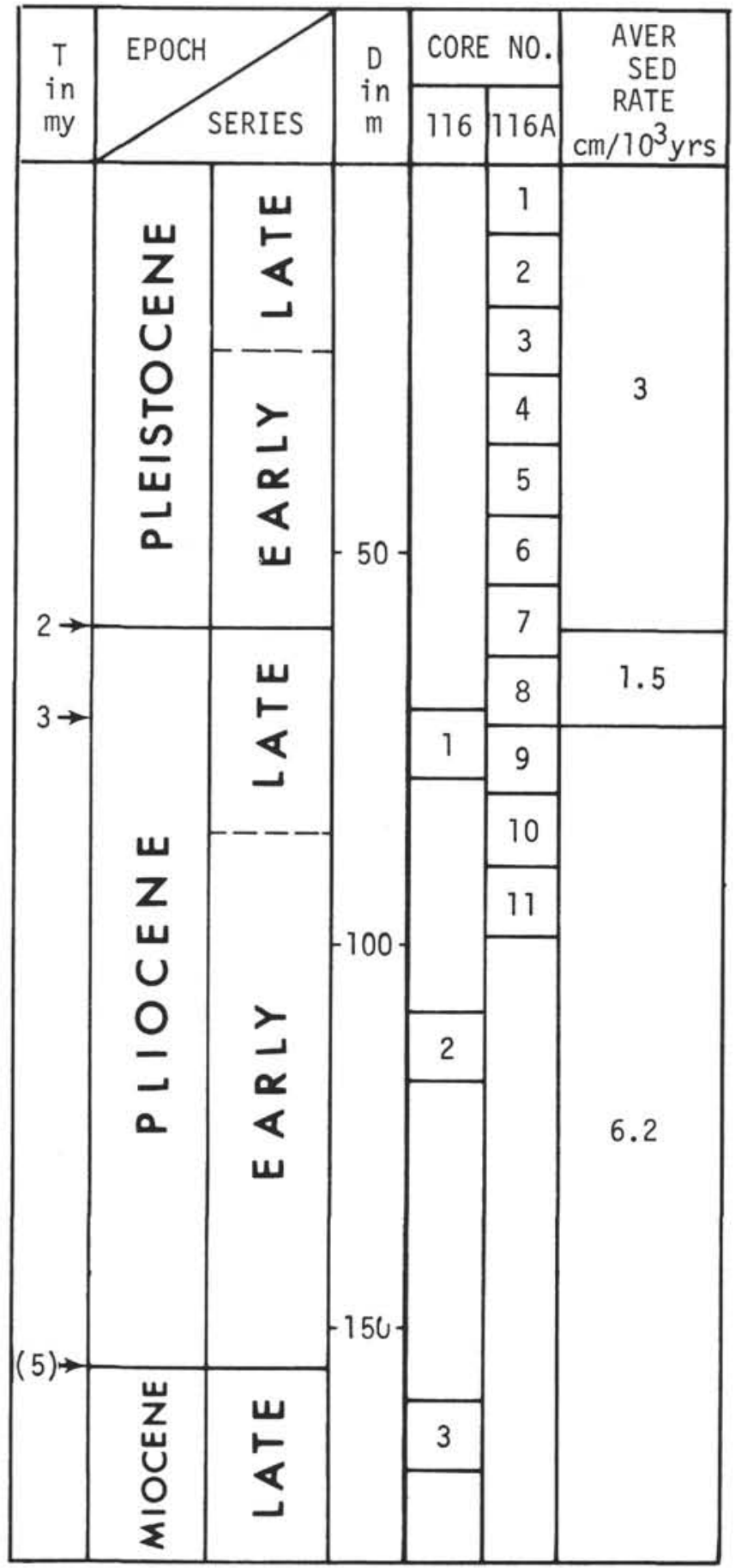

Figure 32. Estimated Late Miocene - Pleistocene average sedimentation rates at Site 116.

\section{ESTIMATED RATES OF SEDIMENTATION (SITE 117)}

An estimated average rate of sedimentation during the late Oligocene of about $1 \mathrm{~cm} / 1000 \mathrm{yrs}$ is suggested by calcareous nannoplankton data from Cores 117-1 to 3. An unconformity separates upper Oligocene from lower Eocene at about 147 meters. Calcareous nannofossil data suggest an average sedimentation rate of about $3.1 \mathrm{~cm} / 1000$ yrs during the late Paleocene at Site 117.

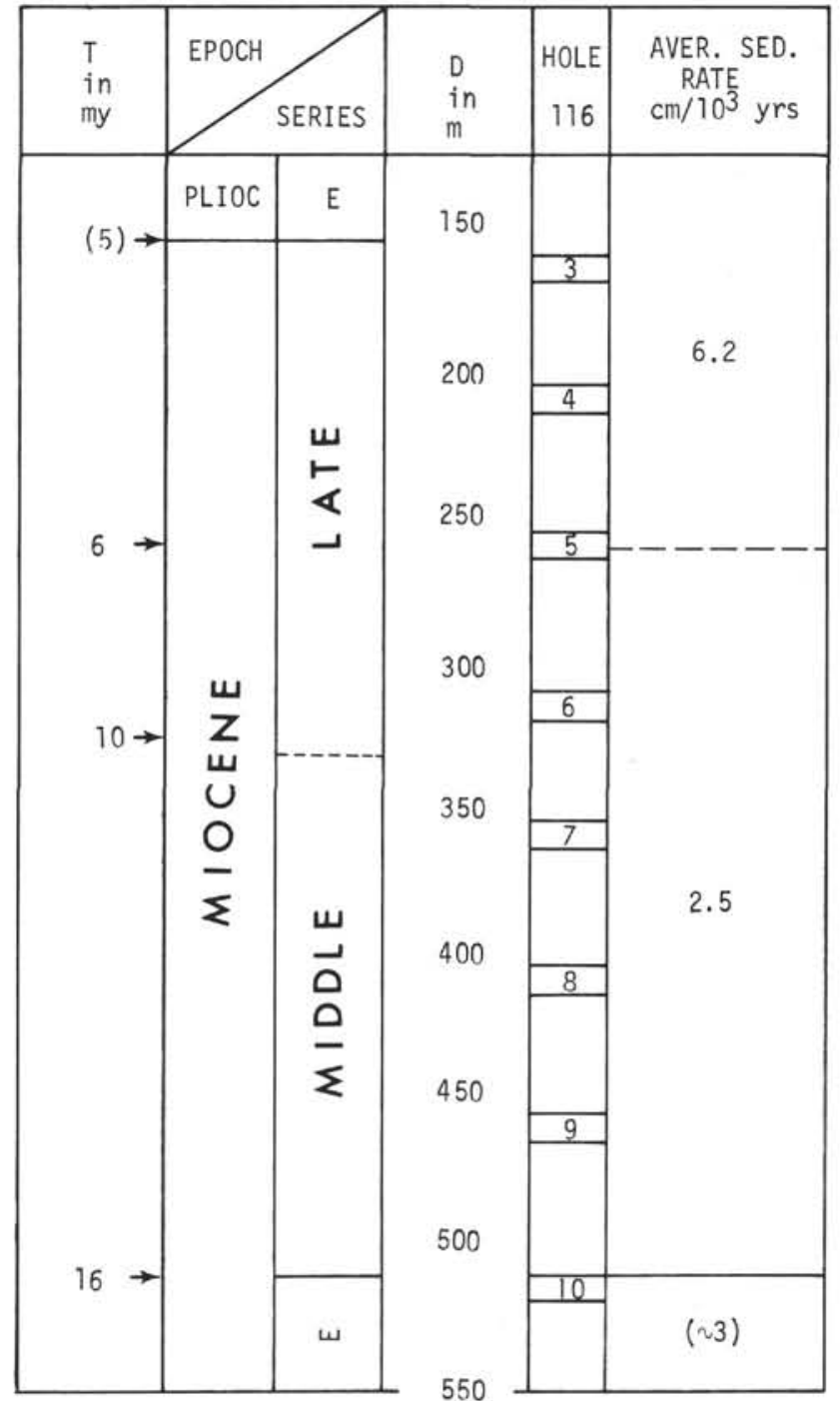

Figure 33. Estimated Middle-Late Miocene average sedimentation rates at Site 116.

TABLE 10

\begin{tabular}{|c|c|c|}
\hline Time Span & $\begin{array}{c}\text { Uncorrected } \\
\text { Rate }\end{array}$ & $\begin{array}{c}\text { Corrected } \\
\text { Rate }\end{array}$ \\
\hline m.y. & \multicolumn{2}{|c|}{$\mathrm{cm} / 1000 \mathrm{yrs}$} \\
\hline $0-25$ & 3.0 & 4 \\
$35.0-37.5$ & 3.7 & 5 \\
\hline
\end{tabular}

The rate of deposition of the Oligocene sediments is not defined precisely enough for it to be worthwhile applying a correction for natural consolidation. Similarly, the spacing of density measurements below 150 meters does not allow one to confidently assign a density gradient to this region and so the $3.1 \mathrm{~cm} / 1000$ yrs average rate between 150 and 311 meters remains uncorrected. 


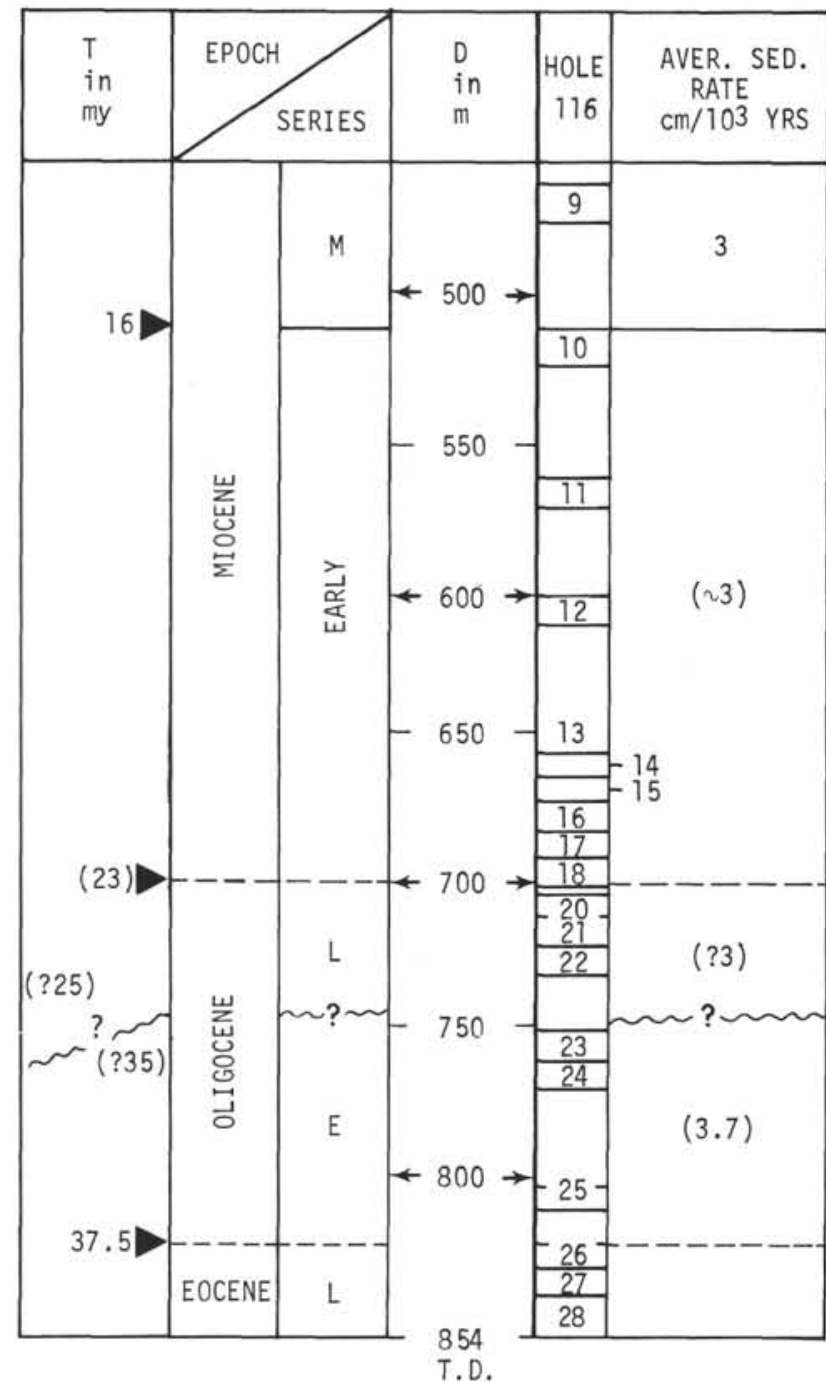

Figure 34. Estimated Late Eocene-Early Miocene average sedimentation rates at Site 116.

\section{DISCUSSION (116 and 117)}

\section{Introduction}

Two sites were drilled in the Hatton-Rockall Basin. The hole at the first site (116) terminated at 854 meters in cherty limestones of Late Eocene age. In order to reach lower stratigraphic levels drilling was continued at a new site to the east on the lower flanks of the Rockall Bank where seismic profiling showed that the subsurface strata was considerably more shallow. The expected continuity in stratigraphic section was found at Site 117, and the hole bottomed at 313 meters in a weathered olivine basalt which was overlain by shallow water conglomerates, silty clays and mudstones of Late Paleocene age. Pertinent data regarding Sites 116 and 117 are shown below. (Table 11)

A relatively complete sequence of Cenozoic sediments is present in the Hatton-Rockall Basin. The gradual sinking of this basin to its present depth during the Cenozoic is reflected in the nature of the sediments: predominantly detrital in the lower part, with a gradually increasing
TABLE 11

\begin{tabular}{|l|c|c|c|}
\hline & $\begin{array}{c}\text { Total Cored } \\
(\mathrm{m})\end{array}$ & $\begin{array}{c}\text { Core } \\
\text { Recovered } \\
(\mathrm{m})\end{array}$ & $\begin{array}{c}\text { Total } \\
\text { Penetration } \\
(\mathrm{m})\end{array}$ \\
\hline Hole 116 & 226 & 195.3 & 854 \\
Hole 116A & 99 & 89.1 & 99 \\
Hole 117 & 20 & 85.0 & 156 \\
Hole 117A & 66 & 34.3 & 313 \\
\hline
\end{tabular}

proportion of pelagic material in the younger horizons. Two unconformities were recorded: at Site 116 between the Upper Oligocene/Lower Oligocene-representing a timeinterval of about 10 million years; at Site 117 between the Oligocene/Lower Eocene-representing about 20 million years.

\section{Cenozoic Biogeography}

One of the objectives in drilling Sites 116 and 117 was to delineate Cenozoic high latitude paleobiogeography. Sediments representative of each of the Cenozoic epochs were recovered in the course of drilling these two sites. The sequential sinking of Hatton-Rockall Bank is reflected in the microfaunas so that one obtains a picture of the gradual development of deeper water benthonic faunas in addition to the climatically induced changes in planktonic foraminiferal faunas.

In the Late Paleocene and Early Eocene benthonic foraminiferal and bryozoan faunas exhibit a marked similarity with contemporaneous faunas recorded from Europe and North America. In the Oligocene, closer connections with Europe are seen in the bryozoan faunas. Middle Cenozoic (Oligocene-Early Miocene) benthonic foraminiferal faunas exhibit a marked similarity with contemporaneous faunas recorded in both the Caribbean and Mediterranean regions. The present day North Atlantic benthonic foraminiferal fauna appear to have developed in the Middle Miocene, about 15 million years ago.

A gradual provincialization of the planktonic foraminiferal fauna during the Cenozoic is seen in the sedimentary sequence at these two sites. The presence of keeled globorotaliids in the Middle and Late Miocene and the fact that the Late Pliocene-Pleistocene interval consists primarily of nannofossil oozes with relatively minor amounts of glacially derived clastic sediments suggests that the Gulf Stream may have flowed in the vicinity of Hatton-Rockall Bank throughout the Late Cenozoic.

\section{The Nature of Reflector 4}

The seismic profiles across Hatton-Rockall Basin (Figures 2 and 3) show reflector 4 to be a major boundary between the essentially horizontally bedded sediments above and the transparent sediments below. A principal objective of Hole 116 was to penetrate this reflector and to determine its cause.

At Site 116, reflector 4 is a complex and rather diffuse reflector at $0.80 \pm .03$ second (Figure 7). Assuming a mean velocity from the sea bed to the reflector of $1.75 \mathrm{~km} / \mathrm{sec}$, 


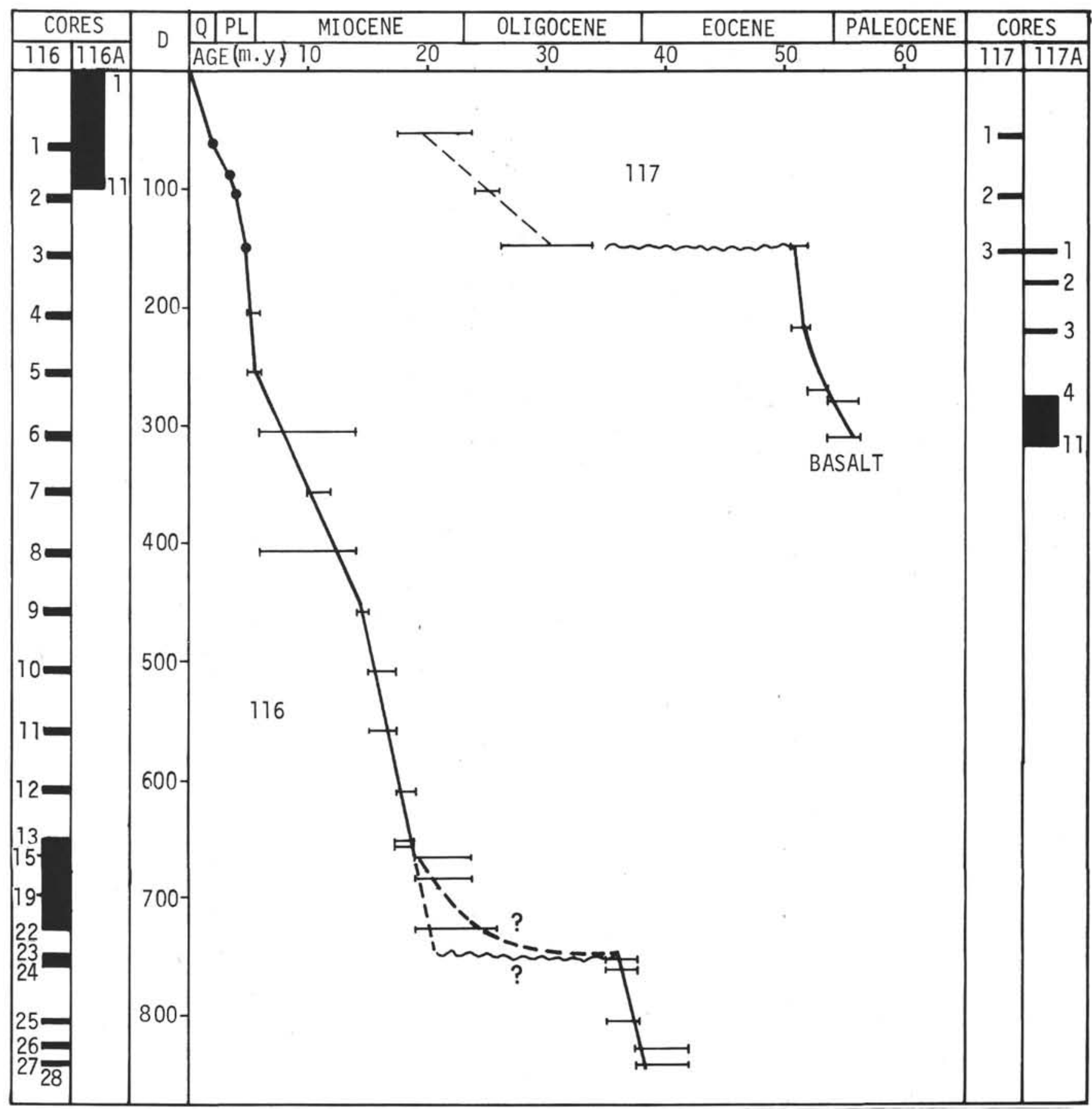

Figure 35. Age vs. depth relationship at Sites 116 and 117 based upon calcareous nannoplankton.

its expected depth would be $700 \pm 25$ meters. The first cherty layers were cored at 670 meters; drilling became considerably harder at 700 meters with the advent of layers of hard chalk and chert (116-20-5); and, the unconformity between the Upper and Lower Oligocene came between 730 and 750 meters. The resolution of the seismic data and the lack of knowledge of the interval velocity does not enable reflector 4 to be correlated positively with any one of these depths. The measurement of the acoustic impedance of recovered core material (see Physical Properties) suggests that it arises from the increased lithification of the chalk below 700 meters. To associate it with the unconformity at 740 meters would require a mean velocity to the reflector of $1.85 \mathrm{~km} / \mathrm{sec}$, which is higher than one would expect for the rather rapidly deposited nannofossil oozes above. At Site 117, reflector 4 lies in the top 150 meters and is associated with the Oligocene cherty limestones which lie above the unconformity with the Lower Eocene clays. The paucity of cores and the broken nature of the recovered material here made it difficult to study quantitatively the physical properties of the reflector 4 region.

Although at both sites the reflector seems to be associated with hard cherty layers, there is little doubt that 
on the basin-wide scale, reflector 4 is associated with an angular unconformity since the layers above it can be seen to pinch out as the reflector approaches the surface at the margins of the basin. There appears to be a correlation of the age and lithology of the top 150 meters at Site 117 with the sediments at 700 meters at Site 116 (Figure 36).

The maximum depth below sea bed of reflector 4 in the two sections of the Hatton-Rockall Basin to the west and northwest of Site 116 is 1.0 second (or 875 meters at 1.75 $\mathrm{km} / \mathrm{sec}$ ). An extrapolation to this depth of the sedimentation rate of $3.0 \mathrm{~cm} / 1000 \mathrm{yrs}$ found for the sediments above the unconformity at Site 116 gives an age of 29 million years, in contrast to the age of 36 million years found below the unconformity. In other words, a depositional unconformity probably exists over the entire basin, of some of some 7 million years in the center and increasing to 15 million years at Site 116 and about 20 million years or more at Site 117.

A short section of the Discovery-29 seismic reflection profile has been digitized and processed by deconvolution with the propagated pulse and with time varied filtering. Reflector 4 is revealed in greater detail and is shown to be a complex mixture of topographic highs giving low energy hyperbolic echoes, with the intervening depressions filled with multiple strong reflectors covering a time range of about 0.1 second. The rough topography of the low energy reflector may well correlate with the unconformity between the Lower and Upper Oligocene at 740 meters in Site 116. Its roughness may be due to minor tectonic disturbances during the Middle Oligocene which have given rise to the faulting and the tilted bedding of the chalks and limestones of the lower cores of Hole 116. The fractured appearance of reflector 4 near Site 117 is suggested by the cliffs and benches seen on the seismic reflection profile. Matthews and Smith (1971) have searched for evidence of major normal faulting on reflector 4 from the Discovery-29 profiles and conclude that in no case does the throw of such faults, as might be postulated, exceed 0.2 second. They suggest that an alternative cause of the hyperbolic echoes in reflector 4 might be mud diapirs. The faulting observed in the cores may be associated with this diapirism. However the absence of such faulting immediately above the unconformity suggests that any such movements ceased after the Middle Oligocene.

The first sedimentation above the unconformity appears to have occurred in the depressions in the horizon. On the whole, these are flat-bedded and not draped, suggesting that gravity controlled currents transported the sediments there. The sediments are relatively rich in silica, and in Hole 116 up to 660 meters, are partly lithified and cherty.

It is concluded, therefore, that reflector 4 arises from lithified sediments accummulated in depressions of an unconformity, that may have suffered minor tectonic disturbances in the Middle Oligocene.

\section{The Sediments Above Reflector 4}

At Site 116, the top 700 meters are Miocene and Pliocene-Pleistocene nannofossil calcareous ooze mostly in the size range of clay and silt, and sedimented at a rate of between 3 and $4 \mathrm{~cm} / 1000$ yrs without interruption. Pyrite was common, indicating an oxygen poor environment.
The seismic profiles across the Hatton-Rockall Basin show that this body of sediment is extensive. It is confined to the east by the basement high of Rockall Bank and to the west by that of Hatton Bank (Figure 1). To the northeast it is very restricted by George Bligh Bank, but to the southwest it divides around a volcanic seamount at $55.5^{\circ} \mathrm{N}, 20^{\circ} \mathrm{W}$. The passage of Glomar Challenger away from Site 117 demonstrated the southerly extent of the sediments of Hatton-Rockall Basin (Figure 37). The basin is approximately 100 kilometers wide, 400 kilometers long and the sediments above reflector 4 average a thickness of about 600 meters. The sediments are characterized by:

(a) Approximately horizontal stratification independent of the underlying topography of reflector 4 .

(b) A sharp boundary against basement highs, which have little or no sediment cover.

(c) A marginal channel on both sides of the basin and moats around the three basement highs at the southwestern end. (Figure 1). Older buried marginal channels can be seen in the seismic profiles.

(d) A domed upper surface, the axis of which lies in the center of the southwestern part of the basin.

(e) An upper surface indented by small regularly spaced valleys (?) believed to be oriented NE-SW (Figure 6). The internal structure also shows a wavy pattern. (cf. discussion on site survey, Appendix II). These features are believed to be related to the wavy surface found on such sediment ridges as the Feni and Gardar Ridges.

These features are similar to those found on sediment ridges which have been formed by the fallout of sediment from ocean bottom currents, which are discussed at greater length in Chapter 11. In Rockall Trough just east of Rockall Plateau, the Feni Ridge has been attributed to the flow of Norwegian Sea water down the western side of the trough (Johnson and Schneider, 1969; Jones, Ewing, Ewing and Eittreim, 1970). A similar mechanism built the Gardar Ridge and the Site 114 ridge in the Iceland Basin between Rockall Plateau and the Reykjanes Ridge. It is plausible to postulate, therefore, that the Miocene sediments of Hatton-Rockall Basin have been deposited from a bottom current flowing between the two Banks.

However, whereas the Feni, Gardar and Site 114 ridges clearly result from an ocean current banked up by Coriolis force against the western side of a basin, the sediments and channels in the Hatton-Rockall Basin do not show this asymmetry. If the axis of highest velocity lies above the marginal channel and Coriolis force is dominant, then the pattern of channels indicate that the bottom current travels northwards along the eastern side and southwards along the western side of the basin. If, however, the basin is too narrow or too shallow to allow appreciable banking up of the current or if the flow fills the entire cross section of the basin, then marginal channels could form simultaneously on both sides due to local acceleration by restriction. A uniform flow to the southwest is the simpler hypothesis and explains the moats around the seamounts at the southwest end of the basin. The source of this bottom current must then be in the vicinity of George Bligh Bank. Northeast of this it may derive from the upper part of Norwegian Sea water overflowing between Faroe Island and 
SITE 116

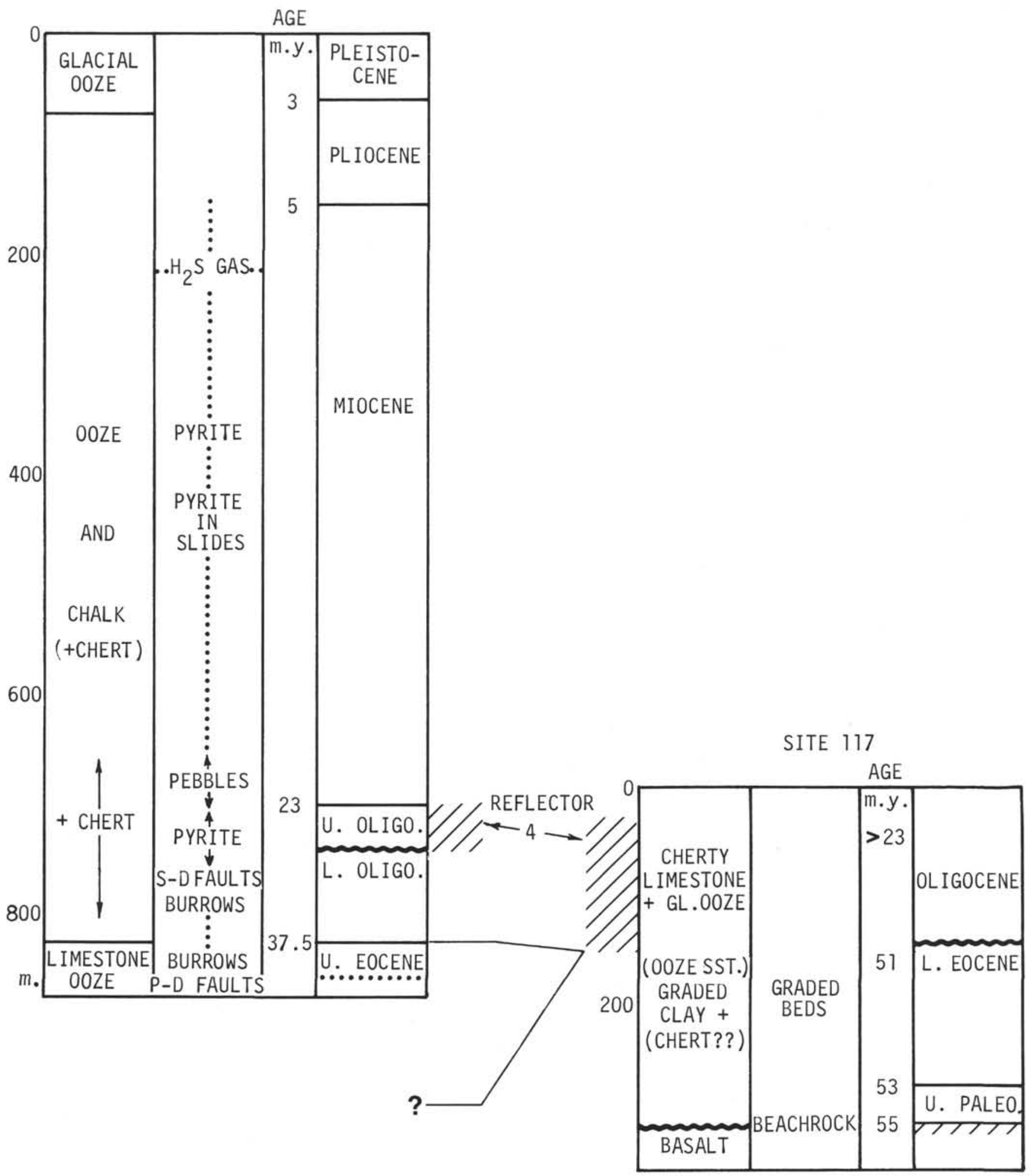

400

m

Figure 36. Comparison of lithology and stratigraphy of Holes 116 and 117. P-D is post-depositional and S-D is syndepositional. 
Scotland, the lower part traveling along the eastern ridge of Rockall Bank and forming the Feni Ridge. If this is so, there may be some similarity between the sediments of Feni Ridge and those of Hatton-Rockall Basin.

The oldest sediments of this sequence that were sampled at Site 116 were Upper Oligocene (25 million years), although further west the sequence may have started about 30 million years ago. The comparatively constant sedimentation rate and the uniform stratification of the sediments indicates that the sedimentation mechanism here has been constant during this time, and therefore that a southwest-going bottom current has been flowing for at least 30 million years.

\section{The Sediments Below Reflector 4}

The seismic profiles show reflector 4 to be underlain by a relatively transparent layer bounded below by reflector 5 in the center of the basin and by the basement rocks of Rockall and Hatton Banks at the margins. In contrast to the Miocene bottom current sediments above reflector 4, this layer is draped onto the flanks of the banks. In many places it is 0.7 -second thick $(700$ meters at $2.0 \mathrm{~km} / \mathrm{sec})$. The processed section the of Discovery-29 profile shows some sub-horizontal reflectors near to the base of the layer filling depressions in the more rugged reflector 5 . In places there are suggestions of overlapping hyperbolae in the layer indicating discrete reflectors.

Hole 116 penetrated reflector 4 and terminated in the top of the transparent layer, in Upper Eocene chalky limestone. In the discussion on the physical properties, it was suggested that the lack of reflections in the transparent layer was related to the absence of rapid physical (and therefore lithological) changes below the limestone and that this therefore constituted the transparent layer. On the other hand, the transparent layer below reflector 4 at Site 117 (150 to 300 meters) was shown to consist of a rather uniform dense gray clay of Lower Eocene and Upper Paleocene age with high terrigenous content and containing shallow water ostracods and bryozoa. By age comparison, this represents the lower part of the transparent layer below 116 (equivalent to a depth of 2400 meters below sea level if the sedimentation rate in the Upper Eocene of Hole 116 is extrapolated downwards.)

These two conflicting data on the nature of the transparent layer need to be resolved. The continuity of the transparent layer between 117 and 116 is quite certain. Two interpretations are possible to explain the data: (a) There is a gradual facies change from clay to limestone from 117 to 116 corresponding to a progressively changing environment of deposition away from Rockall Bank, or (b) that there is clay at the base of the transparent layer below 116 as well as below 117, but that there is a gradual facies change at Site 116 from clay near the bottom to limestone higher up, corresponding, perhaps, to a progressively deeper environment as the basement below HattonRockall Basin sank. Some evidence of a shallower water environment for the deposition of the Upper Eocene and Lower Oligocene limestones of Hole 116 comes from the species diversity of the foraminifera, and from the presence of Braarudosphaera bigelowi which is known at present to live in restricted seas. These data support the sinking hypothesis.

\section{The Nature of Reflector 5}

Reflector 5 was seen below the transparent layer on the Discovery-29 and 33 seismic profiles across the whole basin, but only near the margins on the Glomar Challenger profiles. In the central section of the Discovery-29 profile (Figure 3), continuity could not be established with any certainty between reflector 5 and the basement of Hatton or Rockall Banks. In the southern basin, reflector 5 could be seen on the Glomar Challenger record (Figure 37) on the low frequency recorder, rising from about 1.5 seconds below the seabed to merge with the base of the magnetic (and therefore probably volcanic) seamount at the southwest end of the basin. Seismic refraction data in the basin by Scrutton (personal communication) suggest that reflector 5 is not the top of the crystalline basement, but may represent another sediment horizon. The processed seismic reflection record in the southern basin shows the reflector to be extremely irregular and probably faulted, with additional reflecting horizons lying within the depressions.

It must be concluded, therefore, that although Hole 117 sampled a basaltic basement below the transparent layer, there is inadequate data to correlate reflector 5 below the Hatton-Rockall Basin with this, and that the nature of the reflector will only be determined by further drilling.

\section{Environmental Conditions During Sedimentation}

A variety of data from studies of the flora and fauna, and of the lithology, enable some estimates to be made of the depth of the sea during the periods of sedimentation represented in Holes 116 and 117.

(a) Quantitative micropaleontological analysis. Shipboard estimates of the ratios of benthic to planktonic foraminifera led to a depth of deposition/age relationship which was the basis of the subsidence curve published in Laughton et al. (1970). Subsequent laboratory studies, presented in detail above, have altered these conclusions. At Site 117, the sea bed subsided from sea level to 200 meters in the Late Paleocene to early Early Eocene (53 million years), and to 500-800 meters by late Early Eocene ( 51 million years). At Site 116, the Upper Eocene (38 million years) basal section probably originated at a water depth of 700 to 1000 meters, the Lower and Upper Oligocene (25 to 37 million years) at over 1000 meters, the early Lower Miocene (19 to 23 million years) at over 1200 meters and the later sediments at over 1500 meters, until sediment accumulation reduced the depth to the present 1151 meters. It is realized that these calculations are such rough approximations that one could argue that they are meaningless. Still, it is believed that they have relative value, suggesting a trend and indicating an order of magnitude.

(b) Ostracod studies (see R. H. Benson above). In Hole $117 \mathrm{~A}$, late Paleocene ostracods are predominantly sighted suggesting a depth of 100 to 600 meters. Oligocene ostracods in Hole 117 are blind and belong to an environment similar in depth to that in which they were recovered.

(c) Bryozoa studies (see Cheetham and Håkansson above). Oldest Paleocene ( 56 million years) samples above basement at Hole $117 \mathrm{~A}$ are thought to have come from 


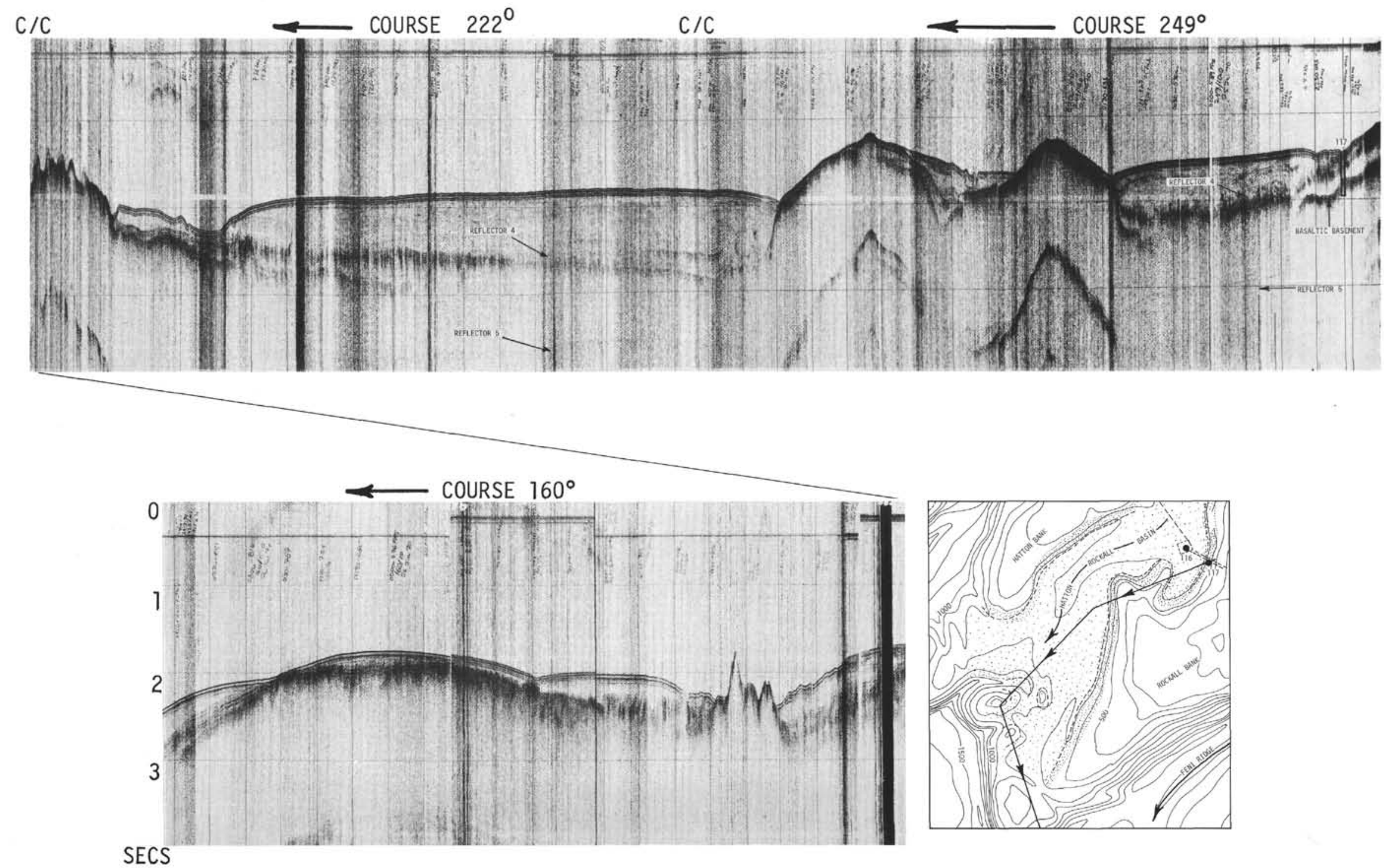

Figure 37. Seismic reflection profile by Glomar Challenger along the Hatton-Rockall Basin southwest from Site 117 showing the marginal channels against the basement highs and the moats associated with the seamounts at the southwestern end of the basin. 
about 30 to 60 meters depth, and the youngest Paleocene (54 million years) from about 60 meters. The older Late Oligocene (30 million years) bryozoa of Hole 117 indicate a water depth of 150 to 200 meters, whereas, the younger ( 25 million years) bryozoa give 200 to 600 meters.

(d) Radiolaria. The absence of Radiolaria in the Late Paleocene of Site 117 suggests a shallow water environment, in contrast to their presence in the Oligocene.

(e) Other fossil evidence. Molluscs, gastropods and annelid tubes were found in the Paleocene basal sandstone of Hole $117 \mathrm{~A}$, indicating a shallow water environment.

(f) Phosphorite. A nodule was found in Lower Eocene (52 million years) sediments of Hole 117A indicating a depth range of 30 to 300 meters.

(g) Sediment facies. The basal conglomerates in Hole $117 \mathrm{~A}$ are poorly sorted, altered and rounded suggesting a nearshore environment.

(h) Basalts. The vesicular nature of the basalts suggests a shallow water origin.

(i) Nannoplankton. In Hole 116, the early Oligocene nannoplankton suggest a restricted environment such as a basin or gulf.

(j) Burrowing. Burrows of a zoophycos type were found in Hole 116 in the Early Oligocene sediments indicating bathyal depths.

In Figures 38 and 39, the above data is plotted against geological age in order to deduce a subsidence history of the two sites. Sedimentation rates are also plotted such that the area beneath the curve up to a given age indicates the sediment accumulation to that time.

At Site 117, the evidence for the Late Paleocene is mutually consistent and indicates a shallow or nearshore environment for the basal sediments ( 56 million years) and progressive deepening to about 600 meters in the Early Eocene (51 million years). There is no data for Middle Eocene to Middle Oligocene since there are no sediments.

In the late Oligocene, there is a substantial disagreement between the bryozoa data, and the ostracod and planktonic data which remains unresolved. If one accepts the upper bathyal depths of the bryozoa, two major episodes of subsidence are implied. For the purposes of the subsequent discussion, the simpler hypothesis of one episode of subsidence is followed, the discrepancy being noted for future investigation.

At Site 116, the data provide a consistent story of progressive subsidence from middle bathyal depths in Early Oligocene to the present depth in Middle Miocene.

It must be emphasized that the criteria on which these environmental data are founded are in many cases very tentative, and that the depth ranges deduced are subject to revision as more is known of the determining environmental factors.

\section{Tectonic History of Rockall Plateau}

At Site 117 (Figure 39), subsidence started very soon after the nearshore sediments were laid down 56 million years ago, and by Early Eocene ( 51 million years) basement had dropped to 600-700 meters depth, at a mean rate of 14 $\mathrm{cm} / 1000 \mathrm{yrs}$. If this mean rate is continued to the present basement depth of 1350 meters, the subsidence would have ceased in Middle Eocene (47 million years). It is possible, however, that it slowed down or stopped in Early Eocene and renewed tectonic activity in Early Oligocene brought it to its present depth, (assuming the ostracod data is accepted in preference to the bryozoa data). There is some suggestion from the quantitative micropaleontological analysis that some sinking took place during the Early Miocene, as it did at Site 116, although the data is poor. Tectonic activity after the Paleocene is indicated in the Upper Paleocene cores by the presence of slickensides and faulted sediment layers. The step-like bottom and subbottom topography of the west flank of Rockall Bank (Figure 10) suggests that the faulting was widespread in the region. Several episodes of tectonic activity are therefore likely at Site 117.

The oldest data available from Site 116 (Figure 39) are Late Eocene. The increase in planktonics and the decrease in ostracods suggest that at that time the sea was still deepening over the site. Slickensides, microfaulting and dipping laminations testify to Late Eocene tectonic activity. During the Oligocene, on the other hand, no subsidence seems to have taken place. A gradual decrease in planktonics even suggests some shallowing which can be explained by sediment accumulation. The beginning of the Early Miocene possibly was a period of renewed subsidence for Site 116. One could interpret the depth of deposition of Core 19 (23 million years old, 700 meters deep) as 1200 meters, and of Core 14 (19 million years old, 660 meters deep) as 1500 meters. Consequently, Site 116 went down 340 meters during 4 million years, that is $8.5 \mathrm{~cm} / 1000 \mathrm{yrs}$. The data suggest, therefore, a total subsidence of 900 meters at this rate between Late Oligocene ( 25 million years) and Early Miocene (18 million years), followed by a gradual shoaling of the sea bed as the late Tertiary sediments accumulated.

A simpler subsidence curve (shown by dashed lines in Figure 39) ignores the possible lack of subsidence during the Oligocene, and gives a subsidence of 1200 meters between the start of the Oligocene ( 38 million years) and the Middle Miocene (13 million years) equivalent to a mean rate of $4.8 \mathrm{~cm} / 1000 \mathrm{yrs}$.

Data from both sites together suggest that Rockall Plateau subsided in two periods: during the PaleoceneEocene, and during the Early Miocene. During the Oligocene and after the Early Miocene, the plateau seems to have been stable. If there was no differential sinking or tilting between Site 117 and the bulk of Rockall Bank, the top of the bank would have had an elevation of 1400 meters above sea level during the Paleocene. However, the western flank of Rockall Bank appears to be substantially faulted so that the top of the bank was probably considerably lower than this.

The evidence available suggests that there was substantial relative vertical movement between Sites 117 and 116. The inferred depths of the Oligocene at 116 and 117 are similar, so that the Early Miocene subsidence at 116 gave rise to differential movement. If the pre-Oligocene subsidence at 117 also affected Site 116, then reflector 5 would have been near sea-level during the Paleocene. If it is a sedimentary horizon, then the sediments would consist of shelf or continental facies. 
SITE 117

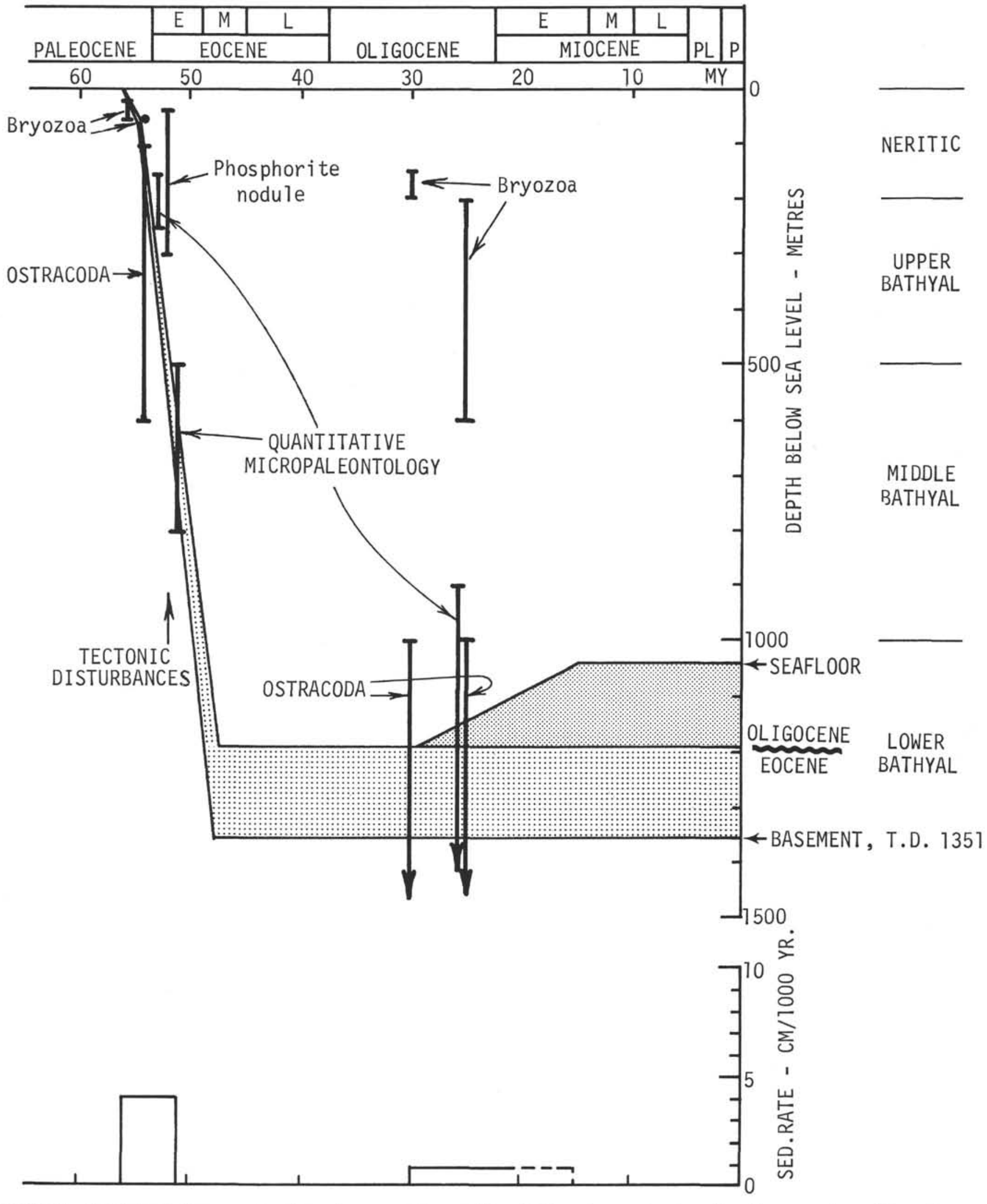

Figure 38. Crustal subsidence and sediment accumulation at Site 117 based on estimates of environmental conditions from the core material. The area beneath the curve up to a given age indicates the sediment accumulation to that time. The denser shading indicates sediment above the Oligocene-Eocene disconformity. 
SITE 116

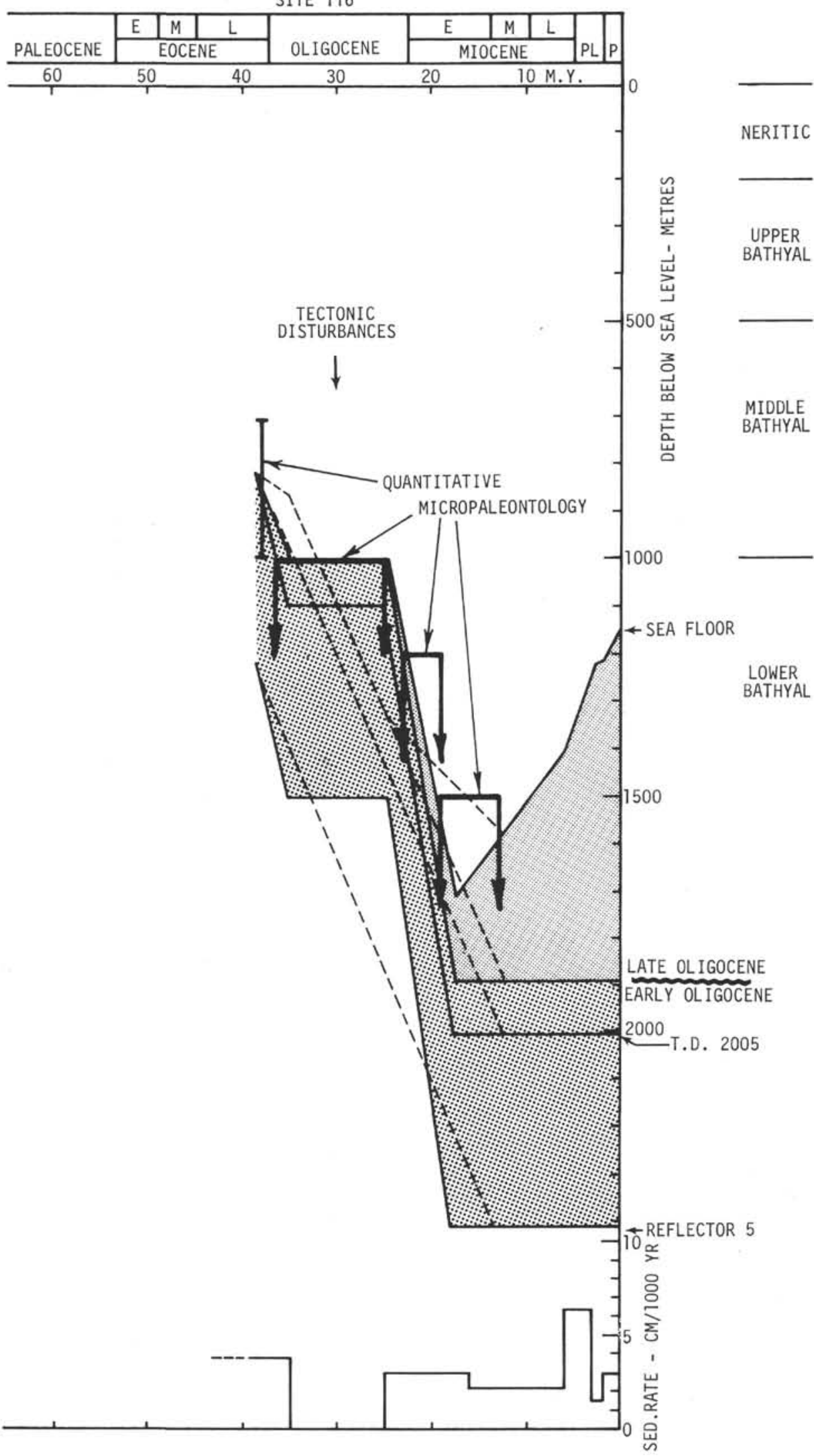

Figure 39. Crustal subsidence and sediment accumulation at Site 116 based on estimates of environmental conditions from the core material. The area beneath the curve up to a given age indicates the sediment accumulation to that time. The denser shading indicates sediment above the Oligocene-Eocene disconformity. 
In conclusion, the evidence from Sites 116 and 117 strongly support the hypothesis that Rockall Plateau is a continental fragment detached from Greenland some 60 million years ago and subsequently subsided by at least 1400 meters, and probably in the center by 2500 meters.

\section{REFERENCES}

Ascoli, P., 1969. First data on the ostracod biostratigraphy of the Possagno and Brendola sections (Paleogene, ne Italy). Mem. du B.R.G.M. 69, 50.

Avery, O. E., Vogt, P. R. and Higgs, R. H., 1969. Morphology, magnetic anomalies and evolution of the Northeast Atlantic and Labrador Sea. Pt. II. Magnetic anomalies (abstract). Trans. Am. Geophys. Union. 50, 184.

Bandy, O. L., 1963. Dominant paralic foraminifera of Southern California and the Gulf of California. Contr. Cushman Found. Foram. Res. XIV, 127, textfig. 1-2, table 1-3.

Bandy, O. L. and Arnal, R. E., 1957. Distribution of Recent foraminifera off west coast of Central America. Bull. Am. Assoc. Petrol. Geol. 41 (9), 2037, 3 figs., tables I-III.

Bandy, O. L., 1960. Concepts of foraminiferal paleoecology. Bull. Am. Assoc. Petrol. Geol. 44 (12), 1921, 14 figs.

, Ingle, J. C. and Resig, J. M., 1964. Facies trends, San Pedro Bay, California. Bull. Geol. Soc. Am. 75, 403, 10 figs.

Bandy, O. L., 1965. Modification of formainiferal distribution by the Orange County Outfall, California. Ocean Science and Ocean Engineering. 55, 10 figs., 1 table.

, 1965. Foraminiferal trends, Hyperion Outfall, California. Limnology and Oceanography. 10 (3), 314, 14 figs., 2 tables.

Bandy, O. L. and Rodolfo, K. S., 1964. Distribution of foraminifera and sediments, Peru-Chili Trench area. Deep Sea Res. 11, 817, 8 figs. 3 tables.

Benson, R. H., 1966. Recent marine Podocopid ostracodes. Oceanogr. Mar. Biol. Ann. Rev. 4, 213.

1969. Preliminary report on the study of abyssal ostracodes. Taxonomy, Morphology and Ecology of Recent Ostracodes. J. W. Neale (Ed.). Edinburg (Oliver \& Boyd) 475.

1971. A new Cenozoic deep-sea genus, Abyssocythere (Crustacea, Ostracoda, Trachyleberididae) with descriptions of five new species. Smithsonirn Contr. Paleobiology. 7.

Bold, W. A. van den, 1957. Ostracoda from the Paleocene of Trinidad. Micropaleontology. 3, 1-18, pl. 1-4.

1960. Eocene and Oligocene Ostracoda of Trinidad. Micropaleontology. 6, 145-196, pl. 1-8.

Boltovskoy, E., 1965. Los foraminiferos recientes. Sci. Publ. Secretaria Marina Servicio de Hidrografia Naval. 510 pp., 114 figs.

Bowen, R. N. C., 1953. Ostracoda from the London clay. Proc. Geol. Ass. 64, 276.

Brady, G. S., 1880. Report on the Ostracoda Dredged by "H. M. S. Challenger" during the years 1873-1876. Repts. Voyage H. M. S. Challenger; Zool. 1, 1-84, pl. $1-43$.

Braga, Giampietro, 1963. I Briozoi del Terziario veneto, Io. contributo. Boll. Soc. Paleont. Ital. 2 (1), 16-55, pls. 2-5.

Bromley, R. G. 1967. Marine phosphorites as depth indicators. Marine Geol. 5, 503.
Bullard, E. C., Everett, J. E. and Smith, A. G., 1965. The fit of the continents around the Atlantic. Phil Trans. Roy. Soc. $258 \mathrm{~A}, 41$.

Cann, J. R., B \& W, 1969. Spilites from the Carlsberg Ridge, Indian Ocean. J. Petrol. 10, 1.

Canu, Ferdinand and Bassler, R. S., 1933. The bryozoan fauna of the Vincentown limesand. U. S. Nat. Museum Bull. 165, 108 pp., 21 pls.

Caralp, M., Lamy, A. and Pujos, M., 1970. Contribution à la connaissance de la distribution bathymetrique des Foraminifères dans le Golfe de Gascogne. Rev. Esp. Micropal. 2 (1), 55, 9 figs., 5 Ann.

Chayes, F., 1970. The alkali-silica balance in Cenozoic and Recent volcanic rocks of basaltic composition. (Abst. of Meeting). 11-12 Nov. 1970; Volcanism and the structure of the earth. Phil Trans. Roy. Soc. 9, in press.

Cheetham, A. H., 1963. Late Eocene zoogeography of the eastern Gulf Coast region. Geol Soc. Am. Mem. 91, 113 pp., 3 pls.

1966. Cheilostomatous Polyzoa from the Upper Bracklesham Beds (Eocene) of Sussex. Brit. Museum (Nat. Hist.) Bull. Geol. 13(1), 1.

in press. Cheilostome bryozoa of late Eocene age from Eua, Tonga. U. S. Geol. Surv. Profess. Paper.

Cook, P. L., Some "sand fauna" Polyzoa (Bryozoa) from eastern Africa and the northern Indian Ocean. Cahiers de Biologie Marine. 7, 207-223, pls. 1,2.

Ericson, D. B., Ewing, M. and Wollin, G., 1964. The Pleistocene Epoch in deep-sea sediments. Science. 146, 723.

Flexer, A. and Starinsky, A., 1970. Correlation between phosphate content and the foraminiferal plankton/ benthos ratio in chalks (Late Cretaceous, Northern Israel): Paleoenvironmental significance? Sedimentology. 14, 245, 5 figs., 1 table.

Friend, J. K. and Riedel, W. R., 1967. Cenozoic orosphaerid radiolarians from tropical Pacific sediments. Micropaleontology. 13 (2), 217.

Gevirtz, J. L., 1969. Paraecology of benthonic foraminifera and associated microorganisms of the continental shelf off Long Island, New York. University Microfilms, Inc., Ann Arbor Michigan. 1, 25 figs.

, Park, R. A., and Friedman, G. M., 1971. Paraecology of benthonic Foraminifera and associated micro-organisms of the continental shelf off Long Island, New York. J. Paleont.. 45, 153, 23 figs.

Gibson, T. G., Hazel, J. E. and Mello, J. F., 1968. Fossiliferous rocks from submarine canyons off the northeastern United States.U. S. Geol. Survey Profess. Papers. 600-D, D222-230.

Grimsdale, T. F. and van Morkhoven, F. P. C. M., 1955. The ratio between pelagic and benthonic foraminifera as a means of estimating depth of deposition of sedimentary rocks. 4th World Petrol. Congr. Proc. Sect. I/D, Paper 4, 473, 15 figs.

Gupta, B. K. S., 1971. The benthonic foraminifera of the tail of the Grand Banks. Micropaleont. 17, 69, 2 pls., 10 figs.

Harmer, S. F., 1926. The Polyzoa of the Siboga Expedition, part II, Cheilostomata Anasca. Siboga Exped. Repts. 28b, 181-501, pls. 13-34.

Hazel, J. E., 1965. Notes on the Ostracode Genus Trachyleberidea Bowen. J. Paleontology. 39, 501.

Hinte, J. E. van, 1959. Globigerinidae van de Snellius Expeditie. (unpublished report, Utrecht).

Johnson, G. L. and Schneider, E. D., 1969. Depositional ridges in the North Atlantic. Earth Planet Sci. Letters. 6, 416. 
Jones, E. J. W., Ewing, M., Ewing, J. I. and Eittreim, S. L., 1970. Influences of Norwegian Sea overflow water on sedimentation in the northern north Atlantic and Labrador Sea. J. Geophys. Res. 75, 1655.

Jones, J. G., 1969. Pillow lavas as depth indicators. Am. J. Sci. 267, 181.

Kafescioglu, I. A., 1969. Quantitative distribution of foraminifera on the continental shelf and uppermost continental slope off Massachusetts, Eastern United States. University Microfilms, Inc., Ann Arbor, Michigan. 146 pp., 56 figs., Tables I-XVI.

Keij. A. J., 1963. The relative abundance of Recent planktonic foraminifera in seabed samples collected offshore Brunei and Sabah. Borneo Region. Malaysia Geol. Surv. Ann. Report. 146, figs. 42-45.

Kling, S. A., 1971. Radiolaria: Leg 6 of the Deep Sea Drilling Project. In Fischer, A. G. et al., 1971, Initial Reports of the Deep Sea Drilling Project, Volume VI. Washington (U. S. Government Printing Office), 1069.

Labracherie, Monique and Prud'homme, Janine, 1966. Essai d'interprétation de paléomilieux grace à la méthode de distribution des formes zoariales chez les bryozoaires. Bull. Soc. Géol. France. 8 (7), 102.

1967. Observations paléoécologiques sur les bryozoaires des formations classuques du Blayais. Actes Soc. Linnéene Bordeaux. 104B (10), 4-9, pls. 1, 2.

Lagaaij, Robert and Gautier, Y. V., 1965. Bryozoan assemblages from marine sediments of the Rhone delta, France. Micropaleontology. 11 (1), 39.

Larwood, G. P., Medd, A. W., Owens, D. E. and Tavener-Smith, Ronald, 1967. Bryozoa. In The Fossil Record. London (Geol. Soc. London), 379-395.

Laughton, A. S., et al., 1970. Deep Sea Drilling Project Leg 12. Geotimes. Nov., 10-14.

MacDonald, G. A. 1963. Physical properties of erupting Hawaiian magmas. Bull. Geol. Soc. Am., 74, 1071.

MacGregor, M. and MacGregor, A. G., 1948. The Midland Valley of Scotland. British Regional Geology. Edinburgh, (H. M. S. O.), 310.

Matthews, D. H., 1962. Altered lavas from the floor of the eastern North Atlantic. Nature. 194, 368.

Mathews, D. H. and Smith, S. G., 1971. The sinking of Rockall Plateau. Geophys. J. Ray Astron. Soc. 23499.

Melson, W. G., Thompson, G. and van Andel, T. H., 1968. Volcanism and metamorphism in the mid-Atlantic Ridge, $22^{\circ}$ N. latitude. J. Geophys. Res. 73, 5925.

Miller, J. A. and Mohr, P. A., 1965. Potassium-argon age determination on rocks from St. Kilda and Rockall. Scottish J. Geol. 193.

Moorbath, S. and Welke, H., 1969. Isotopic evidence for the continental affinity of the Rockall Bank, North Atlantic. Earth Planet Sci. Letters 5, 211.

Moore, J. G., 1965. Petrology of deep-sea basalt near Hawaii. Am. J. Sci. 263, 40.

Moore, T. C., Jr. In press. Sections on Radiolaria. In Initial Reports of the Deep Sea Drilling Project, Volume VIII. Washington (U. S. Government Printing Office).

MUNSELL BOOK OF COLOR. 1969. Baltimore (Munsell Color Company).
Norton, R. D., 1930. Ecologic relations of some foraminifera. Bull., Scripps Inst. Oceanography. 2, 331, 6 tables, 3 figs.

Parasnis, D. S., 1952. A study of rock densities in the English Midlands. Mon. Notices, Roy. Astron. Soc. Geophys. Suppl. 6, 252.

Phemister, J., 1960. Scotland: The Northern Highlands. British Regional Geology. Edinburgh (H. M. S. O.), 45.

Pringle, J., 1948. The South of Scotland. British Regional Geology. Edinburgh (H. M. S. O.), 76.

Read, H. H., 1948. The Grampian Highlands. British Regional Geology. Edinburgh (H. M. S. O.), 69.

Riedel, W. R. and Sanfilippo, A., 1970. Radiolaria, Leg 4, Deep Sea Drilling Project. In Bader, R. G. et al., 1970. Initial Reports of the Deep Sea Drilling Project, Volume $I V$. Washington (U. S. Government Printing Office), 503.

Riedel, W. R. and Sanfilippo. A. In press. Cénozoic Radiolaria from the western tropical Pacific, DSDP Leg VII. In Initial Reports of the Deep Sea Drilling Project, Volume VII. Washington (U. S. Government Printing Office).

Roberts, D. G., 1969. New Tertiary volcanic centre on the Rockall Bank, eastern North Atlantic ocean. Nature. 223, 819.

Roberts, D. G., 1971. New geophysical evidence on the origin of Rockall Plateau and Trough. Deep-Sea Res. 18, 353.

Roberts, D. G., Bishop, D. G., Laughton, A. S., Ziolkowski, A. M., Scrutton, R. A. and Matthews, D. H., 1970. New sedimentary basin on Rockall Plateau. Nature. 225, 170.

Rouvillois, A., 1971. Biocoenose et taphocoenose de foraminiféres sur le plateau continental atlantique au large de I'lle d'Yeu. Rev. Micropal. 13, 15 figs., 3 pls.

Sabine, P. A., 1965. Rockall-an unusual occurrence of Tertiary granite. Proc. Geol. Soc. London. 51, 16.

Scrutton, R. A., 1970. Results of a seismic refraction experiment on Rockall Bank. Nature. 227, 826.

Scrutton, R. A. and Roberts, D. G., 1971. In "The Geology of the East Atlantic Continental Margin" SCOR WG 31 Symposium, Cambridge. Publ. by Inst. Geol. Sci. Rep. 70/14, 77-87. Structure of Rockall Plateau and Trough, north-east Atlantic.

Seaton, D. D., 1967. Zooplankton investigations on Rockall Bank, May, June, and September 1967. Ann. Biol., Copenh. 24, 86, 3 figs.

Steele, J. H., Baird, I. E. and Johnston, R., 1971. Evidence of upwelling on Rockall Bank. Deep Sea Res. 18, 261, 5 figs.

Stehli, F. G. and Creath, W. B., 1964. Foraminiferal ratios and regional environments. Bull. Am. Assoc. Petrol. Geologists. 48 (11), 1810, 9 figs.

Vine, F. J., 1966. Spreading of the ocean floor: new evidence. Science 154, 1405.

Vogt, P. R., Ostenso, N. A. and Johnson, G. L. 1970. Magnetic and bathymetric data bearing on sea-floor spreading north of Iceland. J. Geophys. Res. 75, 903.

Yoder, H. S., and Tilley, C. E., 1962. Origin of basalt magmas: an experimental study of natural and synthetic rock systems. J. Petrol. 3342 . 


\section{PLATES}

Plate 1

Plate 2

Plate 3

Plate 4

Plate 5

Plate 6

Plate 7

Plate 8
Basalt Core (117A-11).

Photomicrographs of basalt (117A-11).

Vesicle in basalt (117A-11).

Annelid tubes of Ditrupa. (Photo J. v. Hinte, courtesy Imperial Oil Enterprises Ltd).

Burrowed sandstone from Site 117. (Photo J. v. Hinte, courtesy Imperial Oil Enterprises Ltd).

Slickensides, small faults and tilted bedding. (Photo J. v. Hinte, courtesy Imperial Oil Enterprises Ltd).

Zoophycoid burrows seen at Site 116. (Photo J. v. Hinte, courtesy Imperial Oil Enterprises Ltd).

Comparison of photographs of Cores 116-25 and $117-25$ to illustrate the similarity of the lithology of these two cores. 


\section{PLATE 1}
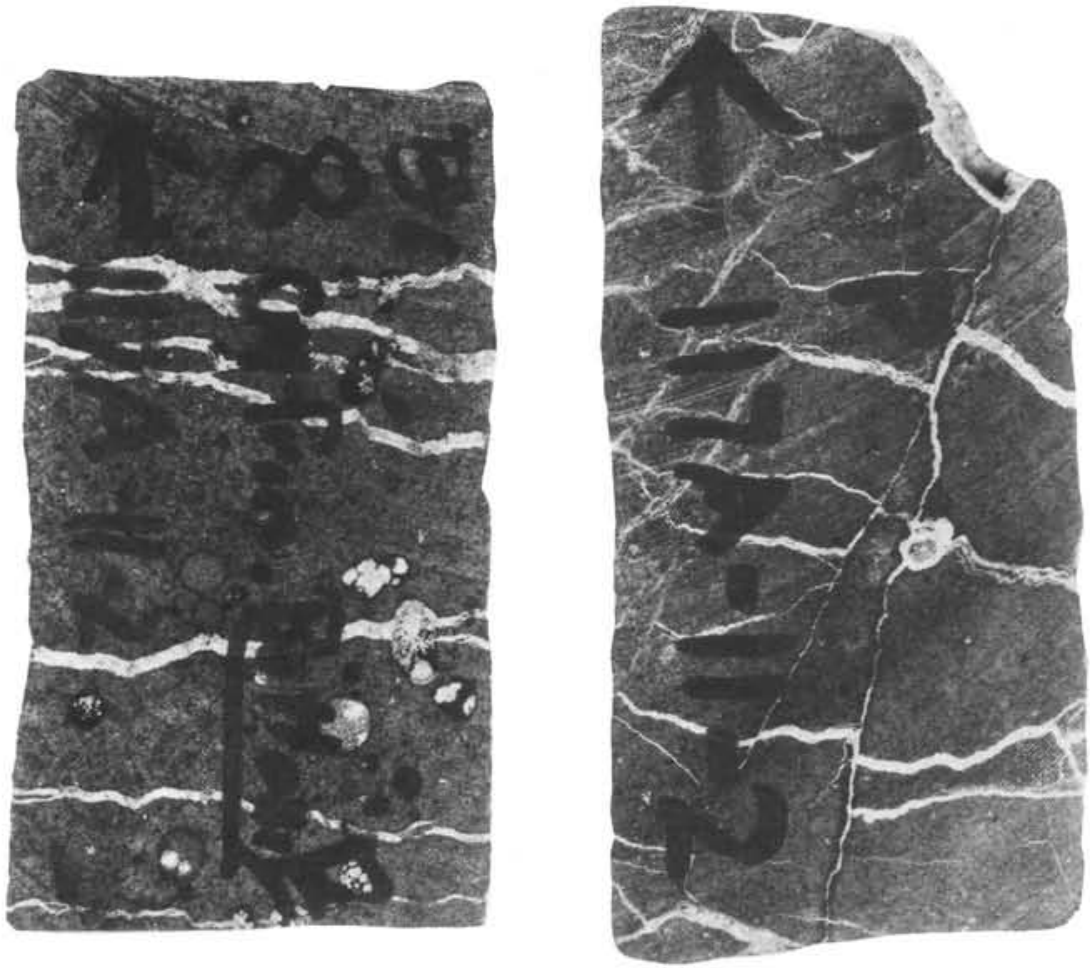

Specimen F7159 (right, showing vesicle), F7160 (left). Cut face. Approximately true scale. MN 24296.
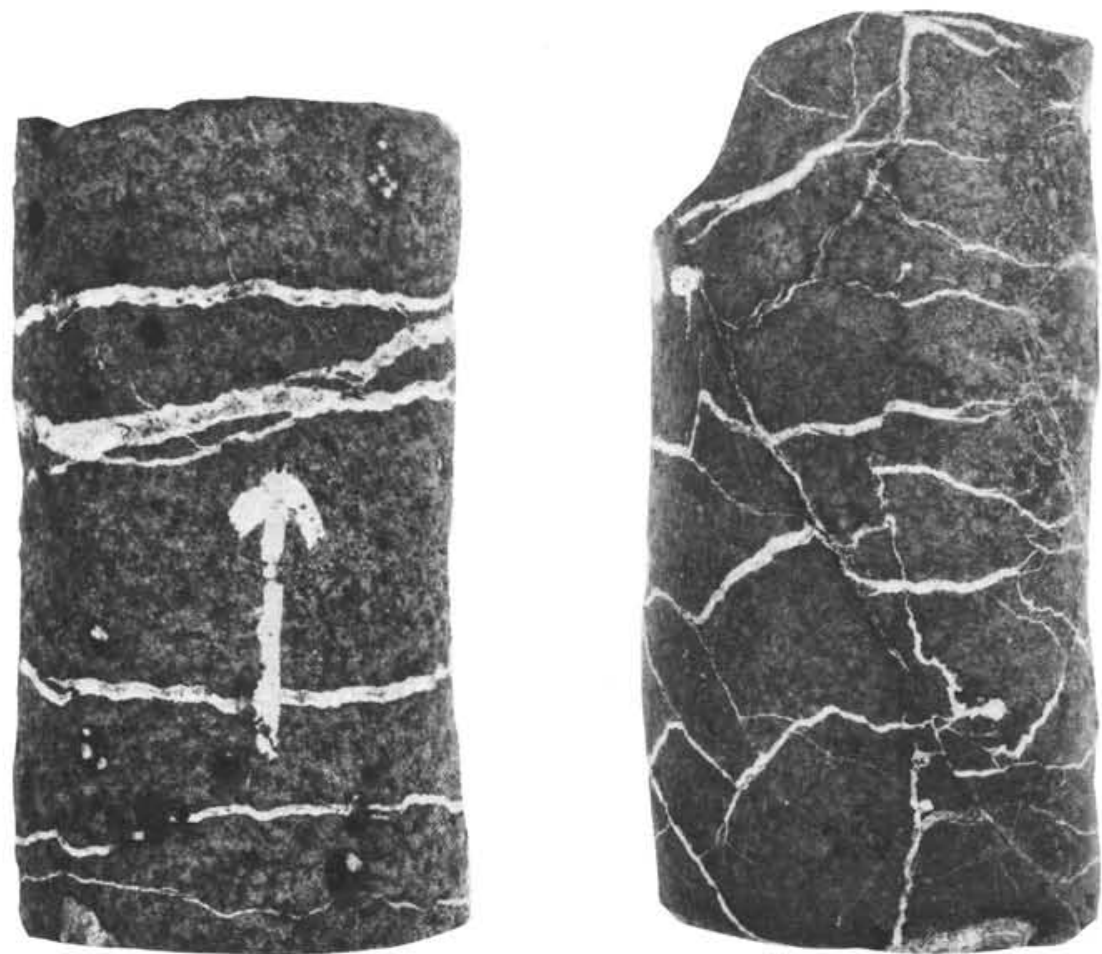

Specimens as above. Outside surface of core segments. MN 24295 
PLATE 2
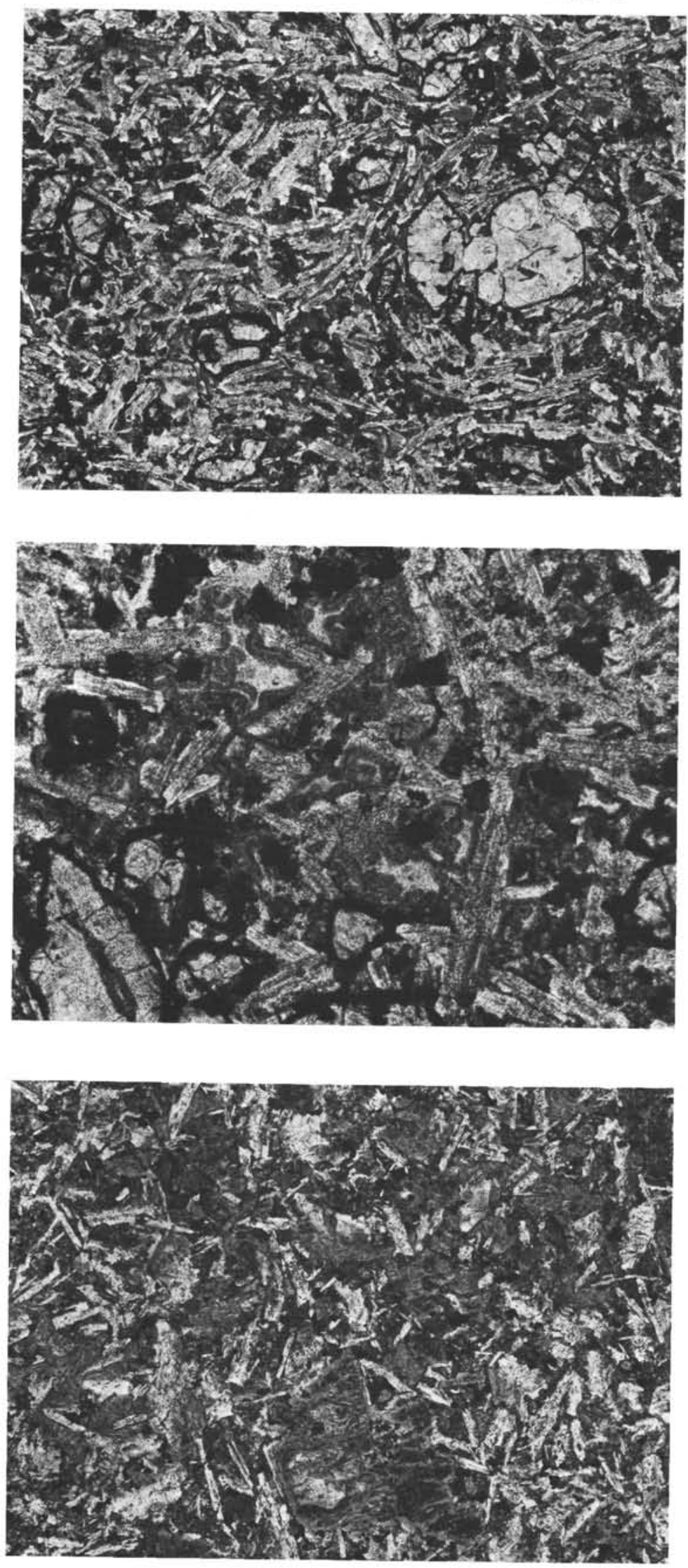

1. Pseudomorphs after olivine in groundmass showing some flow texture. F7159 X25. Plane polarised light.
2. Groundmass of olivine-basalt. Altered plagioclase and interstitial chlorite.F7159 X70. Plane polarised light.
3. Chloritised olivine-basalt. F7160, X25 Plane polarised light. 
PLATE 3

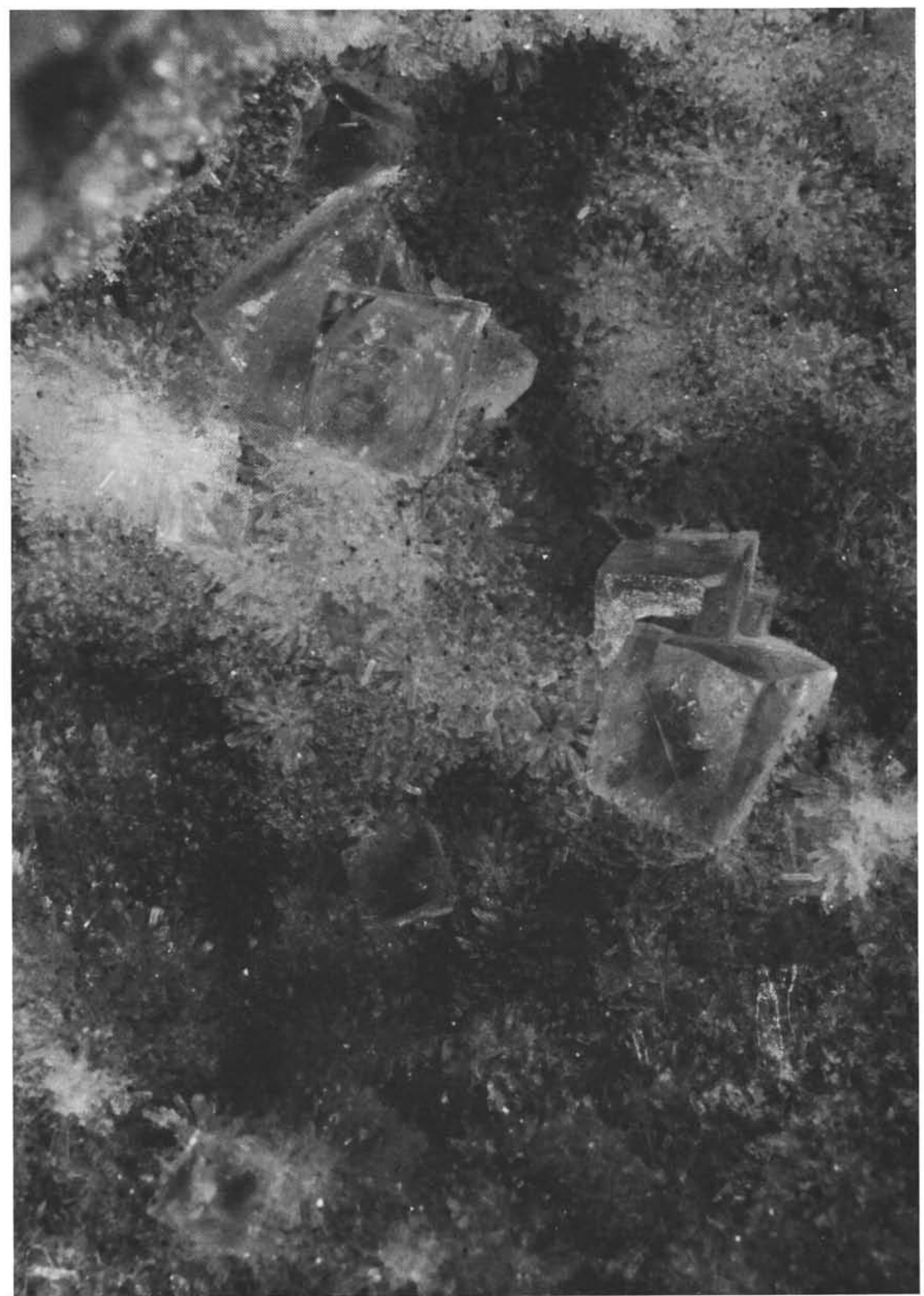

Calcite euhedra on natrolite. Magnification X18 


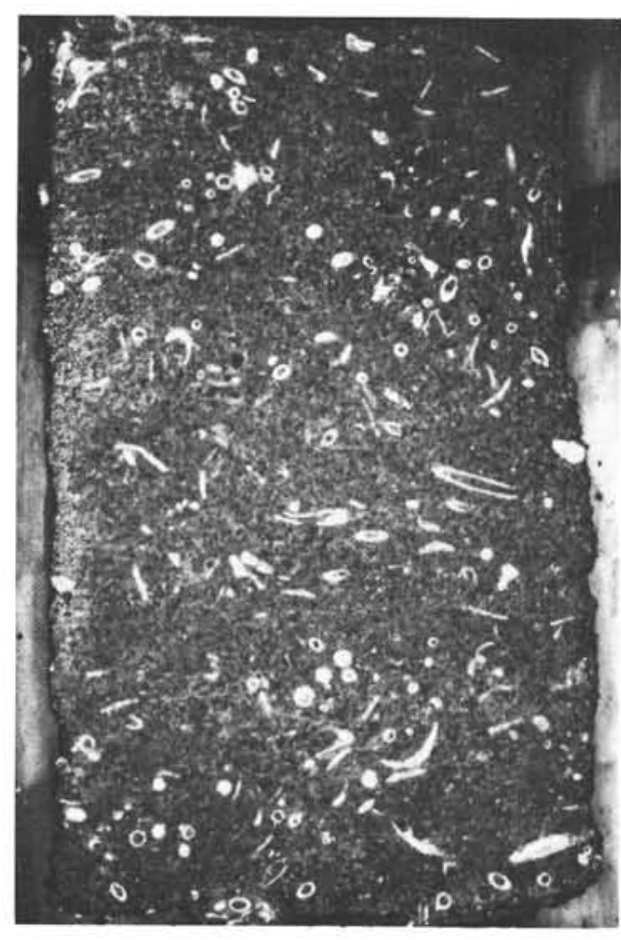

$0 \cdot 10 \mathrm{~cm}$
Plate 4

CORE No. 9, 303-304 m. PALEOCENE.

Section I. Ditrupa sandstone.
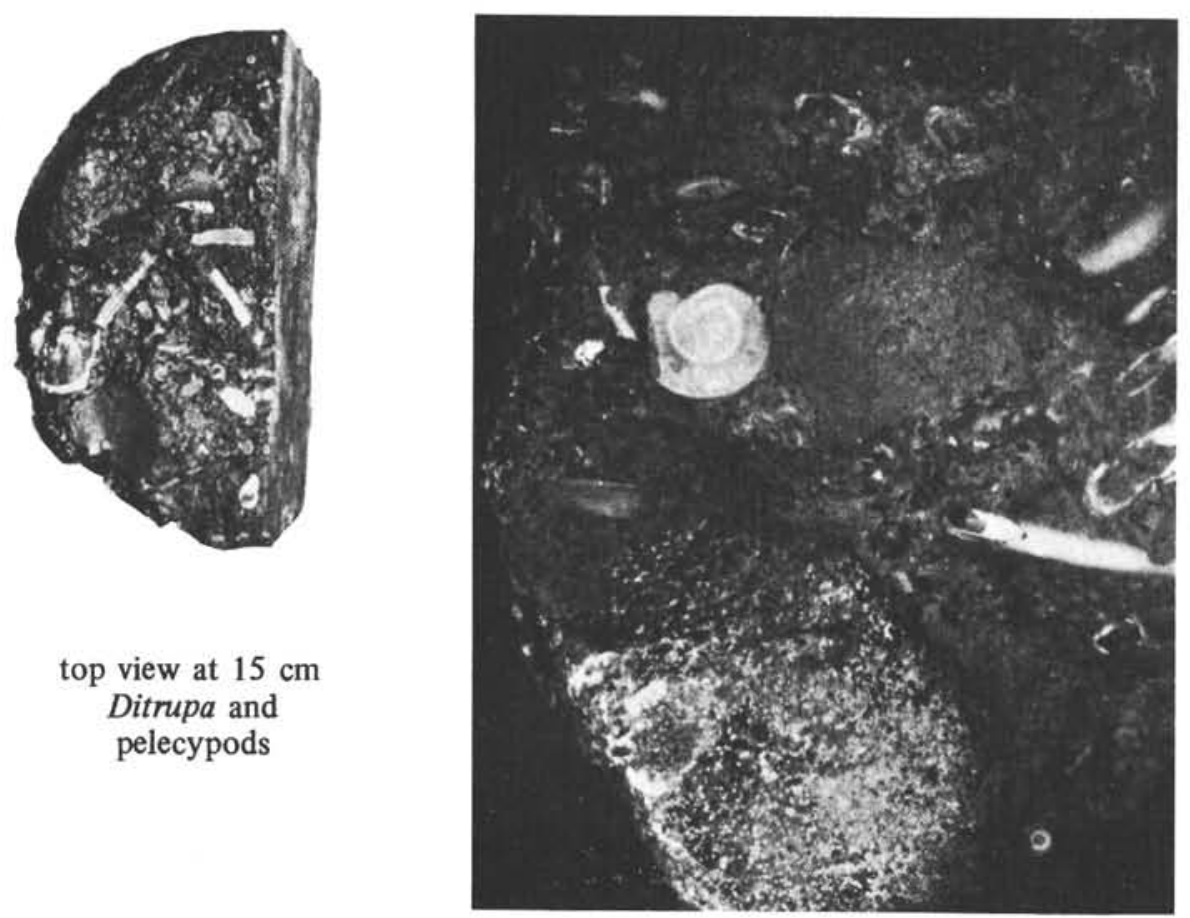

$22-28 \mathrm{~cm} . \mathrm{X} 3$

with Operculinoides 


\section{PLATE 5}

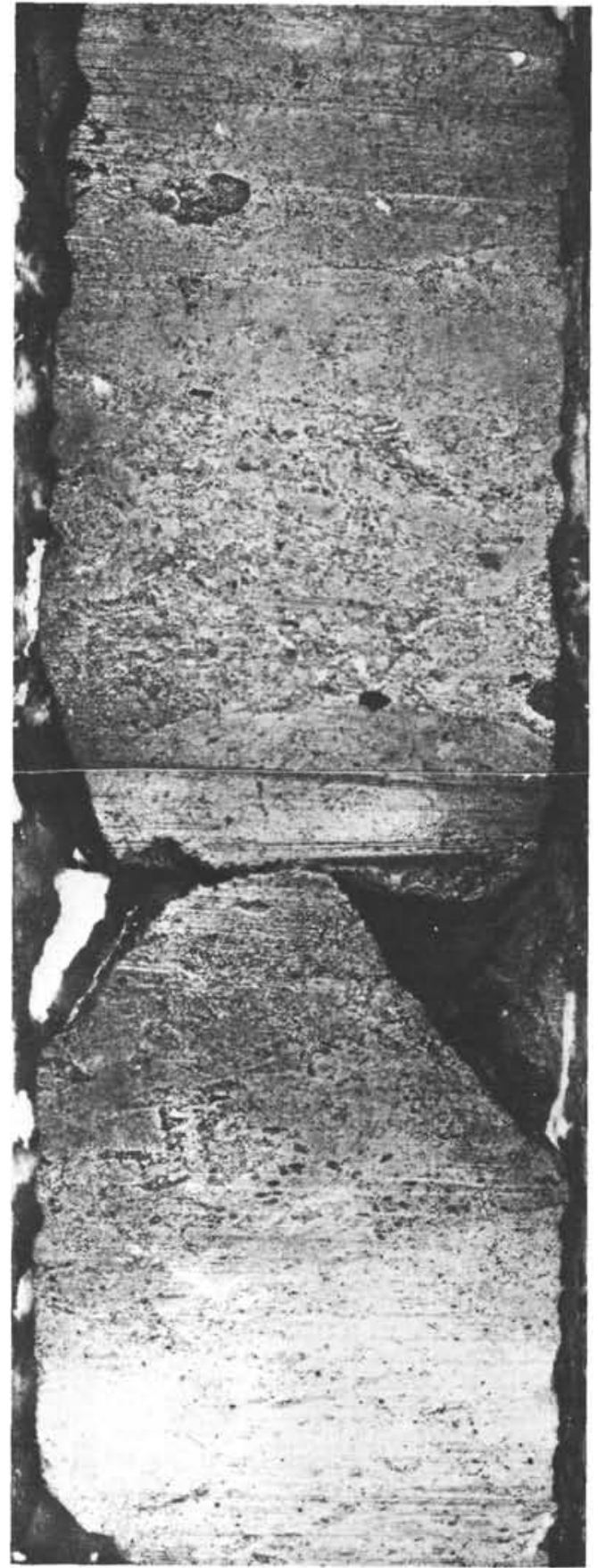

CORE No. 7, 289-294 m. UPPER PALEOCENE. Section 1, 21.40 cm. Cherned, argillaceous volcanic detritus with fossils.

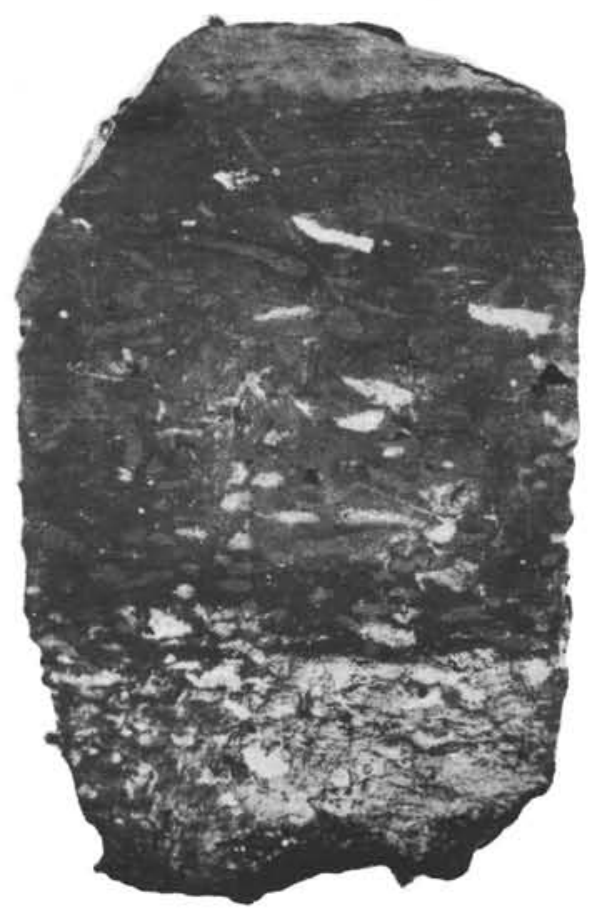

CORE No. 7, 289-294 m. PALEOCENE. Section 2, $140-150 \mathrm{~cm}$. Burrowed clay and volcanic detritus with fossils.

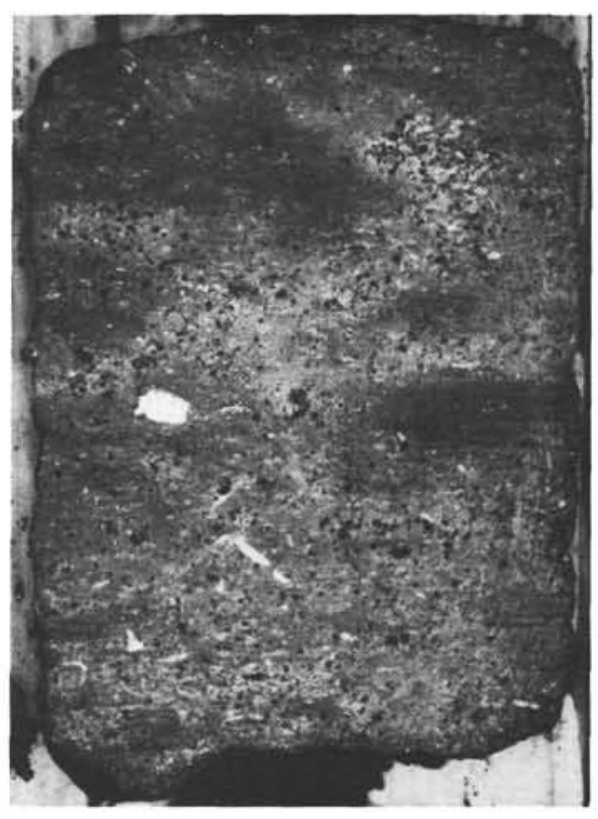

CORE No. 8, 294-303 m. PALEOCENE. Section No. 1, 114-121 cm. Clay with fossils and basaltic fragments. 


\section{PLATE 6}

CORE No. $27,831-890 \mathrm{~m}$. OLIGOCENE.
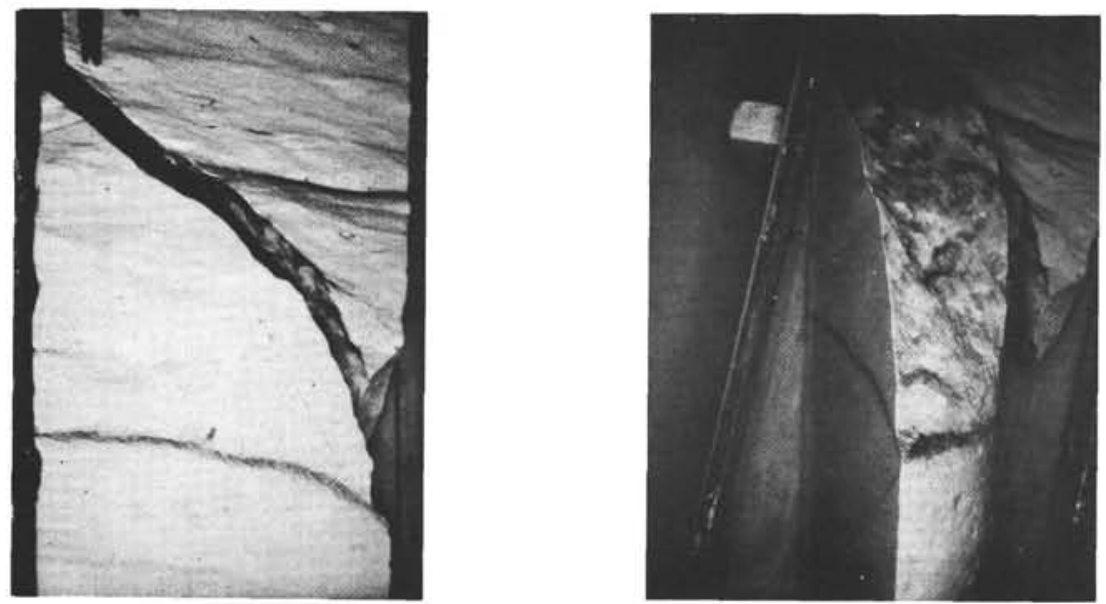

Section 2, 82-92 cm.

Fault with slicken sides; Zoophycos.
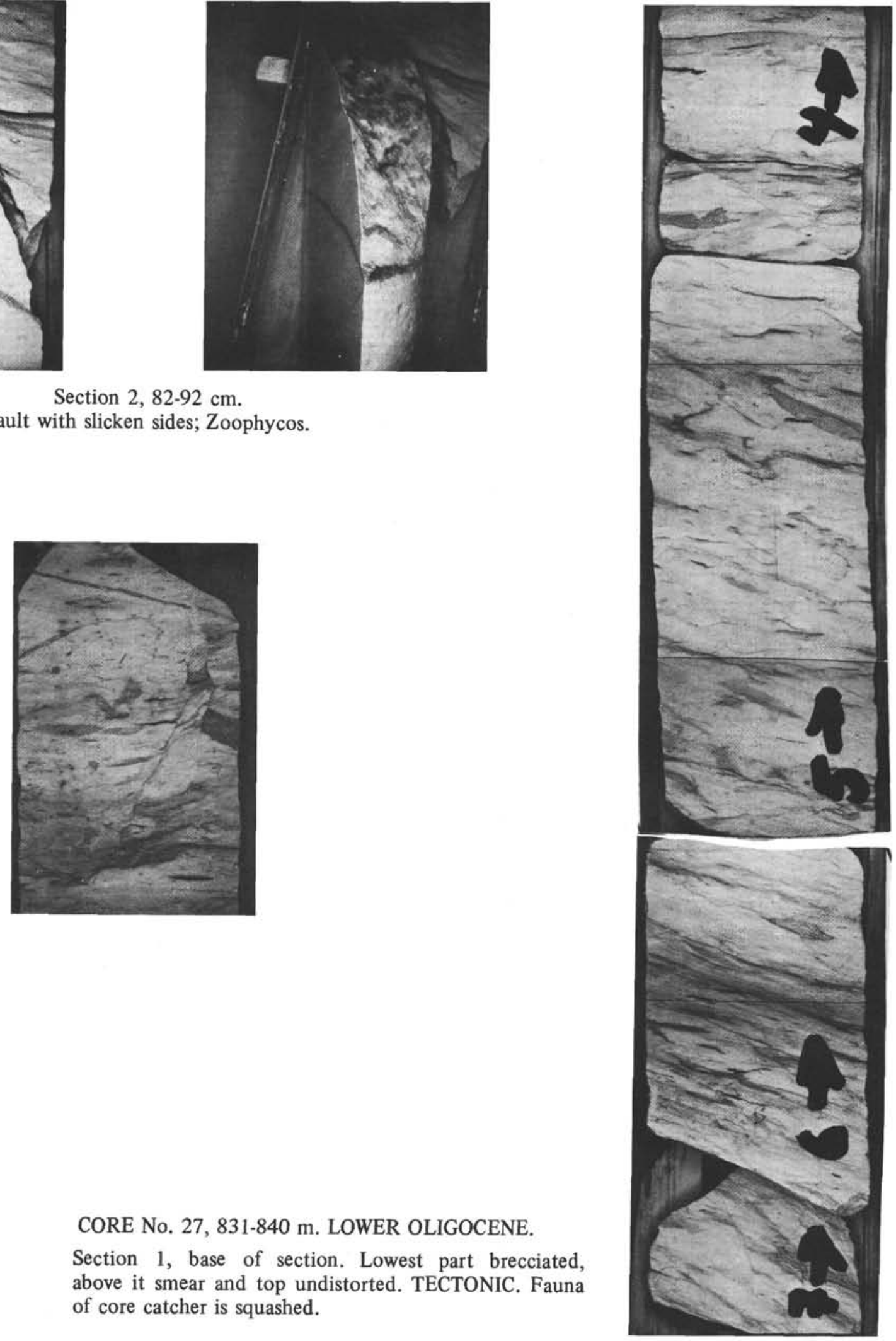

CORE No. 27, 831-840 m. LOWER OLIGOCENE.

Section 1, base of section. Lowest part brecciated, above it smear and top undistorted. TECTONIC. Fauna of core catcher is squashed. 
PLATE 7

CORE No. 26 ,

825-831 m. OLIGOCENE.

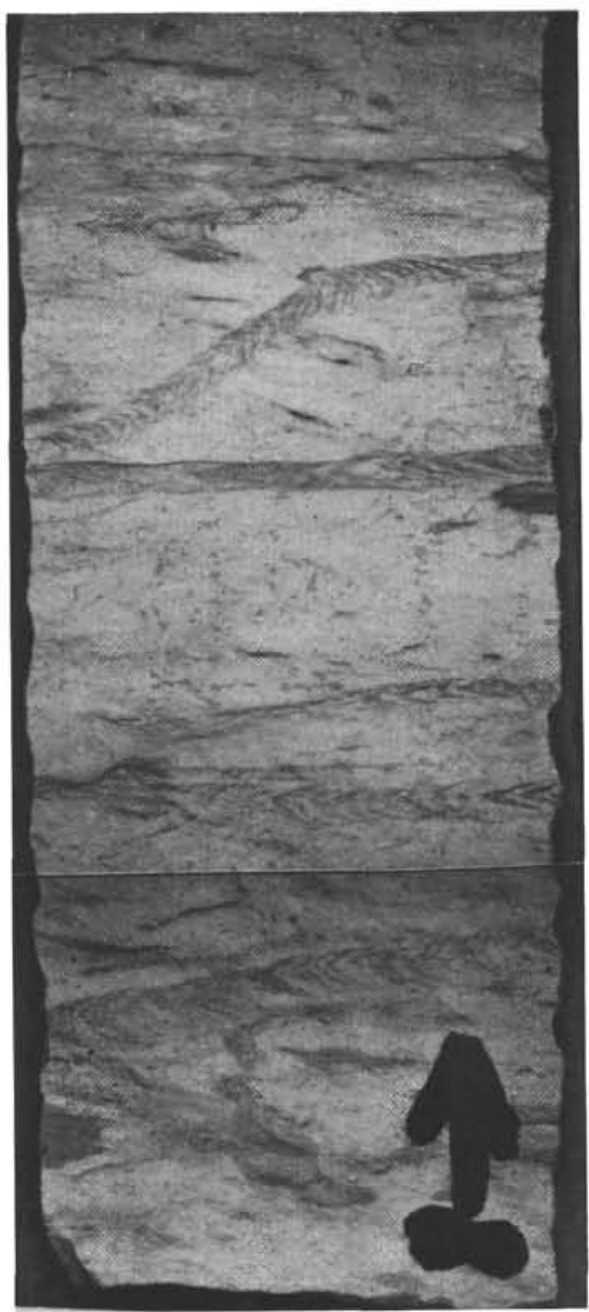

Section 3, 112-134 cm. Burrowed chalk with Zoophycos. 

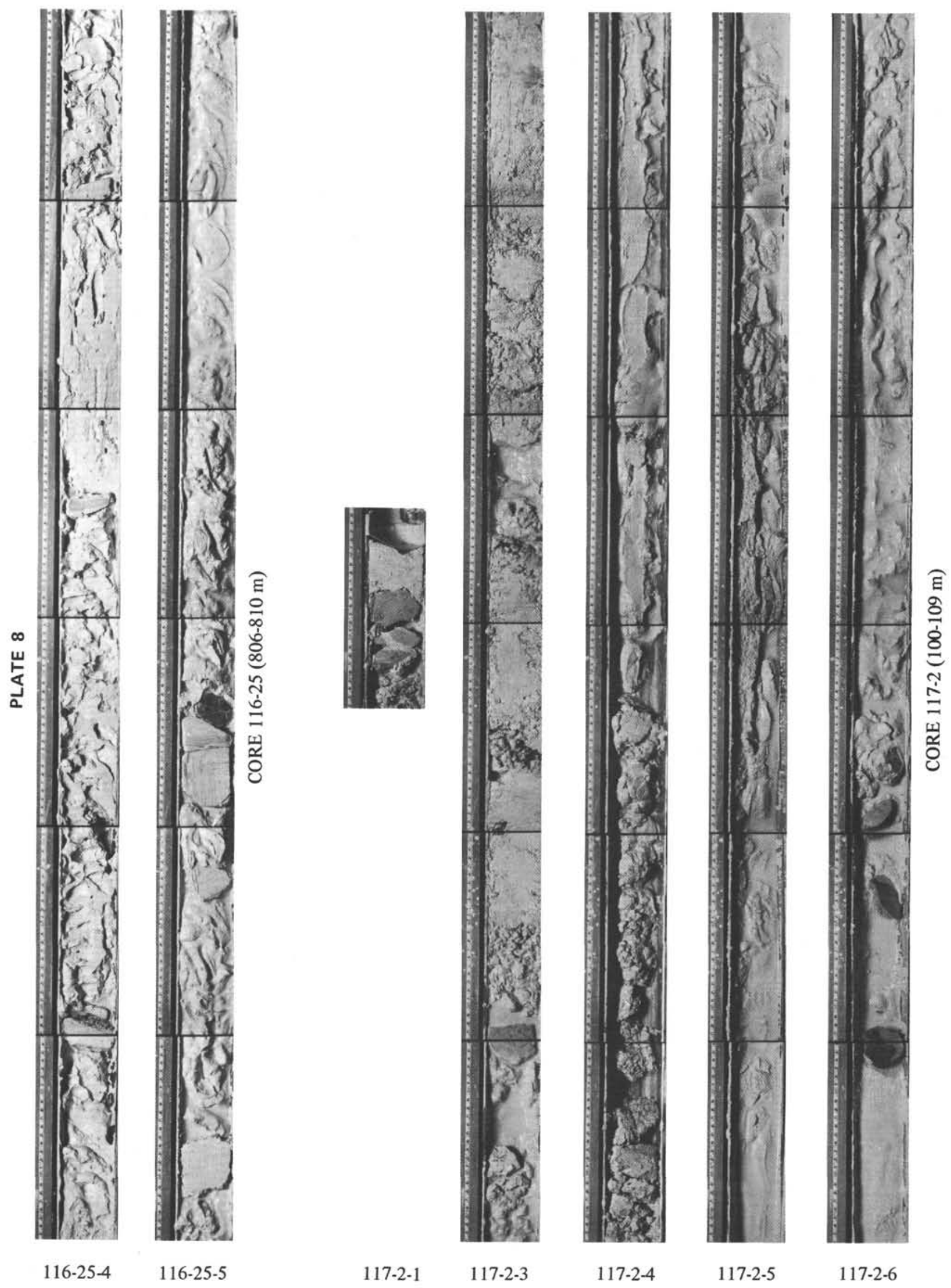

PLATE 9

Diagenetic mobilization of biogenous silica, Site 116

Figure 1 Fragments of Ethmodiscus rex (Rattray). X420. 12-116-14-CC; BN-2.

Figure 2 Fragment of Ethmodiscus sp. cf. E. rex (Rattray) illustrating poreless fringed margin. $\times 420$. 12-116-15-CC; BN-2; Y11/3.

Figure 3 Typical chert fragment with foraminiferal walls replaced by clear chalcedonic silica; matrix of cloudy amorphous silica. X273. 12-116-20-CC.

Figure 4 Corroded orosphaerid radiolarian spine. $\times 68$. 12-116-20-CC; BN-1; T4/4. 
PLATE 9

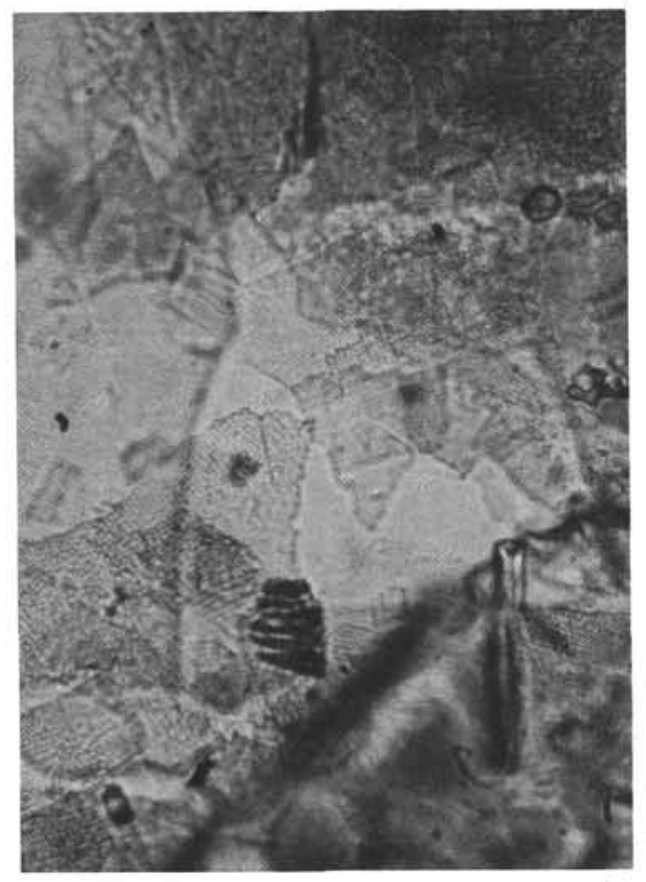

1

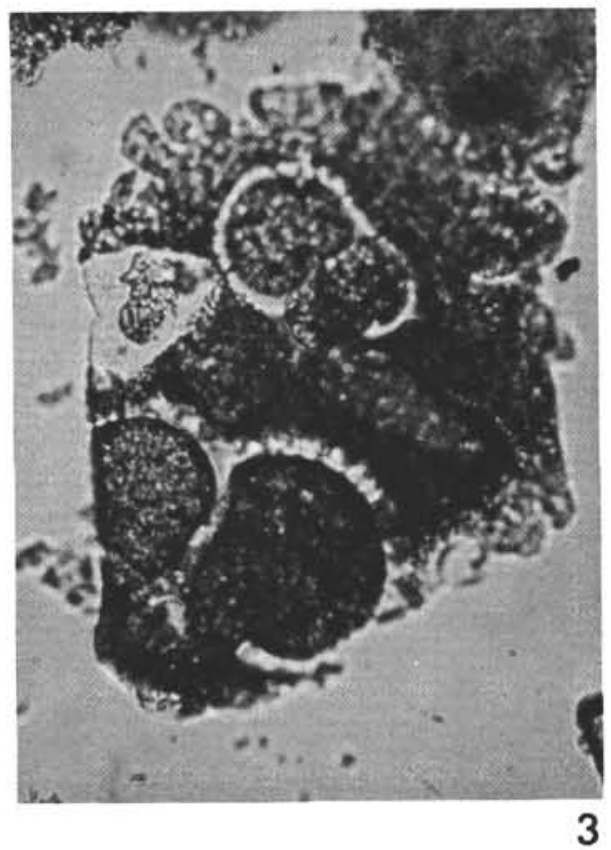

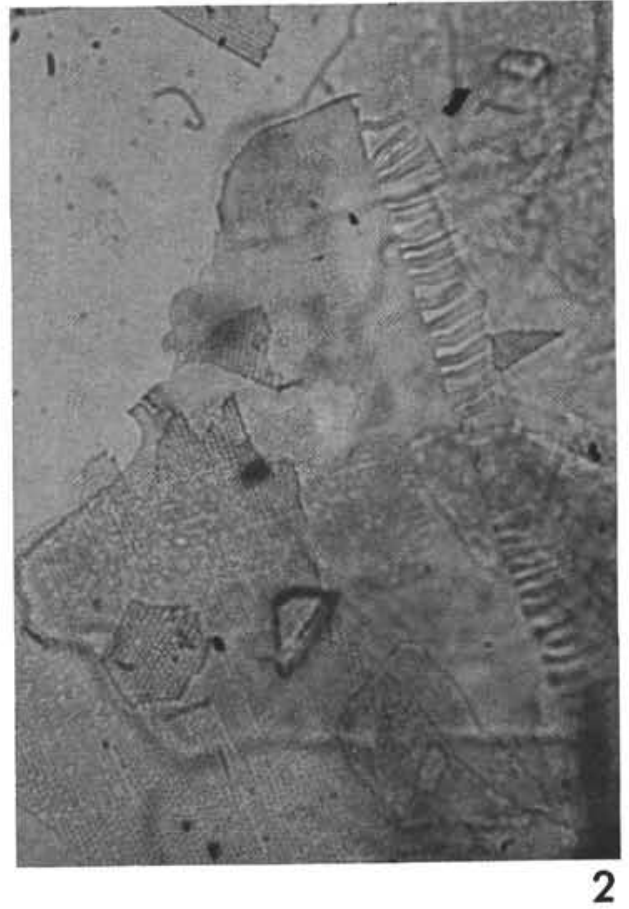

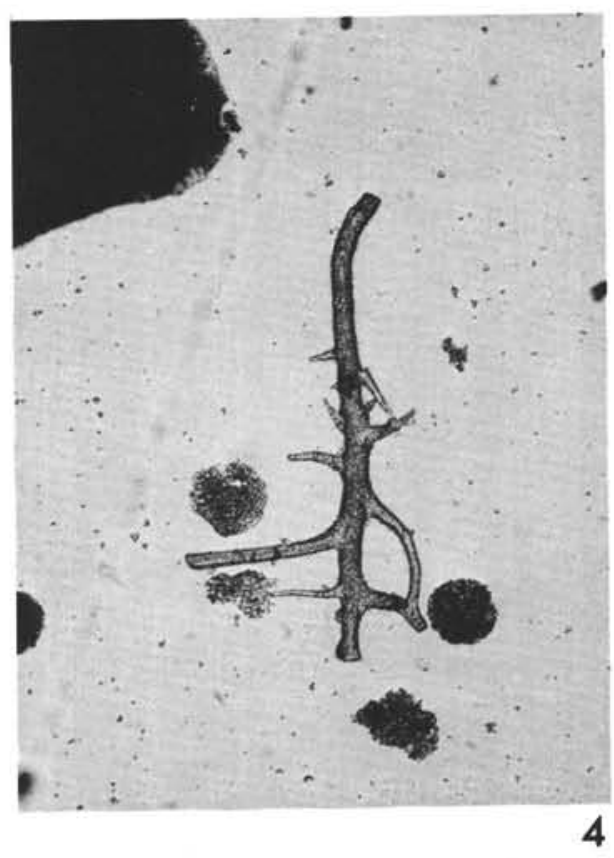


PLATE 10

Diagenetic mobilization of biogenous silica, Site 116

Figures 1, 2 Well-preserved biogenous silica. X42. 1: 12-116-9-CC; BN-2.2: 12-116-10-CC; BN-1.

Figure 3 Mobolized biogenous silica typical of Core 11. Masses of cloudy amorphous silica, internal casts of foraminifera, angular chert fragments, corroded sponge spicules. $\times 42$. 12-116-11-CC; BN-1.

Figure 4 Little or no silica alteration in Core $12 . \times 42$. 12-116-12-CC; BN-1. 
PLATE 10
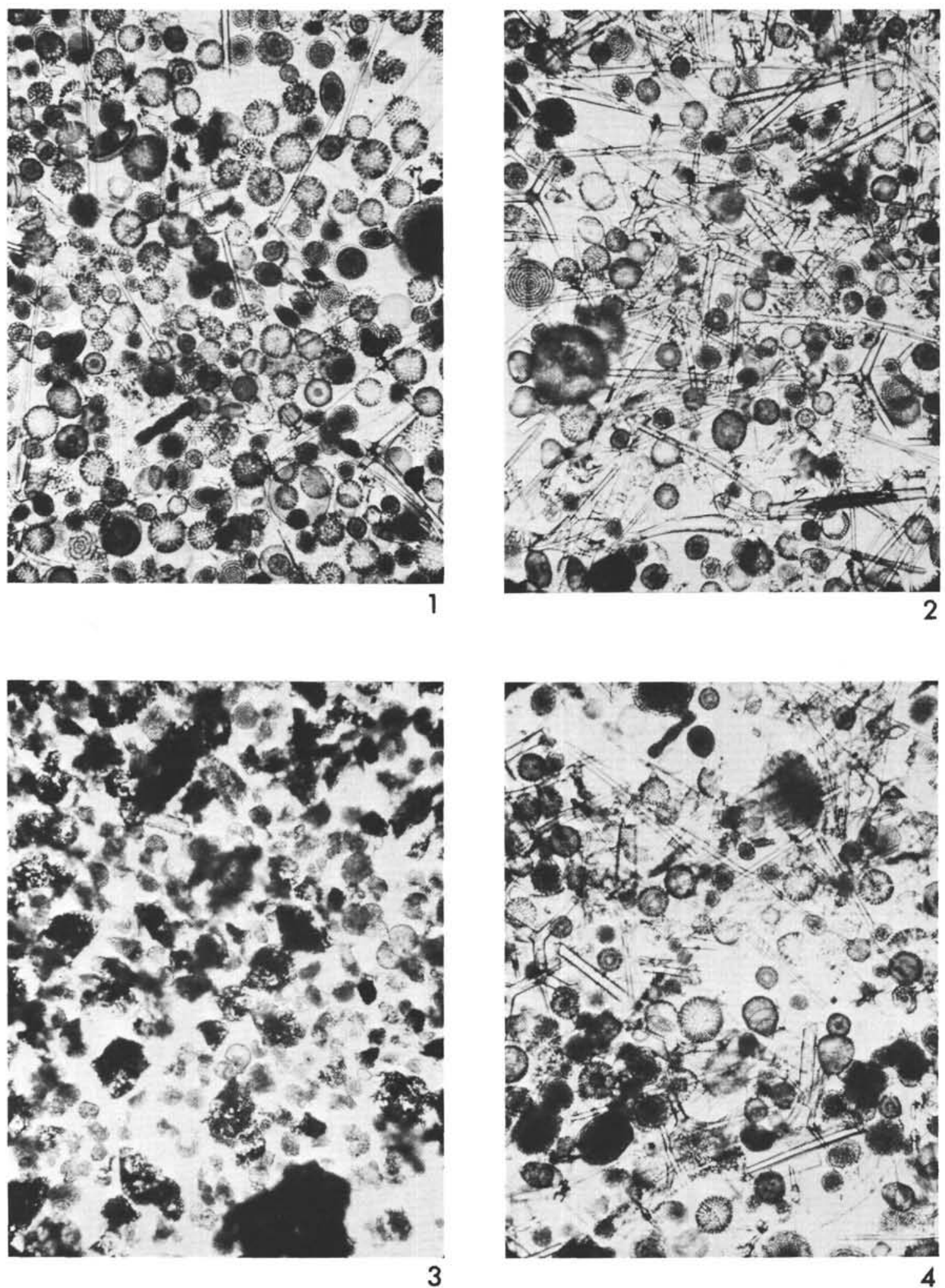
PLATE 11

(All illustrations $\times 60$ )

Figures 1, 2 "Hermanites"

1. Left valve, side stereo view; USNM 170742.

117A-8-1, 130-134 cm. Discoaster multiradiatus Zone, Paleocene.

2. Left valve, side stereo view; USNM 170743.

117A-8-1, Discoaster multiradiatus Zone, Paleocene.

Figure 3 Poseidonamicus

Left valve, side stereo view; USNM 170744.

117-2-6, Sphenolithus ciperoensis Zone (calcareous nannoplankton), Zone P21-P22 (planktonic foraminifera), Late Oligocene.

Figure 4 Henryhowella

Left valve, side stereo view; USNM 170745.

117-2-6, Bottom. Sphenolithus ciperoensis Zone (Calcareous nannoplankton), Zone P21-P22 (planktonic foraminifera), Late Oligocene.

Figure 5

Agrenocythere

Left valve, side stereo view; USNM 170746.

117A-7-1, 95-100 cm. Discoaster multiradiatus Zone, Paleocene.

Figure $6 \quad$ Bythocypris

Right valve, side stereo view; USNM 170747.

117-2-6, Bottom. Spehnolithus ciperoensis Zone (calcareous nannoplankton), Zone P21-P22 (planktonic foraminifera), Late Oligocene. 
PLATE 11
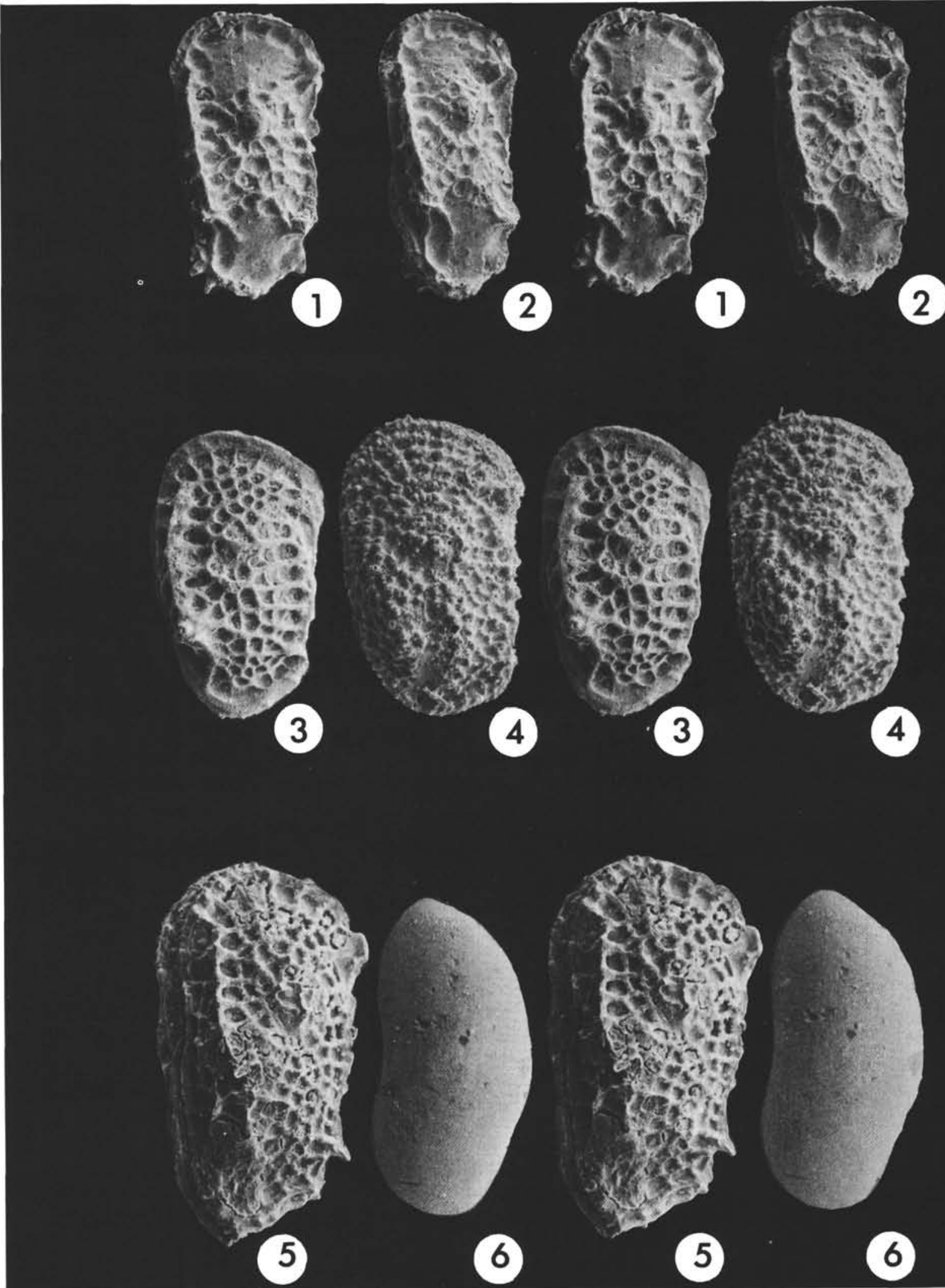
PLATE 12

(Illustrations 1-3, X40;4-6, X60)

Figure 1

\section{Bairdia}

Left valve, side stereo view; USNM 170748.

117-2-6, Bottom. Sphenolithus ciperoensis Zone (calcareous nannoplankton), Zone P21-P22 (planktonic foraminifera), Late Oligocene.

Figure 2

Krithe

Left valve, side stereo view; USNM 170749.

117-2-6, Bottom. Sphenolithus ciperoensis Zone (calcareous nannoplankton), Zone P21-P22 (planktonic foraminifera), Late Oligocene.

Figure $3 \quad$ Echinocythereis

Left valve, side stereo view; USNM 170750.

117-2-6, Bottom. Sphenolithus ciperoensis Zone (calcareous nannoplankton), Zone P21-P22 (planktonic foraminifera), Late Oligocene.

Figure 4

Phacorhabdotus

Left valve, side stereo view; USNM 170751.

117A-8-1, 130-134 cm. Globigerina triloculinoides

Zone, Paleocene.

Figure 5. Trachyleberidea

Left valve, side stereo view; USNM 170752.

117A-8-1, 130-134 cm. Globigerina triloculinoides

Zone, Paleocene.

Figure 6

Hazelina

Left valve, side stereo view; USNM 170753.

117A-8-1, 130-134 cm. Globigerina triloculinoides

Zone, Paleocene. 
PLATE 12

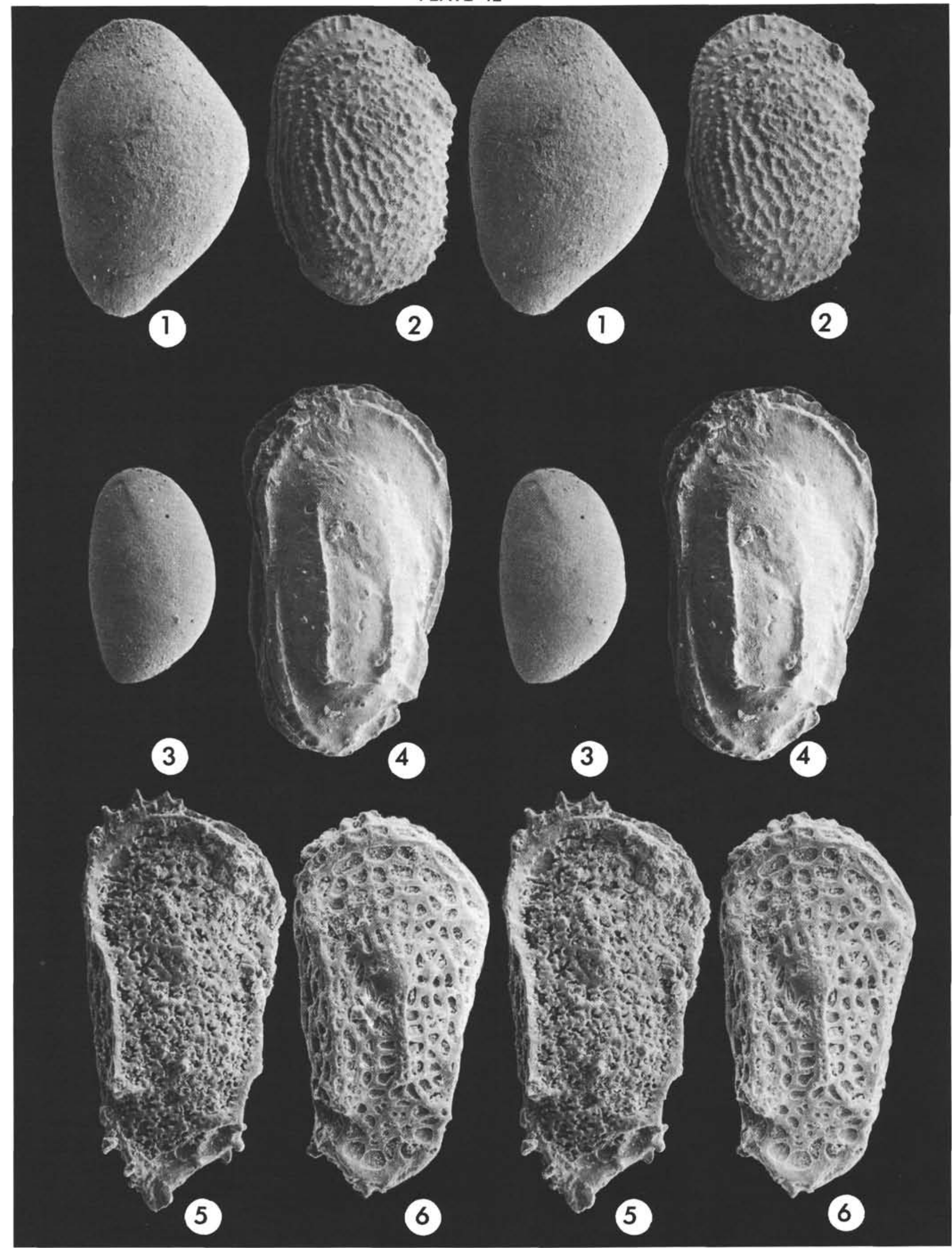




\section{PLATE 13}

Late Oligocene Bryozoa, Site 117)

(All specimens $\times 50$; from ?Sphenolithus distensus Zone)

Figures 1, 2, 4 membraniporidra aff. $M$. similis Canu \& Bassler 1. Basal view, USNM 171624. 2. Zooecia, USNM 171622. 4. Avicularim, USNM 171623. 117-3-1, $30-35 \mathrm{~cm}$.

Figure $3 \quad$ Lunulites spl 1

3a. Frontal view; 3b. basal view; USNM 171627. $117-3-1,30-35 \mathrm{~cm}$.

Figure $5 \quad$ Membraniporidra aff. m. porrecta Canu \& Bassler Bilaminate fragment, USNM 171621. 117-3-1, 30-35 $\mathrm{cm}$.

Figures 6,7 Antropora? oculifera Canu \& Bassler 6. Tubular fragment with narrow zooecia, USNM 171626.

7. Flat fragment with wide zooecia, USNM 171625. 117-3-1, 30-35. 
PLATE 13

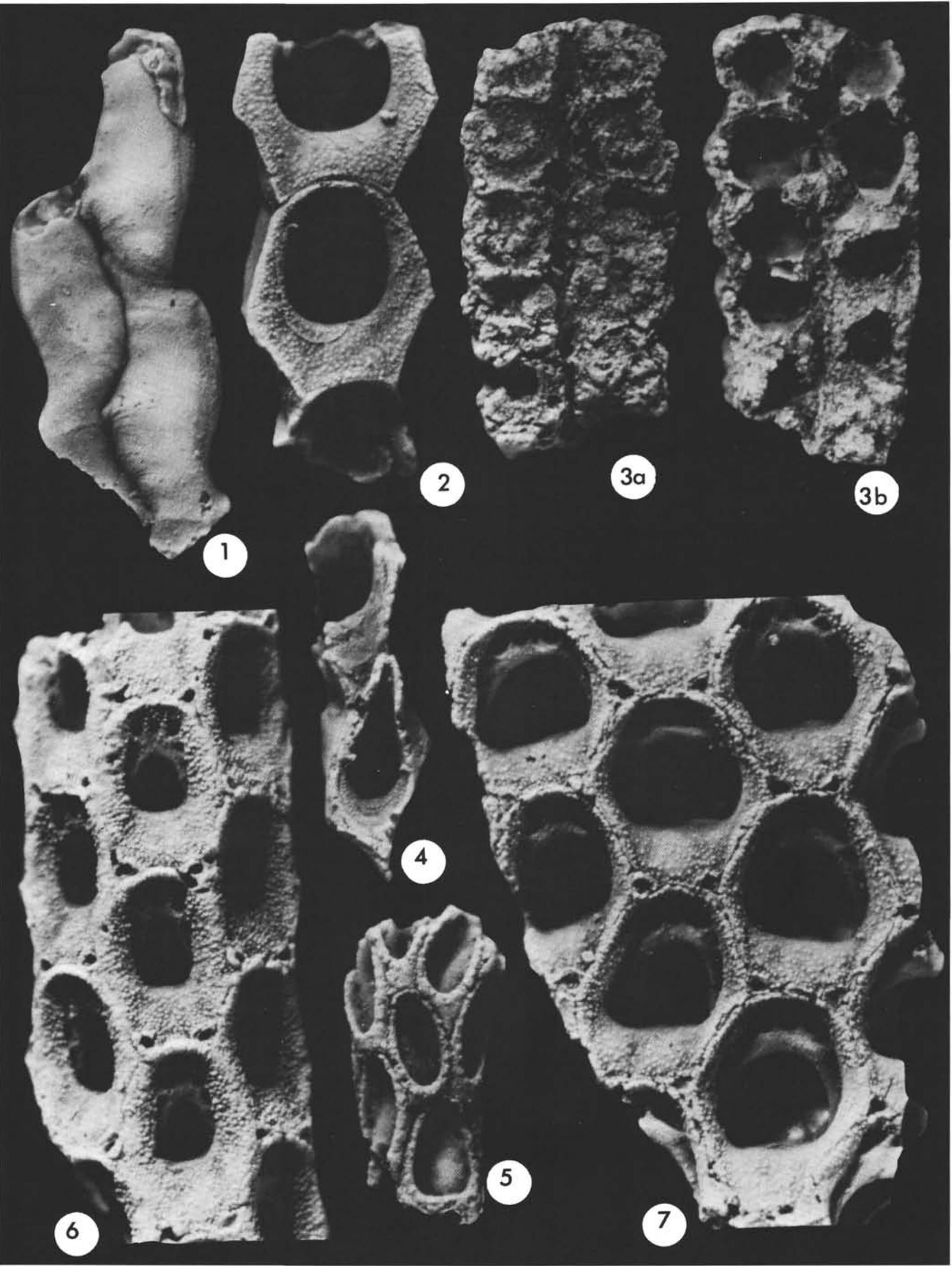


PLATE 14

Late Oligocene Bryozoa, Site 117

(All specimens $\times 50$ )

Figure $1 \quad$ Floridina sp 2

Tubular fragment, USNM 171635. 117-3-1, 30-35 $\mathrm{cm}$. ?Sphenolithus distensus Zone.

Figures 2, $3 \quad$ Floridina sp 3

2. Zooecia, proximal one with ovicell, USNM 171636.

3. Zooecia, and onychocellarium, USNM 171637. 117-3-1, 30-35 cm. ?Sphenolithus distensus Zone.

Figures 4-6 Smittipora? aff. S. ? nelliiformis (Harmer)

4. Broken internode, USNM 171630.

5. Proximal end of internode, USNM 171631.

6. Distal end of internode with paired bases rami, USNM 171629. 117-2-6, Bottom. ?Sphenolithus ciperoensis Zone.

Figure $7 \quad$ Smittipora? sp 2

Ovicelled and nonovicelled zooecia, USNM 171632.

117-3-1, 30-35 cm. ?Sphenolithus distensus Zone.

Figures $8,10 \quad$ Floridina sp 1

8. Ovicelled and nonovicelled zooecia, USNM 171633.

10. Nonovicelled zooecia, USNM 171634. 117-3-1, 30-35 cm.?Sphenolithus distensus Zone.

Figure 9 Onychocella aff. O. laciniosa Canu \& Bassler

Zooecia and onychocellaria, USNM 171628. 117-3-1, $30-35 \mathrm{~cm}$. ?Sphenolithus distensus Zone. 
PLATE 14

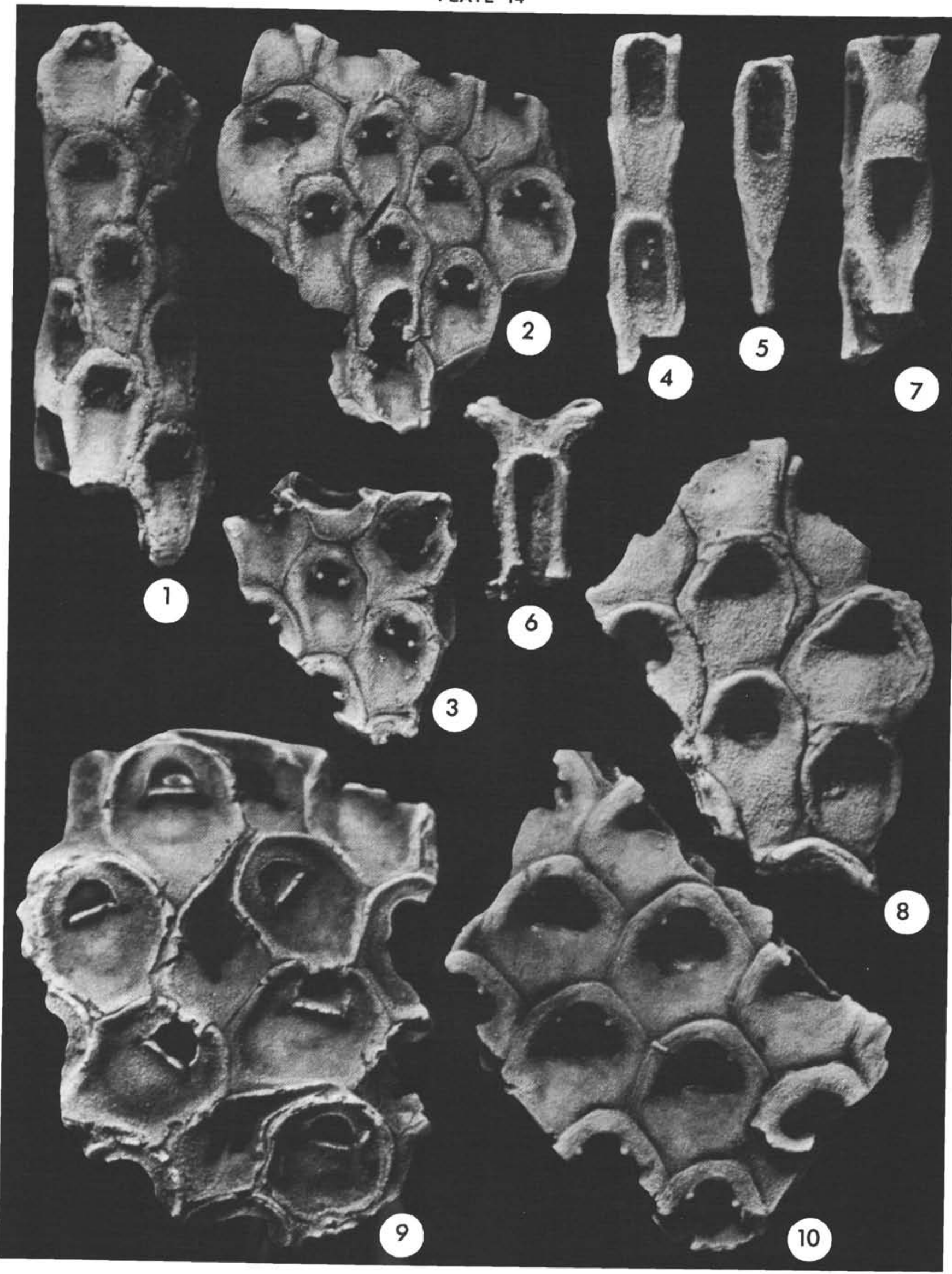




\section{PLATE 15}

Late Oligocene Bryozoa, Site 117

(All specimens $\times 50$; from ?Sphenolithus distensus Zone)

Figures 1-3 Cellaria sp.

1. Doubly tapering fragment with ovicelled and nonovicelled zooecia, avicularia, USNM 171646. 2. Bifurcation with nonovicelled zooecia, USNM 117647. 3. Distally tapering fragment with ovicelled and nonovicelled zooecia, avicularia, USNM 171648. $117-3-1,30-35 \mathrm{~cm}$.

Figure 4 Rosseliana? sp.

Fragment of zoarium encrusting cyclostome, USNM $171639,117-3-1,30-35 \mathrm{~cm}$.

Figure $5 \quad$ Mollia sp. 1

Fragment of zoarium with small interzooecial fenestrae, USNM 171638. 117-3-1, 30-35 cm.

Figure 6-8 Microporina? aff. M. ? polysticha (Reuss)

6. Part of internode with bipartite, lateral basis rami, USNM 171641. 7. Zooecia, USNM 171640. 8. Distal end of internode, USNM $171642.117-3-1,30-35 \mathrm{~cm}$.

Figures 9, 10 Craspedozoem? sp.

9. Frontal view, USNM 171649. 10. Basal view USNM 171650. 117-3-1, 30-35 cm.

Figures 11, 12 Setosella fragilis Canu

11. Edge view of quadriserial fragment, USNM 171644. 12. Frontal view of parts of two zooecia; cryptocyst with slitlike opesiules in distal hollows; USNM 171643. 117-3-1, 30-35 cm.

Figures 13-15 Scrupocellaria elliptica (Waters):

13. Basal view of internode fragment with paired vibracula in axil, USNM 171653. 117-3-1, 30-35 cm. 14. Nonovicelled zooecia with well-preserved scute bases, USNM 171651. 117-2-6, Bottom. 15. Ovicelled zooecia, USNM 171652. $117-3-1,30-35 \mathrm{~cm}$.

Figure $16 \quad$ Steganoporella sp.

Parts of zooecia with steeply descending cryptocyst, wide distal shelf, USNM 171645. 117-3-1, 30-35 cm. 
PLATE 15

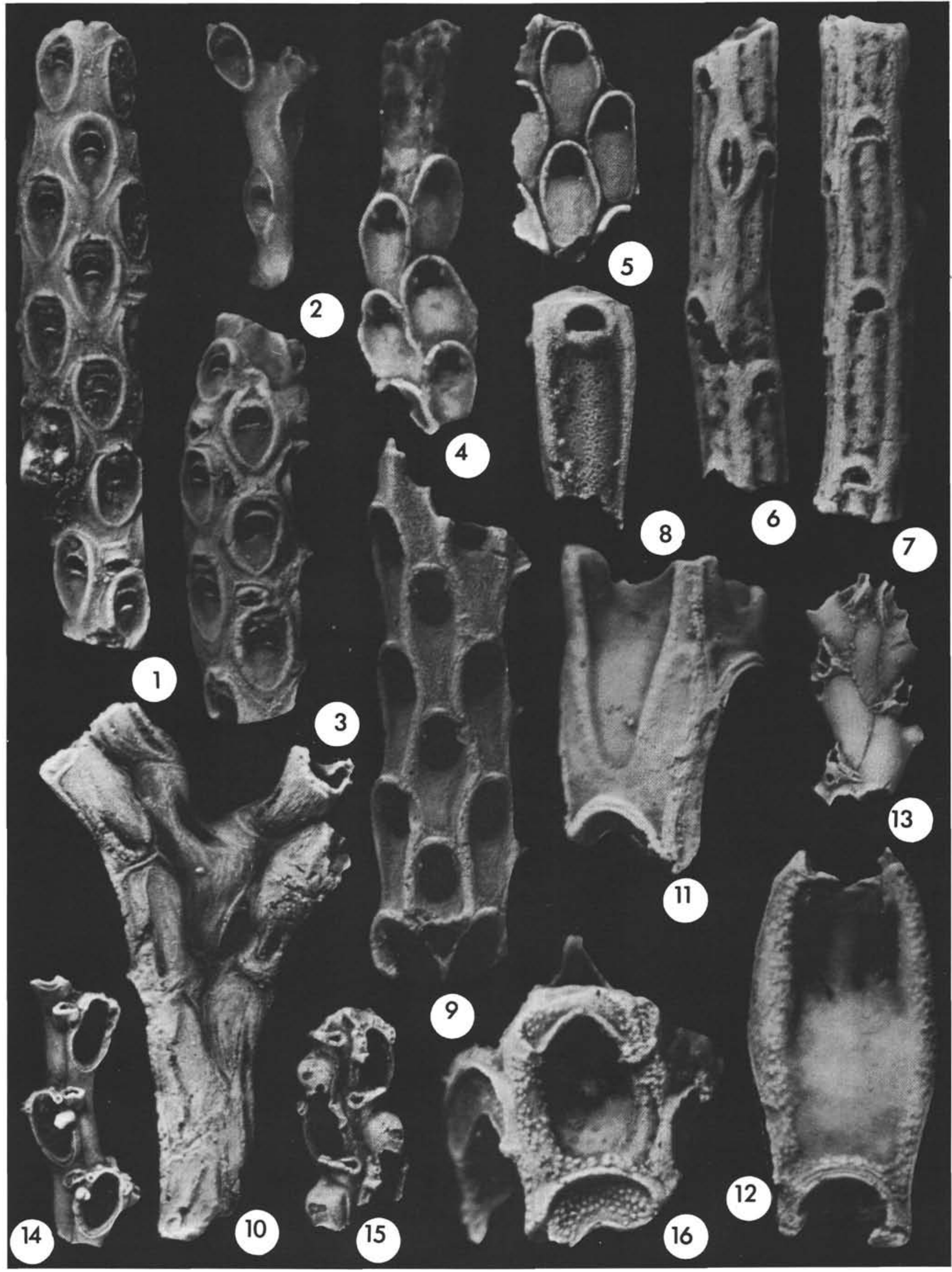


PLATE 16

Late Oligocene Bryozoa, Site 117)

(All specimens $\times 50$; from ?Sphenolithus distensus Zone)

Figures 1, 2 Cribrilaria radiata (Moll)

1. Ovicelled and nonovicelled zooecia, USNM 171654. 2. Zooecia and avicularia, USNM 171655. $117-3-1,30-35 \mathrm{~cm}$.

Figures 3, $4 \quad$ Gephyrotes? aff. G. ? convexa Canu \& Bassler 3. Nonovicelled zooecia, USNM 171657. 4. Nonovicelled and ovicelled zooecia, USNM 171656. $117-3-1,30-35 \mathrm{~cm}$.

Figure $5 \quad$ Escharoides sp 2

Encrusting fragment, USNM 171662. 117-3-1, 30-35 $\mathrm{cm}$.

Figure $6 \quad$ Escharoides sp. 1

Encrusting fragment, USNM 171661, 117-3-1, 30-35 $\mathrm{cm}$.

Figure $7 \quad$ Hippopleurifera $\mathrm{sp}$.

Parts of three zooecia, USNM 171660. 117-3-1, 30-35 $\mathrm{cm}$.

Figure 8,9 Corbulipora? sp.

8. Basal view, showing remnants of Beania-like connecting tubes, USNM 117659. 9. Frontal view, showing coastal shield, oral spine bases, USNM 171658. 117-3-1, 30-35 cm.

Figures 10, 11 Porina sp.

10. Zooecia with small, circumperistomial avicularia, USNM 171663. 11. Heavily calcified zooecia, one with a large proximal-oral avicularium, USNM 171664. 117-3-1, 30-35.

Figure 12 Tubucella cf. T. papillosa (Reuss)

Zooecia, USNM 171665. 117-3-1, 30-35 cm. 
PLATE 16

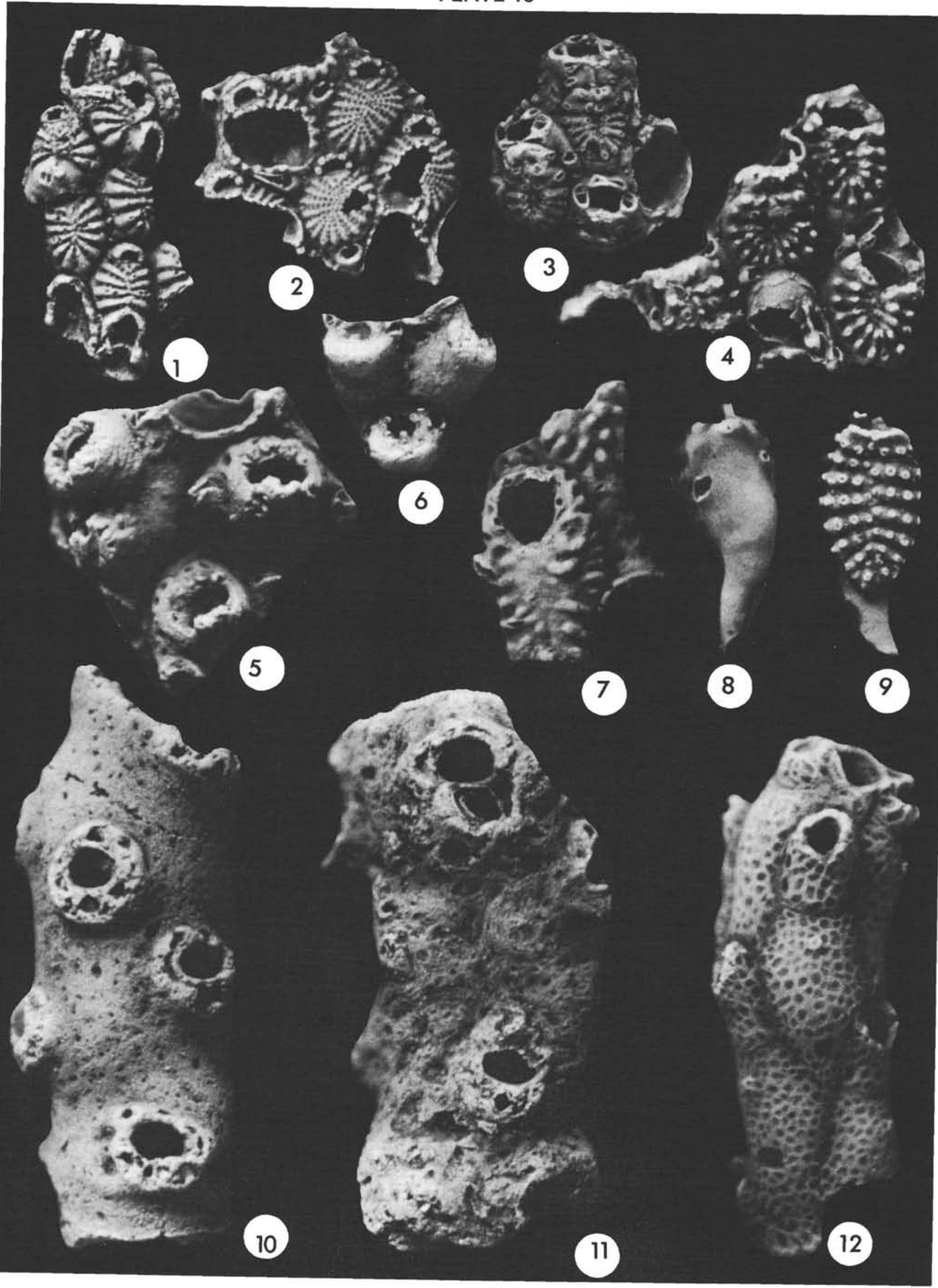


PLATE 17

Late Oligocene Bryozoa, Site 117

(All specimens $\times 50$; from ?Sphenolithus distensus Zone)

Figures 1-4 Adeonellopsis subteres (Roemer)

1. Small, encrusting zooecia, zone of astogenetic change, USNM 171666. 2. Thick-walled zooecia from proximal fragment of large colony, USNM 171668. 3. Large zooecia (gonoecia?), USNM 171669. 4. Thin-walled zooecia on fragment near growing margin, USNM 171667. 117-3-1, 30-35 cm.

Figures 5,6 Adeonella ornatissima (Stoliczka)

5. Thick-walled zooecia and marginal gonoecia with large avicularia, USNM 171671. 6. Thin-walled zooecia and marginal gonoecia with small avicularia, USNM 171670. 117-3-1, 30-35 cm.

Figure $7 \quad$ Schizostomella aff. S. lontensis (Waters)

Subcylindrical fragment with thin-walled zooecia, USNM 171672. 117-3-1, 30-35 cm. 


\section{PLATE 17}

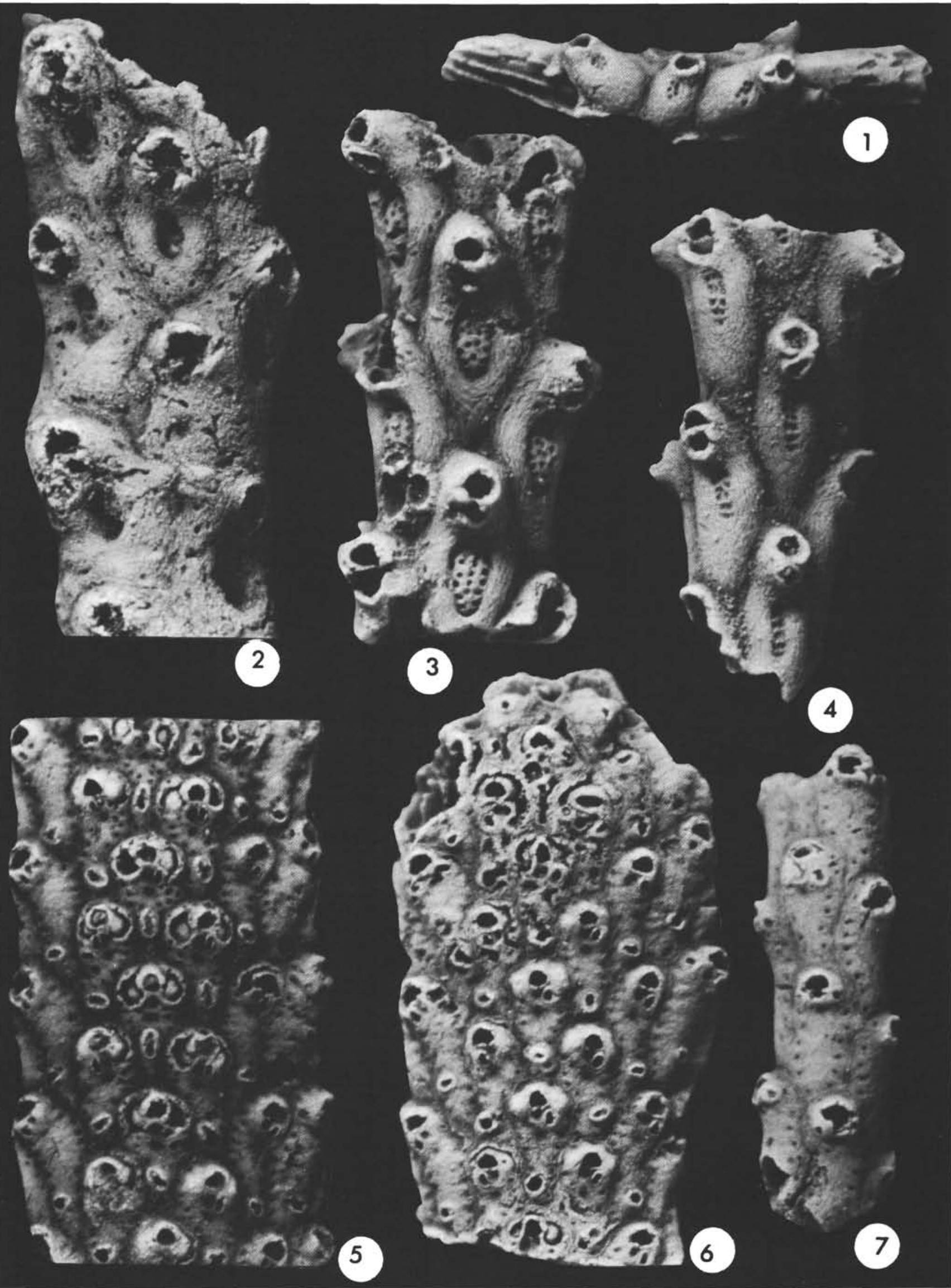


PLATE 18

Late Oligocene Bryozoa, Site 117

(All specimens $\times 50$ )

Figure $1 \quad$ Escharella sp. 2

Encrusting zoarium, USNM 171679. 117-3-1, 30-35

$\mathrm{cm}$. ?Sphenolithus distensus Zone.

Figure 2 Smittoidea variabilis (Canu)

Ovicelled and nonovicelled zooecia, encrusting fragment, USNM 171680. 117-3-1, $30-35 \mathrm{~cm}$. ?Sphenolithus distensus Zone.

Figure 3,4 Schizostomella aff. S. curryi Cheetham

3. Thin-walled zooecia, USNM 171674. 4. Thickwalled zooecia and broken gonoecium, USNM 171675. 117-3-1, 30-35 cm. ?Sphenolithus distensus Zone.

Figure $5 \quad$ Smittoidea sp. 2

Parts of four zooecia, USNM 171682. 117-2-6, Bottom. ?Sphenolithus ciperoensis Zone.

Figure 6 Schizomavella aff. S. trigonostoma Cheetham Fragment, USNM 171677. 117-3-1, 30-35 cm. ?Sphenolithus distensus Zone.

Figure $7 \quad$ Escharella aff. E. selseyensis Cheetham Quadriserial fragment, USNM 171678. 117-3-1, 30-35 $\mathrm{cm}$. ?Sphenolithus distensus Zone.

Figure $8 \quad$ Schizostomella aff. S. lontensis (Waters) Bilaminate fragment with thick-walled zooecia, USNM 171673. 117-3-1, 30-35 cm. ?Sphenolithus distensus Zone.

Figure 9 Dakaria? sp.

Quadriserial fragment, USNM 171676.117-3-1, 30-35 $\mathrm{cm}$. ?Sphenolithus distensus Zone. 
PLATE 18

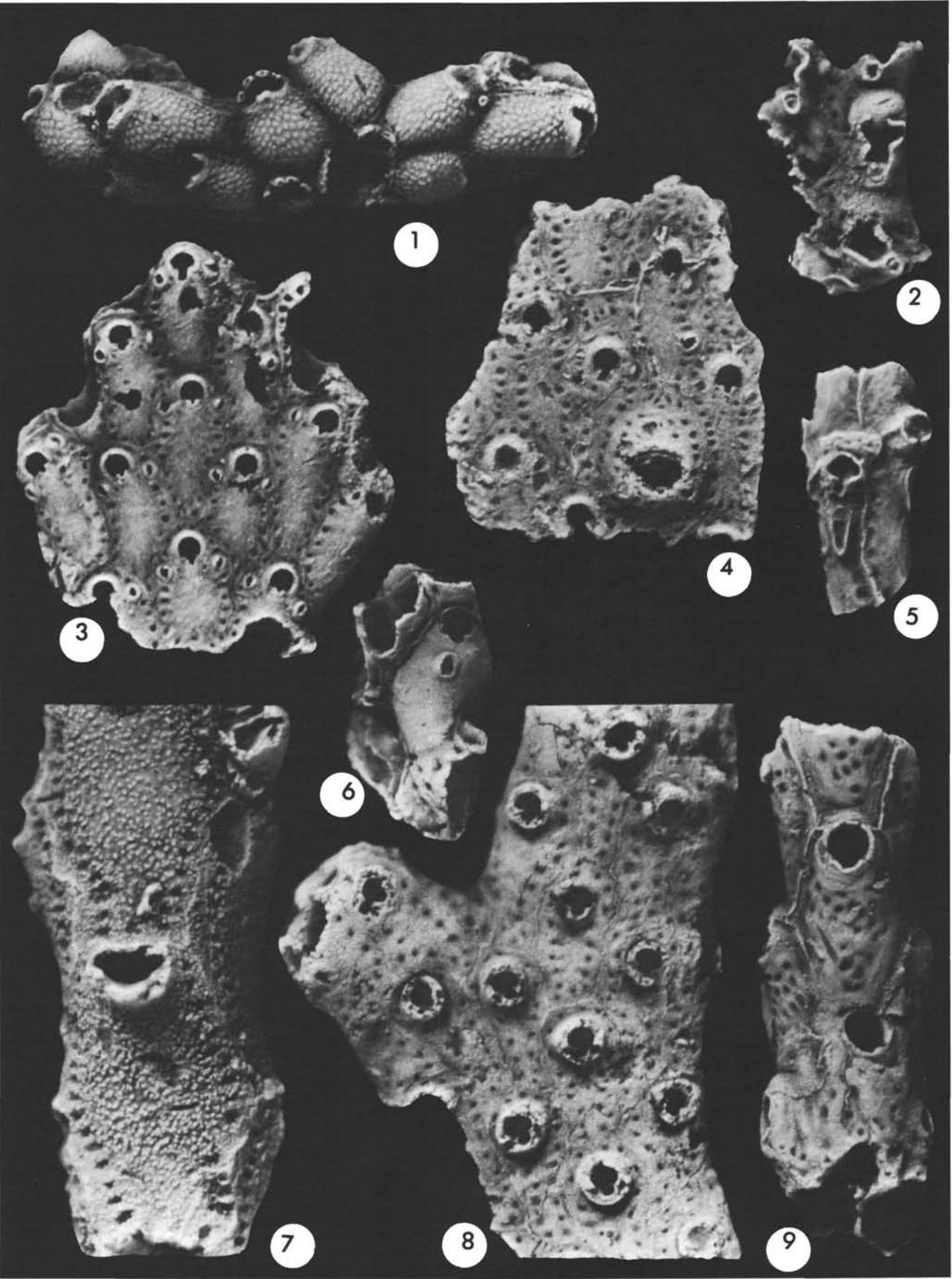


PLATE 19

Late Oligocene Bryozoa, Site 117

(All specimens $\times 50$ )

Figures 1-3 Sertella marginata (Reuss)

1. Reverse view of anastomosis with small, round avicularia. USNM 171685. 2. Reverse view of bifurcation with larger spatulate avicularia, USNM 171684. 3. Ovicelled zooecium with large frontal avicularium and small oral avicularium; nonovicelled zooecia with oral avicularia only; USNM 171683. 117-3-1, 30-35 cm. ?Sphenolithus distensus Zone.

Figure $4 \quad$ Hemiphylactella? sp.

Zooecia with high peristomes surrounding orfice with condyles, USNM 171692. 117-3-1, 30-35 cm. ?Sphenolithus distensus Zone.

Figure $5 \quad$ Smittoidea variabilis (Canu)

Bilaminate fragment with thick-walled zooecia, USNM 171681. 117-3-1, 30-35 cm. ?Sphenolithus distensus Zone.

Figures 6-8 Sparsiporina elegans (Reuss)

6. Reverse view showing lateral rows of zooecia, USNM 171688. 7. Medial and lateral rows of zooecia, USNM 171687. 117-3-1, 30-35 cm. ?Sphenolithus distensus Zone. 8. Ovicelled and nonovicelled zooecia, USNM 171686. 117-3-1, 30-35 cm. ?Sphenolithus ciperoensis Zone.

Figure 9 Bactridium? sp.

Biserial fragment, USNM 171689. 117-3-1, 30-35 cm. ?Sphenolithus distensus Zone. 


\section{PLATE 19}

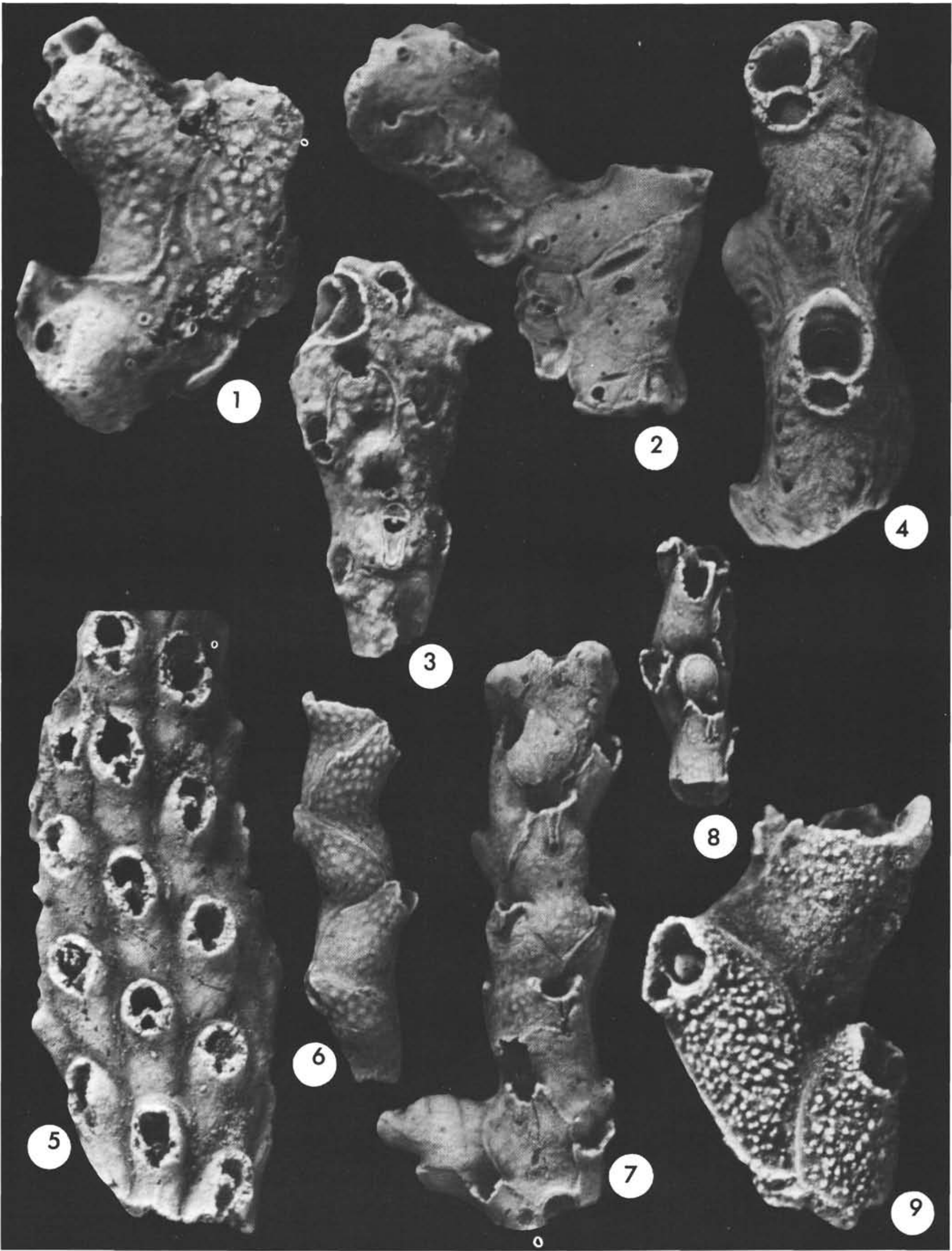


PLATE 20

Late Oligocene Bryozoa, Site 117

(All specimens $\times 50$ )

Figure 1 Ascophoran, gen. A indet.

Parts of zooecia, two ovicelled, USNM 171704.

117-3-1, 30-35 cm. ?Sphenolithus distensus Zone.

Figures 2, 3 Dittosaria prima (Reuss)

2. Frontal view, USNM 171693. 3. Lateral view, USNM 171694. 117-2-6, Bottom. ?Sphenolithus ciperoensis Zone.

Figures 4-7 Pasytheid, n. gen.

4. Proximal end of internode, beginning with single zooecium, USNM 171698. 5. Broken internode with quadriserially arranged zooecia, USNM 171699. 6. Distal end of internode with distal and lateral bases rami, USNM 171697. 7. Zooecia with sinuate orifices and well-developed distolateral avicularia, USNM 171700. 117-2-6, Bottom. ?Sphenolithus ciperoensis Zone.

Figures 8, 9 Gemellipora sp.

8. Lateral view, showing orifices of alternate zooecia, USNM 171695. 9. Frontal view showing twisted orifice, USNM 171696. 117-2-6, Bottom. ?Sphenolithus ciperoensis Zone.

Figure $10 \quad$ Orbitulipora sp.

Nearly complete, discoidal zoarium, USNM 171701. 117-3-1, 30-35 cm. ?Sphenolithus distensus Zone.

Figures 11, 12 Batopora sp.

11. Basal view of four-zooecium zoarium, USNM 171703. 12. Frontal view of larger, hemispherical zoarium, USNM 171702. 117-3-1, 30-35 cm. ?Sphenolithus distensus Zone.

Figures 13, 14 Leiosella aff. L. rostrifera Canu \& Bassler

13. Zooecia with small oral avicularium and larger frontal avicularium; zooecium just above center ovicelled; USNM 171691. 14. Zooecium at lower left ovicelled, USNM 171690. 117-3-1, 30-35 cm. ?Sphenolithus distensus Zone. 


\section{PLATE 20}

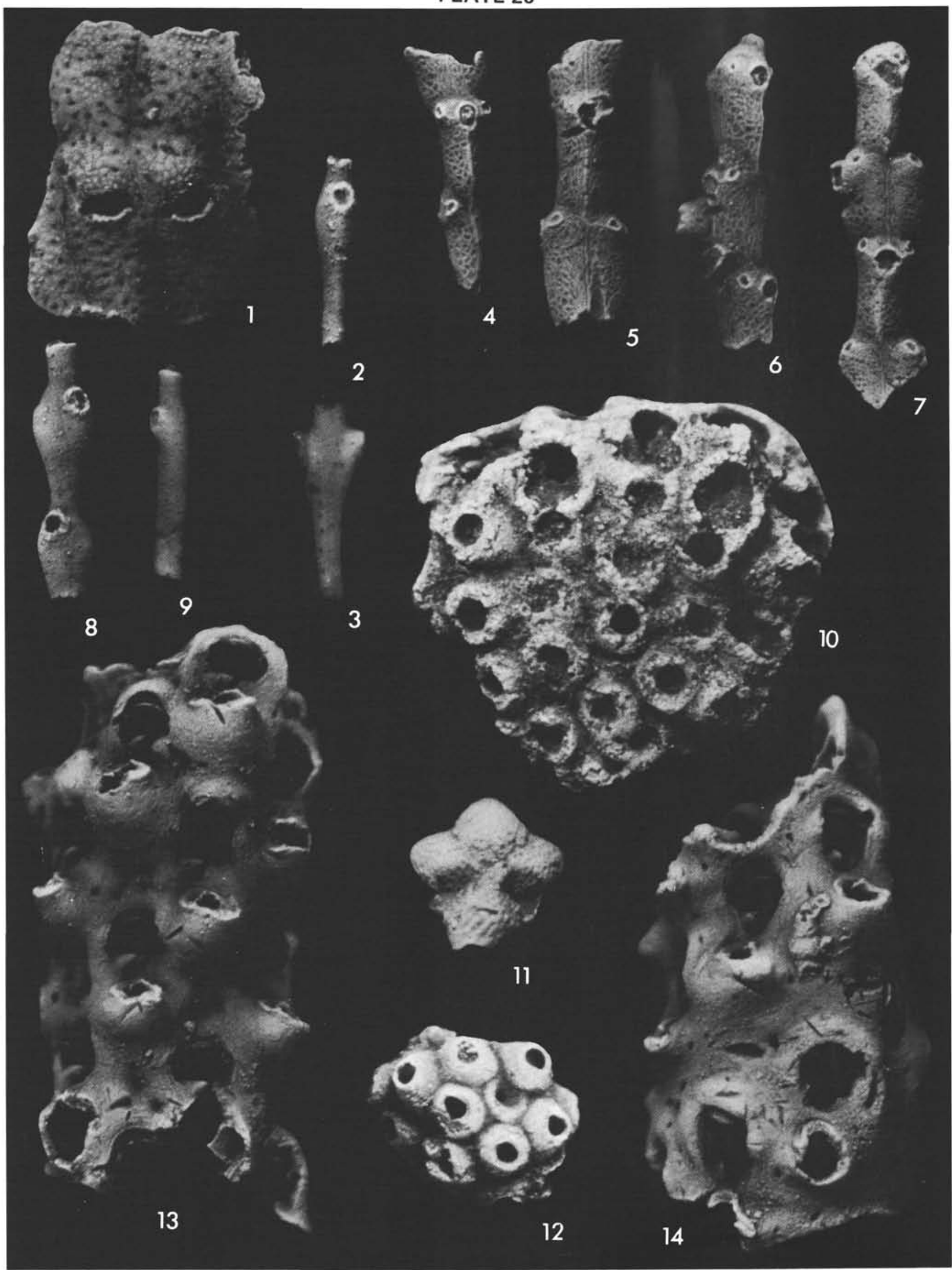


PLATE 21

Late Paleocene Bryozoa, Site 117

(All specimens X 50; from Globigerina triloculinoides - Discoaster multiradiatus Zone)

Figures 1, 4, 5 Calloprid, gen. indet.

1. Basal view, USNM 172386. 4. Ovicelled zooecia, USNM 172385. 5. Zooecia and avicularia, USNM 172384. 117A-8-1, 130-134 cm.

Figures 2, 3 Membraniporidra? sp.

2. Zooecia and avicularia, USNM 172382. 3. Ovicelled and non-ovicelled zooecia, USNM 17283. 117A-8-1, 130-134 cm.

Figure $6 \quad$ Ellisina? sp.

Zooecia and avicularia, USNM 172381. 117A-7-1, $95-100 \mathrm{~cm}$. 


\section{PLATE 21}

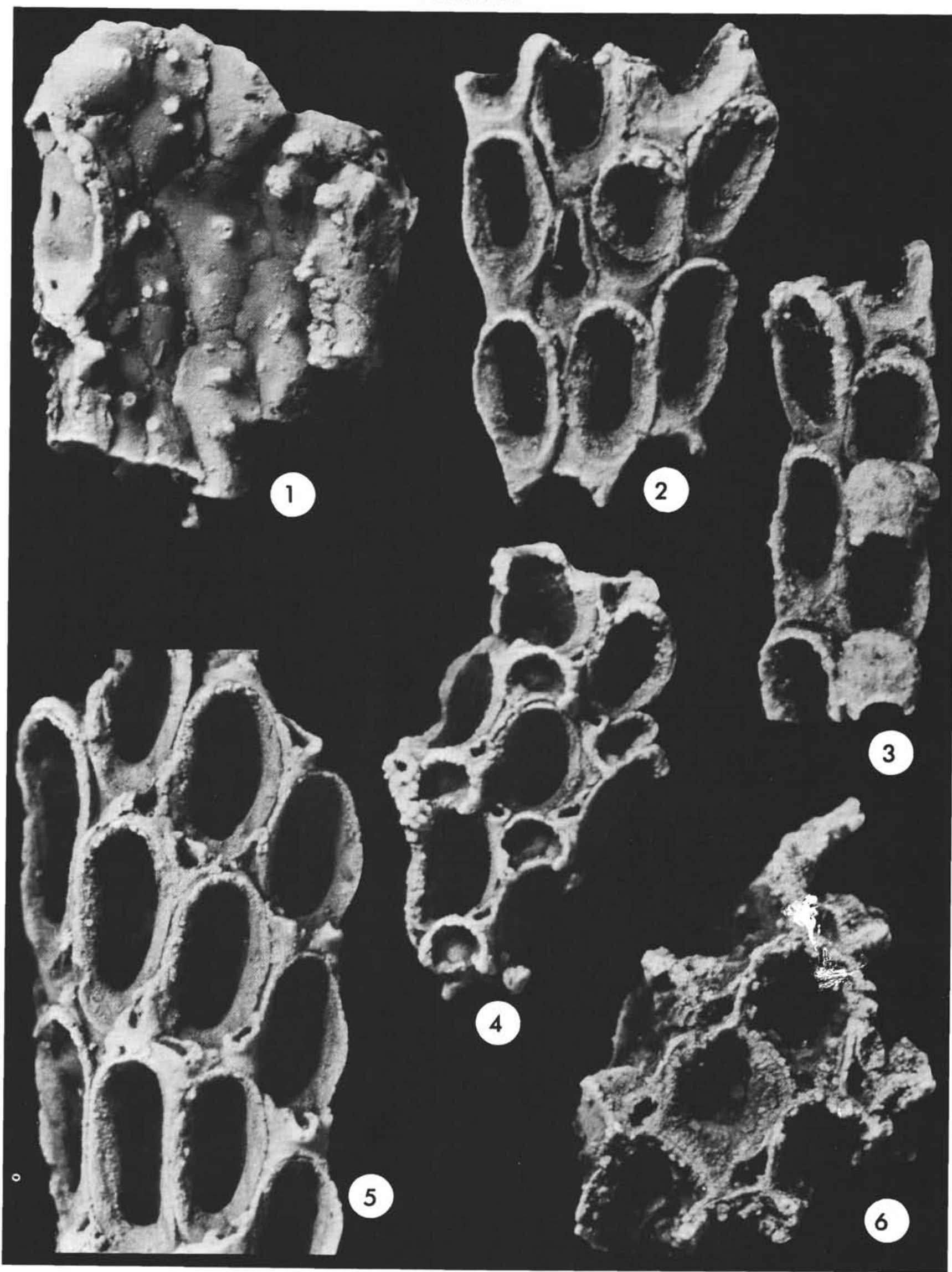


Late Paleocene Bryozoa, Site 117

(All specimens $\times 50$; from Globigerina

triloculinoides - Discoaster multiradiatus Zone)

Figure $1 \quad$ Periporosella ? sp. 1

Zooecia and avicularia (encrusting Coscinopleura sp.), USNM 172387. 117A-4-1, 62-67 cm.

Figure 2 Periporosella ? sp. 2

Zooecia, USNM 172388. 117A-8-1, 130-134 cm.

Figure 3 Stamenocella $\mathrm{cf} . \mathrm{S}$ "oculata Ulrich \& Bassler

Proximal part of internode, showing partly occluded zooecia and avicularia, USNM 172390. 117A-8-1, $130-134 \mathrm{~cm}$.

Figure $4 \quad$ Pithodella sp.

Distal tip of branch, showing zooecia and avicularia, USNM 172389. 117A-7-1, 95-100 cm

Figure $5 \quad$ Lunulites sp. 4

5a. Frontal view; 5b. Basal view; USNM 172395.

$117 \mathrm{~A}-7-1,95-100 \mathrm{~cm}$.

Figure $6 \quad$ Stamenocella sp.

Partly occluded zooecia and avicularia, USNM $172391.117 \mathrm{~A}-4-1,127-132 \mathrm{~cm}$.

Figures 7,8 Lunulites sp. 5

7. Basal view, USNM 172397. 8. Frontal view, USNM

172396. 117 A-7-1, $95-100 \mathrm{~cm}$. 


\section{PLATE 22}
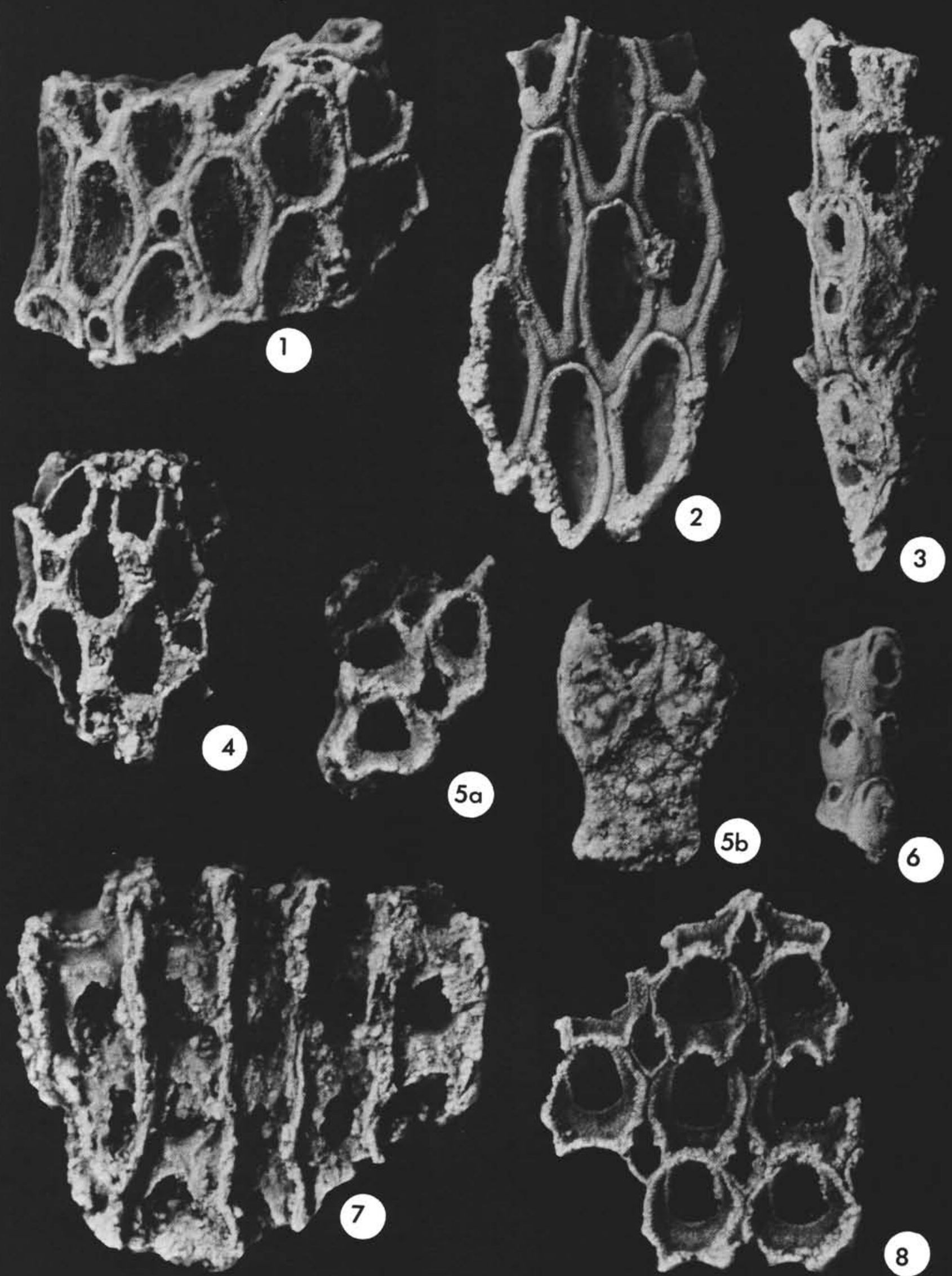

8 
PLATE 23

Late Paleocene Bryozoa, Site 117

(All specimens $\times 50$; from Globigerina triloculinoides - Discoaster multiradiatus Zone)

Figure 1

Figure 2

Figures 3-5

Figure 6

Figure 7

Figures 8, 9 Lunulites sp. 2

1a. Frontal view; lb. Basal view; USNM 172392. $117 \mathrm{~A}-8-1,130-134 \mathrm{~cm}$.

Smittipora? sp. 6 Zooecia, USNM 172404. 117A-7-1, 95-100 cm.

Smittipora? sp. 3 3. Zooecia, USNM 172398. 4. Distal tip of internode, USNM 172400. 5. Proximal tip of internode, USNM 172399. 117A-8-1, 130-134 cm.

Smittipora? sp. 7

Zooecia and ovicells (?), USNM 172405. 117A-7-1, $95-100 \mathrm{~cm}$.

Smittipora? sp. 4

Zooecia, USNM 172401. 117A-4-1, 62-67 cm.

\section{Smittipora? sp. 5}

8. Zooecia, USNM 172402.9. Occluded zooecia and ovicell, USNM 172403. 117A-4-1, 62-67 cm.

Figures 10, 11 Lunulites sp. 3

10. Zooecia and vibracula near the ancestrula, USNM 172394. 11. Part of large zoarium; $a$, frontal view; $b$, basal view; USNM 172393. 117A-8-1, 130-134 cm. 


\section{PLATE 23}

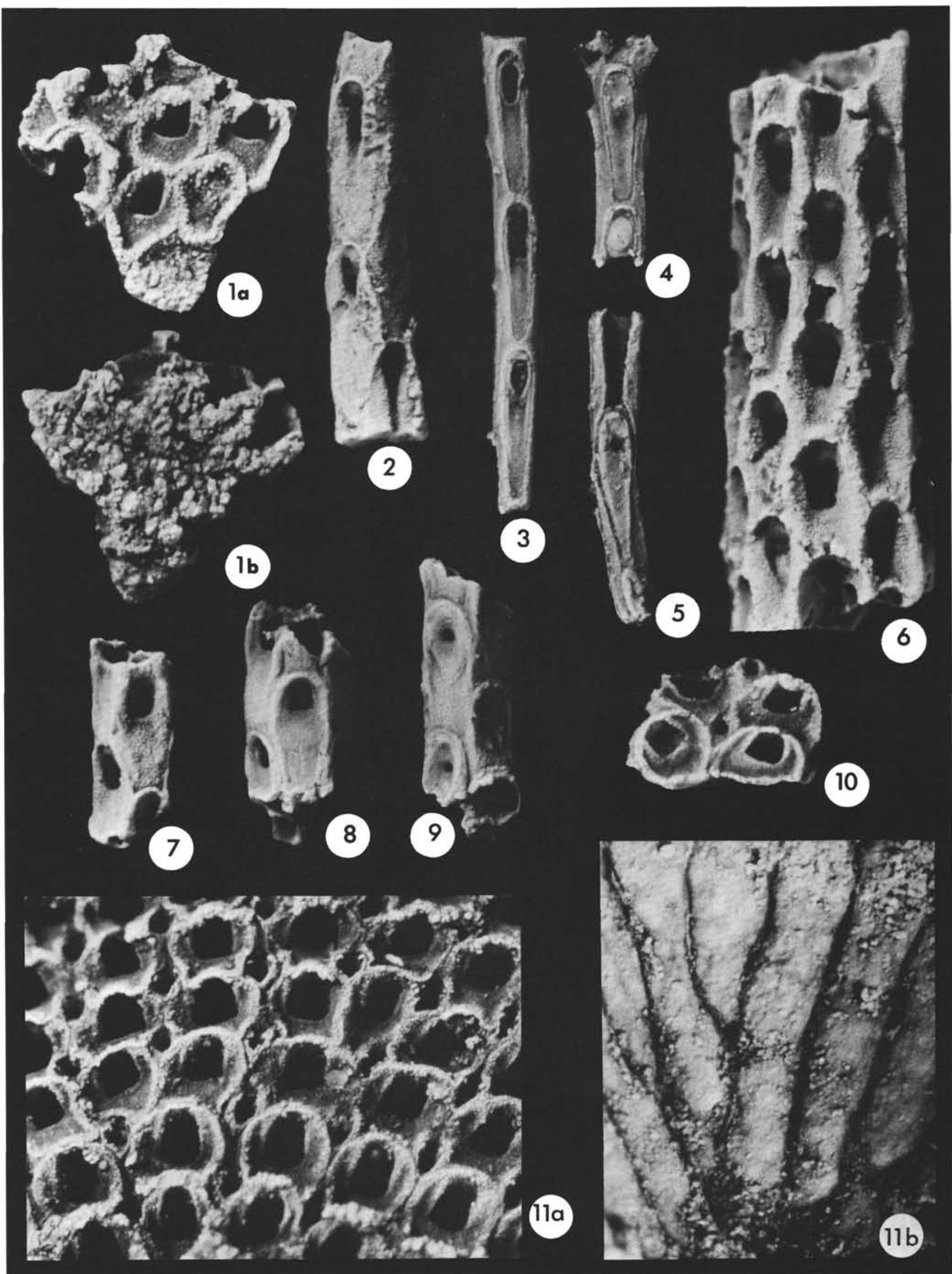


PLATE 24

Late Paleocene Bryozoa, Site 117

(All specimens $\times 50$; from Globigerina

triloculinoides - Discoaster multiradiatus Zone)

Figures 1, 3, 4 Mollia sp. 2

1. Marginal kenozooecia and ovicelled (?) zooecium, USNM 172412. 3. Totally regenerated zooecia, USNM 172413. 4. Normal and occluded zooecia, USNM 172411. 117A-8-1, 130-134 cm.

Figure $2 \quad$ Floridina sp. 6

Subcylindrical fragment (small axial hollow not shown), USNM $172409.117 \mathrm{~A}-4-1,62-67 \mathrm{~cm}$.

Figure $5 \quad$ Floridina sp. 7

Zooecia and part of onychocellarium, USNM 172410. $117 \mathrm{~A}, 4-1,127-132 \mathrm{~cm}$.

Figures 6, 7, 10 Onychocellid, gen. A indet.

6. Fragment of biserial branch, USNM 172414. 7. Tip of branch with occluded zooecia, USNM 172416. 10. Ovicelled and occluded zooecia, USNM 172415. 117A-7-1, 95-100 cm.

Figures $8,11 \quad$ Floridina sp. 5

8. Zooecia and onychocellarium, USNM 172407. $117 \mathrm{~A}-7-1,95-100 \mathrm{~cm}$. 11. Ovicelled and nonovicelled zooecia, some occluded, USNM 172408. 117A-8-1. $130-134 \mathrm{~cm}$.

Figure $9 \quad$ Floridina sp. 4

Widely-spaced zooecia, some occluded, USNM 172406. 117A-7-1, 95-100 cm. 


\section{PLATE 24}
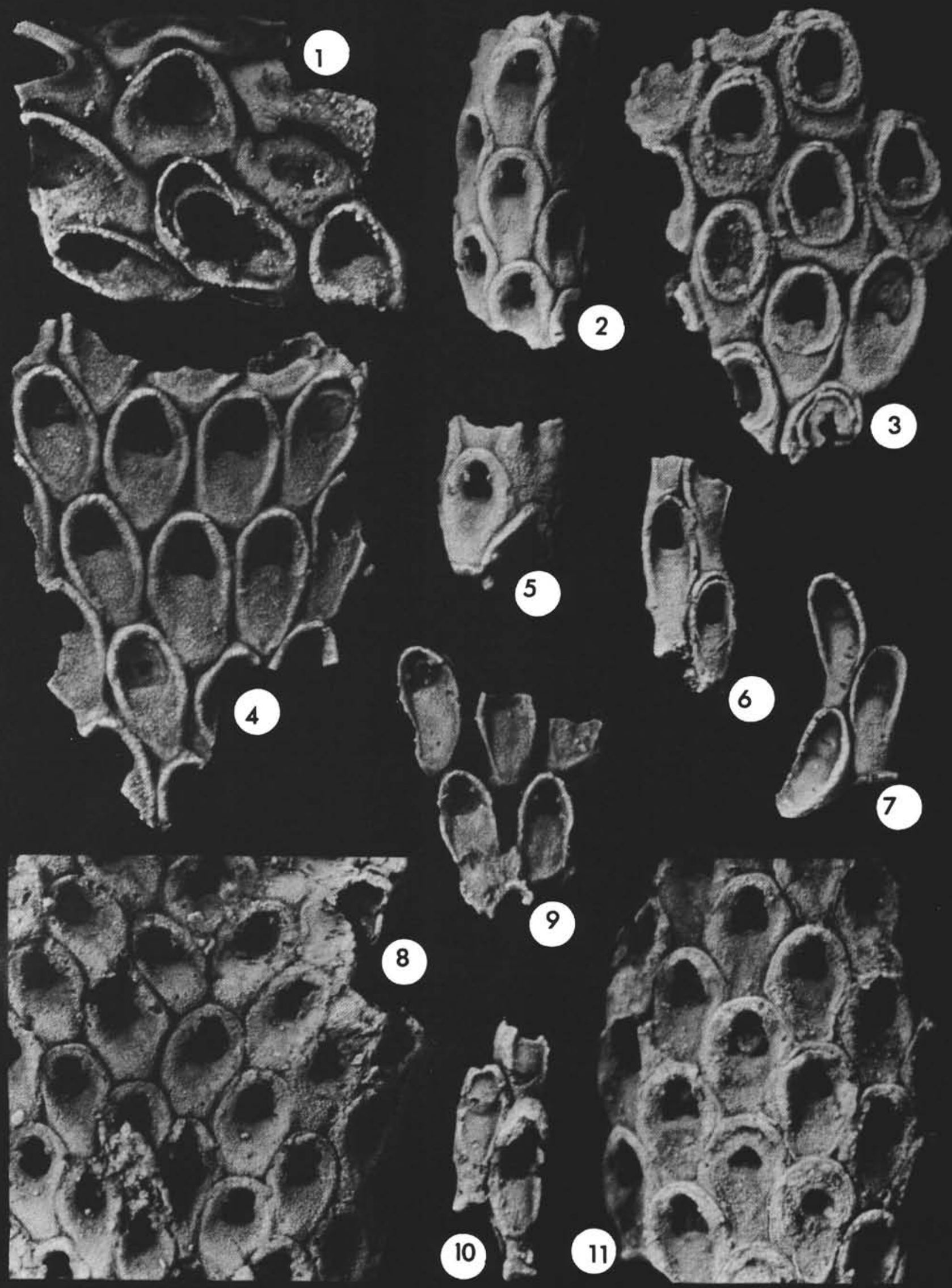
PLATE 25

Late Paleocene Bryozoa, Site 117

(All specimens X 50; from Globigerina

triloculinoides - Discoaster multiradiatus Zone)

Figure 1

Poricellaria sp.

Zooecia and avicularia, proximal part of internode, USNM 172421. 117A-4-1, 127-132 cm.

Figures 2, 5-7 Cosdinopleura sp.

2. Ovicelled zooecia, USNM 172425. 117A-4-1, $127-132 \mathrm{~cm}$. 5. Thick-walled zooecia from proximal part of large zoarium, USNM 172422. 6. Less thick-walled zooecia from median part of large zoarium, USNM 172423.117A-7-1, 95-100 cm.

7. Thin-walled zooecia from distal part of zoarium, USNM 172424. 117 A-4-1, $62-67 \mathrm{~cm}$.

Figure 3 nychocellid, gen. B indet.

Zooecia, USNM 172417. 117A-4-1, 62-67 cm.

Figure $4 \quad$ Semiescharinella? sp. 2

Zooecia and avicularia from proximal part of internode, USNM 172420. 117A-4-1, 127-132 cm. 
PLATE 25

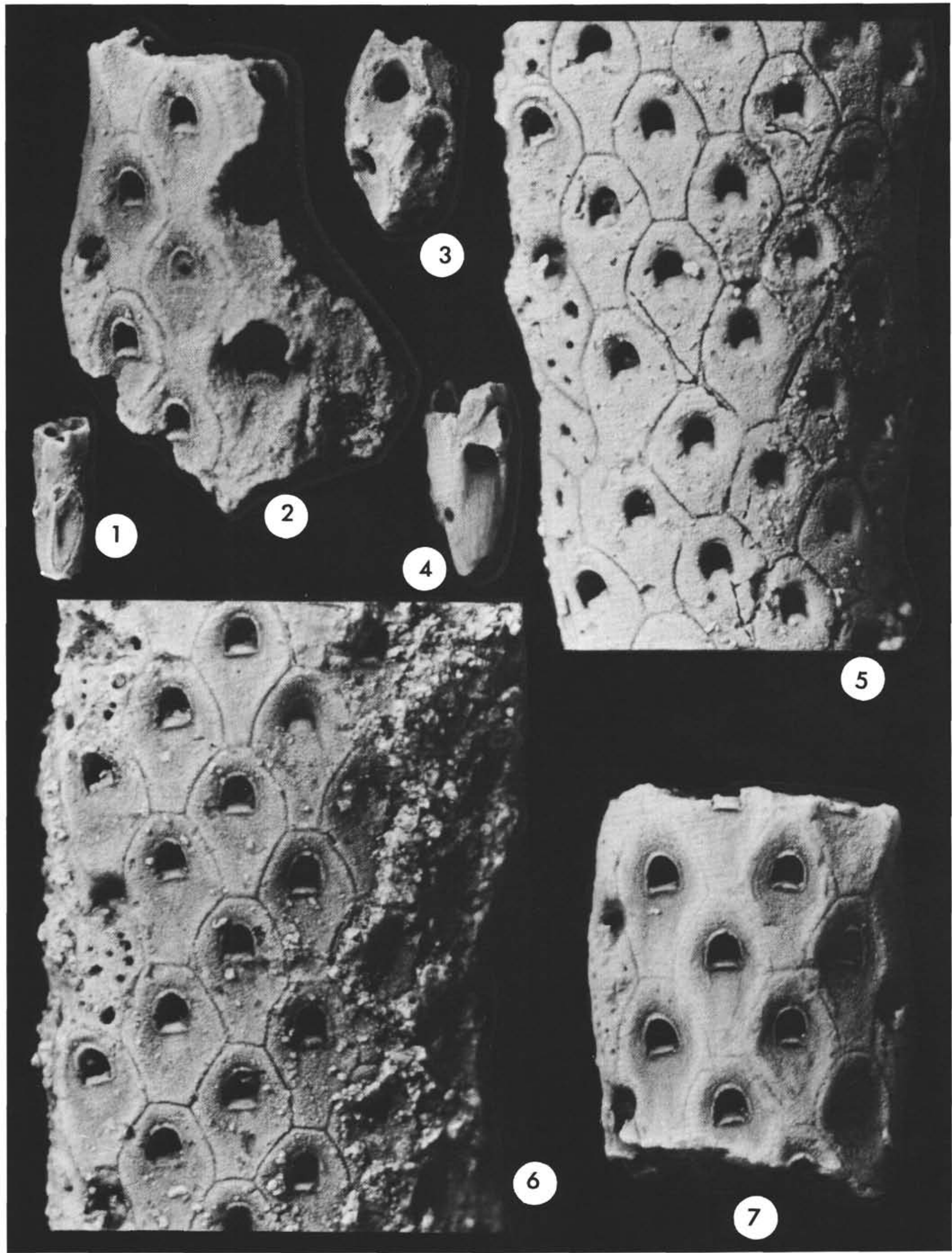


PLATE 26

Late Paleocene Bryozoa, Site 117 (All specimens $\times 50$; from Globigerina triloculinoides - Discoaster multiradiatus Zone)

Figure 1 Balantiostoma cf. septentrionalis (Canu \& Bassler) Ovicelled and non-ovicelled zooecia, USNM 172435. $117 \mathrm{~A}-8-1,130-134 \mathrm{~cm}$.

Figure 2 Microporid, gen. indet. Zooecia, USNM 172418. 117A-4-1, 62-67 cm.

Figure $3 \quad$ Semiescharinella $?$ sp. 1 Zooecia and avicularia, USNM 172419. 117A-8-1, $130-134 \mathrm{~cm}$.

Figures 4, $5 \quad$ Cribrilaria radiata (Moll) 4. Ovicelled and non-ovicelled zooecia, and an avicularium, USNM $172426.117 \mathrm{~A}-4-1,62-67 \mathrm{~cm} .5$. Zooecia, USNM 172427. 117A, 7-1, 95-100 cm.

Figure 6

Pliophloea ? sp.

Ovicelled zooecia and avicularia, USNM 172430. 117A-8-1, 130-134 cm.

Figure 7

Tricephalopora ? sp.

Ovicelled zooecia and avicularia, USNM 172433. 117A-8-1, 130-134 cm. 


\section{PLATE 26}
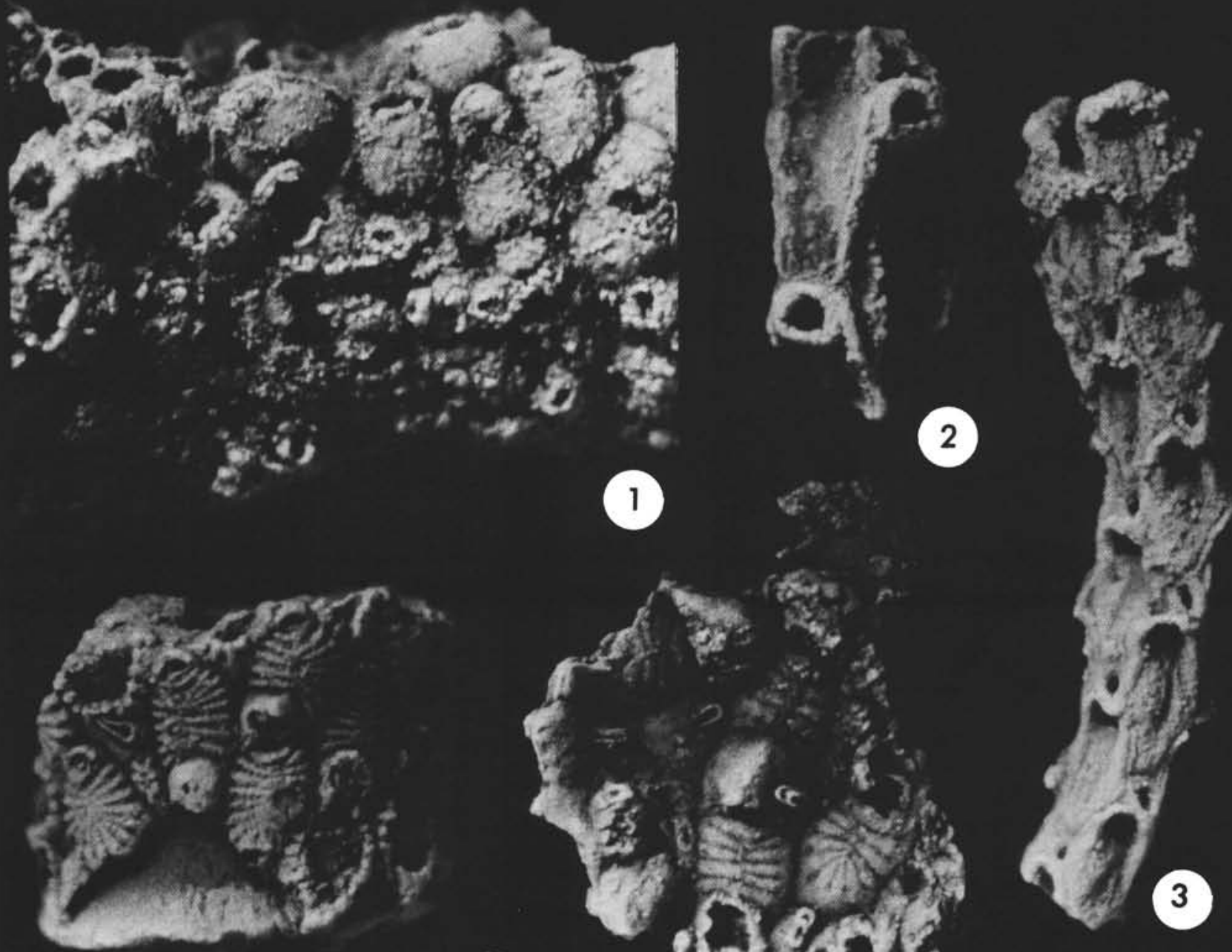

(4)
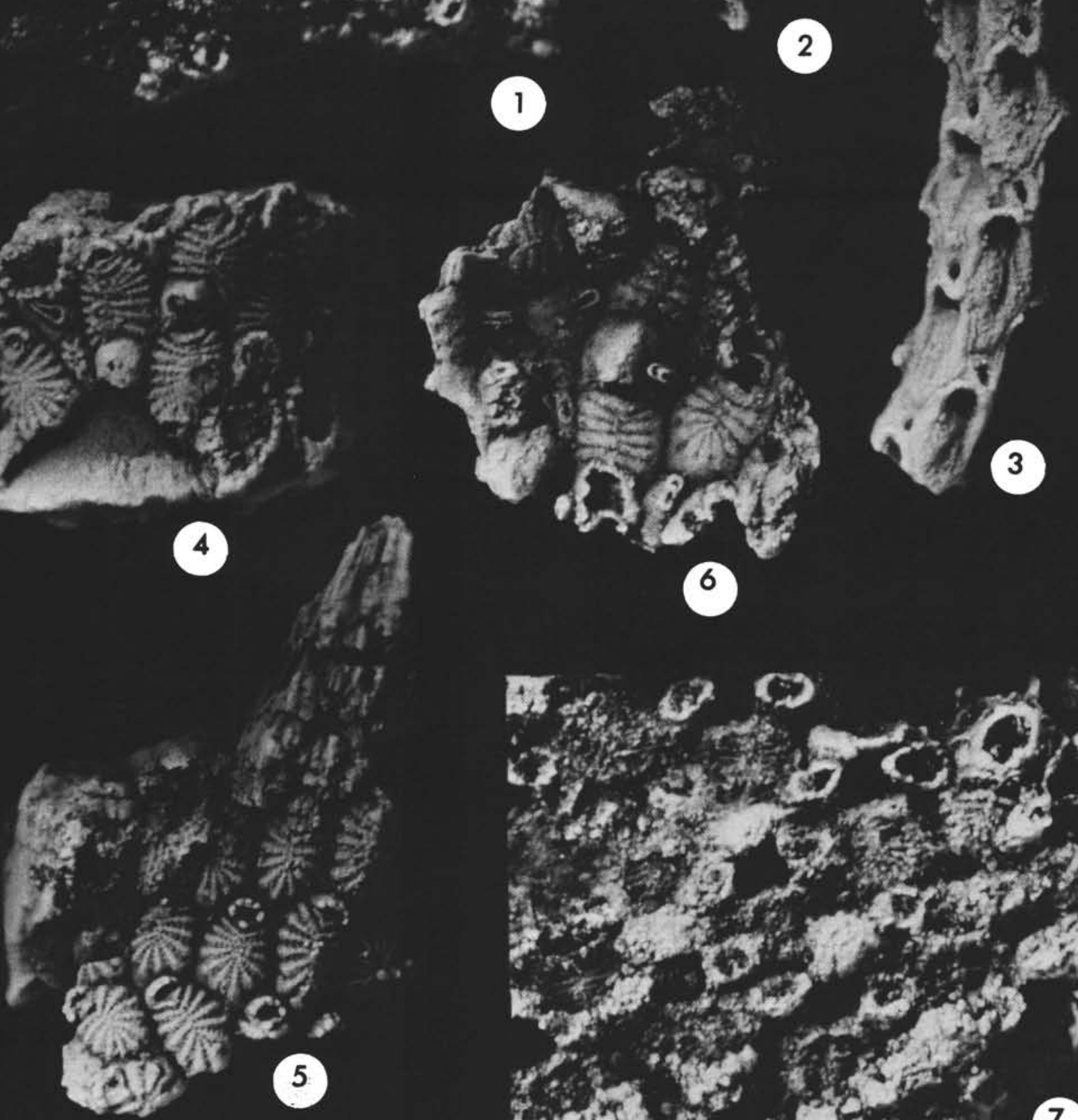

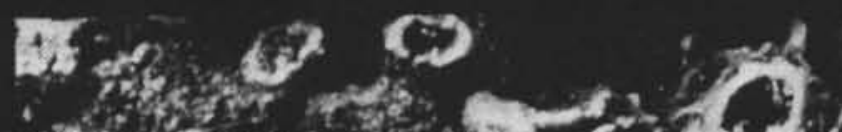

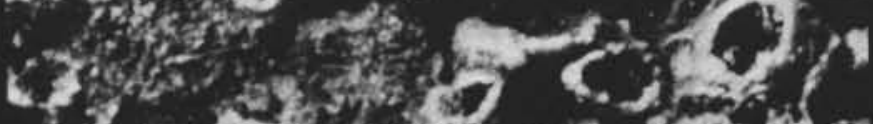

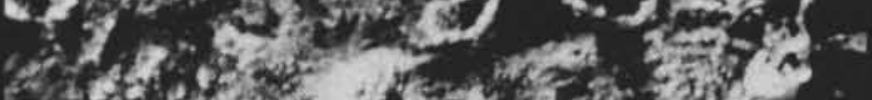

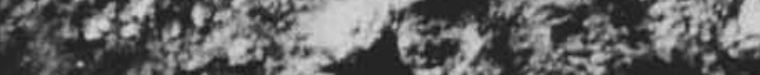

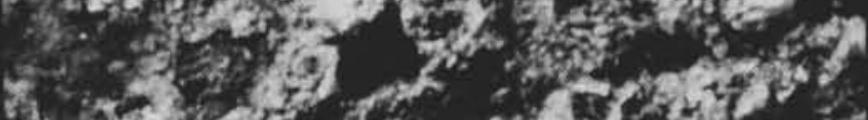

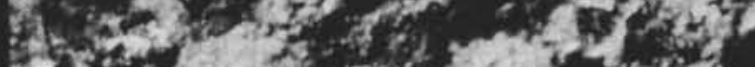

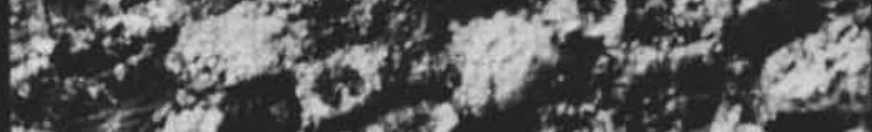

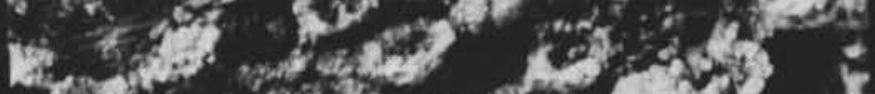

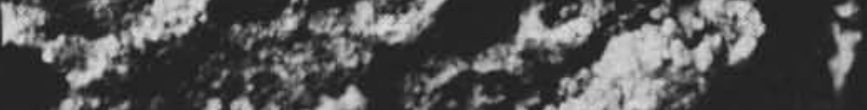

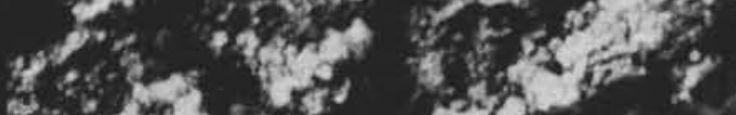

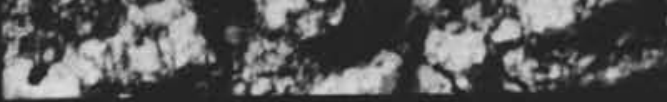


PLATE 27

Late Paleocene Bryozoa, Site 117

(All specimens $\times 50$; from Globigerina

triloculinoides - Discoaster multiradiatus Zone)

Figure $1 \quad$ Kelestoma aff. K. elongatum Marsson Zooecia and avicularium, USNM 172431. 117A, 8-1,130-134 cm.

Figure 2 Kelestoma? aff. K. ? simplex Canu \& Bassler Zooecium and avicularia, USNM 172432. 117A-8-1, $130-134 \mathrm{~cm}$.

Figures 3, $4 \quad$ Pliophloea sp.

3. Zooecia with broad gymnocysts, USNM 172429.

117A-4-1, 62-67 cm. 4. Ovicelled and non-ovicelled zooecia with narrow gymnocysts, and avicularia, USNM 172428. 117A-4-1, 127-132 cm.

Figures 5,7 "Beisselina" sp.

5. Distal part of branch with thin-walled zooecia, USNM 172436. 117A-7-1, 95-100 cm. 7. Thickwalled zooecia from proximal part of large zoarium, USNM 172437. 117A-8-1, 130-134 cm.

Figure $6 \quad$ Castanopora ? sp.

Portions of broken zooecia and an avicularium, USNM 172434. 117A-7-1, 95-100 cm. 


\section{PLATE 27}

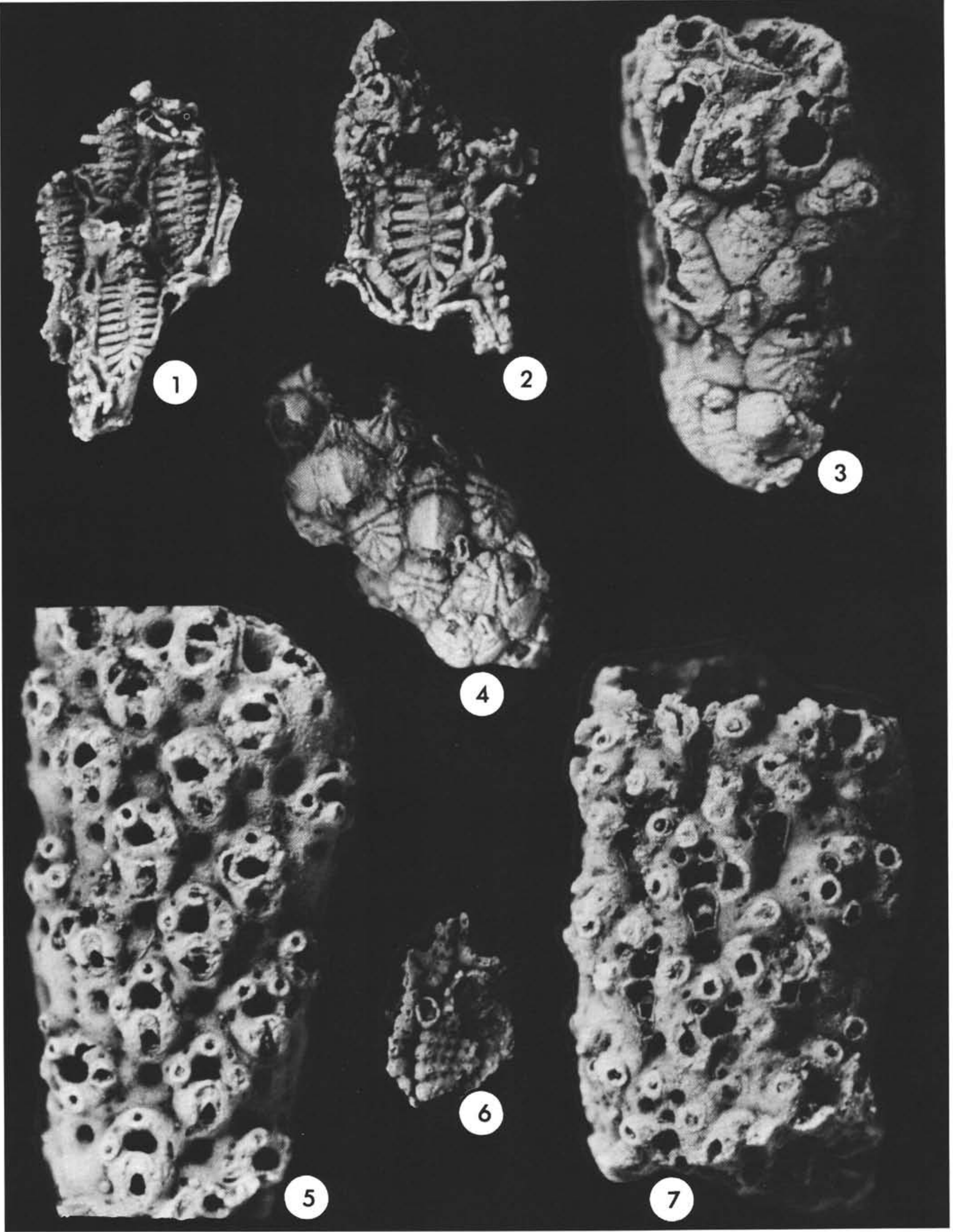


PLATE 28

Late Paleocene Bryozoa, Site 117

(All specimens $\times 50$; from Globigerina

triloculinoides - Discoaster multiradiatus Zone)

Figure 1

Pachythecella? sp.

Zooecia and avicularia (?) from basal part of zoarium, USNM 172439. 117A-4-1, 127-132 cm.

Figure 2 Smittinid ?, gen. indet.

Ovicelled and non-ovicelled zooecia, and avicularia, USNM 172441. 117A-8-1, 130-134 cm.

Figures 3-5 Fissuricella sp.

3. Relatively short, open zooecium, USNM 172447.

4. Closed zooecium, USNM 172448. 5. Long, open zooecium, USNM 172449. 117A-8-1, 130-134 cm.

Figures 6, $7 \quad$ Vitaticellid, n. gen.

6. Basal view of internode fragment, USNM 172445.

117A-4-1, 127-132 cm. 7. Zooecia and avicularia, USNM, 172444. 117A-4-1, 62-67 cm.

Figure 8

Schizostomella? sp. 1

Zooecium with frontal avicularium from distal tip of branch, USNM 172442. 117A-4-1, 127-132 cm.

Figure 9 Ascophoran, gen. B. indet.

Slightly broken zooecium, USNM 172446. 117A-4-1, $127-132 \mathrm{~cm}$.

Figure $10 \quad$ Smittoidea ? sp.

Ovicelled and non-ovicelled, worn zooecia with frontal avicularia, USNM 172440. 117A-8-1, 130-134 $\mathrm{cm}$.

Figure $11 \quad$ Schizostomella ?sp. 2

Zooecia from distal tip of branch, USNM 172443. 117A-4-1, 127-132 cm.

Figure 12 Pachytecella sp.

Zooecia with partly broken oral avicularia, USNM 172438. 117 A-8-1, 130-134 cm. 
PLATE 28

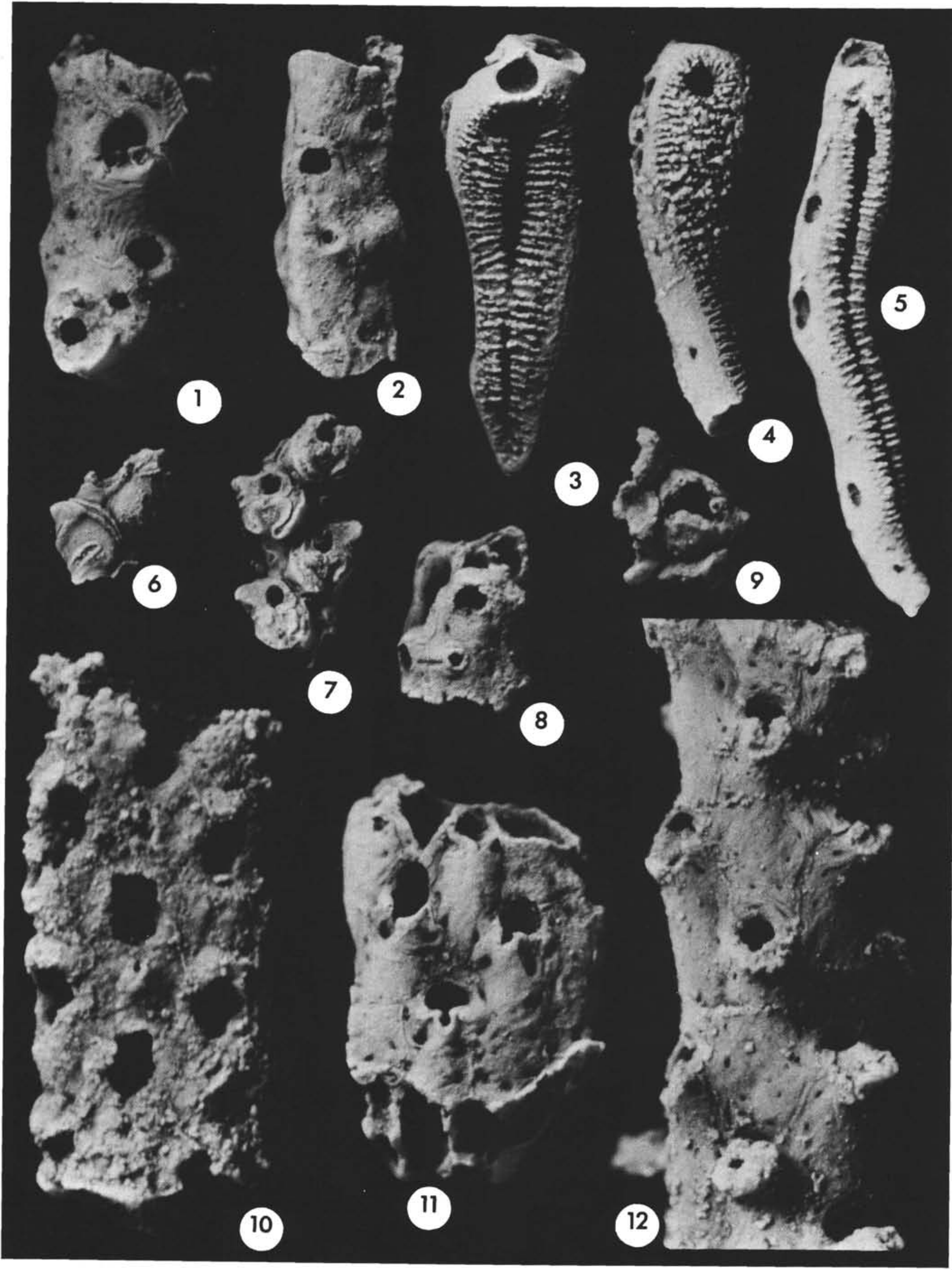




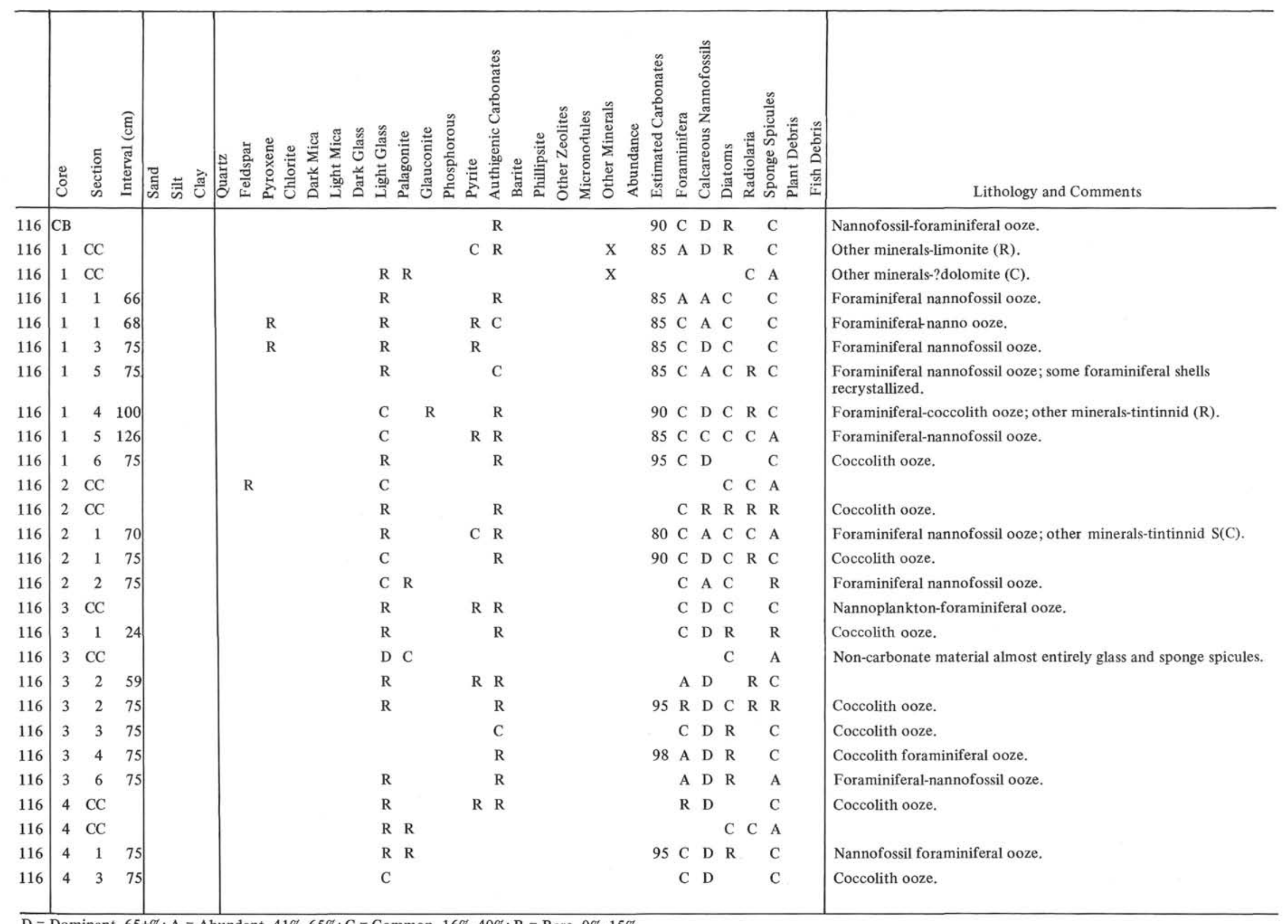




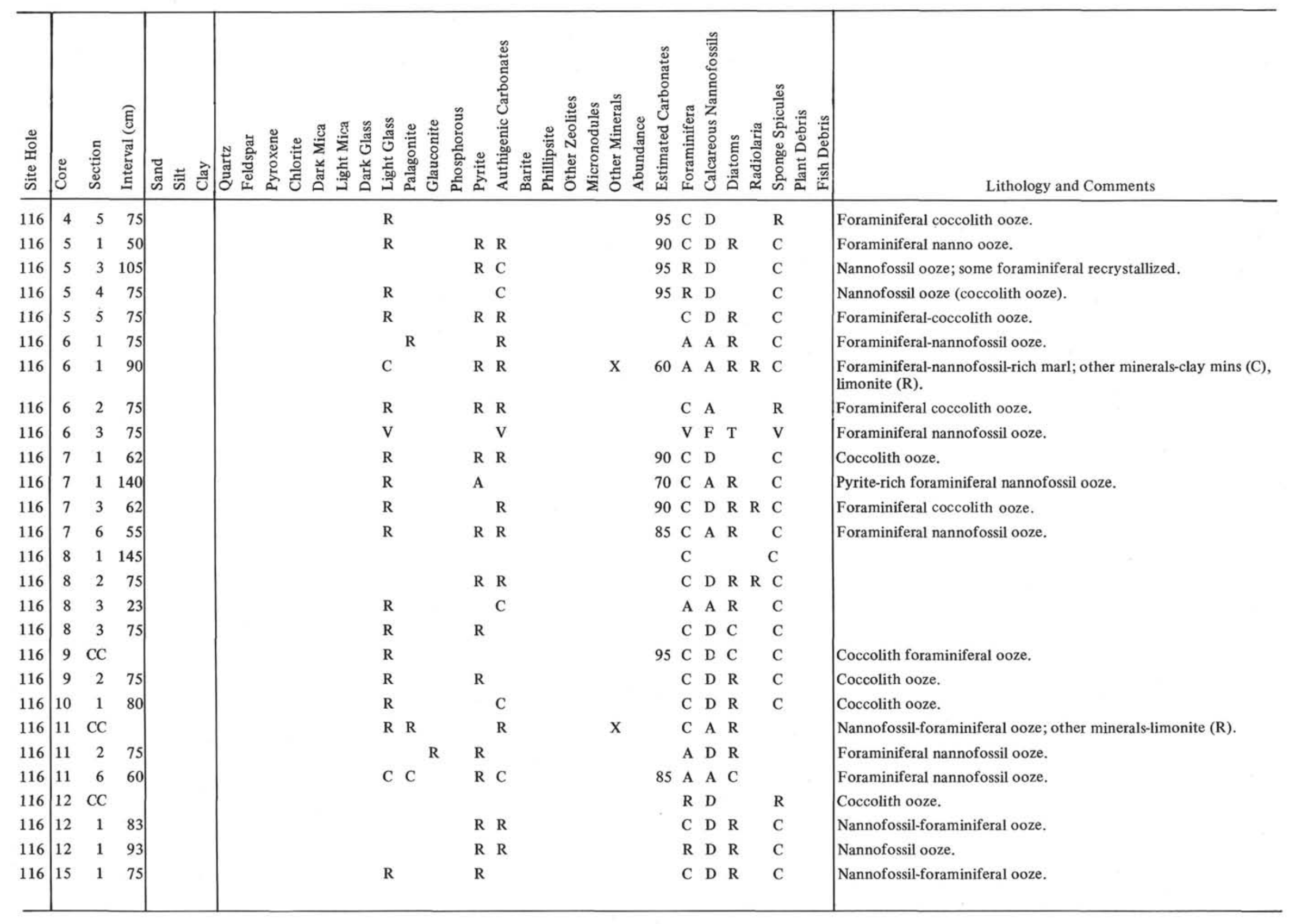




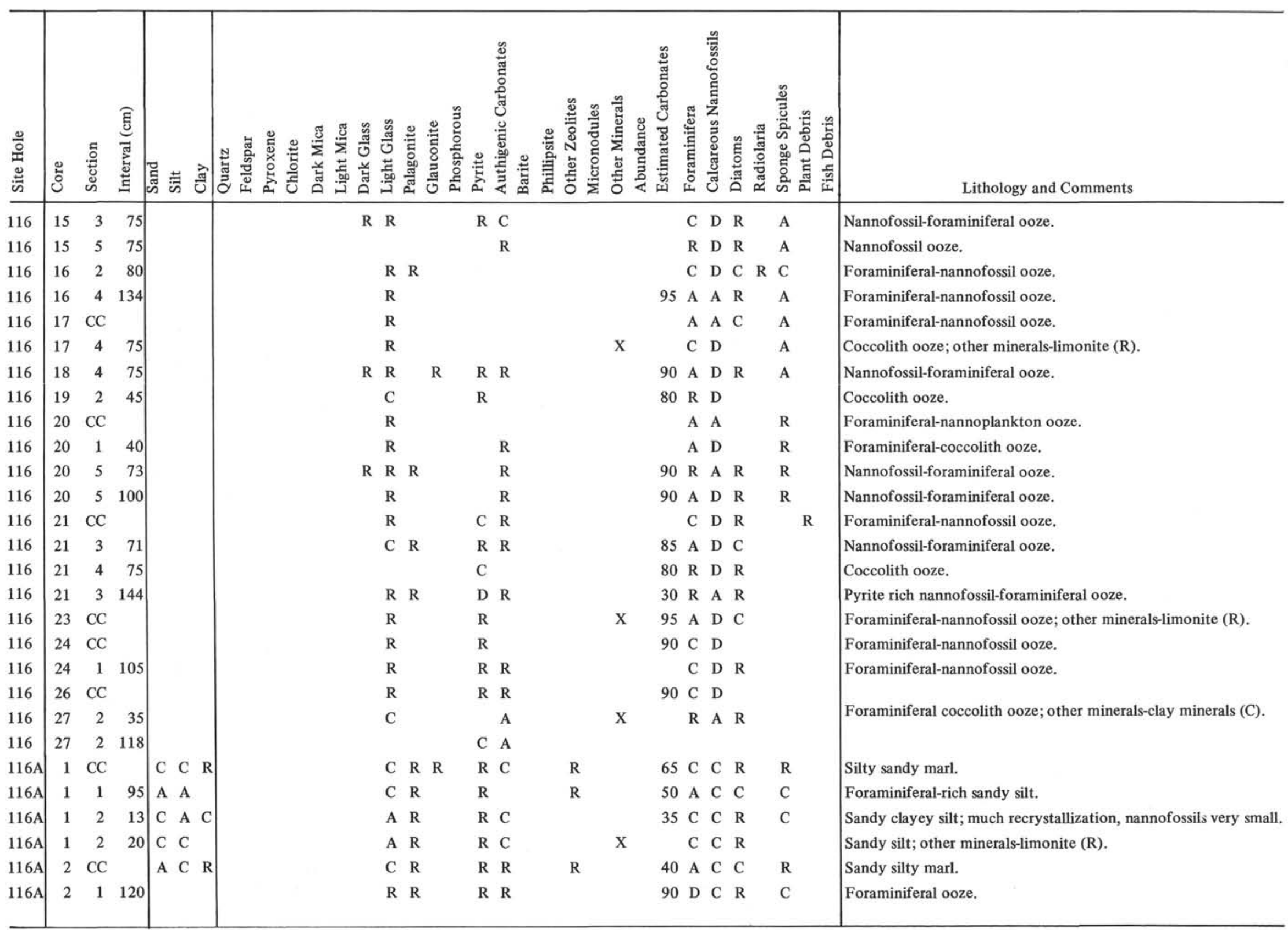




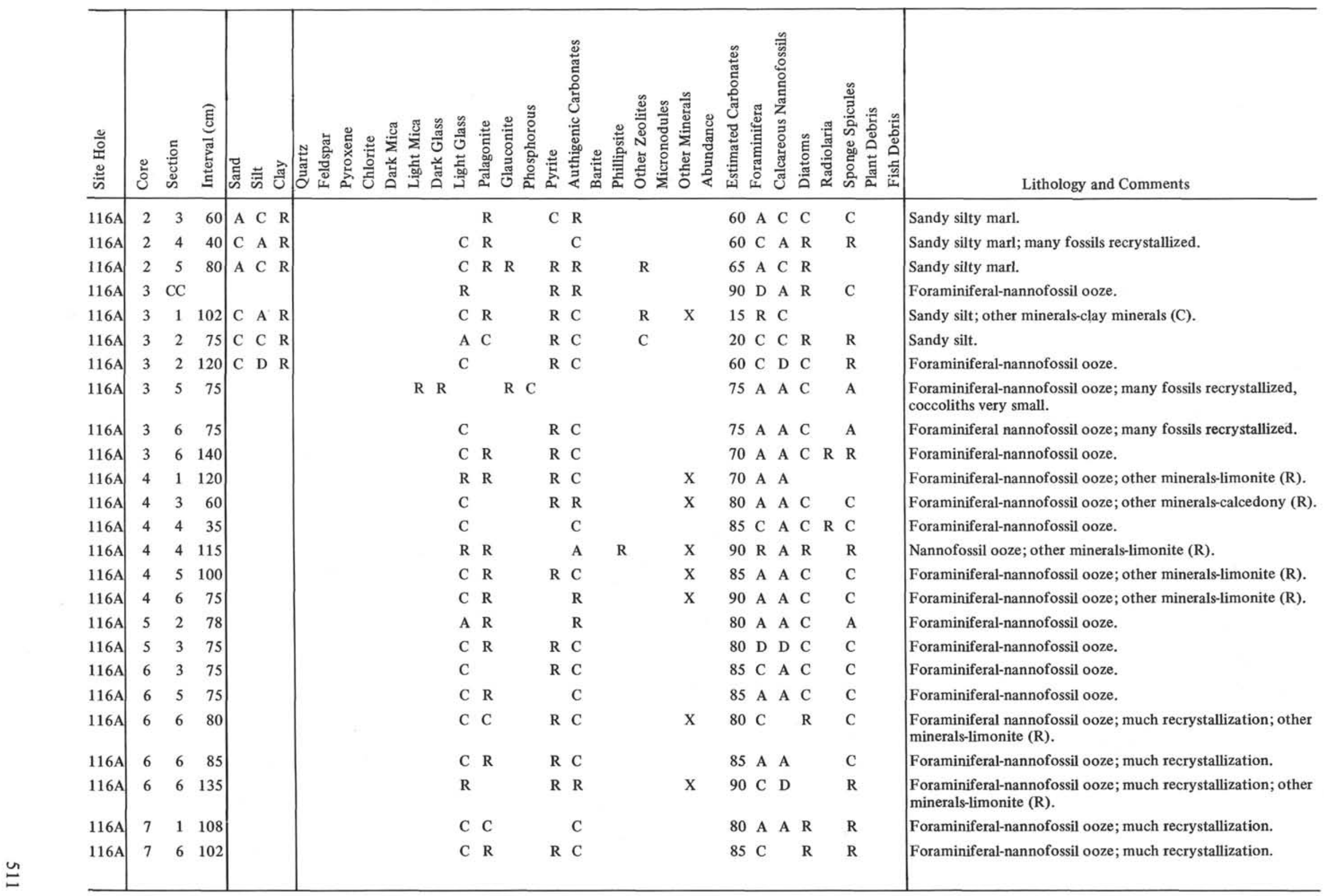




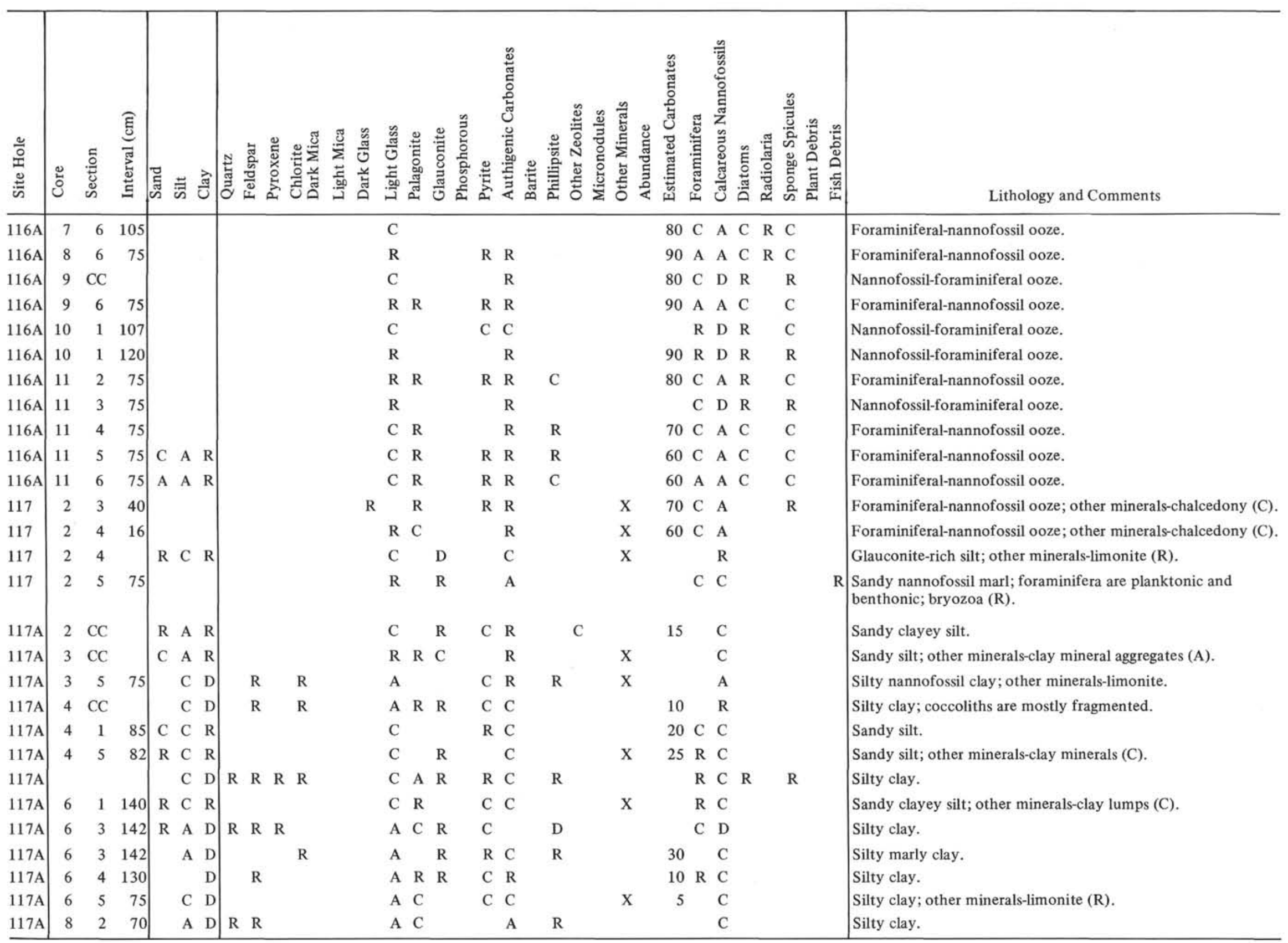


APPENDIX B. GRAIN SIZE DETERMINATIONS ON SAMPLES FROM SITES 116 AND $117^{1}$

\begin{tabular}{|c|c|c|c|c|c|c|c|}
\hline Site & Core & Section & Interval & Per Cent Sand & Per Cent Silt & Per Cent Clay & Classification \\
\hline 116 & 1 & 1 & 25.0 & 6.5 & 35.0 & 58.5 & Silty clay \\
\hline 116 & 1 & 2 & 25.0 & 9.1 & 30.2 & 60.7 & Silty clay \\
\hline 116 & 1 & 3 & 25.0 & 11.4 & 30.0 & 58.6 & Silty clay \\
\hline 116 & 2 & 2 & 24.0 & 6.4 & 44.2 & 49.5 & Silty clay \\
\hline 116 & 3 & 1 & 34.0 & 3.1 & 36.5 & 60.3 & Silty clay \\
\hline 116 & 3 & 6 & 25.0 & 4.1 & 37.5 & 58.4 & Silty clay \\
\hline 116 & 4 & 2 & 54.0 & 1.0 & 40.3 & 58.7 & Silty clay \\
\hline 116 & 4 & 3 & 30.0 & 3.7 & 43.4 & 52.9 & Silty clay \\
\hline 116 & 4 & 5 & 24.0 & 1.9 & 38.5 & 59.6 & Silty clay \\
\hline 116 & 5 & 1 & 44.0 & 2.7 & 49.9 & 47.4 & Clayey silt \\
\hline 116 & 7 & 1 & 37.0 & 5.4 & 52.7 & 41.9 & Clayey silt \\
\hline 116 & 7 & 3 & 10.0 & 3.9 & 43.2 & 52.9 & Silty clay \\
\hline 116 & 8 & 2 & 25.0 & 3.0 & 45.6 & 51.4 & Silty clay \\
\hline 116 & 9 & 1 & 25.0 & 1.7 & 38.6 & 59.7 & Silty clay \\
\hline 116 & 9 & 3 & 24.0 & 2.8 & 40.9 & 56.3 & Silty clay \\
\hline 116 & 10 & 6 & 95.0 & 4.1 & 40.4 & 55.6 & Silty clay \\
\hline 116 & 11 & 2 & 102.0 & 4.9 & 45.3 & 49.8 & Silty clay \\
\hline 116 & 11 & 6 & 112.0 & 10.8 & 57.5 & 31.7 & Clayey silt \\
\hline 116 & 12 & 1 & 64.0 & 1.1 & 22.0 & 76.8 & Clay \\
\hline 116 & 15 & 1 & 70.0 & 8.7 & 45.0 & 46.4 & Silty clay \\
\hline 116 & 21 & 3 & 20.0 & 9.1 & 43.6 & 47.3 & Silty clay \\
\hline 116 & 21 & 4 & 35.0 & 0.9 & 41.0 & 58.1 & Silty clay \\
\hline 116 & 22 & 6 & 137.0 & 1.0 & 40.6 & 58.4 & Silty clay \\
\hline $116 \mathrm{~A}$ & 1 & 1 & 109.0 & 15.6 & 32.0 & 52.4 & Silty clay \\
\hline $116 \mathrm{~A}$ & 2 & 2 & 24.0 & 10.4 & 26.1 & 63.5 & Silty clay \\
\hline $116 \mathrm{~A}$ & 3 & 6 & 24.0 & 8.2 & 12.1 & 79.7 & Clay \\
\hline $116 \mathrm{~A}$ & 4 & 2 & 24.0 & 22.0 & 38.2 & 39.8 & Sand-silt-clay \\
\hline $116 \mathrm{~A}$ & 5 & 2 & 24.0 & 18.1 & 26.7 & 55.1 & Silty clay \\
\hline $116 \mathrm{~A}$ & 5 & 3 & 25.0 & 26.0 & 39.3 & 34.6 & Sand-silt-clay \\
\hline $116 \mathrm{~A}$ & 6 & 2 & 25.0 & 16.1 & 36.3 & 47.7 & Silty clay \\
\hline $116 \mathrm{~A}$ & 7 & 2 & 25.0 & 24.6 & 35.5 & 39.9 & Sand-silt-clay \\
\hline $116 \mathrm{~A}$ & 7 & 4 & 25.0 & 18.6 & 43.2 & 38.2 & Clayey silt \\
\hline $116 \mathrm{~A}$ & 7 & 6 & 30.0 & 32.7 & 41.7 & 25.6 & Sand-silt clay \\
\hline $116 \mathrm{~A}$ & 8 & 2 & 24.0 & 11.1 & 28.3 & 60.6 & Silty clay \\
\hline $116 \mathrm{~A}$ & 9 & 1 & 24.0 & 9.2 & 25.2 & 65.6 & Silty clay \\
\hline
\end{tabular}

\footnotetext{
${ }^{1}$ Analyses carried out under the supervision of G. W. Bode and R. E. Boyce, Scripps Institution of Oceanography.
} 
SHIPBOARD SCIENTIFIC PARTY

APPENDIX B - Continued

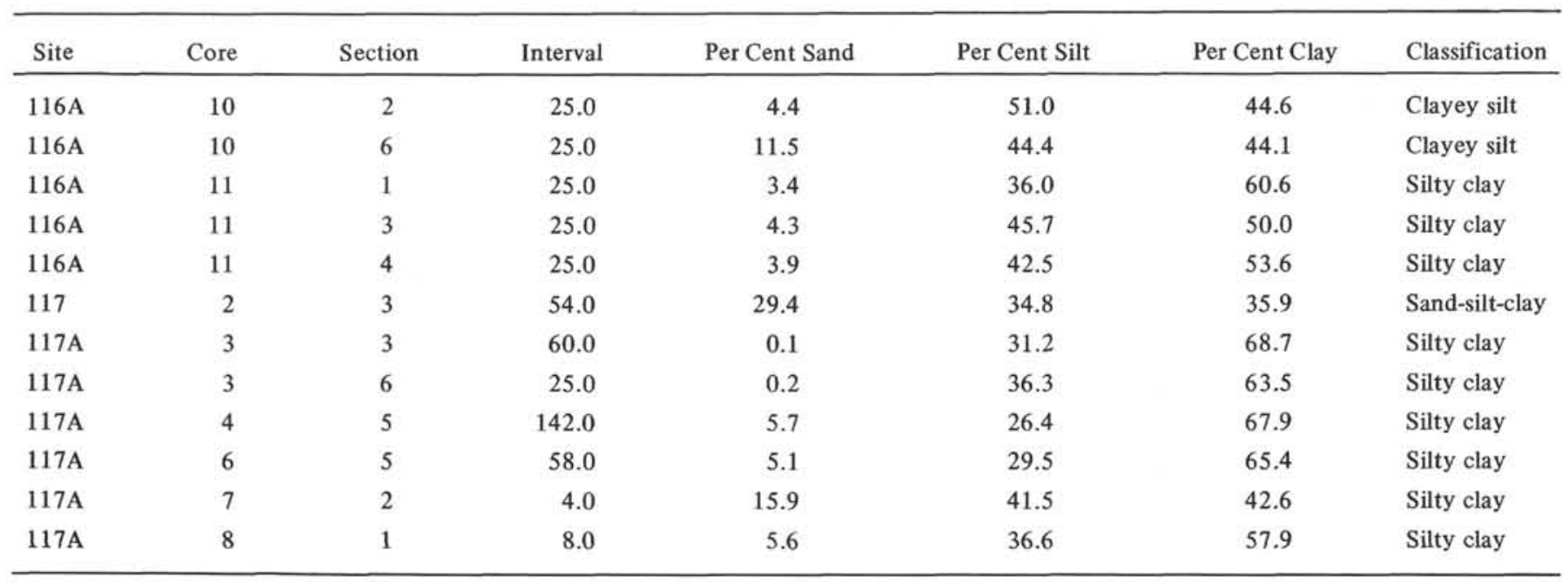




\begin{tabular}{|c|c|c|c|c|c|c|c|}
\hline Site & Core & Section & $\begin{array}{c}\text { Top } \\
\text { Interval }\end{array}$ & $\begin{array}{l}\text { Hole } \\
\text { Depth }\end{array}$ & $\begin{array}{l}\text { Total } \\
\text { Carbon }\end{array}$ & $\begin{array}{l}\text { Organic } \\
\text { Carbon }\end{array}$ & $\mathrm{CaCO}_{3}$ \\
\hline 116 & 1 & 1 & 15.0 & 70.2 & 10.8 & 0.1 & 89 \\
\hline 116 & 1 & 3 & 15.0 & 71.7 & 10.4 & 0.1 & 86 \\
\hline 116 & 1 & 5 & 15.0 & 76.2 & 10.7 & 0.1 & 88 \\
\hline 116 & 2 & 2 & 14.0 & 109.1 & 11.6 & 0.1 & 96 \\
\hline 116 & 3 & 1 & 30.0 & 159.3 & 11.4 & 0.1 & 95 \\
\hline 116 & 3 & 2 & 30.0 & 160.8 & 11.3 & 0.1 & 93 \\
\hline 116 & 3 & 3 & 15.0 & 162.1 & 11.8 & 0.1 & 98 \\
\hline 116 & 3 & 6 & 15.0 & 166.6 & 11.5 & 0.1 & 95 \\
\hline 116 & 4 & 2 & 40.0 & 210.9 & 11.4 & 0.1 & 95 \\
\hline 116 & 4 & 3 & 20.0 & 212.2 & 11.4 & 0.1 & 94 \\
\hline 116 & 4 & 5 & 14.0 & 215.1 & 11.4 & 0.1 & 95 \\
\hline 116 & 5 & 1 & 7.0 & 259.1 & 11.2 & 0.1 & 93 \\
\hline 116 & 5 & 4 & 47.0 & 264.0 & 10.9 & 0.1 & 90 \\
\hline 116 & 6 & 1 & 19.0 & 309.2 & 11.5 & 0.0 & 95 \\
\hline 116 & 6 & 3 & 15.0 & 312.1 & 11.0 & 0.1 & 91 \\
\hline 116 & 7 & 1 & 20.0 & 359.2 & 11.4 & 0.1 & 94 \\
\hline 116 & 7 & 3 & 15.0 & 362.1 & 11.5 & 0.1 & 95 \\
\hline 116 & 8 & 2 & 15.0 & 410.6 & 11.6 & 0.1 & 96 \\
\hline 116 & 9 & 1 & 17.0 & 459.2 & 11.7 & 0.1 & 97 \\
\hline 116 & 9 & 3 & 14.0 & 462.1 & 11.0 & 0.1 & 91 \\
\hline 116 & 10 & 6 & 52.0 & 517.0 & 11.3 & 0.1 & 94 \\
\hline 116 & 12 & 1 & 31.0 & 599.3 & 11.3 & 0.1 & 93 \\
\hline 116 & 15 & 1 & 57.0 & 662.6 & 9.7 & 0.2 & 80 \\
\hline 116 & 15 & 5 & 30.0 & 668.3 & 10.8 & 0.1 & 89 \\
\hline 116 & 16 & 3 & 59.0 & 673.1 & 10.0 & 0.1 & 82 \\
\hline 116 & 17 & 4 & 7.0 & 684.6 & 9.8 & 0.1 & 81 \\
\hline 116 & 17 & 6 & 71.0 & 688.2 & 10.7 & 0.1 & 88 \\
\hline 116 & 20 & 1 & 28.0 & 701.3 & 10.9 & 0.0 & 91 \\
\hline 116 & 20 & 5 & 18.0 & 707.2 & 10.6 & 0.1 & 88 \\
\hline 116 & 21 & 4 & 16.0 & 714.7 & 10.9 & 0.1 & 90 \\
\hline 116 & 22 & 6 & 111.0 & 727.6 & 10.3 & 0.0 & 86 \\
\hline $116 \mathrm{~A}$ & 1 & 1 & 70.0 & 0.7 & 10.4 & 0.3 & 85 \\
\hline $116 \mathrm{~A}$ & 2 & 2 & 15.0 & 10.6 & 9.8 & 0.2 & 80 \\
\hline $116 \mathrm{~A}$ & 3 & 5 & 14.0 & 24.1 & 11.1 & 0.1 & 92 \\
\hline $116 \mathrm{~A}$ & 4 & 2 & 15.0 & 28.6 & 4.2 & 0.2 & 33 \\
\hline $116 \mathrm{~A}$ & 5 & 2 & 14.0 & 37.6 & 6.4 & 0.1 & 52 \\
\hline $116 \mathrm{~A}$ & 5 & 3 & 15.0 & 39.2 & 7.2 & 0.2 & 59 \\
\hline $116 \mathrm{~A}$ & 6 & 2 & 15.0 & 46.7 & 8.3 & 0.1 & 68 \\
\hline $116 \mathrm{~A}$ & 7 & 2 & 15.0 & 55.7 & 8.2 & 0.1 & 67 \\
\hline $116 \mathrm{~A}$ & 7 & 4 & 15.0 & 58.7 & 9.1 & 0.1 & 75 \\
\hline $116 \mathrm{~A}$ & 7 & 6 & 15.0 & 61.7 & 9.5 & 0.1 & 79 \\
\hline $116 \mathrm{~A}$ & 8 & 2 & 14.0 & 64.6 & 7.4 & 0.2 & 60 \\
\hline $116 \mathrm{~A}$ & 9 & 1 & 14.0 & 72.1 & 11.3 & 0.1 & 94 \\
\hline $116 \mathrm{~A}$ & 10 & 2 & 15.0 & 82.7 & 10.8 & 0.1 & 89 \\
\hline $116 \mathrm{~A}$ & 10 & 6 & 15.0 & 88.7 & 11.3 & 0.0 & 94 \\
\hline $116 \mathrm{~A}$ & 11 & 1 & 15.0 & 90.2 & 11.6 & 0.1 & 96 \\
\hline $116 \mathrm{~A}$ & 11 & 3 & 15.0 & 93.2 & 11.2 & 0.2 & 92 \\
\hline $116 \mathrm{~A}$ & 11 & 4 & 15.0 & 94.7 & 11.4 & 0.1 & 94 \\
\hline
\end{tabular}


APPENDIX C - Continued

\begin{tabular}{|c|c|c|c|c|c|c|c|}
\hline Site & Core & Section & $\begin{array}{c}\text { Top } \\
\text { Interval }\end{array}$ & $\begin{array}{l}\text { Hole } \\
\text { Depth }\end{array}$ & $\begin{array}{c}\text { Total } \\
\text { Carbon }\end{array}$ & $\begin{array}{l}\text { Organic } \\
\text { Carbon }\end{array}$ & $\mathrm{CaCO}_{3}$ \\
\hline 117 & 2 & 3 & 50.0 & 103.5 & 9.6 & 0.1 & 79 \\
\hline $117 \mathrm{~A}$ & 3 & 3 & 50.0 & 225.5 & 2.9 & 0.1 & 23 \\
\hline $117 \mathrm{~A}$ & 3 & 6 & 15.0 & 229.6 & 1.9 & 0.2 & 14 \\
\hline $117 \mathrm{~A}$ & 4 & 5 & 30.0 & 276.3 & 3.6 & 0.1 & 29 \\
\hline $117 \mathrm{~A}$ & 6 & 5 & 92.0 & 282.9 & 2.7 & 0.2 & 21 \\
\hline
\end{tabular}

${ }^{1}$ Analyses carried out under the supervision of G. W. Bode and R. E. Boyce, Scripps Institution of Oceanography. 


\section{APPENDIX D, PART 1 LISTS OF SELECTED PLANKTONIC AND BENTHONIC FORAMINIFERA AND AGE DETERMINATIONS (116)}

\section{Hole 116}

\author{
W. A. Berggren
}

Sample 12-116-1-1, 143-146 cm:

PF: $\quad$ Globigerina atlantica (abundant, dominant, sinistral), G. bulloides, Globigerinita glutinata.

BF: $\quad$ Planulina bradii, Anomalinoides cicatricosa, Sigmoilopsis schlumbergeri - all common; Cassidulina subglobosa, Sphaeroidina bulloides, Hoeglundina elegans, Eponides umbonatus, Cibicidoides pseudoungeriana, Gyroidina neosoldanii, Laticarinina halophora, Dentalina advena, Pleurostomella sp., Nodosarella sp.

Also Present: Sponge spicules.

Age: $\quad$ Pliocene (Middle).

Sample 12-116-1-2, 146-149 cm:

PF: Globigerina atlantica (abundant, common), $G$. bulloides, Globigerinita glutinata, Globorotalia crassaformis, G. scitula.

BF: Essentially the same as the preceding sample above, plus Karreriella bradyi.

Also present: Sponge spicules.

Age: $\quad$ Pliocene (Middle).

Sample 12-116-1-3, 143-146 cm:

PF: $\quad$ Same as preceding samples above.

BF: $\quad$ As above plus Stilostomella antillea:

Also present: Sponge spicules; solution effects visible on foraminiferal tests.

Age: $\quad$ Pliocene (Middle).

Sample 12-116-1-4, 141-144 cm:

PF: $\quad$ Same as preceding sample.

BF: $\quad$ As above plus Uvigerina $\mathrm{sp}$.

Also present: Sponge spicules.

Age: $\quad$ Pliocene (Middle).

Sample 12-116-1-5, 144-146 cm:

All data as above.

Age: $\quad$ Pliocene (Middle).

Sample 12-116-1-6, 143-145:

All data essentially the same as above, plus Gyroidina neosoldanii.

Sample 12-116-1, Core Catcher:

PF: $\quad$ Globigerina atlantica (dominant, abundant, sinistral), G. bulloides, Globigerinita glutinata, Globorotalia crassaformis, $G$. inflata, $G$. scitula, Orbulina universa. BF: $\quad$ Cibicidoides pseudoungeriana, C. kullenbergi, $C$. robertsoniana, C. subhaidingeri, Anomalina sp. cf. $A$. globulosa, Laticarinina halophora, Cassidulina subglobosa, Gyroidina neosoldanii, Uvigerina peregrina, $U$. sp. cf. $U$. schwageri, Eponides umbonatus, Planulina bradii, $P$. wuellerstorfi, Stilostomella antillea, Sigmoilopsis schlumbergeri, Sphaeroidina bulloides.

Also present: Sponge spicules, ostracods (common).

Age: $\quad$ Pliocene (Middle).

Remarks: 5-6 chambered forms of G. atlantica exhibit marked similarities to $G$. dutertrei.

Sample 12-116-2-0, 16-18 cm:

PF: Globigerina atlantica (abundant, dominant), $G$. bulloides, Globorotalia crassaformis, G. scitula, Orbulina universa (common).

BF: Essentially same fauna as Sample 12-116-1, Core Catcher with following modification: Uvigerina auberiana present; Uvigerina peregrina not observed.

Also present: Echinoid spines, sponge spicules.

Age: Pliocene (Early).
Sample 12-116-2-1, 145-147 cm:

PF: Globigerina atlantica (dominant, abundant, sinistral), G. bulloides, Orbulina universa, Globorotalia cibaoensis, G. crassula, G. miozea conoidea, G. puncticulata, $G$. crassaformis.

BF: $\quad$ Essentially as above, plus Uvigerina schwageri.

Also present: Ostracods.

Age: $\quad$ Early Pliocene.

Sample 12-116-2-2, 139-142 cm:

PF: Globigerina bulloides (dominant, abundant), Orbulina universa, Globorotalia puncticulata.

BF: $\quad$ Sparse, fauna made up of various elements listed above; also present: Martinottiella nodulosa.

Also present: Ostracods.

Age: Early Pliocene.

Note: Marked change in planktonic foraminiferal fauna between this sample and the one above (abundant $G$. atlantica and $G$. bulloides above.

Sample 12-116-2-3, $150 \mathrm{~cm}$ :

PF: Globigerian bulloides (dominant, abundant), Glo bigerina atlantica, Orbulina universa, Globorotalia puncticulata.

BF: $\quad$ Relatively diverse, as above.

Also present: Ostracods.

Age: $\quad$ Early Pliocene.

Sample 12-116-2-4, $150 \mathrm{~cm}$ :

Data same as above.

Sample 12-116-2-6, Core Catcher:

PF: Globigerina bulloides (dominant, abundant), $G$. atlantica, Orbulina universa, Globorotalia puncticulata, G. acostaensis, G. humerosa.

BF: Cibicidoides pseudoungeriana, C. kullenbergi, Eponides umbonatus, Cassidulina subglobosa, Uvigerina auberiana, Gyroidina soldanii, Planulina wuellerstorfi, Laticarinina halophora, Karreriella bradyi, Sigmoilopsis schlumbergeri, nodosariids, dentalinids.

Also present: Sponge spicules, echinoid spines, ostracods (common) Age: Early Pliocene.

Note: Uvigerina auberiana occurs commonly throughout Core 2; it is replaced by $U$. peregrina in Core 1 above.

Sample 12-116-3-0, 19-22 cm:

PF: Globigerina atlantica, G. bulloides, Orbulina universa,

BF: Varied including Cibicidoides pseudoungeriana, $C$ kullenbergi, Eponides umbonatus, Uvigerina auberiana, U. peregrina, Gyroidina soldanii, Planulina bradii, $P$. weullerstorfi, Laticarinina halophora, Sigmoilopsis schlumbergeri, nodosariids, dentalinids stilostomellids.

Also present: Echinoid spines, sponge spicules, ostracods (rare).

Age: Late Miocene.

Sample 12-116-3-1, 144-147 cm:

Data same as for preceding sample above.

Sample 12-116-3-2, 140-143 cm:

PF: Globigerina atlantica, Globigerina bulloides, Globorotalia margaritae, Orbulina universa.

BF: $\quad$ As above.

Age: Late Miocene.

Sample 12-116-3-3, 142-145 cm:

PF: As above.

BF: $\quad$ As above, plus Eggerella propinqua.

Age: Late Miocene.

Sample 12-116-3-4, 140-143 cm:

PF: Globigerina atlantica, Globigerina bulloides, Orbulina universa, Globorotalia humerosa, Globorotalia margaritae.

BF: $\quad$ Essentially as above, Planulina bradii common.

Age: Late Miocene. 
Sample 12-116-3-5, $150 \mathrm{~cm}$ :

Data essentially same as for preceding sample.

Sample 12-116-3-6, 140-143 cm:

Data essentially same as above.

Sample 12-116-3, Core Catcher:

PF: $\quad$ Globigerina atlantica, Globigerina bulloides, Globorotalia acostaensis, $G$. humerosa, $G$. scitula, Orbulina universa.

BF: $\quad$ Cibicidoides pseudoungeriana, C. kullenbergi, $C$. robertsoniana, Planulina wuellerstorfi, $P$. bradii, Laticarinina halophora, Eponides umbonatus, E. tenera, Gyroidina neosoldanii, Uvigerina auberiana, $U$. schwageri, U. gaudryinoides, Karreriella bradyi, Eggerella bradyi, Martinottiella bradyana, Sigmoilopsis schlumbergeri, Stilostomella sp., dentalinids, nodosariids.

Also present: Sponge spicules, echinoid spines, ostracods.

Age: Late Miocene.

Sample 12-116-4-1, 143-146 cm:

PF: $\quad$ Coarse fraction, sieve no. 100 (149 mm opening): only Globigerina bulloides; fine fraction $149 \mathrm{~mm}$ opening, Globorotalia acostaensis, Globorotalia sp. cf. G. scitula.

BF: $\quad$ Fauna as in Core 3, Core Catcher plus Cibicidoides cicatricosa, Sphaeroidina bulloides, Cassidulina subglobosa.

Age: Late Miocene.

Sample 12-116-4-2, 142-145 cm:

PF: As above, Orbulina universa (dominant, abundant); few G. acostaensis - humerosa.

BF: As above, uvigerinids not observed.

Also present: Sponge spicules, volcanic glass shards.

Age: Late Miocene.

Sample 12-116-4-3, 138-141 cm:

Data essentially the same as preceding sample above.

Sample 12-116-4-4, 135-138 cm:

PF: $\quad$ Globigerina bulloides, Globorotalia acostaensis, $G$. scitula, Orbulina universa.

BF: $\quad$ Rich, diverse, as Sample 12-116-3 Core Catcher (above).

Age: $\quad$ Late Miocene

Sample 12-116-4-5, 141-144 cm:

Data essentially same as above.

Sample 12-116-4-6, 142-144 cm:

Data essentially same as above.

Sample 12-116-4, Core Catcher:

PF: Globorotalia acostaensis, G. humerosa, G. scitula, Globigerina bulloides, G. atlantica, Orbulina universa.

BF: $\quad$ Same fauna as Sample 12-116-3, Core Catcher; Uvigerina auberiana common.

Age: Late Miocene.

Remarks: Typical $G$. atlantica occurs in Core Catcher sample of Core $4 ; G$. humerosa-acostaensis forms occur also.

Sample 12-116-5-0, Bottom:

PF: Globigerina praebulloides (dominant, abundant) $G$. bulloides, $G$. decoraperta, Globorotalia miozea conoidea, $G$. sp. cf. G. subscitula, G. acostaensis.

BF: Rich diverse, including Cibicidoides pseudoungeriana, C. kullenbergi, Anomalinoides globulosa, $A$. cicatricosa, Gyroidina neosoldanii, Melonis barleeanum, Sigmoilopsis schlumbergeri, Laticarinina halophora, Uvigerina auberiana, Pullenia sp., Planulina bradii, Cassidulina subglobosa, Martinottiella bradyana, Eponides umbonatus.

Also present: Sponge spicules, Radiolaria common.

Age: $\quad$ Late Miocene (probably Zone N16).

Sample 12-116-5-1, 53-56 cm:

Planktonic and benthonic fauna essentially same as in preceding sample above; $G$. decoraperta not observed.
Also present: Abundant spicules and radiolaria, ostracods present. Age: $\quad$ Late Miocene (probably Zone N16).

Sample 12-116-5-2, 138-141 cm:

PF: Essentially same as above; inflated, sinuous or cap-like bulla(e) develop on some high-spired globigerinid forms giving a superficial resemblance to Globoquadrina altispira or Globigerina gortanii.

BF: $\quad$ Essentially as above plus Cibicidoides robertsoniana, Planulina wuellerstorfi.

Also present: Abundant spicules and Radiolaria; ostracods present. Age: $\quad$ Late Miocene (probably Zone N16).

Sample 12-116-5-3, 119-122 cm:

Data essentially similar to above; Globigerina zealandica Hornibrook (hispid surface, umbilical "teeth").

Sample 12-116-5-4, 130-133 cm:

PF: As above plus Globigerina zealandica, Orbulina universa.

BF: $\quad$ As above, rich, diverse.

Age: Late Miocene,

Sample 12-116-5-5, 140-143 cm:

Data essentially same as above; $G$. atlantica.

Age: Late Miocene.

Sample 12-116-5-6, Bottom:

Data essentially same as above.

Age: Late Miocene.

Sample 12-116-5, Core Catcher:

PF: $\quad$ Globigerina praebulloides, G. bulloides, G. apertura, G. foliata, Globorotalia acostaensis, G. continuosa, Globorotalia miozea

BF: $\quad$ As above, rich diverse; see faunal list given for Sample 12-116-5-0, Bottom, and remarks under individual samples above, plus Karreriella bradyi, stilostomellids, pleurostomellids, nodosariids, dentalinids.

Also present: Abundant sponge spicules, Radiolaria; ostracods common.

Age: $\quad$ Late Miocene (probably low N16).

Remarks: Core 5, Hole 116 is characterized by a rich and diversified benthonic fauna and a rich, though relatively monotonous, planktonic foraminiferal fauna. The characteristic elements here include a group of globigerinids referred to Globigerina bulloides, $G$. praebulloides and $G$. apertura. $G$. praebulloides is the dominant form. These forms exhibit the morphologic characters and variation mentioned by Lipps (1964, p. $117)$ to occur in the group to which he referred $G$. bulloides, $G$. dubia and $G$. quadrilatera. Most of the forms in Core 5 agree well with $G$. quadrilatera as figured by Lipps (op. cit.), but comparison with the holotype specimen of $G$. quadrilatera has shown that Lipps' specimen is not referable to quadrilatera. We refer these forms to praebulloides. In Core 4 and above the forms are more typical of $G$. bulloides. Globorotalia miozea conoidea occurs in the upper portion of this core (Sections 0, 1-3) but was not observed in the lower portion (Sections 4-6and the Core Catcher sample). The association of these forms together suggests that Core 5 is of Tortonian age and equivalent to the middle of Zone N16.

Sample 12-116-6-1, 141-143 cm:

PF: $\quad$ Globigerina praebulloides, Globorotalia acostaensis, Globigerina obesa, Sphaeroidinellopsis seminulina, S, subdehiscens, Globorotalia menardii, Globoquadrina dehiscens, Orbulina universa.

BF: $\quad$ Rich, diverse (essentially same as in Core 5; see list above).

Also present: Sponge spicules, radiolarians.

Age: $\quad$ Tortonian (Late Miocene).

Sample 12-116-6-2, 143-145 cm:

PF: $\quad$ Globigerina praebulloides, Globorotalia acostaensishumerosa group, Globorotalia miozea, Globigerina spp. indet., Globoquadrina dehiscens.

BF: Diverse, abundant, as above and in Core 5, Planuline bradii common.

Age: $\quad$ Middle-Late Miocene. 
Sample 12-116-6-3, 143-146 cm:

PF: Globigerina praebulloides (abundant, dominant, about 90 per cent of planktonic fauna), Globigerina sp., Globorotalia miozea, G. menardii.

BF: Rich, diverse, as above; plus Saracenaria italica, Planulina bradii common.

Age: $\quad$ Middle-Late Miocene.

Sample 12-116-6-4, 138-141 cm:

$\mathrm{PF}$ and $\mathrm{BF}$ fauna as above; keeled globorotaliids not observed.

Age: Middle Miocene.

Sample 12-116-6, Core Catcher:

PF: $\quad$ Globigerina praebulloides (dominant, abundant), $G$. foliata, $G$. sp. cf. G. druryi, Globoquadrina acostaensis, G. dehiscens, Orbulina universa, Globorotalia miozea, Sphaeroidinellopsis seminulina, S. subdehiscens.

BF: $\quad$ Eponides umbonatus, Planulina bradii (common), Karreriella bradyi, Laticarinina halophora, Gyroidina neosoldanii.

Also present: Abundant sponge spicules; Radiolaria and ostracods. Age: $\quad$ Middle-Late Miocene (probably lower Zone N16).

Remarks The presence of Globorotalia menardii indicates that the bottom of Core 6 is not older than Zone N14. The presence of Globigerina apertura and of forms assigned here to G. acostaensis suggest that Core 6 is within Zone N16.

Sample 12-116-7-0, Bottom:

PF: Very rich (high $\mathrm{P}: \mathrm{B}$ ratio) including, $i$, al., Globigerina praebulloides (dominant, abundant), G. apertura, $G$. nepenthes, Orbulina universa, Globorotalia cultrata (circular outline, thick keel), G. menardii (elongateoval outline), Globorotalia sp. cf. G. scitula (Blow, 1969 , pl. 39, Fig. 4, 10) Globigerinoides triloba, Globigerinoides sp. (high, broad primary aperture; diminutive supplementary aperture), Sphaeroidinellopsis subdehiscens, Globoquadrina dehiscens.

BF: Relatively rich, containing, $i$ al., Eponides umbonatus, Planulina bradii, P. wuellerstorfi, Stilostomella sp., Dorothia sp. Laticarinina halophora, Uvigerina auberiana, Cibicidoides pseudoungeriana, C. kullenbergi, Anomalinoides cicatricosa, Gyroidina neosoldanii, Cassidulina subglobosa.

Also present: Sponge spicules, Radiolaria, ostracods.

Age: $\quad$ Middle-Late Miocene (? N16).

Sample 12-116-7-1, 138-141 cm:

PF: $\quad$ Orbulina universa (dominant, common) Globigerina sp., Globorotalia aff. acostaensis, G. continuosa, $G$. miozea, Globigerina nepenthes (common), GloBF: As above.

Also present: Abundant volcanic scoria and glass.

Age: $\quad$ Middle Miocene (probably Zone N14-N15).

Sample 12-116-7-2, 140-143 cm:

PF: $\quad$ Globigerina praebulloides, G. druryi, Globorotalia aff. acostaensis, G. continuosa, Globorotalia sp. (lowconical, keeled), Globoquadrina dehiscens, Orbulina universa, Globigerinoides obliqua, Globigerinoides sp. (Globigerina nepenthes not observed).

BF: In general, as above, but not as diverse nor as rich (higher P:F ratio).

Age: $\quad$ Middle Miocene (probably Zone N14-N15).

Sample 12-116-7-3, 146-149 cm:

Data essentially same as preceding sample above; $G$. nepenthes not observed.

Age: $\quad$ Middle Miocene (probably Zone N14-N15).

Sample 12-116-7-4, Bottom:

PF: $\quad$ Essentially same as samples above; plus Globigerina nepenthes, Globorotalia siakensis (one specimen), $G$. miozea.

BF: $\quad$ As above.

Also present: Volcanic scoria and glass.

Age: $\quad$ Middle Miocene (probably Zone N14-N15).
Sample 12-116-7-5, Bottom:

PF: $\quad$ Globigerina praebulloides, Globorotalia continuosa (abundant), G. sp. aff. acostaensis, G. miozea, Sphaeroidinellopsis subdehiscens (common).

BF: $\quad$ Rich, diverse, as above.

Age: $\quad$ Middle Miocene (Zone N14-N15).

Sample 12-116-7-6, 133-136 cm:

PF: Globorotalia continuosa $G$ aff. acostaensis, Globigerina sp. cf. G. atlantica (dextral), Globigerina praebulloides, $G$. foliata.

BF: $\quad$ Essentially as above.

Also present: Sponge spicules, ostracods.

Age: $\quad$ Middle-Late Miocene (Zone N15-N16),

Sample 12-116-7, Core Catcher:

PF: Globorotalia aff, acostaensis (dextral), Globorotalia sp. cf. G. scitula (Blow, 1969, pl. 39, figs. 4, 10), Globigerina praebulloides (rare), $G$. bulbosa, Globigerinoides triloba, Globoquadrina dehiscens, Orbulina universa, Sphaeroidinellopsis subdehiscens. BF: Cibicidoides pseudounderiana, C. kullenbergi, Cassidulina subglobosa, Pullenia bulloides, $P$. subcarinata, Gyroidina neosoldanii, G. complanata, Cibicides sp., Lenticulina sp., dentalinids, nodosariids, Eponides tener, E. umbonatus, Laticarinina halophora, Uvigerina auberiana (common), Anomalinoides cicatricosa, Planulina bradii.

Also present: Sponge spicules, ostracods.

Age: $\quad$ Middle-Late Miocene (N15-N16).

Remarks: Core 7 is characterized by $4-5$ chambered forms here assigned to Globorotalia aff. acostaensis. The occurrence of Globigerina nepenthes (Sections 0,1,3,4)(Range Zone N14-N19) and Sphaeroidinelopsis subdehiscens (Range N13-N20) indicate that this core is no older than Zone N14 (Serravallian; Middle Miocene). The occurrence of forms assigned to $G$. aff acostaensis and of several specimens of a compressed globorotaliid identified as Globorotalia sp. cf. G. scitula (which Blow, 1969, p. 356, indicates occurring only in the lower to middle parts of Zone N16) would support an age determination of Zone N16 or Tortonian, Late Miocene. Since the changes observed in the faunas here are gradual and subtle, it may be that the exact relationships of ranges of several taxa are not yet completely understood; alternatively the writer's taxonomy may be at fault. For the present an age assignment of Middle Miocene (pre-Tortonian, approximately equivalent to Zone N14-N15) is made for all of Core 7.

Sample 12-116-8-2, 142-145 cm:

PF: $\quad$ Globigerina praebulloides, Globorotalia continuosa, G. sp. aff. acostaensis, G. miozea (common).

BF: $\quad$ Eponides tener, $E$. umbonatus, Planulina bradii (common), Unigerina rutila, Cibicidoides kullengergi, Melonis barleeanum, Gyroidina sp., Lenticulina sp., nodosariids.

Also present: Radiolarians.

Age: $\quad$ Lower-Middle Miocene.

Note: This sample is characterized by the uncommonly high frequency of specimens of Globorotalia miozea.

Sample 12-116-8-3, 143-146 cm:

PF: Essentially same as above with $G$. praebulloides, $G$. acostaensis, G. miozea present; also Globorotalia sp. cf. G. cultrata.

BF: Essentially as above, plus Gyroidina neosoldanii, Laticarinina halophora.

Age: $\quad$ Early-Middle Miocene.

Sample 12-116-8, Core Catcher:

PF: $\quad$ Globigerina praebulloides, G. praebulloides pseudo ciperoensis, Globigerina parabulloides, Globigerina sp. (bullate), G. zealandica, Globorotalia siakensis (top), G. continuosa, G. miozea, Globorotaloides variabilis, Orbulina universa.

BF: Laticarinina halophora, Eponides umbonatus, Cibicidoides kullenbergi, Planulina wuellerstorfi, P. bradii, P. sp.

Also present: Sponge spicules, Radiolaria.

Age: $\quad$ Middle Miocene. 
Remarks: Core 8 is characterized by a variety of globigerinids and non-keeled globorotaliids which are difficult to distinguish taxonomically. The forms identified as Globigerina pseudociperoensis are similar to specimens identified as Globigerina dubia by Lipps (1964, pl. 1, figs. 5a-c) from the Luisian Stage of California. The presence of Globorotalia siakensis (ranges to Zone N14), Orbulina universa (appears at base Zone N9) and absence of Globigerina nepenthes (appears at base Zone N14) suggests that Core 8 is older than Zone N14; from evidence in Cores 9 and 10 (see below) we know it is younger than Zone N9. Tentative correlation with Zone N12-N13 is made here. Globorotalia miozea is quite common at some levels in Core 8.

\section{Sample 12-116-9-1, 139-142 cm:}

PF: $\quad$ Praeorbulina glomerosa circularis (common), Orbulina suturalis, Globigerina praebulloides, G. sp., Globorotalia peripheroacuta, $G$. praemenardii (exhibiting similarities to $G$. archeomenardii), $G$. siakensis, Globoquadrina baroemoenensis $(=? G$. langhiana), Globigerinoides triloba.

BF: $\quad$ Planulina wuellerstorfi (common), Siphonina tenuicarinata (top), Bulimina sp., Eggerella bradyi, Lenticulina sp., Eponides tener, Sphaeroidina bulloides, Gyroidina neosoldanii.

Also present: Abundant Radiolaria; ostracods, echinoid spines. Age: $\quad$ Middle Miocene (Zone N9/10).

Note: This sample contains the highest occurrence of Globototalia peripheroacuta appears base Zone N10) and Praeorbulina glomerosa circularis (ranges to upper part of Zone N9). Actually, $G$. peripheroacuta may range upward in the stratigraphic section between Cores 9 and 8; it was not observed elsewhere in Core 9. This may be a basal occurrence rather than an upper occurrence. Sample is dated Middle Miocene, approximately Zone N9/N10 boundary. This sample also contains the highest occurrence of Siphonina tenuicarinata, a distinctive and dominant component of Lower Miocene assemblages at this site (see below).

Sample 12-116-9-2, 142-144 cm:

PF: $\quad$ Essentially as above; $G$. praemenardii common; plus Globoquadrina altispira.

BF: $\quad$ Essentially as above, plus Gyroidina complanata.

Age: $\quad$ Middle Miocene (Zone N9-N10).

Sample 12-116-9-3, 137-140 cm:

PF: Essentially as above; Globorotalia praemenardii common; some forms show relationship to G. miozea; Globoquadrina dehiscens also present.

BF: As above; Planulina wuellerstorfi common to abundant.

Also present: Abundant sponge spicules, Radiolaria, ostracods.

Age: Middle Miocene (Zone N10).

Sample 12-116-9, Core Catcher:

PF: Orbulina suturalis, Praeorbulina glomerosa curva, Globorotalia praemenardii, G. aff. miozea, Globigerina spp., Globoquadrina dehiscens.

BF: Gyroidina neosoldanii, G. complanata, Planulina wuellerstorfi, Siphonina tenuicarinata, Eponides umbonatus.

Also present: Abundant radiolarians, spicules.

Age: $\quad$ Middle Miocene (Zone N9-N10).

Remarks: Core 9 is characterized by the common occurrence of Globorotalia praemenardii (range: Zone N10-within Zone N12) and Praeorbulina glomerosa circularis (range latest part Zone N8 to upper part Zone N9). The age of Core 9 is interpreted here as Middle Miocene (equivalent to the latest part of Zone N9-earliest part Zone N10). Siphonina tenuicarinata, a common element in the Lower Miocene sediments at this site, has its highest occurrence within this core (Section 1).

Sample 12-116-10-0, Top:

PF: Orbulina suturalis, Praeorbulina glomerosa circularis, Globoquadrina dehiscens, G. baroemoenensis, Globorotalia praescitula, Globorotalia spp., Globigerina parabulloides, Globigerina spp., Globigerinoides triloba, G. sicana.
BF:

Siphonina tenuicarinata (dominant, common), Planulina renzi (top occurrence), Planulina sp. (robust, biconvex), Cibicidoides sp. aff. pseudoungeriana, Anomalinoides cicatricosa, Oridorsalis ecuadorensis, Pleurostomella sp.

Also present: Abundant Radiolaria, sponge spicules; ostracods common.

Age: $\quad$ Middle Miocene (Zone N9).

Sample 12-116-10-0, Bottom:

$\mathrm{PF}$ and BF: Essentially same as preceding sample above, plus Gyroidina jarvisi (top occurrence).

Age: $\quad$ Middle Miocene (Zone N9).

Sample 12-116-10-1, 87-91 cm:

$\mathrm{PF}$ and BF: Essentially same as above; plus Sphaeroidinellopsis seminulina and Planulina subtenuissima.

Age: $\quad$ Middle Miocene (Zone N9).

Sample 12-116-10-1, 140-144 cm:

Data essentially same as above.

Age: $\quad$ Middle Miocene (Zone N9).

Sample 12-116-10-2, 43-49 cm:

PF: $\quad$ Orbulina suturalis, Praeorbulina glomerosa circularis, P. transitoria, Globigerinoides triloba, G. sicana, Globigerina praebulloides, G. spp., Globoquadrina altispira, G. dehiscens, G. baroemoenensis, Globorotalia praescitula.

BF: As above.

Age: $\quad$ Middle Miocene (Zone N9).

Sample 12-116-10-2, 135-138 cm:

PF: As above, plus Praeorbulina glomerosa glomerosa (top occurrence).

BF: As above.

Age: $\quad$ Middle Miocene (Zone N9).

Sample 12-116-10-3, 62-65 cm:

PF: $\quad$ As above, plus Praeorbulina glomerosa curva (top occurrence), $P$. transitoria, $O$. suturalis (first occurrence).

BF: $\quad$ As above; Siphonina tenuicarinata and Cibicidoides pseudoungeriana common; Planulina renzi also a distinctive element.

Age: $\quad$ Middle Miocene (basal Zone N9).

Sample 12-116-10-3, 143-146 cm:

All data essentially same as above; $P$. glomerosa circularis (first occurrence)

Age: Latest Early Miocene (top Zone N8).

Sample 12-116-10-4, 31-34 cm:

Data essentially same as above.

Age: Late Early Miocene (top Zone N8).

Sample 12-116-10-4, 140-143 cm:

Data essentially same as above.

Age: Late Early Miocene (top Zone N8).

Sample 12-116-10-5, 60-63 cm:

Data essentially same as above.

Age: Late Early Miocene (Zone N8).

Sample 12-116-10-5, 137-140 cm:

Data essentially same as above; plus Anomalina pompilioides (top occurrence); Praeorbulina glomerosa glomerosa (first occurrence).

Age: $\quad$ Late Early Miocene (Zone N8).

Sample 12-116-10-6, 62-65 cm:

Data essentially same as above.

Age: $\quad$ Late Early Miocene (Zone N8).

Sample 12-116-10-6, 141-144 cm:

Data essentially same as above.

Age: $\quad$ Late Early Miocene (Zone N8).

Sample 12-116-10-6, Core Catcher:

PF: $\quad$ Praeorbulina glomerosa curva, Globigerinoides triloba, G. sicana, Globigerina praebulloides, Globigerina sp., Globoquadrina dehiscens, G. altispira, G. baroemoenensis, Sphaeroidinellopsis seminulina. 
Siphonina tenuicarinata (dominant, common), Cibicidoides pseudoungeriana, C. atratiensis (top), Planulina renzi, Planulina sp. aff. wuellerstorfi, Planulina subtenuissima, Gyroidina complanata, $G$. girardana, Anomalina pompilioides, A. alazanensis, Oridorsalis ecuadorensis, Sphaeroidina bulloides, Lenticulina sp. aff. plummerae, $L$. sp.

Age: $\quad$ Late Early Miocene (Zone N8).

Remarks: Core 10 is unique and extremely interesting. Almost the complete evolutionary sequence leading from Globigerinoides sicana to Orbulina suturalis occurs within the 9-meter interval of this core. The more significant aspects of this core are listed below:

1. The first evolutionary appearance of Orbulina $(O$. suturalis) occurs within Section 3; the boundary between Zones N8 and N9 is drawn here.

2. In the lower part of the core (Section 6 and Core Catcher) Globigerinoides triloba and $G$. sicana are common: there is a marked upward decrease in both these taxa as the praeorbulinids develop.

3. In Section 6 and the Core Catcher only Praeorbulina glomerosa curva and some forms transitional between Globigerinoides sicana and $P$. glomerosa curva occur.

4. Sections 2 through 5 are characterized by abundant specimens of Praeorbulina glomerosa glomerosa and P. glomerosa circularis; $P$. glomerosa circularis (which appears in Section 3 ) ranges to the top of Core 9 so that its approximate upward stratigraphic range can be estimated.

5. A rich and diversified benthonic foraminiferal fauna occurs in this core. The last (youngest) occurrence of several long-ranging and stratigraphically important species occurs within this core; Planulina renzi, P. subtenuissima, Gyroidina jarvisi, Anomalina pompilioides, Cibicidoides atratiensis.

6. A significant shift in faunal elements can be seen in this core from those with Oligocene-early Miocene affinities (below) to late Neogene types (above).

7. Radiolarians and siliceous sponge spicules are common to abundant throughout this core.

Sample 12-116-11-0, Top:

PF: $\quad$ Globoquadrina dehiscens, G. baroemoenensis, Sphaeroidinellopsis seminulina, Globigerina praebulloides, $G$. obesa.

BF: Siphonina tenuicarinata (dominant, common), Pyrulina sp., Uvigerina rustica (top occurrence), Melonis barleeanum, Gyroidina girardana, Sphaeroidina bulloides, Cibicidoides sp. aff. pseudoungeriana.

Also present: Organogenic fragments composed of bryozoans, foraminifera.

Age: $\quad$ Early Miocene (Late Burdigalian).

Note: Presence of $S$. seminulina (first appearance in Zone N6) and absence of Praeorbulina (appears near base Zone N8) suggests that this level is equivalent to Zones N6 or N7. From other evidence (see below) this level (and core) is correlated with Zone N7.

Sample 12-116-11-0, Bottom:

PF: $\quad$ Sphaeroidinellopsis seminulina (dominant, abundant), globoquadrinids and globigerinids (see above) subordinate.

BF: $\quad$ As above, plus Planulina renzi, Anomalina sp.

Age: $\quad$ Early Miocene (Late Burdigalian).

Sample 12-116-11-1, Bottom:

Data essentially same as above; $S$. seminulina abundant.

Age: $\quad$ Early Miocene (Burdigalian).

Sample 12-116-11-2, 142-145 cm:

PF: $\quad$ As in preceding sample, few Globorotalia siakensis.

BF: As above, plus Anomalinoides cicatricosa; Melonis

pompilioides, Siphonina tenuicarinata not observed.

Age: $\quad$ Early Miocene (Burdigalian).

Sample 12-116-11-3, Bottom:

$\mathrm{PF}$ and $\mathrm{BF}$ : As in preceding sample above: benthonics, including Siphonina tenuicarinata, generally reduced in size. Recrystallized, indurated pieces of organogenic limestone common.

Age:
Sample 12-116-11-4, Bottom:

$\mathrm{PF}$ and $\mathrm{BF}$ : As in preceding sample above.

Age: $\quad$ Early Miocene (Burdigalian).

Sample 12-116-11-5, Bottom:

$\mathrm{PF}$ and $\mathrm{BF}$ : As above. Organogenic limestone, moderately indurated.

Age: $\quad$ Early Miocene (Burdigalian).

Sample 12-116-11-6, 140-143 cm:

PF and BF: Essentially same as above; preservable elements rarer than above as larger amounts organogenic limestone fragments and recrystallized limestone present.

Age: $\quad$ Early Miocene (Burdigalian).

Sample 12-116-11, Core Catcher:

PF: $\quad$ Rare in 125-micron fraction, common in 63-micron fraction; preservation fair to poor. Sphaeroidinelle seminulina, Globoquadrina dehiscens, $G$. baroemoenensis, Globigerina praebulloides, Globigerina spp.

BF: Small, specifically indeterminate; cibicidids, anomalinids, bolivinids, siphoninids.

Also present: Organogenic detritus, recrystallized limestone and scattered glauconite and (?) phosphatic grains; foraminifera replaced by glauconite in some instances. Early Miocene (Burdigalian).

Age: $\quad$ This core shows a marked gradation upward from partially indurated organogenic limestone (with recrystallized fragments) to a relatively pure foraminiferal-nannofossil ooze. The lithologic sequence represents a foraminiferal-nannofossil ooze exhibiting decreasing degree of lithification upwards. In the upper part (Sections 1 and 2) Sphaeroidinellopsis seminulina is abundant and the globoquadrinids form a minor component of the planktonic foraminiferal assemblage. The presence of $S$. seminulina and absence of Praeorbulina suggest that Core 11 is within the interval of Zones N6-N7. The core is assigned a late Early Miocene age (Zone N7 equivalent) on the basis of the last (youngest) occurrence of Globigerinita dissimilis (which is within Zone N6) in Core 13 (see below).

Sample 12-116-12-1, 144-147 cm:

PF: Globoquadrina dehiscens (dominant, common), $G$. baroemoenensis, Sphaeroidinellopsis seminulina, Globorotaloides suteri, Globorotalia birnageae, $G$. semivera.

BF: Siphonina tenuicarinata (dominant, common), Gyroidina girardana, Lenticulina sp., Siphogenerina multicostata, Anomalina alazanensis, Cibicides sp.

Age: $\quad$ Early Miocene (Burdigalian).

Sample 12-116-12-2, 143-146 cm:

PF: Abundant planktonic foraminifers (but low species diversity) including Globorotaloides suteri, Globoquadrina dehiscens, Globorotalia siakensis, (abundant, dominant), Globigerina spp.

BF: As above; also Gyroidina jarvisi, Uvigerina Age: $\quad$ Early Miocene (Burdigalian).

Sample 12-116-12-3, 135-138 cm:

Data essentially same as above.

Age: $\quad$ Early Miocene (Burdigalian).

Sample 12-116-12-4, 124-127 cm:

PF: $\quad$ Essentially same as above, including Globorotalia birnageae, and $G$. semivera.

BF: $\quad$ Essentially as above.

Age: $\quad$ Early Miocene (Burdigalian).

Sample 12-116-12-5, Bottom:

PF: Globoquadrina dehiscens, G. baroemoenensis, Globorotalia siakensis, G. semivera, G. birnageae, Globorotaloides suteri, Globigerina sp.

BF: Rich, diverse fauna including, $i$ al., Siphonina tenuicarinata, (dominant, abundant), Gyroidina girardana, G. jarvisi, Lenticulina sp., Anomalina alazanensis, Planulina renzi, Uvigerina basicordata, Stilostomella curvatura.

Age: $\quad$ Early Miocene (Burdigalian). 
Sample 12-116-12-6, 143-146 cm:

PF: As above.

BF: As above, plus Siphogenerina multicostata.

Age: $\quad$ Early Miocene (Burdigalian).

Sample 12-116-12, Core Catcher:

PF: Globoquadrina dehiscens, G. baroemoenensis, Globorotalia birnageae, Globorotaloides suteri, Globigerina sp.

BF: Siphonina tenuicarinata (dominant, common), Gyroidina girardana, G. jarvisi, Planulina renzi, Anomalina alazanensis, Cassidulina sp.

Also present: Abundant sponge spicules and pyrite.

Age: $\quad$ Early Miocene (Burdigalian).

Remarks: Core 12 is characterized by the occurrence of abundant globoquadrinids throughout. The common occurrence of Globorotalia birnageae and Globorotaloides suteri suggest that Core 12 is of Early Miocene (Burdigalian) age, approximately equivalent to Zone N7 of Blow. Sphaeroidinellopsis seminulina was not observed in Core 12. Samples within this core contain a rich planktonic and benthonic fauna which are well preserved; Siphonina tenuicarinata is the dominant benthonic form throughout the core. Sample 12-116-13, Core Catcher:

PF: $\quad$ Globoquadrina sp. cf. G. dehiscens, Globigerinita dissimilis, Globorotaloides suteri, Globigerina sp.

BF: Sparse, including Planulina renzi, Vulvulina sp. cibicidids, Oridorsalis ecuadorensis, Gyroidina jarvisi.

Also present: Radiolaria, spicules.

Age: $\quad$ Early Miocene (Aquitanian-Burdigalian).

Remarks: Only the Core Catcher was recovered from Core 13 . The sample is chalky, specimens few and mostly broken, preservation generally poor to fair. Presence of single specimen of Globigerinita dissimilis suggests Core 13 is at or near Zone N6/N7 boundary (i.e., extinction of $G$. dissimilis).

Sample 12-116-14, Core Catcher:

PF: $\quad$ Sparse, small globoquadrinids and globigerinids.

BF: $\quad$ Sparse, Siphonina tenuicarinata.

Also present: Abundant Radiolaria, sponge spicules.

Age: $\quad$ Early Miocene (Aquitanian) (See above, Core 13).

Remarks: Only the Core Catcher and 1.10 centimeter of sediment in section were recovered from Core 14. The sediments are siliceous (Radiolaria) and nannoplankton ooze; foraminifera are scarce and generally small.

Sample 12-116-15-1, 141-143 cm:

PF: Globoquadrina baroemoenensis, G. dehiscens, Globigerinita dissimilis.

BF: Siphonina tenuicarinata, Gyroidina complanata, Planulina renzi, Anomalina alazanensis, Oridorsalis ecuadorensis.

Also present: Abundant Radiolaria and sponge spicules.

Age: $\quad$ Early Miocene (Aquitanian); Zone N6.

Sample 12-116-15-3, 144-147 cm:

Data essentially same as for preceding sample above; sample is a nannofossil-radiolarian ooze.

Age: $\quad$ Early Miocene (Aquitanian); Zone N6.

Sample 12-116-15-5, 146-149 cm:

Data as above; nannofossil-radiolarian ooze; Globoquadrina baroemoenensis present to the exclusion of $G$. dehiscens; $G$. dissimilis present.

Age: $\quad$ Early Miocene (Aquitanian); Zone N6.

Sample 12-116-15-6, 142-145 cm:

Data essentially same as above plus Globoquadrina praedehiscens (highest occurrence observed). Anomalinoides pompilioides present. Age: $\quad$ Early Miocene (Aquitanian); Zone N6.

Sample 12-116-15, Core Catcher:

PF: Globoquadrina baroemoenensis, G. praedehiscens, Globigerinita dissimilis.

BF: Siphonina tenuicarinata, Gyroidina complanata, $G$. girardana, Planulina renzi, Oridorsalis ecuadorensis, cibicidids.

Age: Early Miocene (Aquitanian); Zone N6.
Remarks: Core 15 is a radiolarian-nanno fossil ooze. Planktonic foraminifera play a subordinate role in this core. Characteristic forms include Globoquadrina baroemoenensis and Globigerinita dissimilis. The youngest occurrence of $G$. praedehiscens in this hole was observed in Section 6, suggesting that this core is equivalent to Zone N6. The benthonic foraminiferal fauna is essentially the same as in Cores 11 through 14 above.

Sample 12-116-16-2, 131-134 cm:

PF: $\quad$ Globoquadrina baroemoenensis, G. praedehiscens, $G$. venezuelana, Globigerinita dissimilis.

BF: Siphonina tenuicarinata, Gyroidina girardana Lenticulina sp., Anomalina alazanensis, polymorphinids.

Also present: Abundant radiolarians and sponge spicules.

Age: $\quad$ Early Miocene (Aquitanian).

Sample 12-116-16-4, 136-139 cm:

PF: Globoquadrina praedehiscens (common, dominant), $G$. baroemoenensis, $G$. venezuelana, Globigerinita unicava, $G$. dissimilis.

BF: As above.

Age: $\quad$ Early Miocene (Aquitanian)

Sample 12-116-16, Core Catcher:

PF: $\quad$ Globoquadrina praedehiscens, G. baroemoenensis, $G$. venezuelana, Globigerinita dissimilis.

BF: Siphonina tenuicarinata, Planulina renzi, Gyroidina girardana.

Age: $\quad$ Early Miocene (Aquitanian).

Remarks: Core 16 is a radiolarian-nannofossil ooze and is characterized by the common occurrence of forms here referred to Globoquadrina praedehiscens and $G$. venezuelana. This association is of Early Miocene (Aquitanian) age and is probably equivalent to Zone N6.

Sample 12-116-17-4, 141-144 cm:

PF: $\quad$ Globoquadrina praedehiscens, $G$. venezuelana, $G$. baroemoenensis, G. dehiscens, Globigerina praebulloides.

BF: Siphonina tenuicarinata (dominant, common), Gyroidina girardana, Anomalina alazanensis, Oridorsalis ecuadorana, cibicidids, polymorphinids.

Age: $\quad$ Early Miocene (Aquitanian)

Sample 12-116-17-6, 141-144 cm:

Data essentially same as for preceding sample above.

Sample 12-116-17, Core Catcher:

PF: $\quad$ Globoquadrina praedehiscens, G. dehiscens, Globigerina praebulloides.

BF: $\quad$ Siphonina tenuicarinata, Oridorsalis ecuadorensis, Planulina renzi, Gyroidina girardana, stilostomellids, lagenids, cibicidids, polymorphinids.

Age: $\quad$ Early Miocene (Aquitanian).

Remarks: Core 17 is a nannofossil-radiolarian ooze (see remarks above under Cores 13 through 16). Globoquadrina praedehiscens occurs commonly throughout the interval examined (Sections 4,6 , Core Catcher; Sections 1-3 and 5 were not split). The benthonic forms Siphonina tenuicarinata and Oridorsalis ecuadorensis occur commonly. Core 17 is of Early Miocene (Aquitanian-Burdigalian) age equivalent to Zone N6 or N5.

Sample 12-116-18-4, 143-146 cm:

PF: $\quad$ G. baroemoenesis, Globorotaloides suteri, Globigerina woodi, small globigerinids.

BF: $\quad$ Planulina renzi, Lenticulina sp.

Also present: Radiolaria and sponge spicules.

Age: Early Miocene.

Sample 12-116-18, Core Catcher:

$\mathrm{PF}$ : Globoquadrina baroemoenesis (common, dominant),

G. praedehiscens, Globigerinita dissimilis.

BF: Cibicidoides trincherasensis, Cibicidoides sp., Anomalina pompilioides, Siphonina tenuicarinata, Pullenia sp., Planulina renzi.

Age: $\quad$ Early Miocene. 
Remarks: Six sections were recovered from Core 18, but only section 4 was opened due to the soft, soupy nature of the material. Globoquadrina baroemoenensis is the dominant planktonic foraminifer. Age diagnostic forms are, in general absent. Core 18 is probably of Early Miocene (Aquitanian-Burdigalian) age, equivalent to Zones N5 or N6.

Sample 12-116-19-1, 142-146 cm:

Sample is chalky and there are few disaggregated foraminifera. Globoquadrinids, cibicidids and Siphonina tenuicarinata occur.

Age: Oligocene-Miocene.

Sample 12-116-19-2, 69-72 cm:

PF: Globoquadrina baroemoenensis, Globorotaloides suteri, globigerinids.

BF: Siphonina tenuicarinata, Oridorsalis ecuadorensis, Uvigerina sp., cibicidids.

Also present: Sponge spicules, Radiolaria.

Age: Oligocene-Miocene.

Sample 12-116-19-5, 133-136 cm:

PF: As above.

BF: As above; Siphonina tenuicarinata common.

Age: Oligocene-Miocene.

Sample 12-116-19, Core Catcher:

PF: $\quad$ Globoquadrina baroemoenensis, G. praedehiscens, Globorotaloides suteri, Globigerina spp.

BF: Siphonina tenuicarinata, Cibicidoides trincherasensis, Gyroidina girardana.

Age: Oligocene-Miocene

Remarks: Only Sections 1,2 , and 5 were opened in Core 19. Disaggregated foraminifera are not abundant due to the relatively chalky matrix. A relatively homogeneous planktonic fauna occurs in the core and renders precise age determination difficult. The core is of Oligocene-Miocene age (radiolarians).

Sample 12-116-20-1, 116-119 cm:

Sample is a relatively well-cemented chalk with few disaggregated foraminifera. Globigerinids and globoquadrinids and Siphonina tenuicarinata present.

Age: $\quad$ Late Oligocene (see below).

Sample 12-116-20-5, 125-128 cm:

As above, plus indurated (? chert) fragments.

Age: Late Oligocene.

Sample 12-116-20, Core Catcher:

PF: Globoquadrina baroemoenensis, Globigerinita

BF: Siphonina tenuicarinata, Uvigerina sp.

Age: Late Oligocene.

Remarks: Only Sections 1 and 5 were opened in Core 20. Lack of diagnostic fauna and generally poor fauna renders age determination difficult. Core is Late Oligocene according to radiolarian evidence.

Sample 12-116-21-3, 130-133 cm:

PF: $\quad$ Globoquadrina baroemoenensis, Globigerina venezuelana, Globigerina spp., Globigerinita dissimilis, Globorotalia siakensis.

BF: $\quad$ Siphonina tenuicarinata, Cibicidoides trincherasensis, Oridorsalis ecuadorensis, Vaginulina sp., Gyroidina sp.

Age: Late Oligocene.

Sample 12-116-21-4, 135-137 cm:

PF: Globigerina sp., Globigerinita dissimilis, G. unicava, Globorotaloides suteri

BF: $\quad$ Sparse, Siphonina tenuicarinata.

Age: Late Oligocene.

Sample 12-116-21, Core Catcher:

PF: Globigerina venezuelana, Globigerina sp., Globorotaloides suteri, Globorotalia siakensis, Globigerinita dissimilis, G. unicava.

BF: $\quad$ Sparse, Siphonina tenuicarinata, Gyroidina girardana. Age: $\quad$ Late Oligocene.

Remarks: Only Sections 3 and 4 in Core 21 were split. Chert fragments occur commonly with the chalk. Diagnostic foraminifera are generally absent. Typical globoquadrinids, common above, are rare or absent in Core 21.
Sample 12-116-22-1, Bottom:

Sample appears to be contaminated (Orbulina).

Sample 12-116-22-2, Bottom:

PF: $\quad$ Small globigerinids, including Globigerina praebul-

loides, G. spp., Globigerinita dissimilis.

BF: Siphonina tenuicarinata.

Age: Late Oligocene.

Sample 12-116-22-3, Bottom:

PF: As above:

BF: As above, plus Cibicidoides mexicana (common, highest occurrence) Oridorsalis ecuadorensis.

Age: ?Late Oligocene.

Sample 12-116-22-4, Bottom:

Data as above.

Age: ?Late Oligocene.

Sample 12-116-22-5, Bottom:

Data same as above.

Sample 12-116-22-6, 144-147 cm:

Data same as above.

PF: $\quad$ Globigerinita unicava, G. dissimilis, Globoquadrina

praedehiscens, small globigerinids.

BF: Cibicidoides mexicana, Siphonina tenuicarinato (common), Oridorsalis ecuadorensis, C. trincherasensis, Planulina renzi, Anomalina pompilioides, Lenticulina spp., Vaginulina sp., Gyroidina girardana. Age: $\quad$ ?Late Oligocene.

Remarks: Core 22 was not split with the exception of Section 6. Samples were taken at the bottom of each section, however, and are from within Section 6 . These contain a rather uniform, low diversity planktonic foraminiferal fauna composed of globigerinids and globigerinitids indicating a ?Late Oligocene age. The highest occurrence of the distinct and relatively long-ranging benthonic form Cibicidoides mexicana was noted in this core (Bottom, Section $3)$. Chert fragments occur in all the samples studied from this core. Sample 12-116-23-0, Bottom:

PF: Globigerinita dissimilis (dominant, abundant), G. unicava, G. pera, Globorotalia opima nana.

BF: Siphonina tenuicarinata, Cibicidoides mexicana, Uvigerina mexicana, $U$. havanensis, Anomalina pompilioides, Planulina renzi, Gyroidina sp., Pullenia sp., Lenticulina sp.

Age: $\quad$ Early Oligocene.

Sample 12-116-23-1, Bottom:

Data essentially same as for sample above.

Age: Early Oligocene.

Sample 116-23-2, 124-127 cm:

Data essentially same as above, plus Globigerina tripartita.

Age: $\quad$ Early Oligocene.

The following samples yield the same data as above:

Sample 12-116-23-4, Bottom

Sample 12-116,23-5, Bottom

Sample 12-116-23-6, 135-137 cm

Sample 12-116-23, Core Catcher:

PF: $\quad$ Globigerina angiporoides, Globigerinita dissimilis, $G$. unicava, G. pera, Globorotalia opima nana, Chiloguemgelina sp.

BF: Cibicidoides mexicana, Siphonina tenuicarinata, Anomalina pompilioides, Lenticulina sp., Oridorsalis ecuadorensis.

Age: $\quad$ Early Oligocene.

Remarks: Core 23 is characterized by an abundance of globigerinitids, in particular Globigerinita dissimilis. In the upper part of this core, well-preserved specimens of this species were particularly common. The distinctive Uvigerina mexicana occurs commonly in the upper part of this core, together with Cibicidoides mexicana, Siphonina tenuicarinata and Planulina renzi. U. mexicana is essentially restricted to the Oligocene, ranging up into the Lower Miocene in North Africa. Chert fragments are present in all samples examined.

Sample 12-116-24-1, 142-145 cm:

Cohesive chalk, few disaggregated (free) specimens of foraminifera. No age determination possible. 
Sample 12-116A-2-4, 67-70 cm:

Essentially as above.

Age: Pleistocene.

Sample 12-116A-2, Core Catcher:

PF: Globigerina bulloides (dominant, abundant), $G$. pachyderma (dextral, quantitatively minor), Globorotalia inflata (abundant), $G$. truncatulinoides, $G$. hirsuta, G. crassaformis, G. scitula, Hastigerina siphonifera, Hastigerinella digitata, Orbulina universa.

BF: Pyrgo lucernula, Rupertia stabilis, Uvigerina hollicki, Sigmoilopsis schlumbergeri, Gyroidina neosoldanii, Cibicidoides pseudoungeriana, Bulimina aculeata, Pyrgo murrhyna.

Also present: Pelecypod fragments common, ostracods common (Echinocythereis, Krithe, Cytherella), glacially-rafted quartz and rock fragments.

Age: Pleistocene.

Remarks: Core 2 consists of foraminiferal lutites made up of abundant planktonic foraminifera. The dominant forms include Globigerina bulloides, G. pachyderma, and Globorotalia inflata. The varying frequencies of Globigerina pachyderma are an indication of fluctuating climatic conditions, but no quantitative study of its frequency has been made in this preliminary report.

Sample 12-116A-3-1, 143-146 cm:

Rich planktonic and benthonic fauna and abundant volcanic fragments and glacially-rafted quartz.

PF

Globigerina pachyderma (sinistral, abundant, approximately 90 per cent of total planktonic foraminiferal fauna), Globigerina bulloides.

BF: $\quad$ Sigmoilopsis schlumbergeri, Lenticulina sp., Pyrgo lucernula, Bulimina marginata, Cibicides spp.

Age: $\quad$ Pleistocene (glacial)

Sample 12-116A-3-2, 65-68 cm:

PF: Globigerina pachyderma (sinistral), G. bulloides, Globorotalia inflata, G. scitula ( $G$. quinqueloba in fine fraction).

BF: As above.

Also present: Glacially-rafted quartz abundant in fine fraction.

Age: $\quad$ Pleistocene.

Sample 12-116A-3-2, 141-145 cm:

PF: Globorotalia inflata (abundant), Globigerina bulloides, Globigerina pachyderma, Globorotalia crassaformis, G. scitula, Orbulina universa.

BF: $\quad$ Cibicidoides pseudoungeriana, Cibicides sp., Melonis barleeanum.

Age: Pleistocene.

Sample 12-116A-3-3, Bottom:

Lithology and fauna essentially the same as preceding sample above. Age: Pleistocene.

Sample 12-116A-3-4, Bottom:

PF: $\quad$ Globigerina bulloides, $G$. pachyderma (random coiling), Globorotalia inflata, G. scitula, Globigerinita glutinata, Orbulina universa (Globigerina quinqueloba in smaller fractions).

BF: Pyrgo lucernula, Melonis barleeanum, Karreriella $\mathrm{sp}$. Age: $\quad$ Pleistocene.

Sample 12-116A-3-5, 140-143 cm:

Fauna essentially the same as above, including Globorotalia truncatulinoides and $G$. hirsuta. Relative percentages of the species, however, are changed. Globigerina bulloides is dominant and abundant in this sample.

Age: Pleistocene.

Sample 12-116A-3-5, 145-148 cm:

Brown silty marl with abundant green (epidote) mineral grains, scattered planktonic (globigerinids) and benthonic (nodosariids, lagenids, buliminids, uvigerinids) foraminifera.

Age: $\quad$ Pleistocene.

Sample 12-116A-3-5, 141-144 cm:

PF: $\quad$ Globigerina bulloides (dominant and abundant), $G$. pachyderma (predominantly sinistral), Globorotalia inflata, G. scitula, Globigerinita glutinata (Globigerina quinqueloba in finer fractions).
$\mathrm{BF}$ :

Age: Karreriella sp

Sample 12-116A-3, Core Catcher:

PF: Globigerina bulloides and Globorotalia inflata (dominant and abundant), Globigerina pachyderma (common, sinistral), Orbulina universa, Globorotalia hirsuta, G. crassaformis, G. scitula, Hastigerinella digitata.

BF: $\quad$ Rich diversified, including Karreriella sp., Pyrgo murrhyna, Cibicidoides sp., Sigmoilopsis schlumbergeri, Bulimina marginata, Planulina sp., Sphaeroidina sp., Uvigerina sp., lagenids.

Also present: Sponge spicules (common), ostracods common (Echinocythereis, Krithe, Cytherella), pelecypod fragments, echinoid spines, minor amounts of quartz.

Age: Pleistocene.

Remarks: Core 3 is predominantly a foraminiferal lutite containing an abundant planktonic foraminiferal fauna. Dominant elements throughout most of the core are Globigerina bulloides and Globorotalia inflata, although in the upper part (Section 1) one sample contains fauna dominated almost wholly by sinistrally coiled Globigerina pachyderma.

Sample 12-116A-4-2, 61-64 cm:

PF: Globigerina pachyderma (dominant, abundant, sinistral), G. bulloides, Globorotalia inflata, Globigerinita glutinata, (Globigerina quinqueloba in finer fractions).

BF: $\quad$ Essentially as in samples above.

Also present: Ice-rafted quartz and mineral and rock fragment debris and pelecypod fragments, sponge spicules, echinoid spines and ostracods.

Age: Pleistocene.

Sample 12-116A-4-2, 143-146 cm:

Lithology and fauna essentially the same as preceding sample above. Age: Pleistocene.

Sample 12-116A-4-3, 53-56 cm:

PF: Globigerina bulloides (dominant, abundant), Globorotalia inflata (common), Globigerina pachyderma (random coiling), Orbulina universa.

BF: $\quad$ Cibicidoides pseudoungeriana, Melonis sp., Planulina sp., Cibicides sp., Sigmoilopsis schlumbergeri.

Age: Pleistocene.

Sample 12-116A-4-4, 58-61 cm:

Faunal composition essentially the same as above including Globorotalia scitula, Globigerinita glutinata and G. quinqueloba. Relative percentages changed. Globigerina pachyderma (sinistral) dominant in this sample.

Age: $\quad$ Pleistocene

Sample 12-116A-4-4, 145-148 cm:

Fauna essentially the same as preceding sample above.

Age: Pleistocene.

Sample 12-116A-4-5, 24-26 cm:

PF: Globigerina pachyderma (sinistral), G. bulloides, Globorotalia inflata, $G$. scitula, Globigerinita glutinata, Orbulina universa, Hastigerina siphonifera.

BF: $\quad$ Essentially as in samples above.

Age: Pleistocene.

Sample 12-116A-4-6, 35-37 cm:

Lithology and fauna essentially the same as in preceding sample above.

Age: Pleistocene.

Sample 12-116A-4-6, 143-145 cm:

Lithology and fauna as in preceding sample above.

Age: Pleistocene,

Sample 12-116A-4, Core Catcher:

PF: Globorotalia inflata and Globigerina bulloides (dominant and abundant), Globigerina pachyderma (sinistral), Globorotalia scitula, G. crassula, G. crassaformis, G. truncatulinoides, Orbulina universa, Hastigerina siphonifera. 
Sample 12-116-24, Core Catcher:

PF: $\quad$ Globigerina ampliapertura (top), Globigerinita dissimilis, G. pera, Globorotalia postcretacea, Globorotalia denseconnexa, G. inaeguiconica, G. opima nana, Chiloguembelina sp.

BF: $\quad$ Cibicidoides mexicana, Gyroidina sp., Oridorsalis ecuadorensis, Planulina sp., Uvigerina havanensis.

Age: $\quad$ Early Oligocene.

Remarks: The highest occurrence of Globigerina ampliapertura occurs in Core 24. Chiloguembelinids are common in the Core Catcher sample. The Late Eocene-Mid Oligocene Uvigerina havanensis is also a diagnostic component of the fauna in this core. Sample 12-116-25-3, 139-142 cm:

PF: Globigerinita dissimilis (dominant, common), $G$. unicava, G. pera, Globorotalia opima nana, Chiloguembelina sp.

BF: $\quad$ Siphonina tenuicarinata, Uvigerina mexicana, Pullenia sp., Lenticulina sp., Vaginulina sp., Anomalina alazanensis.

Age: $\quad$ Early Oligocene

Sample 12-116-25-3, Bottom:

Essentially same as above; chalk is more coherent and there are fewer disaggregated (free) specimens of foraminifera.

Age: $\quad$ Early Oligocene.

The same conditions are true for the following samples:

Sample 12-116-25-4, 140-144 cm

Sample 12-116-25-5, 145-147 cm

Sample 12-116-25, Core Catcher:

PF: $\quad$ Globigerinita dissimilis, Globigerinita sp., Globigerina sp. cf., G. prasaepis, Globorotalia inaequiconica, Chiloguembelina (common).

BF: Cibicidoides trincherasensis, Amonalina alazanensis, cibicidids, polymorphinids, Gyroidina sp. (acute periphery).

Age: $\quad$ Early Oligocene.

Sample 12-116-26, Core Catcher:

PF: Globigerinita dissimilis, G. pera, Globigerapsis index, Chiloguembelina sp.

BF: Lenticulina spp., Cibicidoides sp. cf. C. perlucida, siphonodosariids.

Age: Late Eocene (Bartonian).

Remarks: Only the Core Catcher sample was studied in Core 26. A single specimen of Globigerapsis index was found which would suggest that this sample is of Late Eocene age; the Eocene/Oligocene boundary is drawn, accordingly, between Cores 25 and 26 .

Sample 12-116-27-2, 62-63 cm:

Indurated chalk with few disaggregated (free) specimens of foraminifera. Globigerinids, globigerinitids, and chiloguembelinids present; preservation poor (recrystallized and some specimens deformed).

Age: $\quad$ Probably Late Eocene.

Sample 12-116-27-3, 0-7 cm:

Data same as for sample above.

Sample 12-116-27, Core Catcher:

Lithified chalk, few free specimens, material recrystallized and distorted.

PF:

Globigerapsis index, globigerinids, globigerinitids, chiloguembelinids.

BF: Osangularia mexicana, cibicidids.

Age: Late Eocene (Bartonian).

Sample 12-116-28-1, 93-96 cm:

Lithified chalk, poor preservation, specimens distorted, Globigerinids, chiloguembelinids present.

Age: Probably Late Eocene.

Sample 12-116-28-2, $145-148 \mathrm{~cm}$ :

PF: $\quad$ Globigerapsis index, Globigerina galavisi, G. linaperta, $G$. sp., Chiloguembelina sp.

BF: $\quad$ Osangularia mexicana, Oridorsalis ecuadorensis.

Age: Late Eocene (Bartonian).
Sample 12-116-28, Core Catcher:

PF: $\quad$ Globigerapsis index, Globigerina galavisi, G. linaperta, Chiloguembelina sp.

BF: Osangularia mexicana, Oridorsalis ecuadorensis, cibicidids, anomalinids, Gyroidina sp. (acute periphery).

Age: $\quad$ Late Eocene (Bartonian).

Remarks: Core 28 is the only core with a relatively well-preserved upper Eocene fauna. Osangularia mexicana forms the dominant component of the benthonic fauna.

\section{Hole 116A}

Sample 12-116A-1-2, $45-47 \mathrm{~cm}$ :

PF: $\quad$ Globigerina pachyderma, G. bulloides, Globorotalia hirsuta, G. inflata, G. truncatulinoides, Globigerinita glutinata, Orbulina universa.

BF: $\quad$ Sigmoilopsis schlumbergeri, Lenticulina sp., Planulina sp., Uvigerina sp.

Also present: Molluscan fragments, sponge spicules, otoliths, relatively minor amounts of ice-rafted quartz and mineral fragments.

Age: Pleistocene.

Sample 12-116A-1-2, 136-139 cm:

Fauna essentially same as above plus Globorotalia scitula.

Age: Pleistocene.

Sample 12-116A-1-2, 145-148 cm:

PF: Globigerina pachyderma (sinistral), G. bulloides, Globorotalia inflata, G. hirsuta, G. scitula, Orbulina universa.

BF: $\quad$ Sparse, essentially as above.

Also present: Ice-rafted quartz and mineral fragments.

Age: Pleistocene.

Sample 12-116A-1, Core Catcher:

PF: Globigerina bulloides (dominant, abundant), Globigerina pachyderma (sinistral), Globorotalia inflata, $G$. hirsuta, G. scitula, Orbulina universa.

BF: Karreriella sp., Pyrgo murrhyna, Pyrgo lucernula, Sigmoilopsis schlumbergeri, Gaudryina atlantica, Melonis pompilioides, Cibicidoides pseudoungeriana, Quinqueloculina sp., Rupertia stabilis.

Also present: Pelecypod fragments, otoliths, ostracods (Echinocythereis, Krithe), sponge spicules, volcanic rock fragments, volcanic glass and glacially-rafted quartz.

Age: Pleistocene.

Remarks: Core 1 is characterized by a rich cold-temperate planktonic foraminiferal fauna dominated by Globigerina bulloides and sinistrally coiled $G$. pachyderma. Evidence of glaciation is afforded by the scattered to moderate amounts of detrital quartz and various rock and mineral fragments.

Sample 12-116A-2-2, 0-3 cm:

PF: $\quad$ Globigerina bulloides, G. pachyderma, Globorotalia inflata, G. scitula, G. truncatulinoides, Orbulina universa, (Globigerina quinqueloba present in finer fractions).

BF: Sigmoilopsis schlumbergeri, Uvigerina peregrina, Uvigerina auberiana, Melonis pompilioides.

Age: Pleistocene.

Sample 12-116A-2-3, 91-94 cm:

PF: Globigerina bulloides (dominant, abundant), $G$. pachyderma, Globorotalia hirsuta, $G$. inflata, $G$. scitula, Globigerinita glutinata, Orbulina universa.

BF: $\quad$ Essentially as above.

Age: Pleistocene.

Sample 12-116A-2-3, 146-149 cm:

PF: Globigerina pachyderma (sinistral, abundant), $G$. bulloides, Globorotalia inflata, Globigerinita glutinata.

BF: As above.

Also present: Moderate amounts of glacially-rafted quartz in fine fraction.

Age: $\quad$ Pleistocene. 
BF:

Pyrgo murrhyna, Pyrgo lucernula, Cibicidoides pseudoungeriana, Bulimina marginata, Sigmoilopsis schlumbergeri, Eponides tener, Spiroloculina rotunda, Gyroidina sp., Karreriella bradyi, various nodosariids.

Also present: Molluscan shell fragments, echinoid spines and sponge spicules and glacially-rafted quartz debris.

Age: Pleistocene.

Remarks: Core 4 is a foraminiferal lutite containing a rich planktonic foraminiferal fauna. The dominant elements are Globigerina bulloides, G. pachyderma and Globorotalia inflata; the percentages of each varying at different levels. Globorotalia scitula occurs commonly at several levels. Globorotalia truncatulinoides occurs sporadically. Glacially-rafted quartz and rock and fragments occur in varying frequencies throughout the core.

Sample 12-116A-5-1, 143-145 cm:

PF: $\quad$ Globigerina bulloides (dominant and abundant), $G$. pachyderma (sinistral), Globorotalia inflata, $G$. crassaformis, Globigerinita glutinata, Orbulina universa.

BF: $\quad$ Cibicidoides pseudoungeriana, Sigmoilopsis schlumbergeri, Melonis barleeanum, Bulimina marginata.

Also present: Molluscan fragments, echinoid spines, sponge spicules, glacially-rafted quartz and rock fragments.

Age: Pleistocene.

Sample 12-116A-5-2, 145-147 cm:

PF: $\quad$ Globigerina bulloides, G. pachyderma, Globorotalia inflata, G. scitula, G. truncatulinoides, G. crassaformia, Hastigerina siphonifera, Globigerinita

BF: $\quad$ Essentially as above.

Age: Pleistocene.

Sample 12-116A-5-3, 51-54 cm:

Lithology and fauna essentially the same as above.

Age: Pleistocene.

Sample 12-116A-5-3, 145-148 cm:

Fauna essentially the same as preceding samples above.

Age: Pleistocene.

Sample 12-116A-5-4 46-49 cm:

Fauna essentially the same as preceding samples above:

Age: Pleistocene.

Sample 12-116A-5-4, 143-146 cm:

Planktonic foraminiferal fauna essentially same as above. Benthonic foraminiferal fauna diverse, consisting of Bulimina marginata, Uvigerina peregrina, Cibicidoides pseudoungeriana, various cibicidids and lagenids and nodosariids.

Age: Pleistocene.

Sample 12-116A-5, Core Catcher:

PF: Globigerina pachýderma (dominant, abundant, sinistral), G. bulloides (abundant), Globorotalia inflata (common) and Globorotalia crassaformis, G. hirsuta, G. scitula, Hastigerina siphonifera.

BF: Melonis barleeanum, various polymorphinids, Bulimina marginata, Uvigerina peregrina, Karreriella bradyi, Cibicidoides pseudoungeriana, Eponides tener, Sigmoilopsis schlumbergeri, Pyrgo murrhyna, Planulina sp. , Lenticulina sp., nodosariids.

Also present: Echinoid fragments, pelecypod fragments, ostracods (Echinocythereis, Krithe, Cytherella), minor amounts of quartz and rock fragments.

Age: Pleistocene.

Remarks: Core 5 is a foraminiferal lutite containing abundant planktonic foraminifera. The dominant elements are Globigerina bulloides, $G$. pachyderma and Globorotalia inflata, the percentages of which fluctuate in the various samples.

Sample 12-116A-6-1, 50-53 cm:

PF: $\quad$ Globigerina bulloides, G. pachyderma (sinistral), Globorotalia inflata, G. crassaformis, G. scitula, Orbulina universa. Globigerinita glutinata.

BF: $\quad$ Essentially as above.

Also present: Minor amounts of quartz and rock fragments.

Age: $\quad$ Pleistocene.
Sample 12-116A-6-1, 146-149 cm:

Fauna essentially the same as preceding samples above; Globigerina pachyderma predominantly dextrally coiled.

Sample 12-116A-6-2, 30-33 cm:

PF: $\quad$ Globigerina bulloides, Globorotalia inflata (dominant and abundant), Globigerina pachyderma (less common, dextral), Globorotalia crassaformis.

BF: Uvigerina peregrina, Gyroidina sp., Cibicidoides sp., Bulimina marginata.

Also present: Echinoid spines, sponge spicules, ostracods (Echinocythereis), minor amounts of quartz.

Age: Pleistocene.

Sample 12-116A-6-2, 145-148 cm:

Fauna essentially the same as preceding sample above.

Sample 12-116A-6-3, 59-62 cm:

Planktonic foraminiferal fauna essentially the same as above. Dominant elements are Globigerina bulloides and Globorotalia inflata.

Age:

Pleistocene.

Sample 12-116A-6-3, 142-145 cm:

As above. Globigerina pachyderma predominantly sinistrally coiled. Age: Pleistocene.

Sample 12-116A-6-4, 37-40 cm:

Fauna essentially the same as above, including Hastigerina siphonifera and Globorotalia crassaformis.

Age: Pleistocene.

Sample 12-116A-6-4, 145-148 cm:

Fauna essentially the same as above.

Age: Pleistocene.

Sample 12-116A-6-5, 54-57 cm:

Planktonic fauna essentially the same as above. Relative increase in Globorotalia crassaformis.

Age: Pleistocene.

Sample 12-116A-6-5, 145-148 cm:

Fauna essentially the same as above.

Age: Pleistocene.

Sample 12-116A-6-6, 57-59 cm:

PF: $\quad$ Globigerina bulloides, Globorotalis inflata (dominant, abundant), Orbulina universa, Globorotalia crassaformis, Globigerinita glutinata, Globorotalia scitula, Globigerina pachyderma.

BF: $\quad$ Cibicidoides sp., Sigmoilopsis schlumbergeri, Angulogerina sp.

Also present: Only minor amounts of quartz in fine fraction.

Age: Pleistocene.

Sample 12-116A-6-6, 130-133 cm:

Fauna essentially the same as sample above. Globigerina bulloides abundant; Globorotalia inflata relatively less common.

Age: Pleistocene.

Sample 12-116A-6, Core Catcher:

PF: Globigerina bulloides (abundant), Globorotalia crassaformis and $G$. hirsuta (common), $G$. pachyderma (rare).

BF: Sigmoilopsis schlumbergeri, Karreriella bradyi, Cibicidoides pseudoungeriana, Sphaeroidina bulloides, Gyroidina neosoldanii, Pyrgo murrhyna.

Also present: Sponge spicules, echinoid spines, ostracods (Echinoicythereis, Krithe), minor amount of quartz grains in fine fraction.

Age: Pleistocene.

Remarks: Core 6 is characterized by a change in the planktonic foraminiferal fauna from one in the lower parts of Core 6 in which the dominant elements are Globigerina bulloides and Globorotalia crassaformis to a fauna in the upper part of the core in which the dominant elements are Globigerina bulloides and Globorotalia inflata. A change in the relative frequency of the dominant faunal elements appears to be at the expense of Globigerina pachyderma, which is less common in Core 6 than in cores above. 
Sample 12-116A-7-2, 50-53 cm:

PF: Globigerina bulloides (dominant, abundant), Globorotalia crassaformis, $G$. inflata, $G$. hirsuta, Globigerina pachyderma (predominantly dextral), Globigerinita glutinata, Orbulina universa.

BF: $\quad$ Cibicidoides pseudoungeriana, Sigmoilopsis schlumbergeri, Gyroidina neosoldanii.

Also present: Echinoid spines, sponge spicules, ostracods (Echinocythereis).

Age: Pleistocene.

Sample 12-116A-7-2, 143-146 cm:

PF: Globigerina bulloides (dominant, abundant), Globorotalia inflata, G. scitula, Hastigerina siphonifera, Orbulina universa, Globigerinita glutinata, GloBF: As above.

\section{Age: Pleistocene.}

Sample 12-116A-7-3, 45-48 cm:

Fauna essentially the same as preceding sample above, including Globorotalia hirsuta.

Age: $\quad$ Pleistocene.

Sample 12-116A-7-3, 145-148 cm:

PF: Globigerina bulloides (common), G. pachyderma (rare, dextral), Globorotalia inflata, $G$. scitula, $G$. hirsuta, Orbulina universa, Globigerinita glutinata.

BF: $\quad$ Sigmoilopsis schlumbergeri, Karreriella bradyi

Age: $\quad$ Pleistocene.

Sample 12-116A-7-4, 45-48 cm:

Lithology and fauna essentially the same as the preceding sample above, including Hastigerina siphonifera.

Age: Pleistocene.

Sample 12-116A-7-4, 141-147 cm:

Lithology and fauna essentially the same as sample above.

Age: Pleistocene.

Sample 12-116A-7-5, 59-62 cm:

PF: $\quad$ Globigerina bulloides, G. pachyderma (rare, dextral), Globorotalia crassaformis, G. scitula, Globigerinita glutinata, Orbulina universa.

BF: Pyrgo lucernula, Sigmoilopsis schlumbergeri, Cibicidoides pseudoungeriana, various cibicidids.

Age: $\quad$ Pleistocene.

Sample 12-116A-7-5, 146-149 cm:

Fauna essentially the same as the preceding samples above.

Age: Pleistocene.

Sample 12-116A-7-6, 140-143 cm:

PF: Globigerina atlantica (dominant, abundant, sinistral; wide morphologic variation including four and five chambered evolute forms, as well as high-spired involute forms with final cap-like chamber obscuring umbilical region), Globigerina bulloides, Globorotalia scitual.

BF: Sigmoilopsis schlumbergeri, various cibicidids, Gaudryina sp.

Late Pliocene.

Age:

Remarks: There is a significant lithologic and faunal change between Sample 7-5, 146-149 $\mathrm{cm}$ and Sample 7-6, 140-143 cm. The former is primarily a coccolith planktonic foraminiferal lutite, containing abundant planktonic foraminifera, sponge spicules, echinoid spines, and volcanic glass shards. Very little detrital material is present in the fine fraction. The latter sample, however, contains a significant amount of glacially-rafted quartz and rock fragment detritus. Whereas the sample from Section 5 contains a relatively diverse planktonic foraminiferal fauna in which the dominant elements are robust, large individuals of Globigerina bulloides and Orbulina universa, the sample from Section 6 contains a rich planktonic foraminiferal fauna of which 95 per cent consists of the single species Globigerina atlantica, which has been recorded at other sites in the North Atlantic as the dominant element in Pliocene faunas. The Pliocene-Pleistocene boundary is accordingly drawn between Section 5 and Section 6 in Hole 116A.
Sample 12-116A-7, Core Catcher:

PF: Globigerina atlantica (dominant, abundant; over 95 per cent of the fauna, sinistral), G. bulloides, Globorotalia hirsuta.

BF: Melonis barleeanum, polymorphinids, Lenticulina spp., Planulina sp., Cibicides lobatulus, Gyroidina sp., Sigmoilopsis schlumbergeri.

Also present: Sponge spicules, abundant, rounded and angular, glacially-rafted quartz and rock fragments and volcanic glass shards as well as broken pelecypod fragments.

Age: Late Pliocene.

Remarks: Sections 1 through 5 of Core 7 consist of foraminiferal lutite with rich planktonic faunas dominated by robust, large individuals of Globigerina bulloides and Orbulina universa. Globorotalia crassaformis occurs in relatively large numbers in some samples. As noted above, a marked lithologic and faunal change occurs between Sections 5 and 6 and the Pliocene-Pleistocene boundary has been drawn between Sections 5 and 6 based on the abundant presence of Globigerina atlantica in Section 6 and in the Core Catcher sample.

Sample 12-116A-8-1, 122-125 cm:

PF: Globigerina atlantica (dominant, abundant, sinistral), G. bulloides, Globorotalia crassaformis, Orbulina universa.

BF: Gyroidina sp., Cibicidoides sp., Sigmoilopsis schlumbergeri.

Age: Late Pliocene.

Sample 12-116A-8-1, 138-141 cm:

PF: Globigerina atlantica (dominant, abundant, sinistral), G. bulloides, G. pachyderma (small, rare, essentially sinistral), Globorotalia hirsuta, G. inflata.

BF: Vulvulina pennatula (relatively common), Sigmoilopsis schlumbergeri, Pyrgo sp., Cibicidoides pseudoungeriana.

Age: Late Pliocene.

Sample 12-116A-8-2, $41-44 \mathrm{~cm}$ :

Lithology and fauna essentially the same as in preceding sample above.

Age: Late Pliocene.

Sample 12-116A-8-2, 143-146 cm:

Fauna essentially the same as in preceding samples above. Globigerina atlantica and Orbulina universa are the dominant faunal elements. Globorotalia inflata occurs as a relatively minor element of the fauna.

Age: Late Pliocene.

Sample 12-116A-8-3, 65-68 cm:

Foraminiferal fauna essentially the same as that recorded above. Globigerina praedigitata also observed in planktonic foraminiferal fauna; Cibicidoides robertsoniana present in benthonic fauna.

Age: Late Pliocene.

Sample 12-116A-8-3, 143-146 cm:

Faunal composition as in preceding samples above.

Age: Late Pliocene.

Sample 12-116A-8-4, 143-146 cm:

Fauna essentially the same as in samples above. Globorotalia puncticulata also observed as a rare element.

Age: Late Pliocene.

Sample 12-116A-8-5, 49-52 cm:

PF: Globigerina atlantica (dominant, abundant, sinistral). $G$. bulloides, Globigerinita glutinata, Globorotalia crassaformis, G. scitula, Orbulina universa.

BF: Cibicidoides pseudoungeriana, Sigmoilopsis schlumbergeri, Lenticulina sp., Cibicidoides robertsoniana.

Age: $\quad$ Late Pliocene.

Sample 12-116A-8-5, 132-136 cm:

Fauna essentially the same as in preceding sample above.

Age: Late Pliocene. 
Sample 12-116A-8-6, 67-70 cm:

PF: $\quad$ Globigerina atlantica (dominant, abundant, sinistral), $G$. bulloides, Globorotalia scitula, $G$. puncticulata, $G$. crassaformis, Globigerina sp., cf. G. pachyderma (dextral) Orbulina universa.

BF: $\quad$ Relatively rich and diverse, containing among others Gyroidina sp., Eponides sp., Cibicidoides pseudoungeriana, Sigmoilopsis schlumbergeri

Also present: Abundant sponge spicules, some Radiolaria and relatively numerous ostracods.

Age: Late Pliocene.

Sample 12-116A-8-6, 144-147 cm:

Fauna essentially the same as in samples above.

Age: Late Pliocene.

Sample 12-116A-8, Core Catcher:

PF: $\quad$ Rich planktonic foraminifera dominated almost wholly by Globigerina atlantica; also present Globigerina bulloides, Orbulina universa. No globorotaliids observed.

BF: Rich and diverse, . including among others, Laticarinina halophora, Planulina bradii, Pullenia sp., Martinotiella sp., Cibicidoides pseudoungeriana, Anomalinoides cicatricosa, Karreriella bradyi, Pyrgo sp.

Also present: Abundant sponge spicules. Ostracods relatively common.

Age: Late Pliocene.

Remarks: Core 8 is a coccolith-foraminiferal ooze containing a rich planktonic-foraminiferal fauna dominated by sinistrally coiled Globigerina atlantica. Specimens referable to Globigerina pachyderma occur sporadically at some levels in this core. Quartz and other detrital fragments are almost wholly absent from most of the samples but occur sporadically in others in relatively minor amounts.

Sample 12-116A-9-1, $42-45 \mathrm{~cm}$ :

$\mathrm{PF}$ : $\quad$ Globigerina atlantica (dominant, abundant, sinistral), G. bulloides, Globigerinita glutinata, Globorotalia scitula, $G$. inflata, Orbulina universa, Globigerinoides sp., Globigerina pachyderma (predominately dextral, rare).

BF: Diverse, relatively abundant, including among others Sigmoilopsis schlumbergeri, Cibicidoides pseudoungeriana, various lagenids, lenticulinids, cibicidids, Gyroidina sp.

Also present: Sponge spicules, glacially-rafted quartz and rock fragment detritus.

Age: Late Pliocene.

Sample 12-116A-9-1, 147-150 cm:

PF: Globigerina atlantica, G. bulloides, G. pachyderma (rare), Globigerinita glutinata, Globorotalia scitula, $G$. crassaformis, G. puncticulata, G. inflata, Orbulina

BF: $\quad$ Essentially as above.

Age: Late Pliocene.

The following samples were examined and found to contain essentially the same fauna as that listed above:

Sample 12-116A-9-2, 67-70 cm

Sample 12-116A-9-2, 146-149 cm

At this point a change in fauna is noted between Section 2 and Section 3. Samples above contain a fauna dominated by Globigerina atlantica with subordinate amounts of Globigerina bulloides and Orbulina universa. In the samples listed below the dominant element is Globigerina bulloides, which, together with Orbulina universa makes up over 90 per cent of the total fauna. Globigerina atlantica occurs but sporadically in these samples. Globorotalia puncticulata, $G$. crassaformis and $G$. scitula occur consistently throughout the interval below. These samples include:

Sample 12-116A-9-3, 69-72 cm

Sample 12-116A-9-3, 144-147 cm

Sample 12-116A-9-4, 65-68 cm

Sample 12-116A-9-4, 145-148 cm

Sample 12-116A-9-5, 50-53 cm
Sample $\quad 12-116 \mathrm{~A}-9-5, \quad 145-148 \quad \mathrm{~cm} \quad$ (G. puncticulata particularly well developed in this sample)

Sample 12-116A-9-6, 60-63 cm

Sample 12-116A-9-6, 145-148 cm

Sample 12-116A-9, Core Catcher:

PF: Globigerina atlantica (abundant, sinistral), $G$. bulloides, Orbulina universa, Globigerinita glutinata, Globorotalia scitula.

BF: $\quad$ Sigmoilopsis schlumbergeri, Anomalinoides globulosa, Planulina wuellerstorfi, P. bradii, Pyrgo murrhyna, Cibicidoides pseudoungeriana, Eggerella bradyi, Laticarinina halophora, Sphaeroidina bulloides, Stilostomella sp., nodosariids.

Age: Late Pliocene.

Remarks: Core 9 contains a rich planktonic foraminiferal fauna The dominant element in Sections 1 and 2 is Globigerina atlantica, in Sections 3 to 5 Globigerina bulloides, and again in Section 6 and the Core Catcher sample Globigerina atlantica.Orbulina universa is a common accessory form throughout this core. Globorotalia puncticulata occurs consistently in moderate amounts in Core 9.

Sample 12-116A-10-1, 100-103 cm:

PF: Globigerina atlantica (dominant, abundant), $G$. bulloides, Orbulina universa.

BF: $\quad$ Cassidulina subglobosa, Cibicidoides sp., Sigmoilopsis Age: $\quad$ Late Pliocene.

Sample 12-116A-10-1, 146-149 cm:

PF: Globigerina atlantica (dominant, abundant), $G$. bulloides, Orbulina universa, Globorotalia scitula, $G$. crassaformis

BF: Cassidulina subglobosa, Anomalinoides globosa, Laticarinina halophora, Cibicidoides pseudoungeriana, Uvigerina sp.

Age: Late Pliocene

The following samples were examined and found to contain essentially the same fauna:

Sample 12-116A-10-2, 47-50 cm

Sample 12-116A-10-2, 143-146 cm

Sample 12-116A-10-3, 68-71 cm

Sample 12-116A-10-3, 144-147 cm (G. puncticulata observed as a rare element in this sample; benthonic fauna relatively abundant and diverse)

Sample 12-116A-10-4, 3-6 cm

Sample 12-116A-10-4, 67-70 cm (fauna generally as above but including specimens referable to Globorotalia crassaformis and $G$. scitula)

Sample 12-116A-10-5, 65-68 cm

Sample 12-116A-10-5, 144-147 cm

Sample 12-116A-10-6, 65-68 cm (G. puncticulata occurs rarely in this sample)

Sample 12-116A-10-6, 143-146 cm

Sample 12-116A-10, Core Catcher:

PF: Globigerina atlantica (dominant, abundant), $G$. bulloides, Globorotalia scitula, G. puncticulata, Orbulina universa.

BF: $\quad$ Rich diverse fauna including Pyrgo murrhyna, Planulina wuellerstorfi, Gyroidina neosoldanii, Gyroidina sp., Uvigerina hollicki, Melonis bar. leeanum, Fissurina cucullata, Parafrondicularia sp. cf. $P$. advena, Sigmoilopsis schlumbergeri, Cassidulina subglobosa, Cibicidoides pseudoungeriana, Anomalinoides globosa, Laticarinina halophora, Martinotiella nodulosa, Stilostomella abyssorum.

Age: Late Pliocene.

Remarks: Core 10 is characterized throughout by rich planktonic and relatively rich and diverse benthonic foraminiferal fauna. The planktonic fauna is dominated by Globigerina atlantica and Orbulina universa. Specimens referable to Globorotalia puncticulata occur sporadically throughout Core 10. Typical Globorotalia puncticulata has not been recorded in pre-Pliocene sediments. Globorotalia inflata was not found in Core 10. 
Sample 12-116A-11-0, Bottom:

PF: Globigerina atlantica (common), G. bulloides, Globorotalia puncticulata, Orbulina universa.

BF: Relatively rich and diverse, Cibicidoides pseudoungeriana Sigmoilopsis schlumbergeri, Gyroidinoides neosoldanii, Melonis barleeanum, Pullenia sp., Sphaeroidina bulloides, Pleurostomella sp., Laticarinina halophora, Uvigerina sp.

Age: $\quad$ Early-Late Pliocene.

The following samples have been examined and found to contain an essentially similar planktonic and benthonic foraminiferal fauna:

Sample 12-116A-11-1, 35-38 cm (Globorotalia scitula occurs relatively commonly in this sample)

Sample 12-116A-11-1, 143-146 cm

Sample 12-116A-11-2, 55-58 cm

Sample 12-116A-11-2, 144-147 cm

Sample 12-116A-11-3, 64-67 cm

Sample 12-116A-11-3, 145-148 cm

Sample 12-116A-11-4, 64-67 cm

Sample 12-116A-11-4, 144-147 cm

Sample 12-116A-11-5, 32-35 cm

Sample 12-116A-11-5, 144-147 cm

Sample 12-116A-11-6, 60-63 cm

Sample 12-116A-11-6, 143-146 cm

Sample 12-116A-11, Core Catcher:

PF: $\quad$ Globigerina atlantica (dominant, abundant, sinistral) G. bulloides, Orbulina universa, Globorotalia puncticulata, G. scitula.

BF: Rich, diverse; Cibicidoides pseudoungeriana, Uvigerina asperula Eggerella bradyi, Sigmoilopsis schlumbergeri, Textularia sp. Sphaeroidina bulloides, Laticarinina halophora, Cassidulina subglobosa, Melonis pompilioides, Gyroidina neosoldanii, Planulina wuellerstorfi, Planulina bradii.

Also present: Echinoid spines.

Age: $\quad$ Early-Late Pliocene.

Remarks: Core 11 is characterized by a rich planktonic and benthonic foraminiferal fauna throughout. The planktonic foraminiferal fauna is dominated by Globigerina atlantica. A significant feature of Core 11 is the relatively high percentage of Globorotalia puncticulata. The relatively high percentage of $G$. puncticulata appears to be at the expense of Globigerina bulloides, which occurs in significantly lower frequencies than in the cores above. Globorotalia scitula occurs consistently throughout this core.

\section{APPENDIX D, PART 2. LISTS OF SELECTED PLANKTONIC AND BENTHONIC FORAMINIFERA AND AGE DETERMINATIONS (117)}

\section{W. A. Berggren}

Sample 12-117-1, Core Catcher:

Bryozoan limestone and chert gravel (caused by drilling).

PF: $\quad$ Globigerinita unicava, Globorotaloides suteri, Globoquadrina sp., small globigerinids, globigerinitids.

BF: $\quad$ Rich, diverse, includes Heterolepa mexicana, Planulina renzi, Vulvulina jarvisi, Siphonina tenuicarinata, large, robust lenticulinids, dentalinids, Eponides sp., Gyroidina sp.

Also present: Pleistocene contaminants, particularly planktonic foraminifera: Globigerina pachyderma, $G$. bulloides, Globorotalia inflata, G. crassaformis.

Age: Late Oligocene - Early Miocene.

Remarks: Only the core catcher was obtained from Core 1. A mixed fauna occurs in a bryozoan limestone and chert gravel mixture.

The association of Globigerinita unicava, Globorotaloides suteri and Globoquadrina sp. support a Late Oligocene-Early Miocene determination based on calcareous nannoplankton.

Sample 12-117-2, Top:

Cherty limestone with mixed fauna.

PF: $\quad$ Globigerina galavisi, Globigerinita unicava, G. pera, G. sp. cf. G. praestainforthi, Globorotalia opima.
BF :

Heterolepa mexicana, Cibicidoides sp. cf. C. perlucida, Gyroidina soldanii, Pullenia sp., Anomalinoides pompilioides, Eponides repandus, Vulvulina jarvisi, large nodosariids, dentalinids, lagenids, Siphonina tenuistriata, Uvigerina sp., Pullenia sp., Bulimina sp. Age: $\quad$ Late Oligocene (Zone P21-P22).

Sample 12-117-2-3, 145-148 cm:

Glauconitic chalk ooze with rich foraminiferal and bryozoan fauna PF: $\quad$ Rich, relatively diverse, including i.al., Globigerinita unicava, Globorotaloides suteri (common), Globigerina prasaepis (common), G. praebulloides ss., $G$. praebulloides occlusa, Globorotalia opima nana.

BF: $\quad$ Rich, diverse and essentially same as above.

Age: $\quad$ Late Oligocene ( ? P22).

Sample 12-117-2-4, 146-149 cm:

Glauconitic chalk with rich foraminiferal and bryozoan fauna (as above).

PF:

Globigerinita dissimilis, G. unicava, G. pera, Globigerina praebulloides s.s., G. prasaepis, G. galavisi, $G$. tripartita, Globorotaloides suteri, Globorotalia opima nana.

BF: $\quad$ Rich, diverse, essentially as above.

Age: $\quad$ Early-Late Oligocene (P21-P22).

Sample 12-117-2-6, 143-146 cm:

Data essentially same as above.

Sample 12-117-2, Core Catcher:

PF: Globigerina galavisi, G. tripartita, G. praebulloides s.s., G. prasaepis, Globigerinita unicava, G. dissimilis, Globorotalia opima nana, Globorotaloides suteri.

BF: Heterolepa mexicana, Cibicidoides sp. cf. C. perlucida, Siphonina tenuicarinata, Anomalina alazanensis, Vulvulina jarvisi, Uvigerina sp., Anomalinoides pompilioides, Gyroidina spp.

Age: Oligocene.

Remarks: Core 2 is essentially a foraminiferal-nannofossil ooze with abundant bryozoa-echinoid fragments, in places silicified. A rich benthonic and planktonic foraminiferal fauna occurs throughout the core. The association of globigerinitids and $G$. suteri and $G$. prasaepis indicate that Core 2 is of Oligocene age. The presence of G. opima opima indicates that this core may be close to the P21/P22 boundary; this determination is supported by the questionable assignment of Core 2 to the Sphenolithus ciperoensis Zone.

Sample 12-117-3-1, 0-3 cm:

Silicified limestone, chalk-ooze and rock chips resulting from drilling. Foraminiferal fauna essentially as above (see Core 2) but with abundant Pleistocene contaminants (Globigerina pachyderma, $G$. bulloides, Globorotalia scitula, G. inflata). Oligocene planktonic foraminifera as in Core 2.

Age: Oligocene.

Sample 12-117-3, Core Catcher:

PF: $\quad$ Globigerina galavisi, $G$. angiporoides, Globigerinita unicava, G. dissimilis, G. pera, Globigerapsis sp.

BF: $\quad H e t e r o l e p a ~ m e x i c a n a$, Cibicidoides $\mathrm{sp}$. $\mathrm{cf}$. C. perlucida $(=? C$ pippeni), $C$. trincherasensis, Anomalinoides pompilioides, Anomalina alazanensis, Eponides rapandus, Cassidulina subglobosa, Gyroidina soldanii, Lenticulina sp.

Also present: Abundant bryozoan fragments.

Age: $\quad$ Eocene.

Remarks: Only Section 1 and Core Catcher retrieved from Core 3. Rich and diverse benthonic foraminiferal fauna, mostly indigenous probably, but some contaminants from above may be present. The presence of a large globigerapsid in the Core Catcher suggests that this level is of middle or late Eocene age; it is questionably referred to the Early Eocene Marthasterites tribrachiatus Zone (calcareous nannoplankton).

\section{Hole 117A}

Sample 12-117A-1-1, 40-42 cm:

PF: Globigerina angiporoides (dominant, abundant), Globigerinita unicava, Globigerina praebulloides occlusa. 
$\mathrm{BF}$ :

Heterolepa mexicana (dominant, abundant), Stilostomella verneuili, Stilostomella spp., Lenticulina spp., Anomalinoides pompilioides, Bolivina sp., Angulogerina sp., Gyroidina sp (acute periphery).

Age: Oligocene.

Sample 12-117A-1-1, 78-80 cm:

This sample contains Oligocene planktonic and benthonic foraminiferal contaminants. Indigenous elements consist of benthonic foraminifera, Radiolaria and echinoid spines which have been replaced by zeolites and other indeterminate minerals.

Age: $\quad$ Early Eocene (on basis of nannofossils).

Sample 12-117A-1, Core Catcher:

Same remarks as for sample above.

Remarks: Core 1 contains an unconformity separating Oligocene and Lower Eocene sediments. The Lower Eocene sediments consist of sands and silty clays in which foraminifera and Radiolaria have been replaced by zeolites.

Sample 12-117A-2, Core Catcher:

This sample, the only one recovered from Core 2, consists of sand and silty clay with Radiolaria replaced by zeolites and some glauconitic fecal pellets. No foraminifera present.

Age: $\quad$ Early Eocene (nannofossils).

Sample 12-117A-3-1, 145-147 cm:

Silty clay with glauconite.

PF: $\quad$ Globigerina patagonica, acarininids.

BF: Cibicidids, anomalinids ( $A$. grosserugosa), buliminids, cassidulinids, gyroidinids, pulleniids.

Age: $\quad$ Early Eocene (Ypresian).

Sample 12-117A-3-2, 124-128 cm:

PF: $\quad$ Globigerina patagonica, acarininids.

BF: Anomalinoides grosserugosa, cibicidids, buliminids, Osangularia pteromphalia, lenticulinids.

Age: $\quad$ Early Eocene (Ypresian).

Sample 12-117A-3-3, 143-145 cm:

PF: $\quad$ Globigerina patagonica, acarininids.

BF: Anomalinoides grosserugosa, Anomalina acuta, Lenticulina alatolimbata, Lenticulina decorata, Cibicidoides sulzensis, Osangularia pteromphalia, Gyroidina sp., nodosariids, Verneuilina sp., Angulogerina sp., Eponides sp.

Age: $\quad$ Early Eocene (Y presian).

Sample 12-117A-3-6, 145-148 cm:

Similar to above; only fine fraction left after preparation.

Sample 12-117A-3, Core Catcher:

PF: $\quad$ Globigerina patagonica, acarininids (pan fraction).

BF: $\quad$ Bathysiphon sp., Anomalina acuta.

Age: $\quad$ Early Eocene (Ypresian).

Remarks: Core 3 consists primarily of $\tan$, brown and gray silty clays with varying amounts of glauconite. Planktonic foraminifera occur sporadically; 4-5 chambered acarininids (?A. pentacamerata) are common at some levels. Benthonic foraminifera characteristic of the Paleocene-Lower Eocene of Europe include Anomalinoides grosserugosa, Anomalina acuta, Lenticulina decorata, Cibicidoides sulzensis and Osangularia pteromphalia.

Sample 12-117A-4-0, $5 \mathrm{~cm}$ :

Olive-gray silty clay with abundant bryozoan fragments. Planktonic foraminifera not observed.

BF: $\quad$ Cibicidoides proprias, $C$. hercegovinensis, cibicidids, Stomatorbina sp., Textularia sp., Lenticulina sp., polymorphinids, nodosariids.

Age: Late Paleocene-Early Eocene.

Sample 12-117A-4-1, 140-143 cm:

Lithology and fauna as above. Globigerinids in pan fraction.

BF: Vulvulina sp., Verneuilina sp., Lenticulina sp., Eponides sp., Stomatorbina sp., Planulina sp., Osangularia pteromphalia, Cibicidoides proprias, $C$. hercegovinensis, nodosariids.

Age: $\quad$ Late Paleocene-Early Eocene.

Sample 12-117A-4-2, Bottom:

Lithology and fauna as above.
Sample 12-117A-4-4, Bottom:

Lithology and fauna as above; Cibicidoides hercegovenensis common, robust and large. Globigerinids present in pan fraction.

Sample 12-117A-4-6, 143-146 cm:

Lithology and fauna as above.

Sample 12-117A-4, Core Catcher:

PF: Globigerina triangularis, G. velascoensis, acarininids (pan fraction).

BF: Osangularia pteromphalia (dominant, common), Cibicidoides hercegovinensis, C. proprias, Pullenia corryelli, Anomalinoides sp., cf. A. danica, Lenticulina spp., nodosariids, Eponides plummerae, Alabamina obtusa, Vulvulina sp., Polymorphina sp.

Also present: Ostracods (Bairdia, Cytherella).

Age: $\quad$ Late Paleocene

Remarks: Cibicidids which lived attached to a substrate (algae, etc.) are present and indicate that the bryozoan-bearing clays and mudstones were probably formed in inner-middle neritic environments (less than 100 meters water depth).

Sample 12-117A-5-1, 127-130 cm:

Brown silty clay; fauna essentially same as for sample above (Core 4, Core Catcher).

Sample 12-117A-5-1, 142-145 cm:

Lithology and fauna essentially similar to above; Allomorphina halli also present.

Sample 12-117A-5, Bottom:

PF: $\quad$ Globigerina triangularis.

BF: $\quad$ Cibicidoides proprias, $C$. hercegovinensis, Osangularia pteromphalia, Anomalinoides sp., Lenticulina spp., nodosariids.

Age: Late Paleocene.

Sample 12-117A-6-1, 147-150 cm:

Brown silty clay with bryozoans.

PF: $\quad$ Globigerina triangularis, acarininids.

BF: Osangularia pteromphalia, Cibicidoides proprias, C.

Age: hercegovinensis,

Sample 12-117A-6-4, 146-149 cm:

Undiagnostic.

Sample 12-117A-6-5, 133-135 cm:

PF: $\quad$ Globigerina triangularis, acarininids

BF: Essentially as in samples above, plus Lenticulina midwayensis

Age: Late Paleocene.

Sample 12-117A-6, Core Catcher:

Bryozoan bearing silty clay.

PF: $\quad$ Globigerina triangularis

BF: Osangularia pteromphalia, Anomalinoides danica, nodosariids, Allomorphina halli, Lenticulina midwayensis, Alabamina obtusa, Vulvulina.

Also present: Pelecypods, fecal pellets, echinoid spines, ostracods (Bairdia, Cytherella).

Age: Late Paleocene.

Remarks: Core 6 is composed of brown and gray silty clay containing variable amounts of bryozoans and molluscan fragments. Planktonic foraminifera are rare; a single globigerinid species, $G$. triangularis, and small acarininids (probably one or two species) occur sporadically. Distinctive benthonic elements include Cibicidoides proprius, $C$. hercegovinensis, Osangularia pteromphalia and Anomalinoides danica.

Sample 12-117A-7-3, 142-145 cm:

Bryozoan mudstone.

$\mathrm{PF}$ : Globigerina triangularis, $G$, velascoensis.

BF: Anomalinoides danica, Cibicidoides hercegovinensis, cibicidids, lenticulinids, nodosariids.

Also present: Ostracods, molluscs (pectenids, gastropods).

Age: Late Paleocene.

Sample 12-117A-7-4, 139-142 cm:

PF: $\quad$ Globigerina triangularis, $G$. velasconensis.

BF: Essentially same as above plus Lenticulina

Age: midwayensis, Karreria fallax, Anomalinoides acuta.

Age: Late Paleocene. 
Sample 12-117A-7, Core Catcher:

Bryozoan mudstone with rich and diverse benthonic foraminiferal fauna.

PF:

Globigerina triangularis, $G$, velascoensis.

$\mathrm{BF}$ :

Anomalinoides danica, A. acuta, Gavelinella neelyi, Cibicides sp., Osangularia pteromphalia, Lenticulina midwayensis, Dentalina plummerae, nodosariids, Pullenia sp., Vulvulina sp., Karreria fallax, Ammodiscus sp.

Age: $\quad$ Late Paleocene.

Remarks: Core 7 is a bryozoan-rich mudstone with a diverse benthonic foraminiferal fauna of inner-middle neritic affinities.

Sample 12-117A-8-1, 4-6 cm:

Bryozoan mudstone with relatively diverse benthonic foraminiferal fauna.

PF: $\quad$ Globigerina triangularis, G. velascoensis.

BF: Anomalinoides danica, A. acuta, Gavelinella neelyi, Cibicidoides proprias, Osangularia pteromphalia, Lenticulina midwayensis, Vaginulina longiforma, polymorphinids (Guttulina sp.), Gyroidina sp., Vulvulina sp.

Age: Late Paleocene.

Sample 12-117A-8-2, 86-89 cm:

Lithology and fauna essentially same as above.

Sample 12-117A-8, Core Catcher:

PF: $\quad$ Rare, small globigerinids in pan fraction.

BF: Cibicidoides proprias, cibicidids, Lenticulina midwayensis, Marginulina sp., nodosariids, Osangularia pteromphalia, Gyroidina sp., Eponides sp., Verneuilina sp.

Age: Late Paleocene.

Remarks: Core 8 is a bryozoan mudstone with abundant molluscan fragments, fecal pellets and reworked basaltic minerals. Distinctive inner-middle neritic amphi-Atlantic species of benthonic foraminifera occur in this core, as above. Many of the individuals exhibit evidence of abrasion. A relatively large ostreid was found at the bottom of Section 2 .

Sample 12-117A-9, Core Catcher:

Basaltic (reworked) sandstone with shell fragments (molluses, oysters, worm tubes, echinoid spines) and few foraminifera.

PF: $\quad$ Rare, small globigerinids (in pan fraction).

BF: Marginulina sp., polymorphinids, Alabamina sp., Gyroidina sp., Eponides plummerae (these may be contaminants from above). Indigenous fauna consists of a larger foraminifera, Operculina heberti.

Age: Late Paleocene.

Remarks: Core 9 recovered only the Core Catcher sample and a small amount of material in Section 1. It consists of a basaltic (reworked) sandstone with shell fragments of various molluscs and a larger foraminifera: Operculina heberti.

Sample 12-117A-11-1, 25-30 cm:

Thin sections of limestone filling in basalt with calcareous algae, bryozoans, rounded basalt fragments, echinoderms, miliolids, rotaliids and Gypsina.

\section{APPENDIX E. COCCOLITH SPECIES AND STRATIGRAPHIC ASSIGNMENT OF SITES 116 AND 117}

\section{Hole 116}

David Burky

\section{Upper Pliocene \\ (Discoaster brouweri Zone)}

12-116-1-6, 140-141 cm; depth $79 \mathrm{~m}$ :

Coccolithus doronicoides, C. pelagicus [abundant], Coccolithus sp. [tiny], Cyclococcolithina leptopora, C. macintyrei, Discoaster brouweri, D. variabilis variabilis, Helicopontosphaera sellii [common], Scyphosphaera apsteinii Lohmann, Syracosphaera pulchra Lohmann.
Middle Miocene

(Sphenolithus heteromorphus Zone)

12-116-10-6, 139-140 cm; depth $518 \mathrm{~m}$ :

Coccolithus eopelagicus, Cyclococcolithina neogammation, Discoaster sp. cf. D. deflandrei, D. sp. cf. D. exilis, Discolithina segmenta Bukry and Percival, Helicopontosphaera granulata Bukry and Percival, $H$. sp. cf. H. kamptneri, Sphenolithus heteromorphus Deflandre.

\section{Lower Miocene}

(Triquetrorhabdulus carinatus Zone)

12-116-18-4, 140-141 cm; depth $695 \mathrm{~m}$;

Coccolithus pelagicus [abundant], Cyclococcolithina neogammation, Dictyococcites abisectus, D. scrippsae, Discoaster deflandrei, Discolithina sp., Helicopontosphaera parallela (Bramlette and Wilcoxon), Sphenolithus moriformis, Triquetrorhabdulus sp. cf. T. carinatus Martini, Zygrhablithus bijugatus [abundant].

\section{Upper Oligocene \\ (Sphenolithus ciperoensis Zone)}

12-116-21-4, 140-141 cm; depth $716 \mathrm{~m}$ :

Chiasmolithus altus, Coccolithus fenestratus, C. pelagicus, Cyclococcolithina neogammation, Dictyococcites abisectus, D. bisectus, D. scrippsae, Discoaster deflandrei, Discolithina segmenta, Reticulofenestra gartneri, Sphenolithus moriformis, Zygrhablithus bijugatus [abundant].

\section{Lower Oligocene \\ (Helicopontosphaera reticulata Zone)}

12-116-25-5, 141-142 cm; depth $812 \mathrm{~m}$ :

Chiasmolithus oamaruensis, Coccolithus fenestratus, C. pelagicus, Cyclococcolithina formosa, Dictyococcites bisectus, D. scrippsae, Discoaster tani nodifer, Isthmolithus recurvus, Pontosphaera vadosa, Reticulofenestra hillae, $R$. umbilica, Zygrhablithus bijugatus.

\section{Upper Eocene \\ (Discoaster barbadiensis Zone)}

12-116-26-1, 66-67 cm; depth $826 \mathrm{~m}$ :

Coccolithus eopelagicus, Cyclococcolithina formosa, C. neogammation, C. sp. cf. C. reticulata, Dictyococcites bisectus, D. scrippsae, Discoaster sp. cf. D. tani nodifer, D. saipanensis, Isthmolithus recurvus, Lanternithus minutus Stradner, Pontosphaera vadosa, Reticulofenestra hillae, $R$. umbilica, Zygrhablithus bijugatus.

12-116-28-1, 90-91 cm; depth $840 \mathrm{~m}$ :

Chiasmolithus sp. cf. C. expansus, C. oamaruensis, Coccolithus pelagicus, Cyclococcolithina formosa, C. sp. cf. C. reticulata [small], Dictyococcites bisectus, D. scrippsae, Discoaster saipanensis, Reticulofenestra umbilica, Zygrhablithus bijugatus.

\section{Hole 116A}

\section{Upper Pleistocene or Holocene}

12-116A-1 A-2, 133-134 cm; depth 2 m: Coccolithus pelagicus, Cyclococcolithina leptopora, ?Emiliania huxleyi Kamptner, ?Gephyrocapsa ericsonii McIntyre and Be, Helicopontosphaera kamptneri, Syracosphaera sp. cf. S. histrica.

\section{Lower Pleistocene}

(Coccolithus doronicoides Zone)

12-116A-4A-6, 140-141 cm; depth $35 \mathrm{~m}$ :

Coccolithus doronicoides, $C$. pelagicus, Cyclococcolithina leptopora, C. macintyrei, Discolithina japonica, D. multipora s.1., Emiliania annula, Gephyrocapsa caribbeanica, Helicopontosphaera kamptneri, Scyphosphaera sp., Syracosphaera histrica.

12-116A-7A-2, 140-141 cm; depth $56 \mathrm{~m}$ :

Coccolithus neohelis, C. pelagicus, Cyclococcolithina leptopora, C. macintyrei, Helicopontosphaera sellii, Rhabdosphaera clavigera, Syracosphaera sp. 
12-116A-8A-3, 141-142 cm; depth $66 \mathrm{~m}$ :

Acanthoica sp. aff. A. acanthos Schiller, Coccolithus doronicoides, C. pelagicus, Cyclococcolithina leptopora, C. macintyrei, Helicopontosphaera sellii, Rhabdosphaera sp. cf. $R$. stylifera Lohmann, Syracosphaera sp.

\section{Upper Pliocene?}

12-116A-8A-4, 147-148 cm; depth $68 \mathrm{~m}$ :

Coccolithus pelagicus, Cyclococcolithina leptopora, C. macintyrei, Discoaster sp. cf. D. brouweri [rare], Discolithina japonica, Emiliania annula, Helicopontosphaera kamptneri [rare].

\section{Hole 117}

\section{Upper Oligocene \\ (Sphenolithus ciperoensis Zone)}

12-117-2-3, 146-148 cm; depth $102 \mathrm{~m}$ :

Braarudosphaera discula Bramlette and Riedel [rare], Chiasmolithus altus [fantastically abundant], Coccolithus eopelagicus, Cyclococcolithina neogammation, Dictyococcites abisectus, D. bisectus, D. scrippsae, Discoaster deflandrei, Sphenolithus moriformis, Zygrhablithus bijugatus [abundant] .

12-117-2-4, 144-145 cm; depth $103 \mathrm{~m}$ :

Chiasmolithus altus, Coccolithus eopelagicus, Cyclococcolithina neogammation, Dictyococcites abisectus, D. bisectus, D. scrippsae, Discoaster deflandrei, Discolithina sp., Reticulofenestra gartneri, Sphenolithus ciperoensis, S. moriformis, Zygrhablithus bijugatus.

\section{Hole 117A}

\section{Upper Oligocene \\ (Sphenolithus ciperoensis Zone)}

12-117A-1A-1, 54-55 cm; depth $147 \mathrm{~m}$ :

Chiasmolithus altus, Coccolithus eopelagicus, Cyclococcolithina neogammation, Dictyococcites bisectus, D. scrippsae, Helicopontosphaera truncata (Bramlette and Wilcoxon), Zygrhablithus bijugatus.
12-117A-1A-1, 70-71 cm; depth $147 \mathrm{~m}$ :

Chiasmolithus altus, Cyclococcolithina neogammation, Reticulofenestra gartneri. Reworked Lower Eocene taxa: Discoaster lodoensis, D. sp. aff. D. obscurus Martini, Discoasteroides kuepperi, Tribrachiatus orthostylus.

\section{Lower Eocene \\ (Tribrachiatus orthostylus Zone)}

12-117A-3A-1, 131-132 cm; depth $222 \mathrm{~m}$ :

Chiasmolithus grandis, Coccolithus crassus, Cyclococcolithina luminis, Discoaster binodosus, Markalius inversus, Micrantholithus sp., Syracosphaera fimbriata, Transversopontis pulcheroides, Tribrachiatus orthostylus, Zygolithus dubius, Zygrhablithus bijugatus.

12-117A-3A-4, 137-138 cm; depth $226 \mathrm{~m}$ :

Chiphragmalithus calathus Bramlette and Sullivan, Discoaster obscurus, D. sp. aff. D. obscurus, Discoasteroides kuepperi, Lophodolithus nascens, Syracosphaera fimbriata, Tribrachiatus orthostylus, Zygolithus dubius, Zygrhablithus bijugatus.

12-117A-3A-6, 140-141 cm; depth $229 \mathrm{~m}$ :

Discolithina ocellata (Bramlette and Sullivan), Micrantholithus sp., Syracosphaera fimbriata, Transversopontis pulcher, T. pulcheroides, Zygolithus dubius, Z. protenus (Bramlette and Sullivan).

\section{Upper Paleocene or Lower Eocene}

12-117A-4A-1, 136-137 cm; depth $271 \mathrm{~m}$ :

Braarudosphaera bigelowi, Chiasmolithus bidens (Bramlette and Sullivan), Discoaster multiradiatus Bramlette and Riedel, D. ornatus Stradner, Ellipsolithus distichus (Bramlette and Sullivan), Zygolithus chiastus Bramlette and Sullivan, Z. dubius, Z. junctus Bramlette and Sullivan.

12-117A-6A-1, 144-145 cm; depth $276 \mathrm{~m}$ :

Braarudosphaera bigelowi, Chiasmolithus bidens, Discoaster sp. cf. D. diastypus Bramlette and Sullivan, Discolithina ocellata, Ellipsolithus macellus Bramlette and Sullivan, Markalius inversus, Transversopontis pulcheroides, Tribrachiatus contortus (Stradner), [basionym: Discoaster contortus Stradner, 1958, Erdoel-Z. 74: p 187, figs. 35-36], Tribrachiatus orthostylus, Zygrhablitus bijugatus. 

HOLE 116

CORE 1

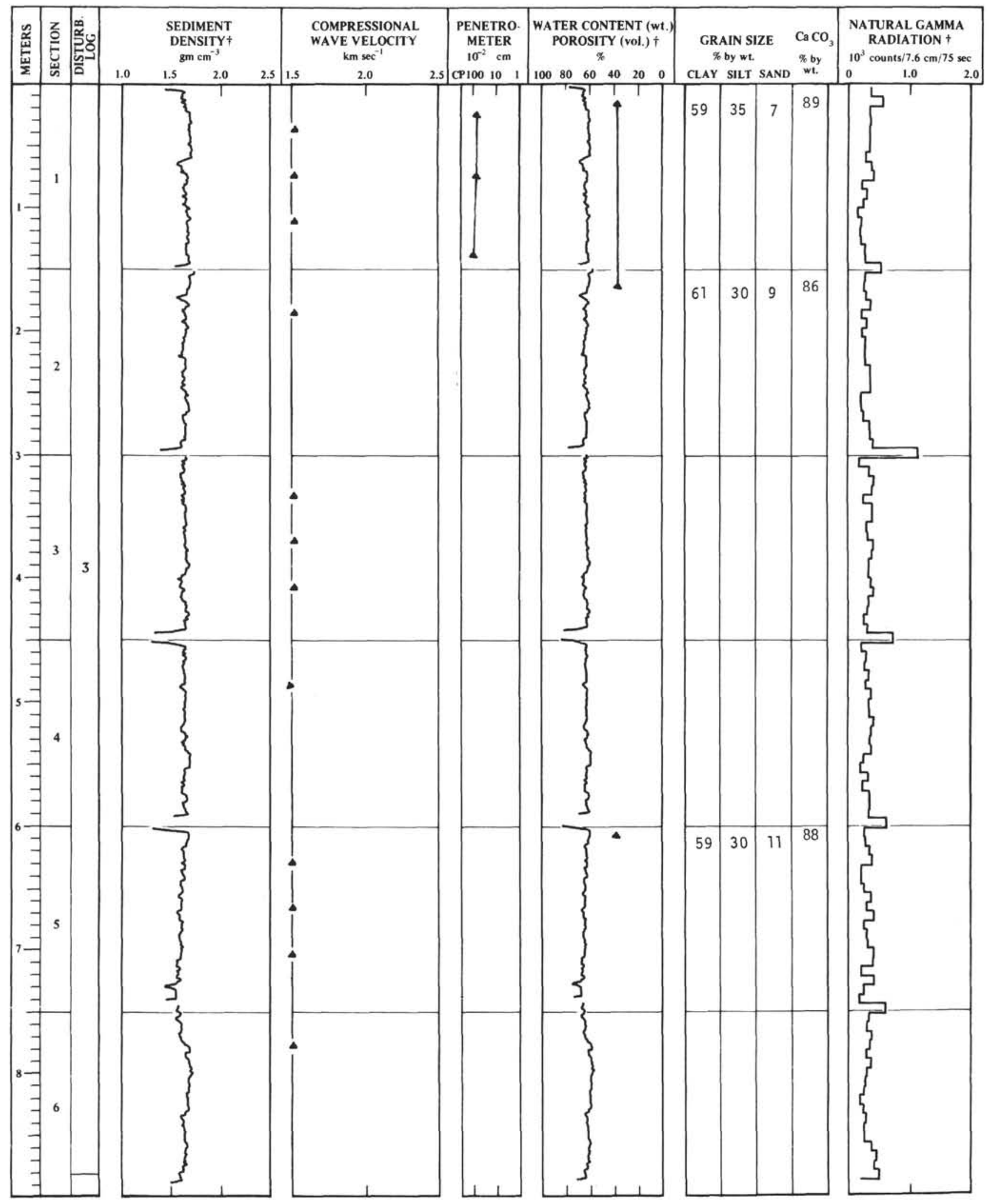

tAdjusted data, see Chapter 2 

HOLE
CORE 1

\begin{tabular}{|c|c|c|c|c|c|c|c|c|}
\hline$\frac{\mathscr{w}}{\frac{1}{2}}$ & 总 & LITHOL. & 造 & & LITHOLOGY & DIAGNOSTIC FOSSILS & $\begin{array}{c}\text { BIO- } \\
\text { STRAT. }\end{array}$ & $\begin{array}{c}\text { TIME } \\
\text { STRAT. }\end{array}$ \\
\hline $\begin{array}{r}\text { J } \\
\\
\\
\end{array}$ & 5 & 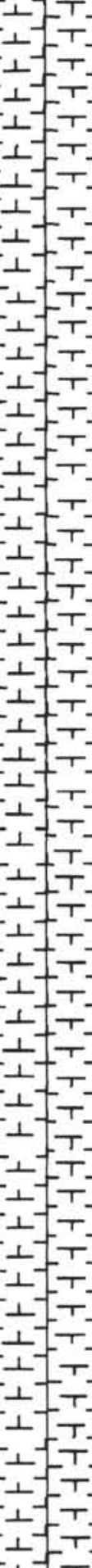 & $\begin{array}{l}\text { XM } \\
\text { R } \\
\text { N } \\
\text { XM }\end{array}$ & N8 & 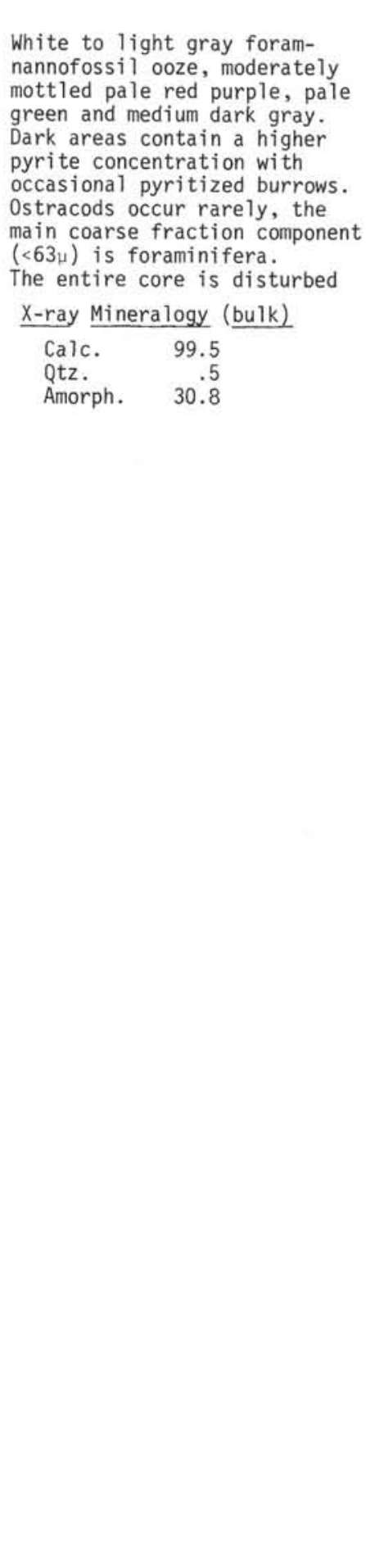 & $\begin{array}{l}\text { Radiolarians common. Spongaster sp. cf. } \\
\text { S. tetras, Druppatractus imregularis, } \\
\text { discoidal and spheroidal spumellarians. } \\
\text { Coccolithus pelagicus, Cyclococcolithus } \\
\text { leptoporus, C. macintyrei, Pseudoemili- } \\
\text { ania lacunosa, Helicopontosphaera } \\
\text { kamptremi, H. sellii, Pontosphaera } \\
\text { discopora, P. scutellum, Syracosphaera } \\
\text { sp., Scyphosphaera apsteini, } \\
\text { Sphenolithus cf. S. neoabies, Discoaster } \\
\text { sp. D. brozweri, D. surculus, D. } \\
\text { pentaradiatus. } \\
\text { Globigerina atlantica, G. bulloides, } \\
\text { Globigerinita glutinata } \\
\text { Flora similar to above } \\
\text { Radiolarians rare. Spongaster sp. cf. } \\
\text { S. tetras. } \\
\text { Assemblage similar to above } \\
\text { Fauna similar to above } \\
\text { G. atlantica, G. bulloides, G. glutinata, } \\
\text { Globorotalia crassaformis, G. scitula } \\
\text { Radiolarians common. Spongaster sp. cf. } \\
\text { Radiolarians rare. Spongaster sp. cf. } \\
\text { S. tetras. Assemblage similar to above. } \\
\text { S. tetras. } \\
\text { Assemblage similar to above. } \\
\text { Flora similar to above } \\
\text { Fauna similar to above } \\
\text { Fauna similar to above } \\
\text { Flora similar to above } \\
\text { Flora similar to above } \\
\text { Radiolarians common. Spongaster sp. cf. } \\
\text { S. tetras. Assemblage similar to above. } \\
\text { Flora similar to above } \\
\text { Reticulofenestra pseudoumbilica } \\
\text { Flora similar to above } \\
\text { Radiolarians common. Spongaster sp. cf. } \\
\text { Assemblage similar to above. } \\
\end{array}$ & 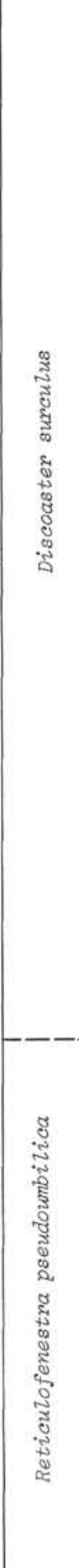 & 岂 \\
\hline & CC & $\frac{1-1}{11}-\frac{T}{T}$ & $\begin{array}{l}\mathrm{R} \\
\mathrm{N} \\
\mathrm{F}\end{array}$ & & & $\begin{array}{l}\text { Radiolarians abundant, Sponaaster sp. cf. } \\
\text { s. tetras, Pterocanium praetextium, } \\
\text { spheroidal and discoidal spumellarians. } \\
\text { Flora \& fauna similar to above. }\end{array}$ & & \\
\hline
\end{tabular}


HOLE 116

CORE 2

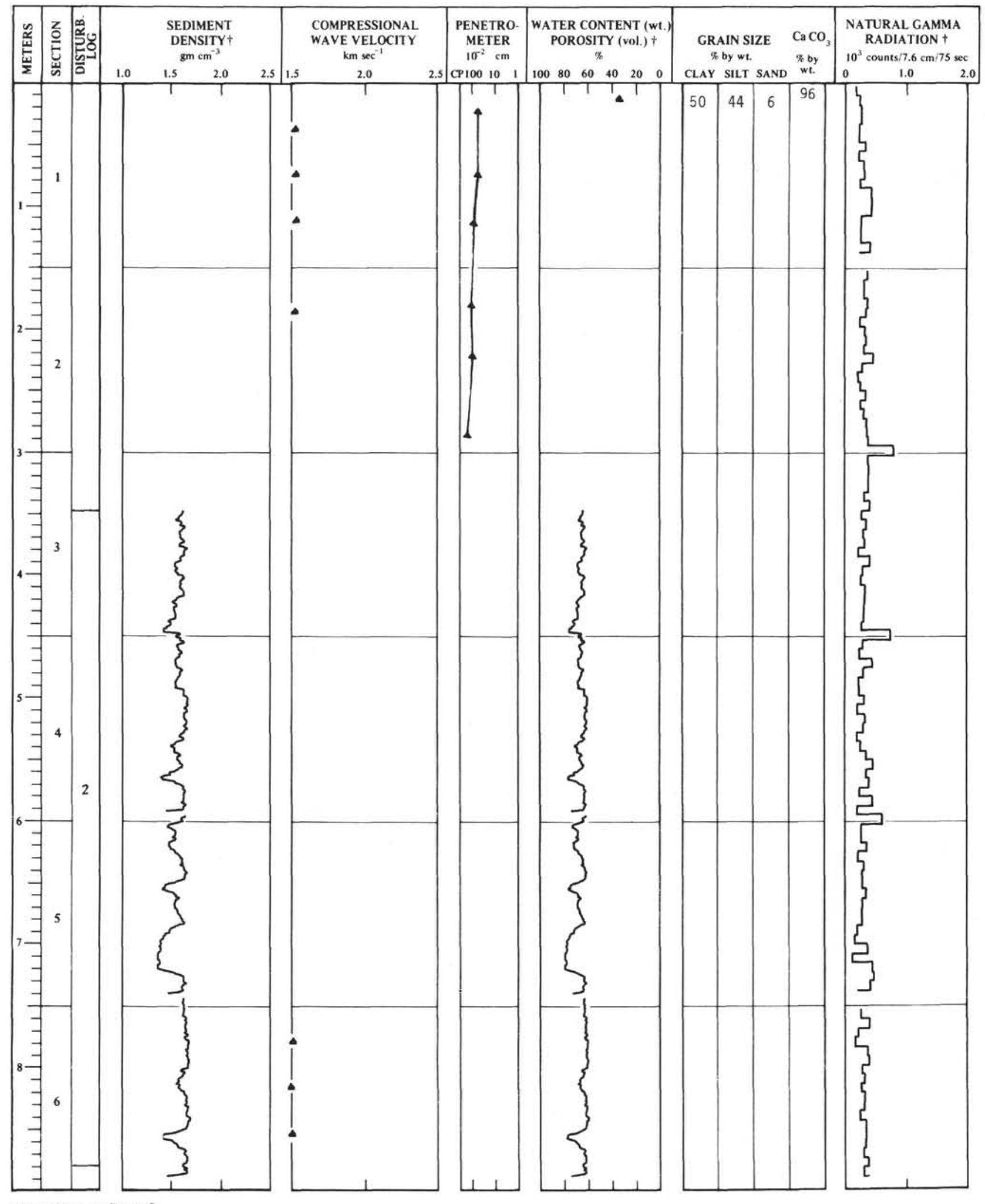




$\begin{array}{llll}\text { HOLE } & 116 & 109 \text { TO } & 118 \mathrm{~m} \\ \text { CORE } & 2 & & \end{array}$

\begin{tabular}{|c|c|c|c|c|c|c|c|}
\hline$\frac{\mathscr{2}}{\frac{2}{2}}$ & 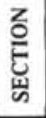 & LITHOL. & $\frac{3}{\sum_{1}^{2}}$ & LITHOLOGY & DIAGNOSTIC FOSSILS & $\begin{array}{l}\text { BIO- } \\
\text { STRAT. }\end{array}$ & $\begin{array}{l}\text { TIME } \\
\text { STRAT. }\end{array}$ \\
\hline 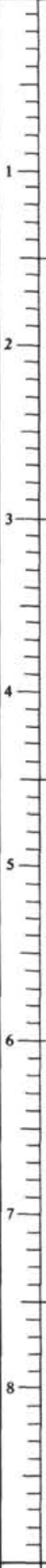 & 5 & $\begin{array}{c}\text { NOT } \\
\text { SPLIT }\end{array}$ & $\underset{R}{N, F}$ & $\begin{array}{l}\text { Light gray and pale greenish } \\
\text { yellow foram-nannofossil ooze } \\
\text { moderately mottled black, yellow } \\
\text { and pale olive. Dark areas } \\
\text { contain high pyrite concentra- } \\
\text { tions. Glass \& glauconite are } \\
\text { rare. Sandier layers with very } \\
\text { high foram concentration occur } \\
\text { in section 1. "Zero" section } \\
(10 \mathrm{~cm}) \text { also present. } \\
\text { X-ray mineralogy } \\
\text { Calc. } 100 \\
\text { Amorph. } 27 \\
\end{array}$ & $\begin{array}{l}\text { Flora similar to above. } \\
\text { Fauna similar to above. } \\
\text { Radiolarians rare. Same as above. } \\
\\
\text { Flora similar to above. } \\
\text { Radiolarians common. Same as above. } \\
\text { Stichocorys peregrina } \\
\text { Core Catcher: } \\
\text { Radiolarians rare. } \\
\text { Flora similar to above } \\
\text { Radiolarians abundant. Sinilar assem- } \\
\text { blage. } \\
\text { Stichocorys peregrina, Artostrobiwm } \\
\text { doliolzm. }\end{array}$ & 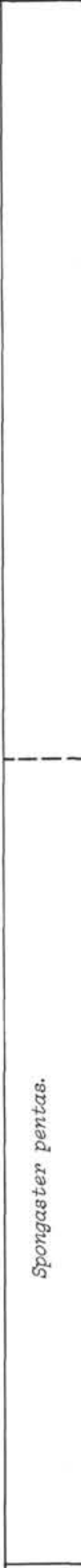 & 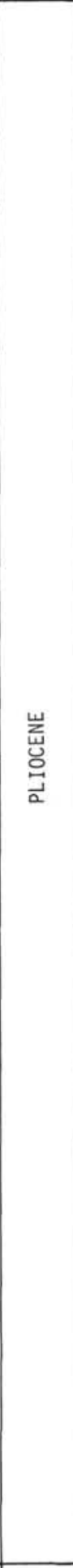 \\
\hline & $\mathrm{cc}$ & & $\begin{array}{l}R \\
N \\
F\end{array}$ & & $\begin{array}{l}\text { Flora sinilar to above } \\
\text { G. bulloides, G. atlantica, 0. universa, } \\
\text { G. puncticulata, G. acostaensis, } \\
\text { G. humerosa }\end{array}$ & & \\
\hline
\end{tabular}


HOLE 116

CORE 3

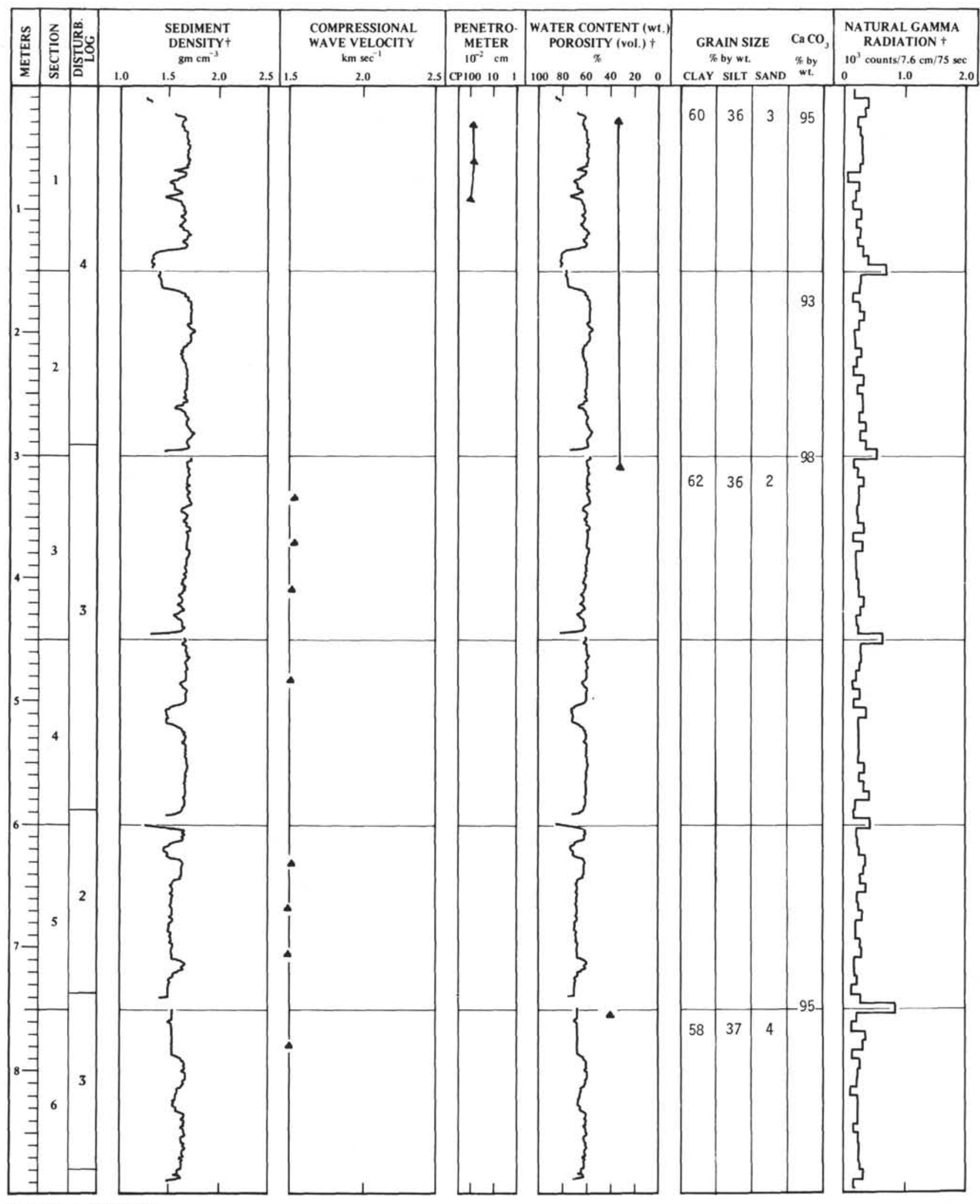


CORE 3

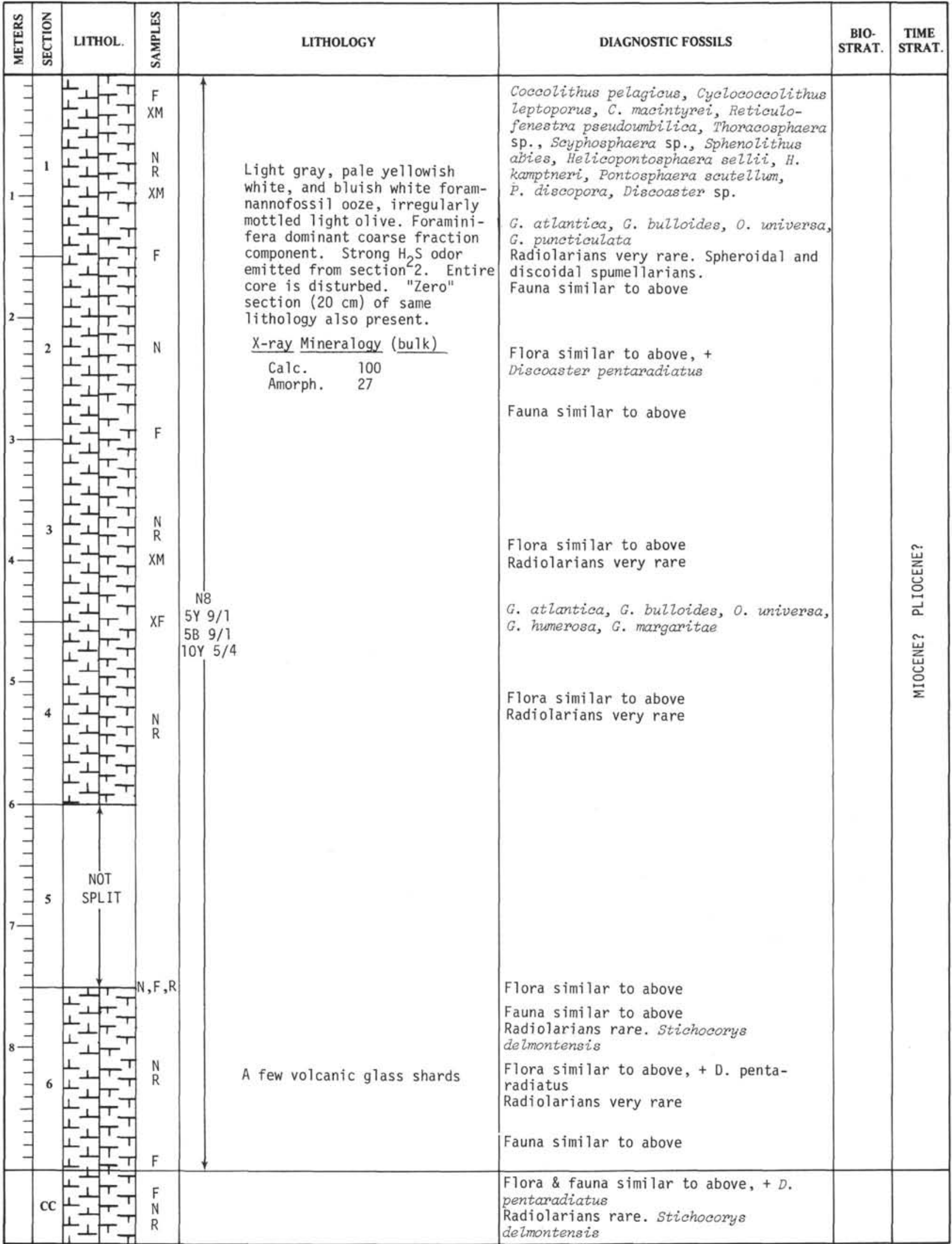


HOLE 116

CORE 4

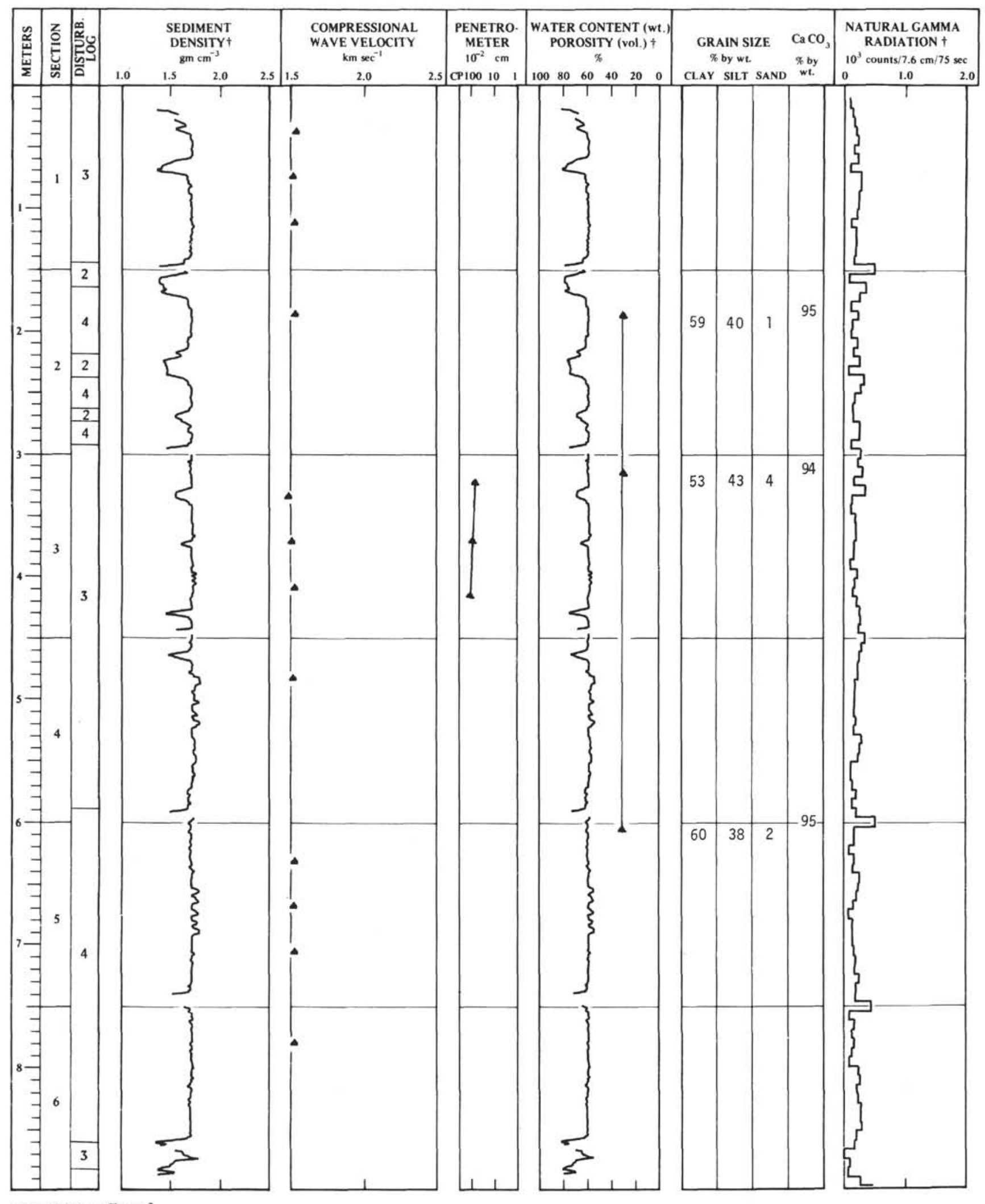




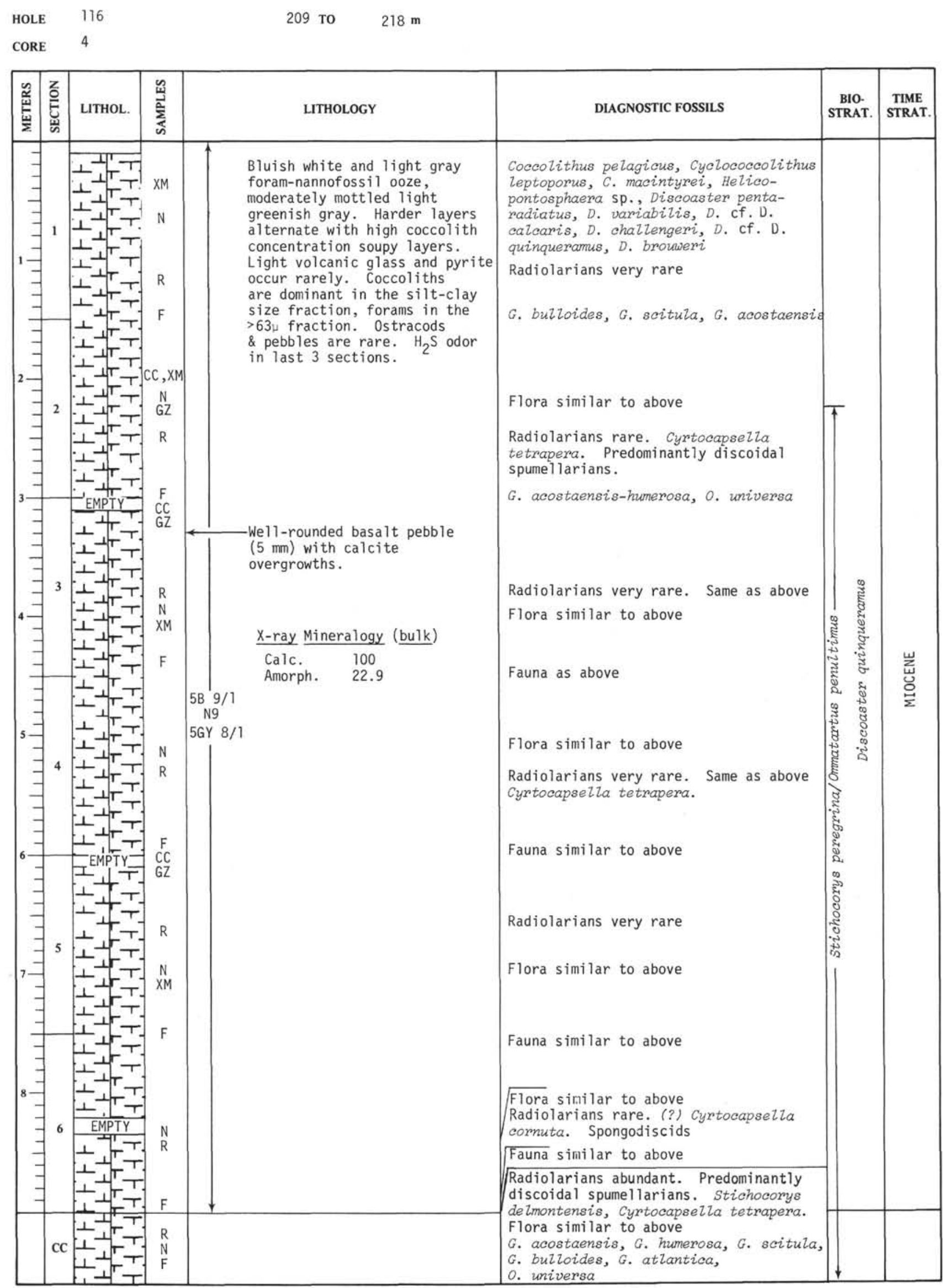


HOLE 116

CORE 5

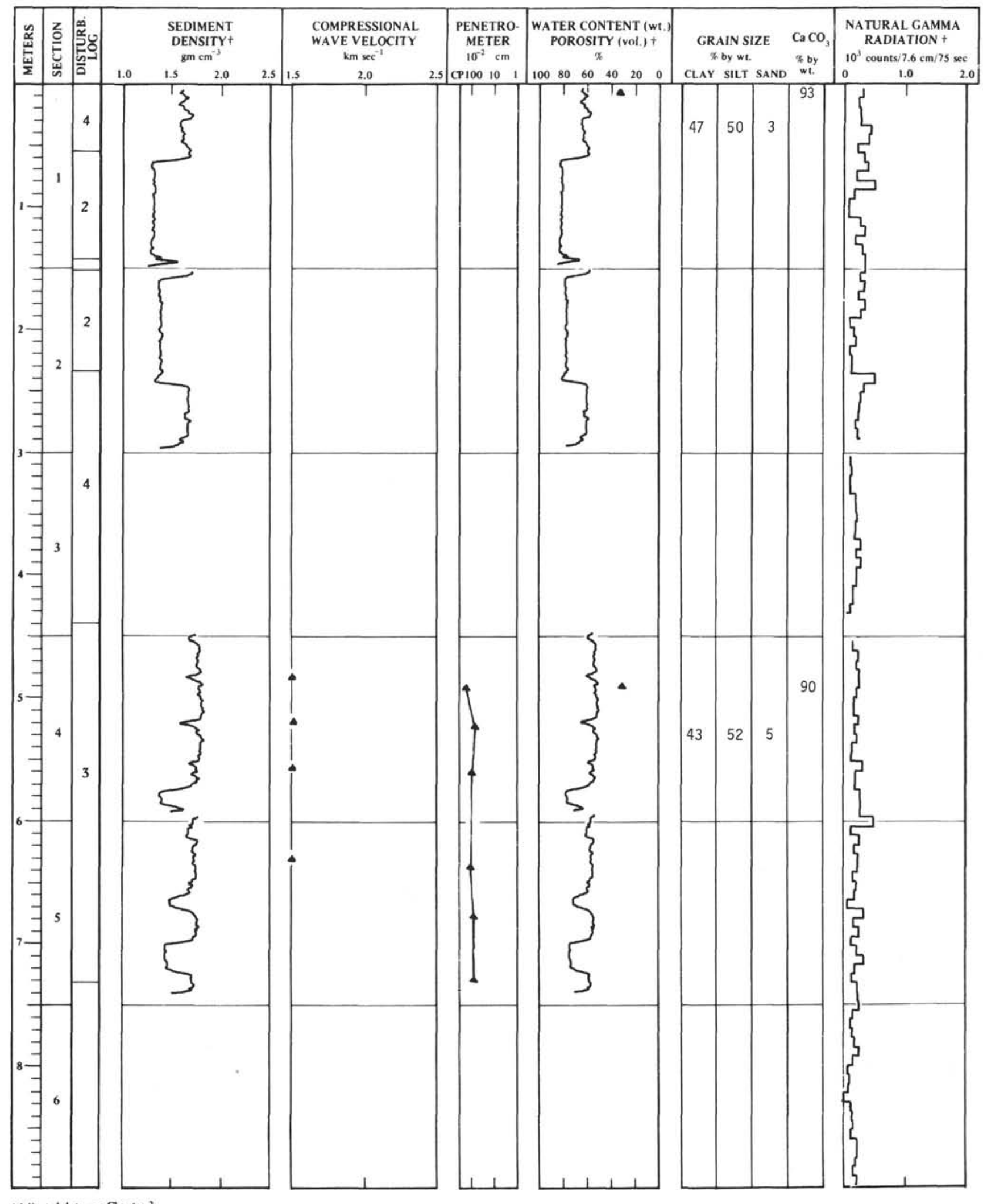



HOLE $\quad 116$
259 то
$268 \mathrm{~m}$
CORE 5

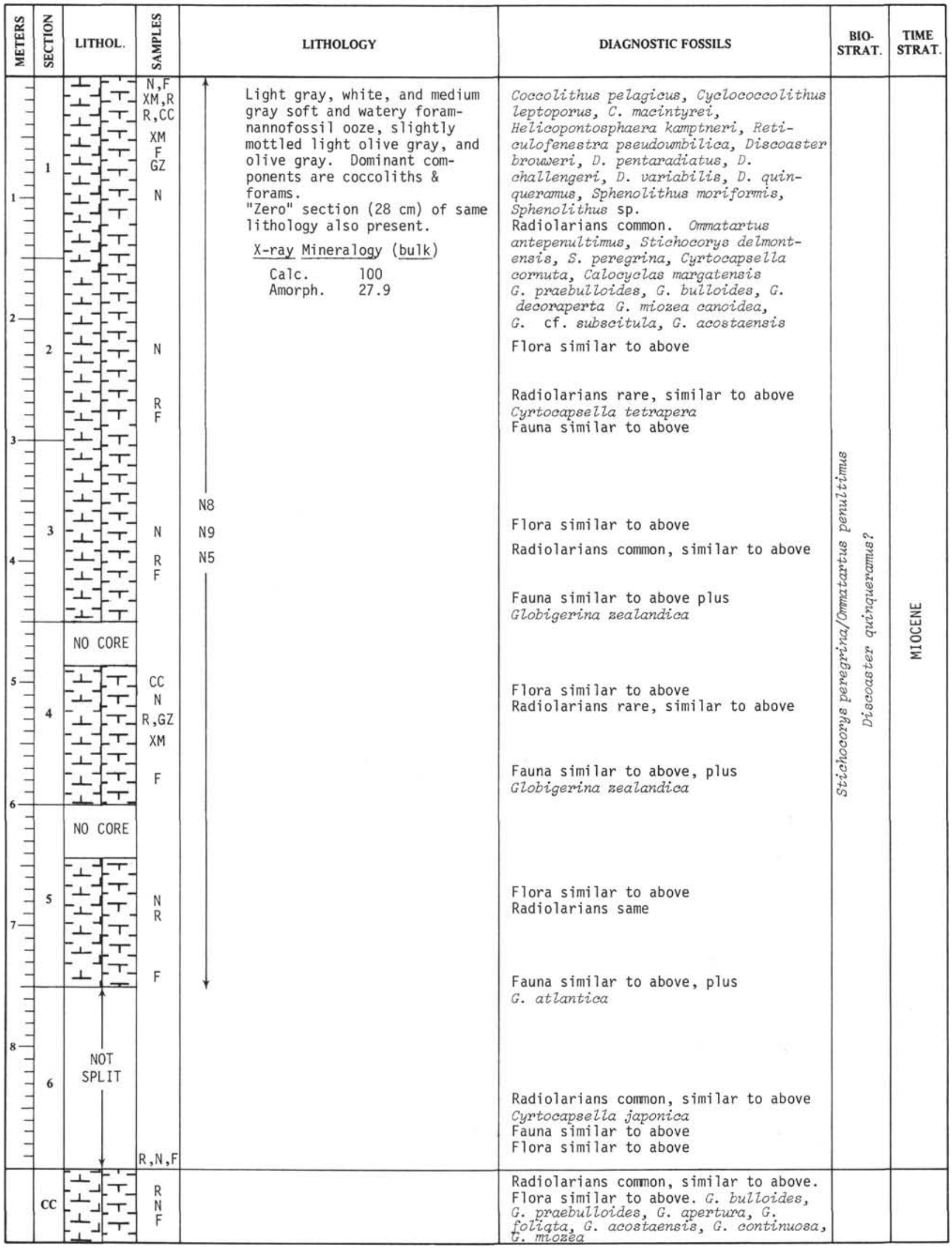


HOLE 116

CORE 6

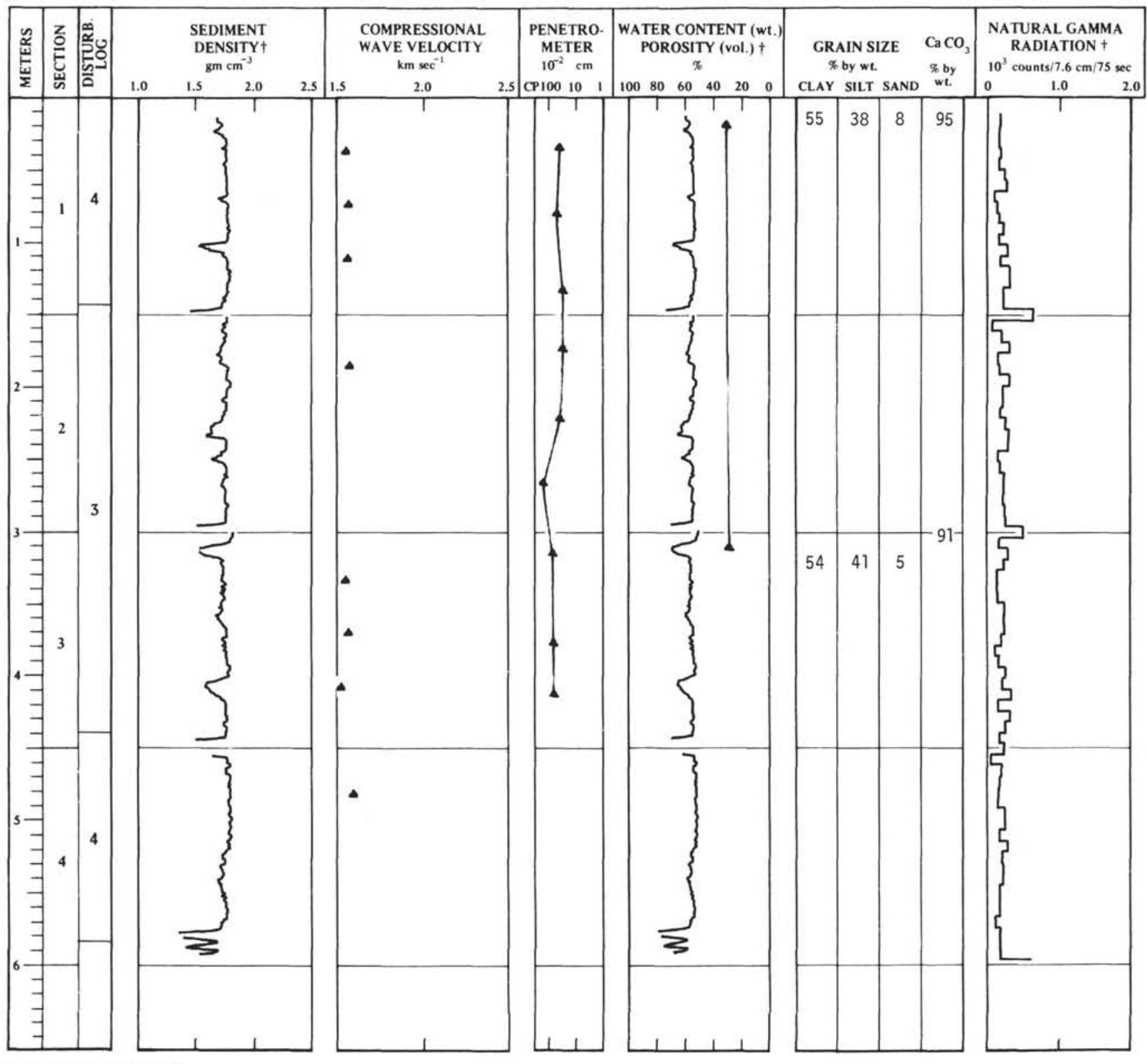

+Adjusted data, see Chapter 2 


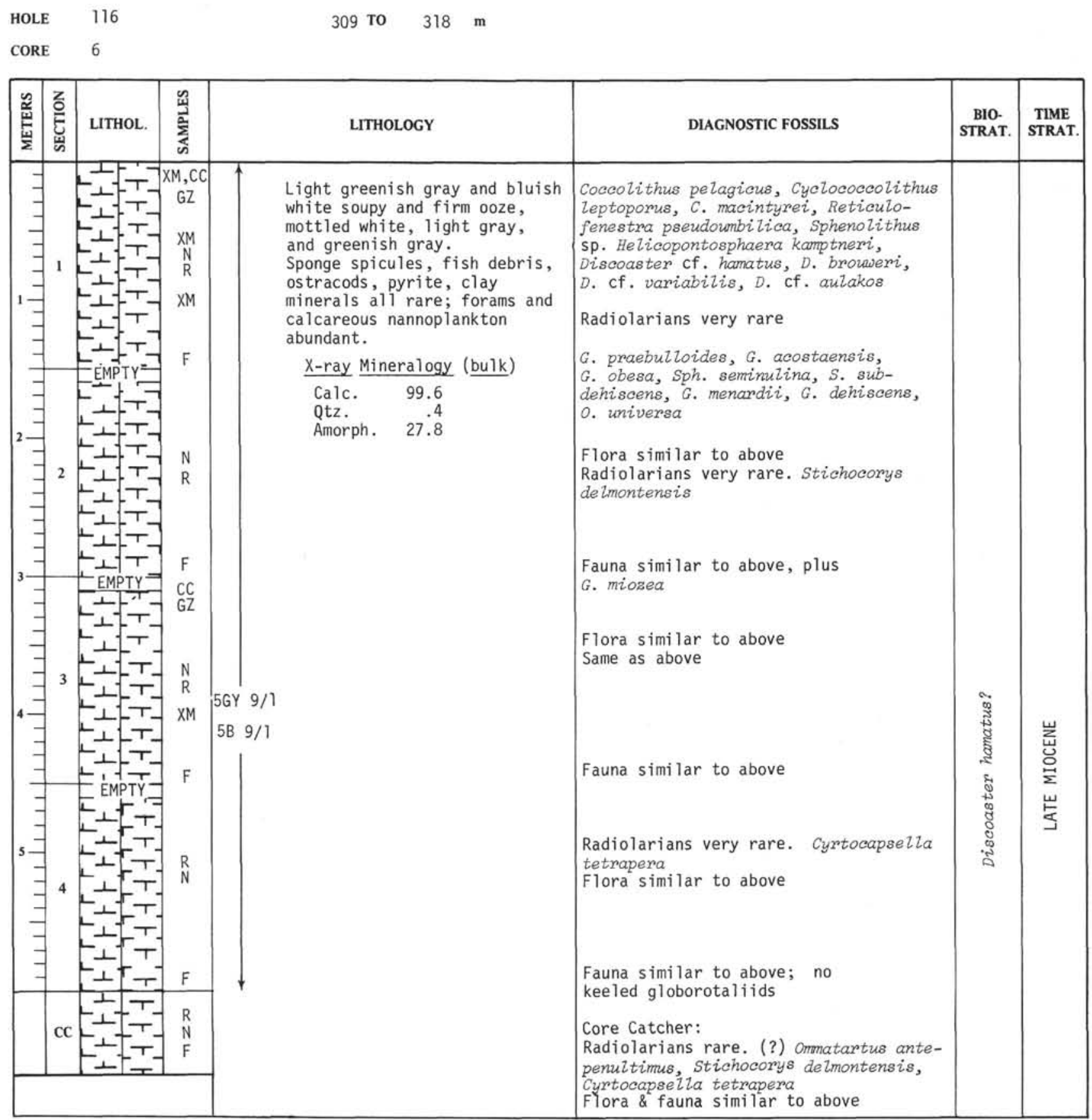


HOLE 116

CORE 7

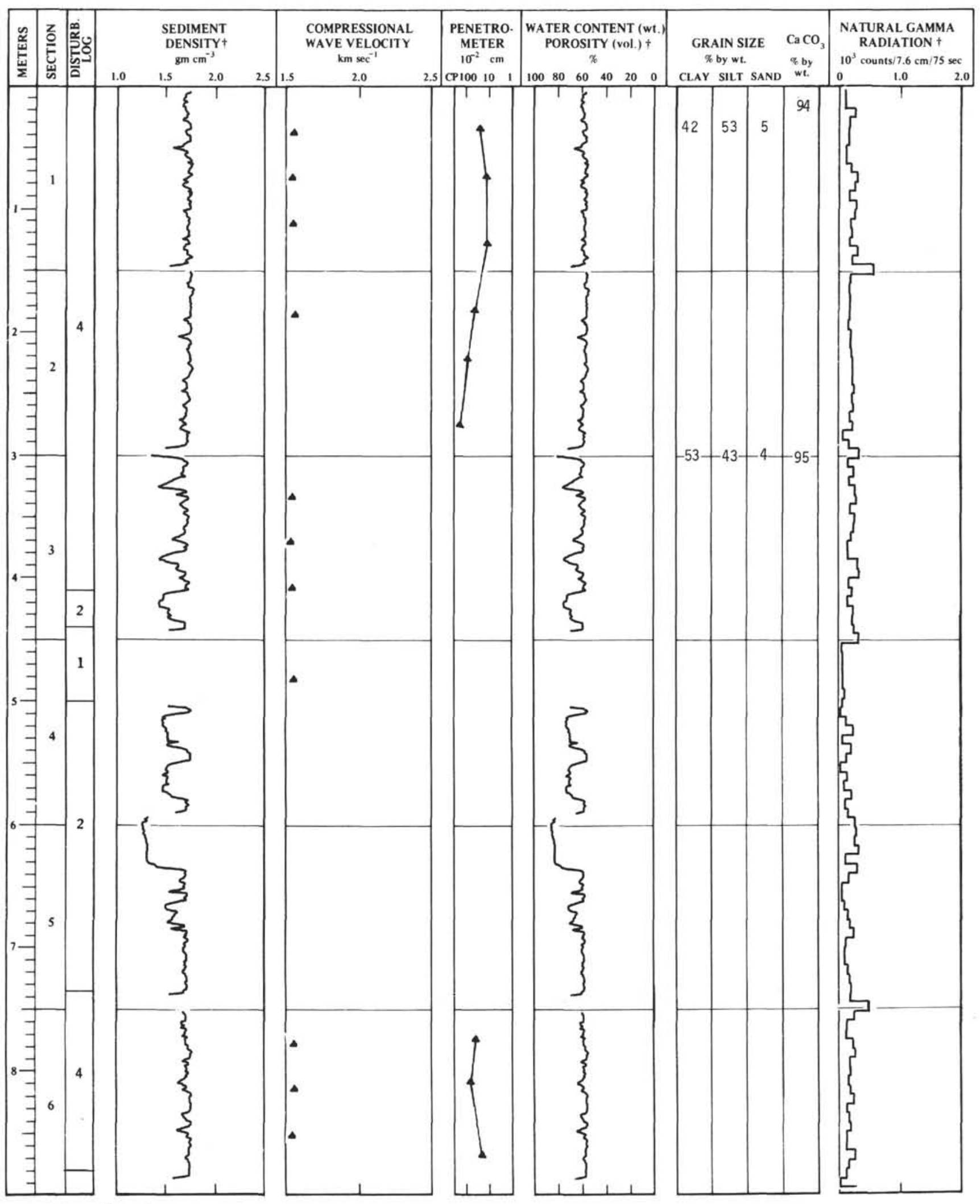


$\begin{array}{llllll}\text { HOLE } & 116 & 359 \text { Tо } & 368 & \mathrm{~m} \\ \text { CORE } & 7 & & & & \end{array}$

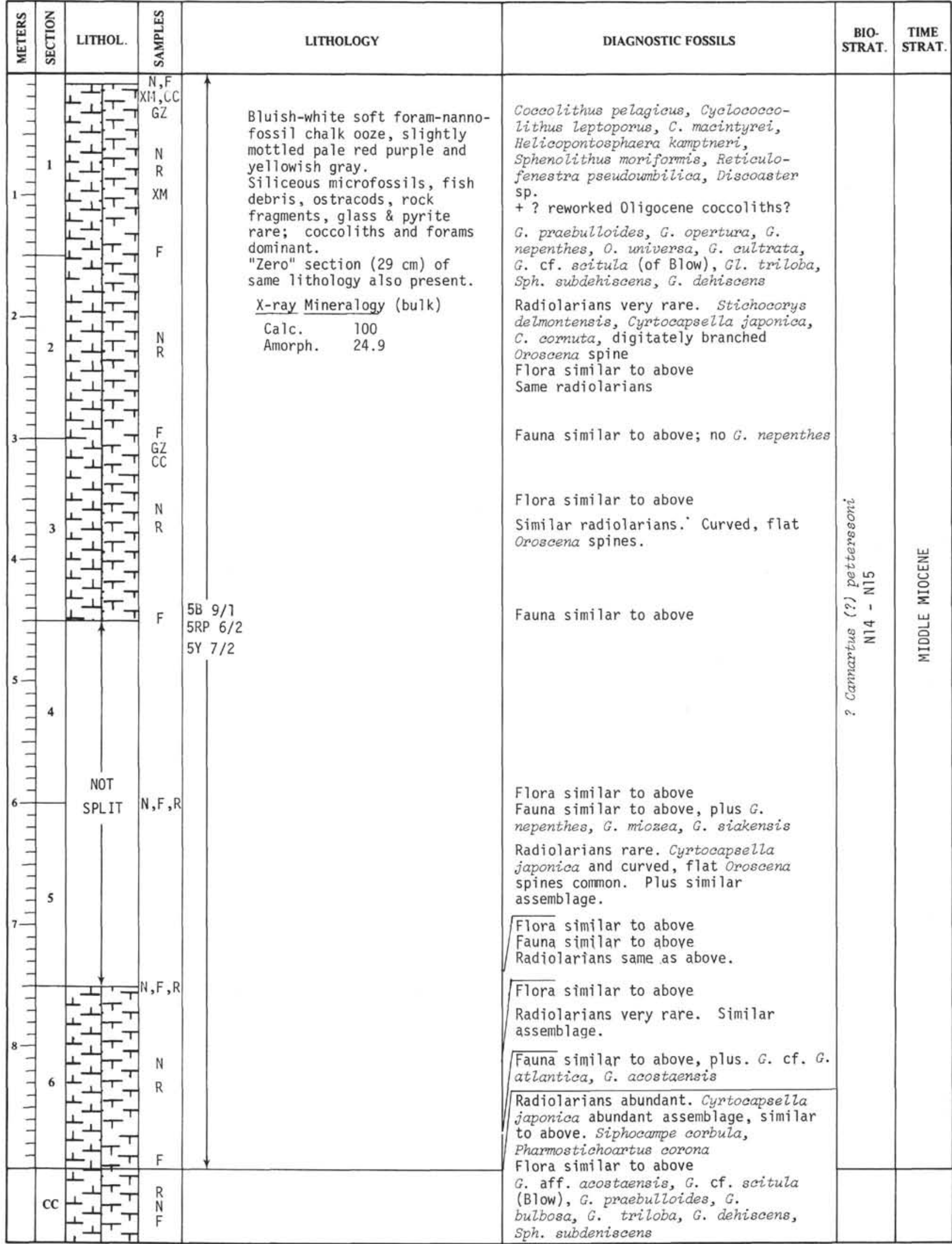


HOLE 116

CORE 8

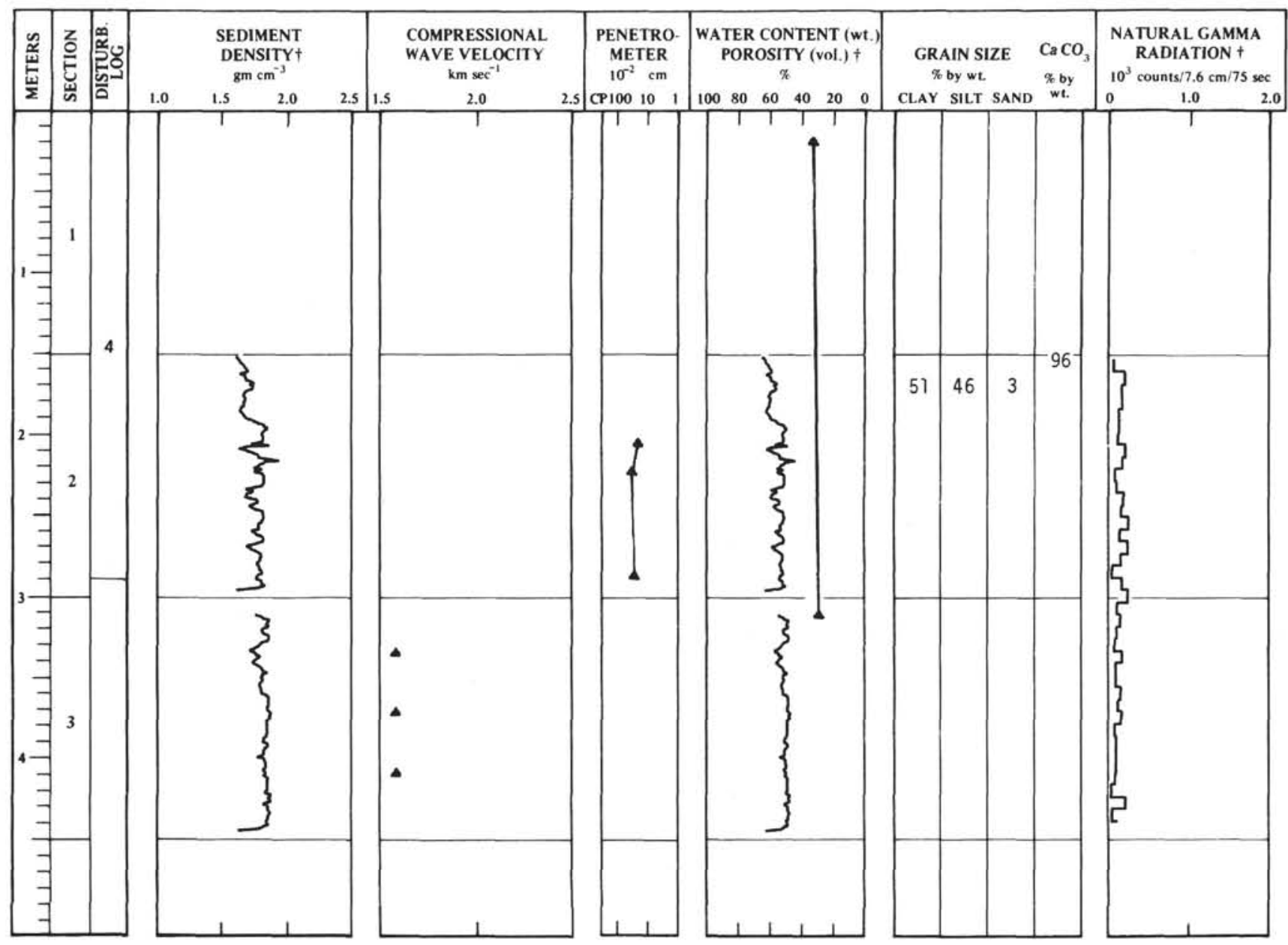

+Adjusted data, see Chapter 2 
$\begin{array}{llrl}\text { HOLE } & 116 & 409 \text { TO } & 418 \mathrm{~m} \\ \text { CORE } & 8 & & \end{array}$

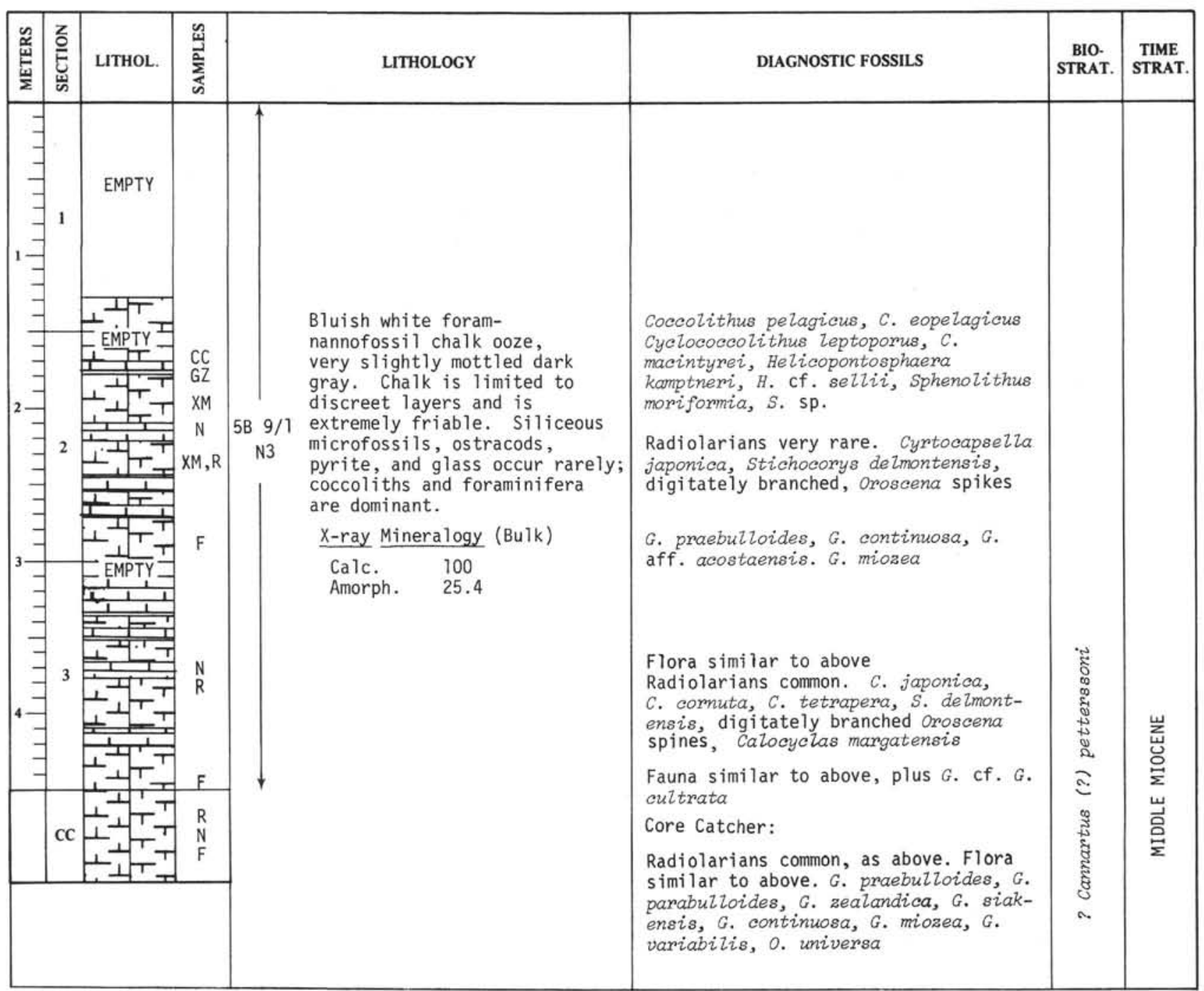


SHIPBOARD SCIENTIFIC PARTY

HOLE 116

CORE 9

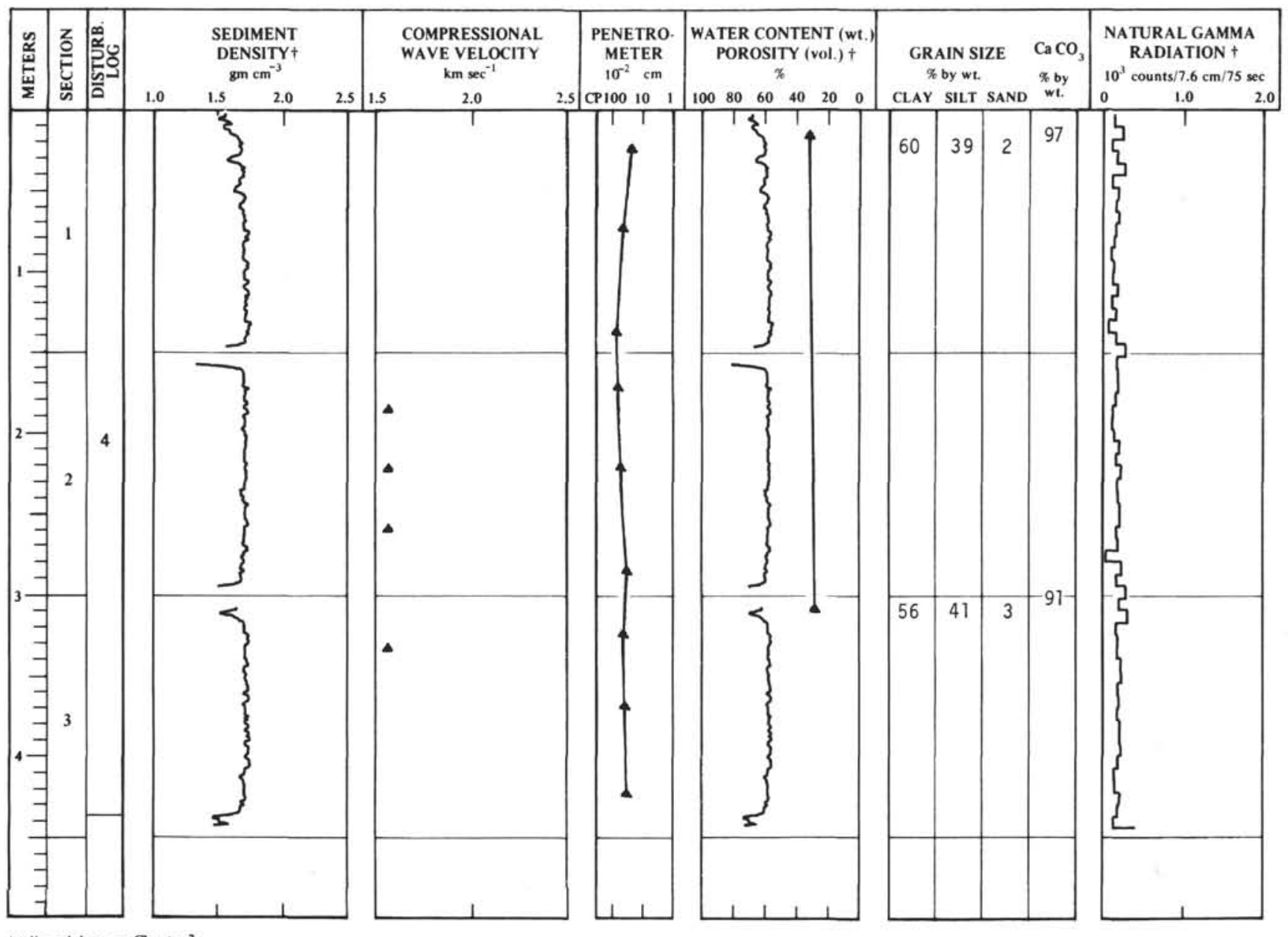

+Adjusted data, see Chapter 2 
HOLE 116

CORE 9

\begin{tabular}{|c|c|c|c|c|c|c|c|c|}
\hline$\frac{\mathscr{z}}{\stackrel{\varkappa}{2}}$ & 孞 & LITHOL. & 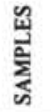 & & LITHOLOGY & DIAGNOSTIC FOSSILS & $\begin{array}{c}\text { BIO. } \\
\text { STRAT. }\end{array}$ & $\begin{array}{l}\text { TIME } \\
\text { STRAT. }\end{array}$ \\
\hline & $\mathrm{Cc}$ & & $\begin{array}{c}X M \\
R \\
N \\
F\end{array}$ & $\left.\right|_{5 B 9 / 1}$ & $\begin{array}{l}\text { Bluish-white foram-nannofossil } \\
\text { chalk ooze slightly mottled } \\
\text { white, medium light gray and } \\
\text { yellowish gray. Ostracods, } \\
\text { fish debris, glass, and } \\
\text { pyrite are rare. } \\
\frac{\text { X-ray Mineralogy (bulk) }}{\text { Calc. } 100} \\
\text { Amorph. } 24.2\end{array}$ & $\begin{array}{l}\text { Coccolithus pelagicus, C. eopelagicus, } \\
\text { Cyclococcolithus leptoporus? } \\
\text { Helicopontosphaera kamptneri, H. cf. H. } \\
\text { parallela, Sphenolithus moriformis, } \\
\text { Reticutofenestra pseudoumbilica, } \\
\text { Disocaster sp., Coronocyclus nitescens. } \\
\text { Radiolarians common. Lithopera renzae, } \\
\text { Cyrtocapsella japonica, C. cornuta, } \\
\text { C. tetrapera, Stichocorys delmontensis, } \\
\text { digitately branched Oroscena spines. } \\
\text { Praeorb. glomerosa circularis, O. } \\
\text { suturalis, G. praebulloides, G. } \\
\text { peripheroacuta, G. praemenardii, G. } \\
\text { siakensis, Globoquadrina baroemoenensis, } \\
\text { G. trilaba } \\
\text { Radiolarians rare. As above. } \\
\text { Flora similar to above } \\
\text { Fauna similar to above. } \\
\text { Flora similar to above } \\
\text { Flora similar to above } \\
\text { Radiolarians abundant. C. tetrapera } \\
\text { abundant; flat, curved Oroscena spines; } \\
\text { plus above. } \\
\text { Flora similar to above } \\
\text { Flora similar to above; G. praemenardii } \\
\text { common } \\
\text { Core Catcher: } \\
\text { Radiolarians abundant. Lithopera } \\
\text { neotera, L. renzae, (?) Cannartus } \\
\text { laticonus, plus assemblage as above. } \\
\text { Flora similar to above. } \\
\text { Pr. glomerosa curva, G. praemenardii, } \\
\text { G. aff. miozea, G. dehiscens } \\
\end{array}$ & 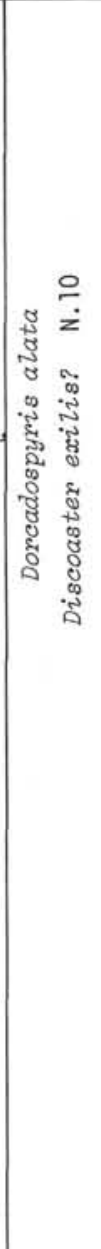 & 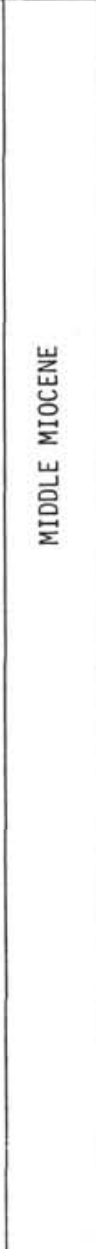 \\
\hline
\end{tabular}


HOLE 116

CORE 10

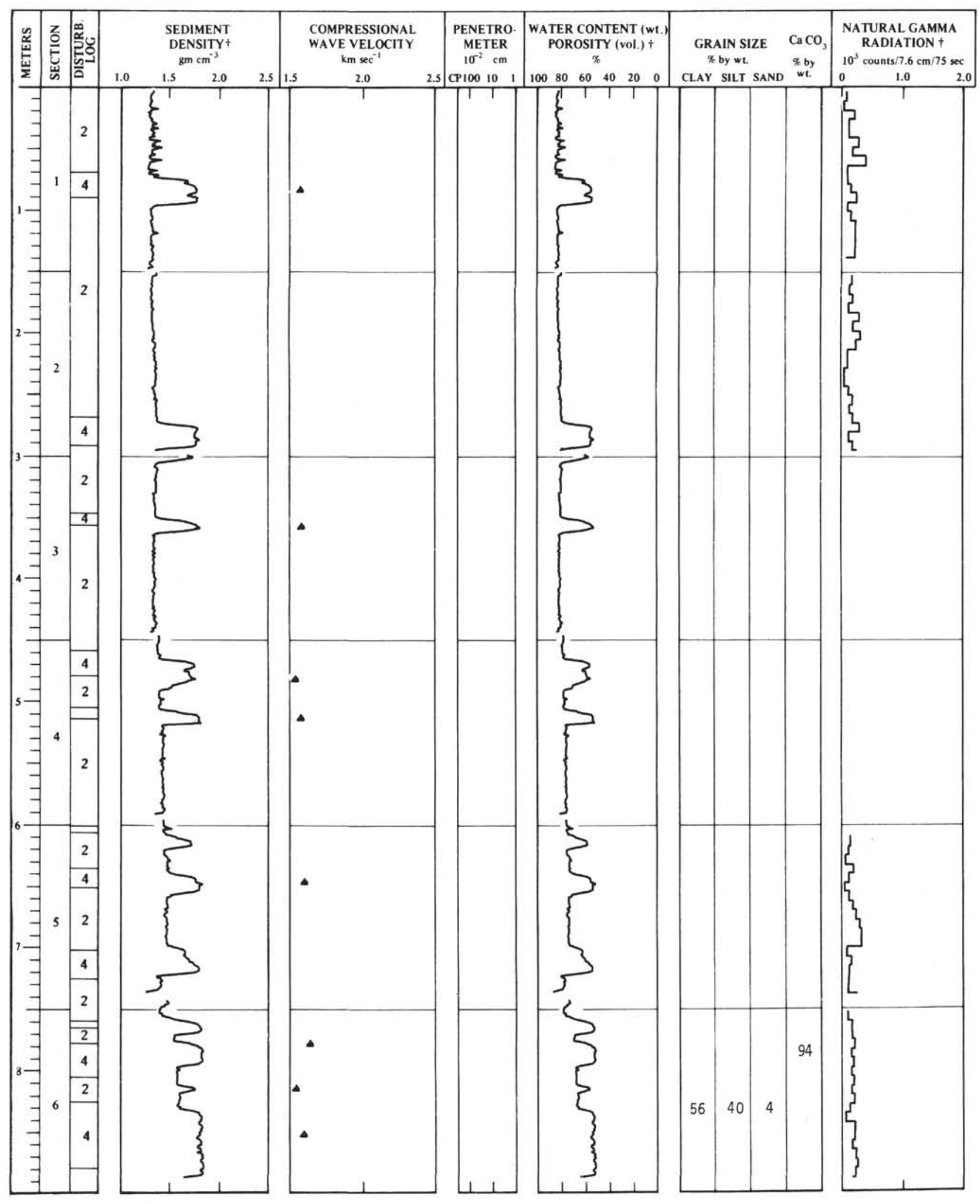

+Adjusted data, see Chapter 2 

HOLE $\quad 116$
509 то
$518 \mathrm{~m}$
CORE 10




HOLE 116

CORE 11

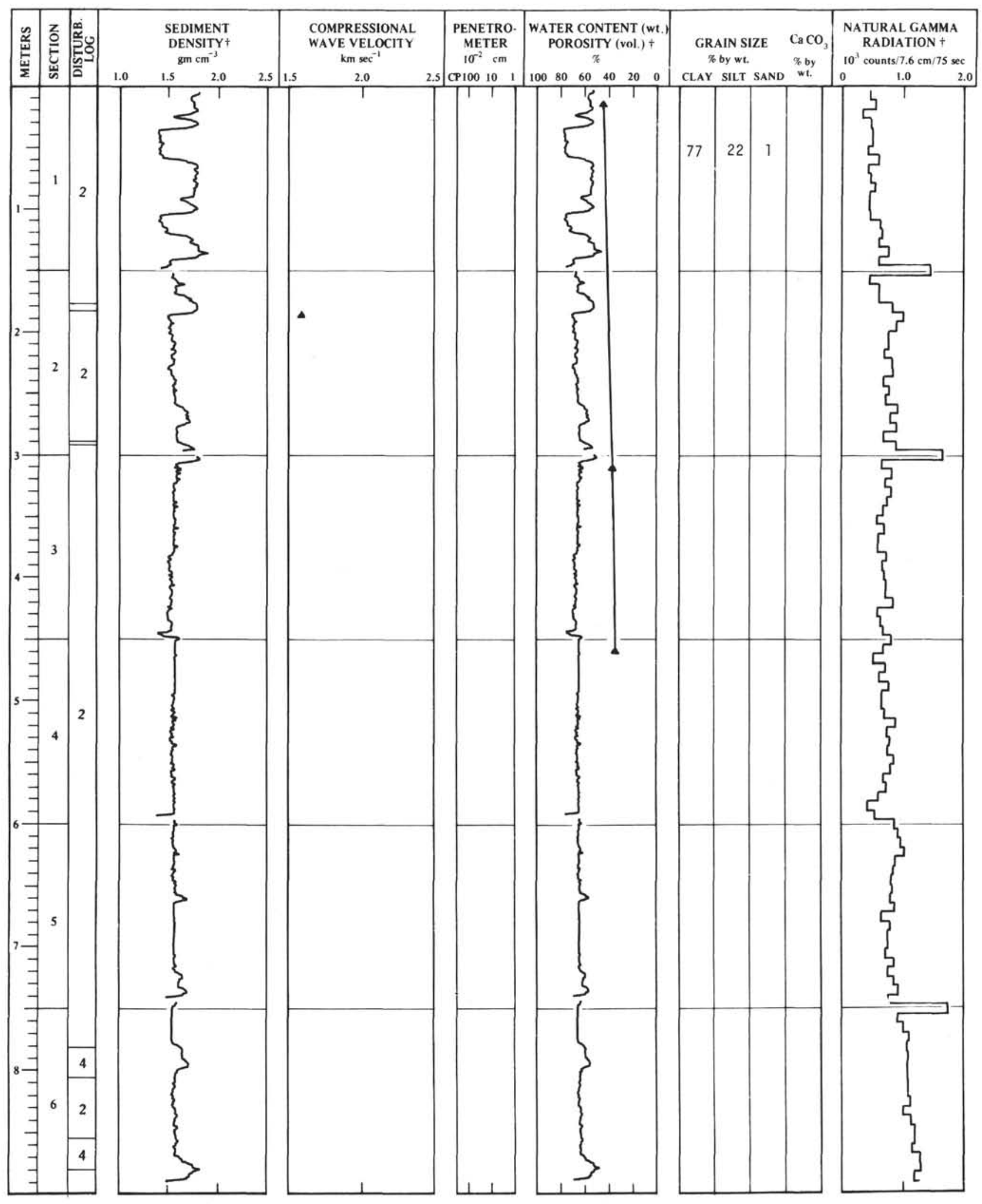

+Adjusted data, see Chapter 2 
HOLE 116

CORE 11

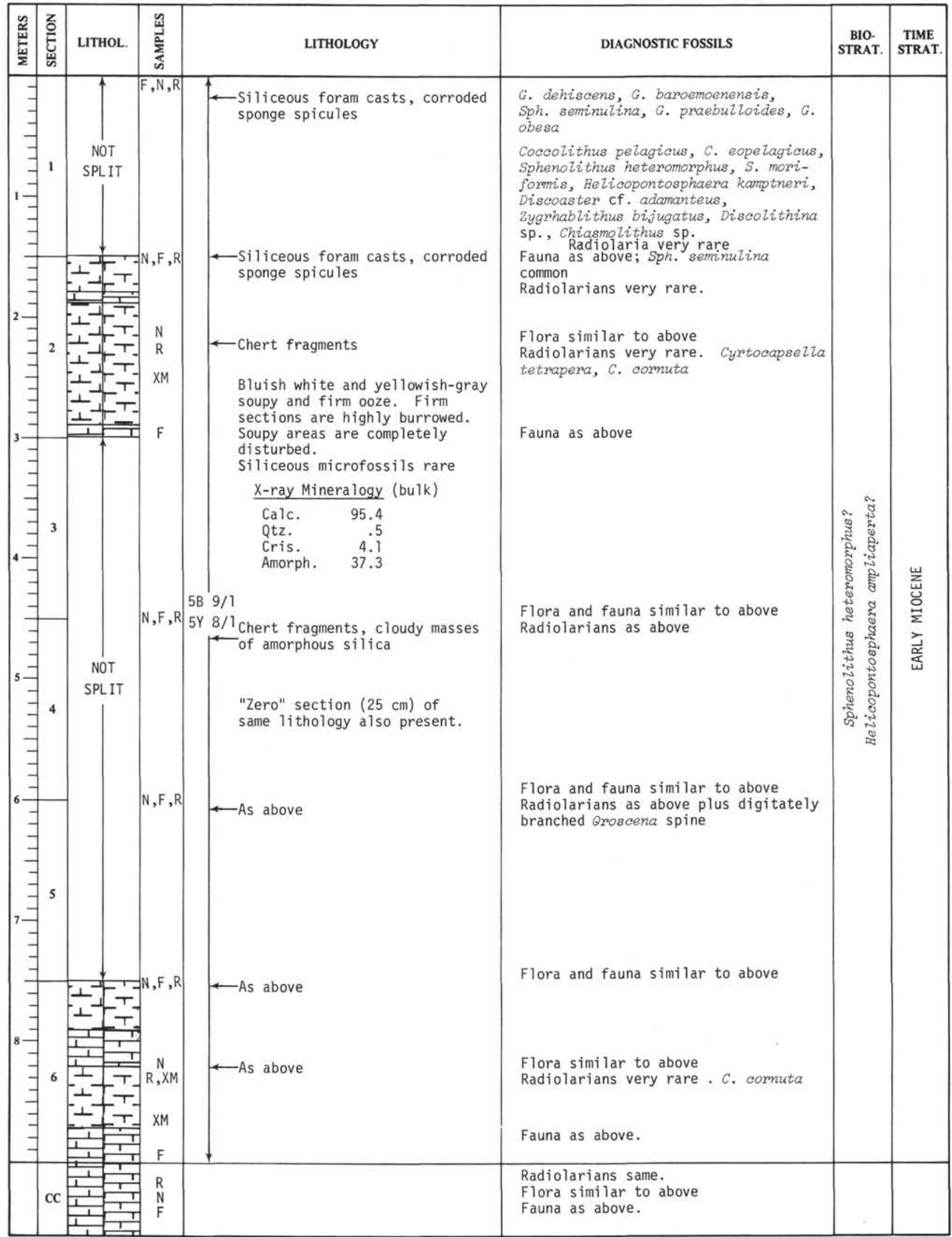




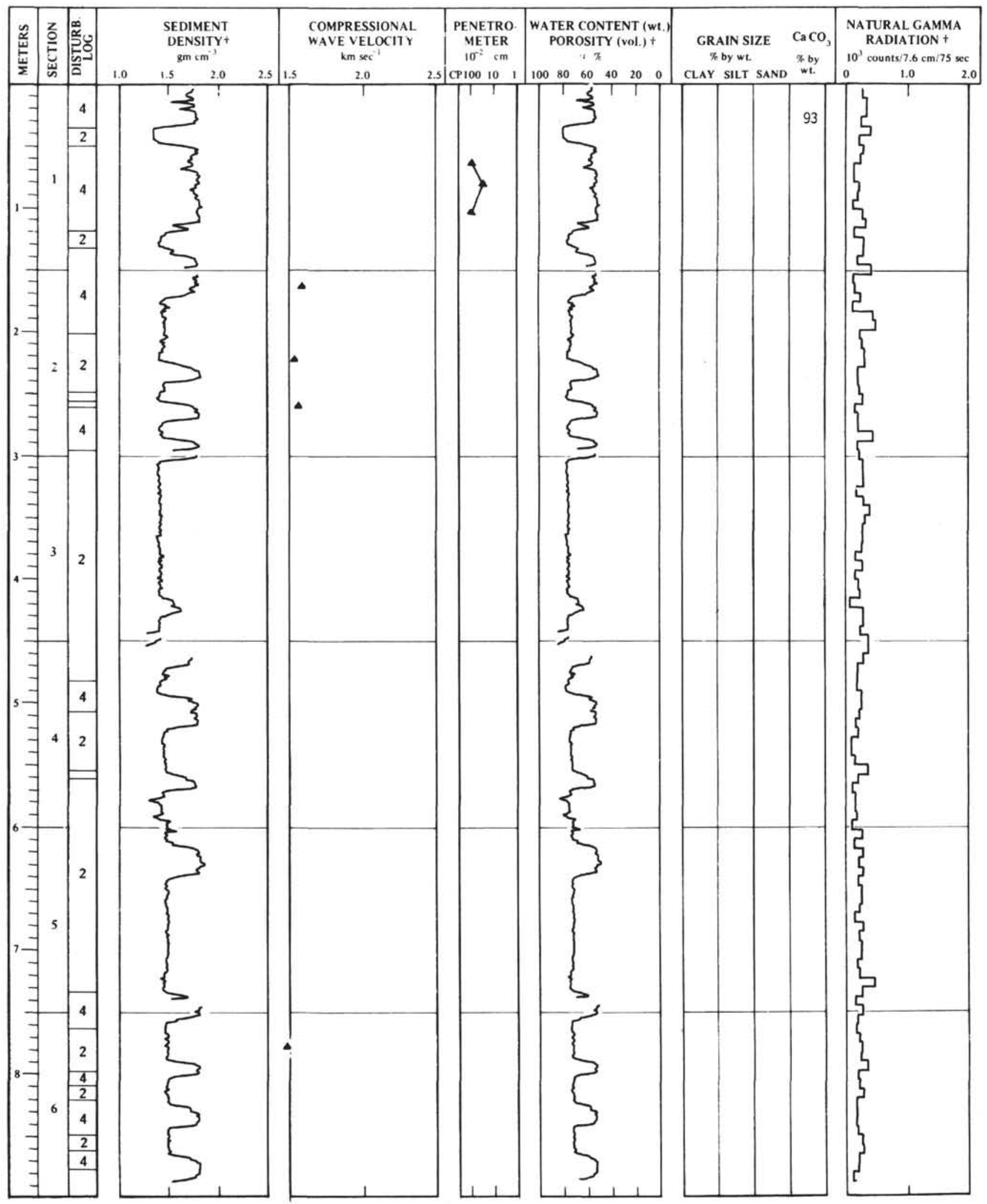

tAdjusted data, see Chapter 2 

HOLE $\quad 116$
599 TO
$608 \mathrm{~m}$
CORE 12

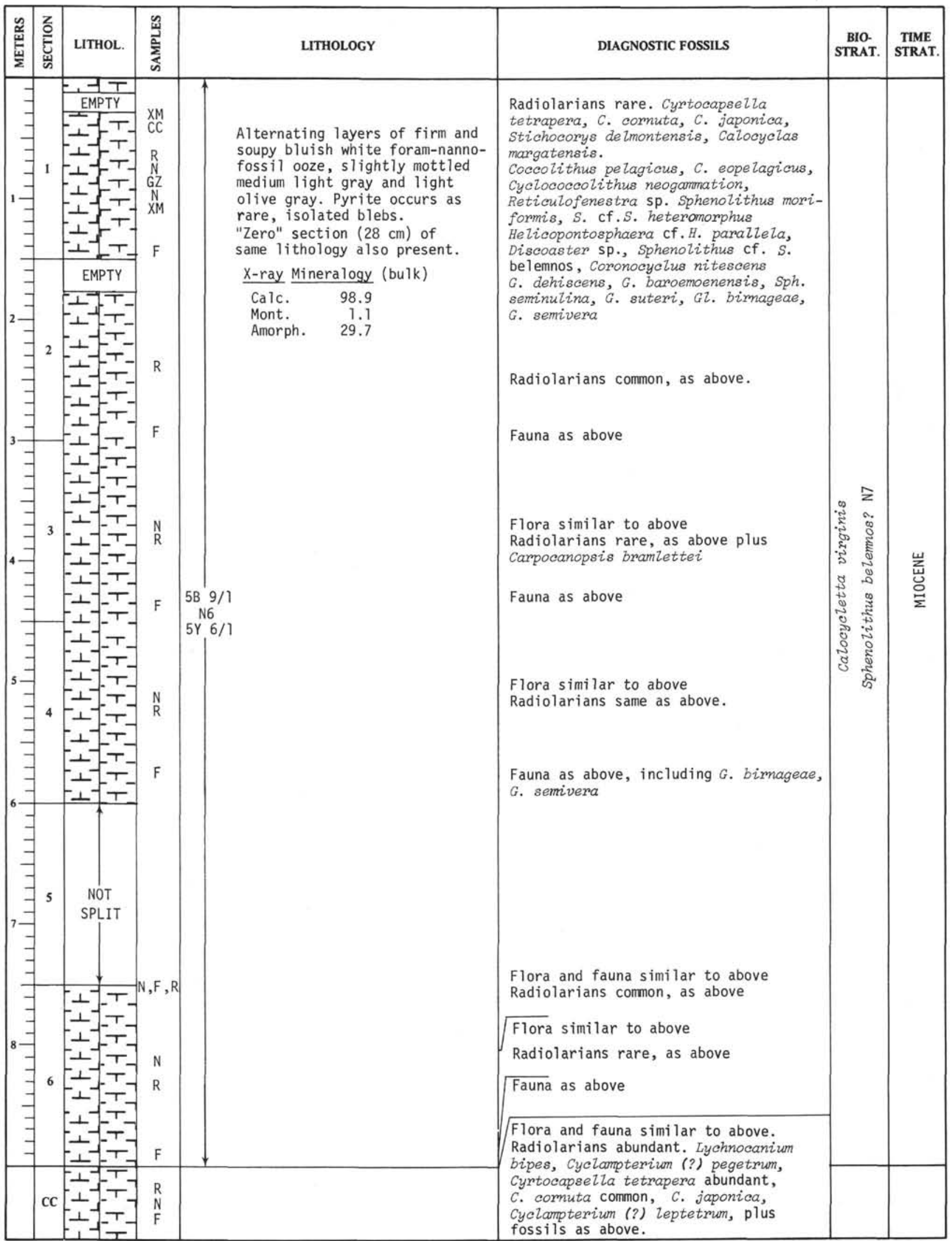




\section{SHIPBOARD SCIENTIFIC PARTY}

HOLE 116

CORE 13

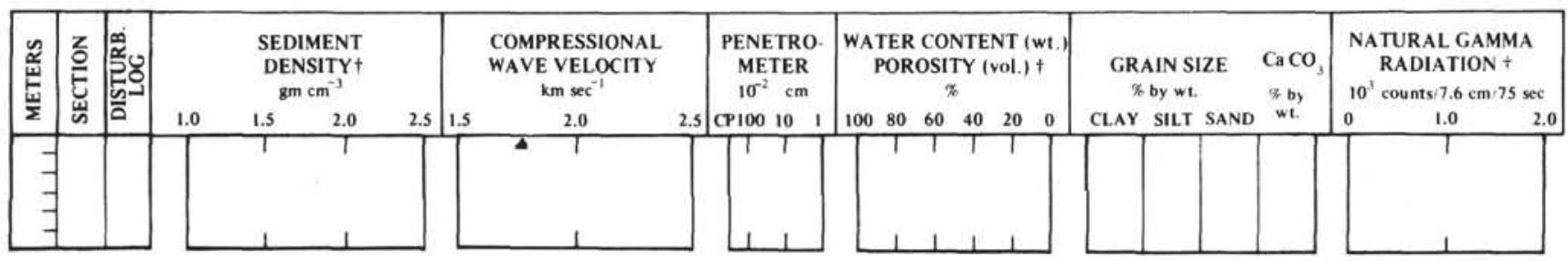

+Adjusted data, see Chapter 2 
HOLE 116

CORE 13

\begin{tabular}{|c|c|c|c|c|c|c|c|}
\hline$\frac{\mathscr{2}}{\tilde{\mu}}$ & ž & LITHOL. & 竞 & LITHOLOGY & DIAGNOSTIC FOSSILS & $\begin{array}{c}\text { BIO. } \\
\text { STRAT. }\end{array}$ & $\begin{array}{c}\text { TIME } \\
\text { STRAT. }\end{array}$ \\
\hline & CC & T) & $\begin{array}{l}\mathrm{F} \\
\mathrm{N} \\
\mathrm{R}\end{array}$ & \multirow[t]{2}{*}{$\begin{array}{l}\text { Core catcher }(11 \mathrm{~cm}) \text { only of } \\
5 B \text { s/1 slightly burrowed, firm white } \\
\text { chalk. }\end{array}$} & \multirow{2}{*}{$\begin{array}{l}\text { Core Catcher: } \\
\text { Globoquadrina cf. dehiscens, G-ita. } \\
\text { dissimilis, G. suteri } \\
\text { Coccolithus pelagicus, C. eopelagicus } \\
\text { Cyclococcolithus neogammation, } \\
\text { Discoaster sp. Sphenolithus mori- } \\
\text { formis, Thoracosphaera sp., Helico- } \\
\text { pontosphaera cf.H. parallela } \\
\text { Radiolarians abundant. Dorea- } \\
\text { dospyms simplex, Stichocorys } \\
\text { delmontensis, Cyrtocapsella cornuta, } \\
\text { C. tetrapera, Calocyclas margatensis, } \\
\text { Cyclampterizm (?) sp. cf. C. (?) milowi }\end{array}$} & \multirow{2}{*}{ 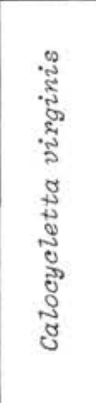 } & \multirow{2}{*}{ 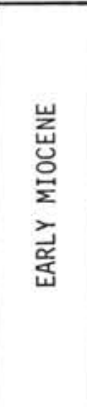 } \\
\hline & & & & & & & \\
\hline
\end{tabular}

HOLE 116

653 то

$662 \mathrm{~m}$

CORE 14

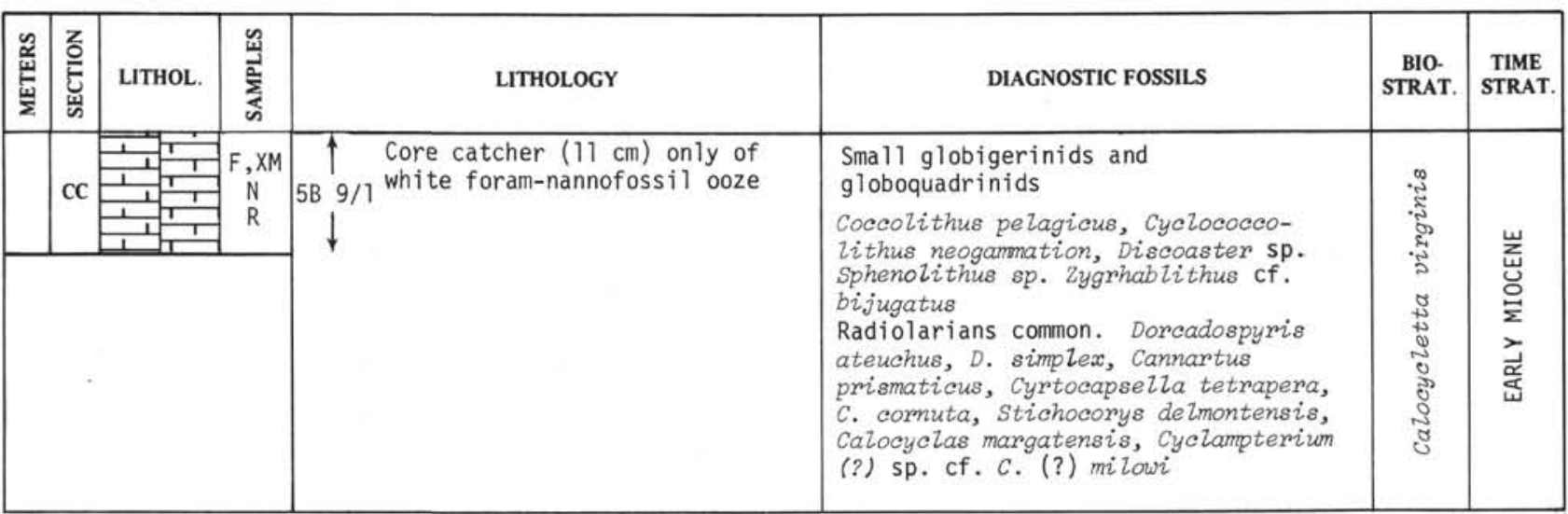


SHIBPOARD SCIENTIFIC PARTY

HOLE 116

CORE 15

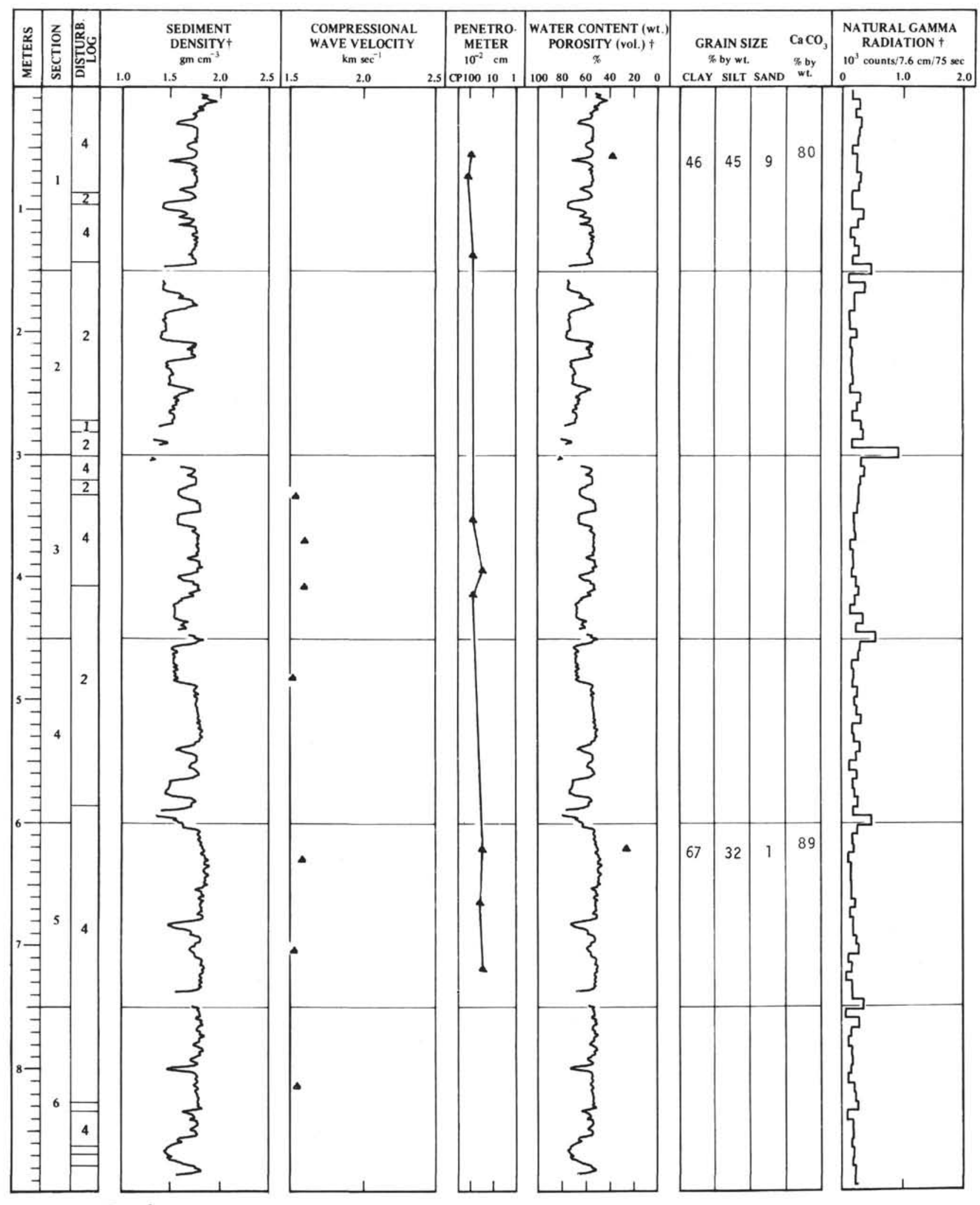




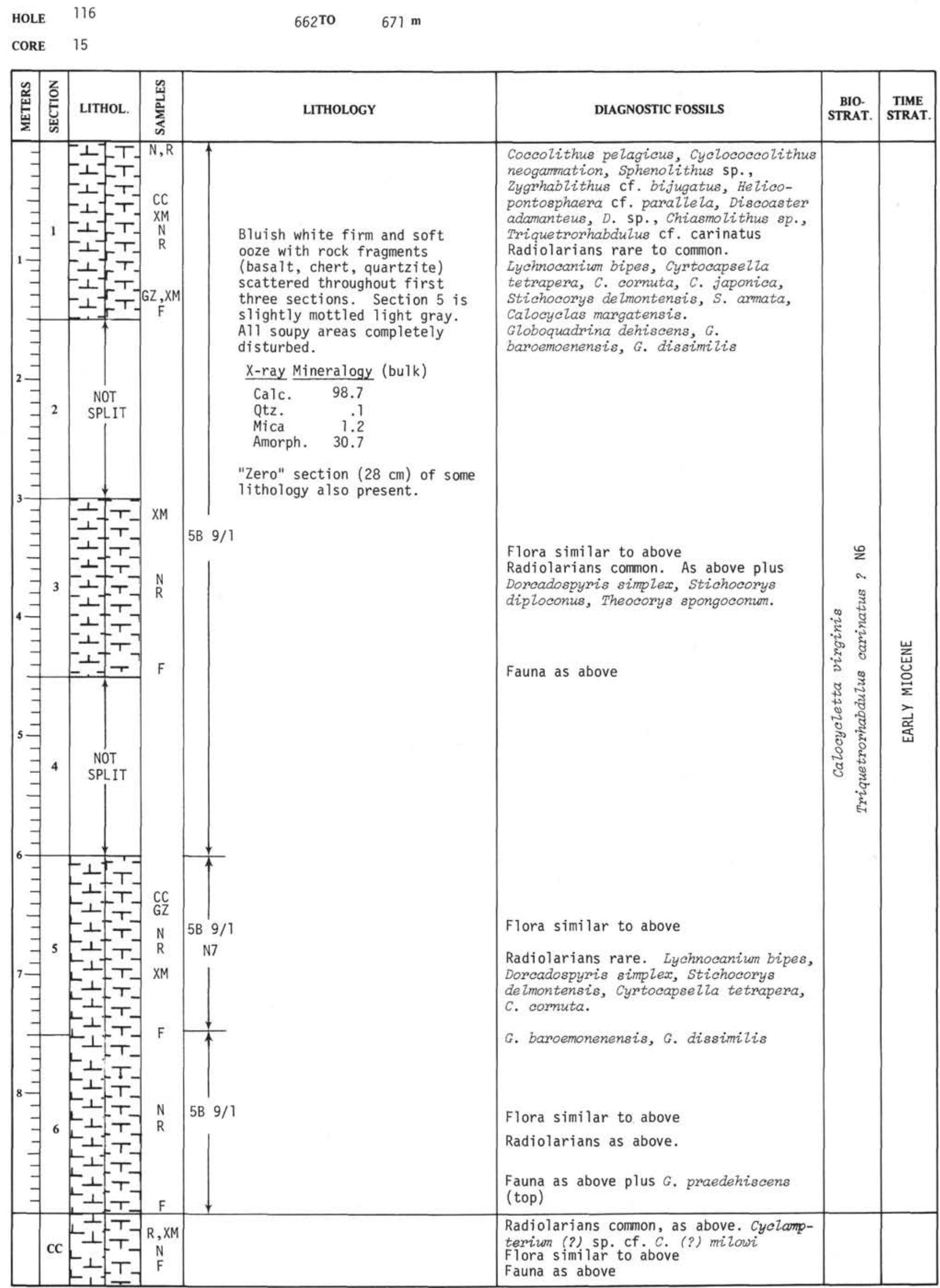


HOLE 116

CORE 16

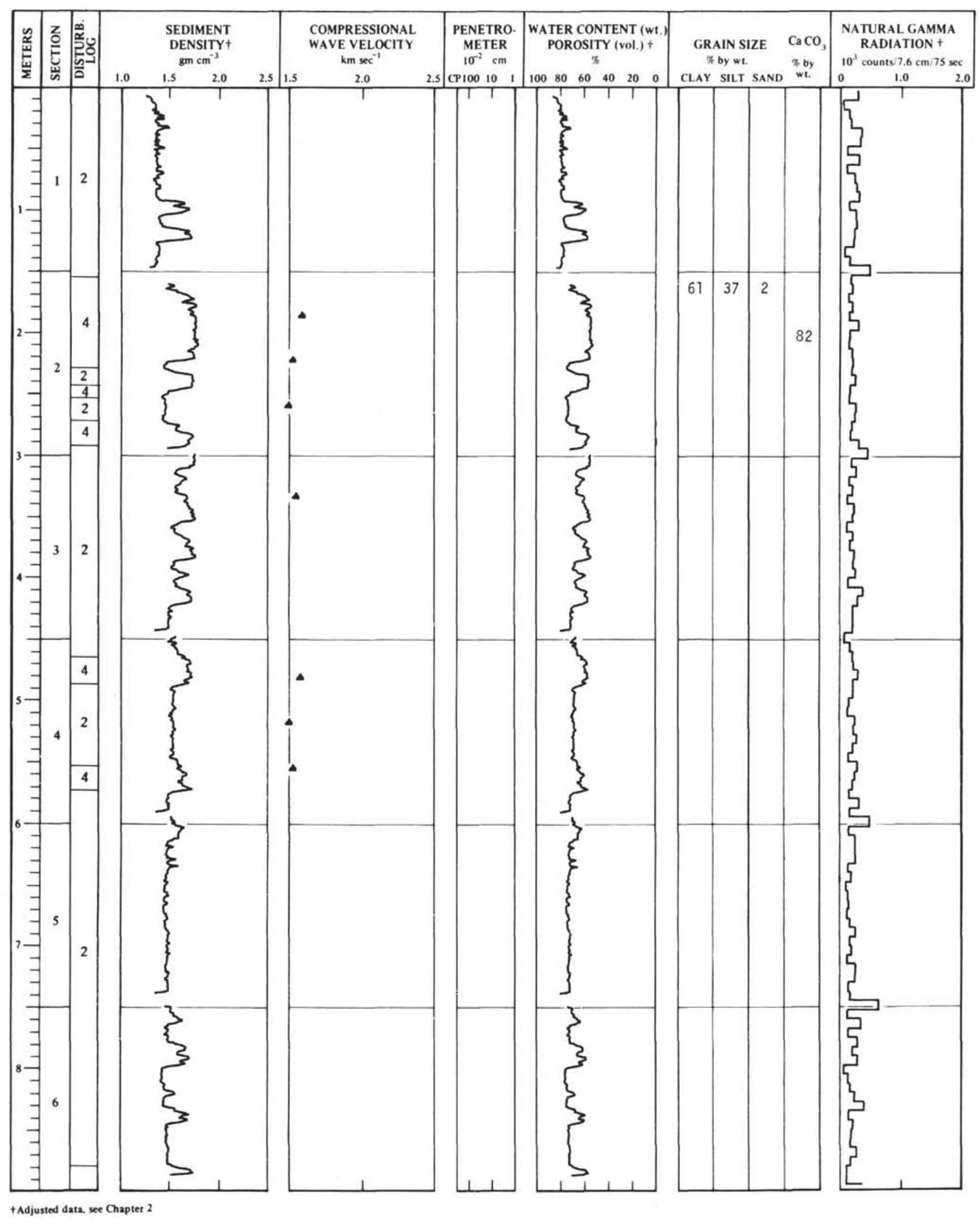




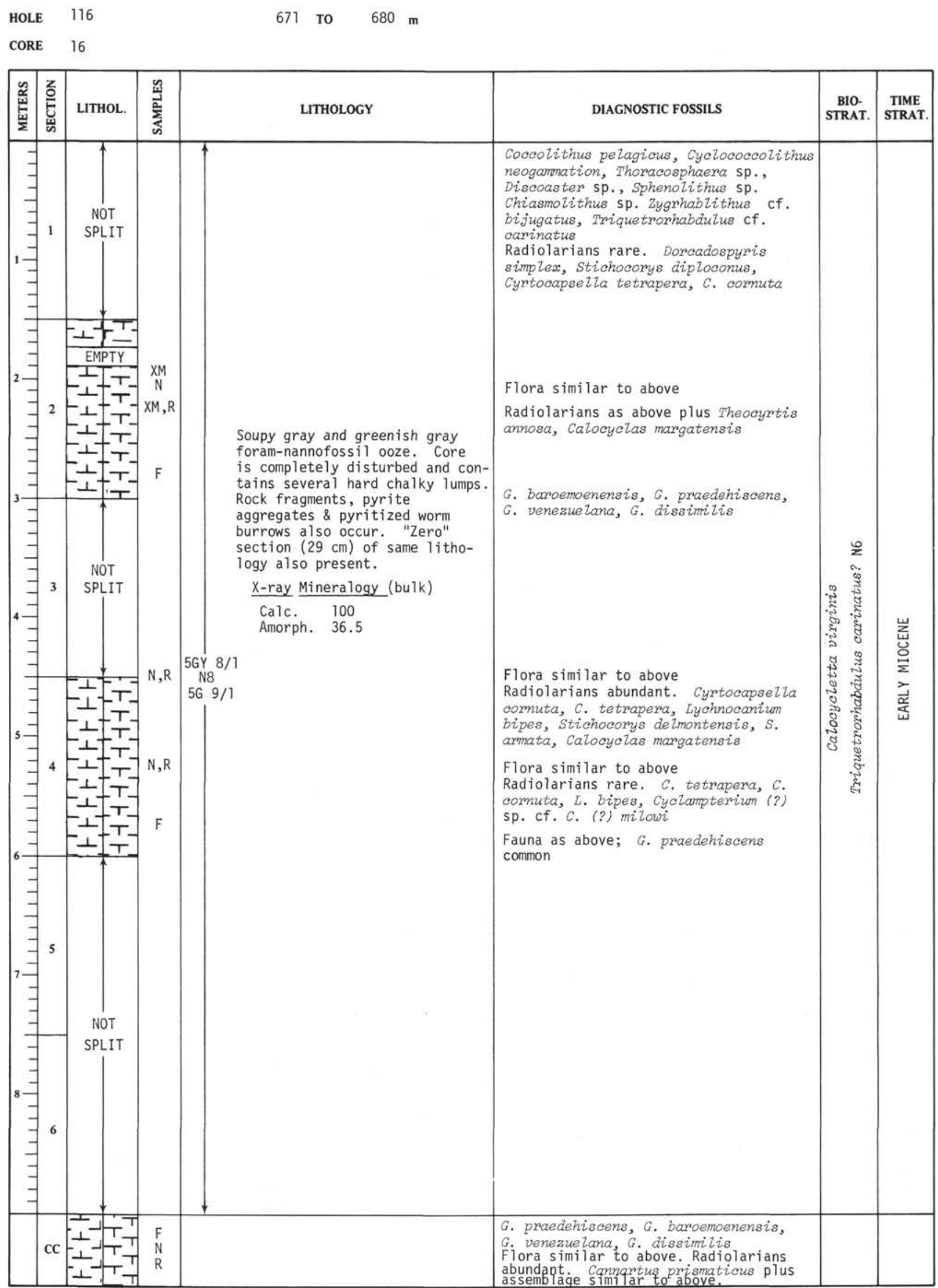


SHIPBOARD SCIENTIFIC PARTY

HOLE 116

CORE 17

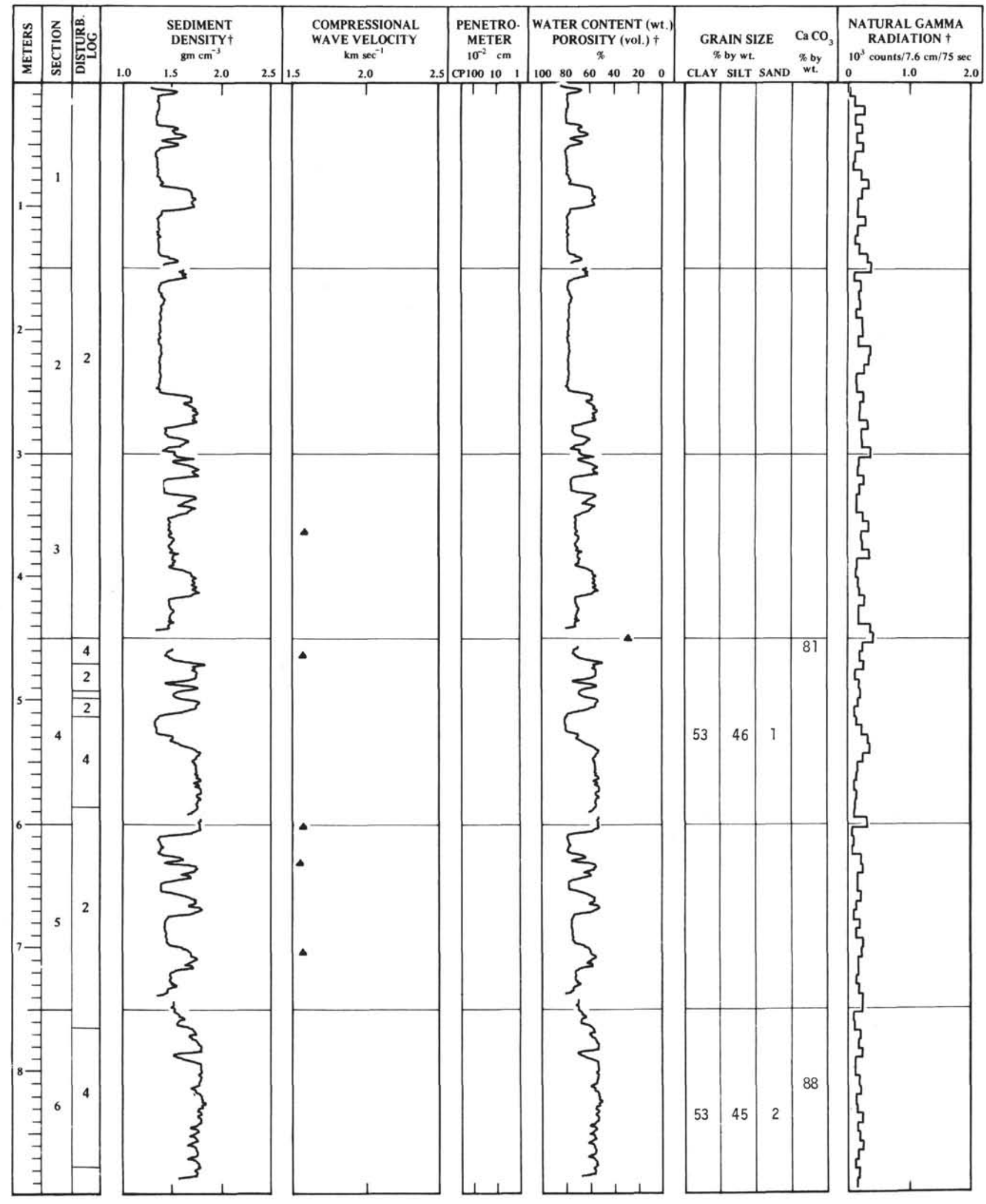

t Adjusted data, see Chapter 2 


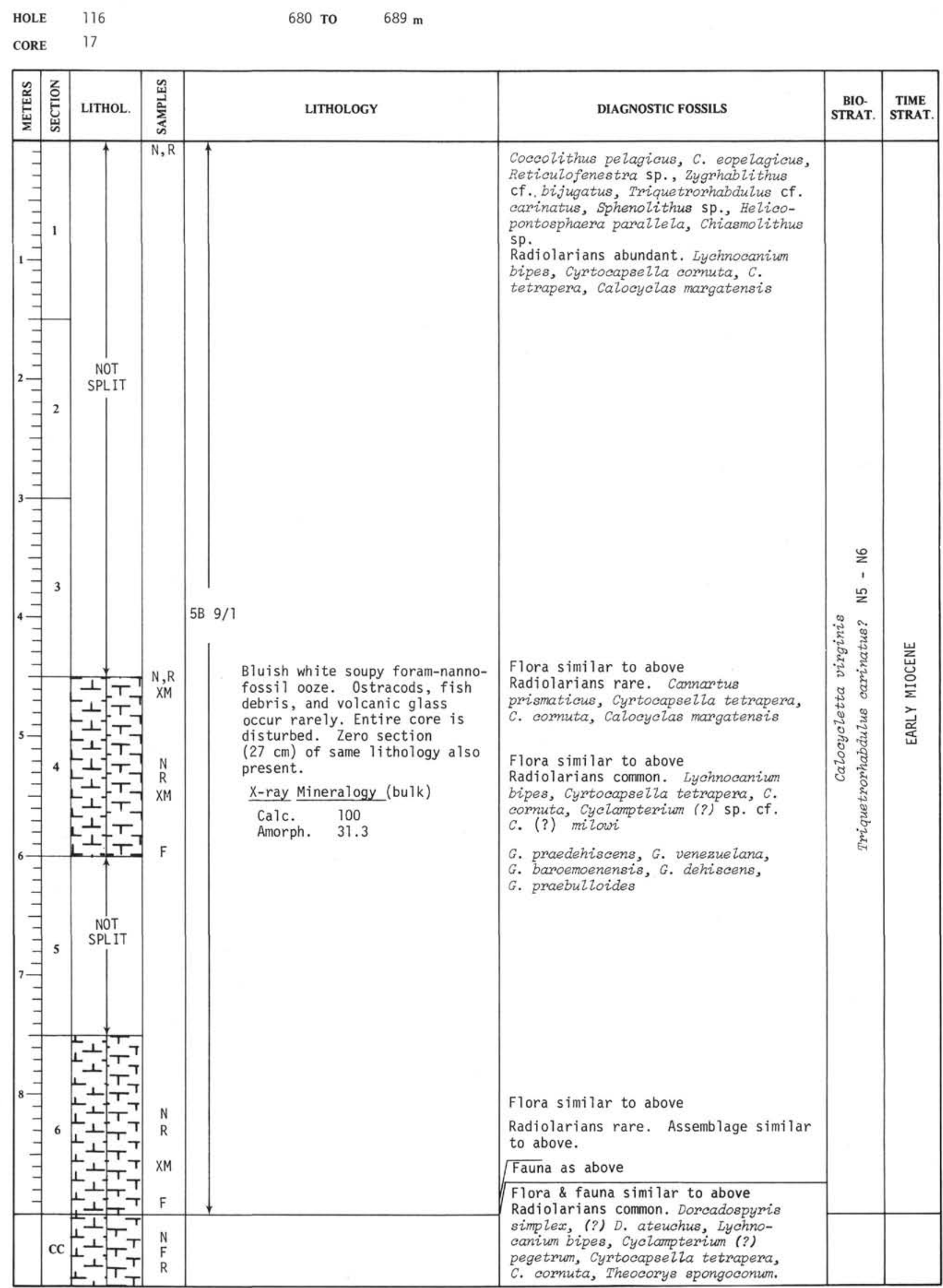




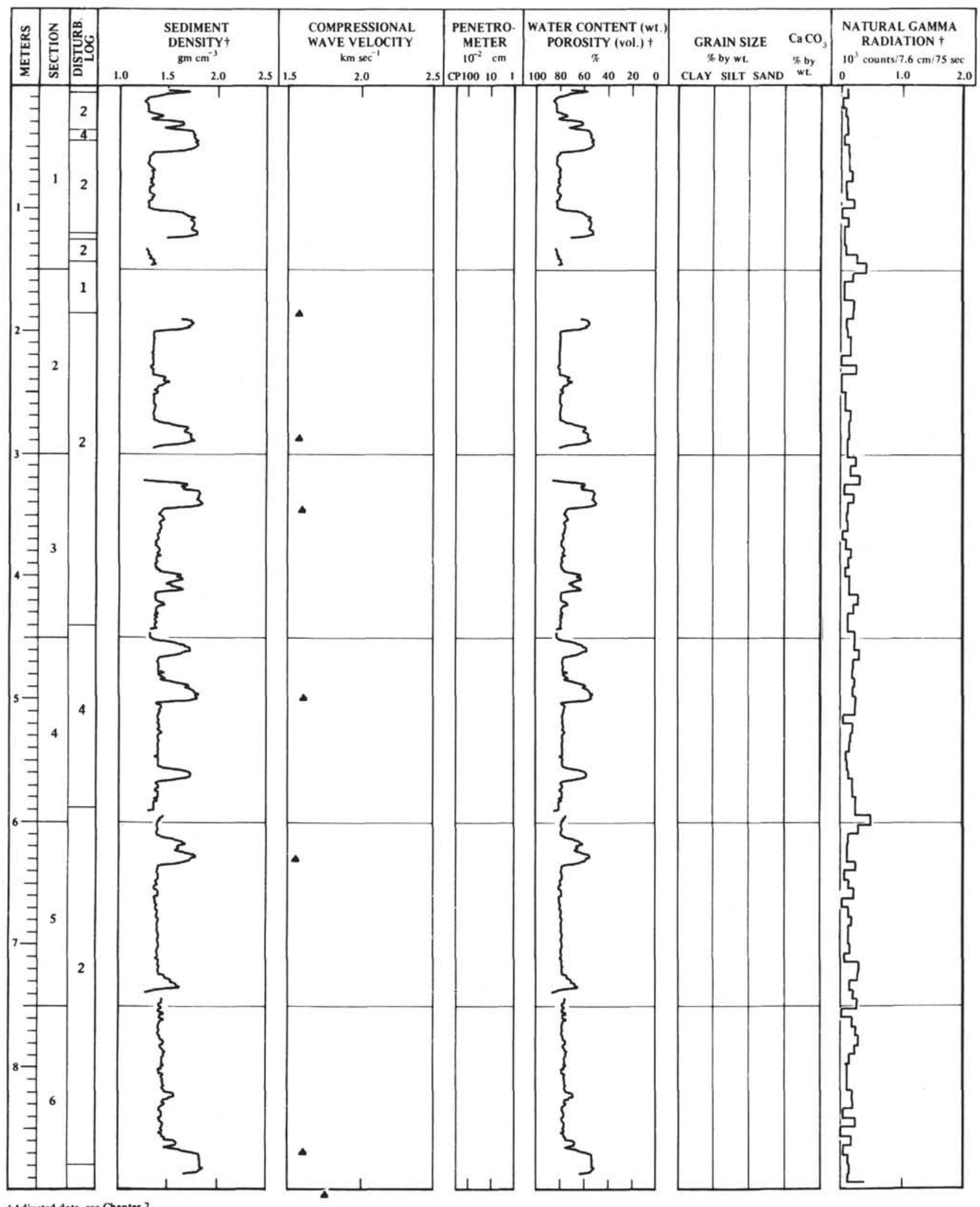


HOLE $\quad 116$

689 To

$698 \mathrm{~m}$

CORE 18

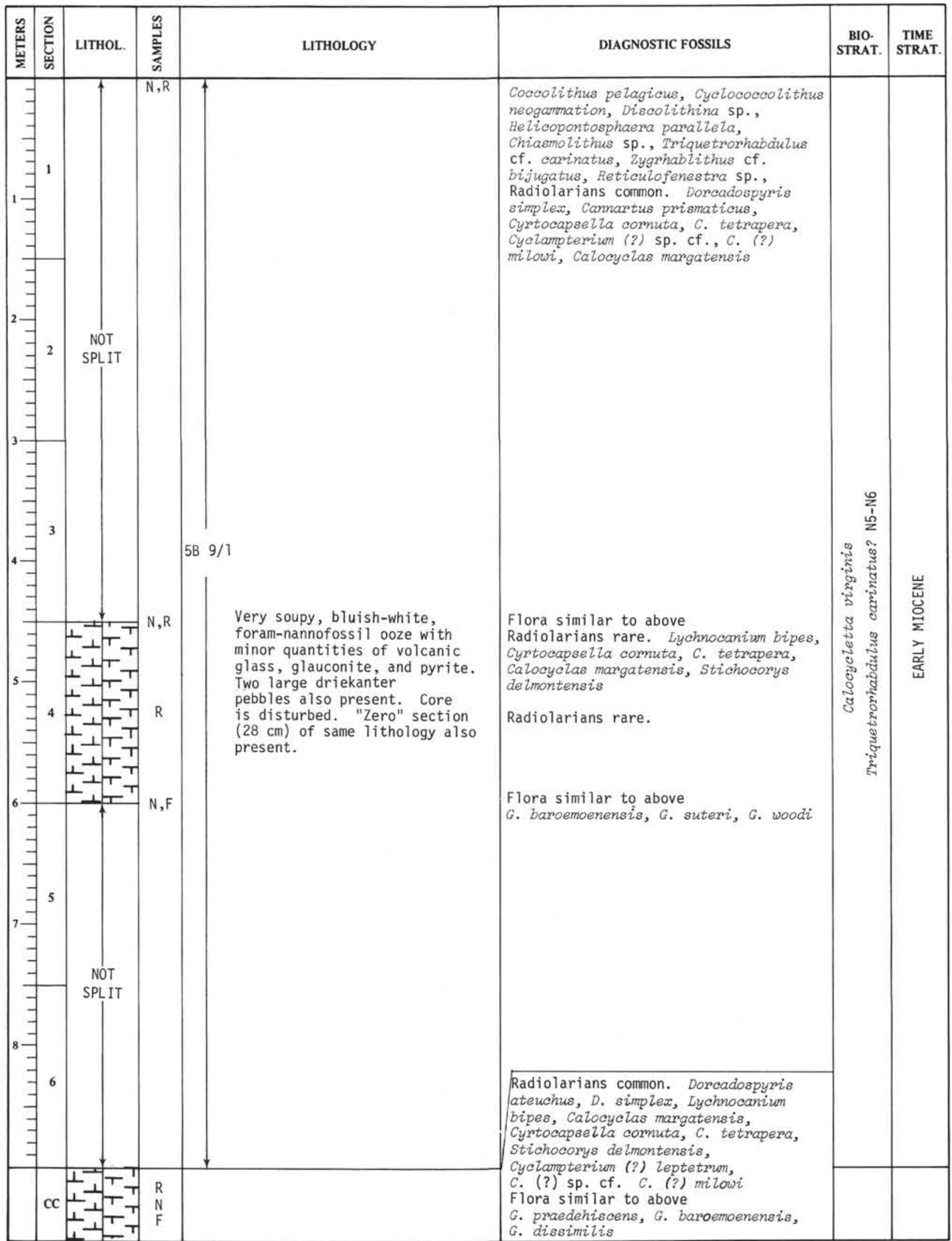


HOLE 116

CORE 19

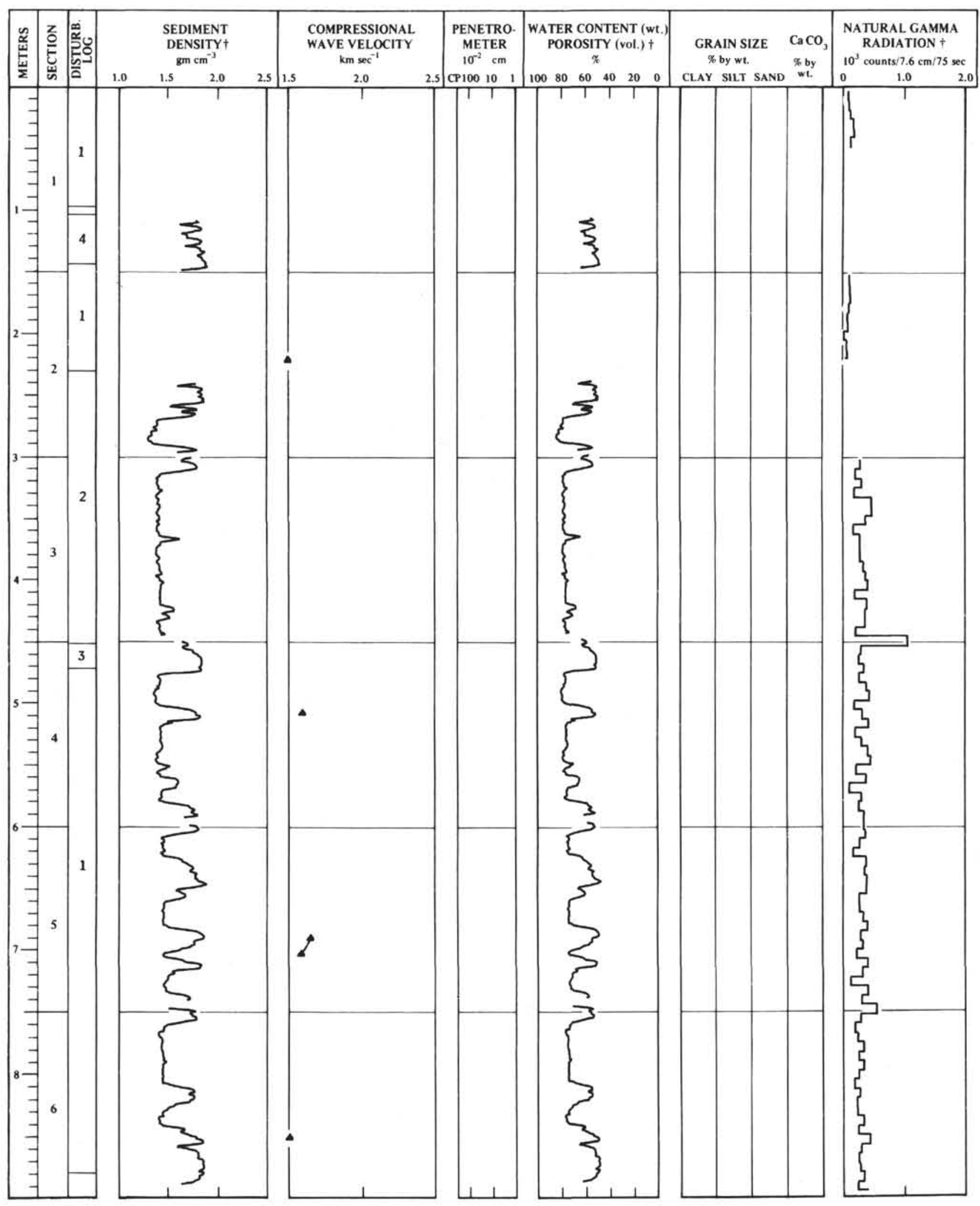

+Adjusted datz see Chapter 2 


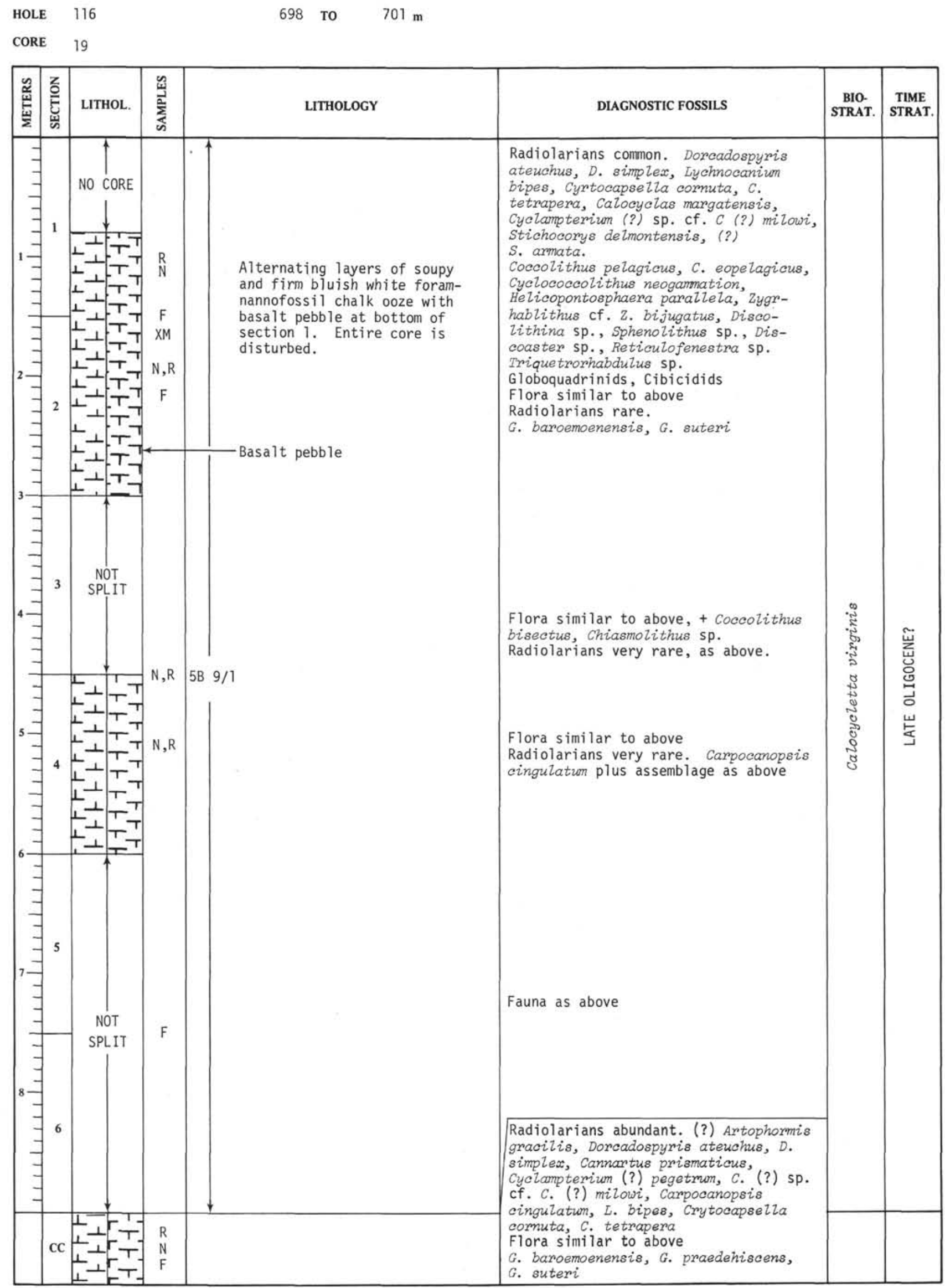


HOLE 116

CORE 20

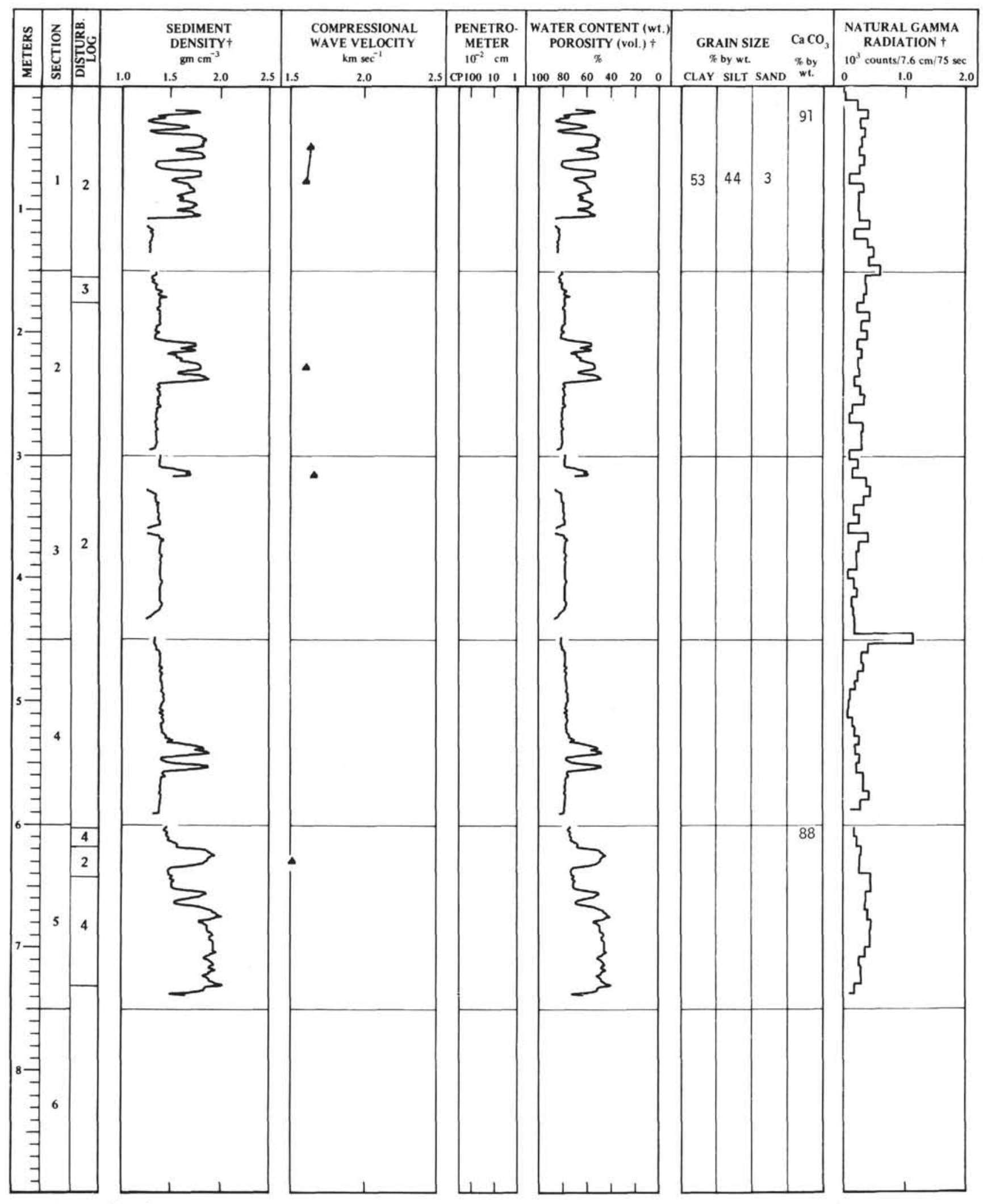

+Adjusted data, see Chapter 2 

HOLE $\quad 116$
701 то
$710 \mathrm{~m}$
CORE 20

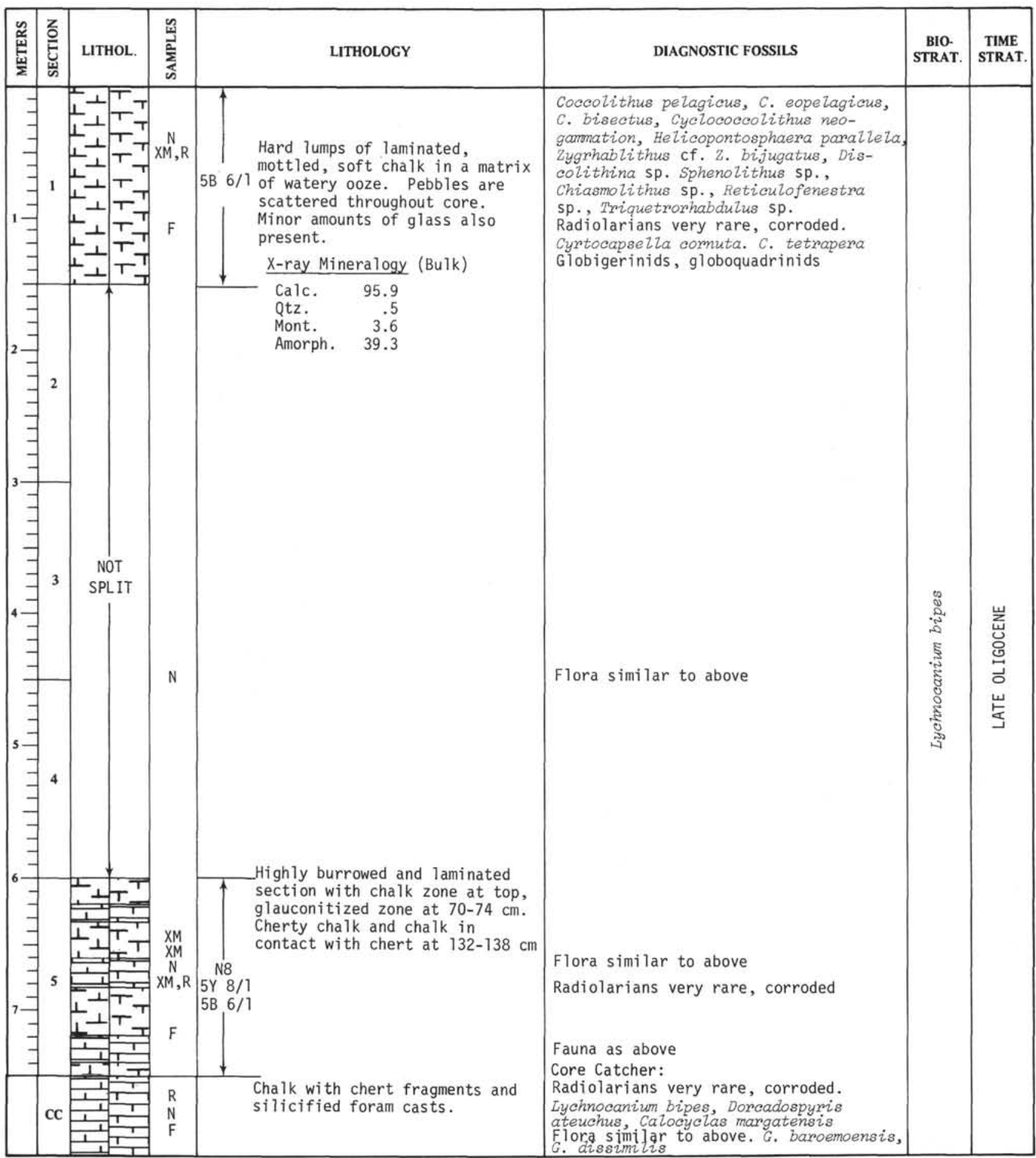


SHIPBOARD SCIFNTIFIC PARTY

HOLE 116

CORE 21

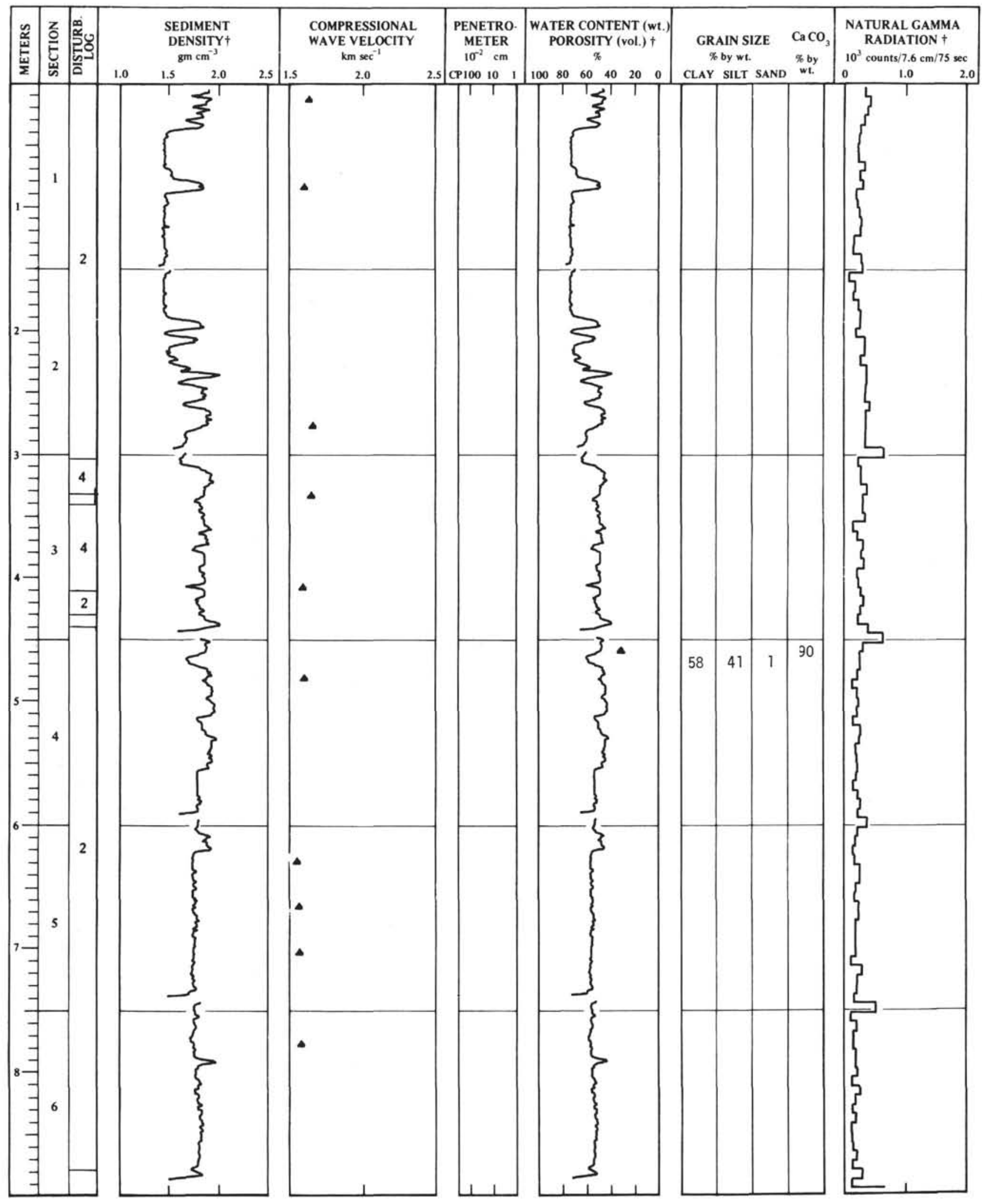

+Adjustod data, see Chapter 2 


$\begin{array}{llll}\text { HOLE } & 116 & 710 \text { TO } & 719 \mathrm{~m} \\ \text { CORE } & 21 & & \end{array}$

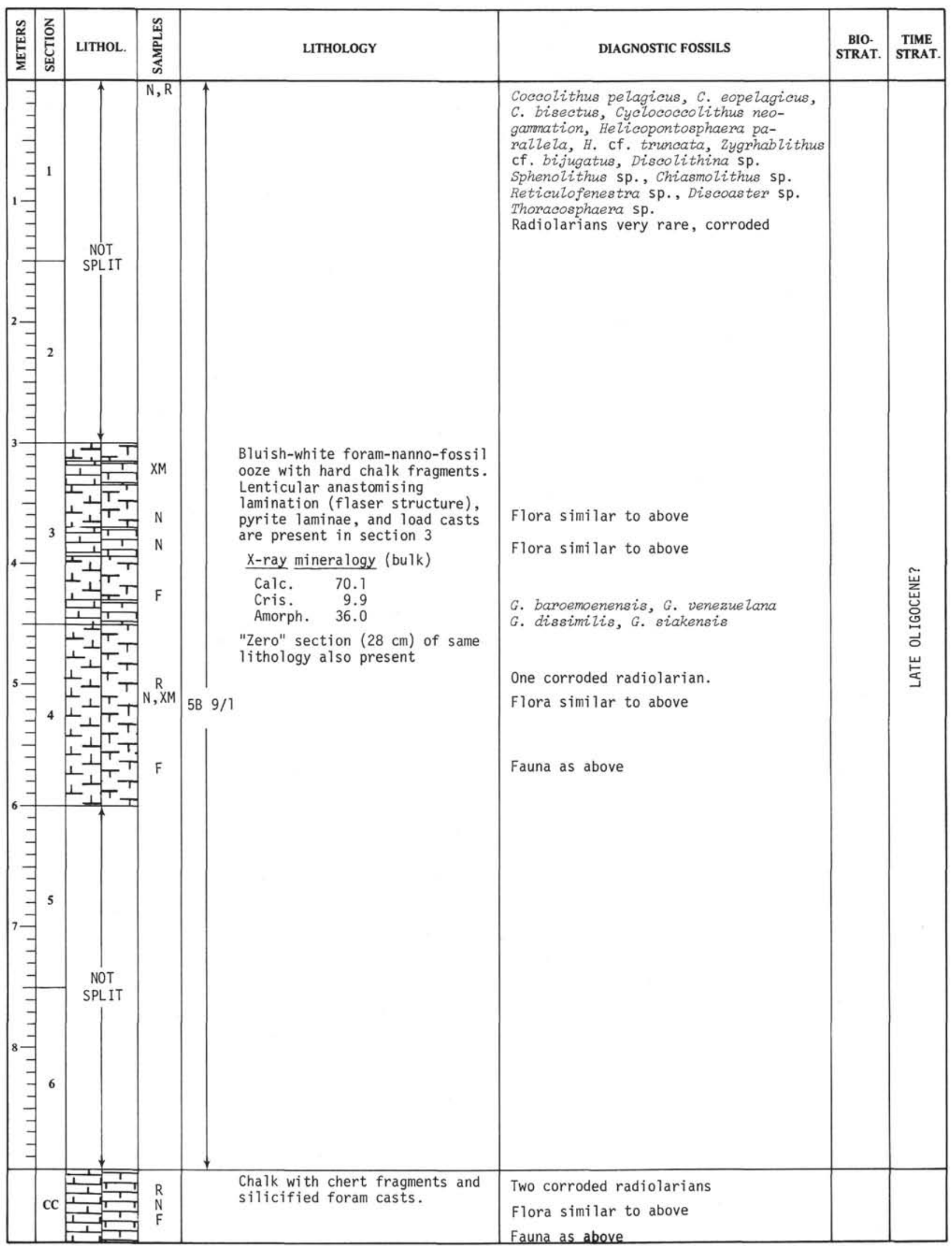


CORE 22

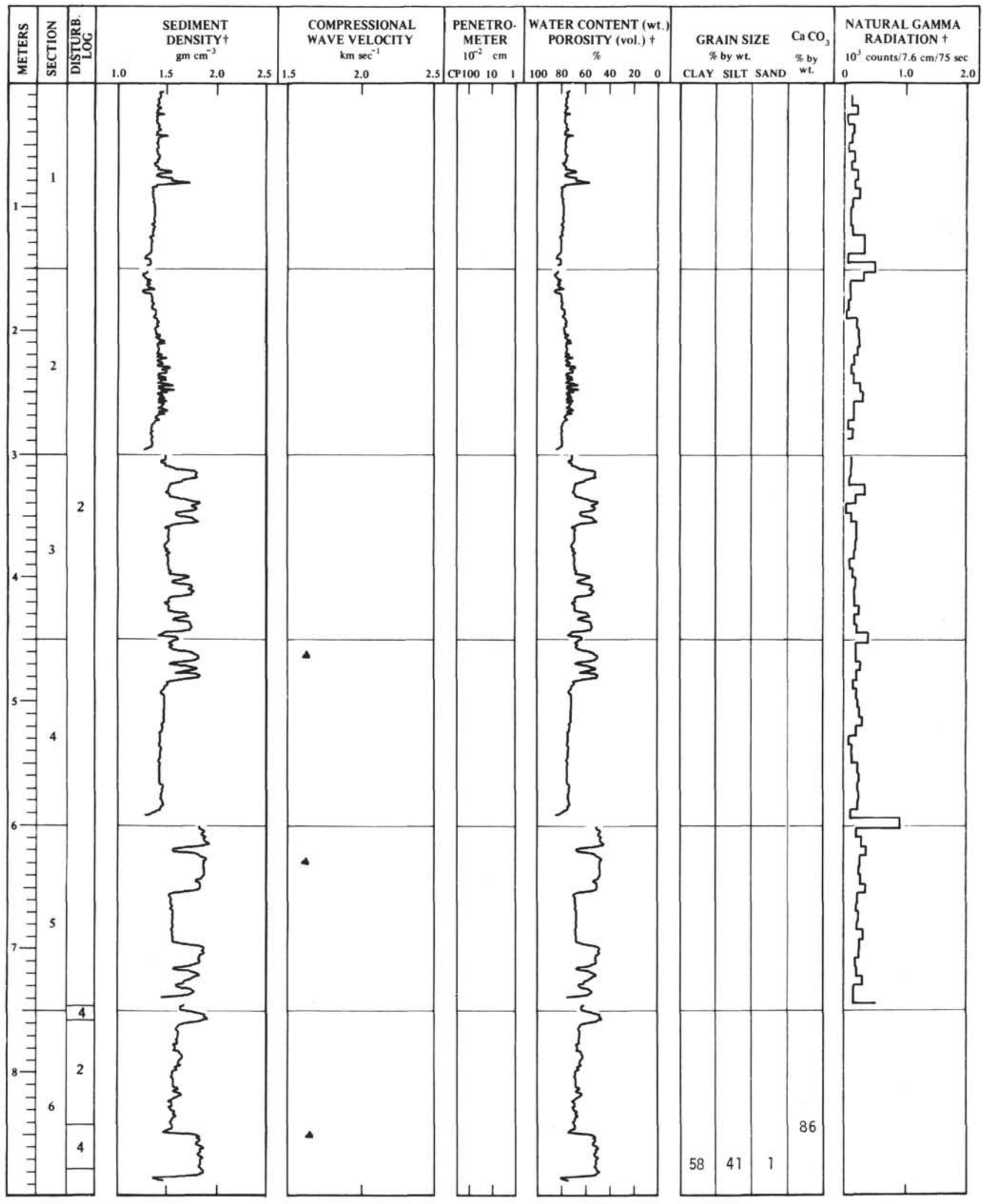


CORE 22

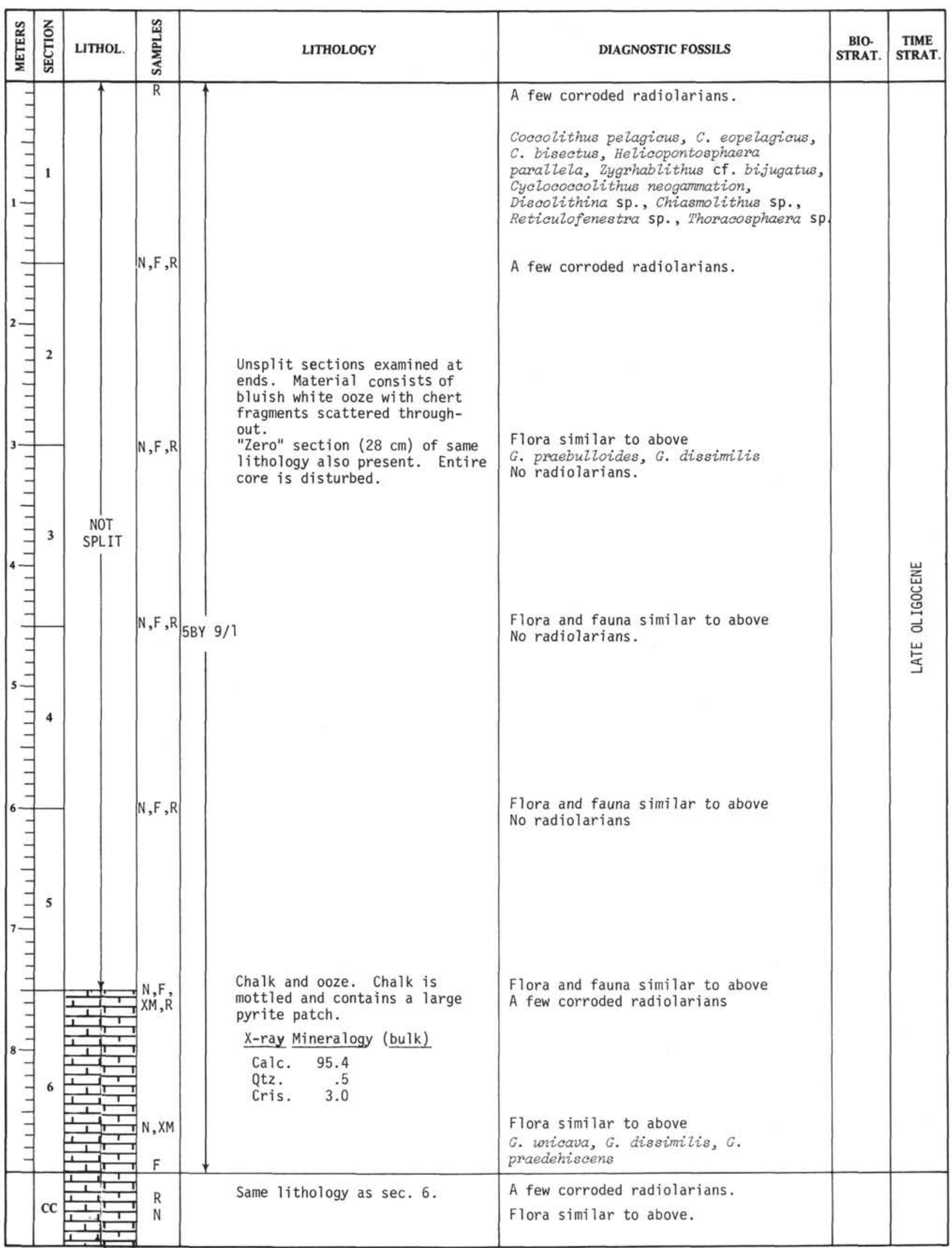


HOLE 116

CORE 23

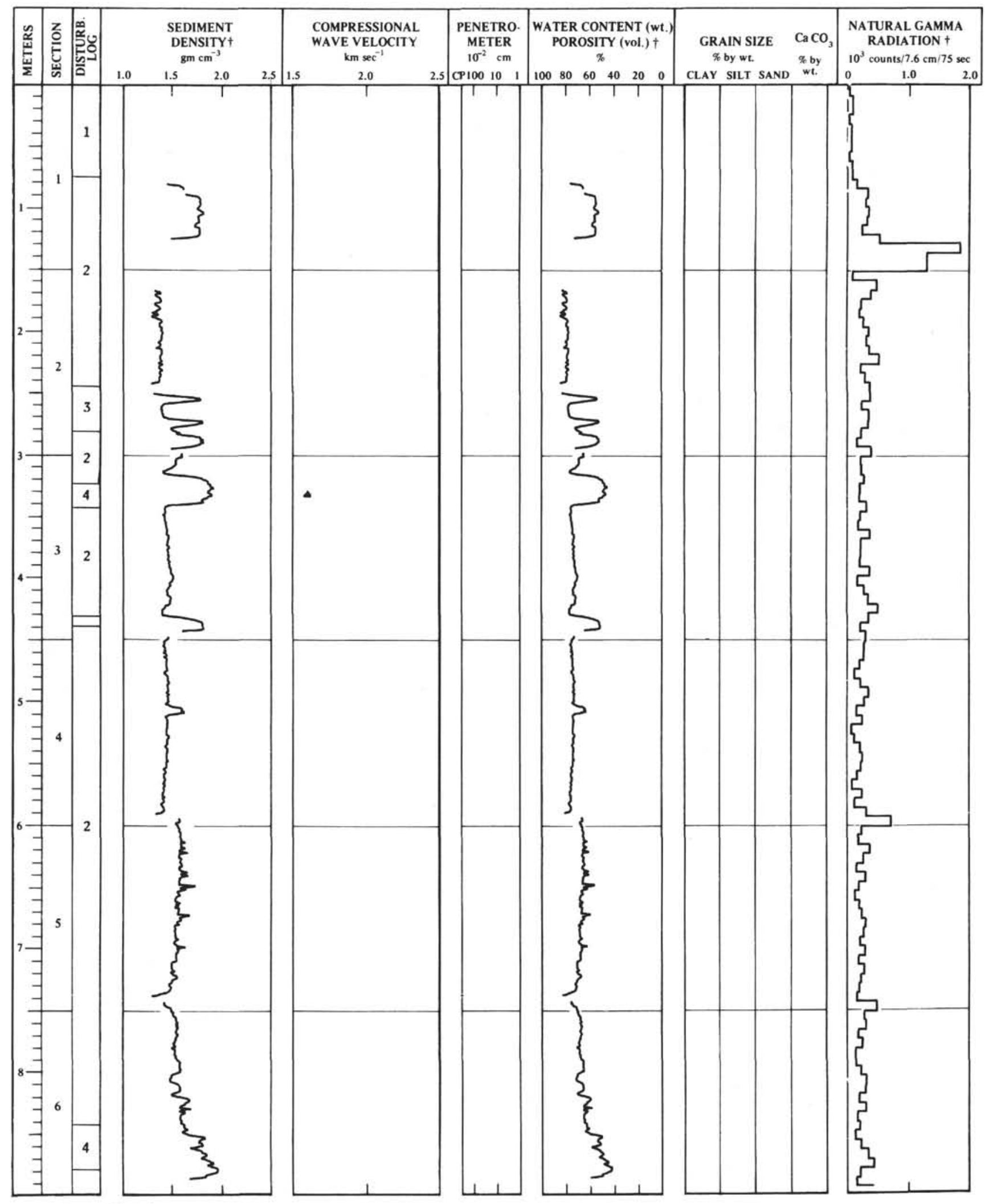

+Adjusted data, see Chapter 2 


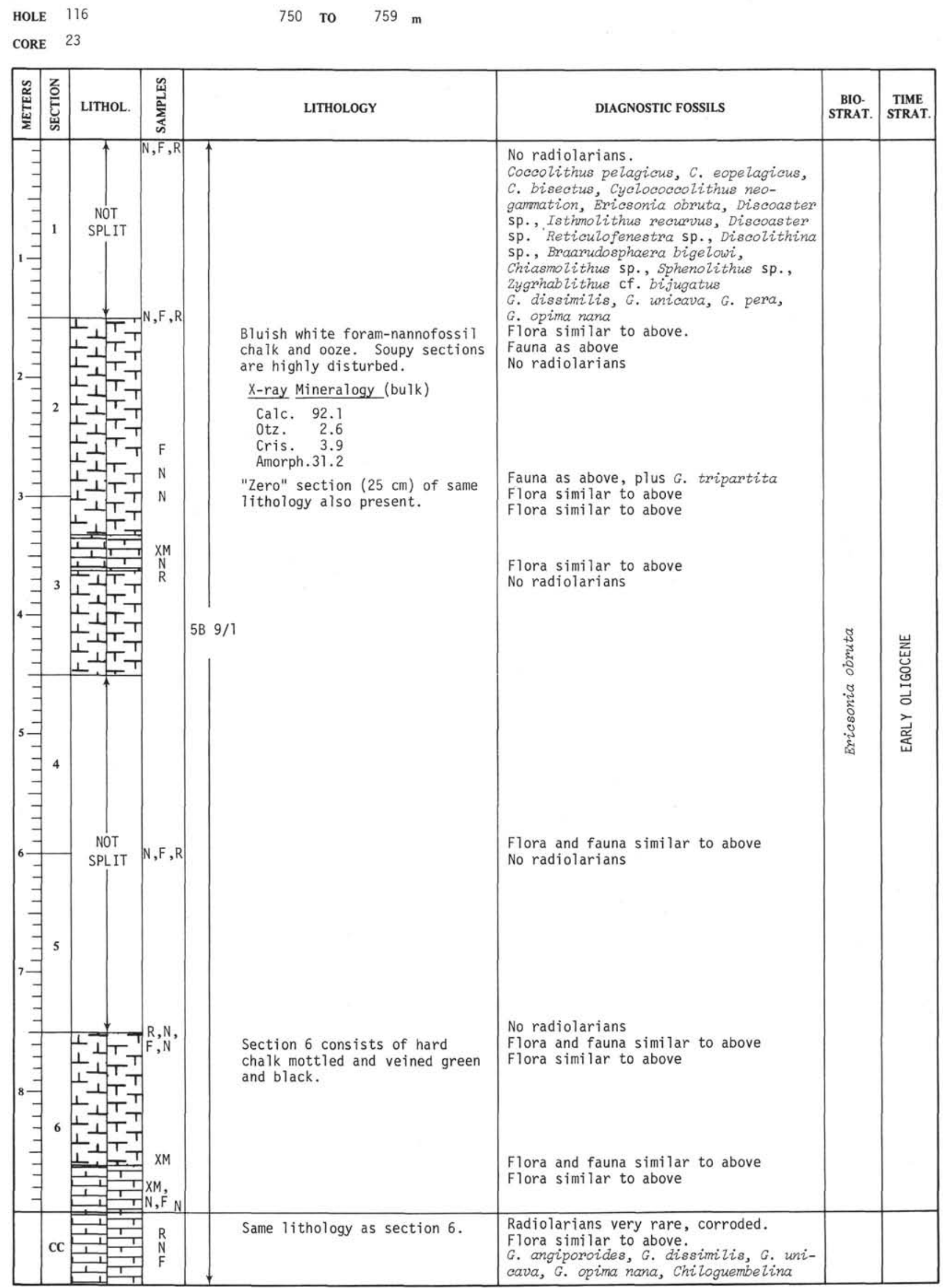


SHIPBOARD SCIENTIFIC PARTY

HOLE 116

CORE 24

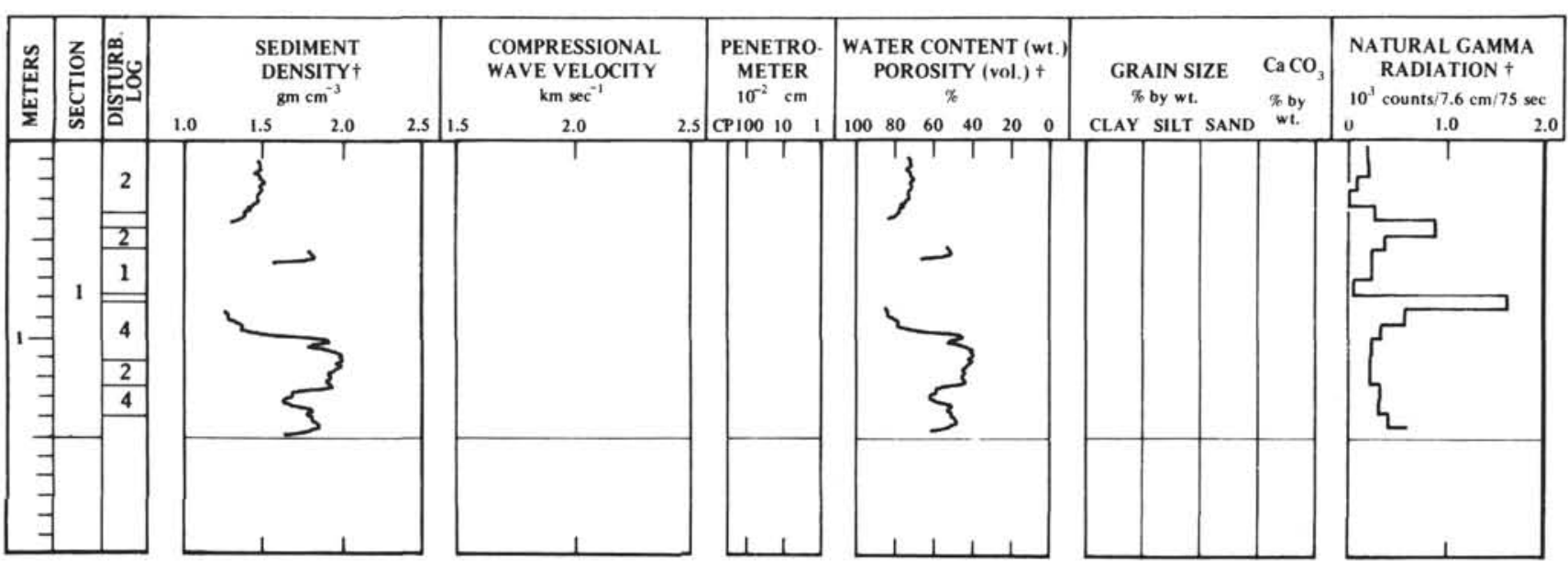

+Adjusted data, see Chapter 2 
HOLE 116

CORE 24

\begin{tabular}{|c|c|c|c|c|c|c|c|c|}
\hline 音 & $\begin{array}{l}\text { 을 } \\
\text { 岁 }\end{array}$ & LITHOL. & 总 & & LITHOLOGY & DIAGNOSTIC FOSSILS & $\begin{array}{l}\text { BIO- } \\
\text { STRAT. }\end{array}$ & $\begin{array}{c}\text { TIME } \\
\text { STRAT. }\end{array}$ \\
\hline & CC & 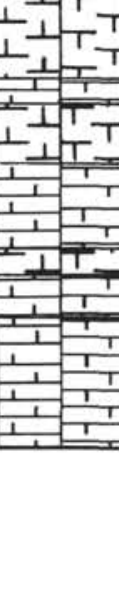 & XM & 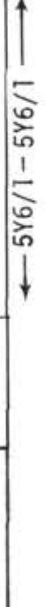 & $\begin{array}{l}\text { Foram-nannofossil chalk and } \\
\text { soupy ooze. The chalk is hard } \\
\text { and heavily mottled. Many } \\
\text { worm burrows are cut by small } \\
\text { faults. Bottom of section } \\
\text { appears brecciated and has a } \\
\text { marbelized appearance. }\end{array}$ & $\begin{array}{l}\text { Coccolithus pelagicus, C. eopelagicus, } \\
\text { C. bisectus, Cyclococcolithus neo- } \\
\text { ganmation, Ericsonia obruta, Dis- } \\
\text { coaster sp. Isthmolithus recurvus, } \\
\text { Discoaster sp. Reticulofenestra sp. } \\
\text { Discolithina sp. Braarudosphaera } \\
\text { bigelowi, Zygrhablithus cf. bijugatus, } \\
\text { Chiasmolithus sp. C. oamaruensis, } \\
\text { Sphenolithus sp., Zygolithus sp. } \\
\text { Radiolarians very rare, corroded. } \\
\text { Few disaggregated (free) foraminifera } \\
\text { Core Catcher: Fe rare, corroded. (?) } \\
\text { Radiolarians very rare } \\
\text { Cyclampterium (?) milowi. Flora } \\
\text { similar to above. G. ampliapetura } \\
\text { (top), G. dissimilis, G. pera, G. } \\
\text { postcretacea, G. denseconnexa, } \\
\text { G. inaeoviconica, G. opima nana, } \\
\text { Chiloquembelina }\end{array}$ & 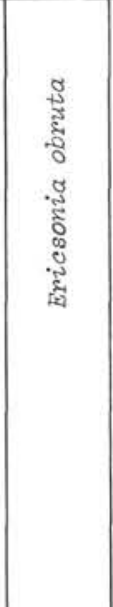 & 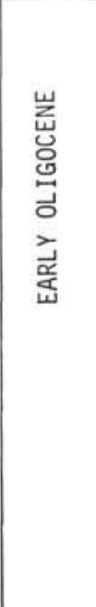 \\
\hline
\end{tabular}


HOLE 116

CORE 25

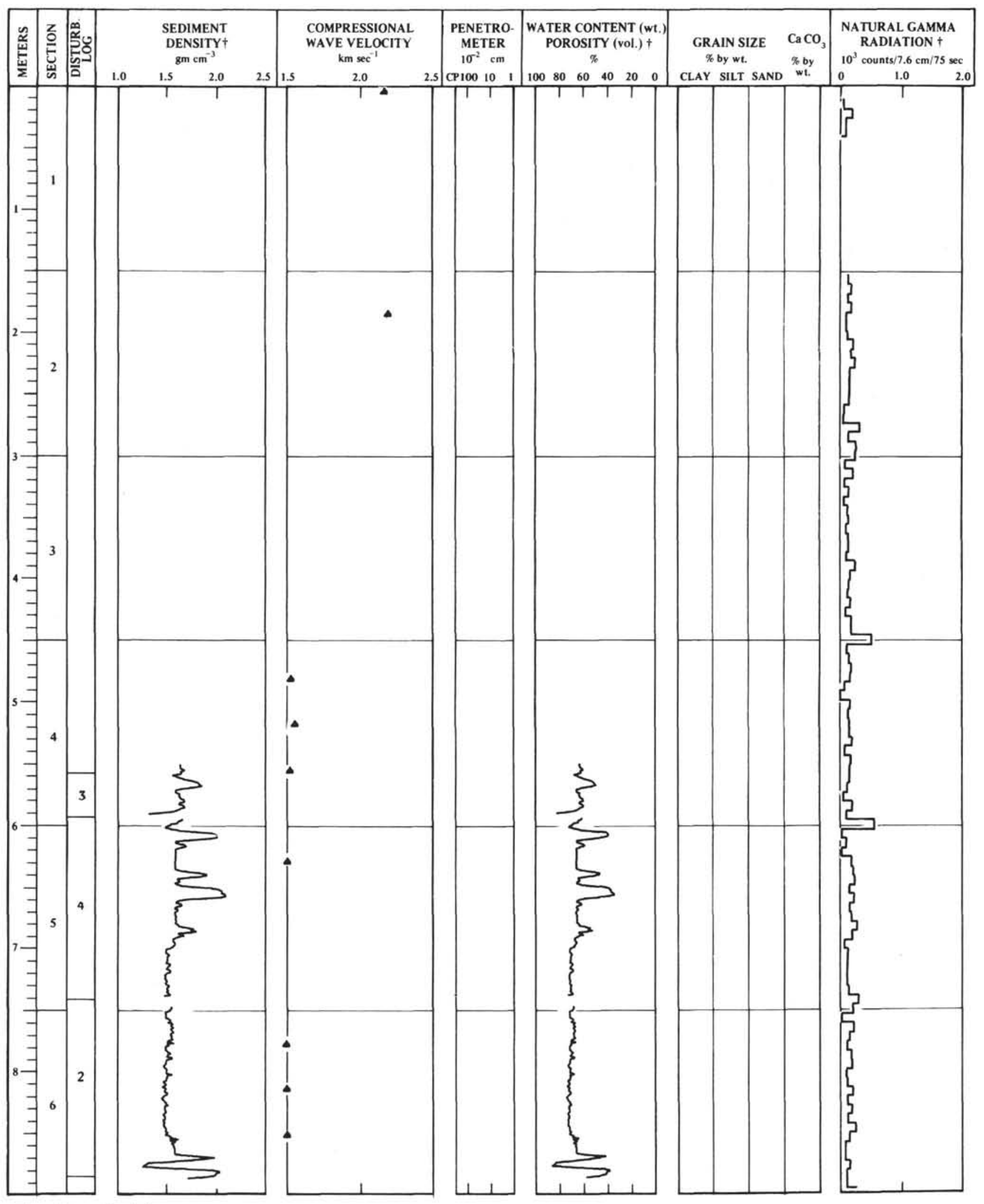




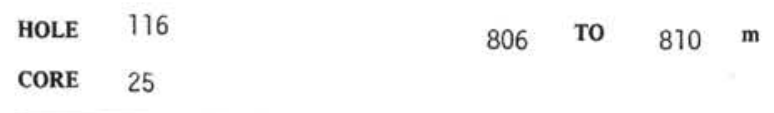

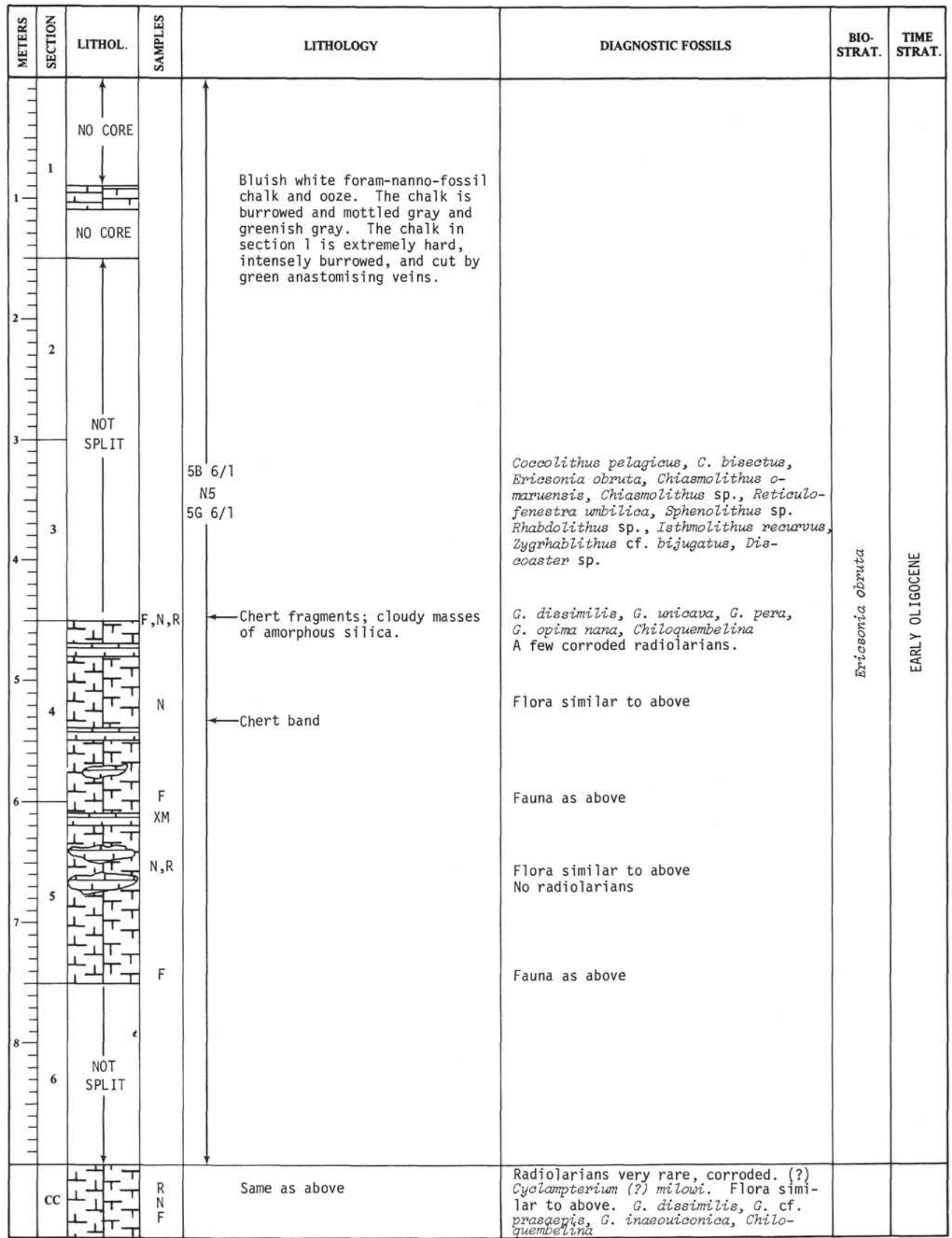


HOLE 116

CORE 26

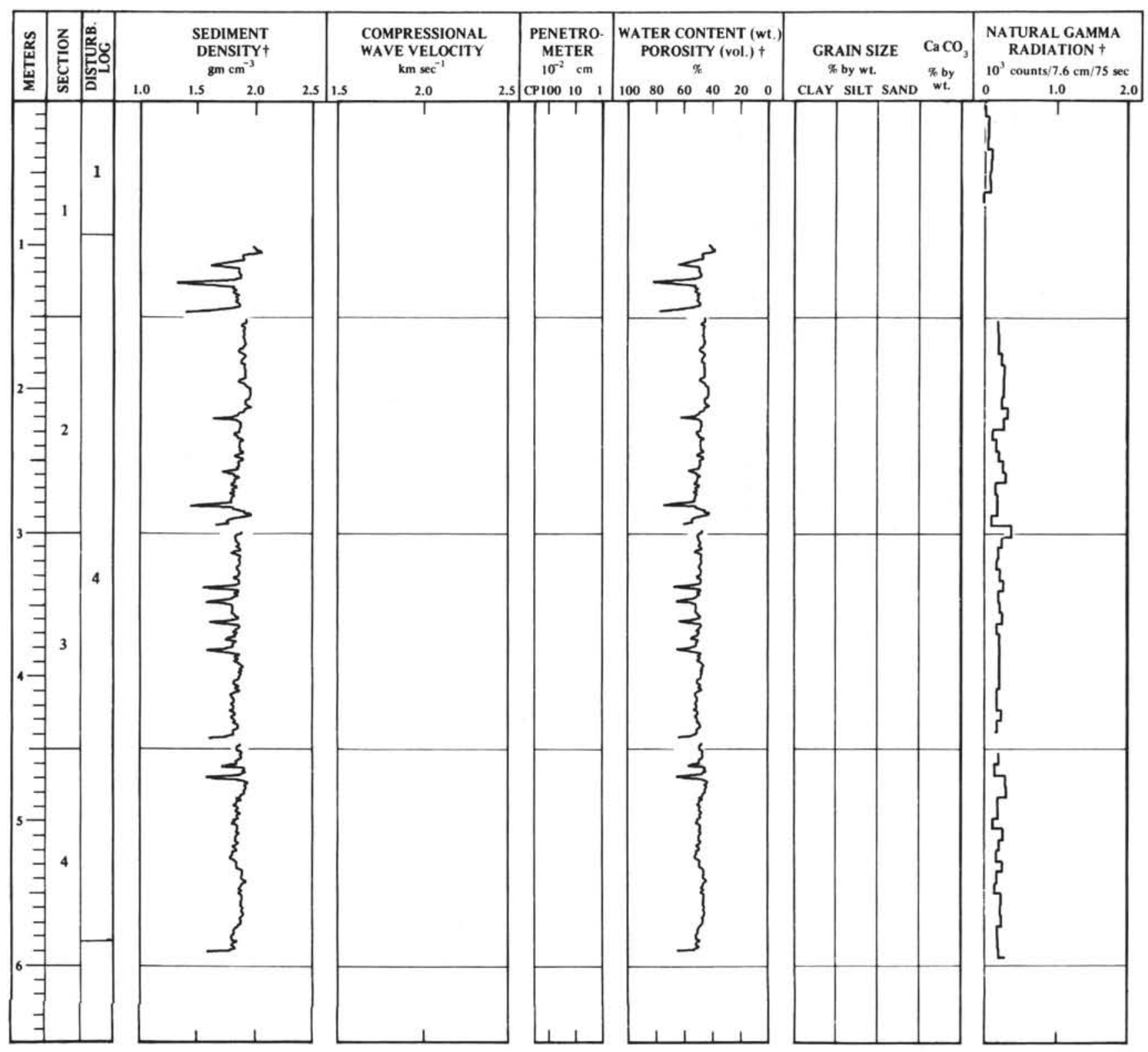

+Adjusted data, see Chapter 2 


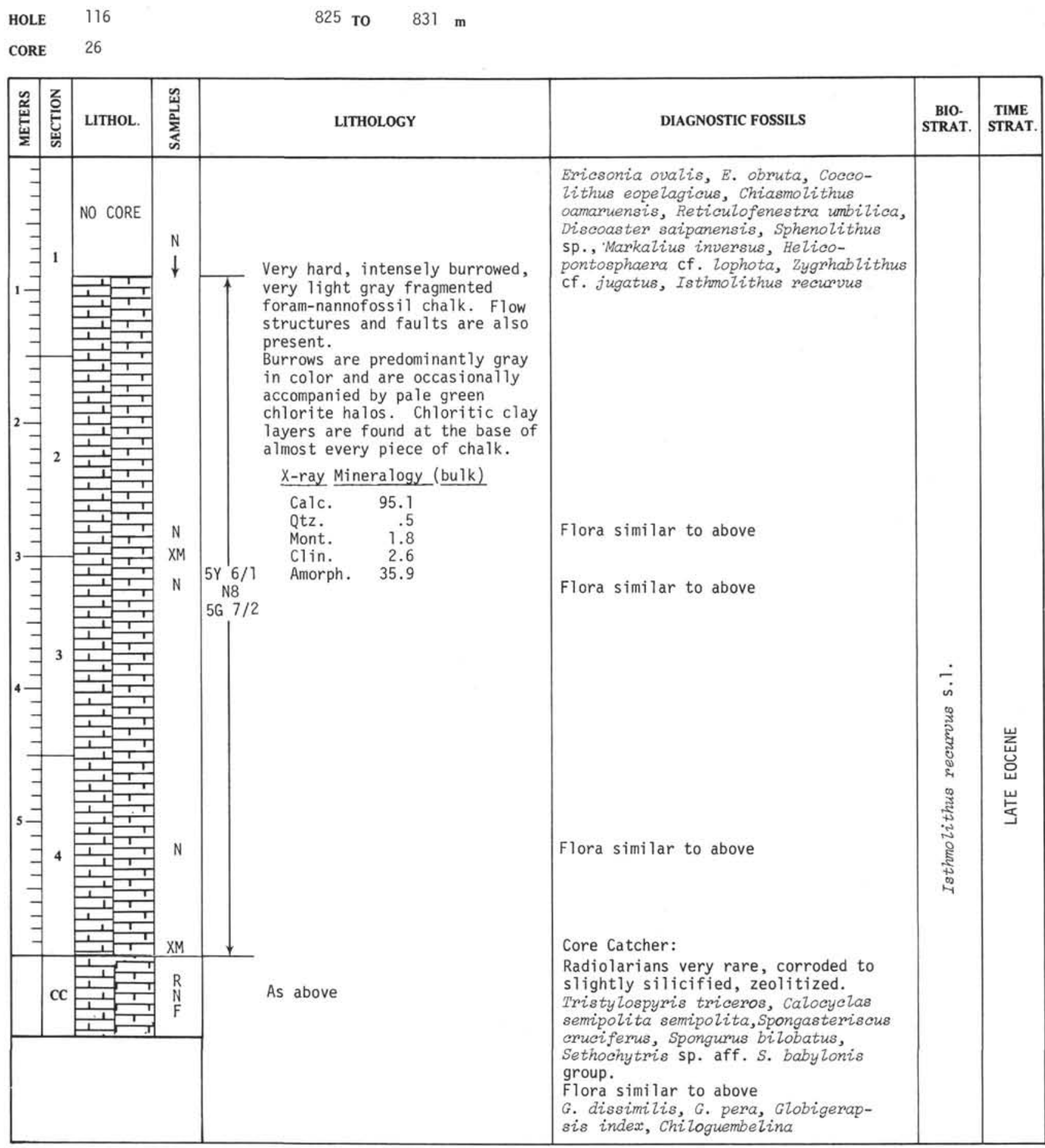


HOLE 116

CORE 27

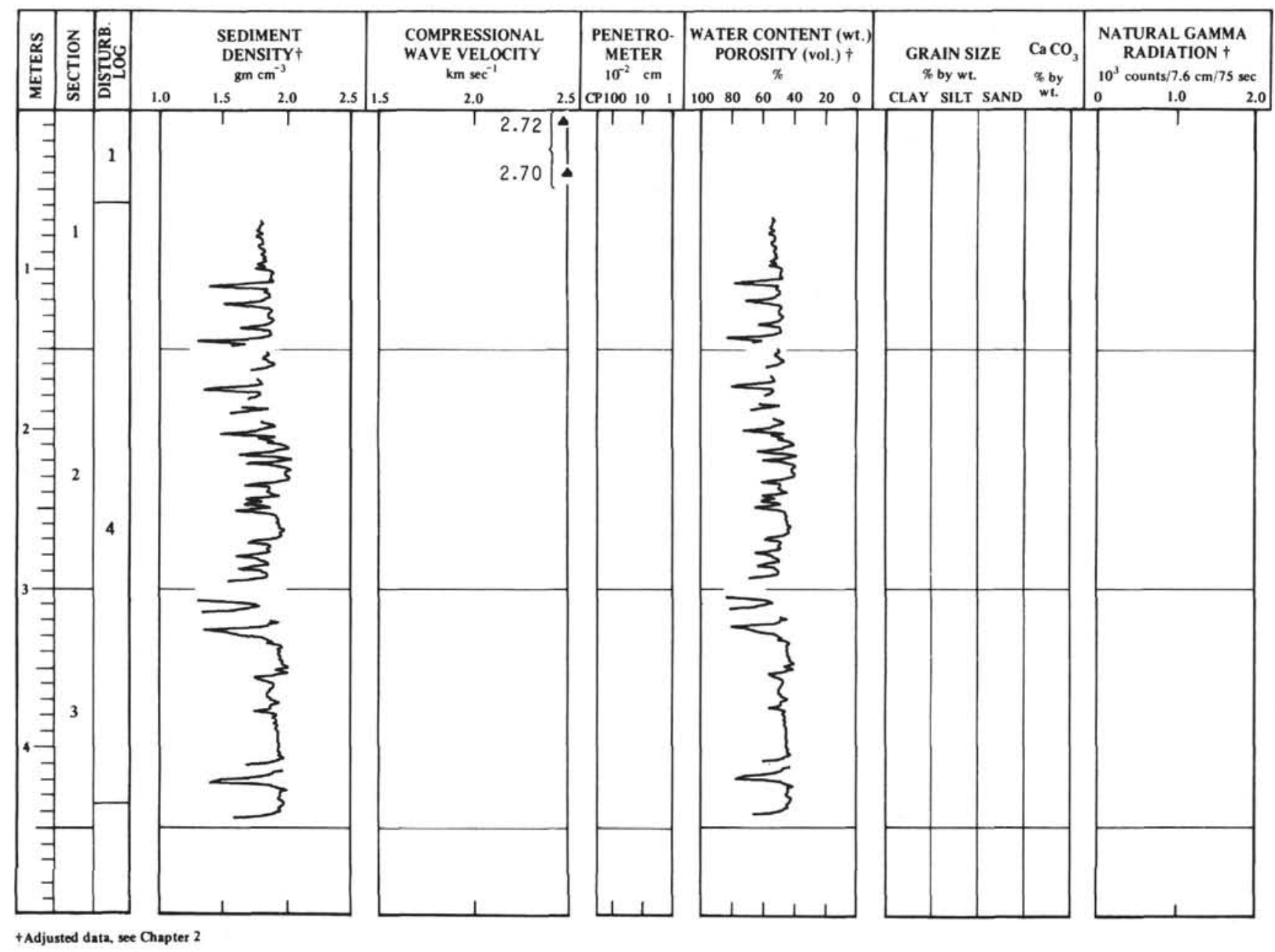



HOLE $\quad 116$
831 тo
$840 \mathrm{~m}$

CORE 27

\begin{tabular}{|c|c|c|c|c|c|c|c|c|}
\hline $\begin{array}{l}\frac{\mathscr{z}}{\mathbf{m}} \\
\frac{1}{\Sigma} \\
\frac{1}{\Sigma}\end{array}$ & 릉 & LITHOL. & 嵒 & & LITHOLOGY & DIAGNOSTIC FOSSILS & $\begin{array}{l}\text { BIO- } \\
\text { STRAT. }\end{array}$ & $\begin{array}{l}\text { TIME } \\
\text { STRAT. }\end{array}$ \\
\hline 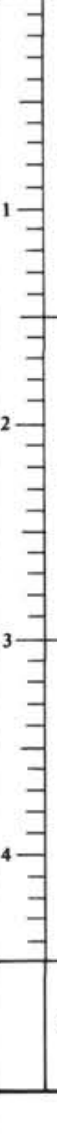 & cc & 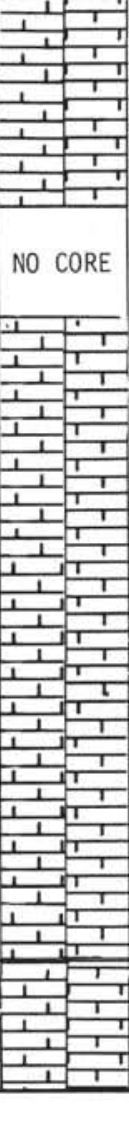 & $\mathrm{R}, \mathrm{F}$ & $\left.\right|_{\substack{N 6 \\
\text { N8 } \\
5 Y \\
\mid}}$ & $\begin{array}{l}\text { Very light gray foram-nanno- } \\
\text { fossil chalk with medium light } \\
\text { gray and light olive gray blebs } \\
\text { and laminations. Laminations } \\
\text { dip at an angle of approximately } \\
33^{\circ} \text { and occur in concentrated } \\
1 \text { areas throughout the core. } \\
\text { Chloritic slickensides appear } \\
\text { in section } 2 \text {. Intense } \\
\text { lamination in section } 3 \text { gives } \\
\text { a marbelized appearance } \\
\text { to the sediment. } \\
\text { X-ray Mineralogy (bulk) } \\
\text { Calc. } 89.6 \\
\text { Cris. } 10.4 \\
\text { Amorph. } 38.0\end{array}$ & $\begin{array}{l}\text { Ericsonia ovalis, Reticulofenestra um- } \\
\text { bilica, Cribrocentrom reticulatw, } \\
\text { Coccolithus eopelagicus, C. bisectus, } \\
\text { Discoaster tani, D. barbadiensis, } \\
\text { Chiasmolithus oamamensis, C. ex- } \\
\text { pansus, Isthmolithus recumvus, } \\
\text { Sphenolithus sp. Bracmidosphaera } \\
\text { bigelowi, Zygrhablithus cf. bijugatus } \\
\text { Three silicified radiolarians. } \\
\text { Indet. globigerinids, chiloguembelinids } \\
\text { Flora similar to above } \\
\text { Fauna as above } \\
\text { Calocyclas semipolita semi- } \\
\text { Flora similar to above } \\
\text { Core Catcher: } \\
\text { Radiolarians very rare, silicified to } \\
\text { corroded. } \\
\text { polita. Flora similar to above. G. } \\
\text { index, globigerinids, chiloguembelinids }\end{array}$ & 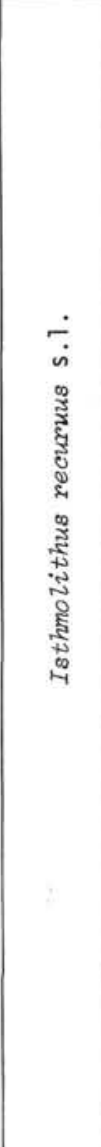 & 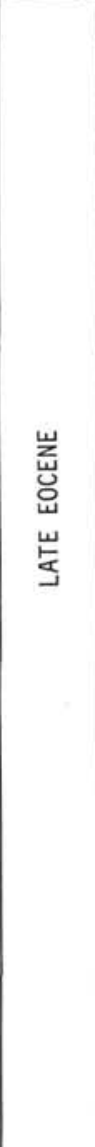 \\
\hline
\end{tabular}


HOLE 116

CORE 28

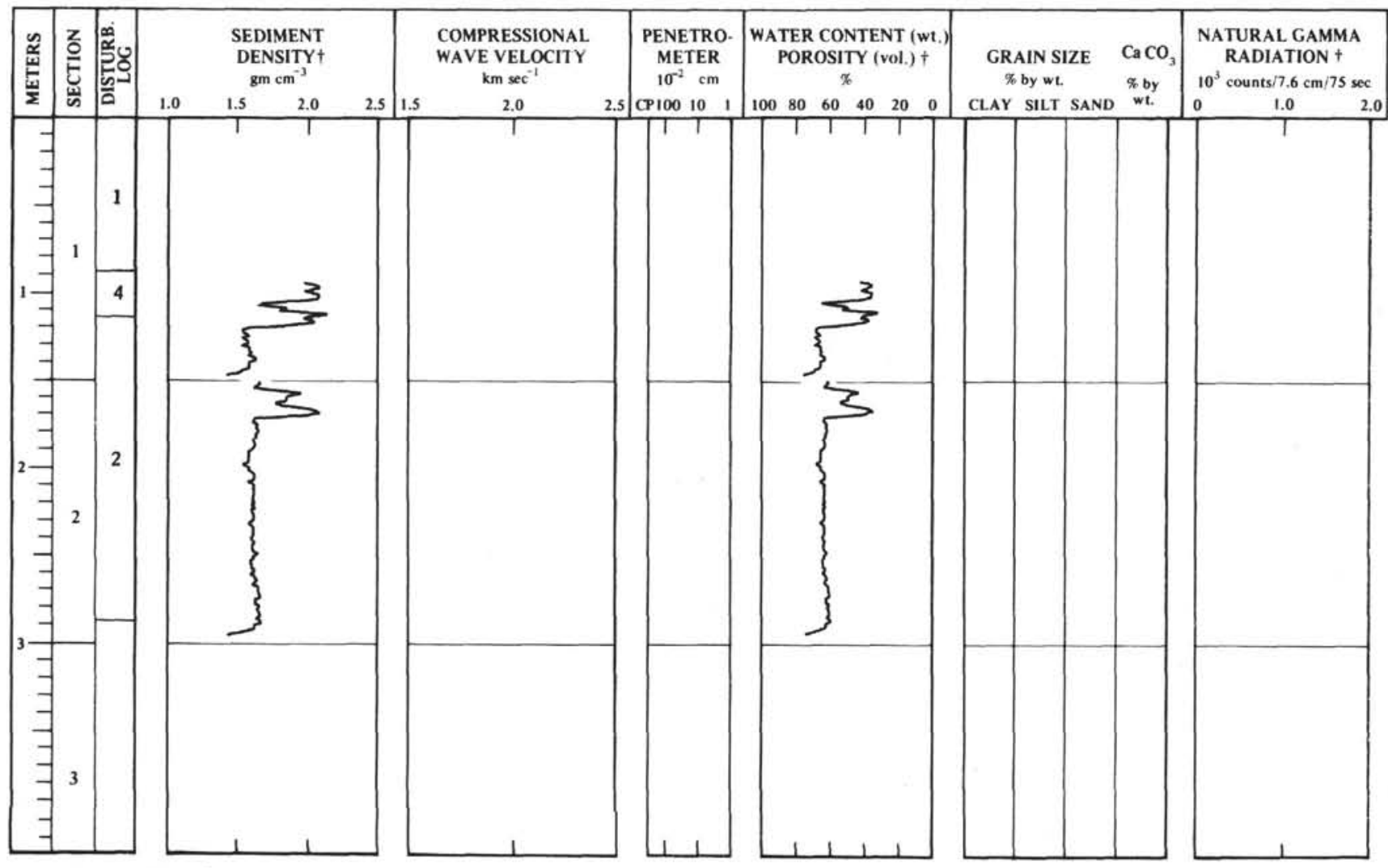

† Adjusted data, see Chapter 2

HOLE 116A

CORE 1

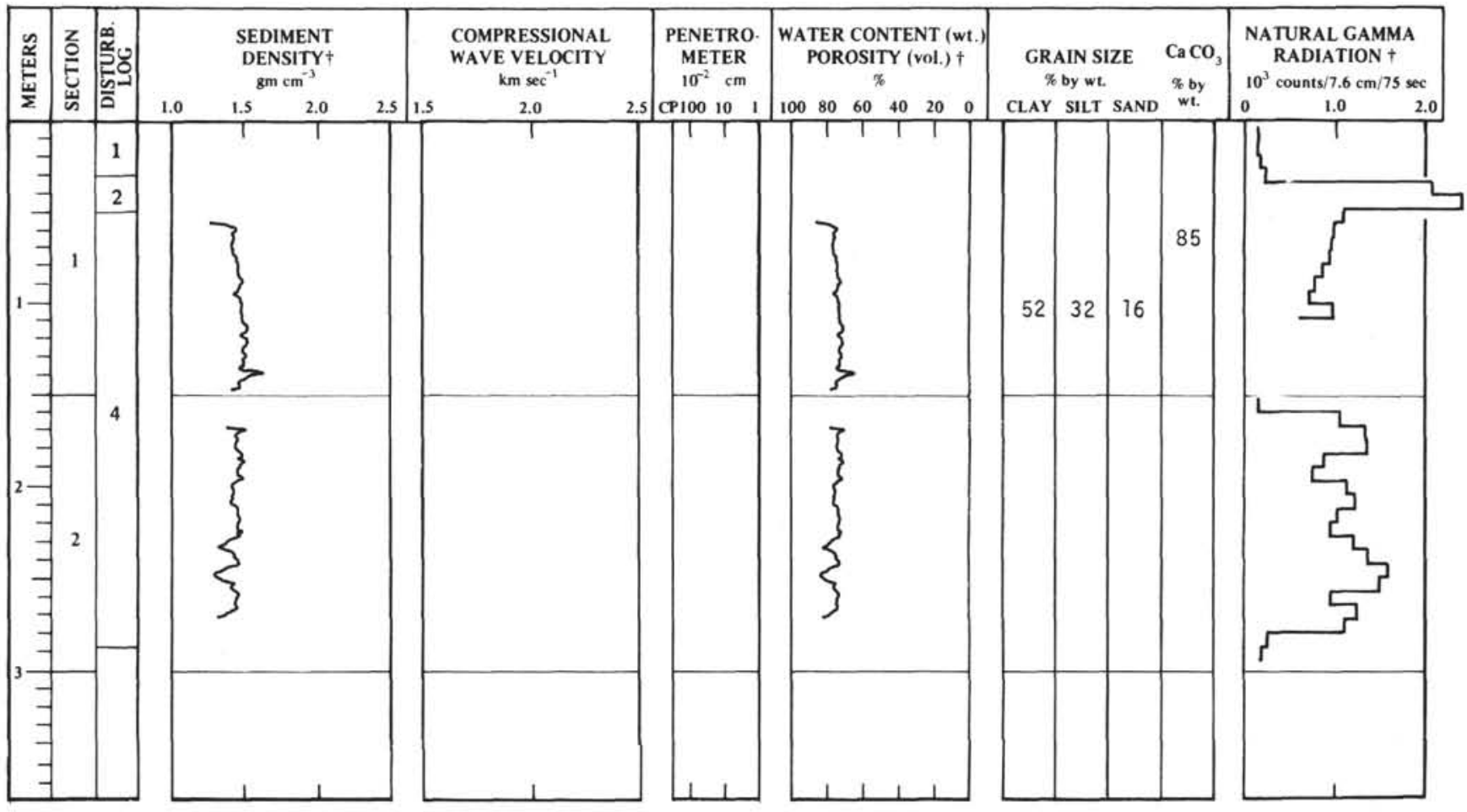

+ Adjusted data, see Chapter 2 

HOLE 116
840 To
$841 \mathrm{~m}$
CORE 28

\begin{tabular}{|c|c|c|c|c|c|c|c|}
\hline 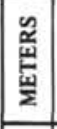 & $\begin{array}{l}z \\
\text { z } \\
\text { 㟧 }\end{array}$ & LITHOL. & 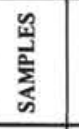 & LITHOLOGY & DIAGNOSTIC FOSSILS & $\begin{array}{c}\text { BIO- } \\
\text { STRAT. }\end{array}$ & $\begin{array}{c}\text { TIME } \\
\text { STRAT. }\end{array}$ \\
\hline 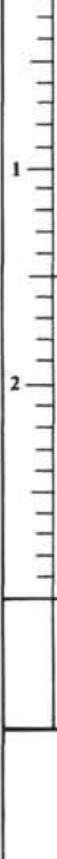 & cc & 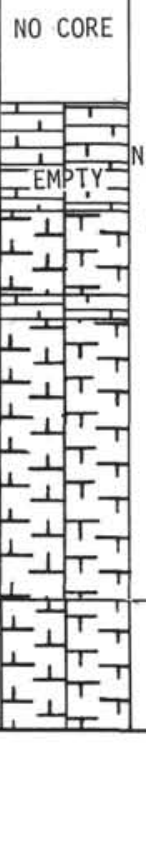 & $\begin{array}{l}\text { N } \\
R \\
R \\
\text { F } \\
\text { F } \\
\\
\end{array}$ & $\begin{array}{l}\text { Hard white foram-nannofossil } \\
\text { chalk in a matrix of fluid } \\
\text { ooze. }\end{array}$ & $\begin{array}{l}\text { Flora similar to above. } \\
\text { No radiolarians } \\
\text { G. index, G. galavisi, G. Linaperta, } \\
\text { Chiloguembelina } \\
\text { Core Catcher: } \\
\text { Flora and fauna similar to above } \\
\text { Radiolarians very rare. Helio- } \\
\text { discus heliastericus, (?) Calo- } \\
\text { cyclas semipolita semipolita, } \\
\text { (?) Lophoconus titanothericeraos }\end{array}$ & 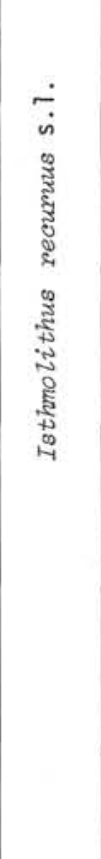 & 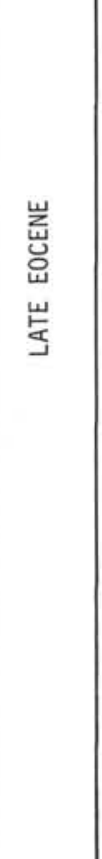 \\
\hline
\end{tabular}
HOLE 116A
0 то
$9 \mathrm{~m}$
CORE I

\begin{tabular}{|c|c|c|c|c|c|c|c|c|}
\hline$\frac{\mathscr{z}}{\frac{2}{2}}$ & $\begin{array}{l}\text { zo } \\
\text { ్ㅐㅀ }\end{array}$ & LITHOL. & $\frac{\mathscr{m}}{\frac{3}{\Sigma}}$ & & LITHOLOGY & DIAGNOSTIC FOSSILS & $\begin{array}{c}\text { BIO- } \\
\text { STRAT. }\end{array}$ & $\begin{array}{c}\text { TIME } \\
\text { STRAT. }\end{array}$ \\
\hline 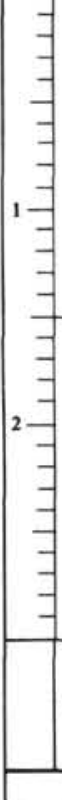 & CC & 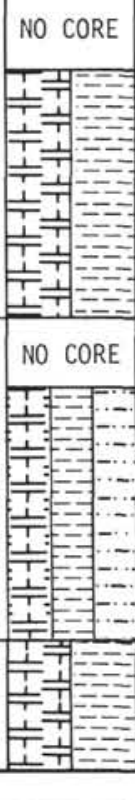 & $\begin{array}{l}\mathrm{N} \\
\mathrm{XM} \\
\mathrm{N} \\
\mathrm{R}\end{array}$ & $\begin{array}{c}\prod_{N 7} \\
N 8 \\
\mid \\
\downarrow \\
\\
2.5 Y \\
5 / 2 \\
2.5 Y \\
4 / 2 \\
5 Y 8 / 1\end{array}$ & $\begin{array}{l}\text { Yellowish gray foram nanno- } \\
\text { fossil marl mud mottled grayish } \\
\text { brown and dark grayish mud } \\
\text { mottled yellowish gray. } \\
\text { Siliceous fossils are rare as } \\
\text { well as quartz, ostracods, and } \\
\text { fish debris. } \\
\frac{\text { X-ray }}{\text { Mineralogy (bulk) }} \\
\text { Calc. } \\
\text { Qtz. } \\
\text { Plag. } \\
\text { Mica } \\
\text { Amorph. }\end{array}$ & $\begin{array}{l}\text { Coccolithus pelagicus, Cyclococcolithus } \\
\text { leptoporus, Syracosphaera sp. } \\
\text { Emiliania huxleyi, Gephyrocapsa } \\
\text { oceanica, G. aperta, Helico- } \\
\text { pontosphaera kamptneri, H. sellii, } \\
\text { Rhabdolithus sp. } \\
\text { Flora similar to above } \\
\text { Radiolarians very rare. Actinomma } \\
\text { antarcticum, Lamprocyclas maritalis } \\
\text { G. pachyderma, G. bulloides, G. } \\
\text { hirsuta, G. inflata, G. truncatulinoides } \\
\text { O. universa } \\
\text { Flora similar to above } \\
\text { Radiolarians very rare } \\
\text { Fauna as above } \\
\text { Fauna as above } \\
\text { Core Catcher: } \\
\text { Fauna as above. Flora similar to above, } \\
\text { less E. huxleyi?, + rew. Late } \\
\text { Cretaceous coccoliths }\end{array}$ & 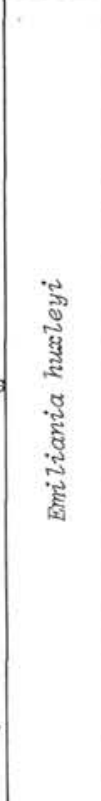 & $\begin{array}{l}\text { 岂 } \\
\text { 号 } \\
\text { 怘 } \\
\text { 岂 }\end{array}$ \\
\hline
\end{tabular}


HOLE 116A

CORE 2

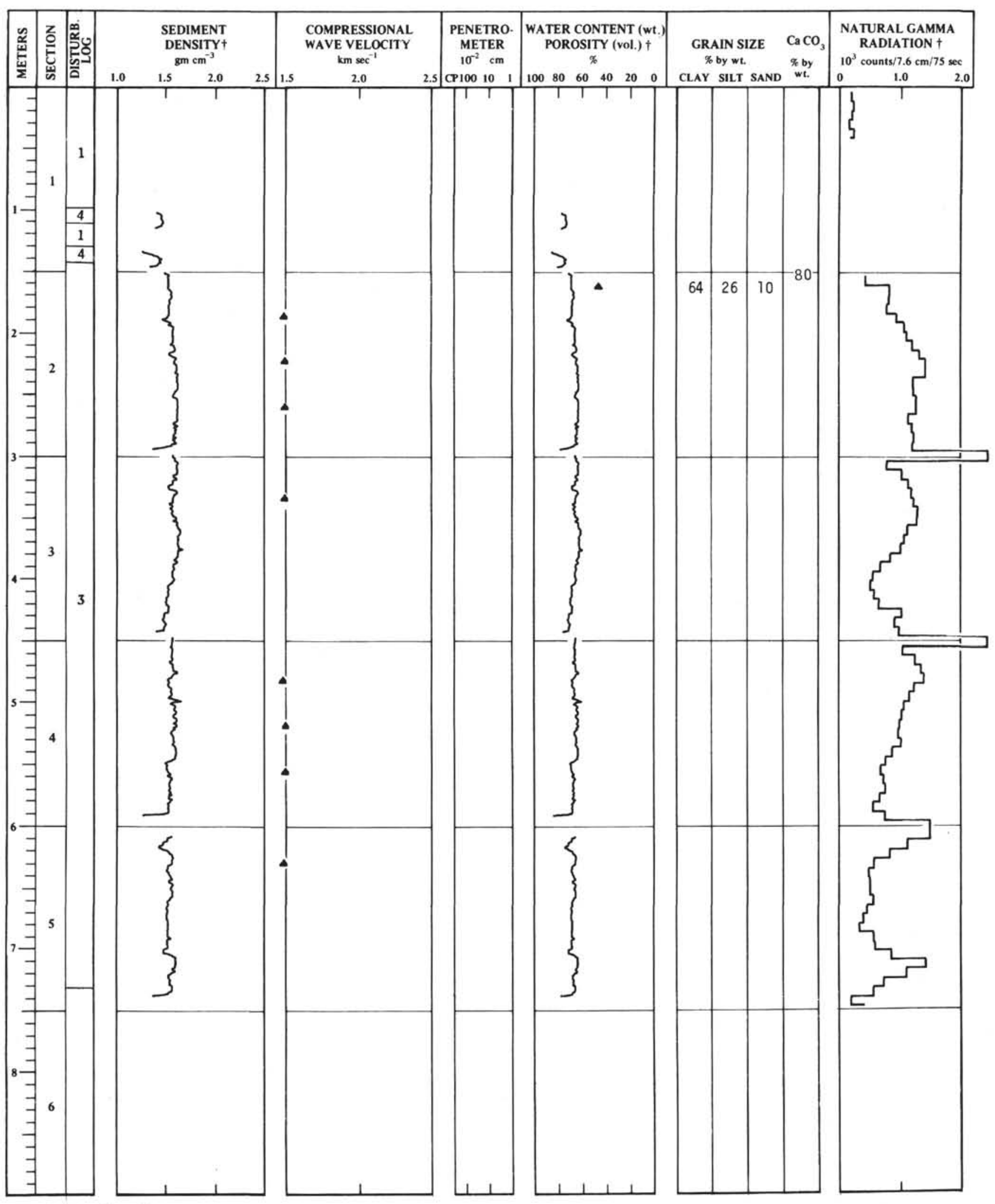




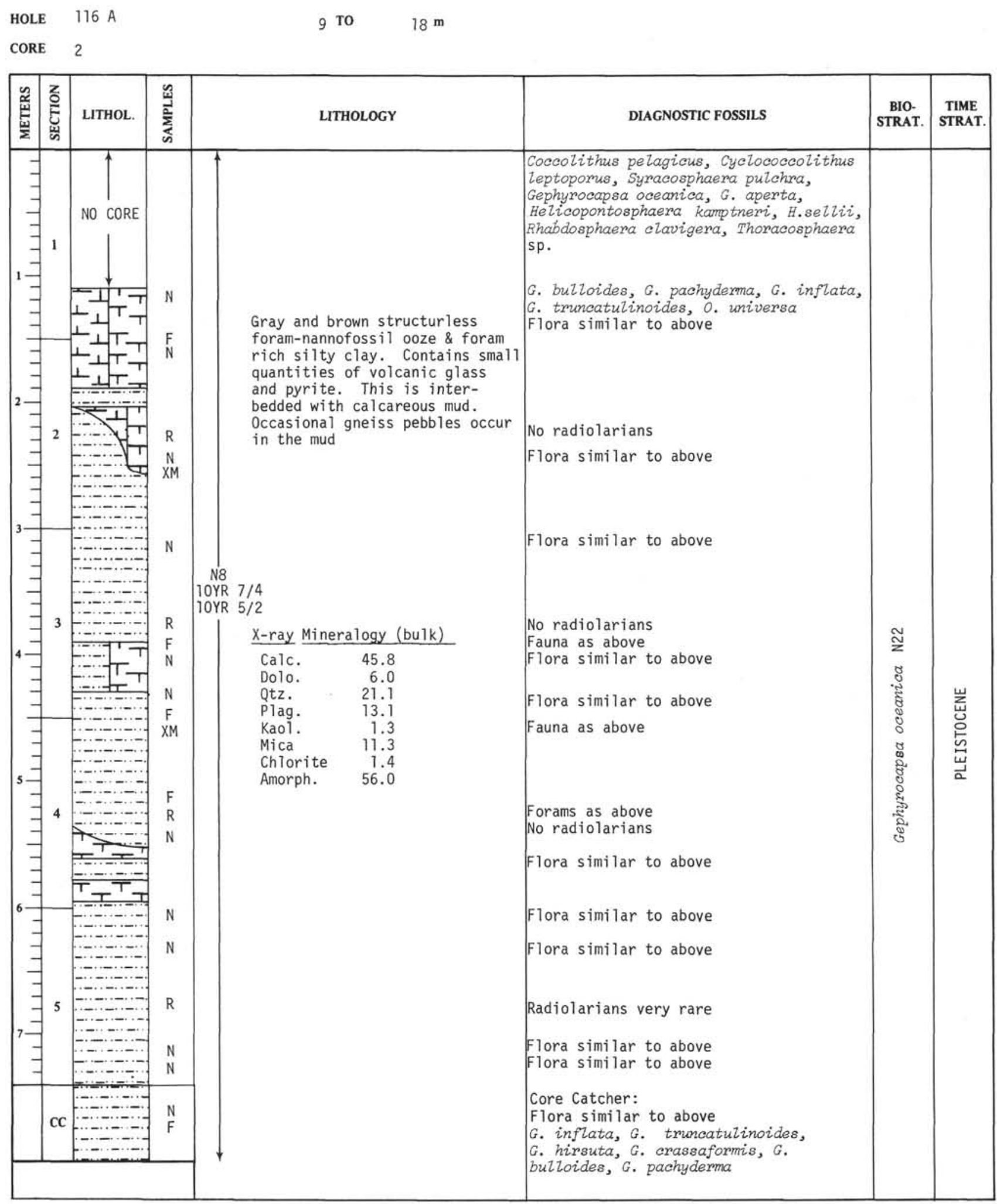


HOLE 116A

CORE 3

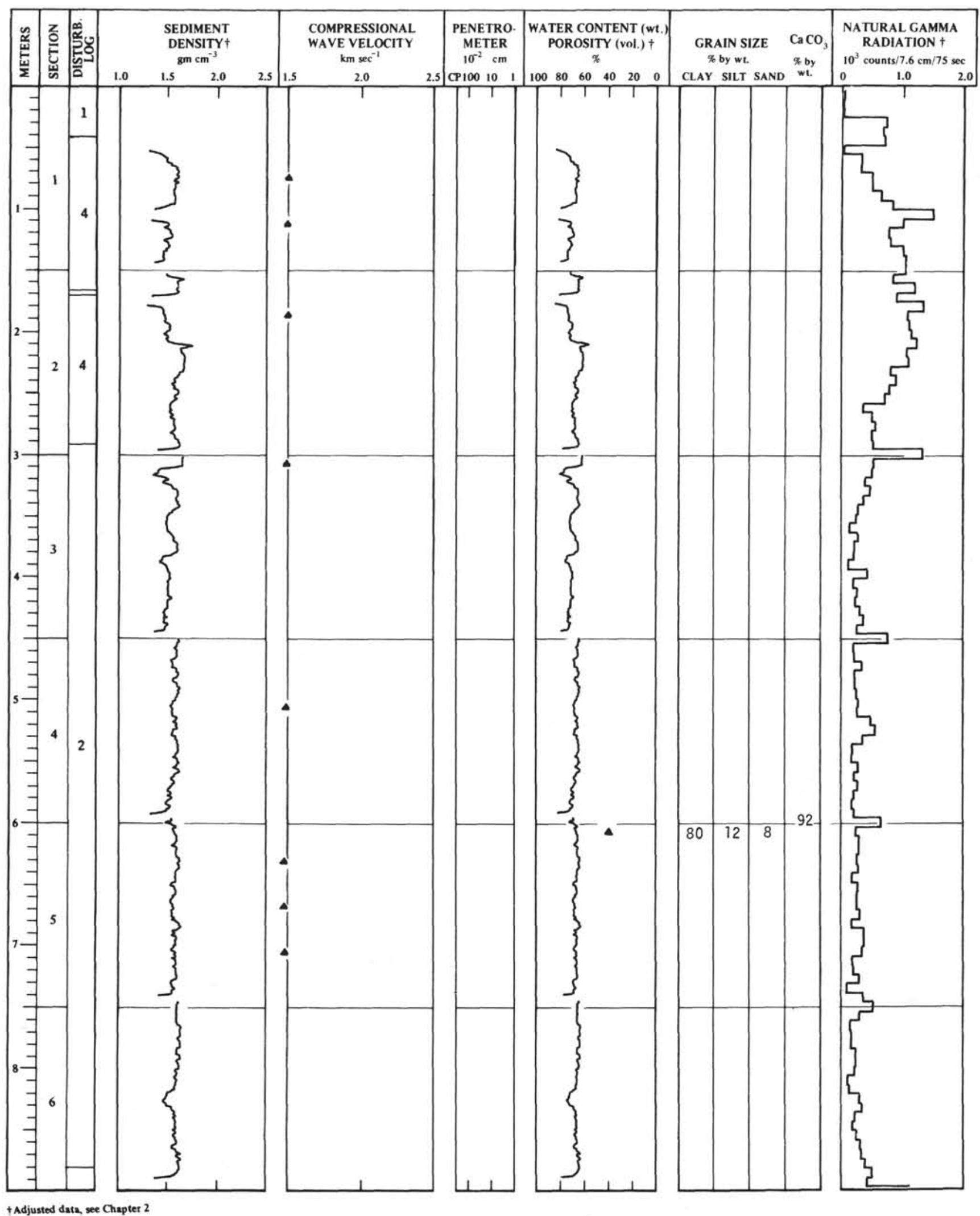


HOLE $116 \mathrm{~A}$

18 To

$27 \mathrm{~m}$

CORE 3

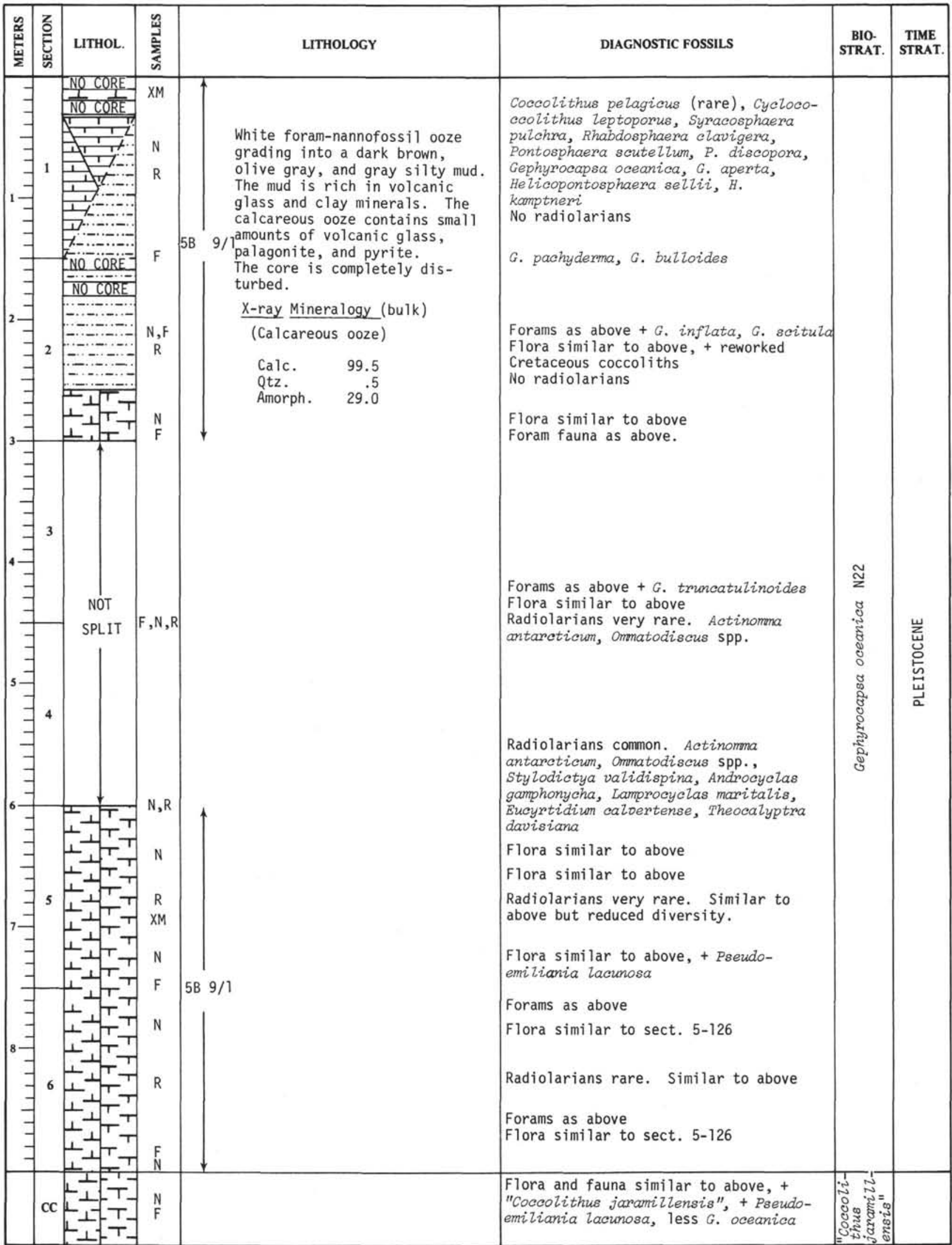


HOLE 116A

CORE 4

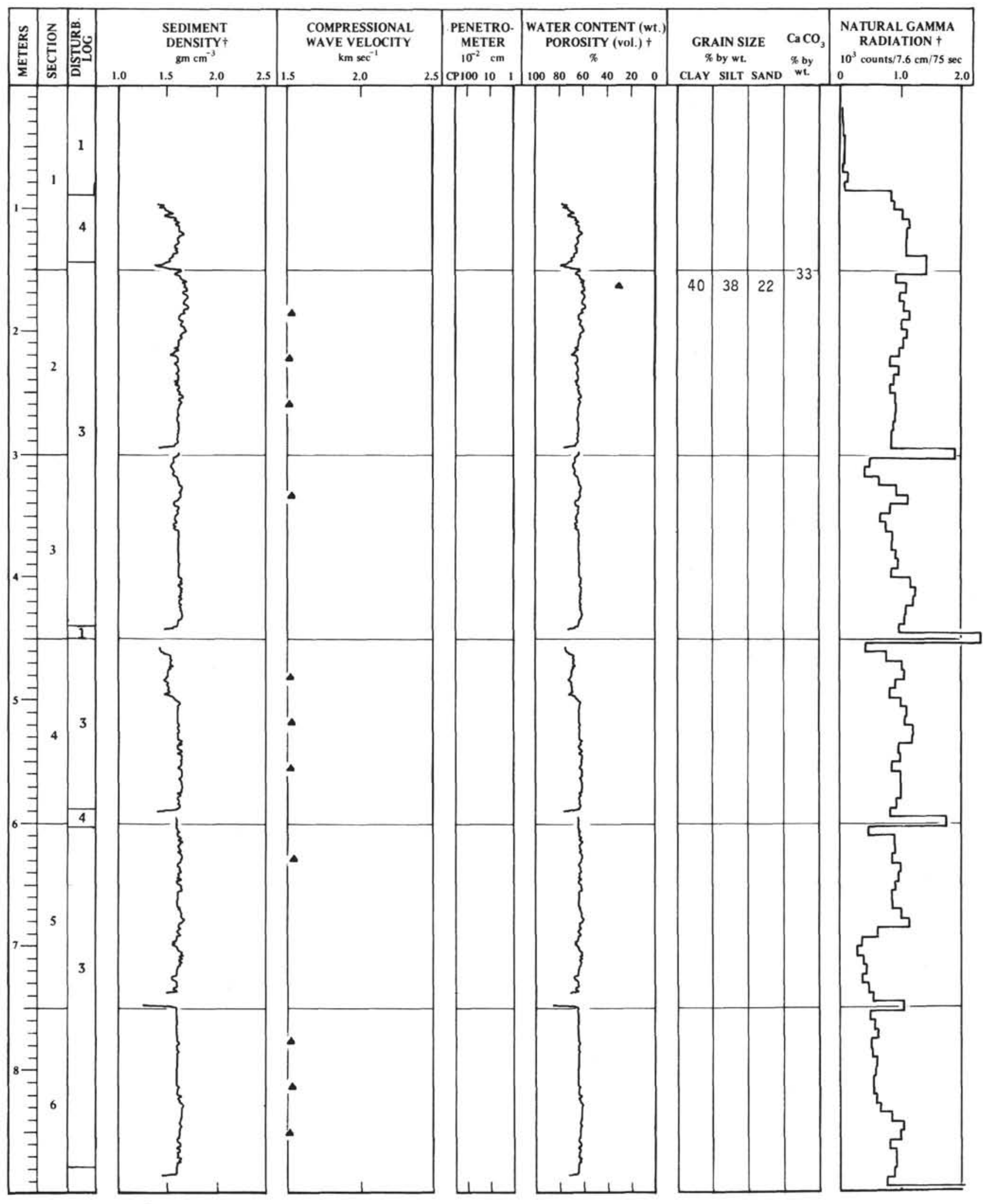




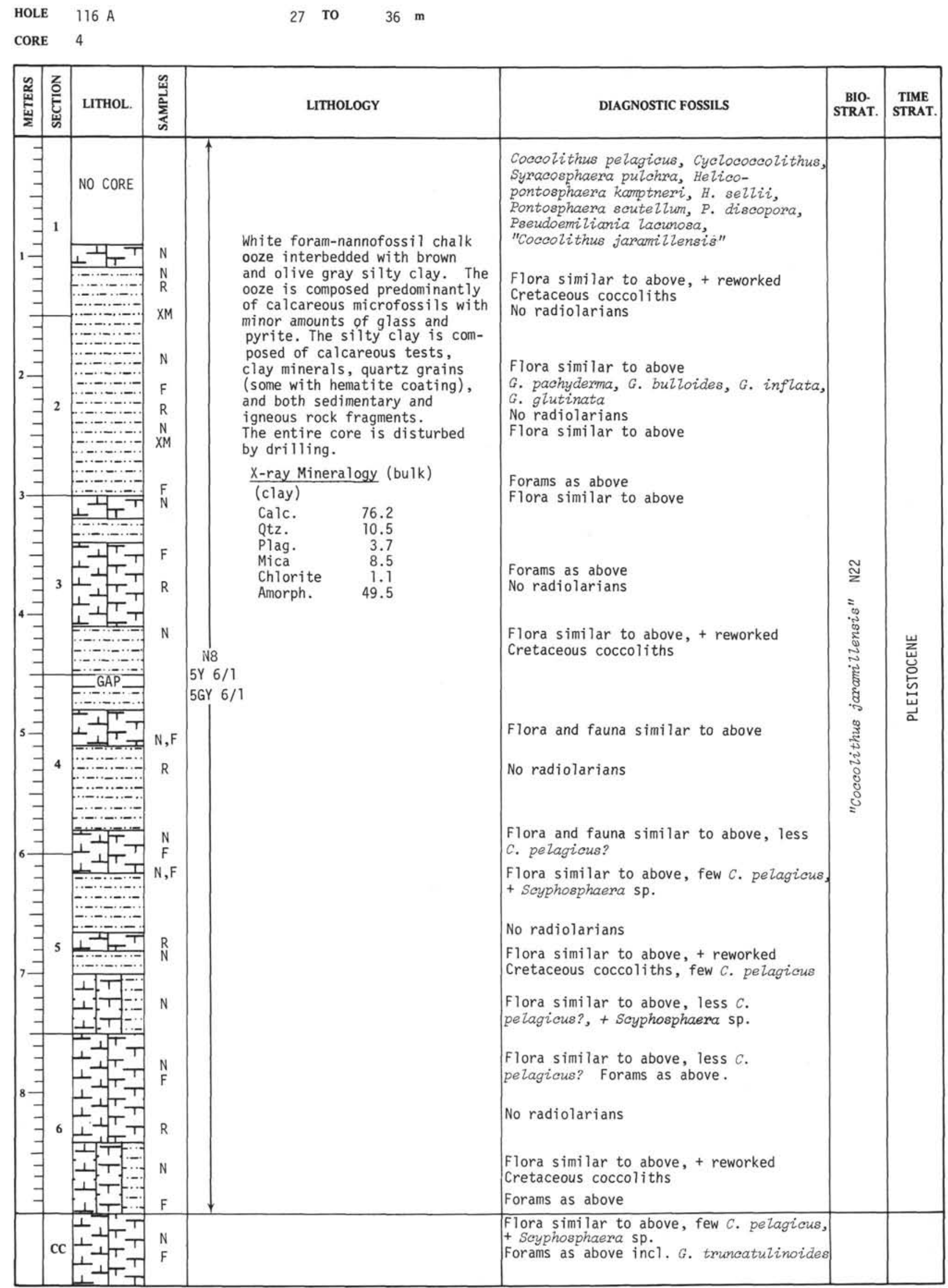


HOLE 116A

CORE 5

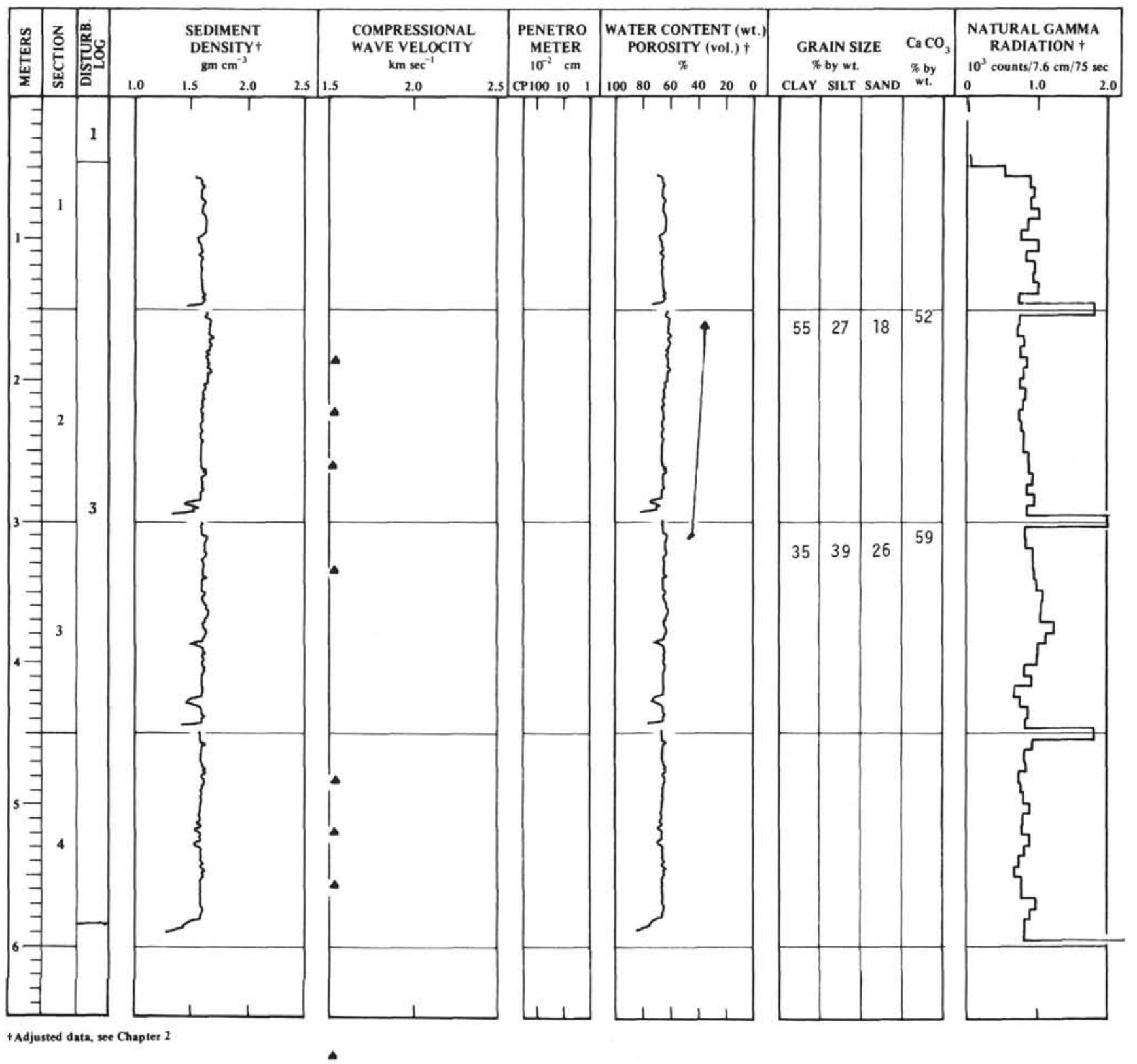


CORE 5

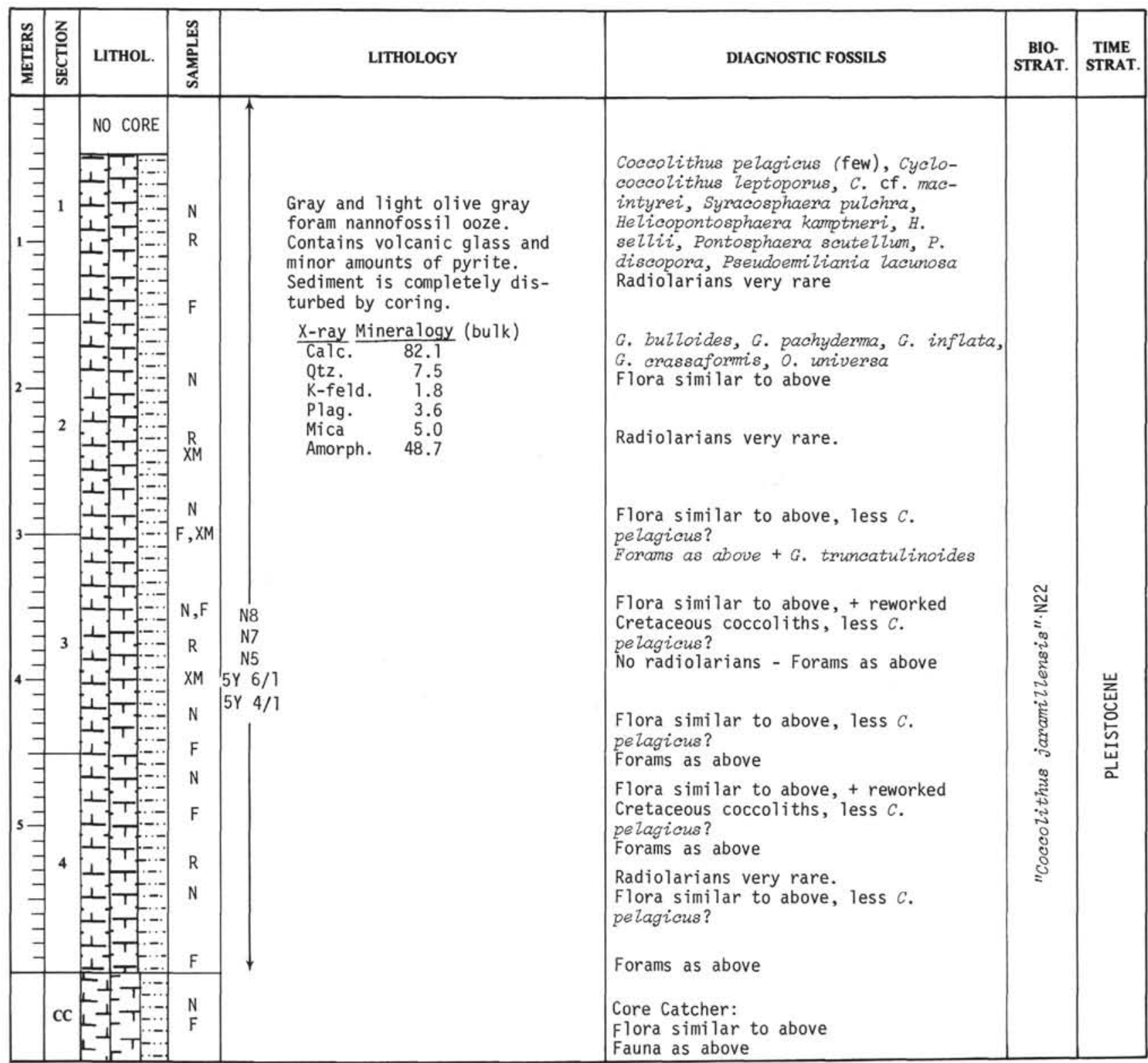


HOLE 116A

CORE 6

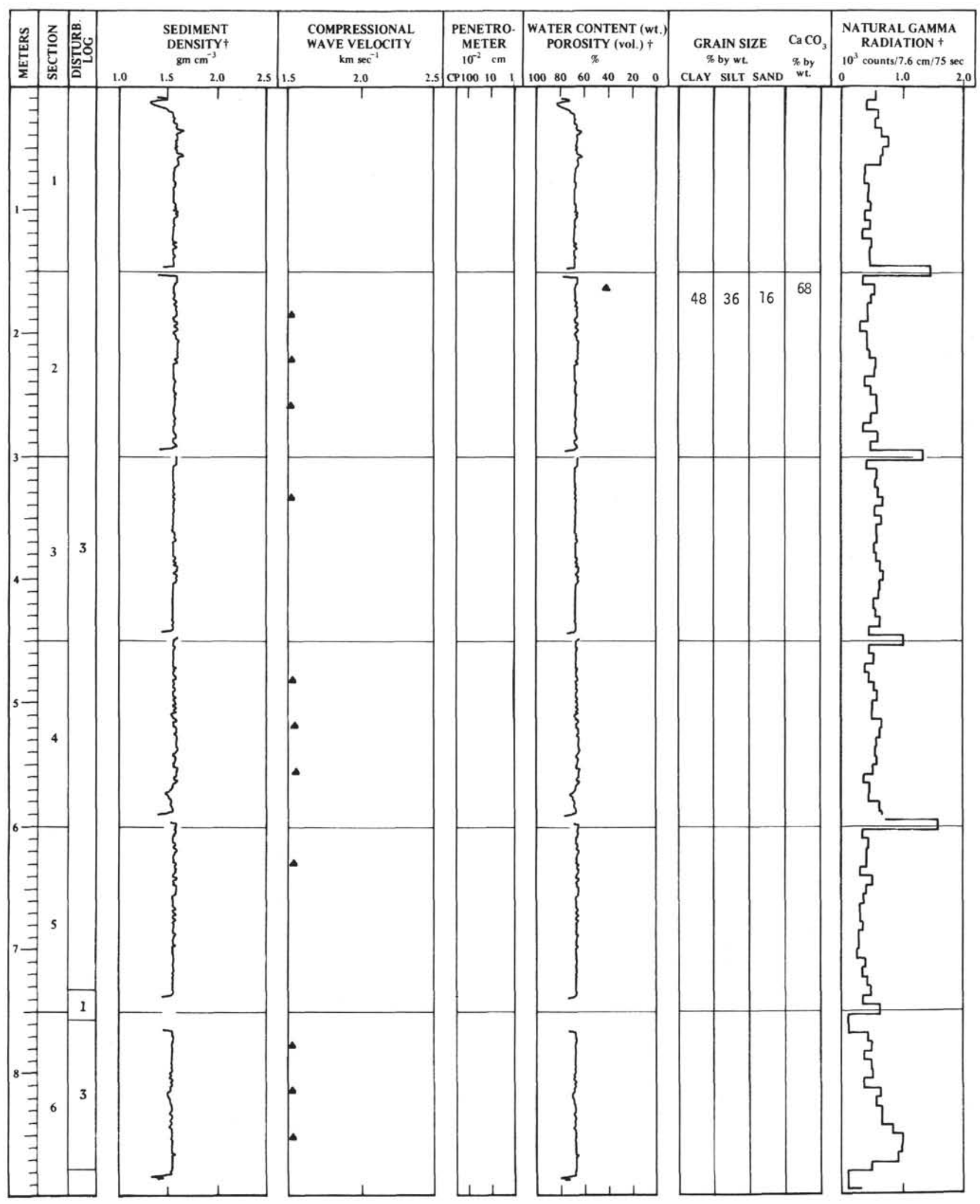

+ Adjusted data, see Chapter 2 
HOLE $116 \mathrm{~A}$

CORE 6

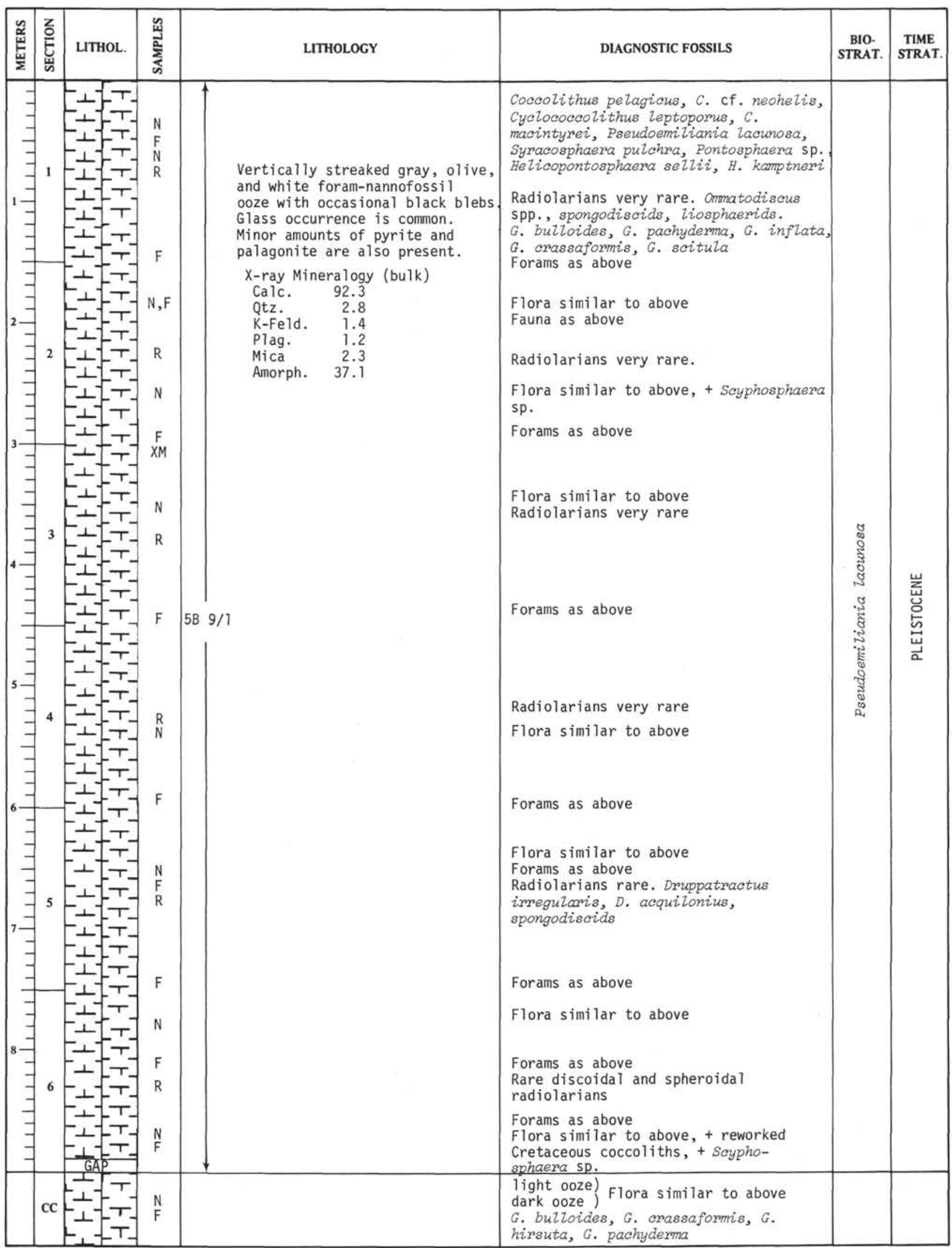


SHIPBOARD SCIENTIFIC PARTY

HOLE 116A

CORE 7

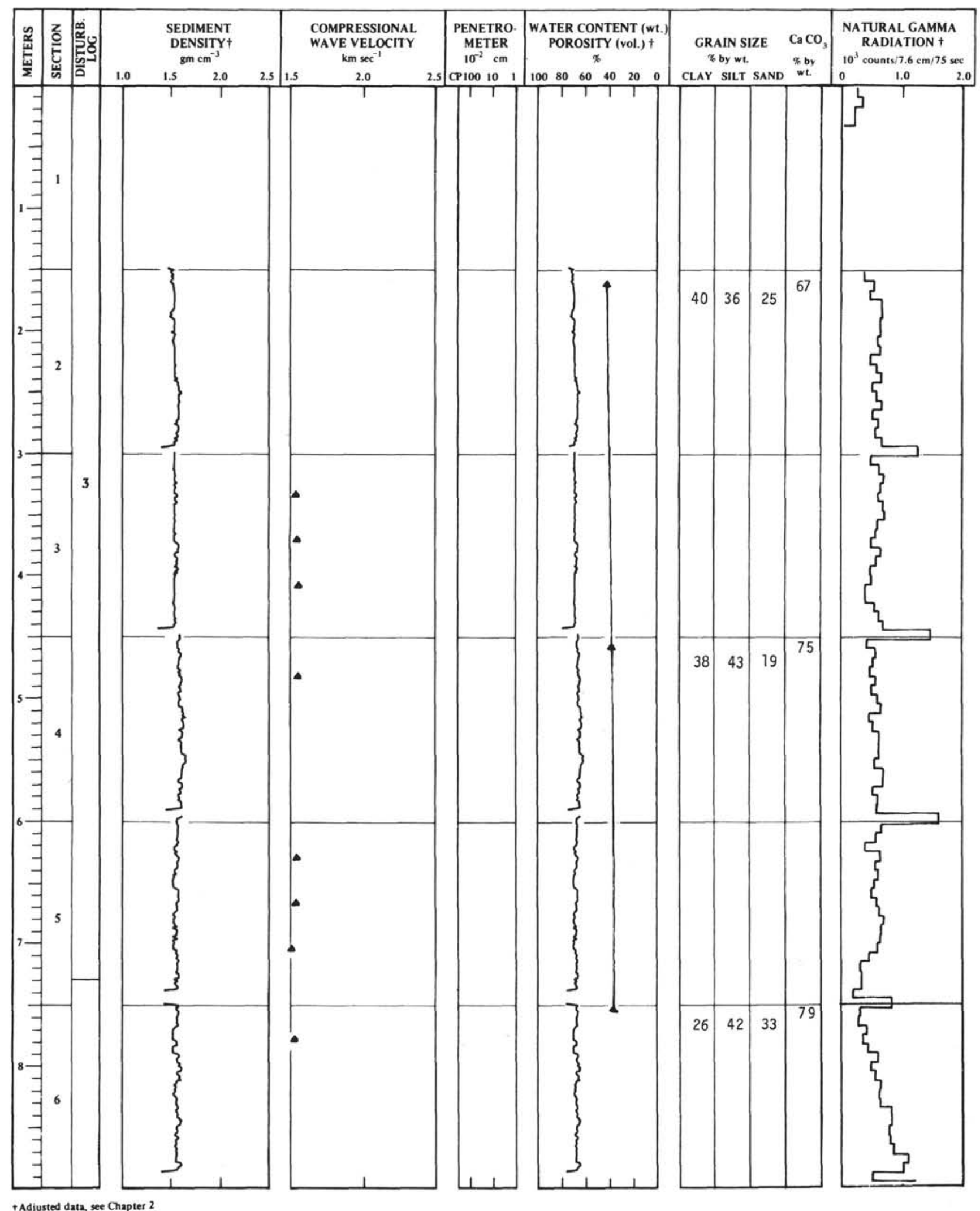



HOLE
$116 \mathrm{~A}$
54 то
$63 \mathrm{~m}$
CORE 7

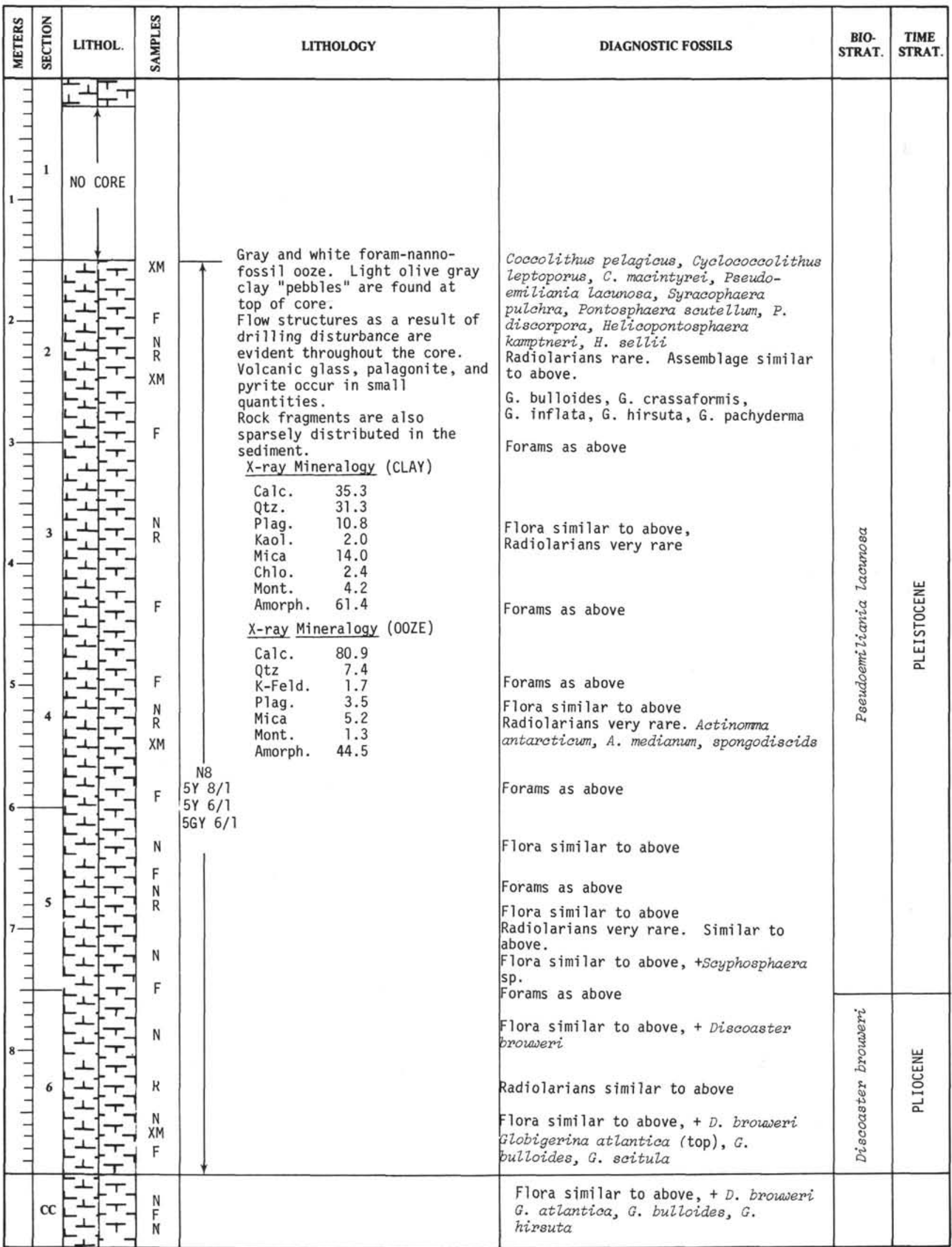


SHIPBOARD SCIENTIFIC PARTY

HOLE $116 \mathrm{~A}$

CORE 8

\begin{tabular}{|c|c|c|c|c|c|c|c|c|c|c|c|c|c|c|}
\hline \multirow[t]{2}{*}{$\frac{\mathscr{z}}{\frac{w}{2}}$} & \multirow{2}{*}{\multicolumn{2}{|c|}{ 孞 }} & \multicolumn{4}{|c|}{$\begin{array}{l}\text { SEDIMENT } \\
\text { DENSITY }{ }^{+} \\
\mathrm{gm} \mathrm{cm}^{-3}\end{array}$} & \multicolumn{2}{|r|}{$\begin{array}{l}\text { COMPRESSIONAL } \\
\text { WAVE VELOCITY } \\
\mathrm{km} \mathrm{sec}^{-1}\end{array}$} & \multirow[t]{2}{*}{$\begin{array}{c}\text { PENETRO- } \\
\text { METER } \\
1 \sigma^{-2} \mathrm{~cm} \\
\text { CP100 } 10 \quad 1\end{array}$} & \multirow[t]{2}{*}{ 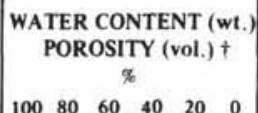 } & \multirow{2}{*}{\multicolumn{3}{|c|}{$\begin{array}{cc}\text { GRAIN SIZE } & \mathrm{CaCO}_{3} \\
\text { \% by wt. } & \begin{array}{c}\% \text { by } \\
\text { CLAY SILT SAND } \\
\text { wt. }\end{array}\end{array}$}} & \multirow[t]{2}{*}{$\begin{array}{l}\text { NATURAL GAMMA } \\
\text { RADIATION }+ \\
10^{3} \text { counts } / 7.6 \mathrm{~cm} / 75 \mathrm{sec} \\
0 \quad 1.0 \quad 2.0\end{array}$} \\
\hline & & & 1.0 & 1.5 & 2.0 & 2.5 & 1.5 & 2.0 & & & & & & \\
\hline & & & & $T$ & $T$ & & & 1 & & \begin{tabular}{lllll|l} 
& 1 & 1 & 1 & 1
\end{tabular} & & & & 7 \\
\hline
\end{tabular}

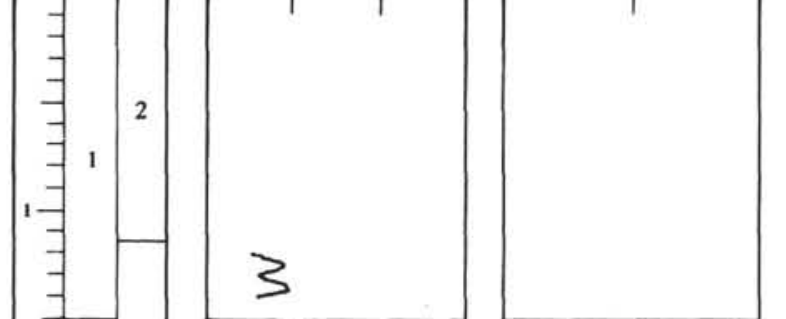

手

$2=$

王 2

手

$4-$

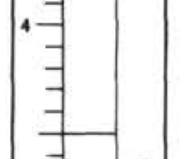

年 $\quad 3$

-
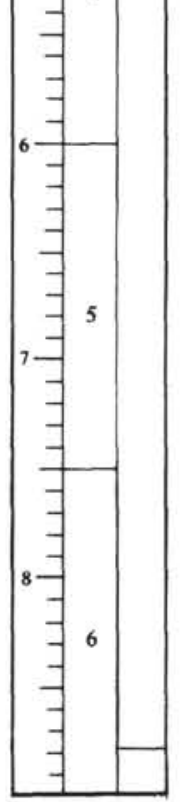

+ Adjusted data see Chapter 2

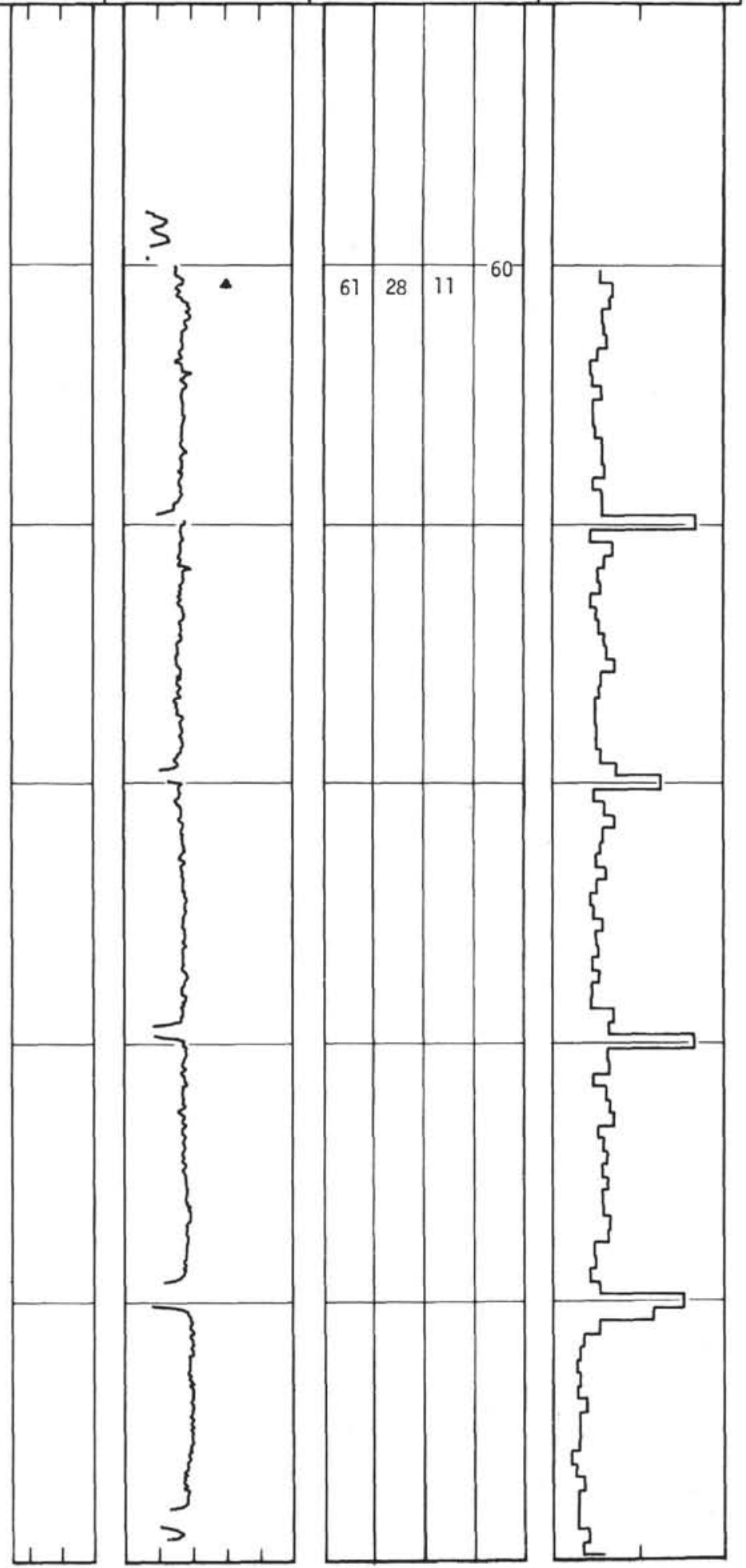


CORE 8

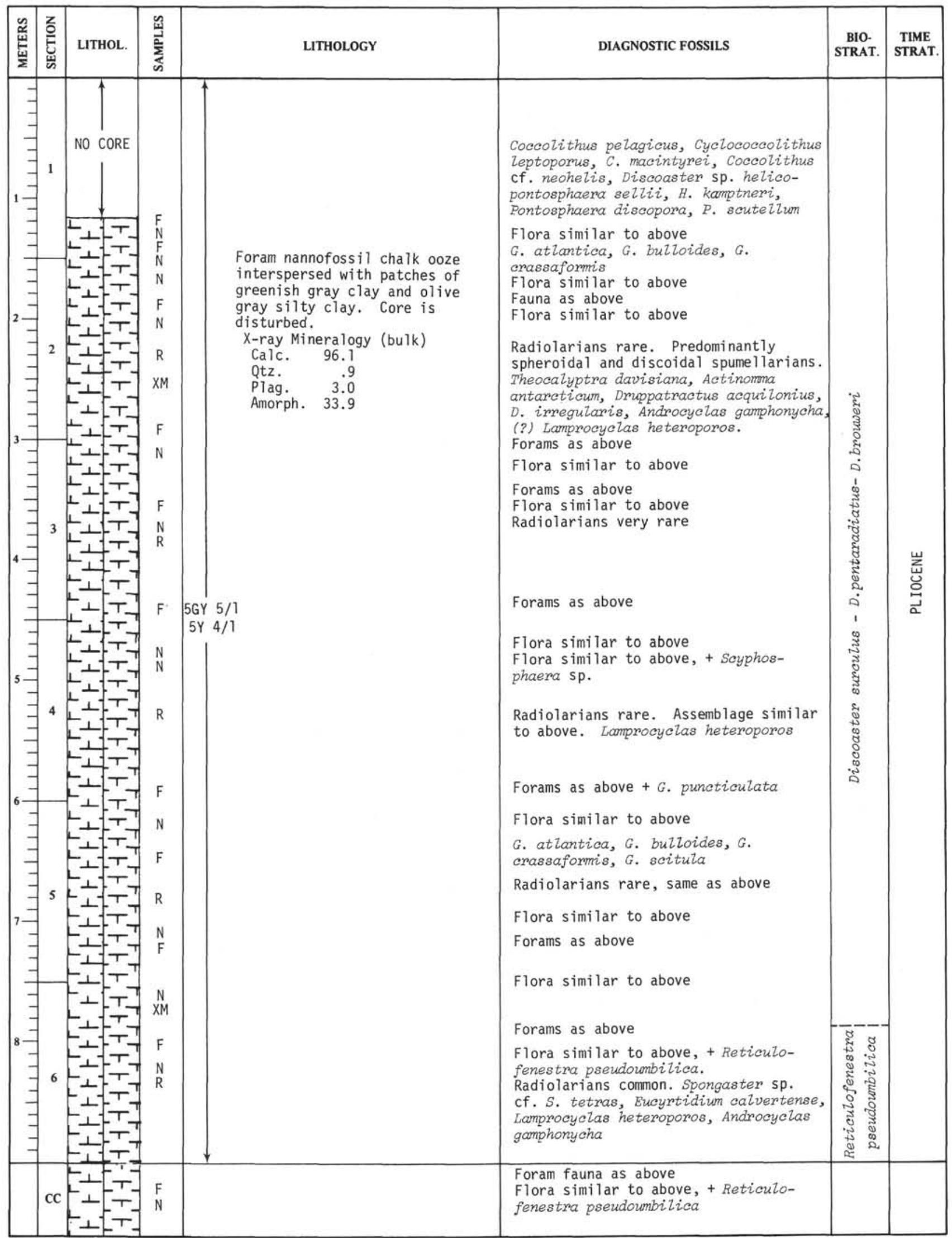


HOLE 116A

CORE 9

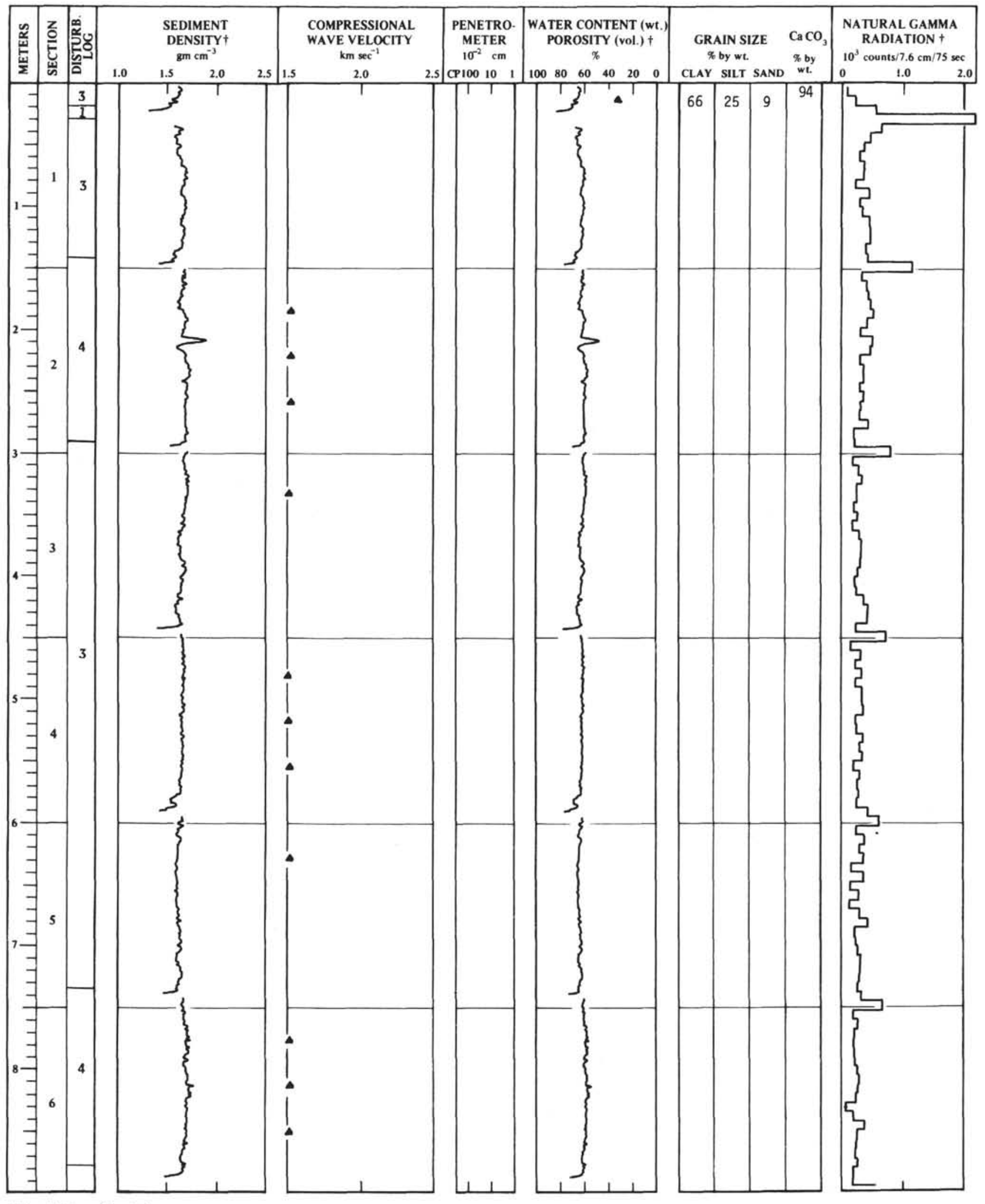


CORE 9

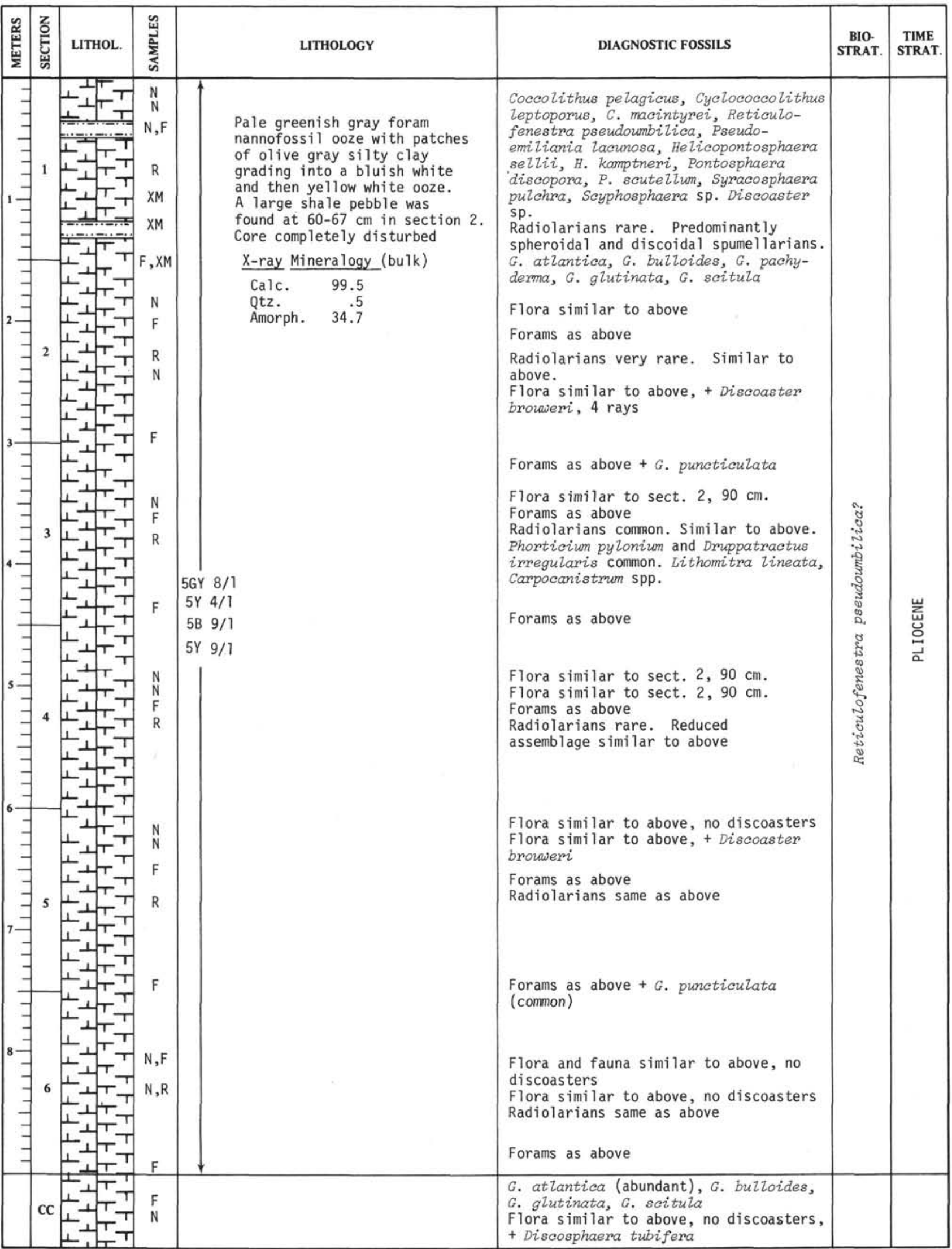


HOLE 116A

CORE 10

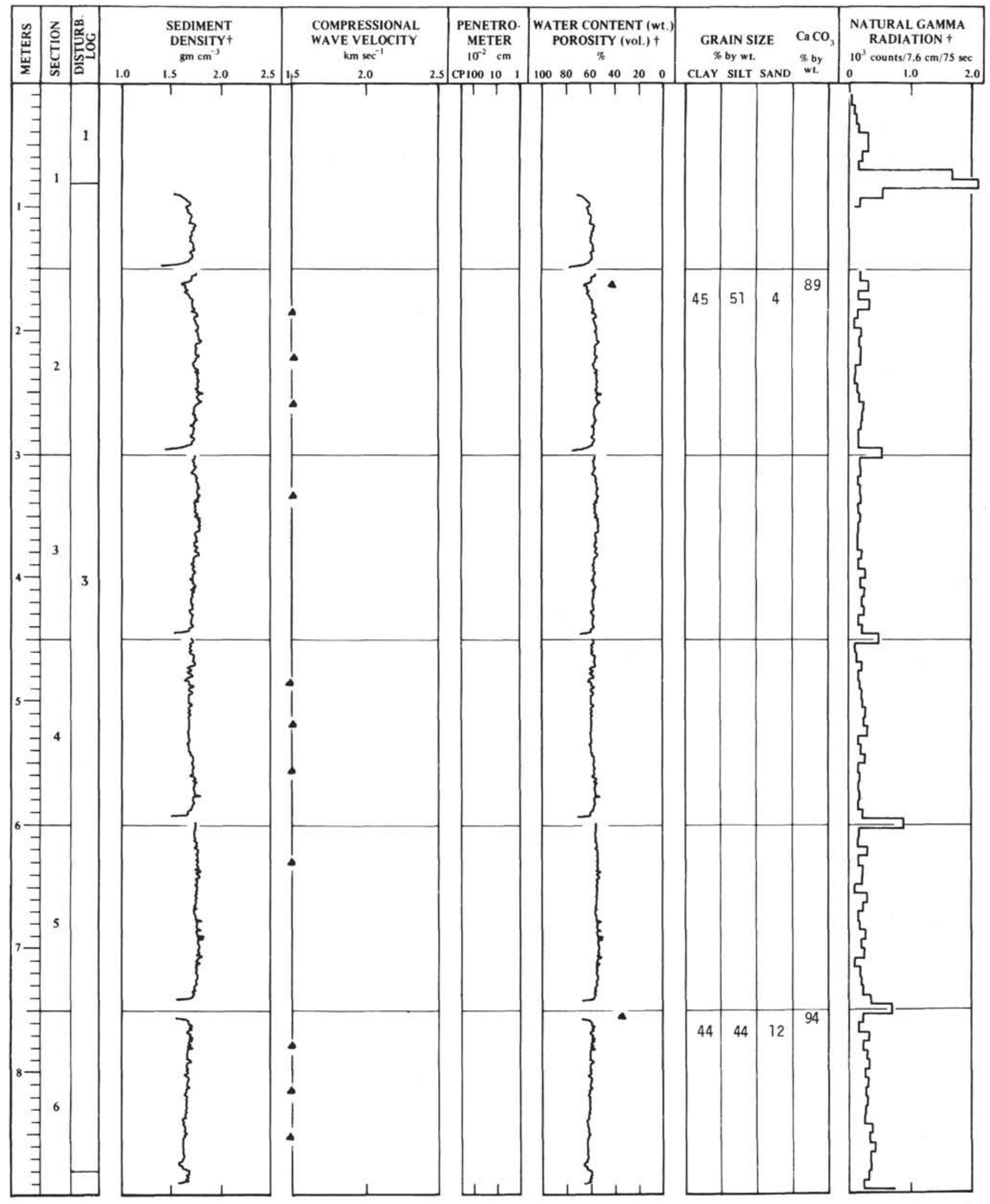




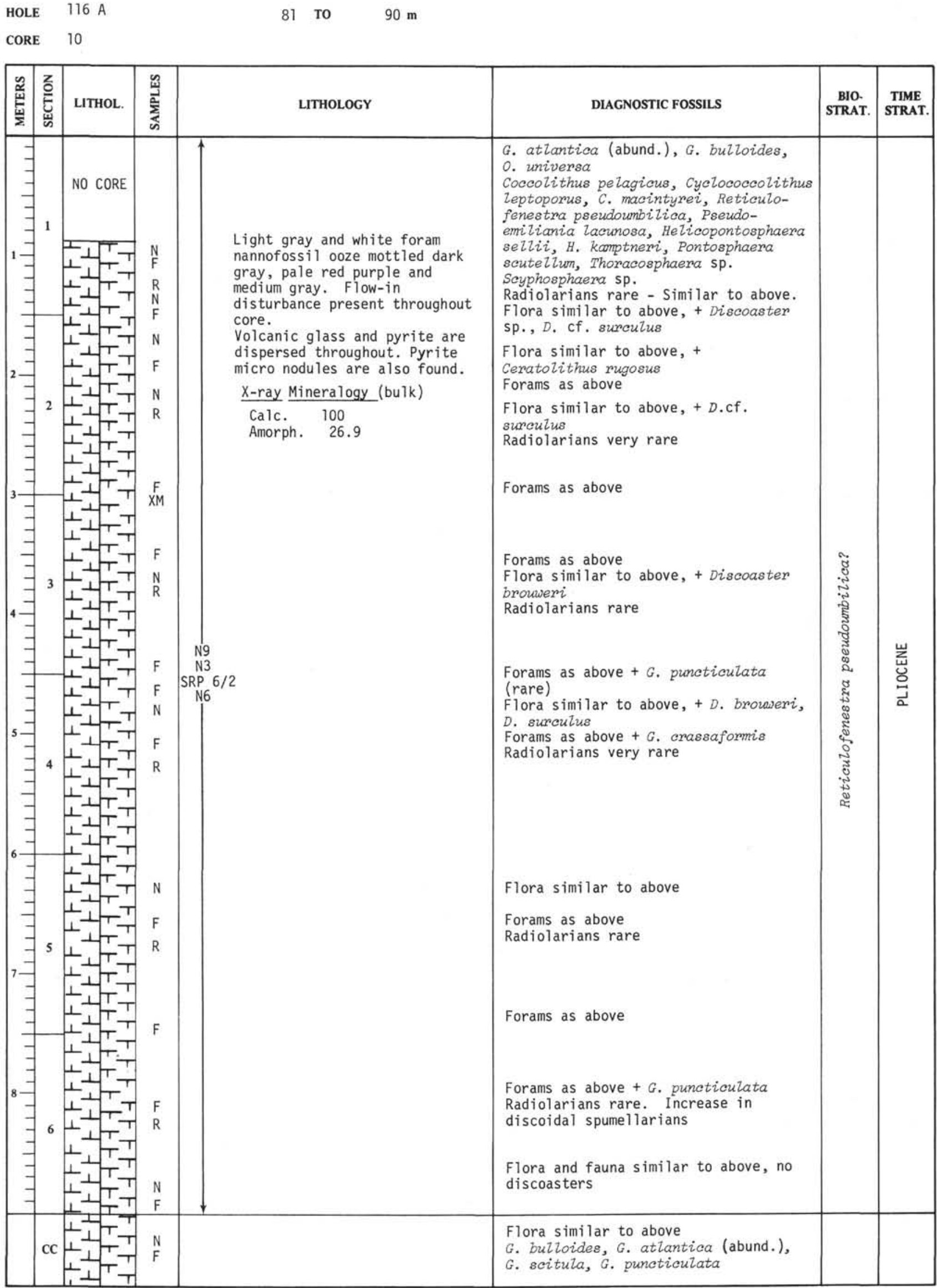


HOLE 116A

CORE 11

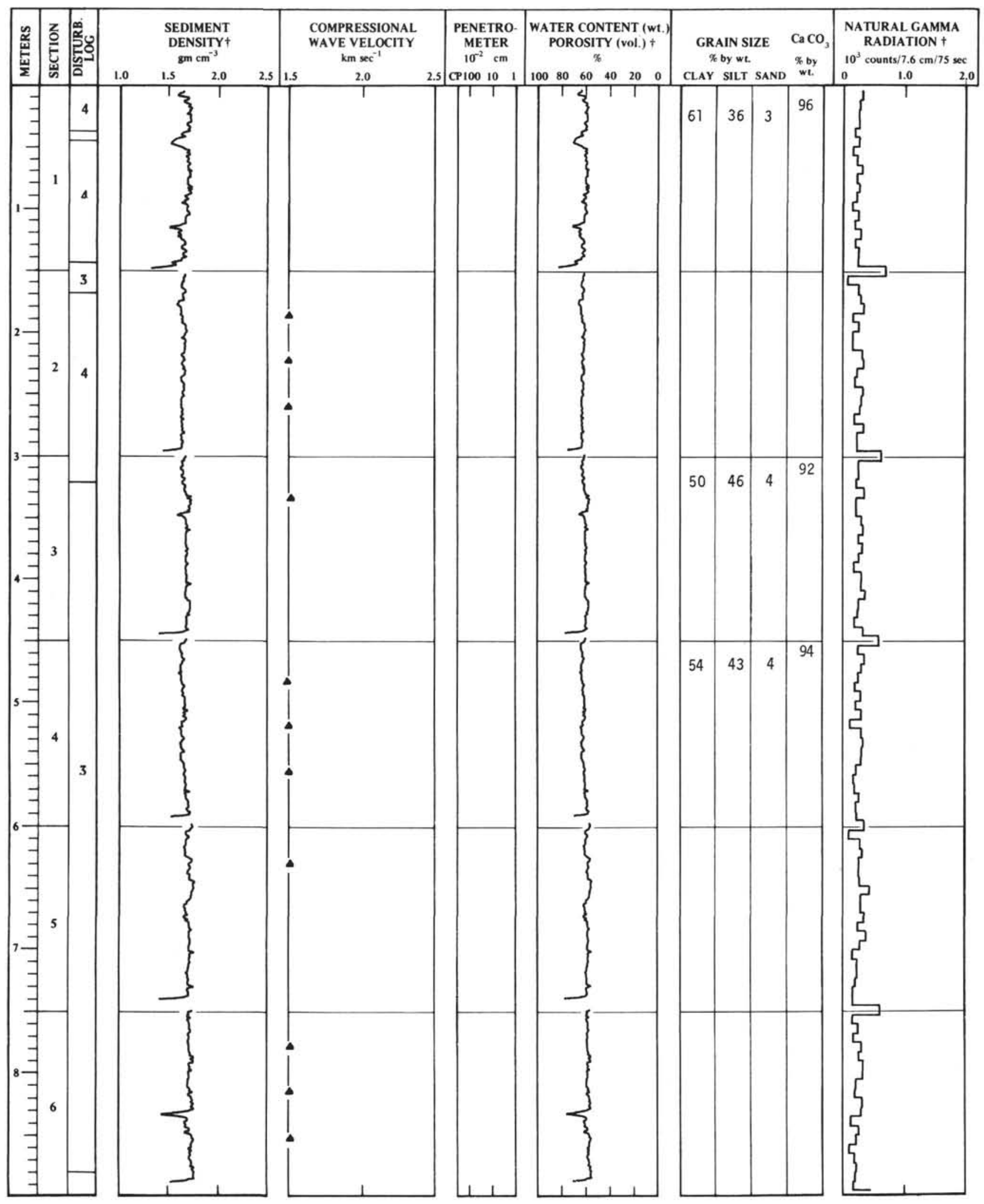



HOLE $116 \mathrm{~A}$
90To
$99 \mathrm{~m}$
CORE 11

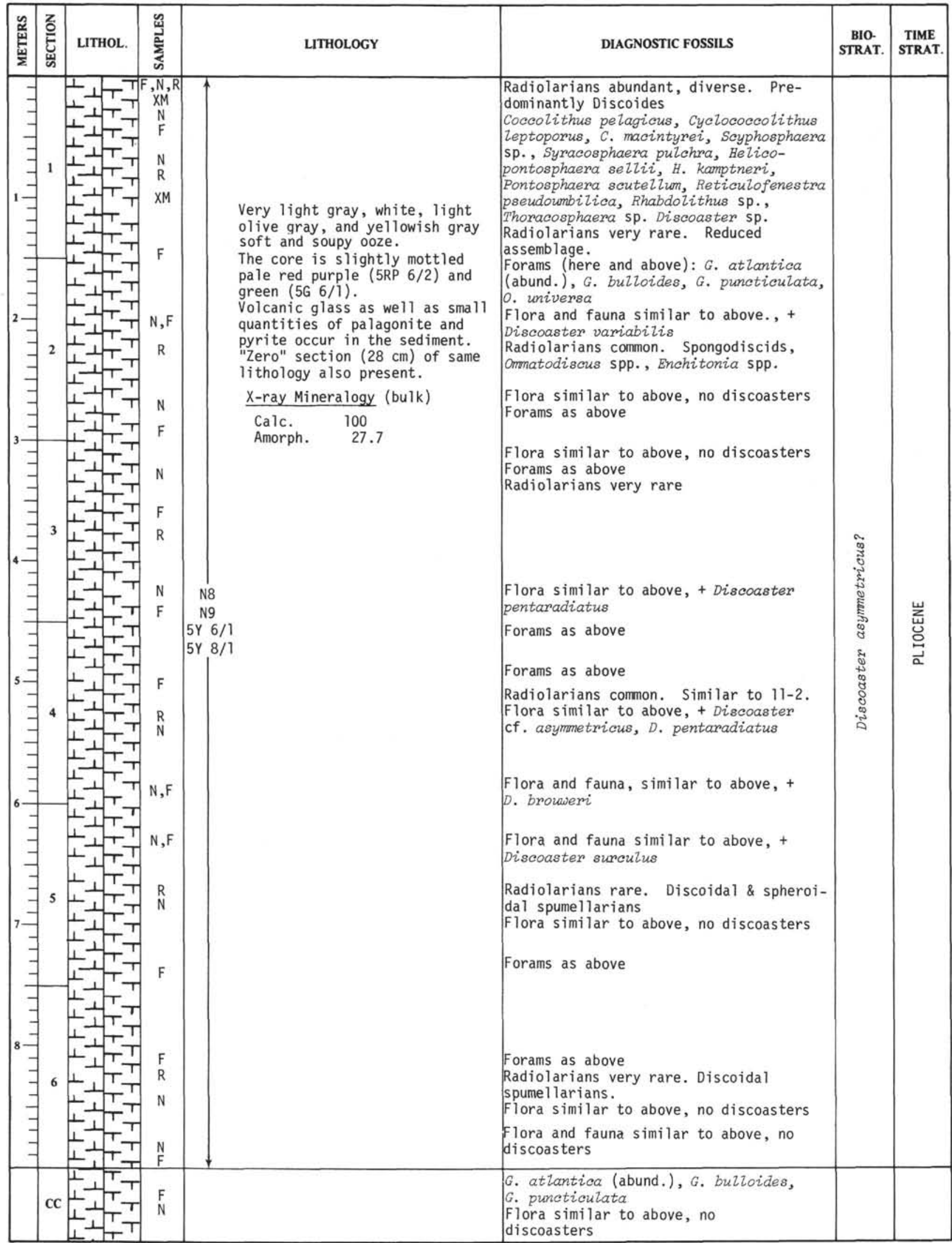


SHIPBOARD SCIENTIFIC PARTY

HOLE 117

CORE 1

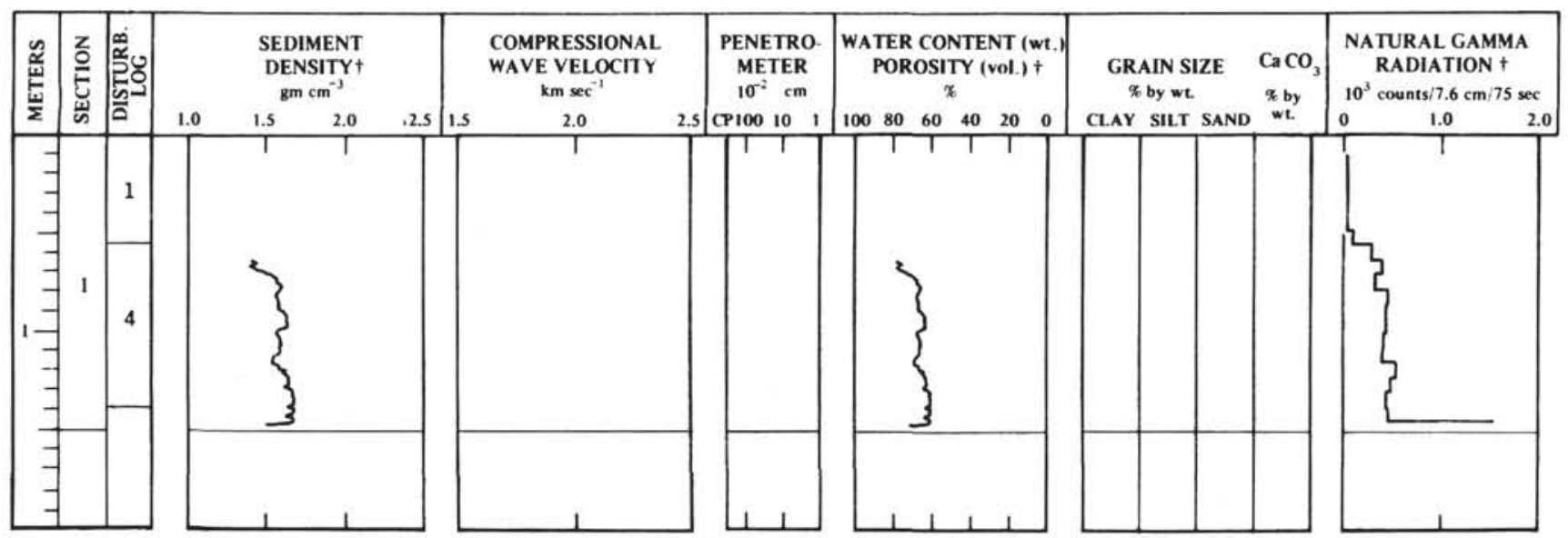

+ Adjusted data. see Chapter 2 
HOLE $\quad 117$

CORE 1
50

To

$52^{\mathrm{m}}$

\begin{tabular}{|c|c|c|c|c|c|c|c|}
\hline$\frac{\mathscr{y}}{\frac{\tilde{n}}{\underline{\omega}}}$ & ž & LITHOL. & 离 & LITHOLOGY & DIAGNOSTIC FOSSILS & $\begin{array}{l}\text { BIO. } \\
\text { STRAT. }\end{array}$ & $\begin{array}{c}\text { TIME } \\
\text { STRAT. }\end{array}$ \\
\hline 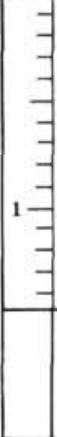 & CC & (1) & $\begin{array}{l}\mathrm{N} \\
\mathrm{XM}\end{array}$ & $\begin{array}{l}\text { White, very light gray, and } \\
\text { yellowish gray limestone and } \\
\text { chert gravel. The gravel is } \\
\text { graded, but this phenomenon is } \\
\text { probably a result of drilling } \\
\text { disturbance. }\end{array}$ & $\begin{array}{l}\text { Coccolithus pelagicus, C. bisectus, } \\
\text { Chiasmolithus sp., Cyclococcolithus } \\
\text { neogammation, Discolithina sp., } \\
\text { Rhabdolithus sp., Sphenolithus sp. } \\
\text { Zygrhablithus cf. bijugatus } \\
\text { Flora similar to above } \\
\text { Core Catcher: } \\
\text { Radiolarians very rare. Cyrtocapsella } \\
\text { tetrapera } \\
\text { Flora similar to above }\end{array}$ & & 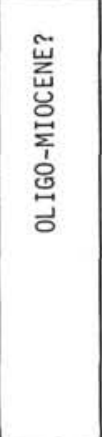 \\
\hline
\end{tabular}


HOLE 117

CORE 2

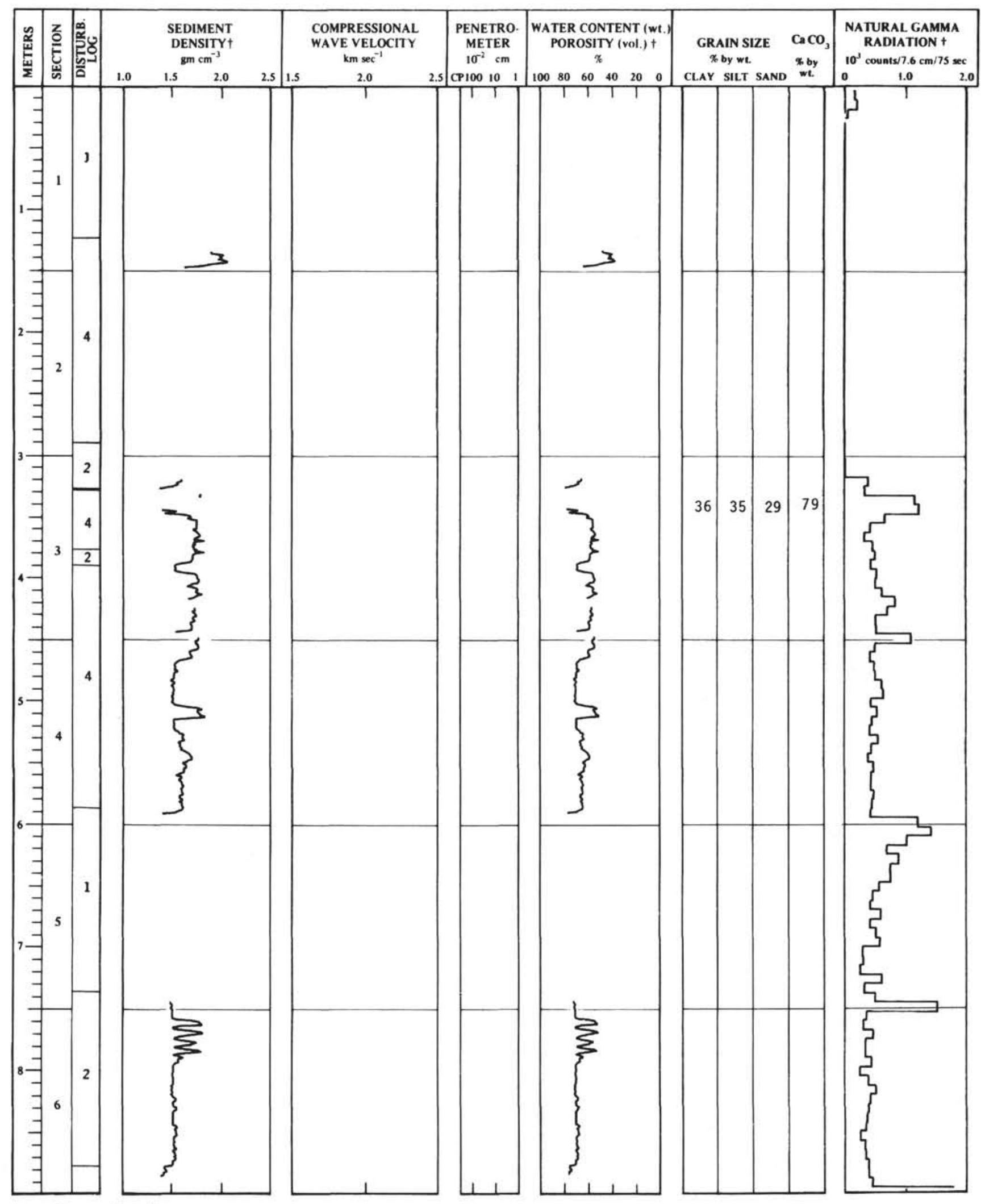

+Adjusted data, see Chapter 2 


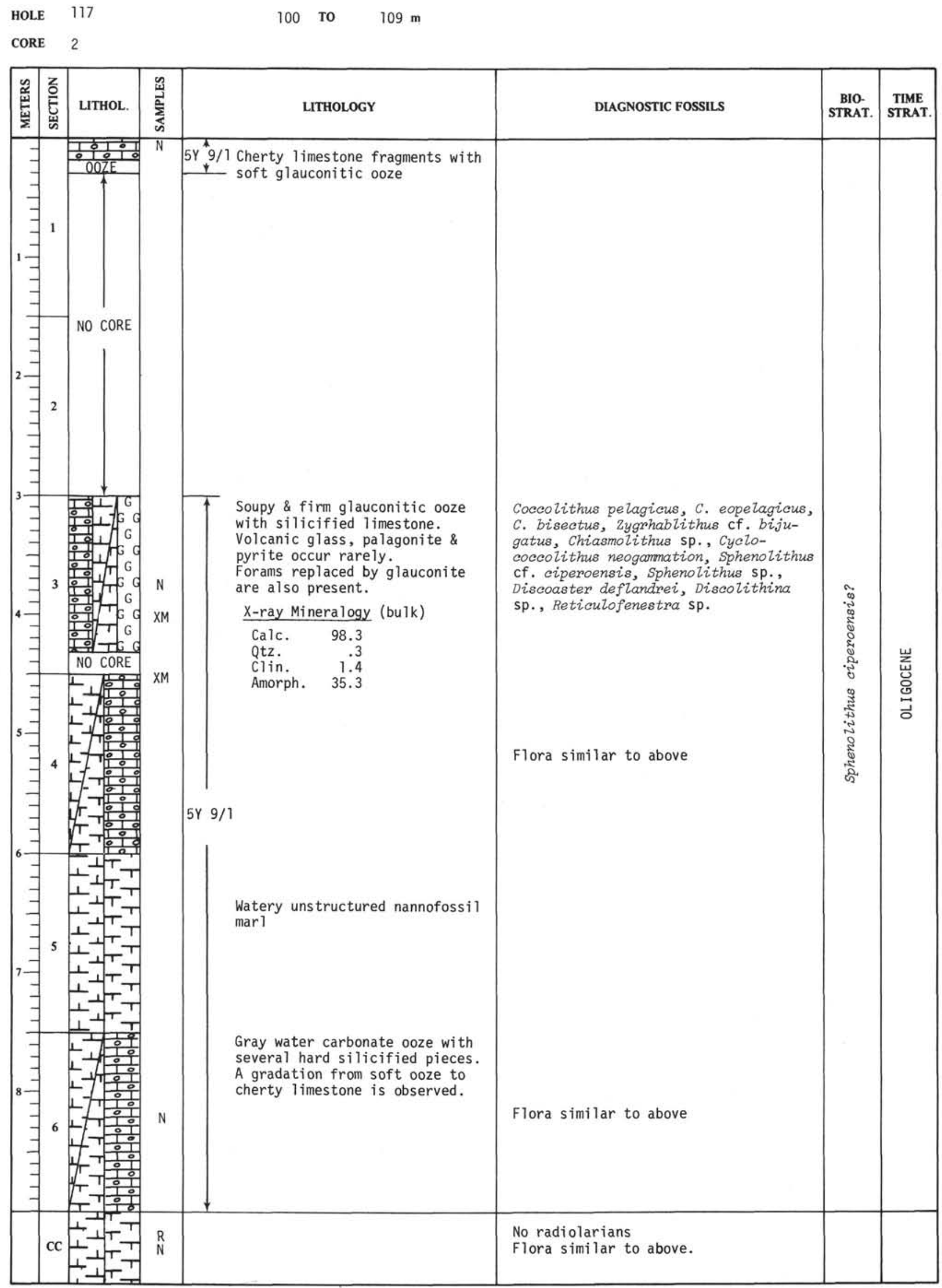


HOLE 117

CORE 3

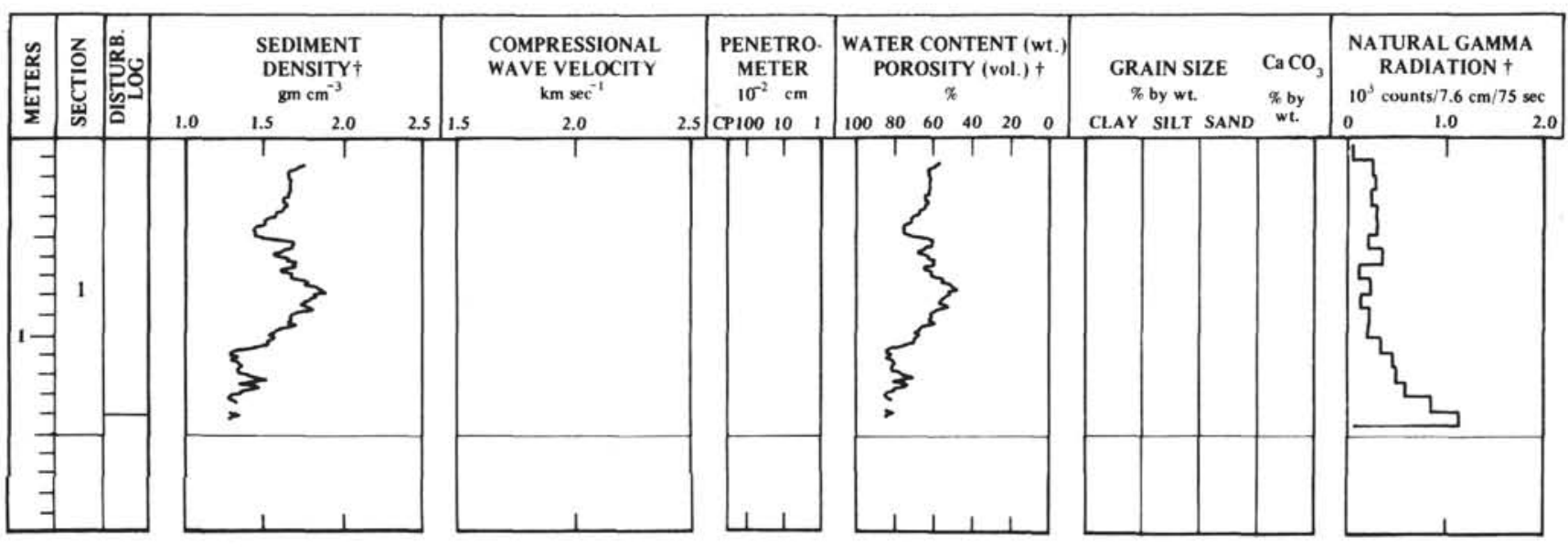

tAdjusted data, see Chapter 2 
HOLE $\quad 117$

147 то 156 m

CORE 3

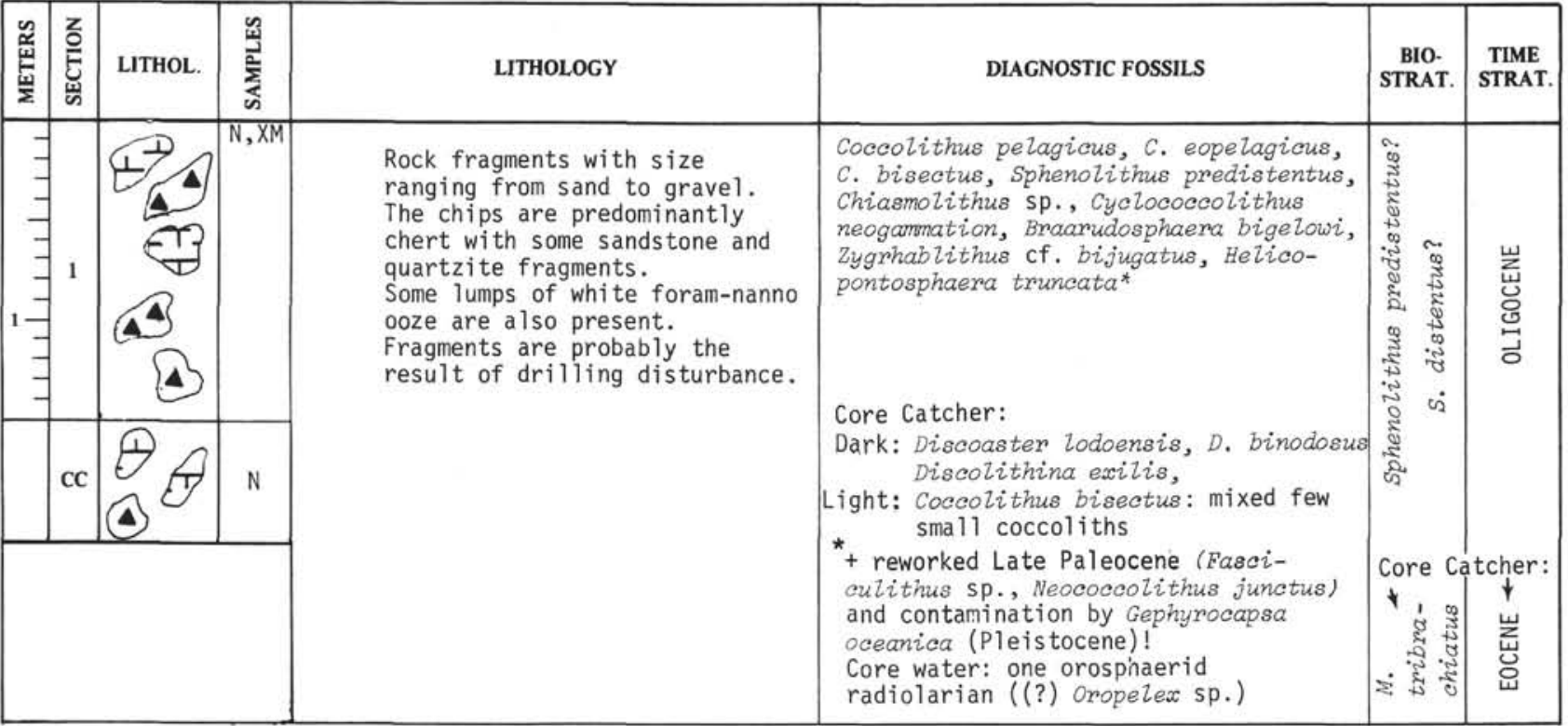




\section{SHIPBOARD SCIENTIFIC PARTY}

HOLE 117A

CORE 1

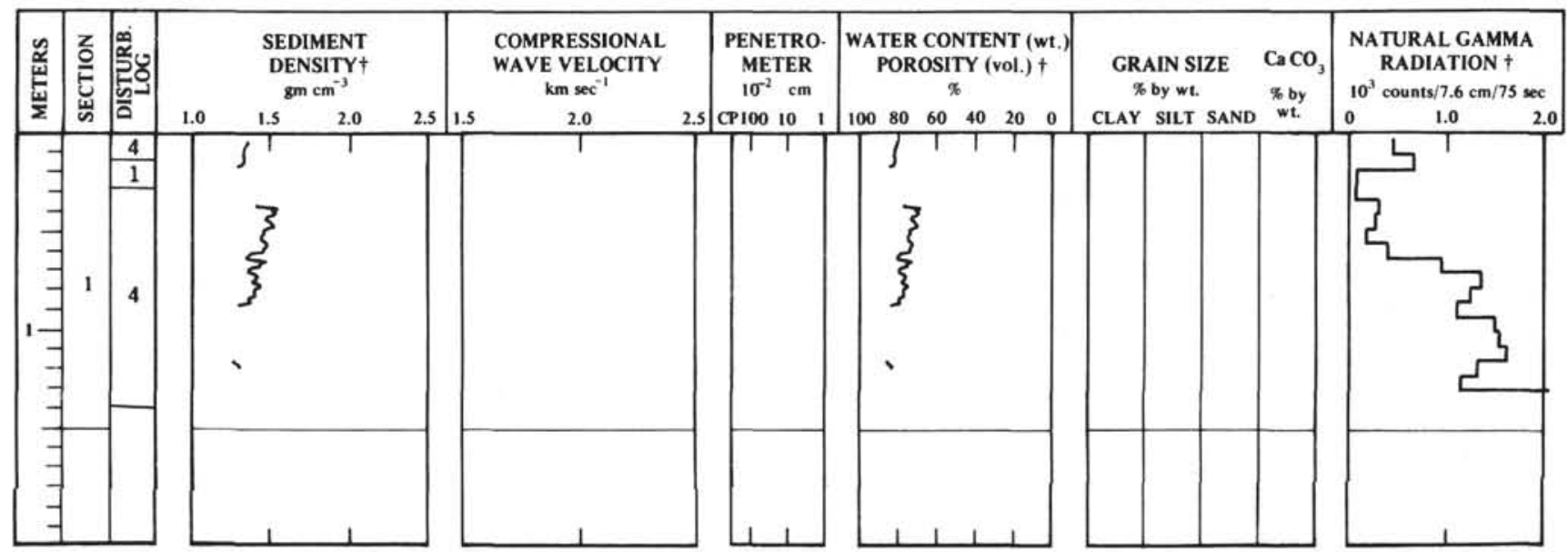

+ Adjusted data, see Chapter 2 


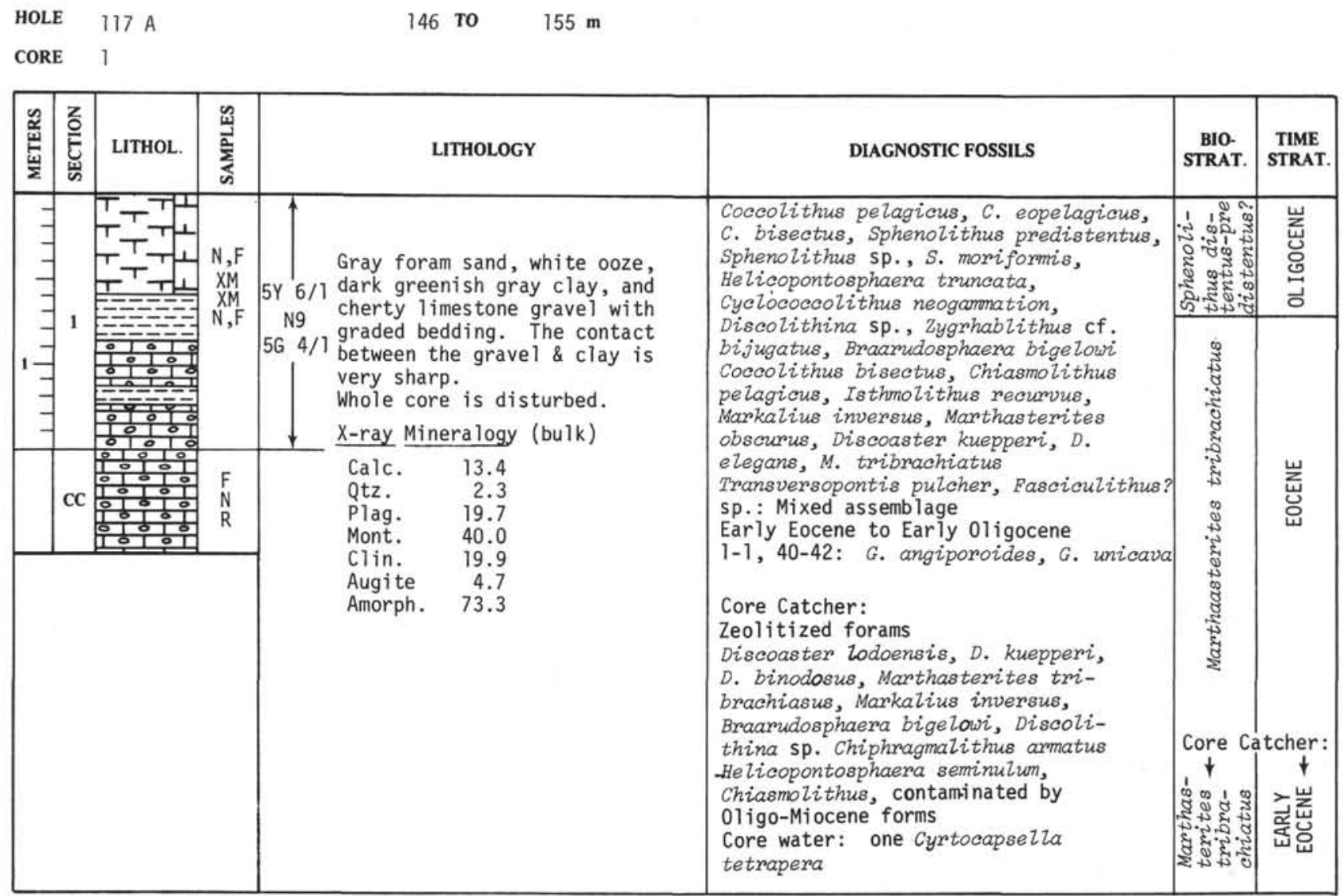

$\begin{array}{llll}\text { HOLE } & 117 \mathrm{~A} & 174 \text { Tо } & 183 \mathrm{~m} \\ \text { CORE } & 2 & & \end{array}$

\begin{tabular}{|c|c|c|c|c|c|c|c|}
\hline$\frac{\tilde{2}}{\frac{2}{2}}$ & ż & LITHOL. & 愛 & LITHOLOGY & DIAGNOSTIC FOSSILS & $\begin{array}{c}\text { BIO- } \\
\text { STRAT. }\end{array}$ & $\begin{array}{l}\text { TIME } \\
\text { STRAT. }\end{array}$ \\
\hline & CC & $\Delta \Delta$ & ${ }_{N}^{F_{X X}}$ & \multirow{2}{*}{$\begin{array}{l}\text { Core Catcher only, consișting of } \\
\text { chert cuttings and gray silty } \\
\text { clay. } \\
\text { Volcanic glass and pyrite occur } \\
\text { commonly with a small amount of } \\
\text { glauconite. }\end{array}$} & \multirow{2}{*}{$\begin{array}{l}\text { No Foraminifera } \\
\text { Marthasterites tribrachiatus, M. } \\
\text { obscums, Discoaster kuepperi, D. } \\
\text { binodosus, Chiasmolithus eograndis, } \\
\text { C. bidens, Neococcolithus protenus, } \\
\text { Chiphragmalithus armatus, Transver- } \\
\text { sopontis pulcher, Toweius occulta- } \\
\text { tus, Ericsonia ovalis, Discolithina } \\
\text { panarizm, D. plana. Assemblage con- } \\
\text { taminated by Oligocene coccoliths: } \\
\text { Coccolithus bisectus, Sphenolithus } \\
\text { sp. Very abundant zeolitized } \\
\text { radiolarians. }\end{array}$} & \multirow[t]{2}{*}{ 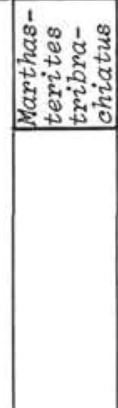 } & خ岂 \\
\hline & & & & & & & \\
\hline
\end{tabular}


HOLE 117A

CORE 3

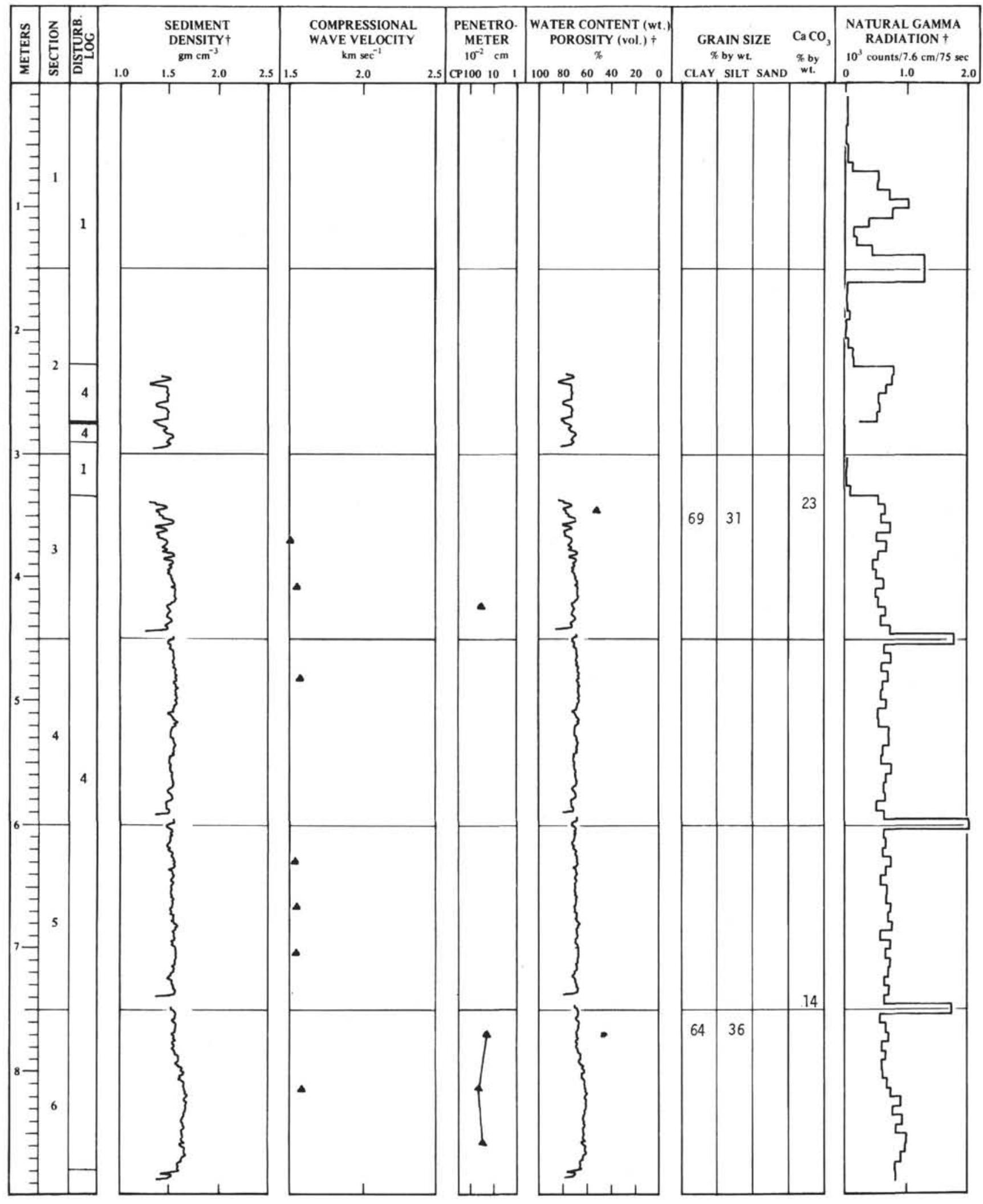

+Adjusted data, see Chapter 2 

HOLE $117 \mathrm{~A}$
CORE 3

\begin{tabular}{|c|c|c|c|c|c|c|c|}
\hline $\begin{array}{l}\stackrel{2}{\approx} \\
\text { 폴 } \\
\frac{1}{\Sigma}\end{array}$ & 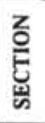 & LITHOL. & 药 & LITHOLOGY & DIAGNOSTIC FOSSILS & $\begin{array}{c}\text { BIO- } \\
\text { STRAT. }\end{array}$ & $\begin{array}{l}\text { TIME } \\
\text { STRAT. }\end{array}$ \\
\hline 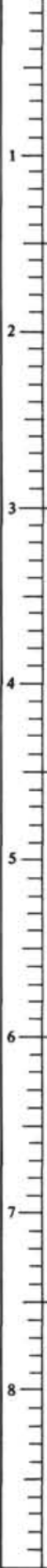 & 4 & 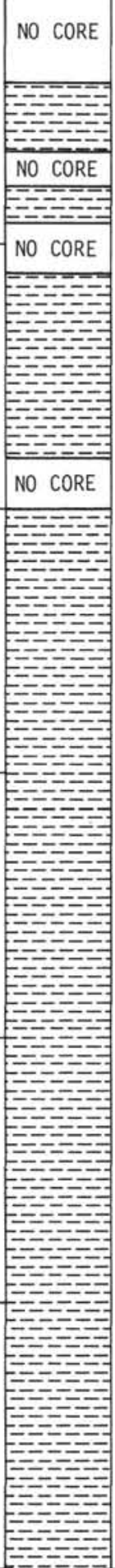 & $\begin{array}{l}\mathrm{N} \\
\mathrm{XM}\end{array}$ & 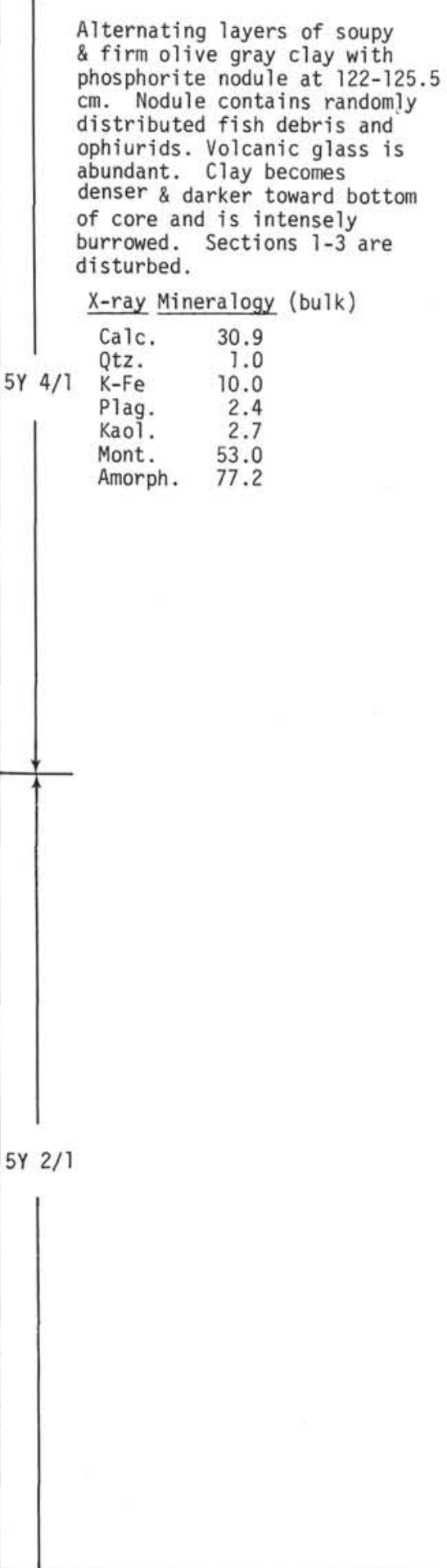 & $\begin{array}{l}\text { Flora similar to above, + Lophodolithus } \\
\text { nascens } \\
\text { Flora similar to above, +L. nascens } \\
\text { Flora similar to above } \\
\text { Foram fauna as above }\end{array}$ & 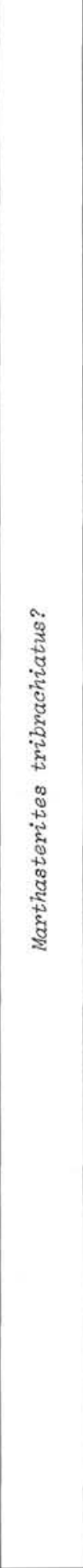 & 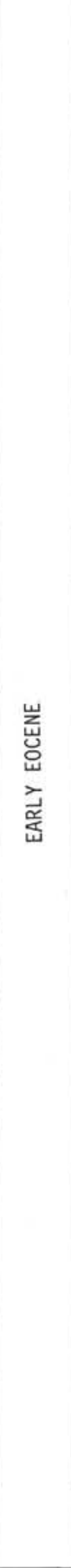 \\
\hline & CC & 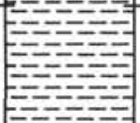 & $\begin{array}{l}R \\
N \\
F\end{array}$ & & $\begin{array}{l}\text { No radiolarians } \\
\text { Flora similar to above } \\
\text { Foram fauna as above }+ \text { An. acuta }\end{array}$ & & \\
\hline
\end{tabular}




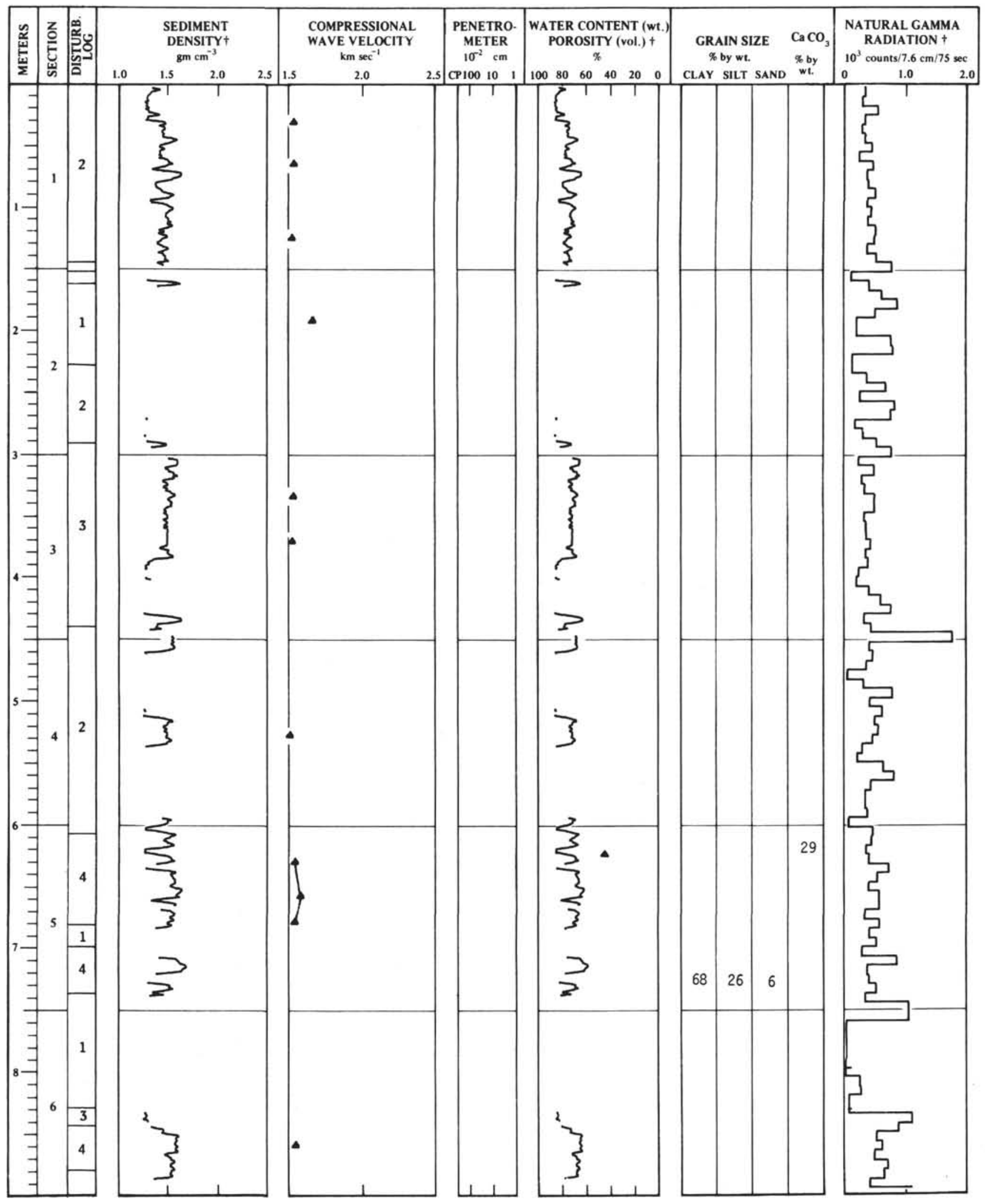

+ Adjusted data, see Chapter 2 

HOLE $117 \mathrm{~A}$
270 то
272 m
CORE 4

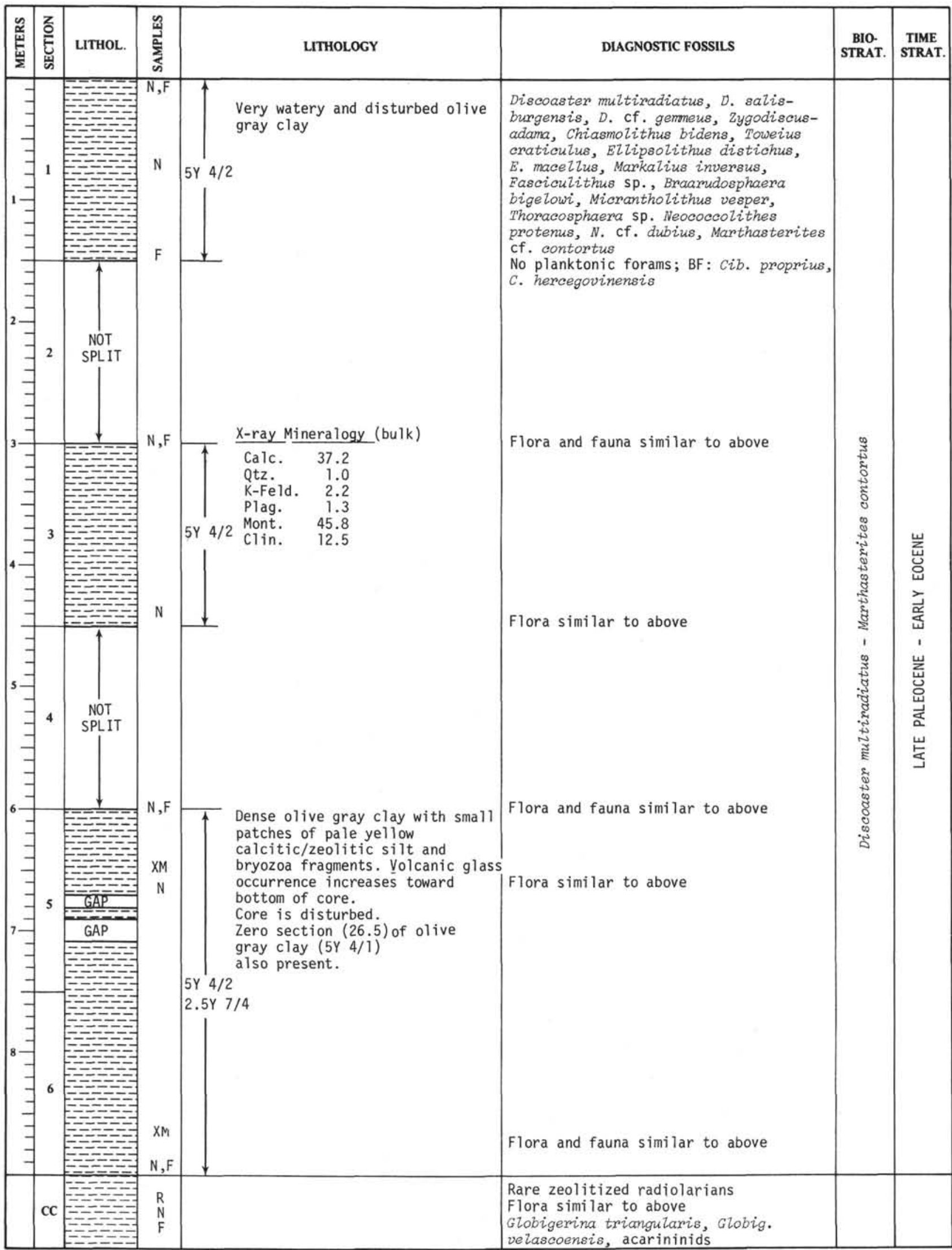


HOLE 117A

CORE 5

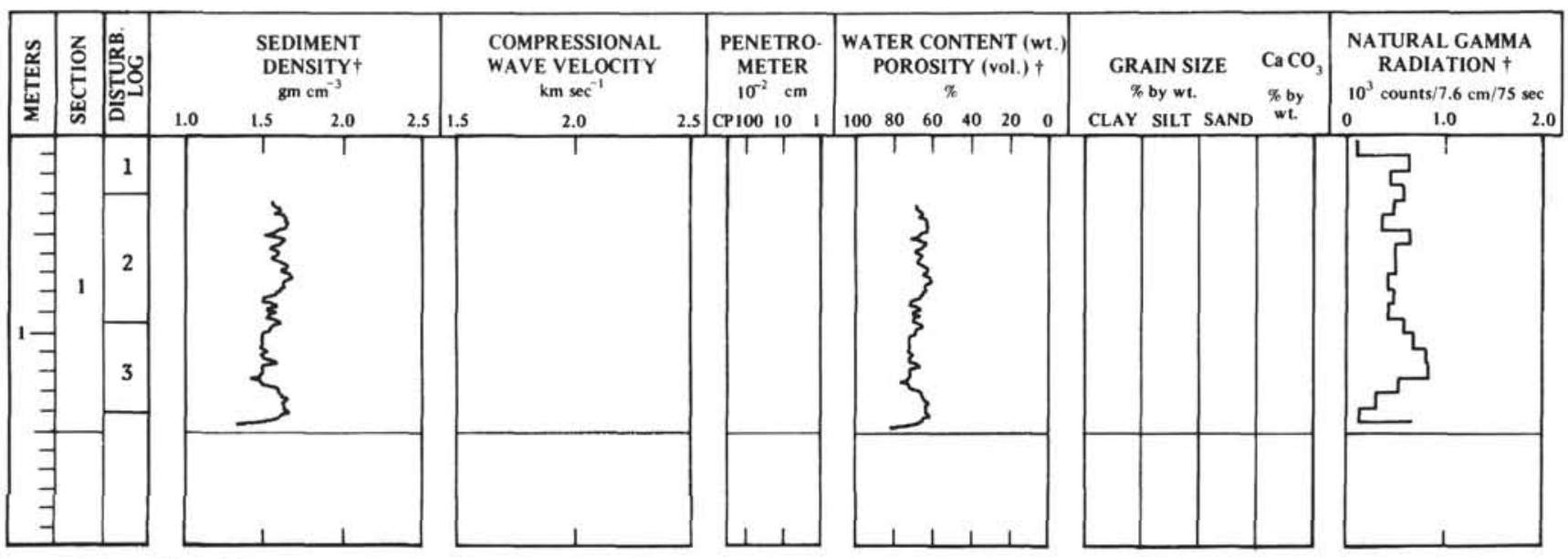

+Adjusted data, see Chapter 2 
HOLE $117 \mathrm{~A} \quad$ 272 To $276 \mathrm{~m}$

CORE 5

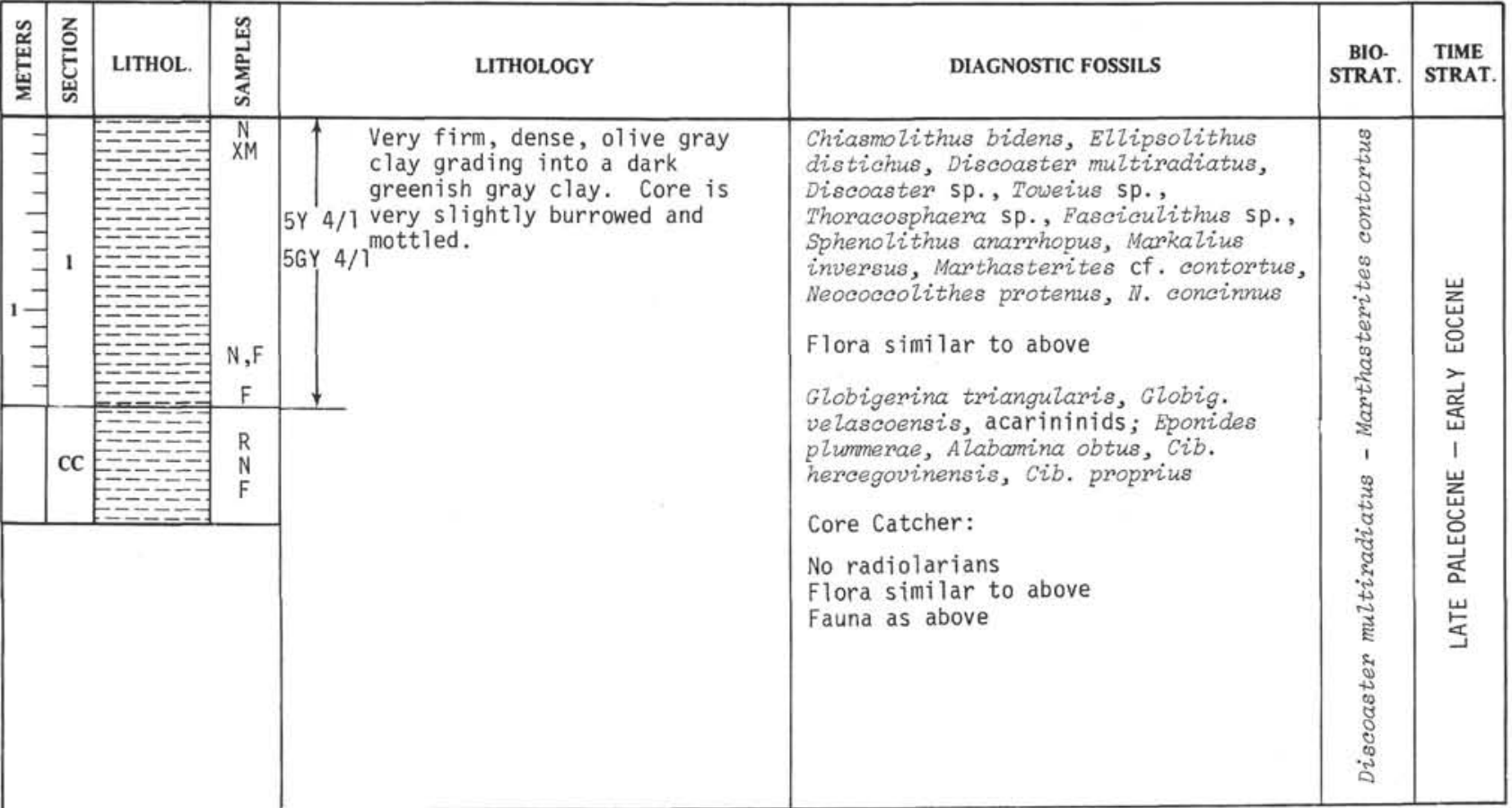


CORE 6

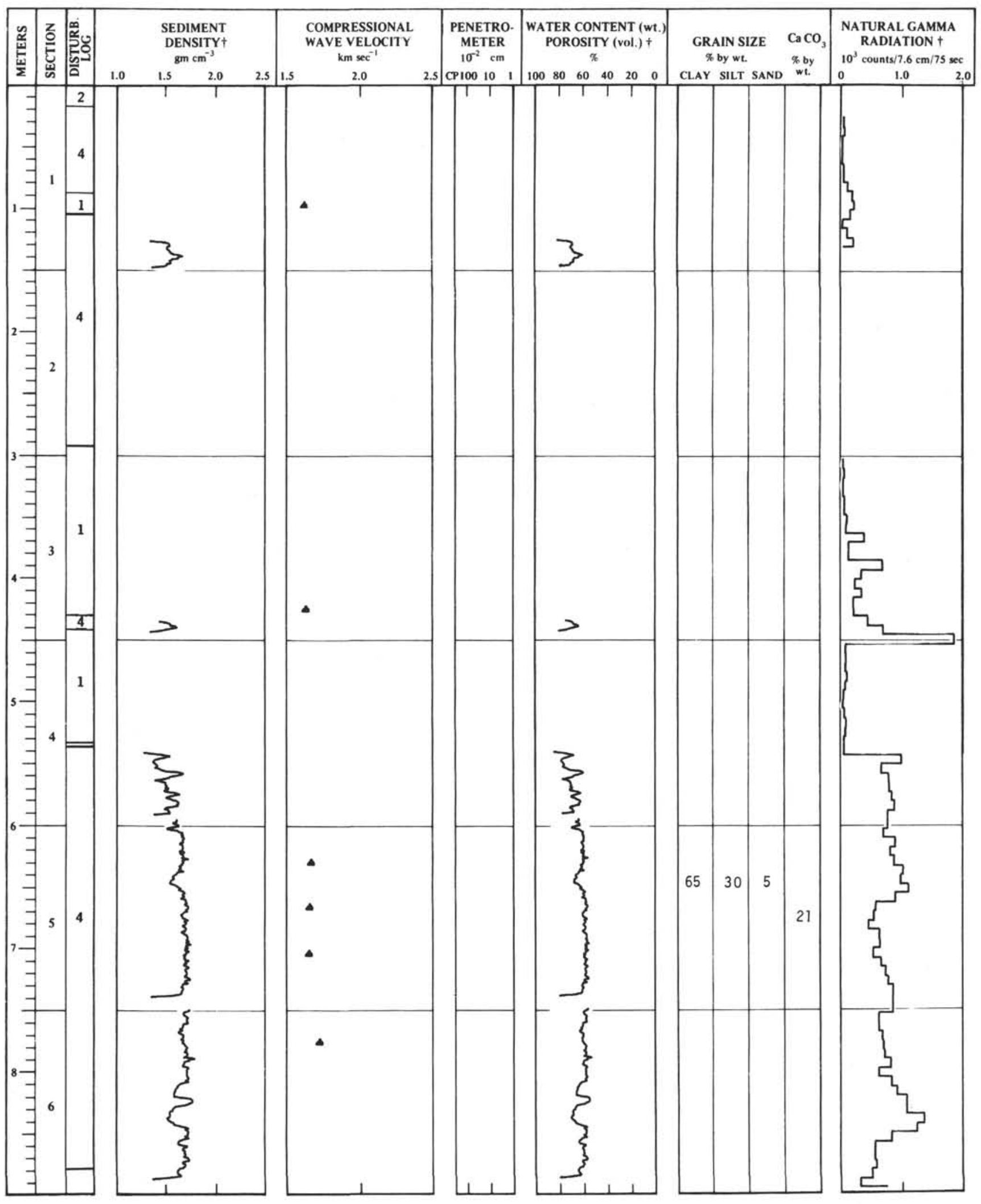

+ Adjusted data, see Chapter 2 

HOLE $117 \mathrm{~A}$
CORE 6

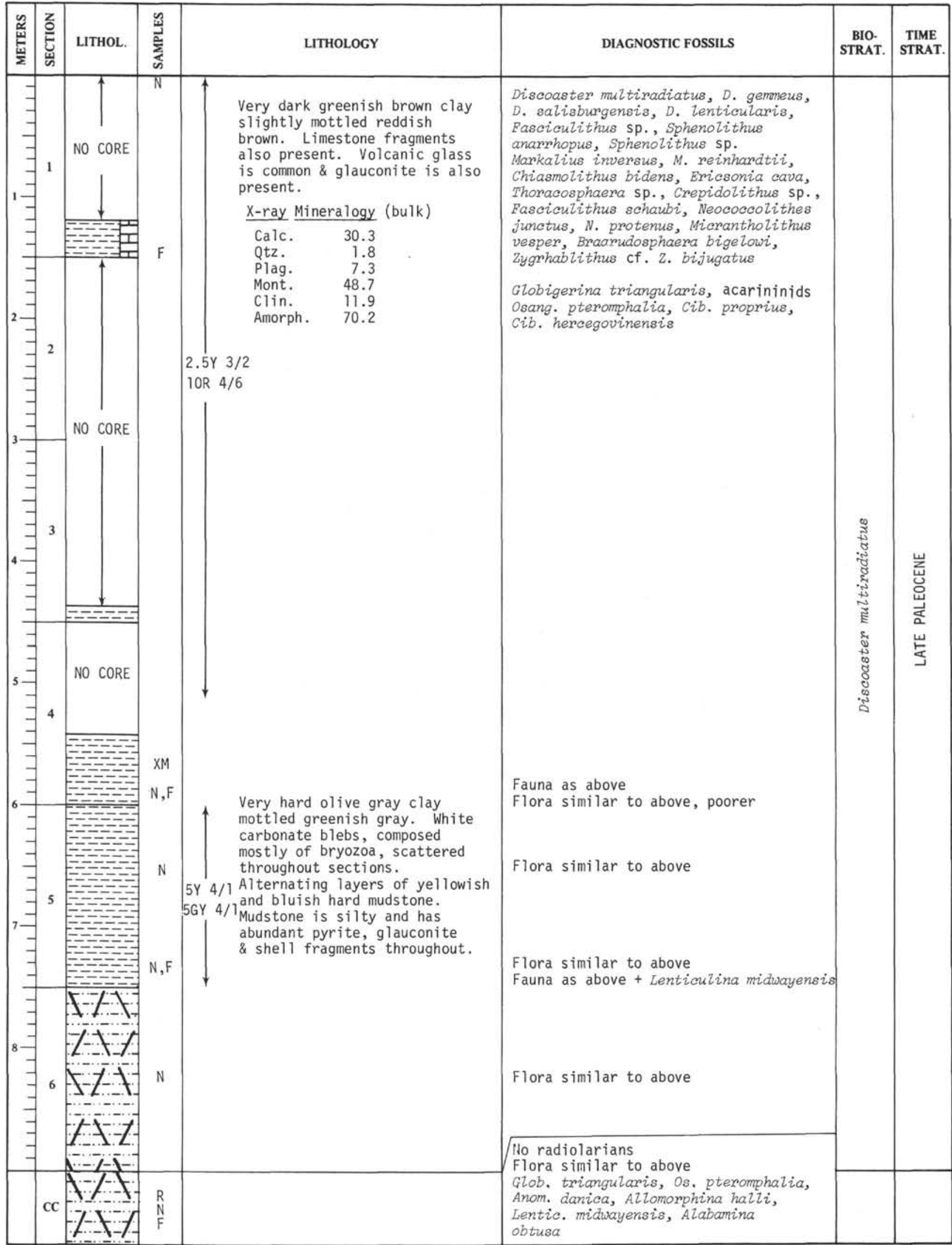


HOLE $117 \mathrm{~A}$

CORE 7

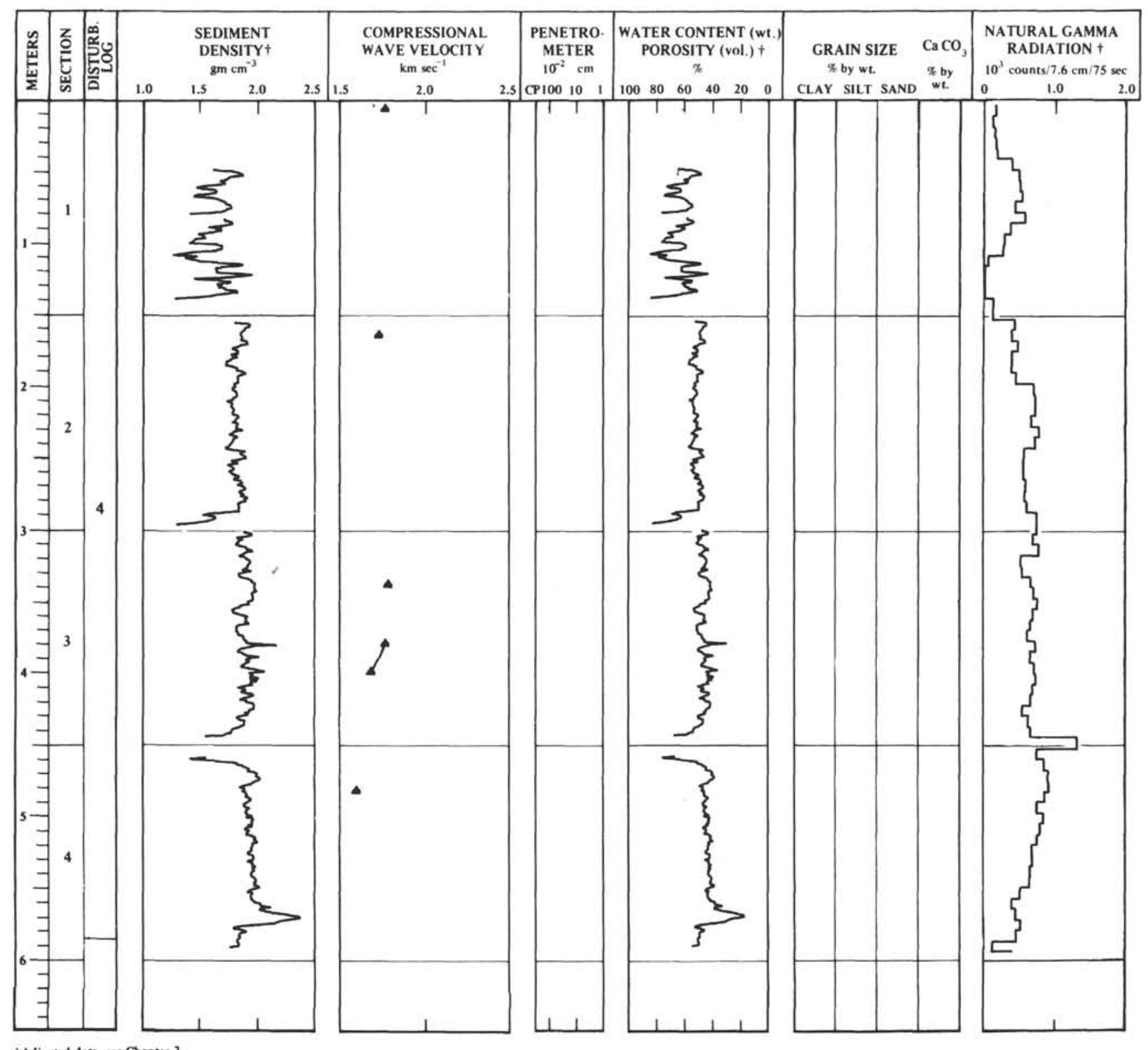




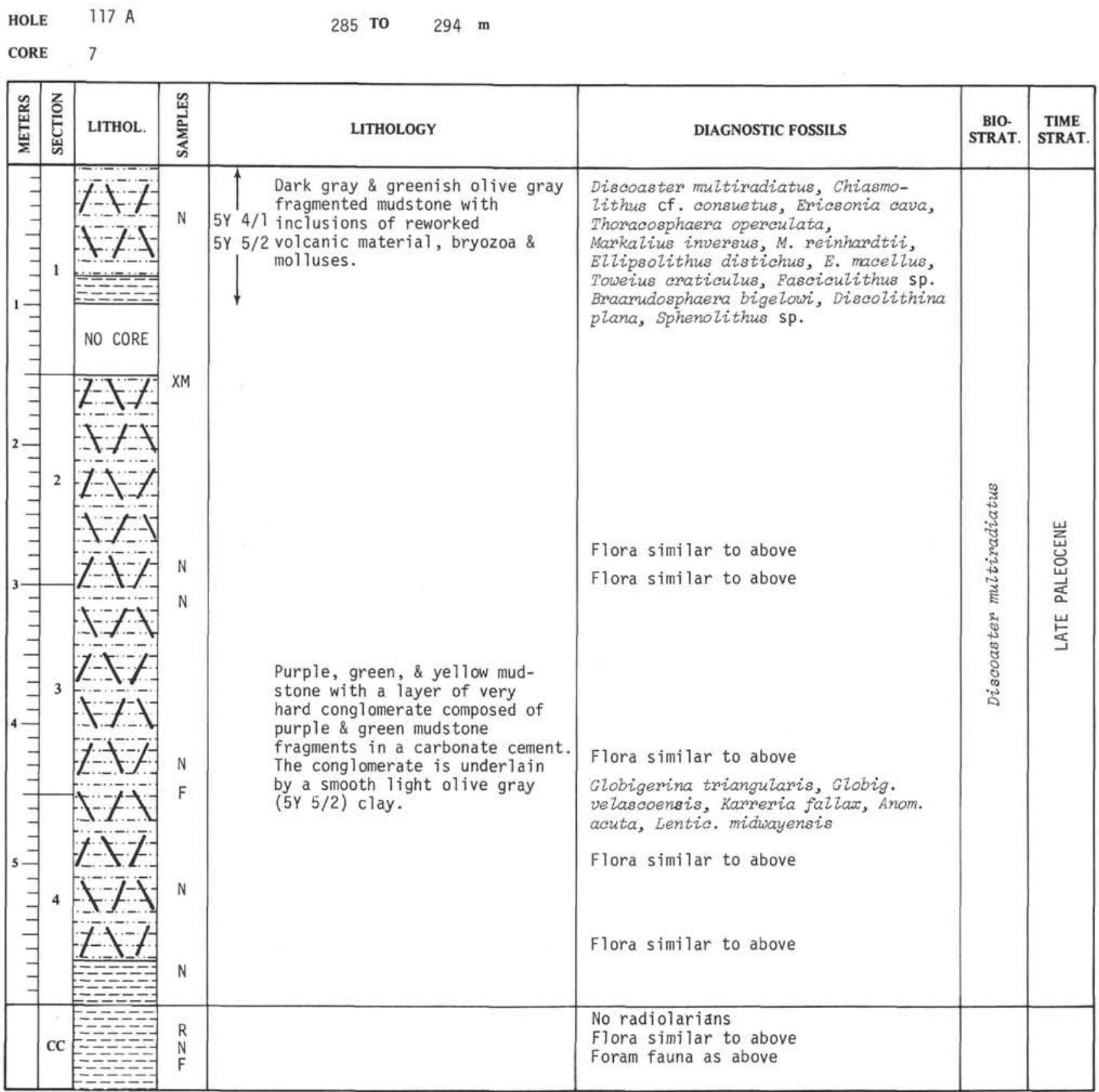


HOLE 117A

CORE 8

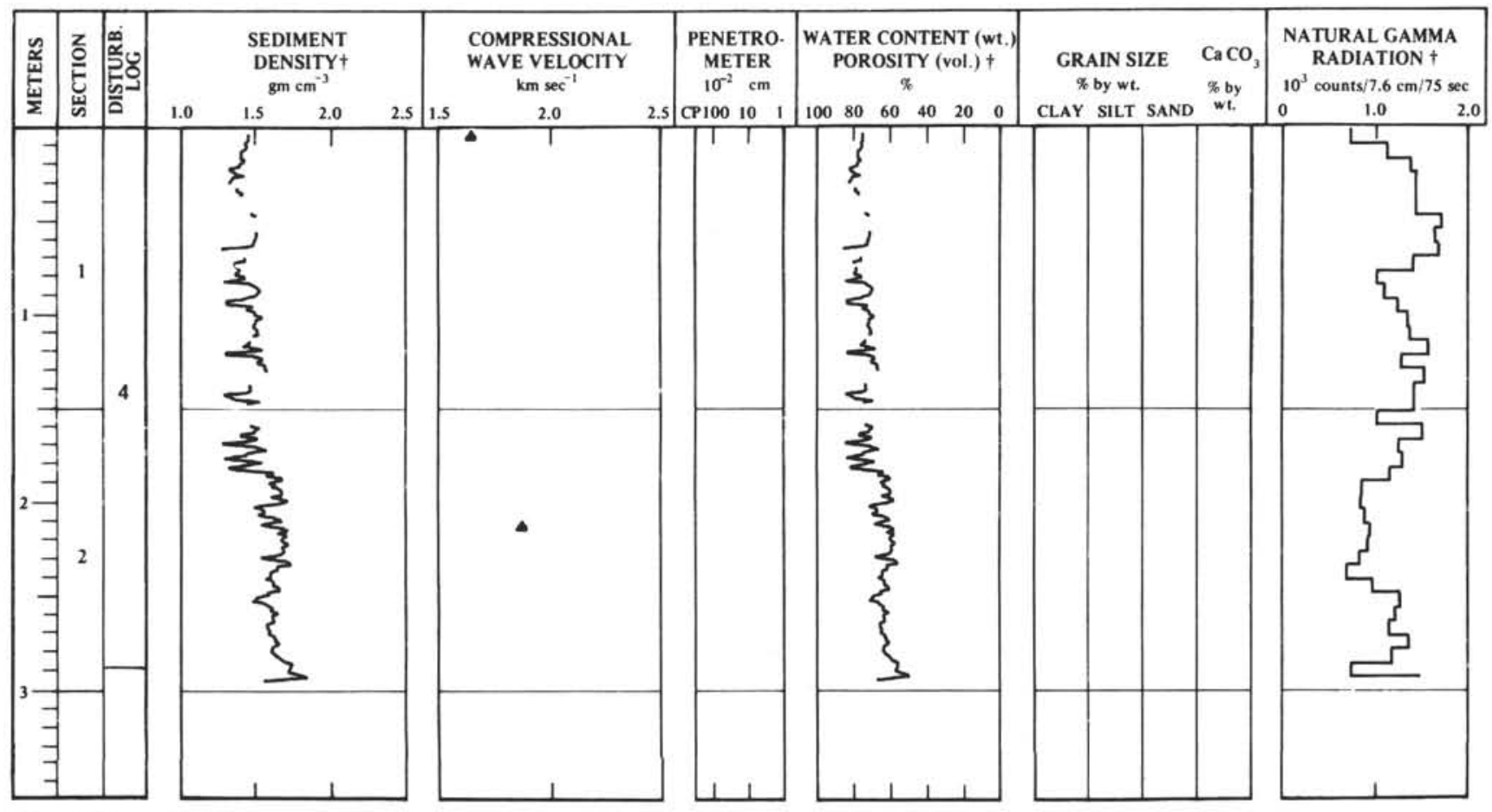

+Adjusted data, see Chapter 2

HOLE IITA

CORE 9

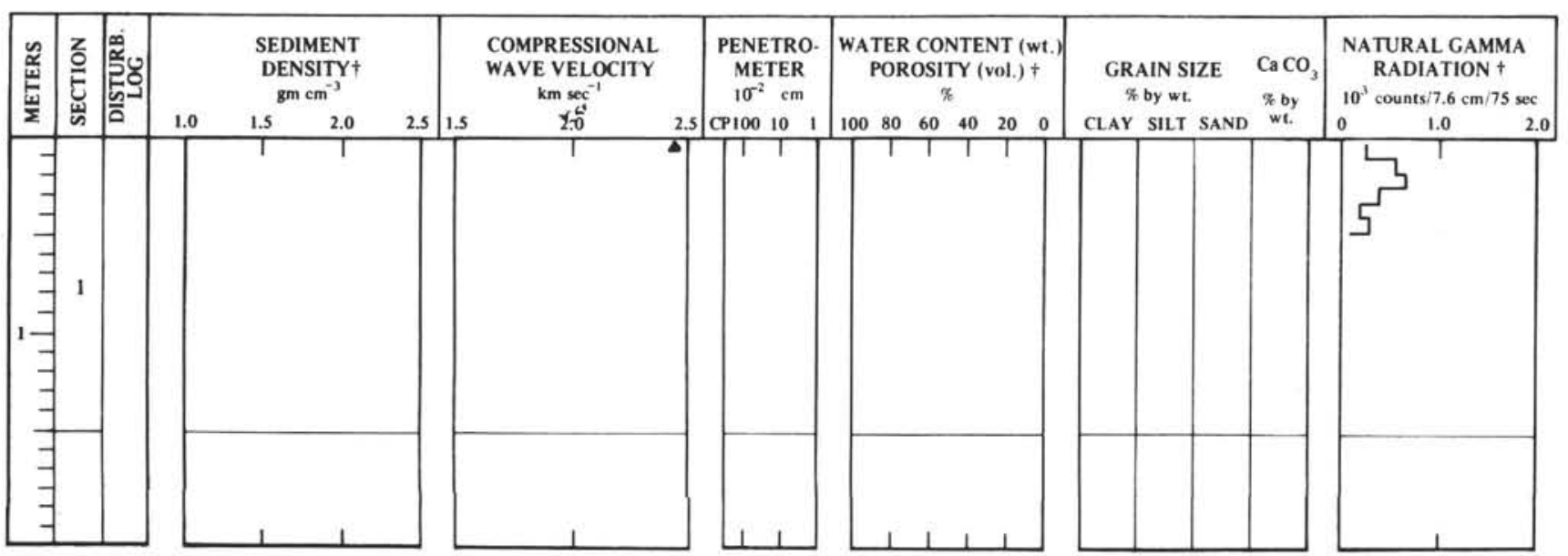

+ Adjusted data, see Chapter 2 

HOLE $\quad 117 \mathrm{~A}$
CORE 8

\begin{tabular}{|c|c|c|c|c|c|c|c|}
\hline 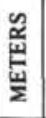 & 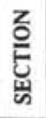 & LITHOL. & $\frac{2}{\frac{1}{2}}$ & LITHOLOGY & DIAGNOSTIC FOSSILS & $\begin{array}{l}\text { BIO- } \\
\text { STRAT. }\end{array}$ & $\begin{array}{c}\text { TIME } \\
\text { STRAT. }\end{array}$ \\
\hline & 1 & mon & $X M, F$ & 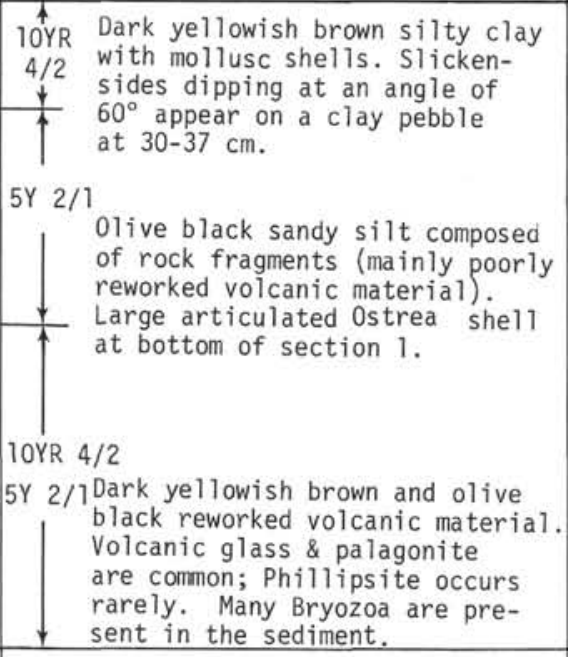 & $\begin{array}{l}\text { Discoaster cf. gemeus, Micranto- } \\
\text { lithus bramlettei, Braamidosphaera } \\
\text { bigelowi, Transversopontis sp. } \\
\text { Crepidolithus sp., Fasciculithus sp. } \\
\text { Neococcolithes cf. dubius, N. protenus } \\
\text { Thoracosphaera sp., Toweius crati- } \\
\text { culus, Crepidolithus sp., Chiasmolithus } \\
\text { consuetus } \\
\text { Flora similar to above, + Discoaster } \\
\text { multiradiatus } \\
\text { Globig. triensularis, G. velascoensis, } \\
\text { Anom. danica, A. acuta, Os. pterom- } \\
\text { phalia } \\
\text { Flora similar to above } \\
\text { Flora similar to above } \\
\text { Foram fauna as above }\end{array}$ & 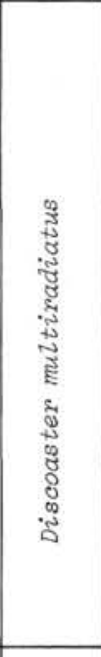 & 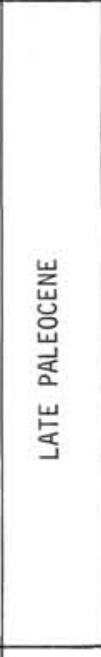 \\
\hline & CC & hon & $\begin{array}{l}\mathrm{F} \\
\mathrm{N} \\
\mathrm{R}\end{array}$ & & $\begin{array}{l}\text { Foram fauna as above } \\
\text { Flora similar to above, + Crucipla- } \\
\text { colithus tenuis } \\
\text { No radiolarians }\end{array}$ & & \\
\hline
\end{tabular}

$\begin{array}{lllll}\text { HOLE } & 117 \mathrm{~A} & 303 & \text { TO } & 304 \mathrm{~m} \\ \text { CORE } & 9 & & & \end{array}$

\begin{tabular}{|c|c|c|c|c|c|c|c|}
\hline 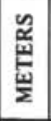 & 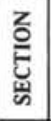 & LITHOL. & 迹 & LITHOLOGY & DIAGNOSTIC FOSSILS & $\begin{array}{l}\text { BIO- } \\
\text { STRAT. }\end{array}$ & $\begin{array}{l}\text { TIME } \\
\text { STRAT }\end{array}$ \\
\hline $\begin{array}{r}- \\
- \\
- \\
- \\
- \\
1 \\
1 \\
- \\
-\end{array}$ & 1 & $\frac{\text { NO CORE }}{4}$ & $\mathrm{~N}$ & $\begin{array}{l}\text { Sandstone with fossil fragments } \\
\text { consisting of mollusc shells } \\
\text { and carbonate annelid worm } \\
\text { burrows }\end{array}$ & $\begin{array}{l}\text { Fasciculithus sp., Ericsonia cava, } \\
\text { Discoaster multiradiatus, Micrantho- } \\
\text { lithus cf. attenuatus, Chiasmolithus } \\
\text { consuetus, Toweius craticulus, } \\
\text { Thoracosphaera sp. }\end{array}$ & 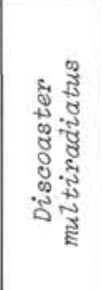 & 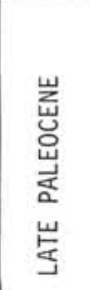 \\
\hline & $\mathrm{cc}$ & $(4)$ & $\begin{array}{l}\mathrm{N} \\
\mathrm{F}\end{array}$ & & $\begin{array}{l}\text { Thoracosphaera sp., Emicsonia cava, } \\
\text { small coccoliths. Small Globigerinids, } \\
\text { Marginulina, Polymorphinids, Eponides } \\
\text { plumerae, Operoulina heberti }\end{array}$ & & \\
\hline
\end{tabular}


HOLE I17A

CORE 10

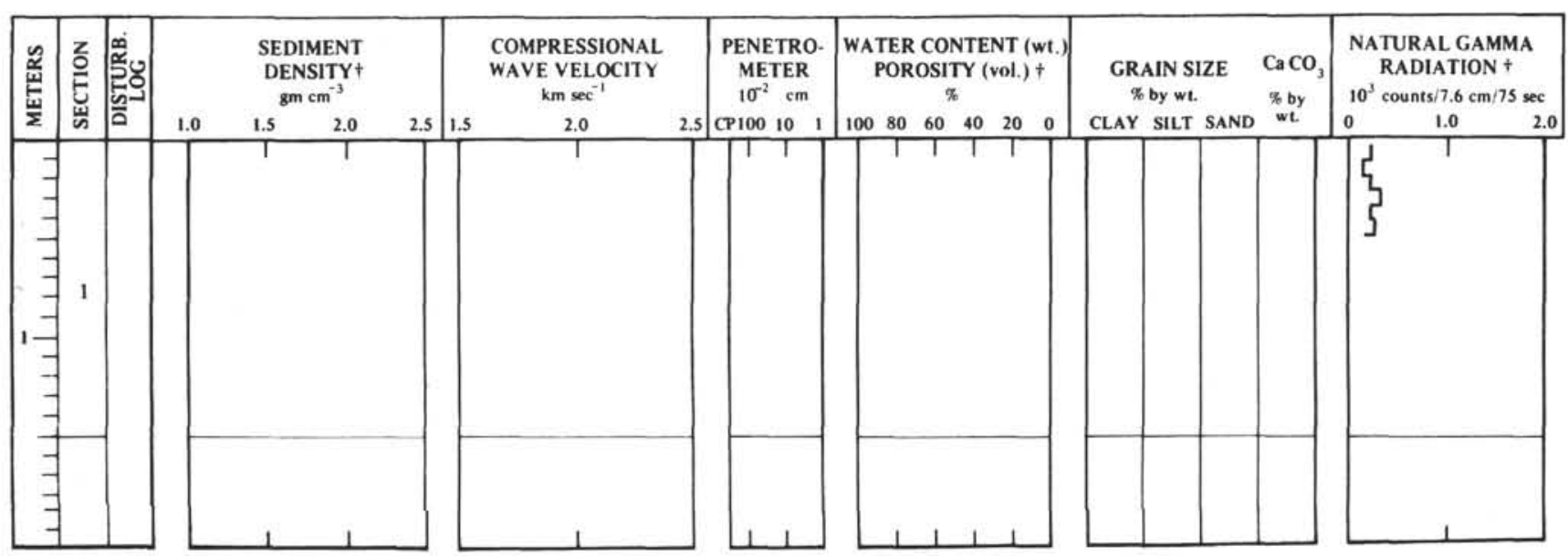

+ Adjusted data see Chapter 2

HOLE 117A

CORE 11

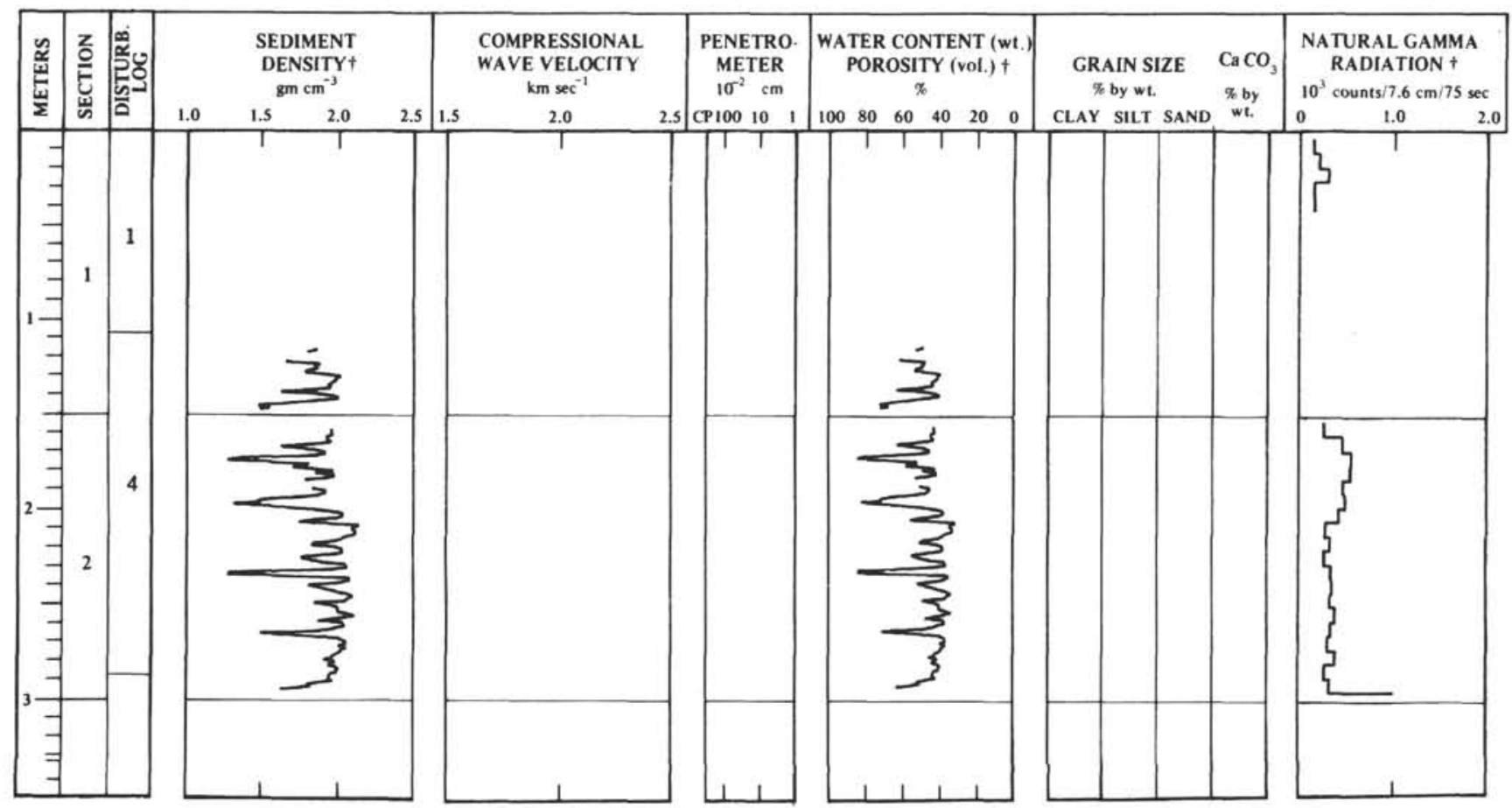

+Adjusted data, see Chapter 2 
HOLE

$117 \mathrm{~A}$

CORE

10

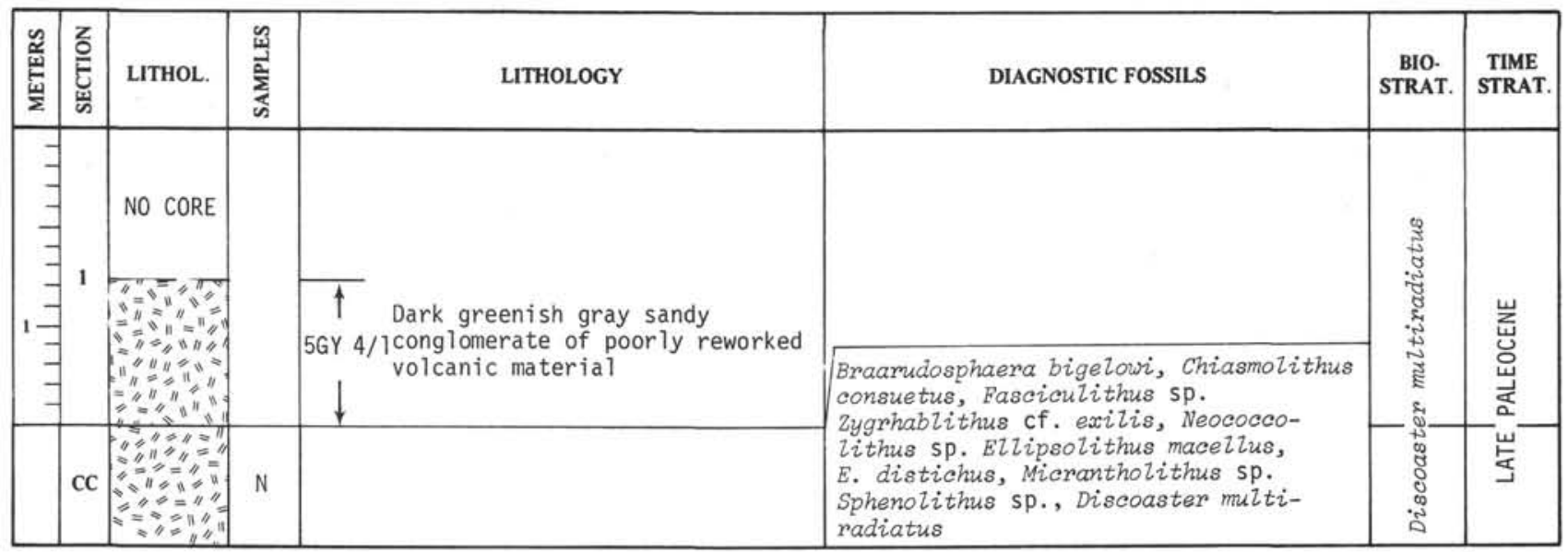
HOLE $\quad 117 \mathrm{~A}$
311 ro
$313 \mathrm{~m}$

CORE 11

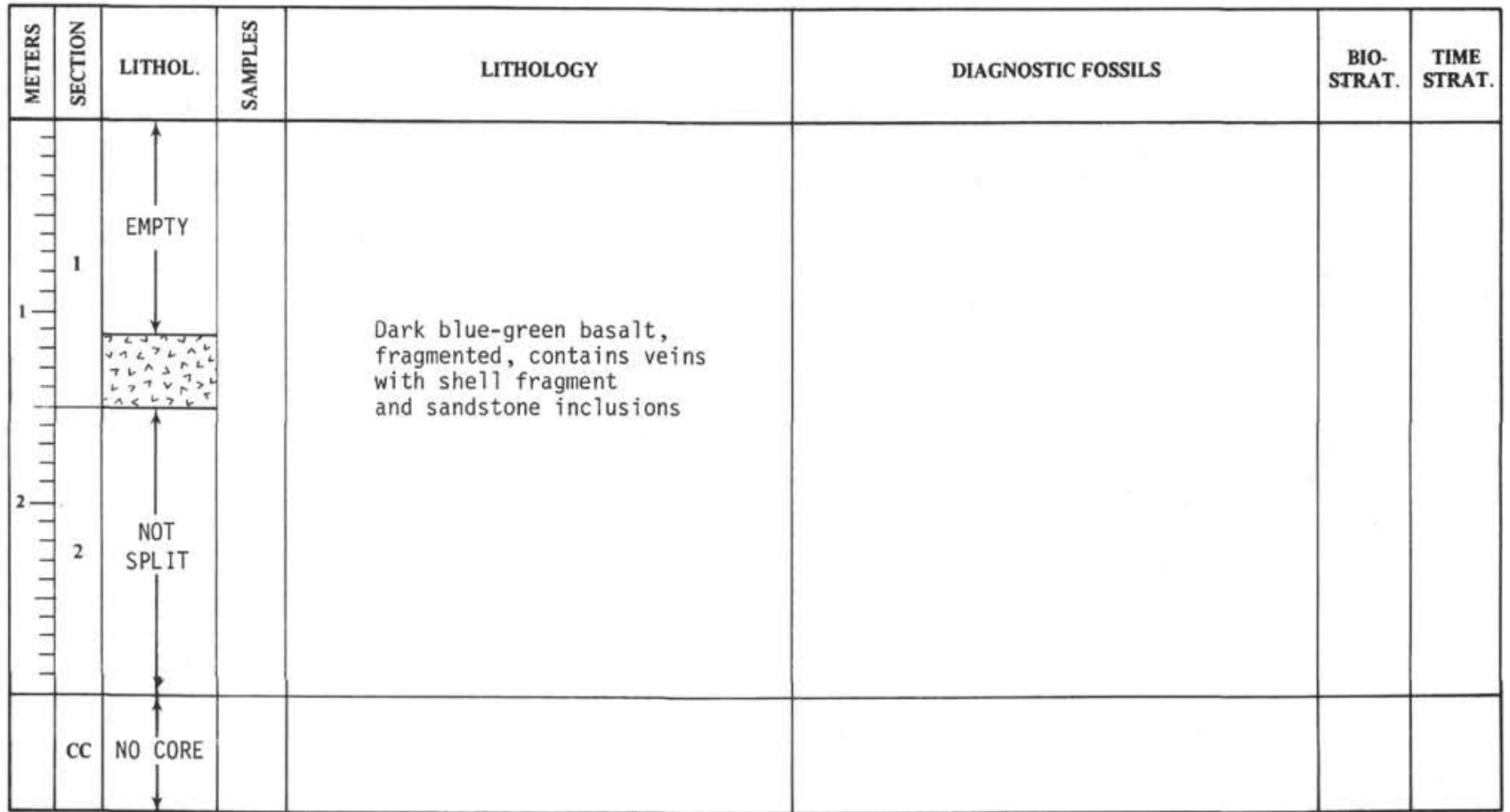


SHIPBOARD SCIENTIFIC PARTY

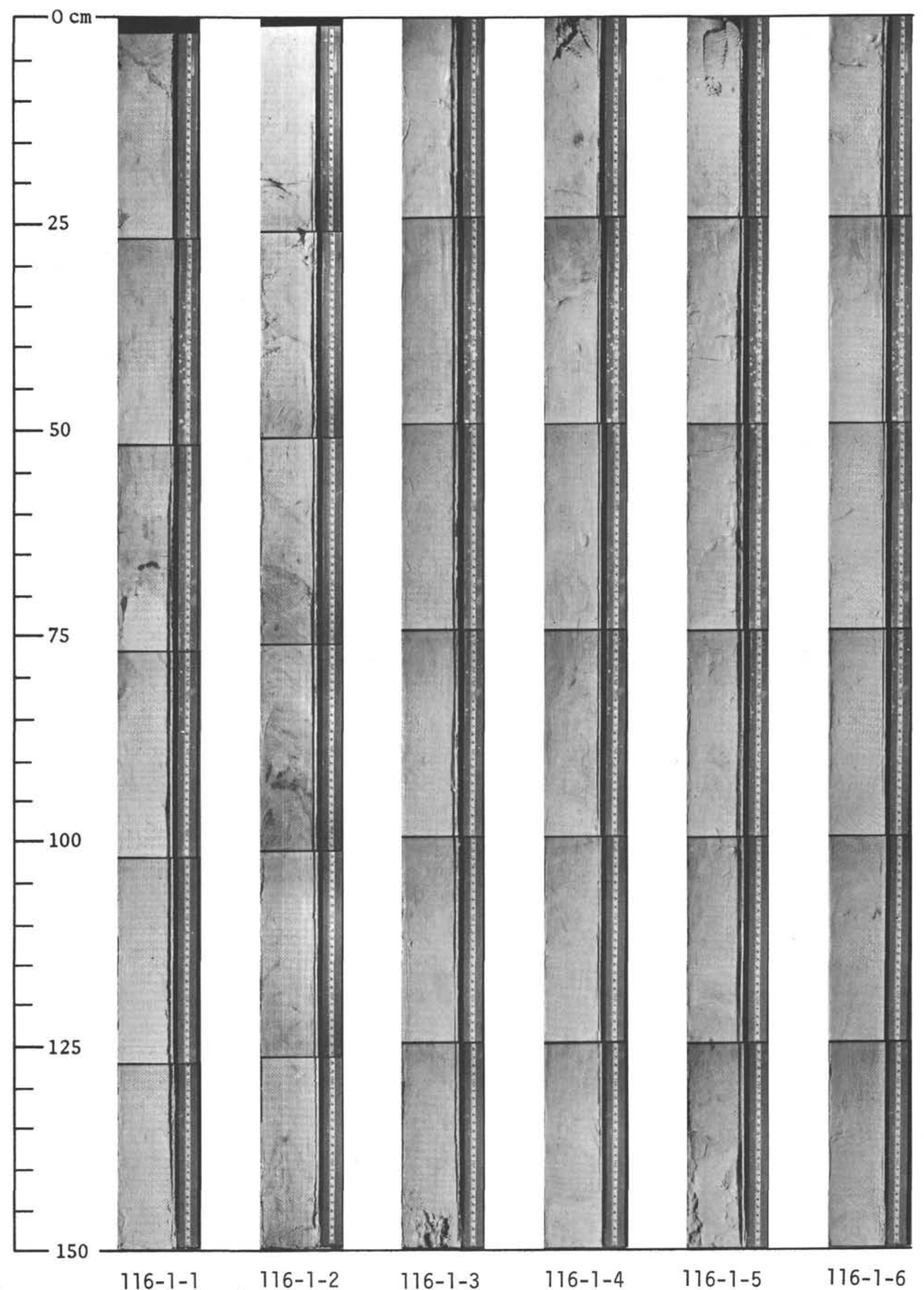




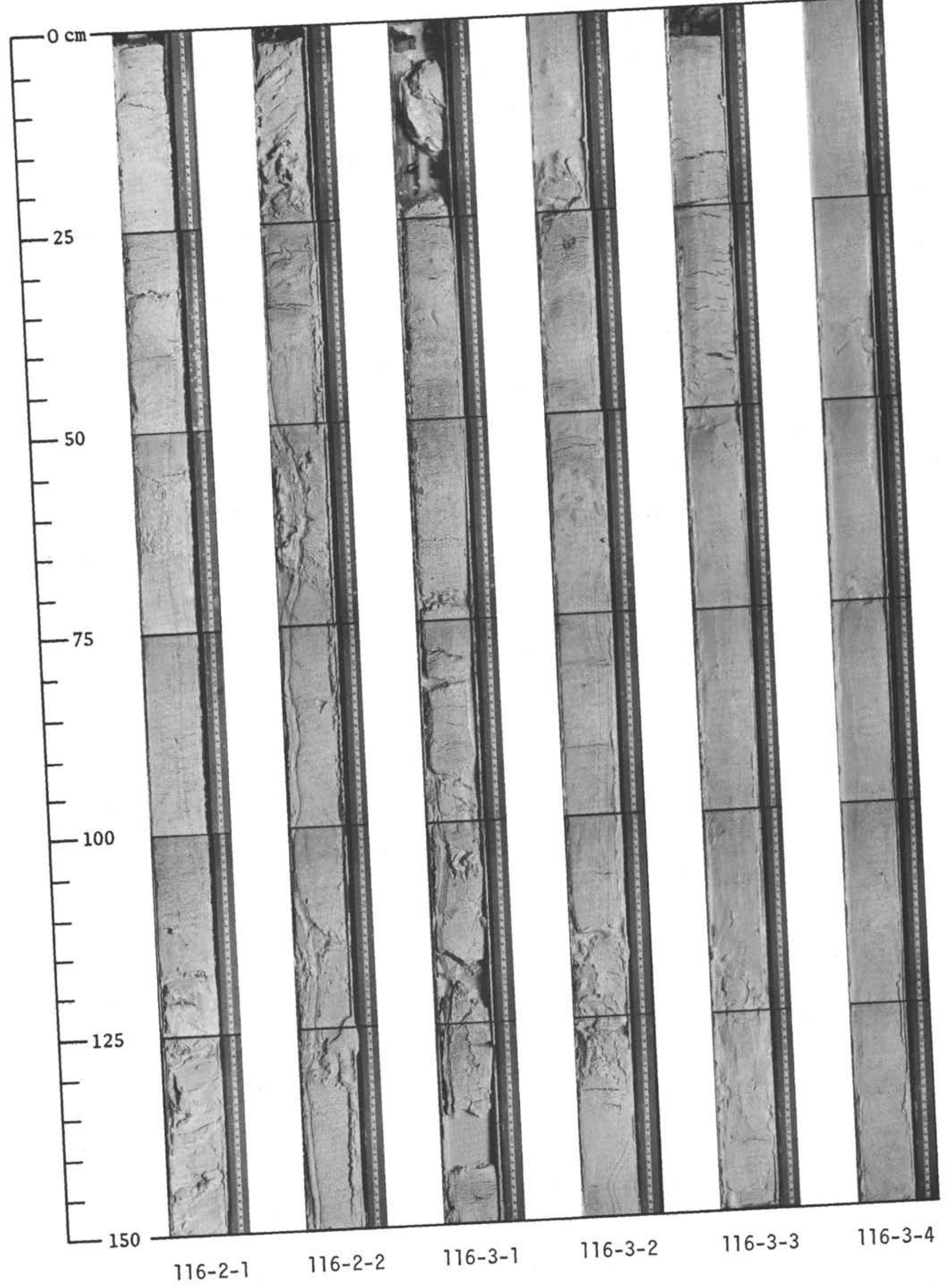


SHIPBOARD SCIENTIFIC PARTY

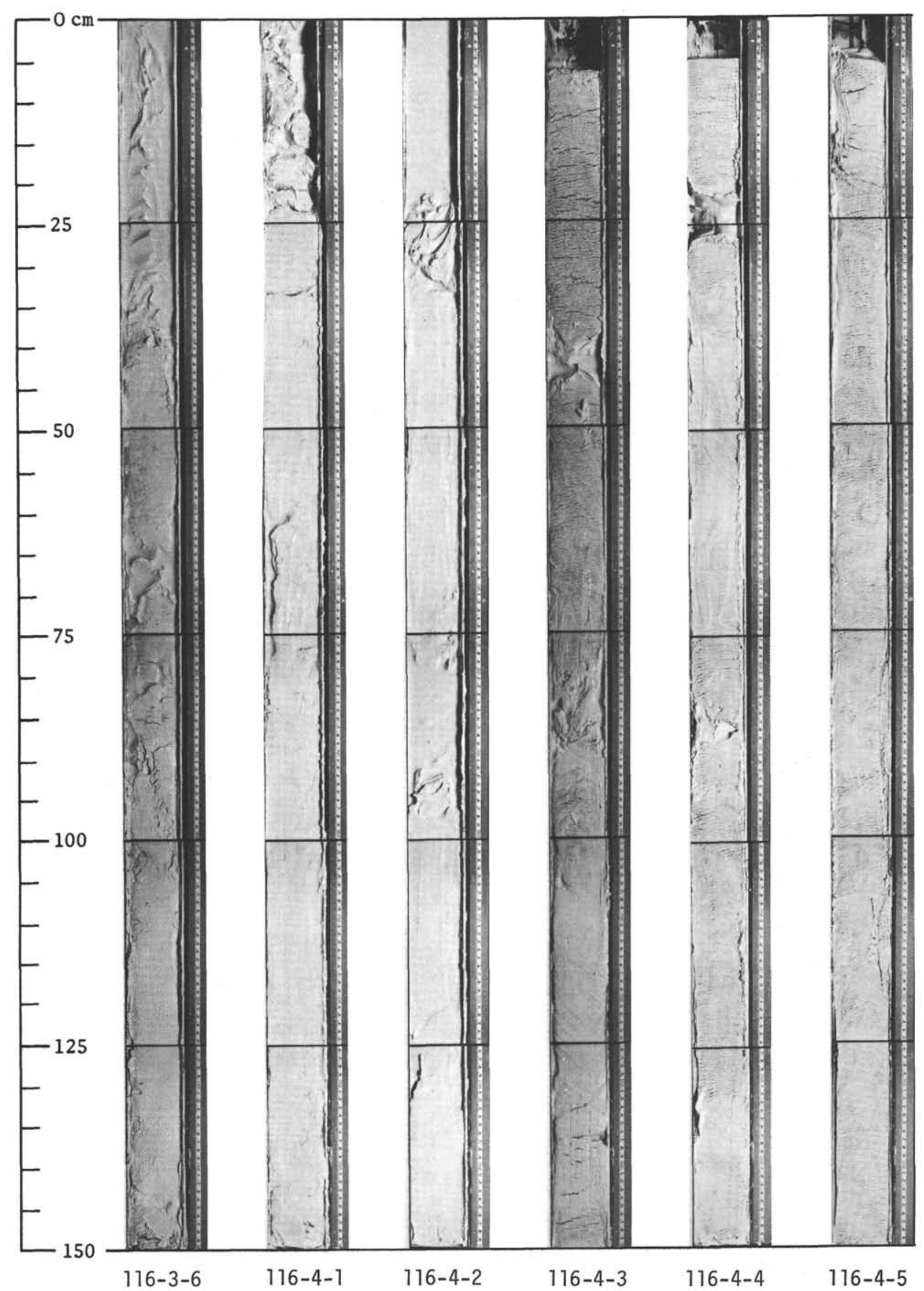




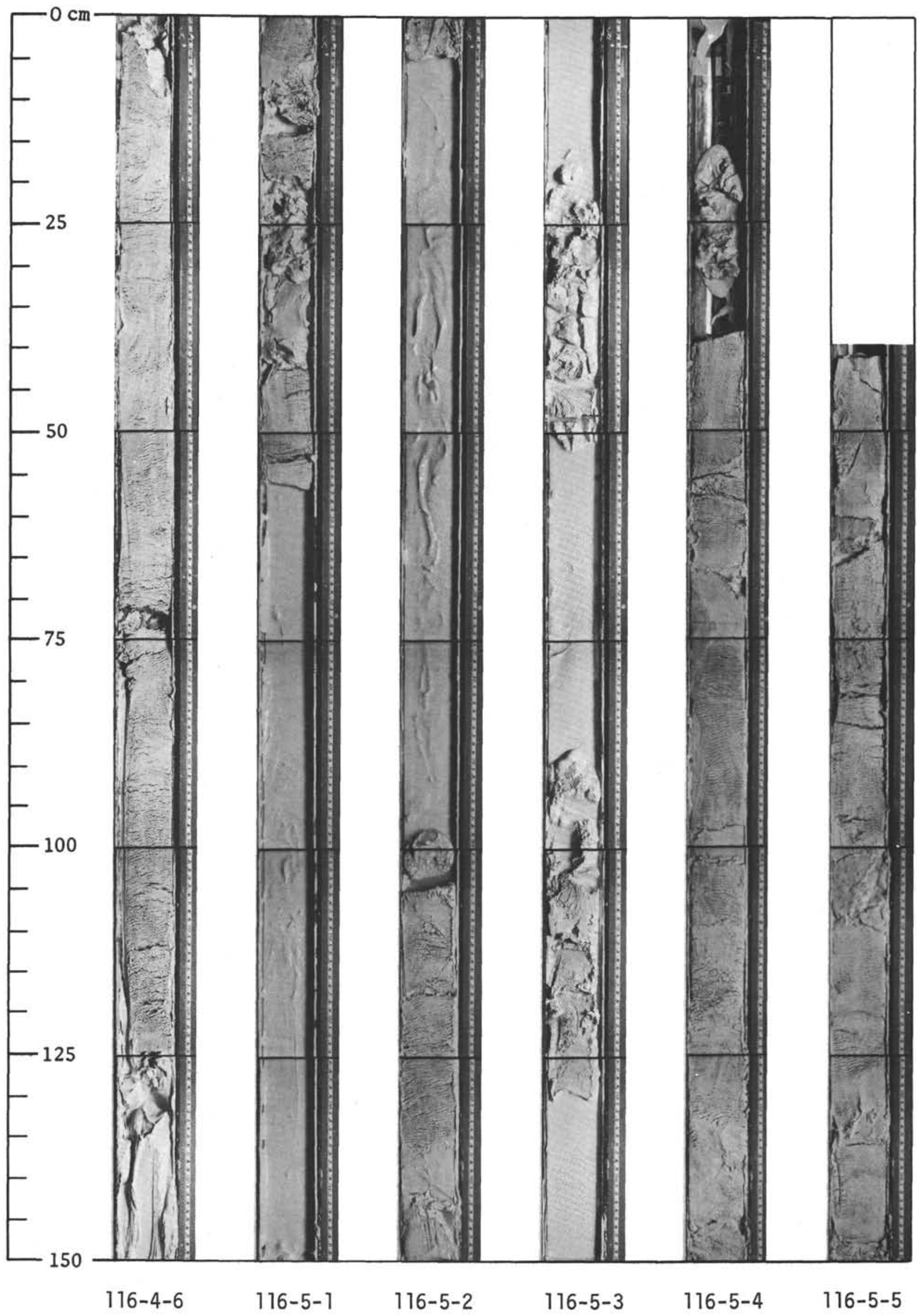




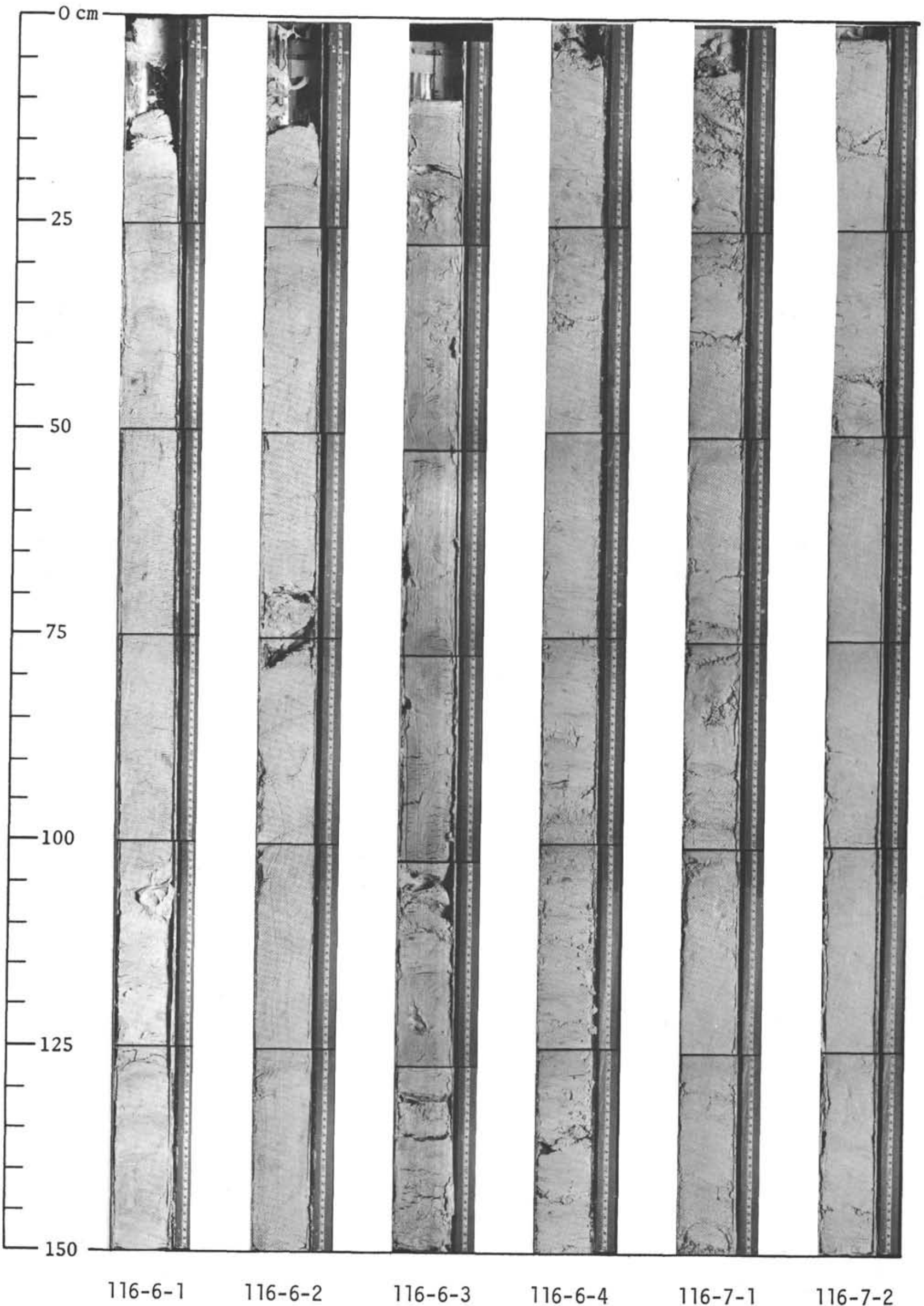




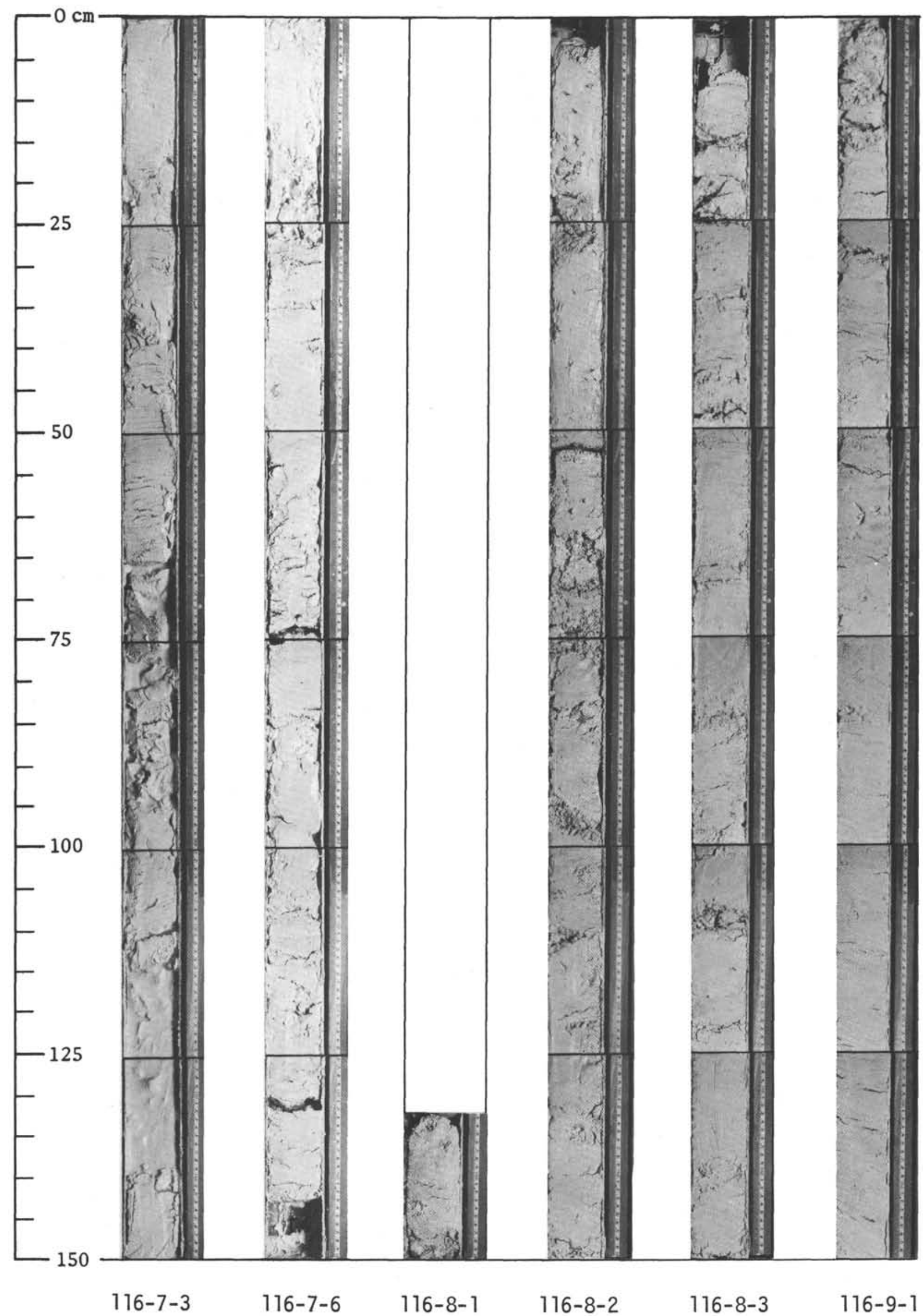




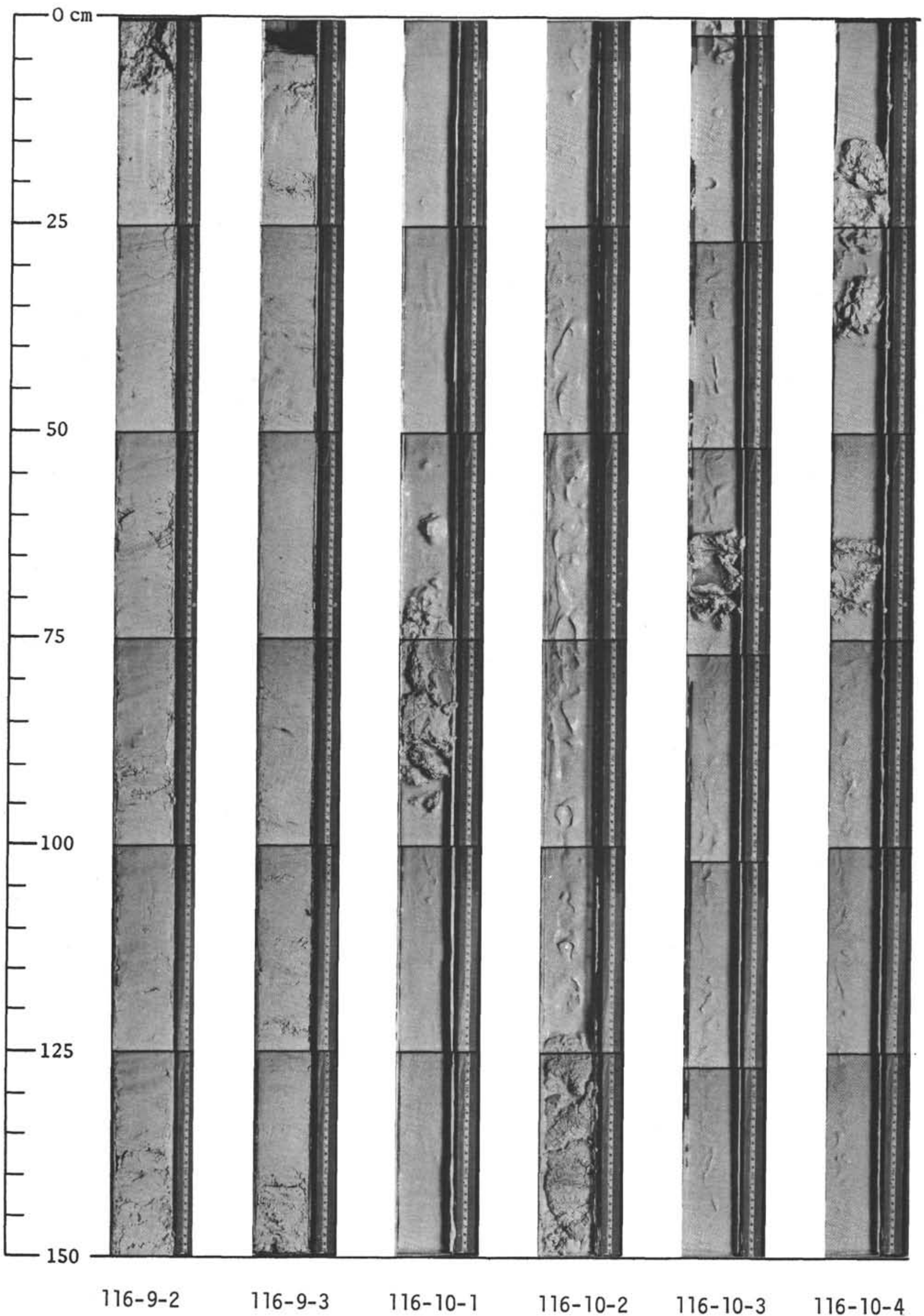




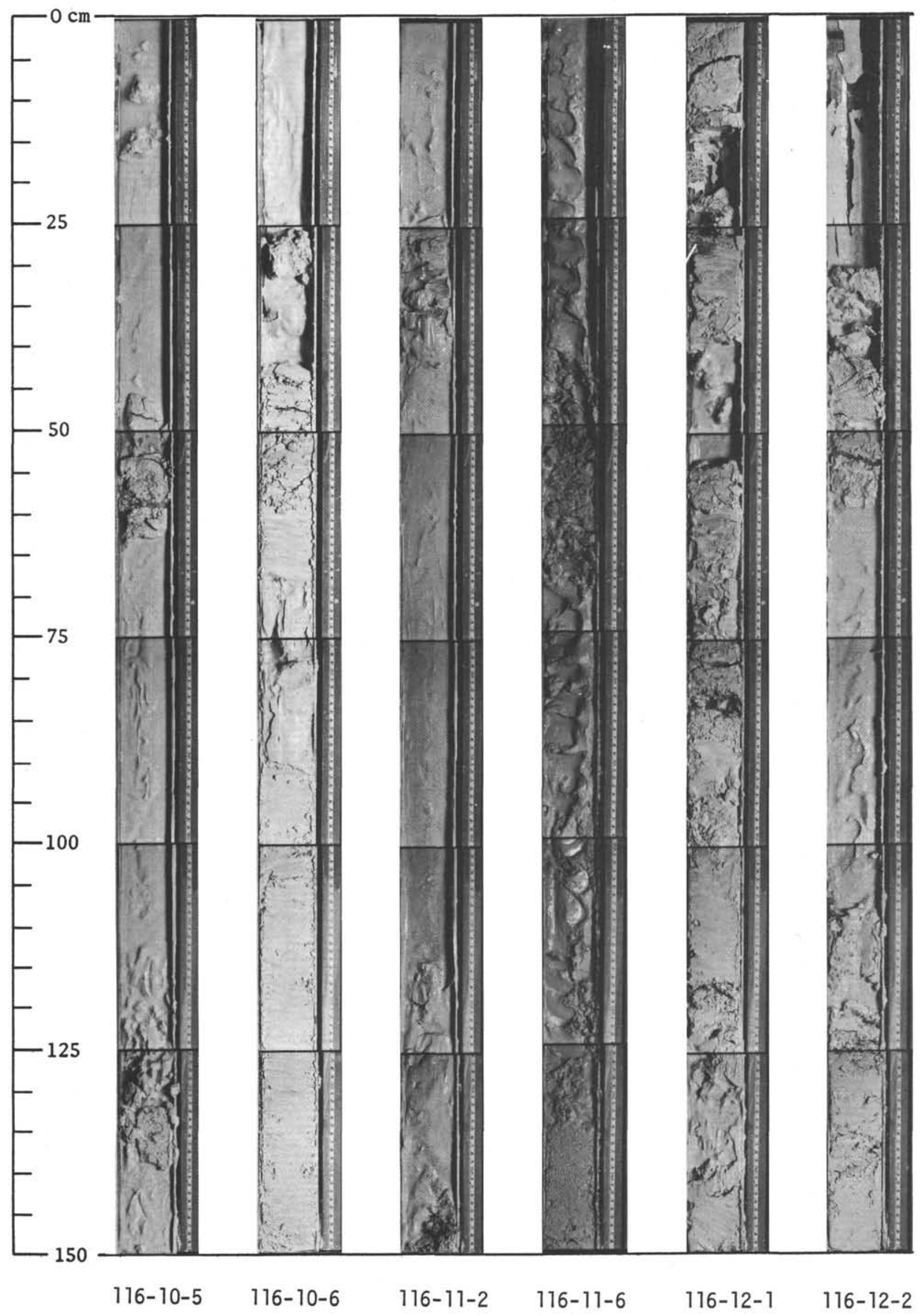




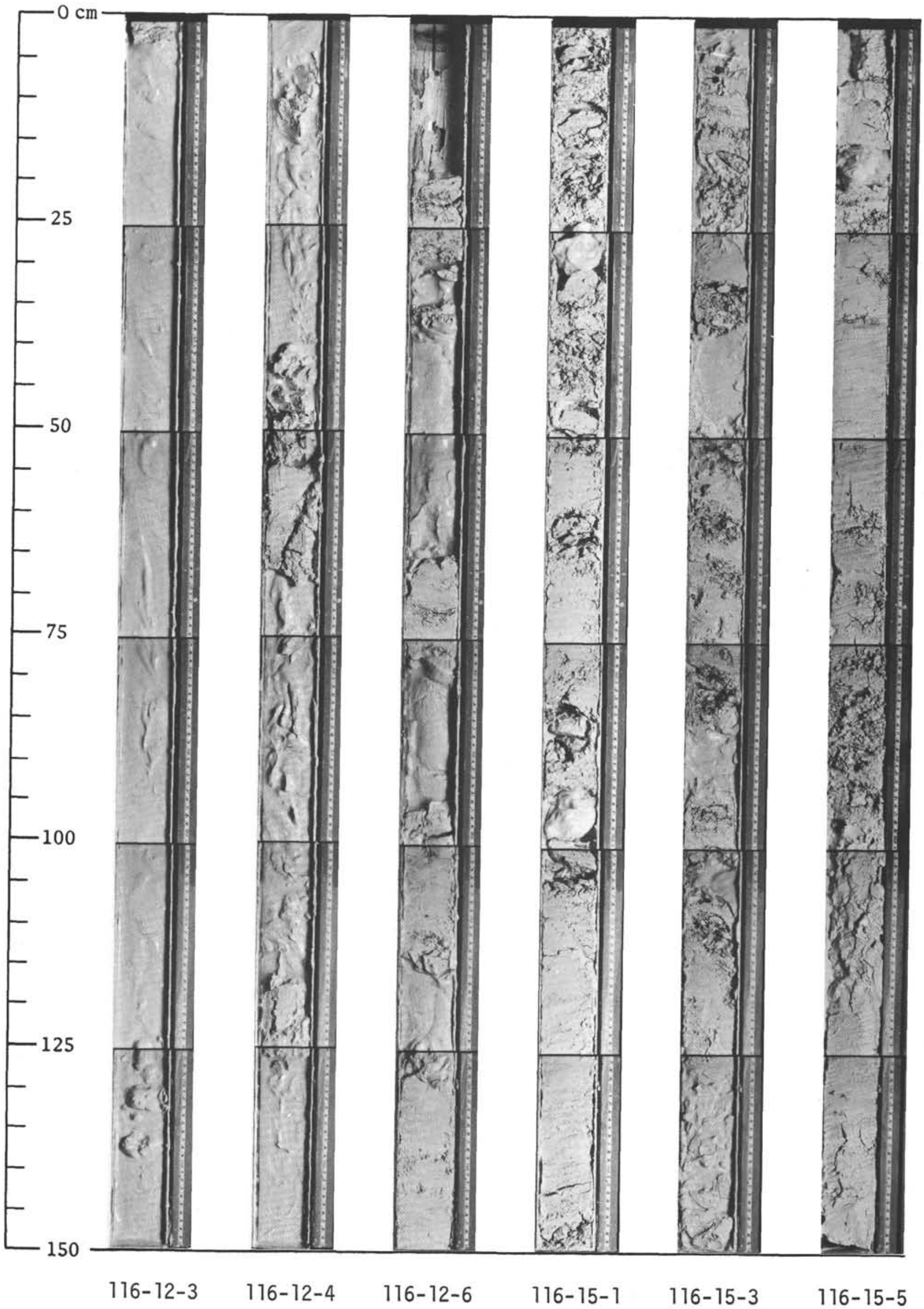




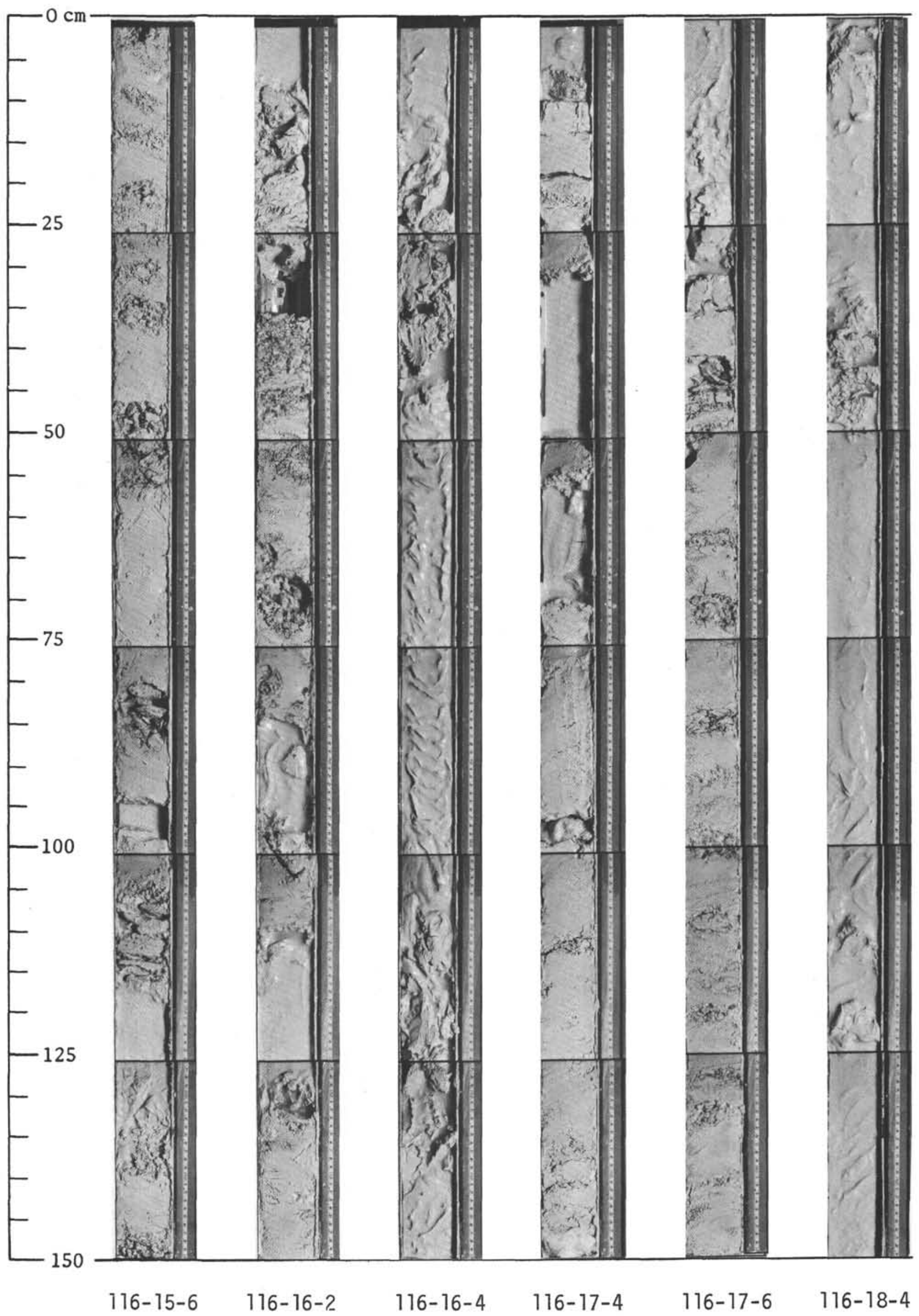




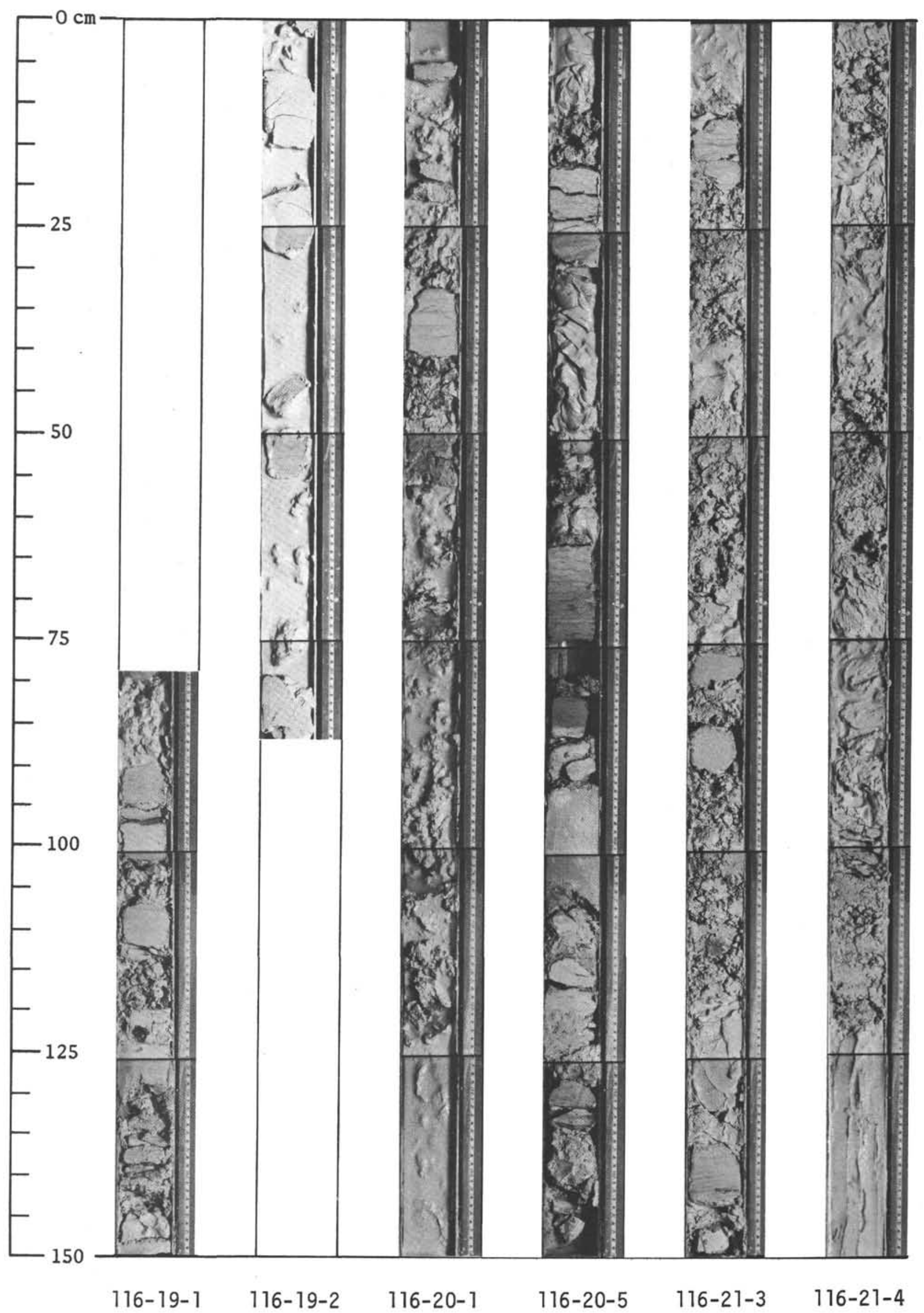




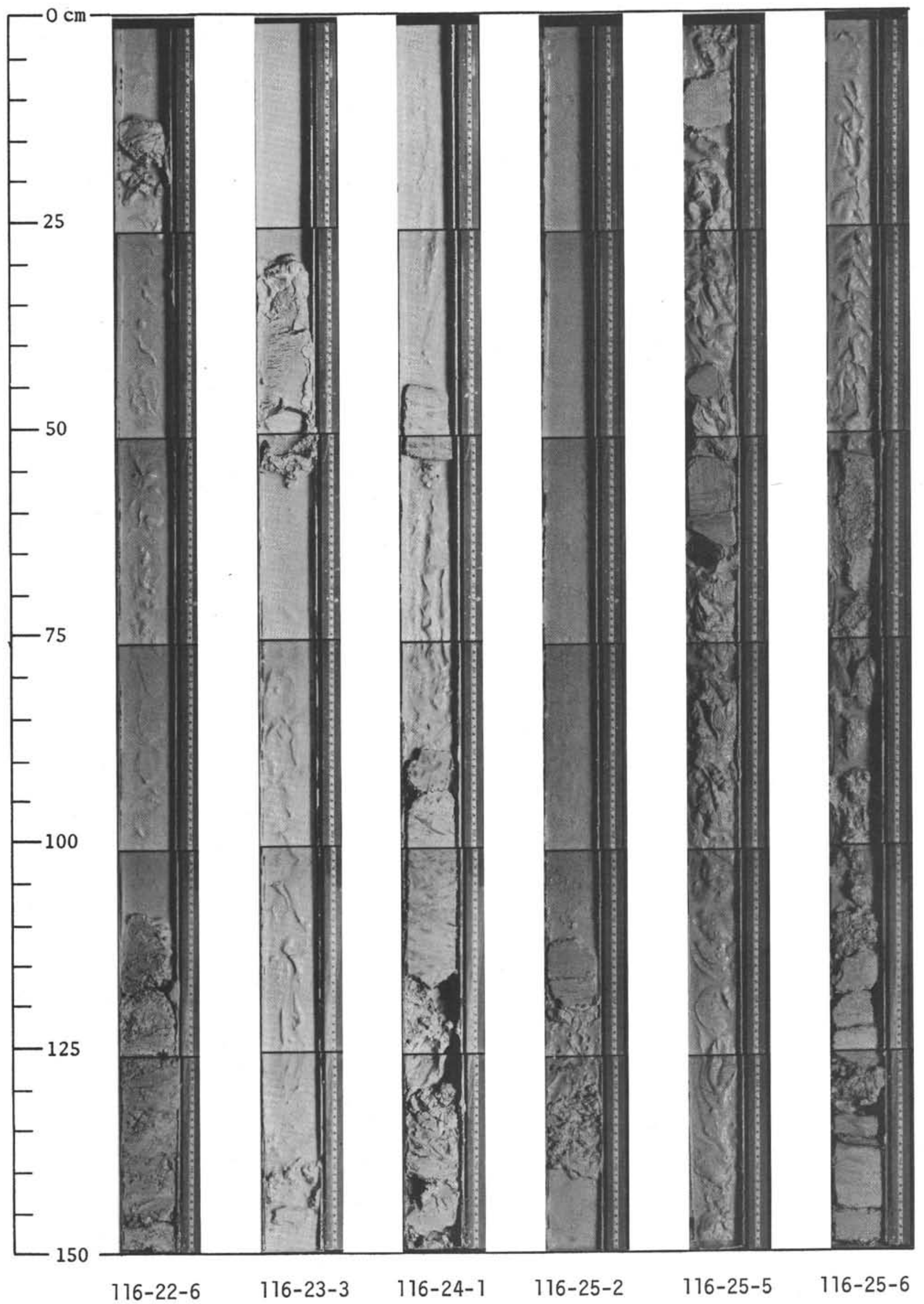




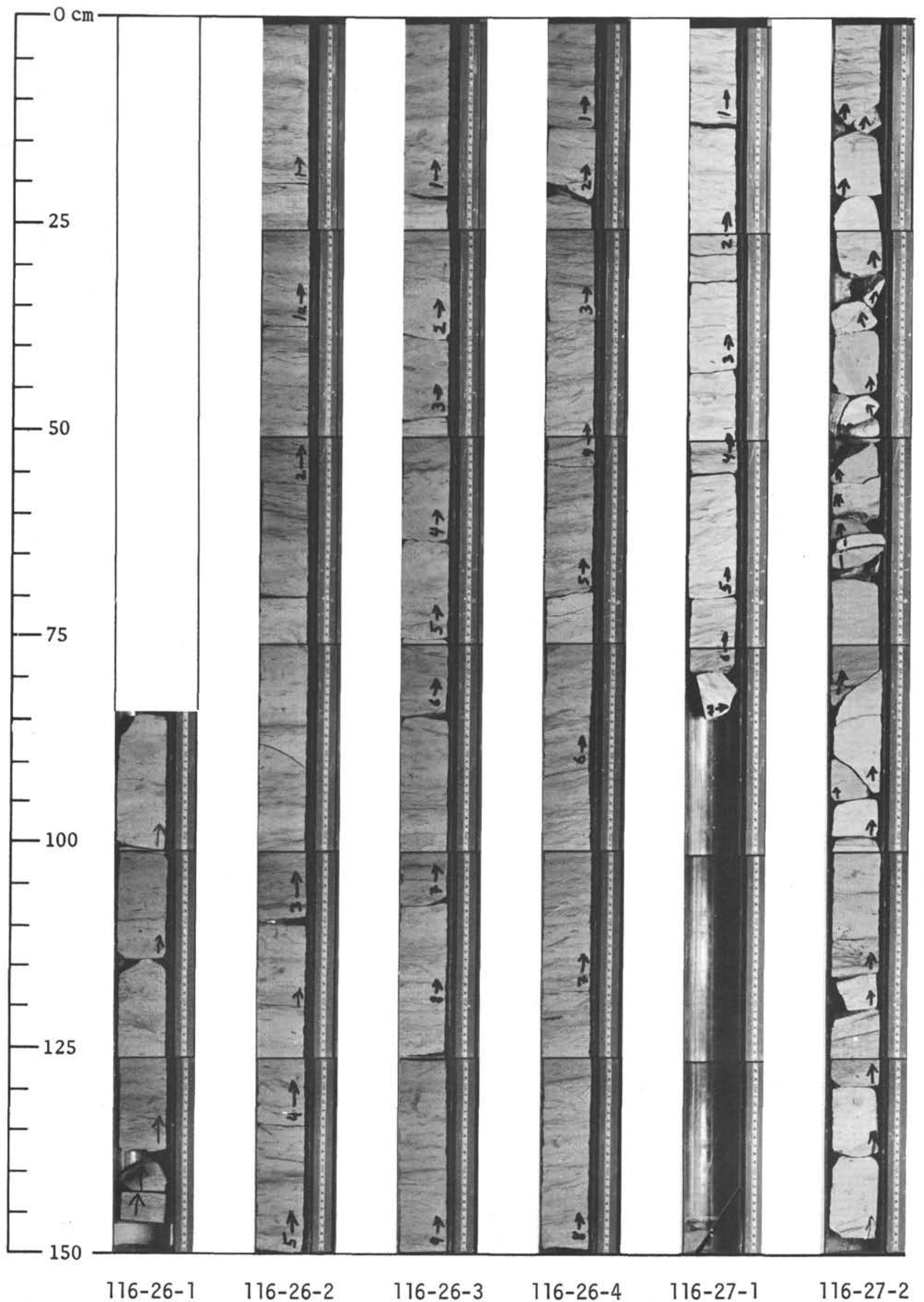




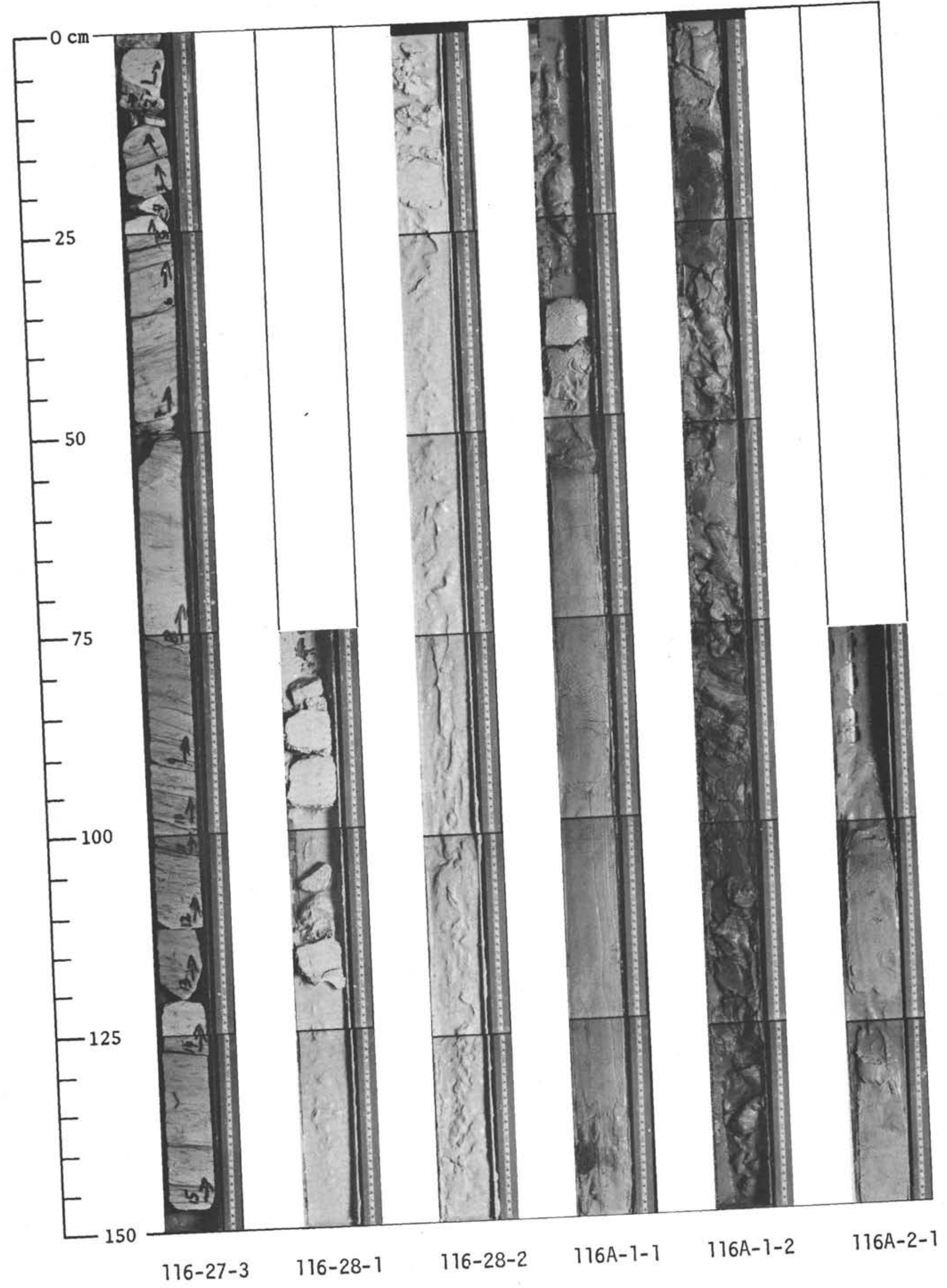




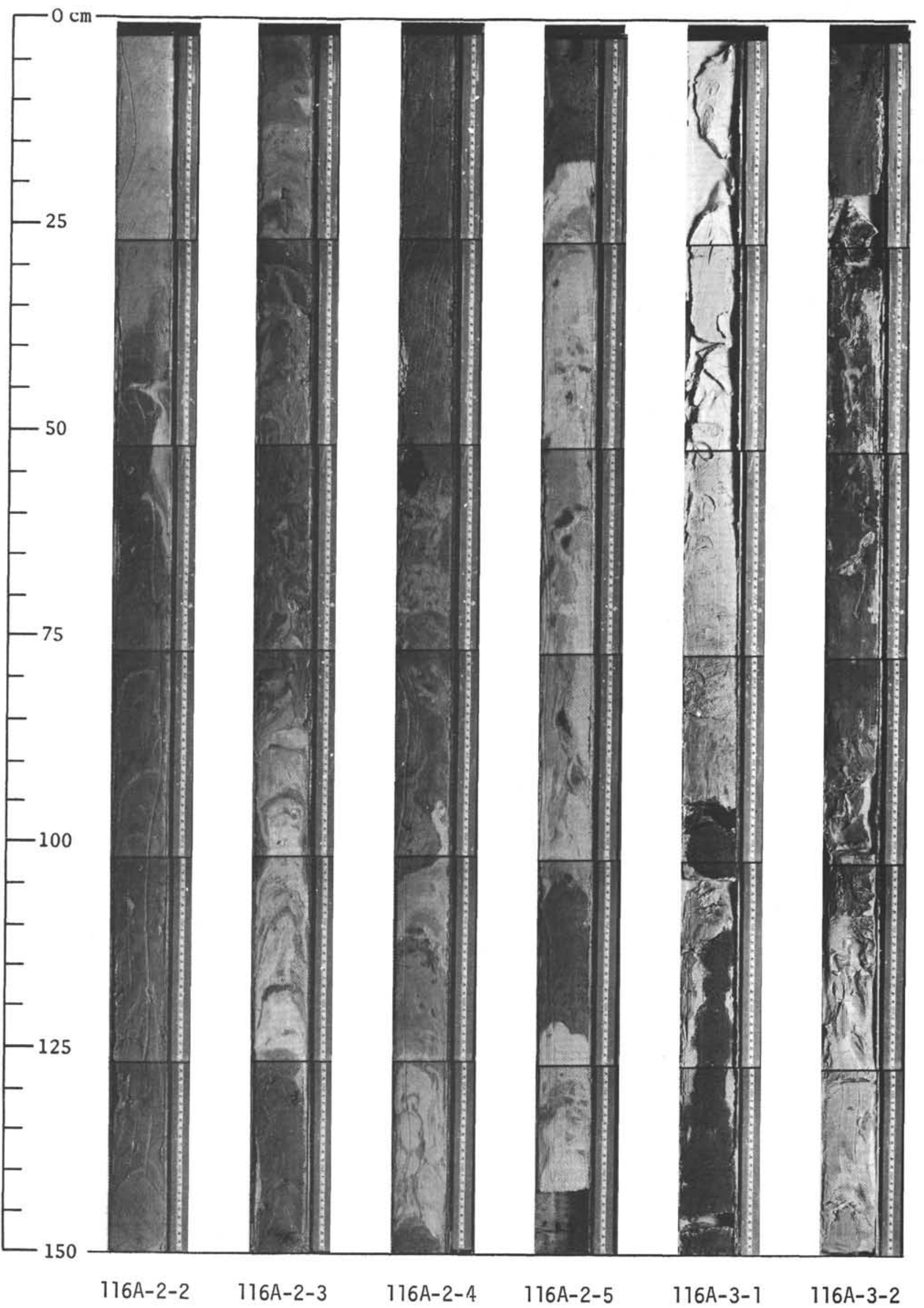


SITE 116 and 117

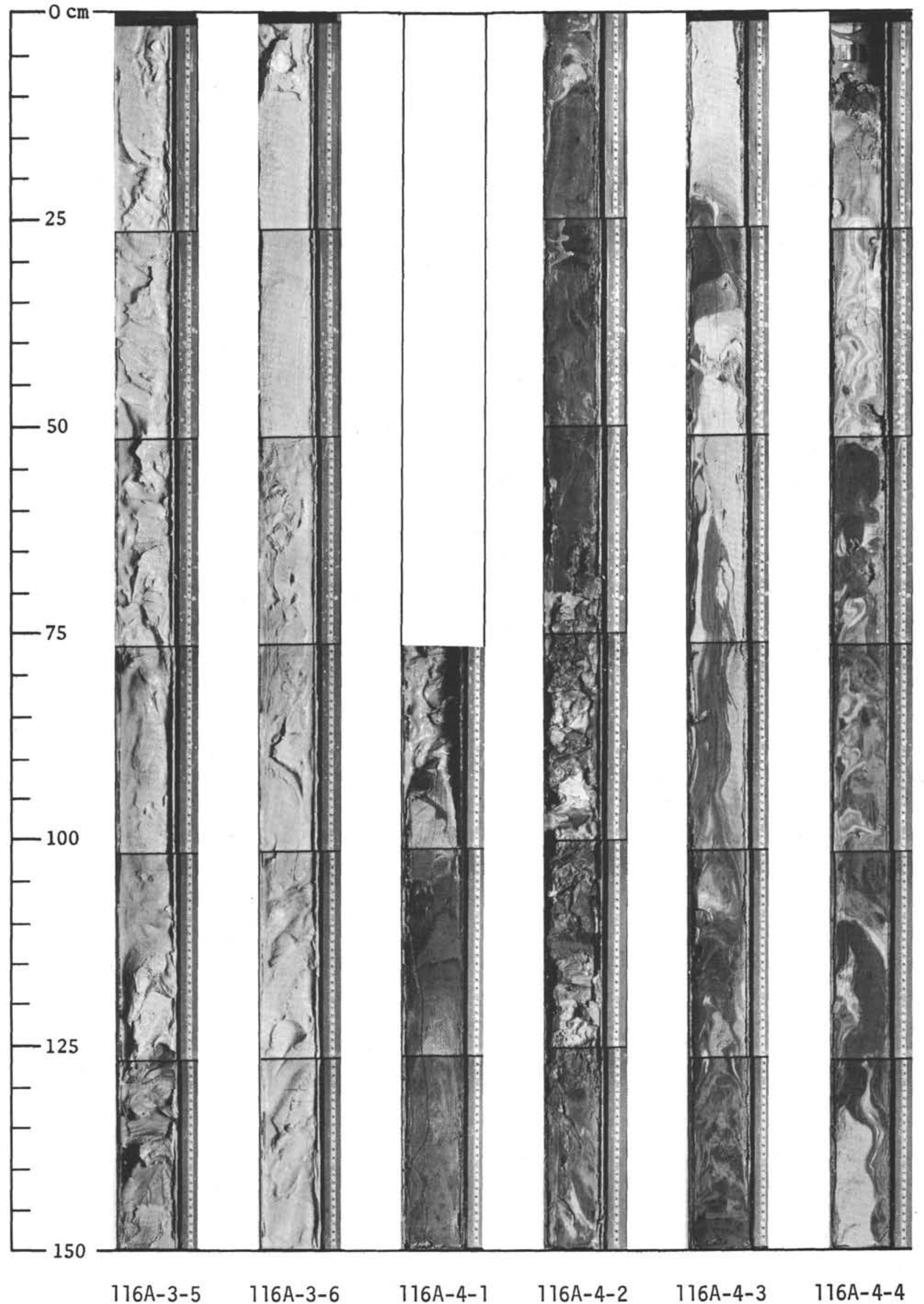




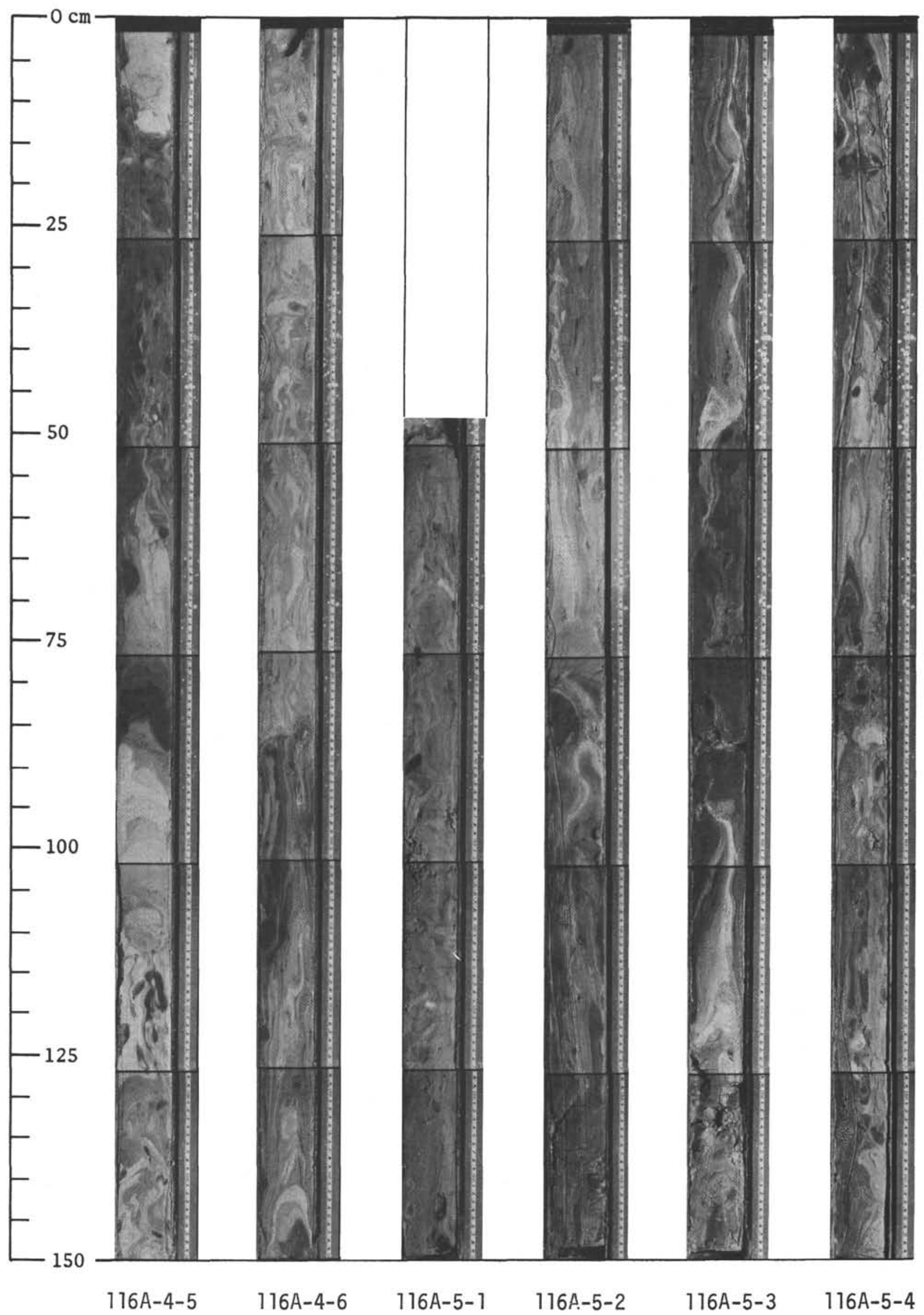




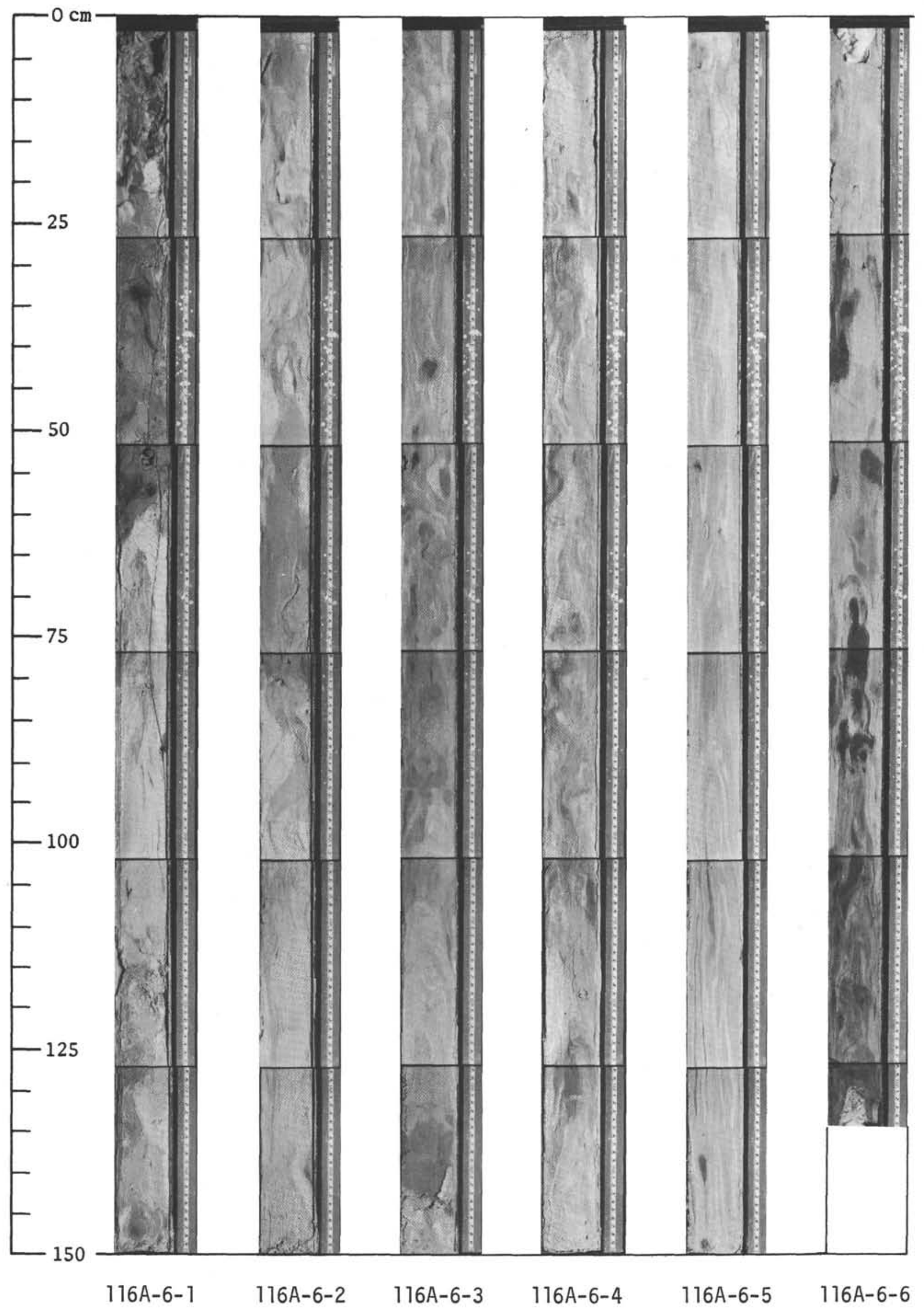




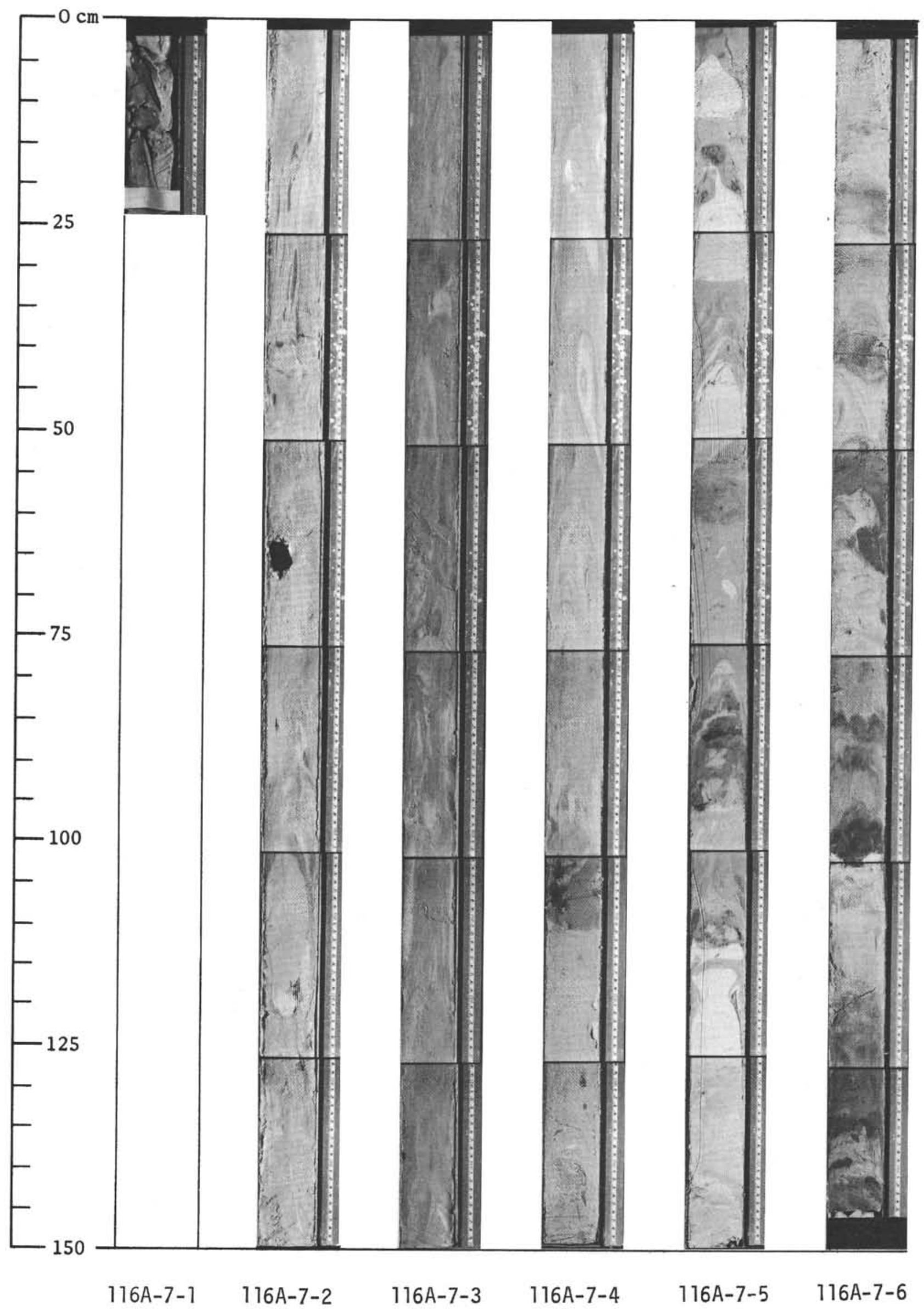




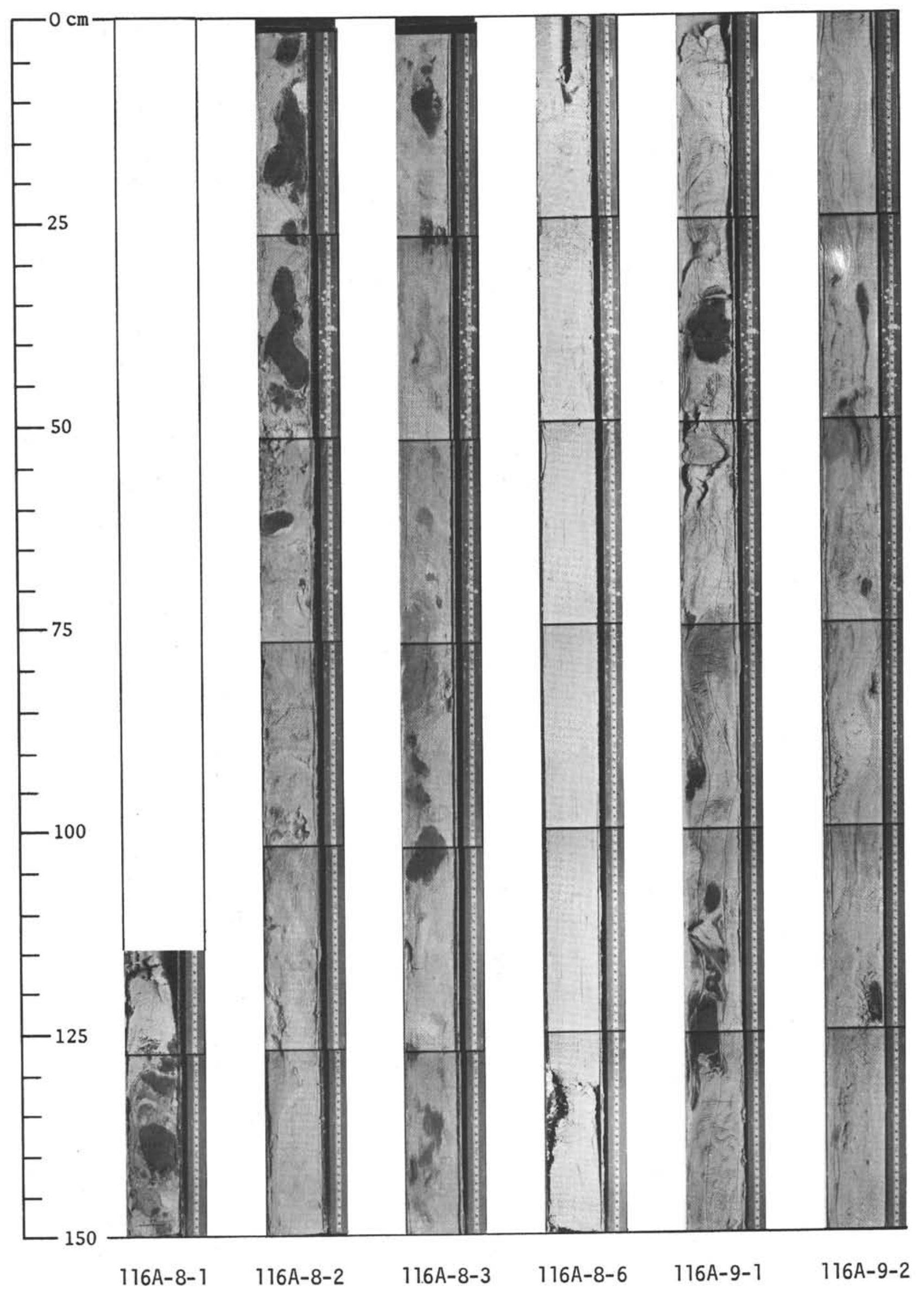


SHIPBOARD SCIENTIFIC PARTY

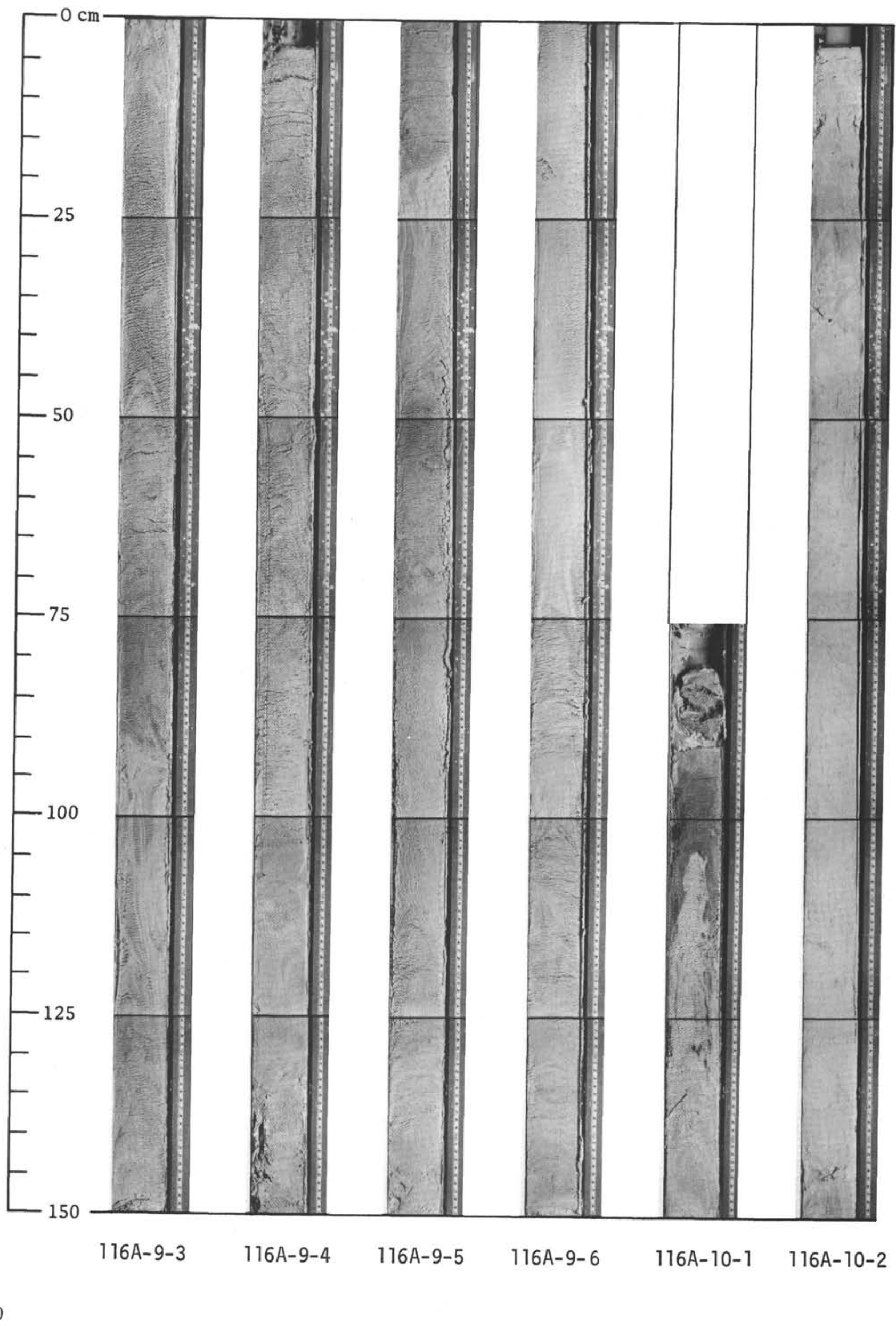




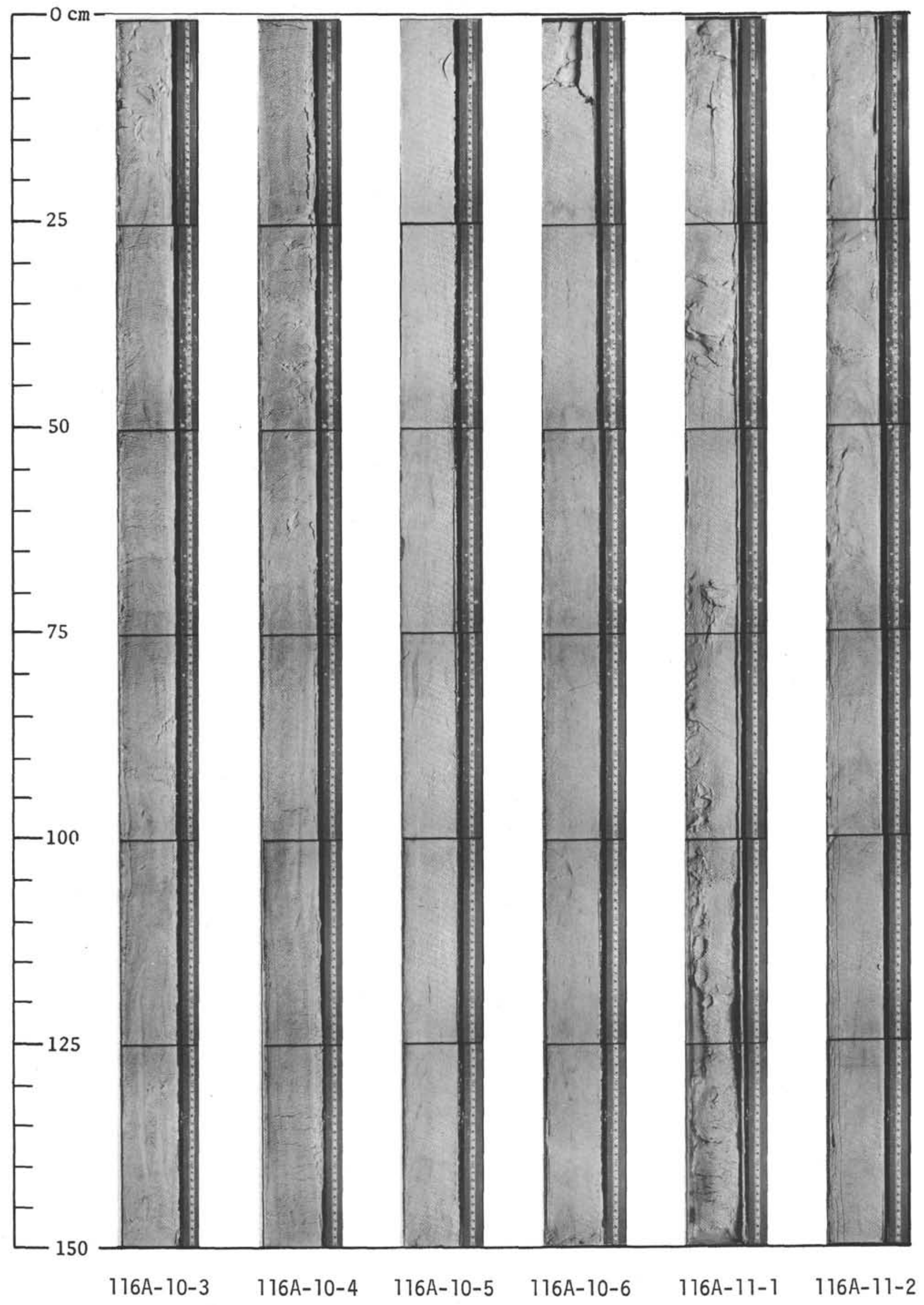




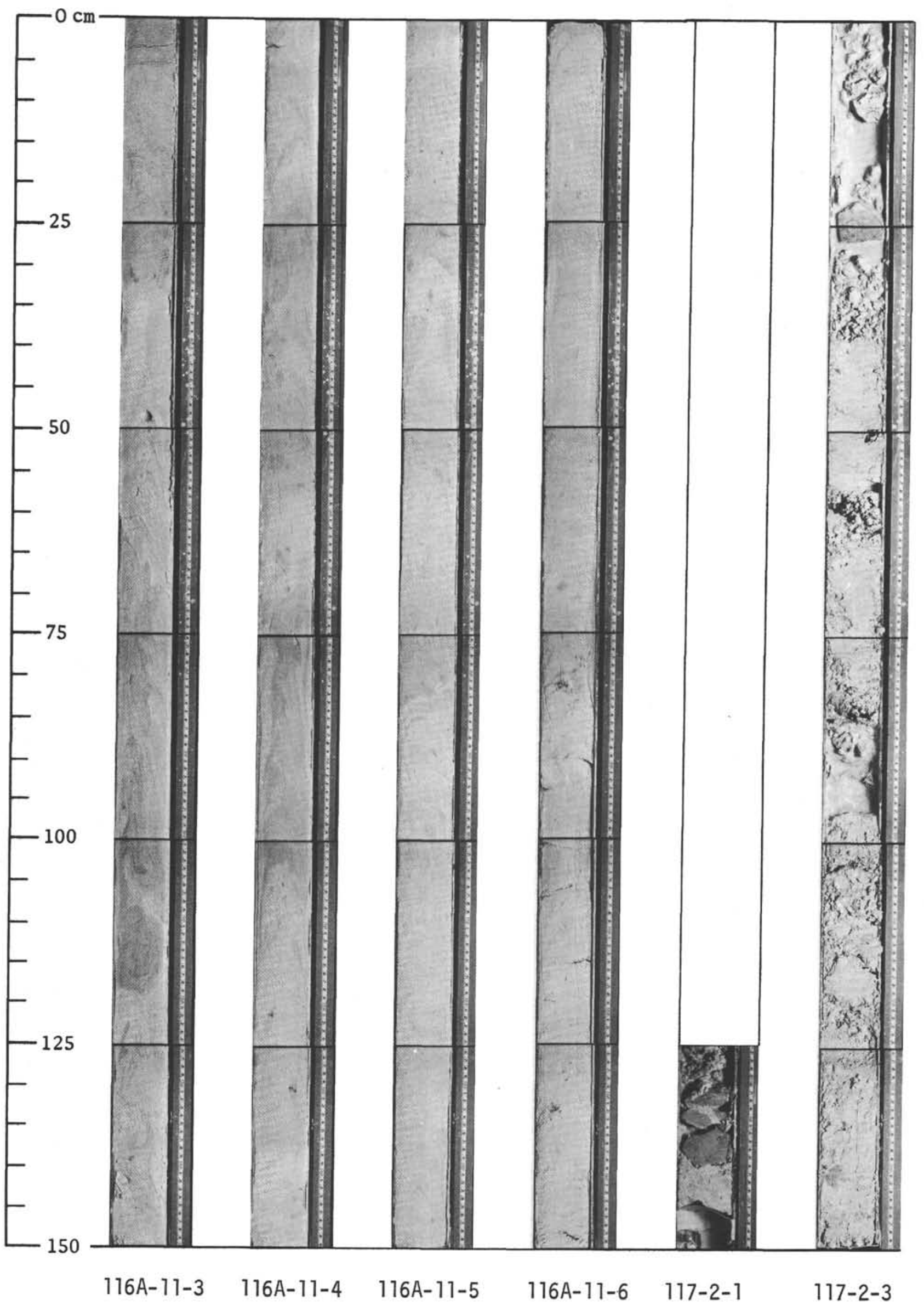




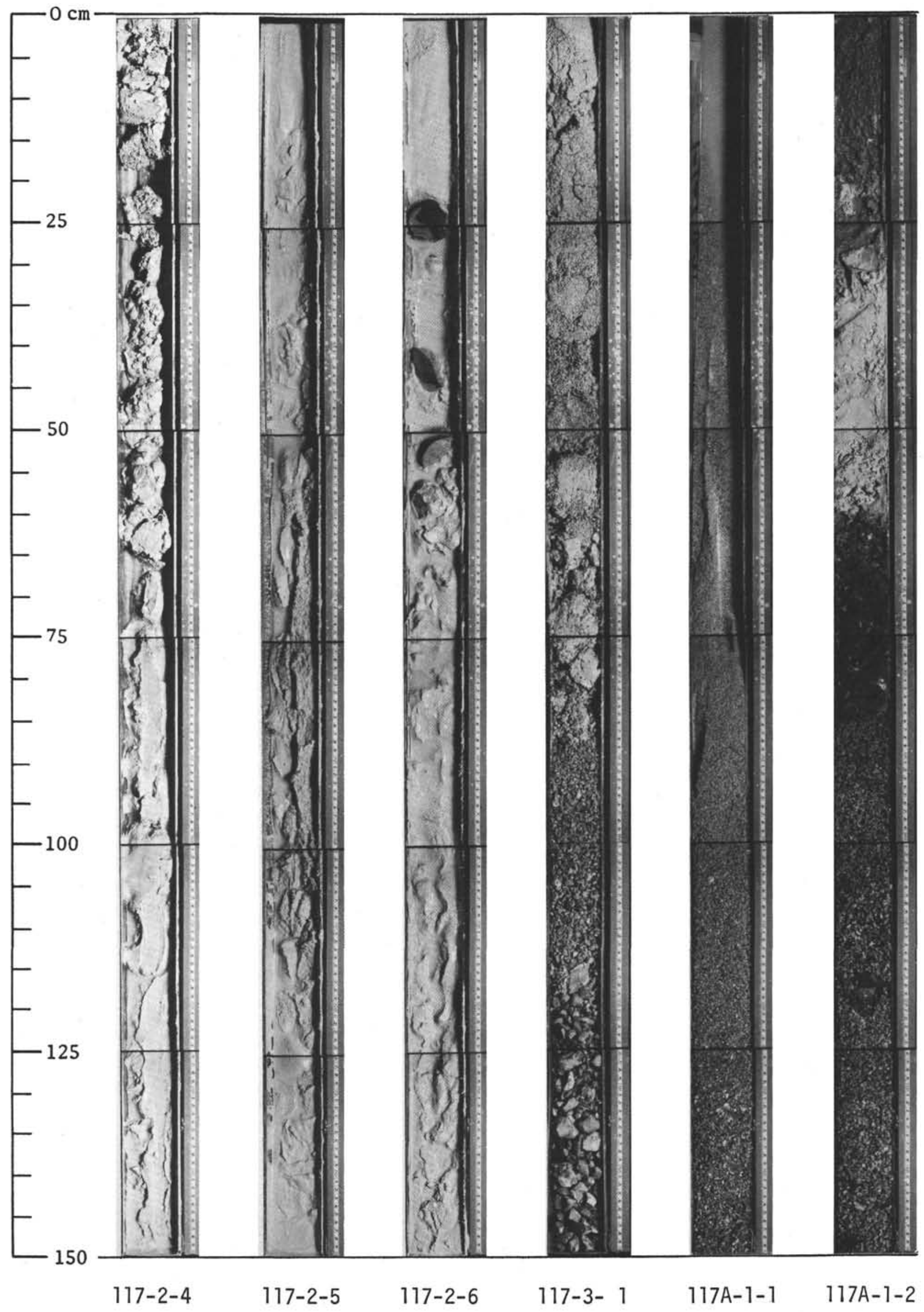




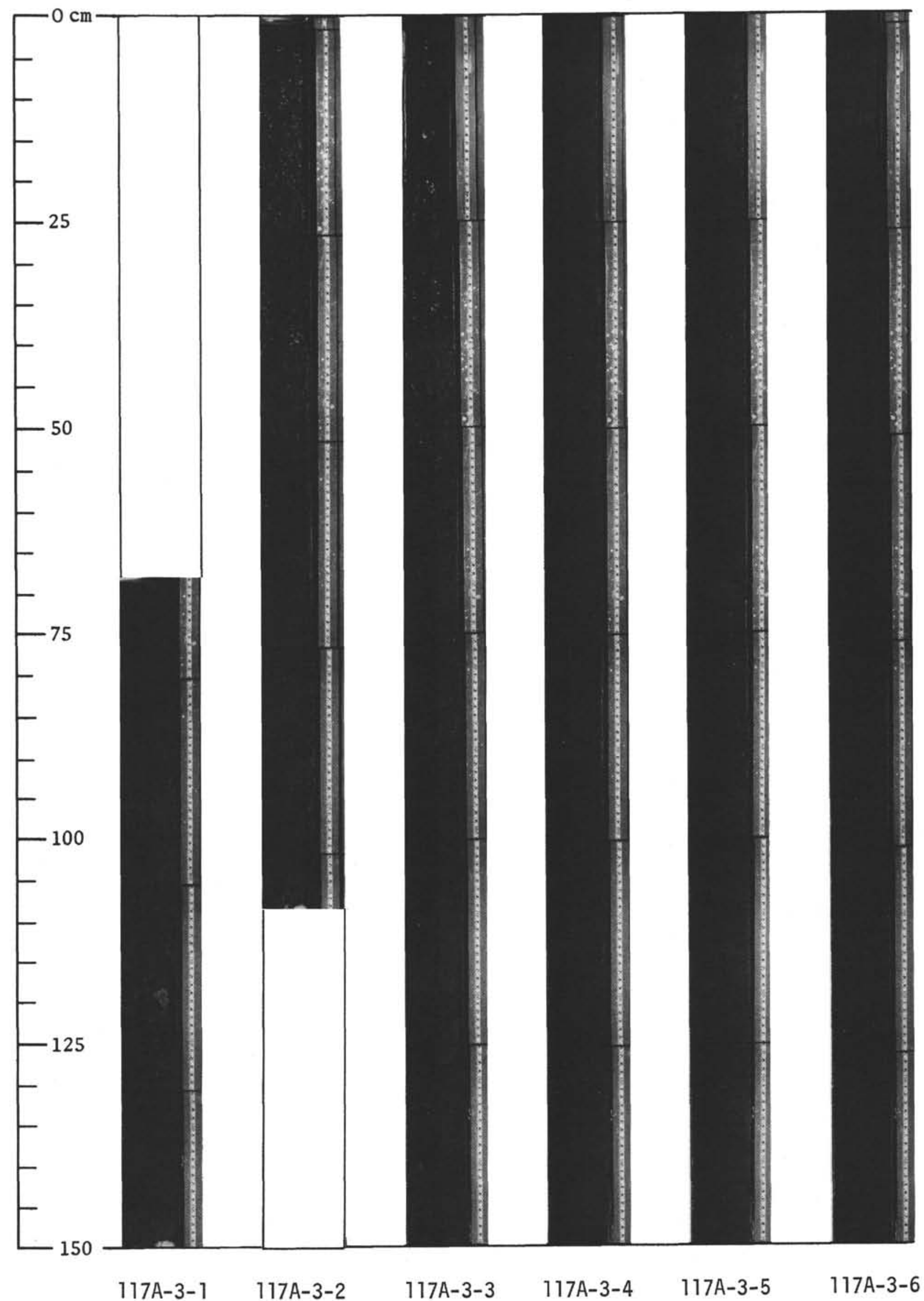




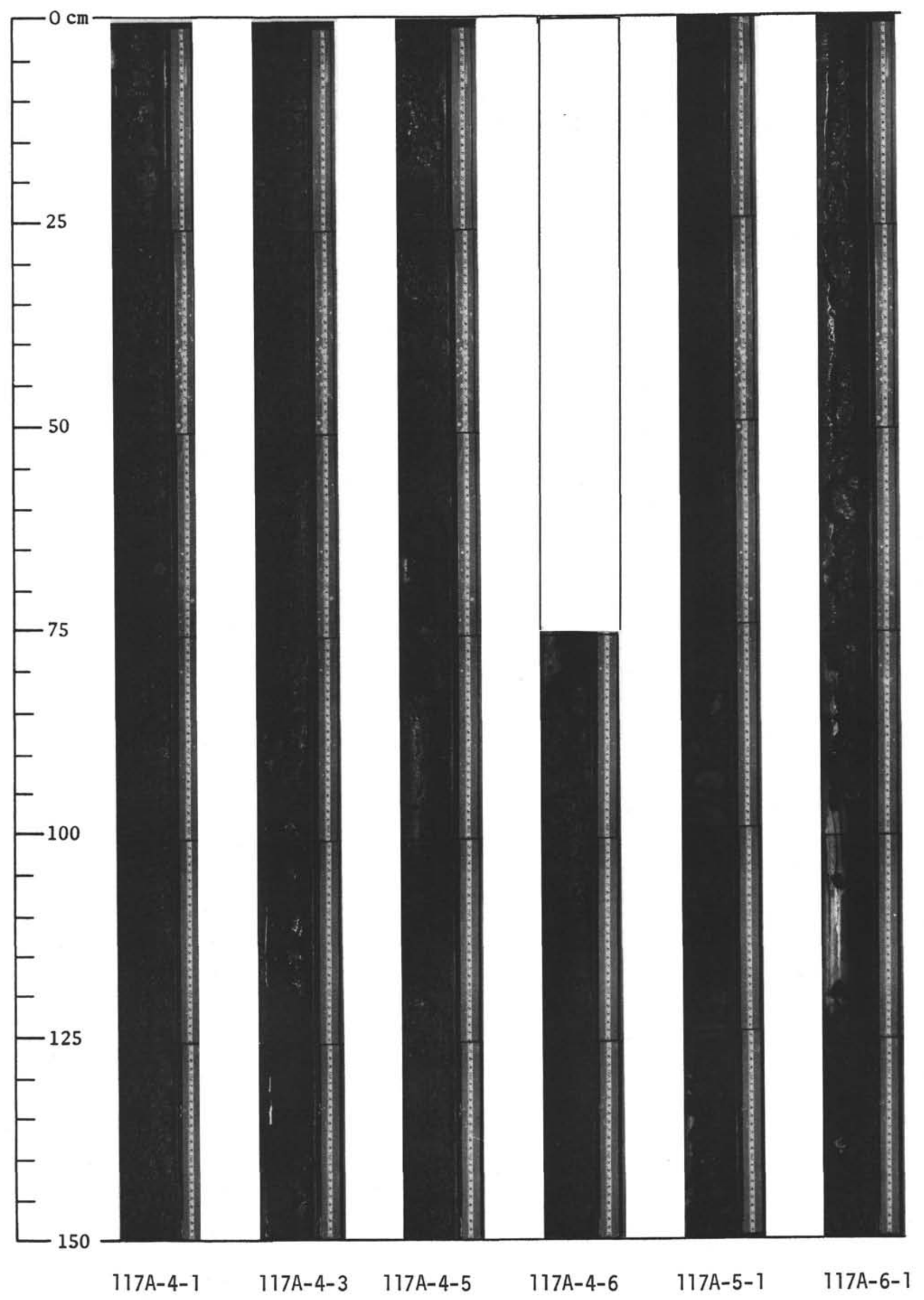


SHIPBOARD SCIENTIFIC PARTY

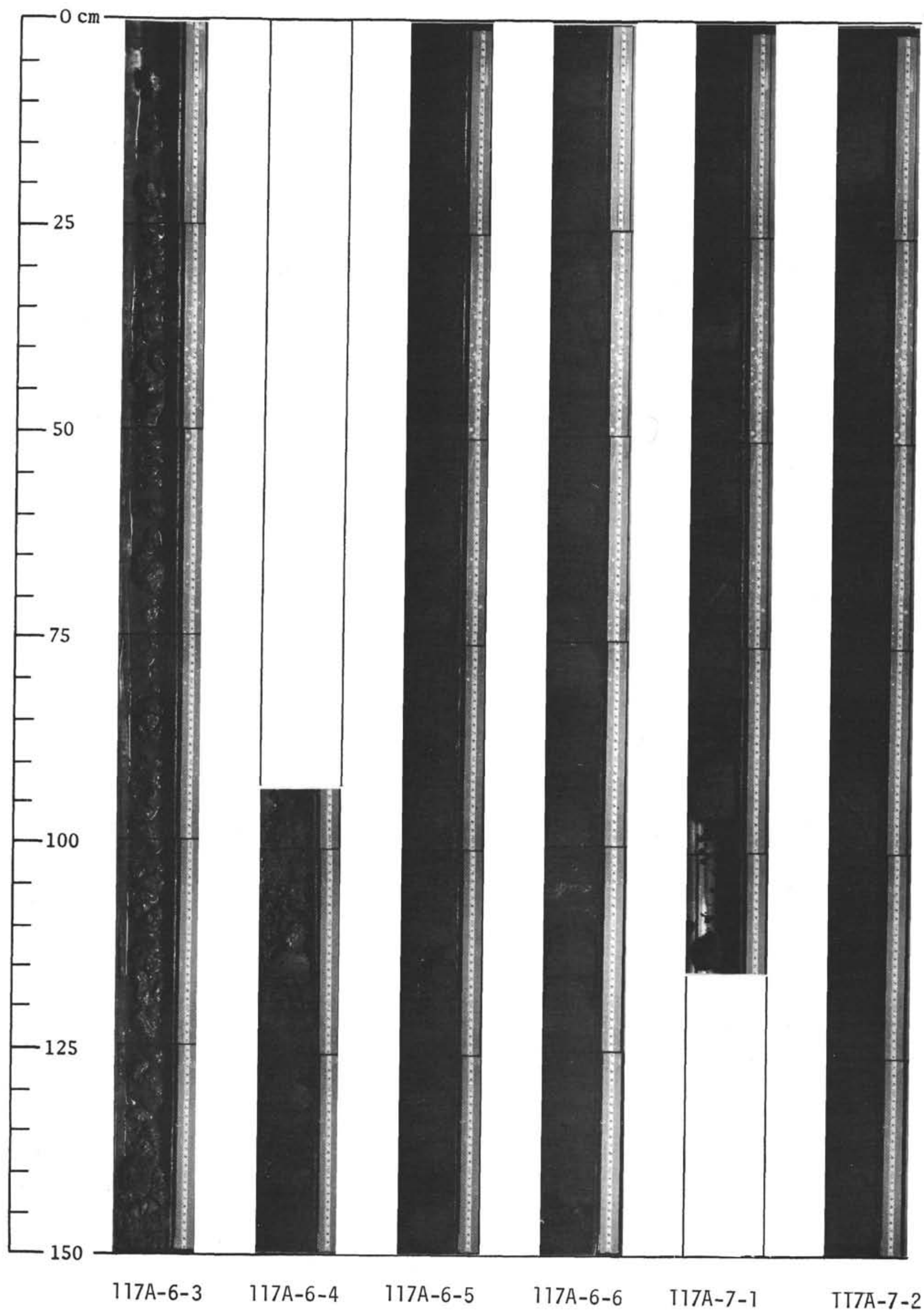




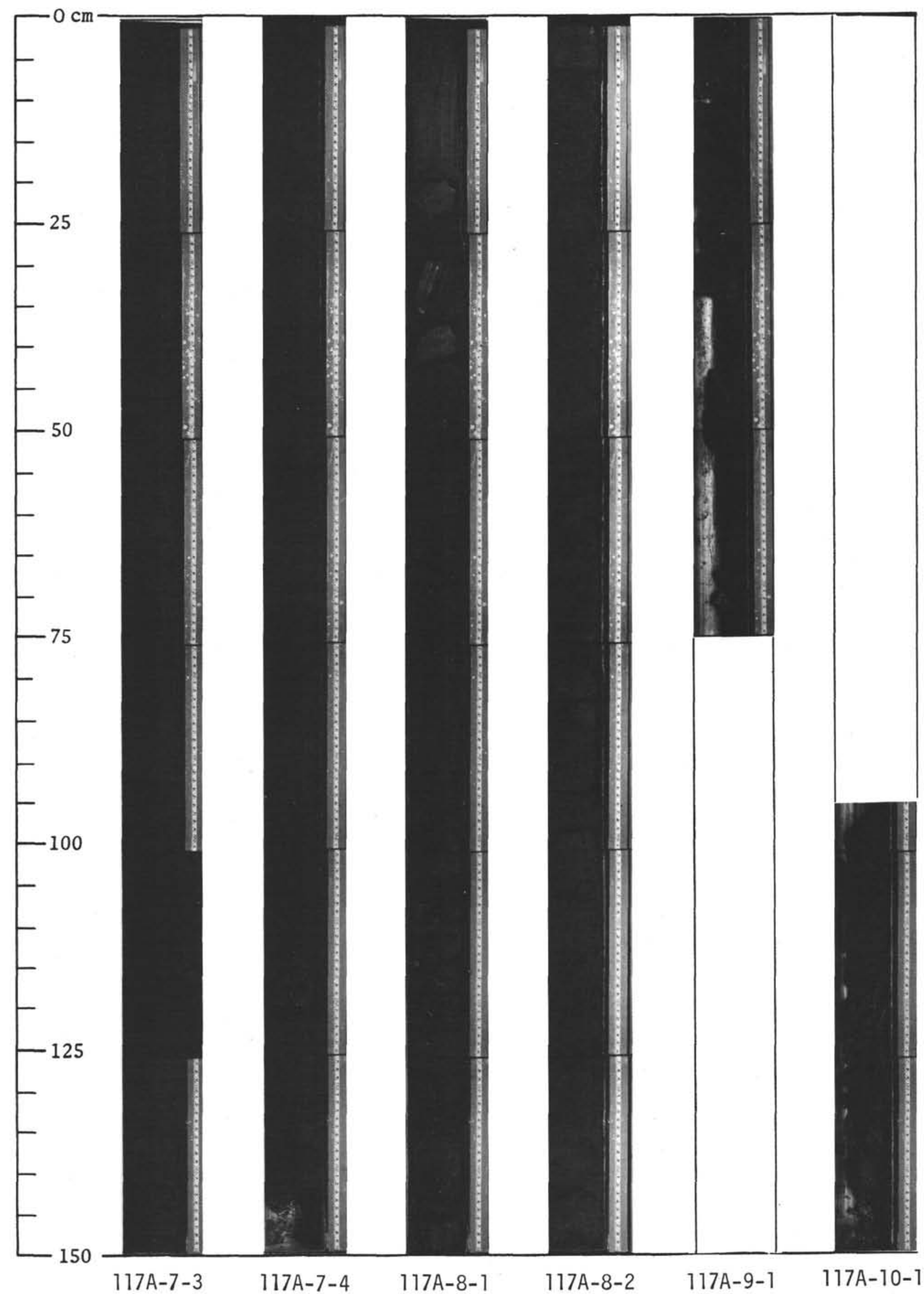


SHIPBOARD SCIENTIFIC PARTY

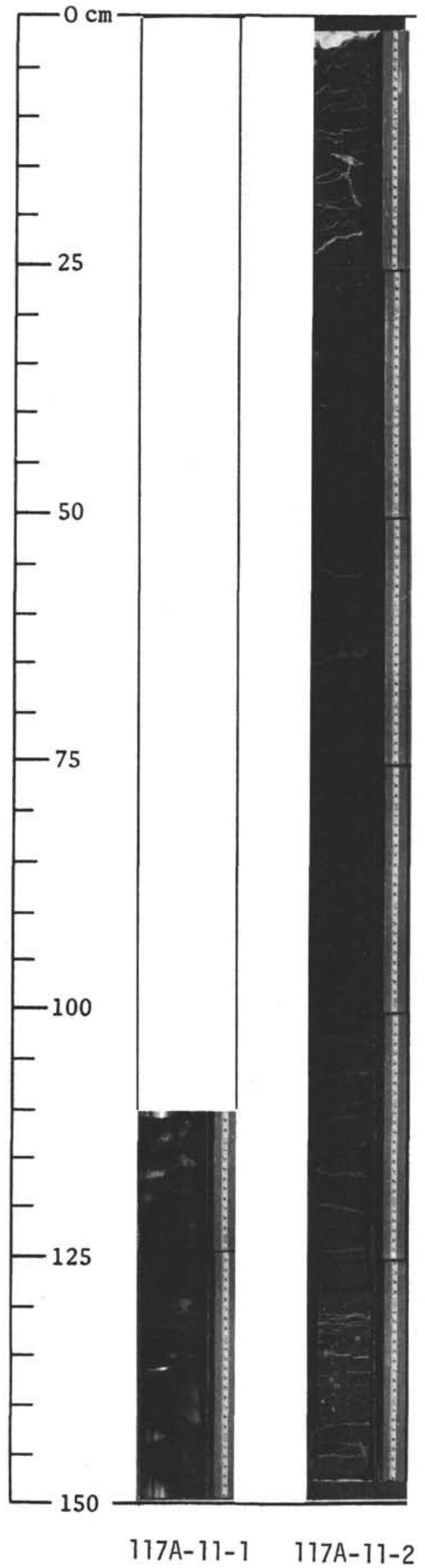





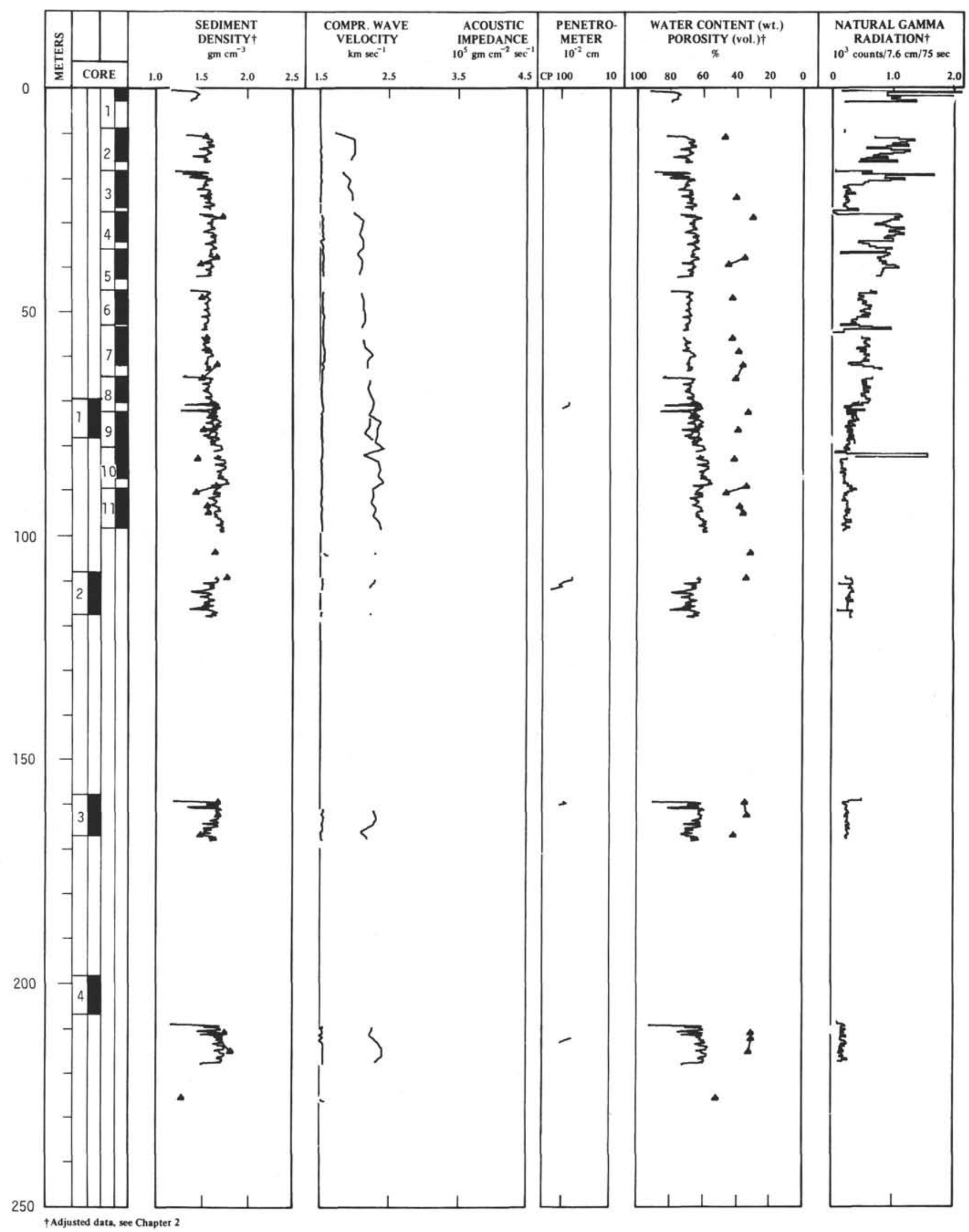


m

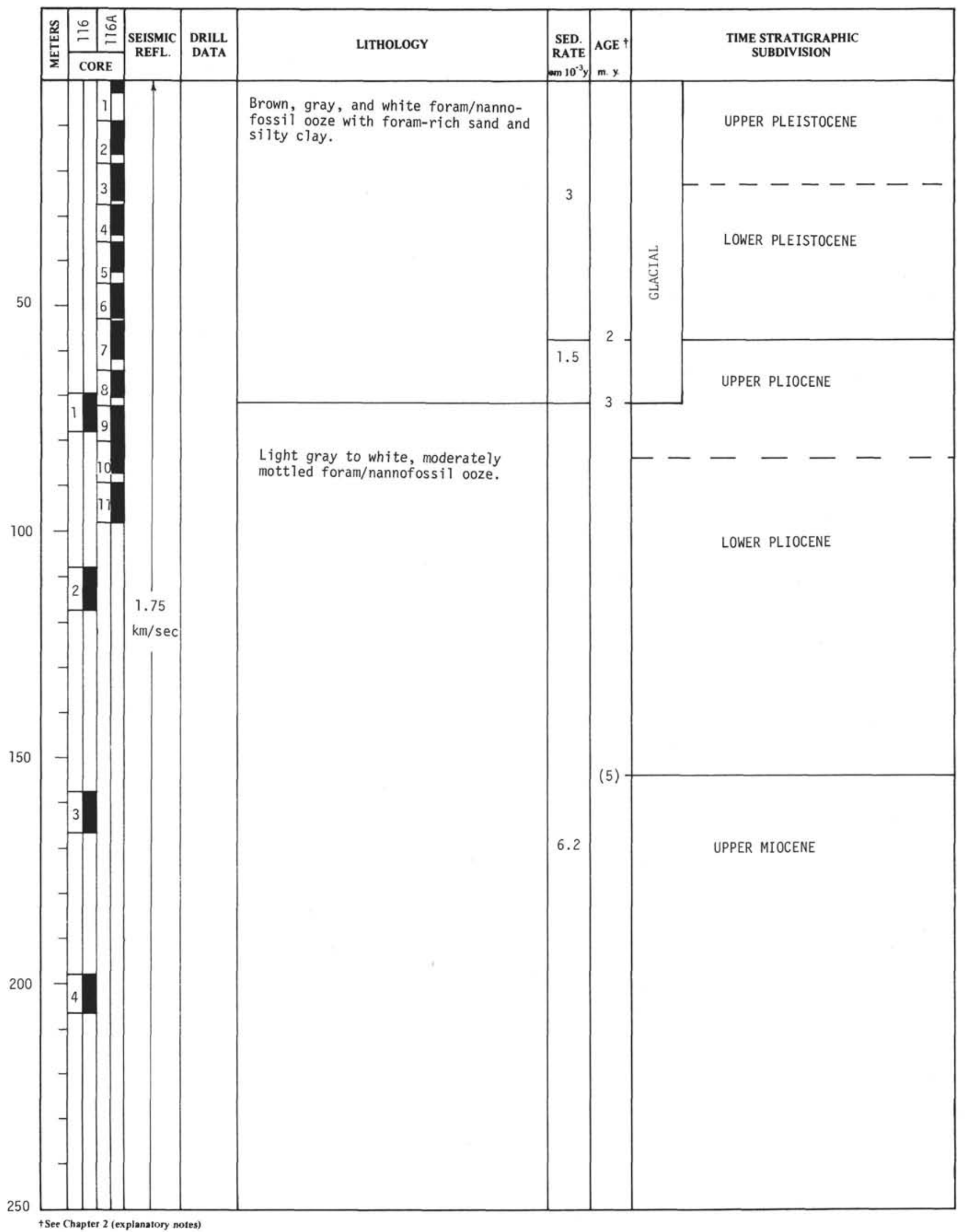




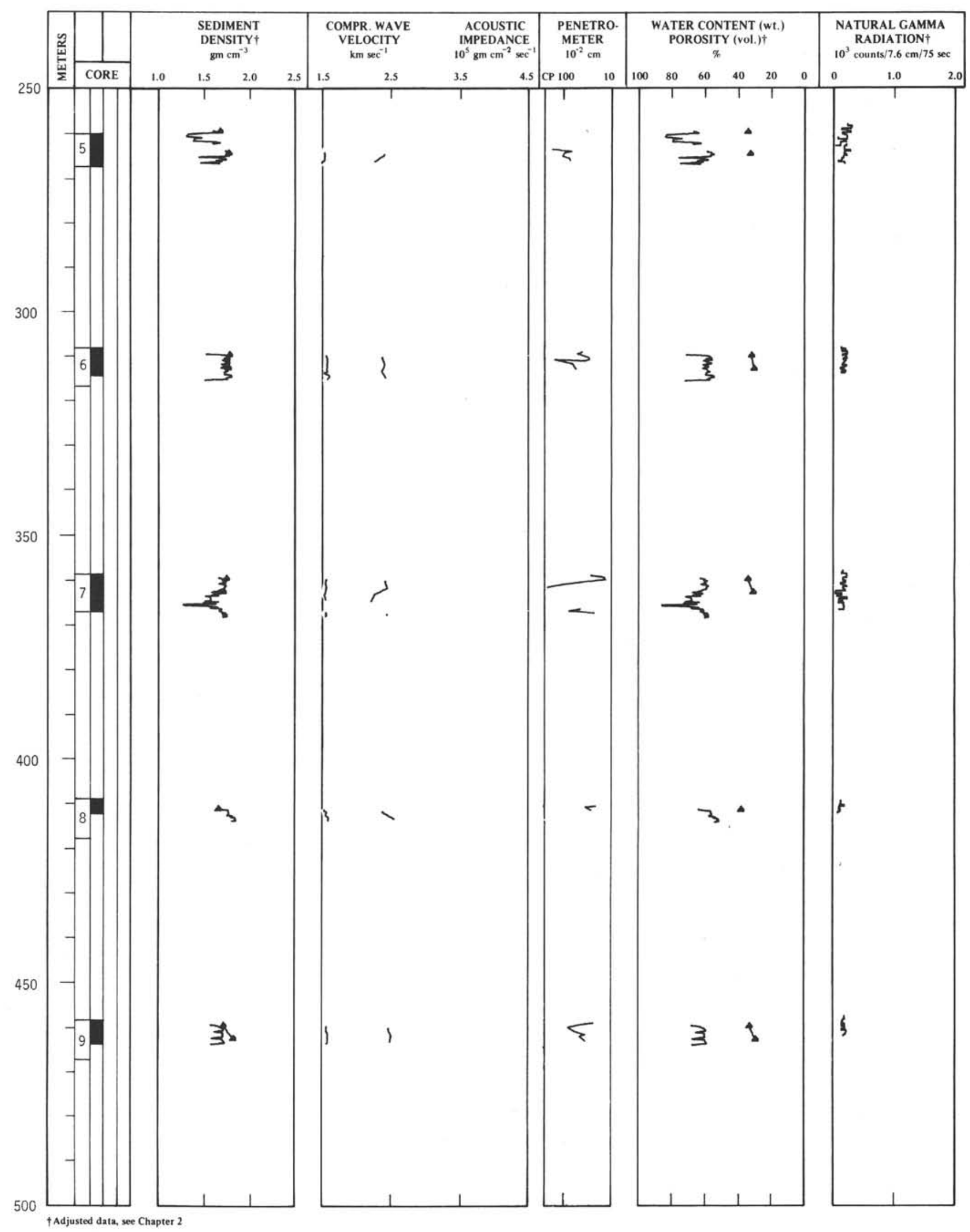




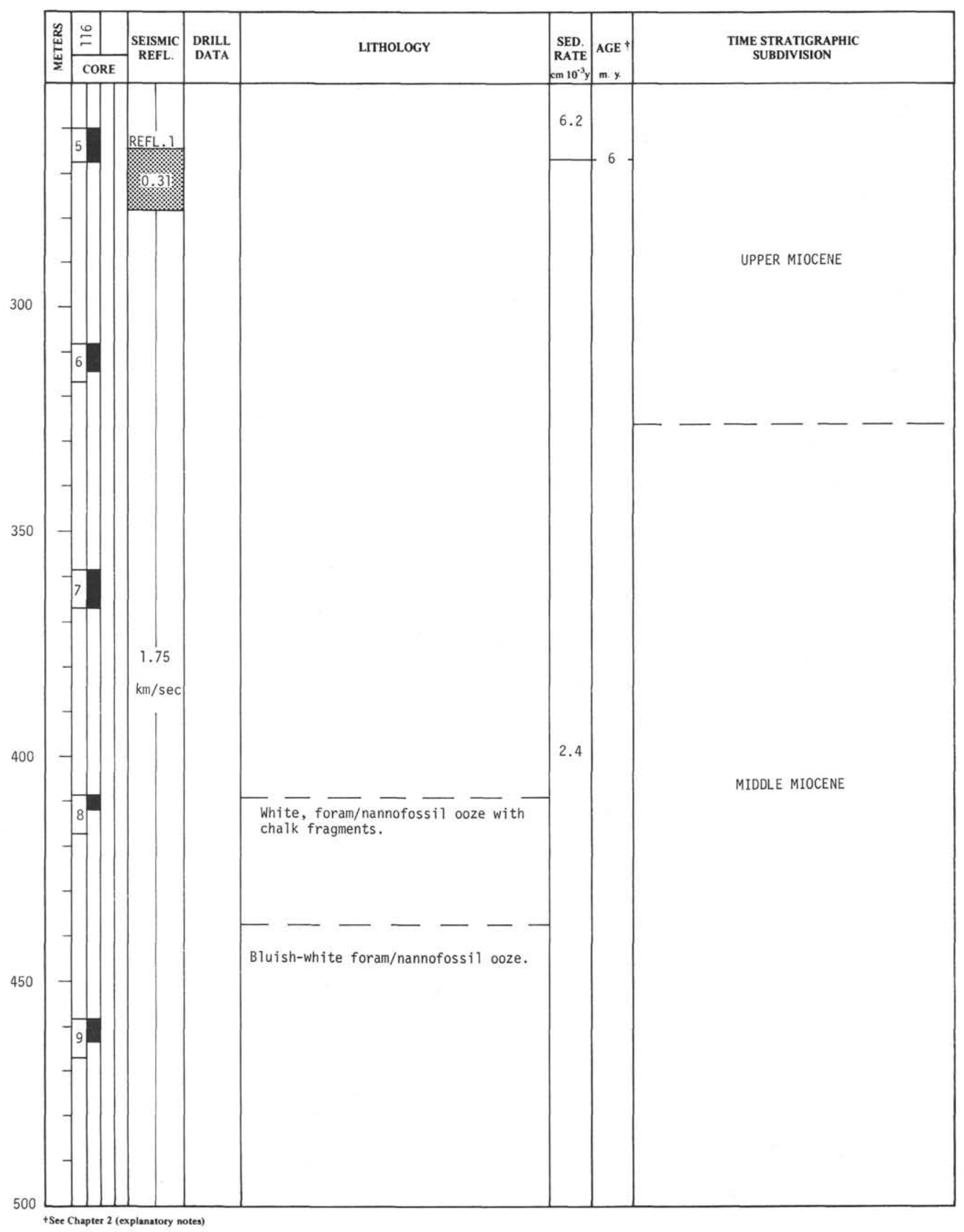




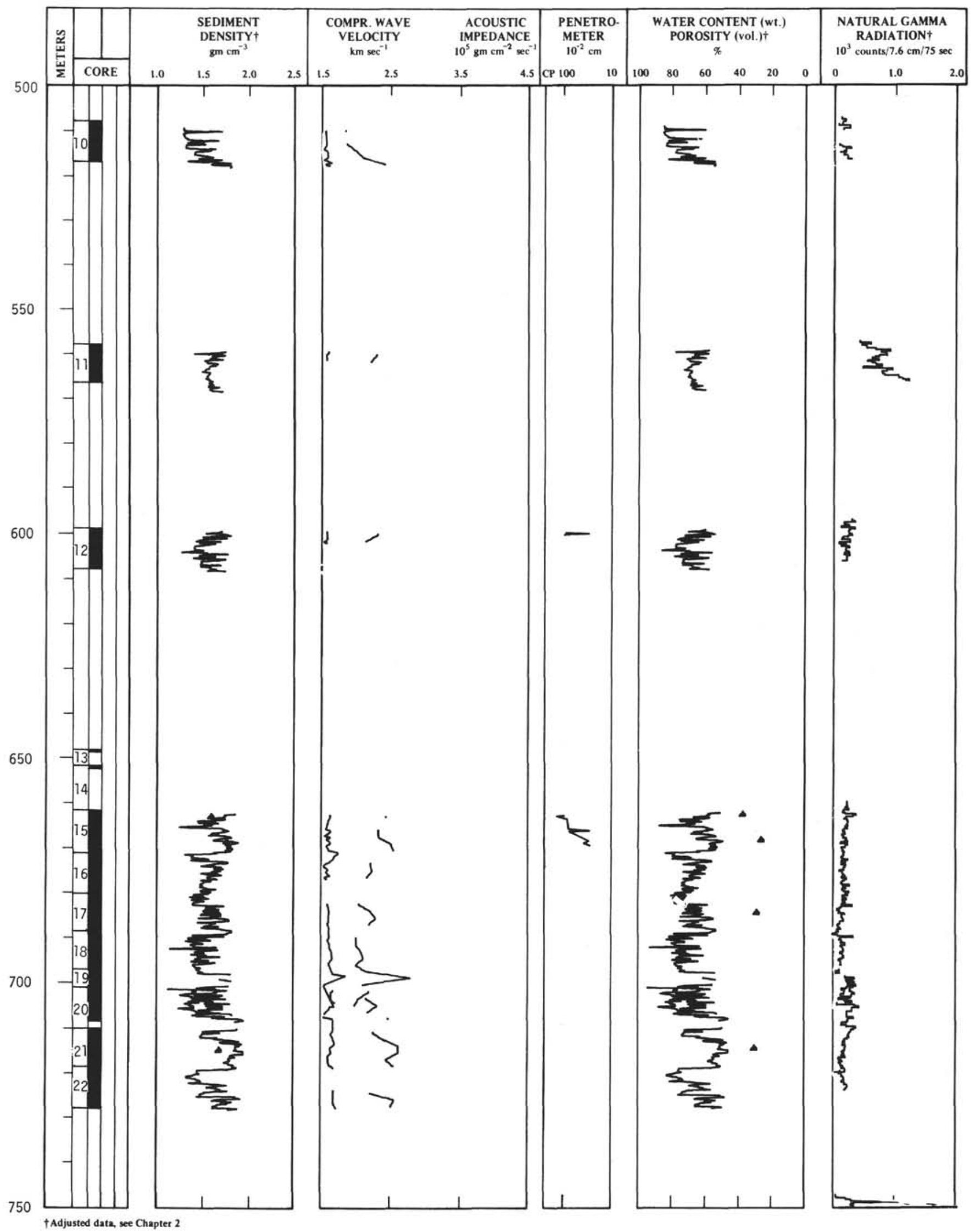




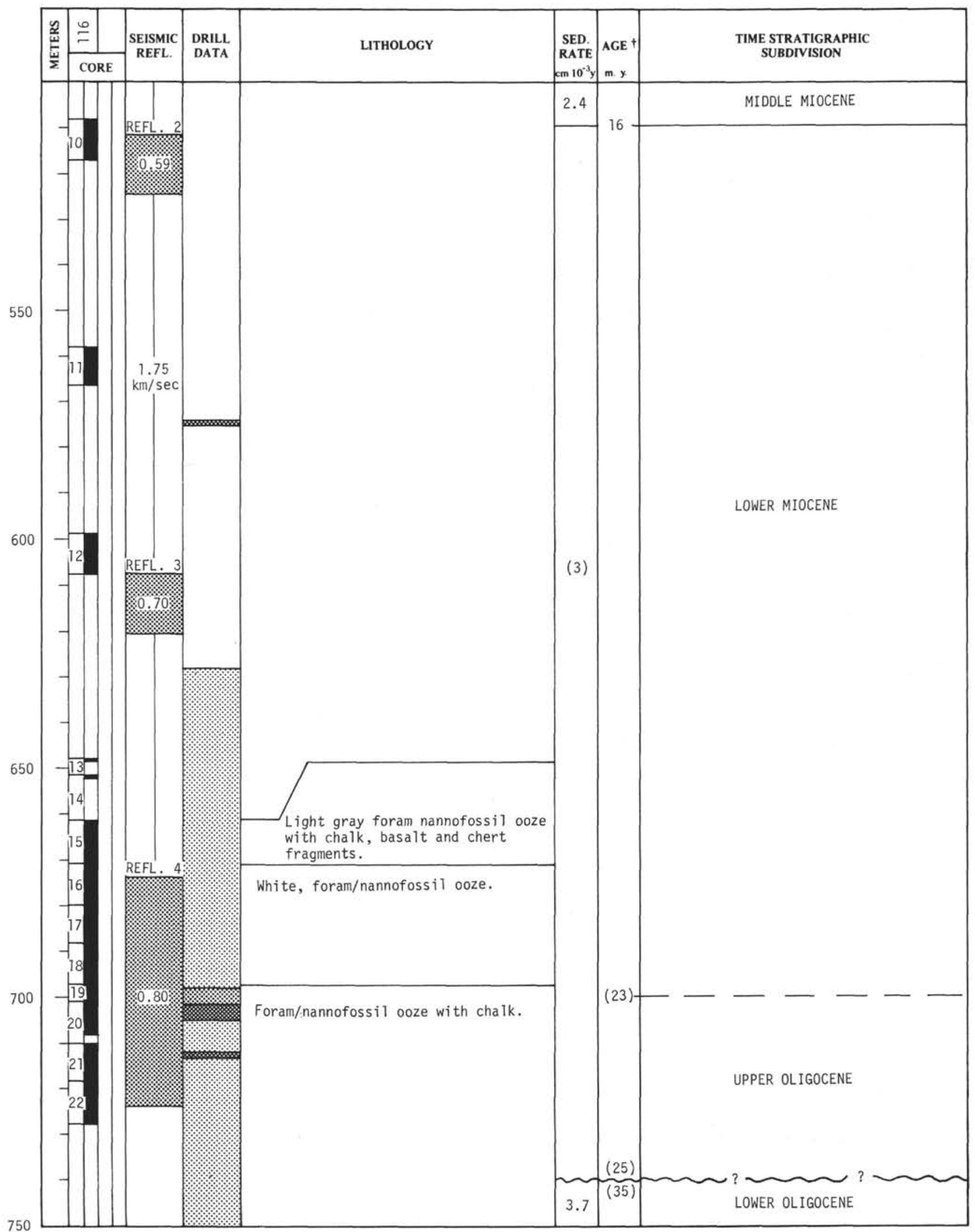




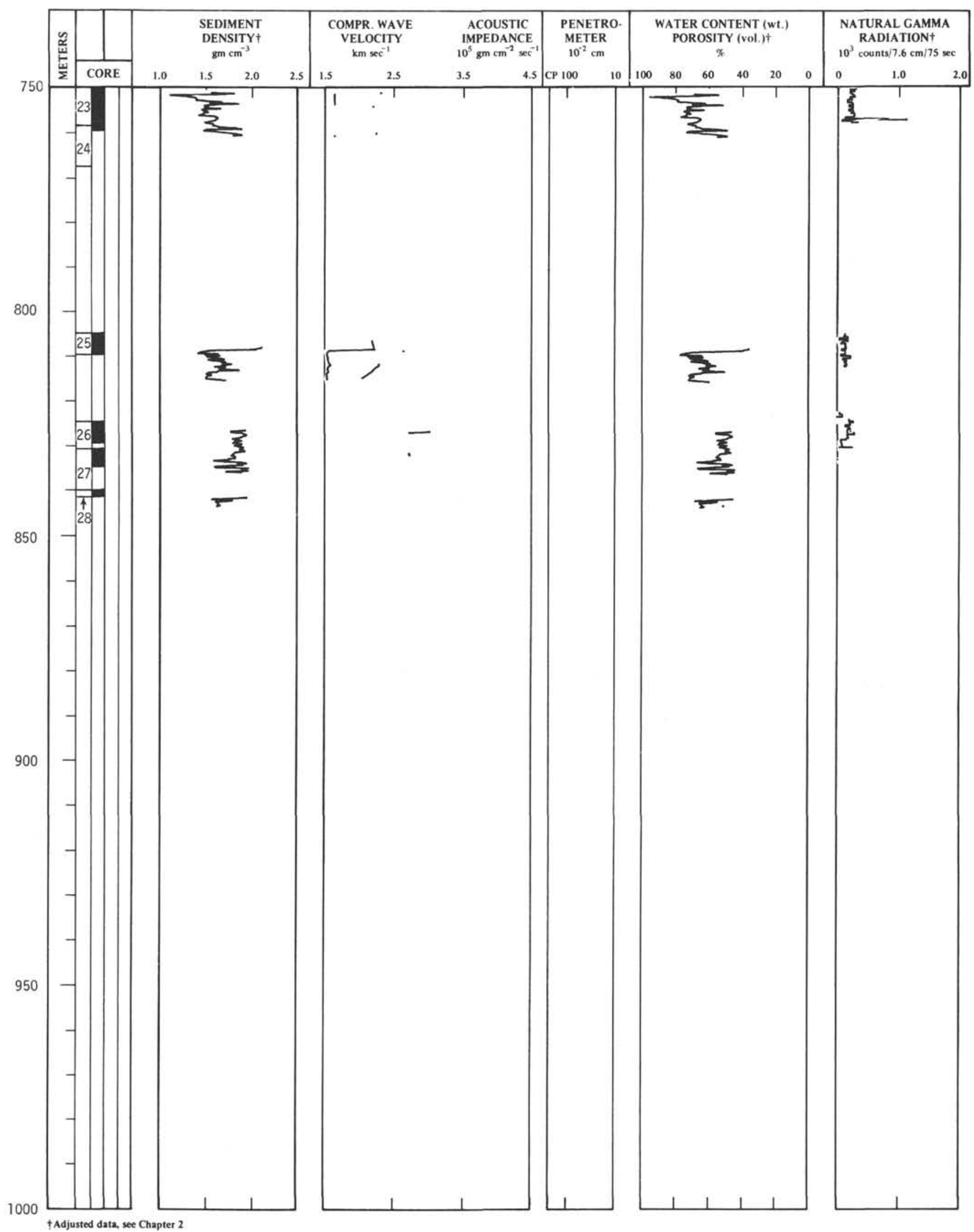


SITE 116

750 T0 -... m

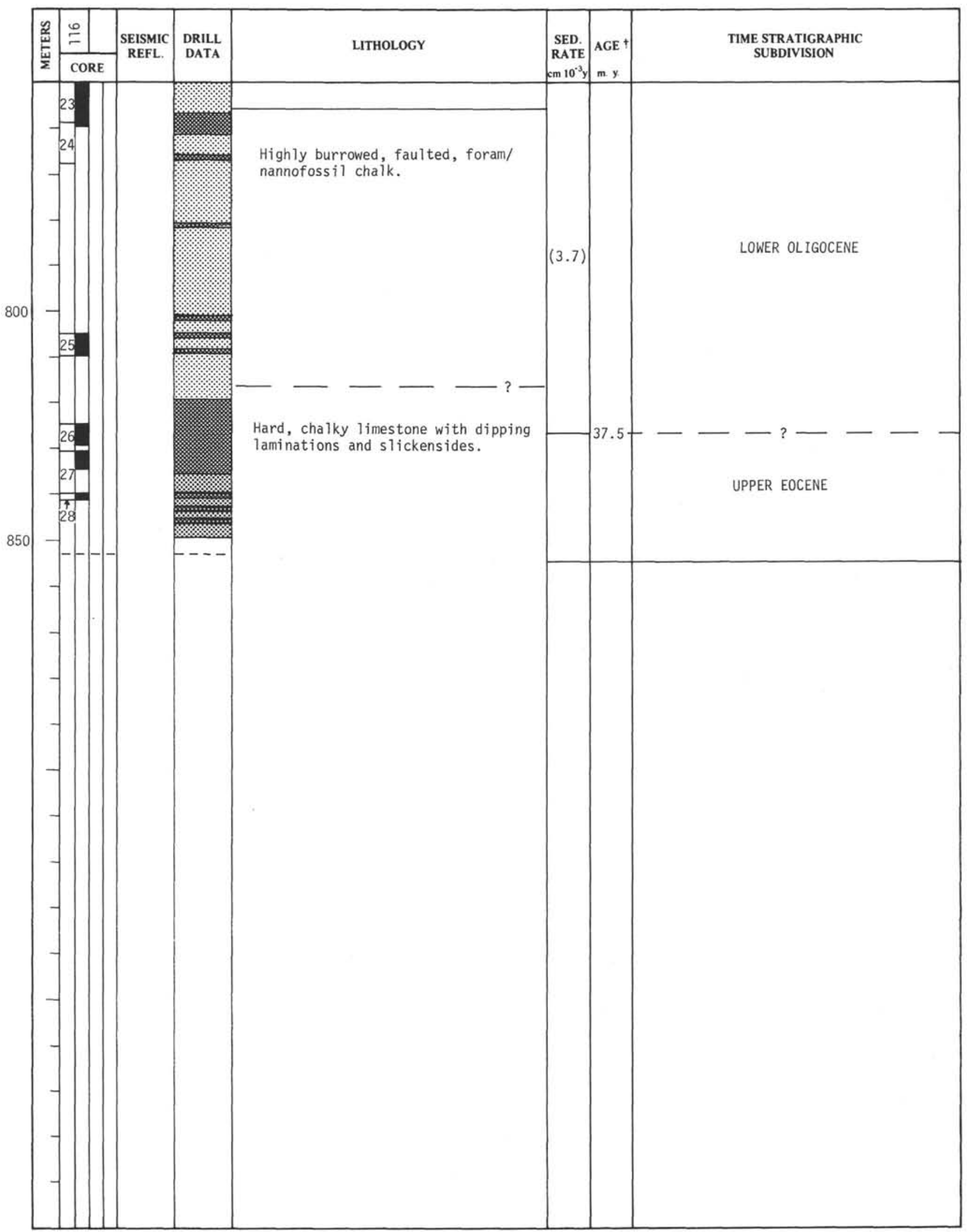

† See Chapter 2 (explanatory notes) 
SITE 117

Om TO $250 \mathrm{~m}$

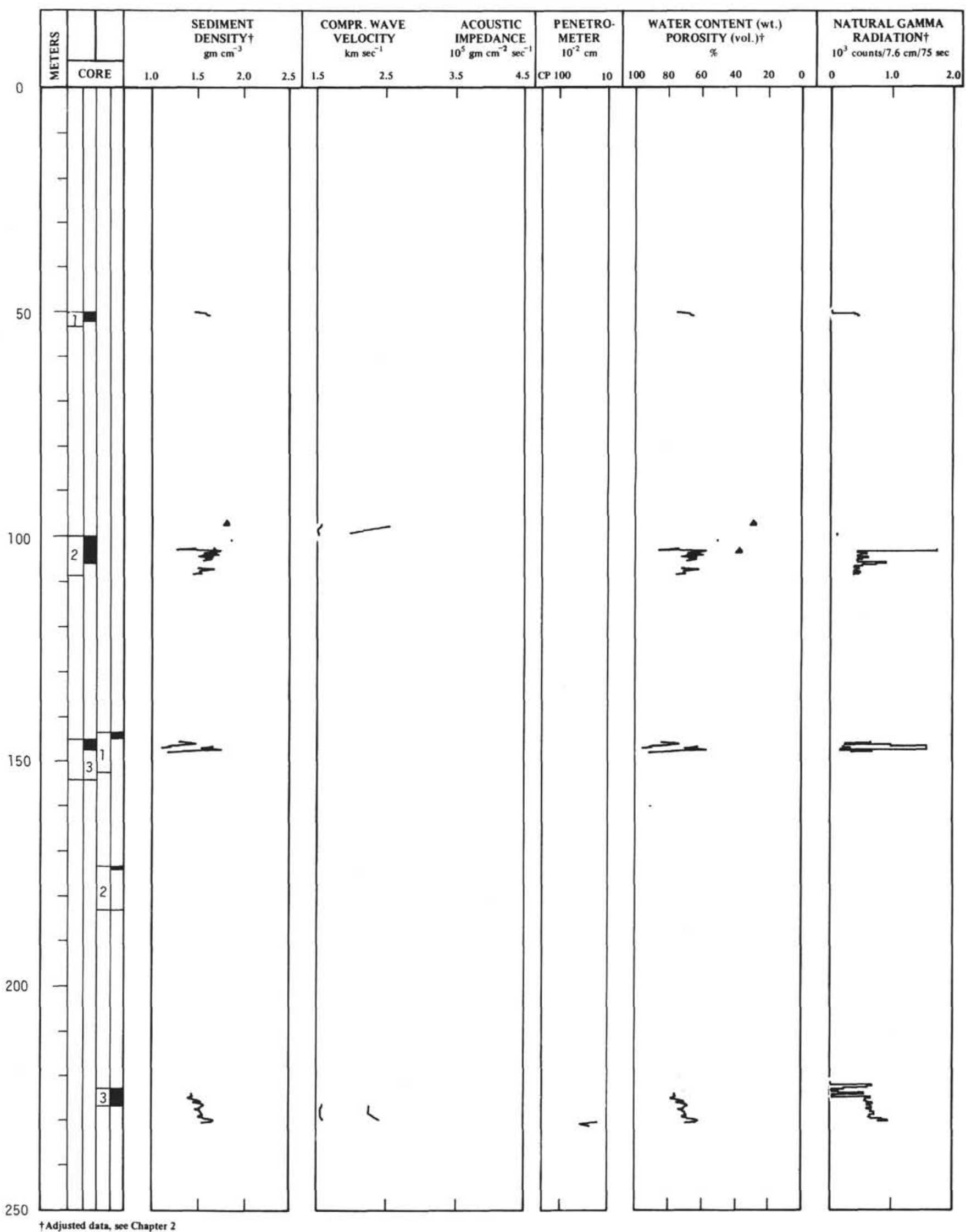




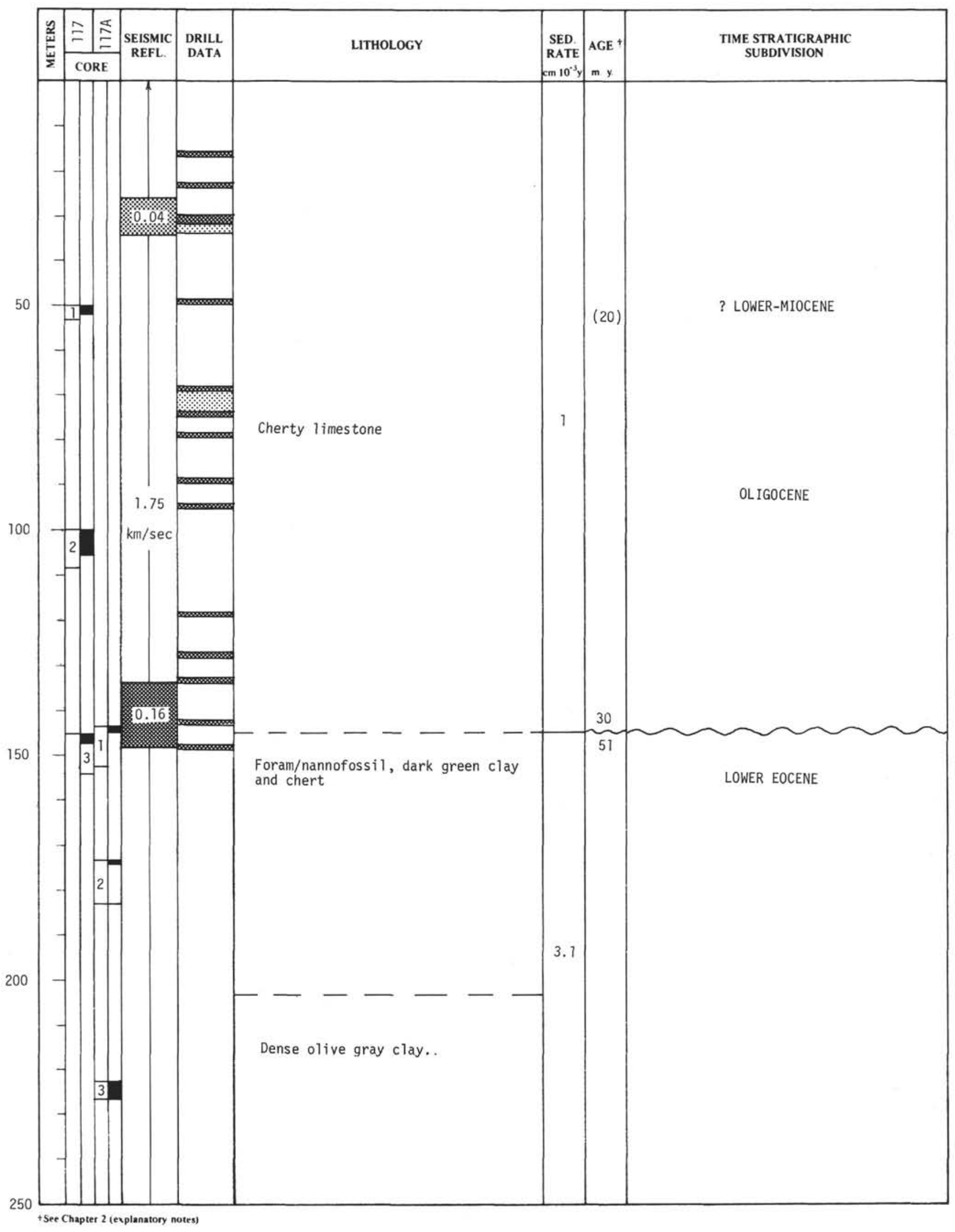




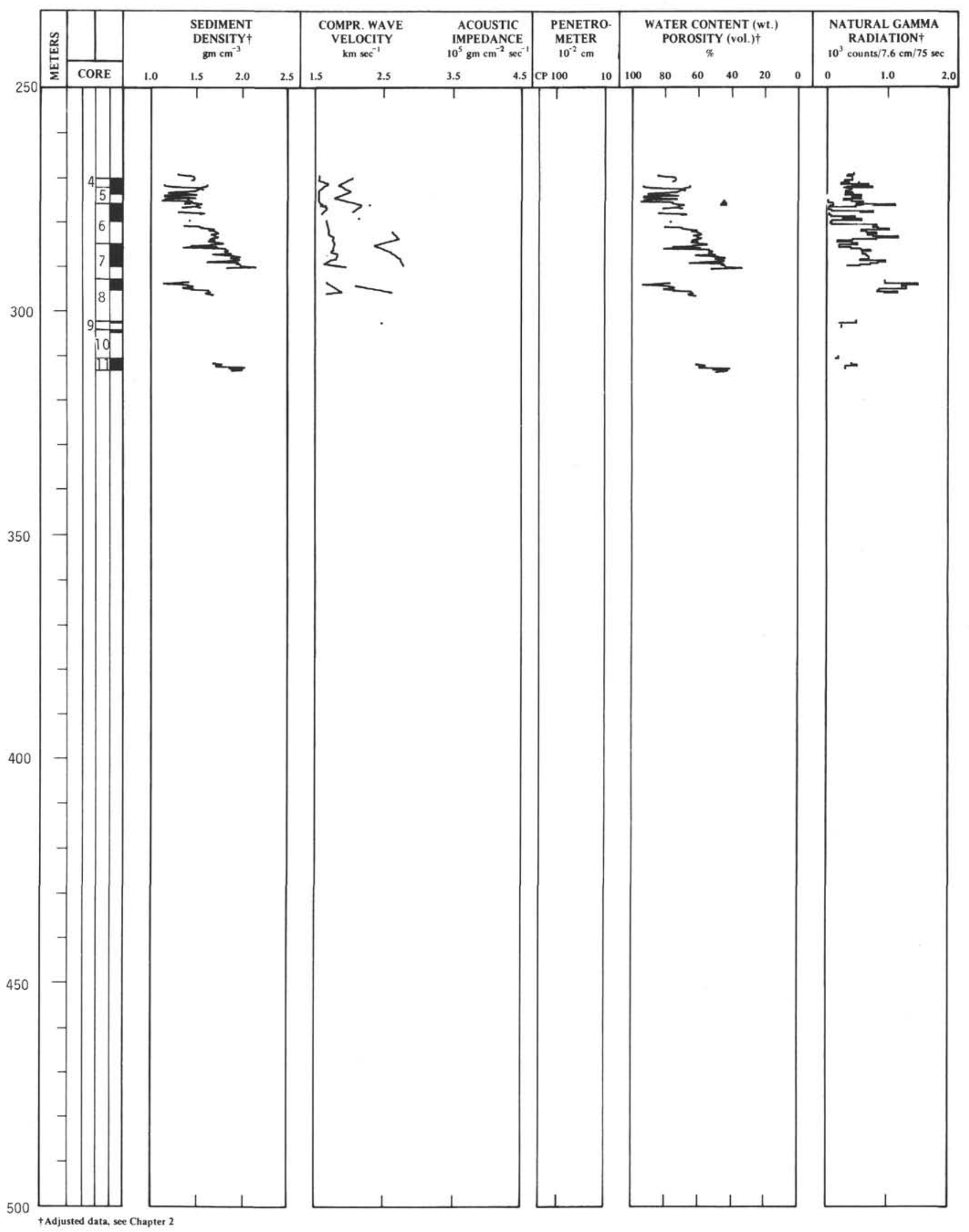




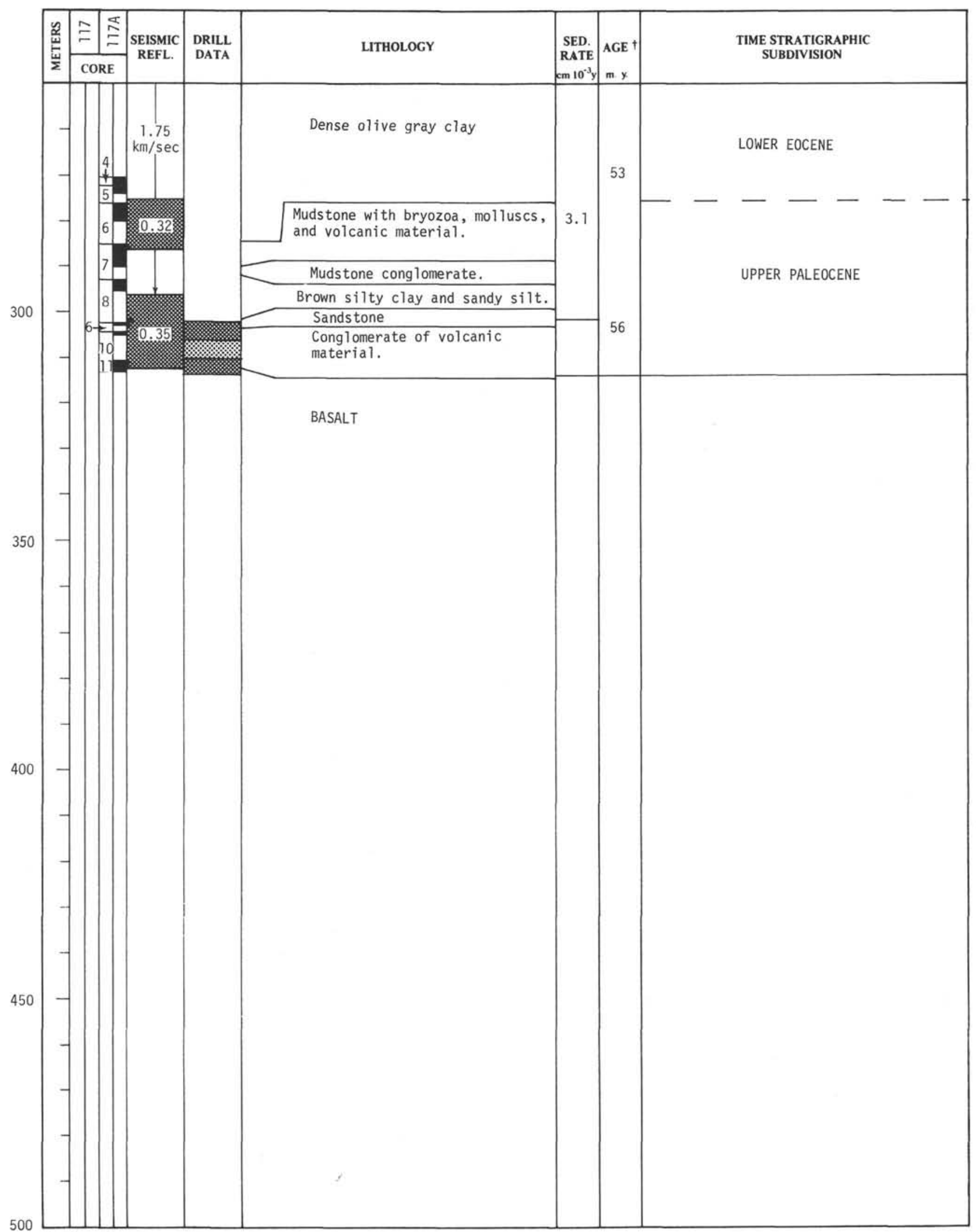

+See Chapter 2 (explanatory notes) 